\title{
WEST VALLEY DEMONSTRATION PROJECT ANNUAL SITE ENVIRONMENTAL REPORT CALENDAR YEAR 2008
}

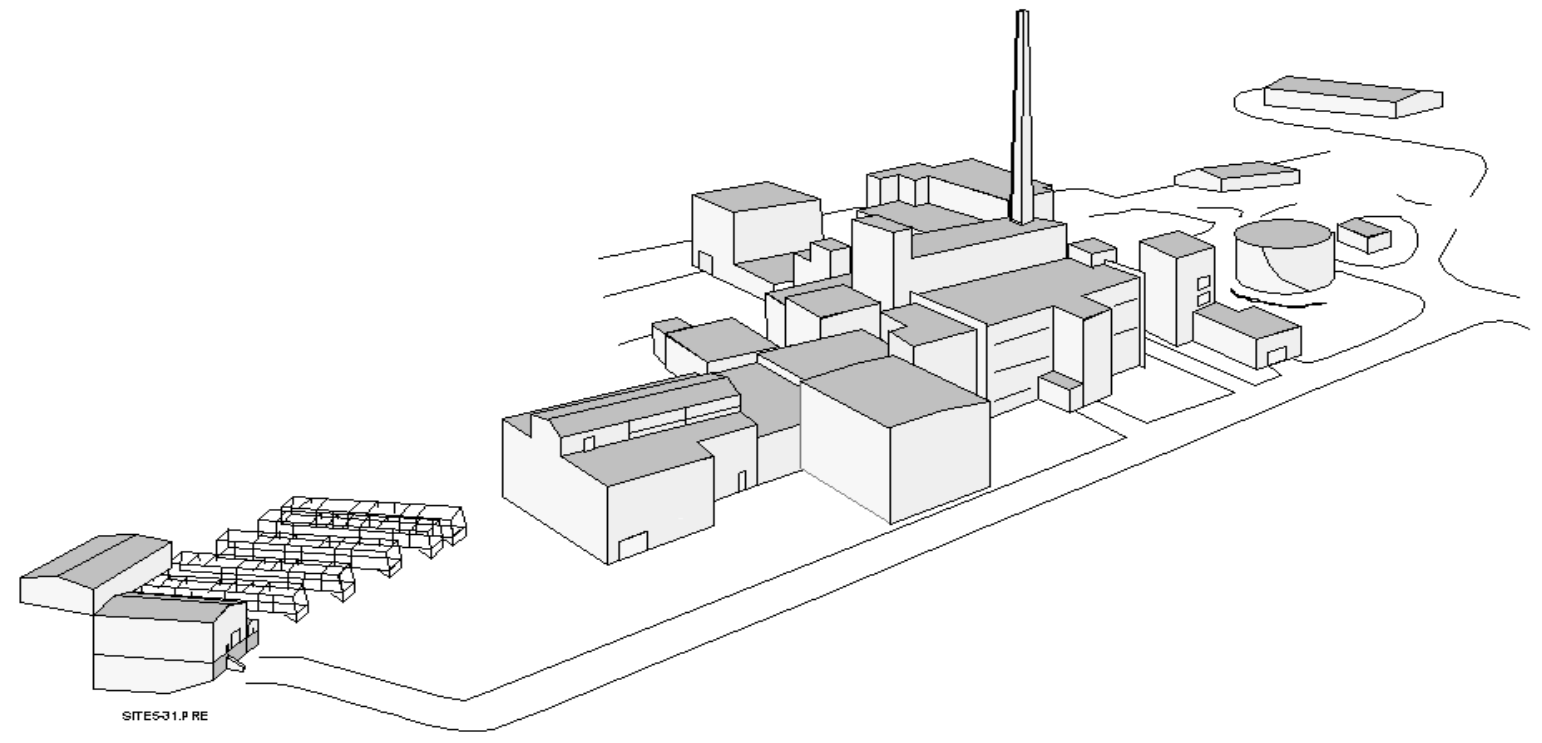

WEST VALLEY ENVIRONMENTAL SERVICES LLC

AND

URS - WASHINGTON DIVISION
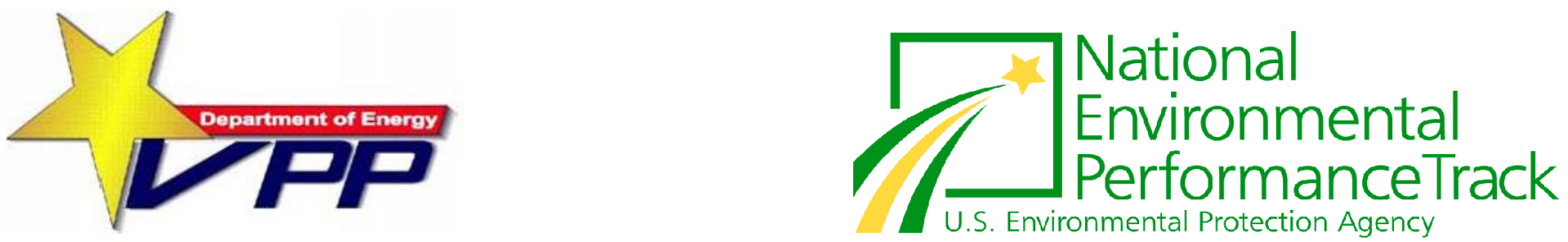

Prepared by: West Valley Environmental Services LLC and URS - Washington Division

Prepared for: U.S. Department of Energy DOE-WVDP 



\section{Department of Energy \\ West Valley Demonstration Project \\ 10282 Rock Springs Road \\ West Valley, NY 14171-9799}

To the Reader:

This report, prepared by the U.S. Department of Energy (DOE) West Valley Demonstration Project (WVDP), summarizes the environmental protection program at the WVDP for calendar year 2008.

Monitoring and surveillance of the WVDP facilities are conducted to verify that public health and safety and the environment are protected. The quality assurance requirements applied to the environmental monitoring program by the DOE ensure the validity and accuracy of the monitoring data.

At the WVDP, radiological air emissions are controlled and permitted by the U.S. Environmental Protection Agency (EPA) under National Emission Standards for Hazardous Air Pollutants, Subpart H, regulations. Nonradiological liquid effluent discharges are controlled and permitted through the New York State Pollutant Discharge Elimination System.

Air, surface water, groundwater, storm water, soil, sediment, and biological samples are collected and analyzed for radiological and nonradiological constituents. The resulting data are evaluated to assess effects of activities at the WVDP on the nearby public and the environment. Radiological monitoring of treated water effluents and facility ventilation system emissions verified that the dose received by off-site residents continues to be minimal.

The calculated dose to the hypothetical maximally exposed off-site individual from airborne radiological emissions in 2008 was much less than one-tenth of one percent of the EPA limit. The dose from combined airborne and waterborne radiological releases in 2008 to the same individual was less than one-tenth of one percent of the DOE limit.

West Valley Environmental Services continued to operate the WVDP in a safe manner during 2008, achieving 1.24 million work hours without a lost-time work accident or illness, while accomplishing complex decontamination and waste management activities. Additional characterization projects were completed and a mitigation project continues in and around the north plateau groundwater strontium-90 plume area. Work was completed to stabilize the inactive Nuclear Regulatory Commission-Licensed Disposal Area (NDA) by installing a slurry wall along two sides of the NDA to prevent lateral groundwater infiltration and placing an impermeable geomembrane cover over the entire NDA.

If you have any questions or comments about the information in this report, please contact the WVDP Communications Department at (716) 942-4555 or complete and return the enclosed survey.

Sincerely,

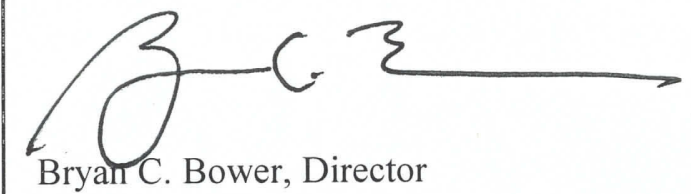

West Valley Demonstration Project 



\section{SUMMARY OF CHANGES TO THE 2008 WVDP ANNUAL SITE ENVIRONMENTAL REPORT}

FROM THE 2007 ANNUAL SITE ENVIRONMENTAL REPORT

This West Valley Demonstration Project (WVDP) Annual Site Environmental Report (ASER), prepared by the U.S. Department of Energy West Valley Demonstration Project office (DOE-WVDP), summarizes the environmental protection program at the WVDP for calendar year (CY) 2008. Monitoring and surveillance of the facilities used by the DOE are conducted to verify protection of public health and safety and the environment. This report is a key component of DOE's effort to keep the public informed of environmental conditions at the WVDP. The quality assurance protocols applied to the environmental monitoring program by the DOE ensure the validity and accuracy of the monitoring data.

In addition to demonstrating compliance with environmental regulations and directives, evaluation of data collected in 2008 continued to indicate that WVDP activities pose no threat to public health or safety, or to the environment.

\section{SPECIAL ISSUES IN CY 2008}

- Safety continued to be a priority in 2008. WVDP employees achieved 1.24 million work hours without a lost-time work-related accident or illness.

- Dismantlement and decontamination of equipment in the Main Plant Process Building (MPPB) continued in 2008. Fuel reprocessing equipment, residual tanks, vessels, and piping were removed from several locations in the MPPB.

- $\quad$ Stored radioactive waste continued to be processed and shipped off site for disposal.

- $\quad$ Three unneeded site facilities were demolished and removed and two more were prepared for demolition, in the continuing effort to reduce the Project's footprint. Five hardstands were cleared of excess materials.

- Work was completed to stabilize the inactive Nuclear Regulatory Commission-Licensed Disposal Area (NDA) to prevent infiltration from surface water and groundwater. A trench was excavated along two sides of the NDA and backfilled with a soil and clay mixture to form an impermeable subsurface barrier to prevent infiltration. The entire landfill was then resurfaced and covered with an impermeable geomembrane.

- Additional subsurface soil and groundwater samples were collected in the summer and fall of 2008 to enhance the characterization of chemical and radiological constituents in the contaminated groundwater plume beneath and downgradient of the MPPB.

- $\quad$ On December 5, 2008, a notice of availability was issued in the Federal Register for the Revised Draft Environmental Impact Statement for Decommissioning and/or Long-Term Stewardship at the West Valley Demonstration Project and Western New York Nuclear Service Center. This notice began a six-month public review period (through June 8,2009 ) which was later extended through September 8,2009 . Also on December 5, 2008, a notice of availability was issued for the Proposed Phase 1 Decommissioning Plan for the West Valley Demonstration Project. Both documents were posted on the DOE-WVDP web site. 
Changes in content for the 2008 ASER are summarized below.

\section{REVISIONS}

- The Environmental Compliance Summary was updated to reflect 2008 compliance status and ongoing National Environmental Policy Act (NEPA) activities at the WVDP.

- Data and text were updated throughout to reflect results from the $\mathrm{CY} 2008$ environmental monitoring program. Data tables, graphs, maps, supplemental information sections, and references were updated.

- Tables and figures applicable to locations at which sampling or monitoring has been discontinued or at which no sampling was done in 2008 have been deleted. (For example, no routine sediment or surface soil samples were collected in 2008 , so these data tables were deleted; the regional meteorological tower was removed in 2008 and the corresponding "wind rose" for this tower was deleted.)

- Appendix F, which contained soil and sediment data in 2007, presents results from the 2008 additional sampling programs to enhance the characterization of chemical and radiological constituents within subsurface soil and groundwater within the north plateau groundwater plume.

- Consistent with previous years' ASERs, and consistent with the "Guidance for the Preparation of the DOE ASERs," noteworthy events or accomplishments that occurred in CY 2009 (up to the time of public distribution) have been included in this 2008 ASER.

- The environmental monitoring program was thoroughly evaluated at the end of CY 2007 and reductions to the program were made. The revised program was implemented in 2008. A list of the changes is provided in the monitoring schedule in Appendix A. The maps in Appendix A, which include all the locations affected by the program changes, have been color-coded to show locations where the monitoring program remained the same, and locations where sampling was reduced. A presentation describing the 2008 WVDP environmental monitoring program was given by WVES to the West Valley Citizen Task Force in February 2008. 


\title{
West Valley Demonstration Project
}

\author{
Annual Site Environmental Report
}

\author{
for
}

Calendar Year 2008

\author{
Prepared for the U.S. Department of Energy \\ West Valley Demonstration Project Office \\ under contract DE-AC30-07CC30000
}

\begin{abstract}
September 2009
West Valley Environmental Services LLC and URS - Washington Division 10282 Rock Springs Road

West Valley, New York 14171-9799
\end{abstract}




\section{Disclaimer}

This report was prepared by the West Valley Environmental Services LLC (WVES) under contract number DE-AC30-07CC30000 with the United States of America, represented by the Department of Energy. Neither the United States Government nor WVES nor any of their contractors, subcontractors, or employees makes any warranty, expressed or implied, or assumes any legal liability or responsibility for any apparatus, product, or process disclosed, or represents that its use would not infringe on privately owned rights. References herein to any specific commercial product, process or service by trade name, trademark, manufacturer, or otherwise does not necessarily constitute or imply its endorsement, recommendation, or favoring by the United States Government or WVES. This report contains a summary of major or significant activities occurring at the West Valley Demonstration Project (WVDP) only and is not a full disclosure of all details associated with WVDP-related activities. The views and opinions of authors expressed in this report may not specifically state or reflect those of the United States Government or any agency thereof. 


\section{Preface}

Environmental monitoring at the West Valley Demonstration Project (WVDP) is conducted by West Valley Environmental Services LLC, under contract to the U.S. Department of Energy. The data collected provide a historical record of radionuclide and radiation levels and chemical data from natural and man-made sources in the survey area. The data also document the chemical and radiological quality of the groundwater on and around the WVDP and of the air and water released by the WVDP. Meteorological data are also presented.

It is the policy at the WVDP to conduct all activities, including design, construction, testing, start-up, commissioning, operation, maintenance, and decontamination and decommissioning, in a manner that is appropriate to the nature, scale, and environmental effects of these activities. The WVDP management is committed to full compliance with applicable federal, New York State, and local laws and regulations for the protection of the environment, to continual improvement, to the prevention and/or minimization of pollution, and to public outreach, including stakeholder involvement.

This report represents a single, comprehensive source of on-site and off-site data collected during 2008. The environmental monitoring program and results are discussed in the body of this report. Additional monitoring information is presented in the appendices. Appendix A contains maps of on-site and off-site sampling locations and a summary of the site environmental monitoring schedule. Appendices B through I can be found in electronic format on the compact disk (as indicated by the $\mathbf{6}$ icon) located inside the back cover. Appendices $B$ through $\mathrm{H}$ contain summaries of data obtained during 2008 and are intended for those readers interested in more detail than is provided in the main body of the report. Appendix I contains a copy of the West Valley Demonstration Project Act.

Requests for additional copies of the 2008 Annual Site Environmental Report and questions regarding the report should be referred to the WVDP Communications Department, 10282 Rock Springs Road, West Valley, New York 14171 (telephone: 716-942-4555). Additional Project information, including WVDP site environmental reports, is available on the internet at http://www.wv.doe.gov. 
This page intentionally left blank 
PREFACE

Purpose of This Report EXE-1

Major Site Programs EXE-1

Safety Emphasis EXE-1

Main Plant Process Building EXE-1

Waste Management EXE-1

Balance of Site Facilities EXE-1

Key Initiatives EXE-1

Environmental Performance Indicators EXE-1

Pollution Prevention/Waste Minimization EXE-2

Environmental Management System EXE-2

Compliance EXE-2

Environmental Monitoring EXE-2

North Plateau Characterization EXE-3

The Nuclear Regulatory Commission-Licensed DIsposal Area EXE-3

Quality Assurance EXE-3

Conclusion EXE-3

INTRODUCTION INT-1

Site Location INT-1

General Environmental Setting ___

Climate

INT-1

Ecology INT-1

Geology and Hydrology INT-1 INT-1

Relevant Demographics INT-1

Historic Timeline of the WNYNSC and the WVDP INT-1

ENVIRONMENTAL COMPLIANCE SUMMARY

ECS-1

Compliance Program ECS-1 Compliance Status ECS-1

2008 Accomplishments and Highlights at the WVDP ECS-9

Safety Emphasis ECS-9

Main Plant Process Building ECS-9

Radioactive Waste Management ECS-9

Balance of Site Facilities ECS-9

Special Projects ECS-9 


\section{ENVIRONMENTAL COMPLIANCE SUMMARY (concluded)}

National Environmental Policy Act ECS-9

Waste Tank Farm Tank and Vault Drying System ECS-10

The Draft EIS and the WVDP Core Team ECS-10

Phase 1 Decommissioning Plan for the West Valley Demonstration Project ECS-13

Resource Conservation and Recovery Act ECS-13

Hazardous Waste Permitting ECS-13 RCRA Part A Permit Application ECS-13

6 NYCRR Part 373-2 Permit Application ECS-14

RCRA §3008(h) Administrative Order on Consent ECS-14 Hazardous Waste Management ECS-15 Mixed Waste Management ECS-16

Nonhazardous, Regulated Waste Management ECS-16

Waste Minimization and Pollution Prevention ECS-16

Environmental Issues ECS-16

Unplanned Releases ECS-16

Request to EPA to Use Environmental Measurements for NESHAP Compliance ECS-16 Lagoon 3 Embankment Inspections ECS-16 Proposed Congressional Legislation ECS-17

NYSERDA Files Suit to Determine Federal Responsibilities at the West Valley Site ECS-17

Project Assessment Activities in 2008 ECS-17

CHAPTER 1. ENVIRONMENTAL MANAGEMENT SYSTEM 1-1

Integrated Safety Management System Implementation 1-1 Environmental Management System 1-1

Environmental Policy 1-2

Environmental Aspects and Impacts

Legal and Other Requirements 1-2

Objectives and Targets 1-2

National Environmental Performance Track

Environmental Management Program

Training, Awareness, and Competence

Voluntary Protection Program STAR Status

10 Code of Federal Regulations 851, “Worker Safety and Health Program” ___ 1-5

Safety-Trained Supervisor Program ___ 1-6

Communication and Community Involvement ___ 1-6

Operational Control ___ 1-6

NRC-Licensed Disposal Area Interceptor Trench and Pretreatment System ___ 1-6

Process Sewer Integrity Evaluation ___ 1-7

Emergency Preparedness and Response ___ 1-7

Environmental Monitoring and Measurement____ 1-7

Environmental Management of Wastewater __ 1-8

Environmental Management of Airborne Emissions ___ 1-8 


\section{CHAPTER 1 (concluded)}

Environmental Performance Measures ___ 1-9

Dose Assessment _ 1-9

Groundwater Monitoring __ 1-9

Environmental Management of Radiation Exposure __ $1-9$

Quality Assurance Program __ 1-9

Responsibility _ 1-10

Planning 1-10

Training _ـ1-10

Control of Design, Procedures, Items, and Documents__1-10

Corrective Action $1-10$

Documentation $1-10$

Quality Control__ 1-10

Field QC_ 1-10

Laboratory QC _ 1-11

Crosschecks_ 1-11

Data Management __ 1-12

Data Verification and Validation __ 1-12

Data Assessment and Reporting___ 1-12

Audits and Assessments__1-12

WVES Surveillance _ـ1-13

WVES QA Audit of the ELAB _ 1-13

WVES QA Surveillance of ELAB Storm Water Monitoring __ 1-13

WVES QA Department Off-Site Audit of the Bioassay Program __ 1-13

ISMS and QA Program Assessment __ 1-13

DOE Audit of WVDP QA Programs __ 1-14

DOE Audit of WVES Environmental Programs

Lessons Learned _ 1-14

Summary _ـ1-14

Changes in the 2008 Environmental Monitoring Program __ 1-14

CHAPTER 2. ENVIRONMENTAL MONITORING __ 2-1

Monitoring Program __ 2-1

Effluent Monitoring __ 2-1

Environmental Surveillance __ 2-1

Data Evaluation__2-1

Effluent Monitoring _ 2-1

Liquid Effluents _ 2-1

State Pollutant Discharge Elimination System Permit-Required Monitoring ___ 2-4

Radiological Air Emissions__2-5

Ventilation and Emission Systems __ 2-5 


\section{CHAPTER 2 (concluded)}

Environmental Surveillance __ 2-6

Surface Water _2-6

Drinking Water $2-10$

Ambient Air 2 2-10

Sediment and Soil _ 2-11

Food _ 2-11

Environmental Radiation _ 2-11

Meteorological Monitoring__ 2-11

Special Monitoring __ 2-13

Background Concentrations in Subsurface Soil on the North Plateau __ 2-13

Sampling of Subsurface Soil on the North Plateau __ 2-13

Sampling for Mitigation of the Leading Edge of the Plume __ 2-13

Monitoring Program Changes _ 2-15

Summary__ 2-15

CHAPTER 3. DOSE ASSESSMENT _ _ 3-1

Sources of Radiation at the West Valley Demonstration Project __ $3-1$

Exposure Pathways__ 3-1

Land Use Survey _ $3-2$

Dose Assessment Methodology ___ 3-2

Measurement of Radionuclide Concentrations in Llquid and Air Releases___ 3-2

Radiation Dose _3-3

Units of Dose Measurement __ 3-3

Measurement of Radionuclide Concentrations in Food ___ 3-4

Dose to the Public ___ 3-4

Predicted Dose From Airborne Emissions __ 3-4

Maximum Dose (Airborne) to an Off-Site Individual __ 3-4

Radon-220_3-6

Collective Population Dose (Airborne) ___ 3-6

Predicted Dose From Waterborne Releases ___ 3-6

Maximum Dose (Waterborne) to an Off-Site Individual___ 3-9

Collective Population Dose (Waterborne) __ 3-9

Predicted Dose From All Pathways __ 3-9

Calculated Dose From Food _ـ 3-11

Risk Assessment __ 3-11

Release of Materials Containing Residual Radioactivity ___ 3-11

Dose to Biota _ 3-11

Summary ___ 3-13 
Groundwater Monitoring Program Overview 4-1

Surface Water Hydrology

Geology _ 4-1

Hydrogeology _ 4-1

Routine Groundwater Monitoring Program __ 4-4

GMP Highlights 1982 Through 2008 _ 4-4

Current Monitoring Well Network __ 4-4

Groundwater Elevation Monitoring __ 4-6

Analytical Trigger Level Evaluation ___ 4-6

Groundwater Sampling Observations on the North Plateau: Sand and Gravel Unit and Strontium-90 Plume __ 4-6

Gross Beta and the Strontium-90 Plume __ 4-6

Monitoring Near Former Lagoon 1 __ 4-9

Monitoring at the Northeast Swamp Drainage __ 4-9

Monitoring at North Plateau Seeps __ 4-9

Radioisotopic Sampling Results_ 4-10

Tritium _4-10

Results for Volatile and Semivolatile Organic Compounds __ 4-11

Strontium-90 Plume Characterization and Remediation Activities in 2008 _ 4-11

Near-Term and Long-Term Plume Management Activities___ 4-11

North Plateau Metals Background Soils Characterization___ 4-12

Sampling and Analysis for Source Area Characterization of the North Plateau Plume __ 4-12

Pre-Design Geoprobe ${ }^{\circledR}$ Investigation for Mitigation of the Leading Edge of the North Plateau Sr-90 Plume __ 4-12

Metals Sampling at Select Wells Within the North Plateau Plume __ 4-13

North Plateau Groundwater Recovery System __ 4-13

North Plateau Groundwater Quality Early Warning Monitoring ___ 4-13

Pilot-Scale PTW __ 4-13

Groundwater Sampling Observations on the South Plateau: Weathered Lavery Till and the NDA ___ 4-15

NDA Monitoring _ 4-15

NDA IM _ 4-15

Additional Monitoring and Investigations __ 4-16

Groundwater Monitoring Downgradient of the Waste Tank Farm ___ 4-16

Investigation of Chromium and Nickel in the S\&G Unit and Evaluation of Corrosion in

Groundwater Monitoring Wells__ 4-16

FRS Pool Water Infiltration__4-16

APPENDIX A. 2008 ENVIRONMENTAL MONITORING PROGRAM __ A-1

Environmental Monitoring Program Drivers and Sampling Rationale ___ A-1

Sampling Schedule __ A-1

Sample Location Code __ A-1

Sampling Type/Medium ___ A-1

Collection Frequency/Total Annual Samples ___ A-1

Measurements/Analyses___A-1

Index of Environmental Monitoring Program Sample Points __ A-3

Summary of Monitoring Program Changes in $2008 \ldots$ A-17

WVDP Annual Site Environmental Report - Calendar Year $2008 \quad$ ix 
Radiation and Radioactivity __ UI-1

Radioactive Decay __UI-1

Some Types of lonizing Radiation___ UI-2

Measurement of Radioactivity __ UI-3

Measurement of Dose___ UI-3

Background Radiation _ UI-3

Potential Health Effects of Radiation ___ UI-3

Data Reporting __ UI-4

CAP88-PC Computer Code___ UI-6

Limits Applicable to Environmental Media ___ UI-6

Dose Standards __ UI-6

Derived Concentration Guides __ UI-7

State Pollutant Discharge Elimination System Permit Requirements___ UI-7

Water Quality Classifications, Standards, and Limits for Ambient Water __ UI-7

Potable Water Standards __ UI-7

Soil and Sediment Concentration Guidelines __ UI-7

Evaluation of Monitoring Data With Respect to Limits __ UI-8

GLOSSARY __ GLO-1

ACRONYMS AND ABBREVIATIONS __ A\&A-1

REFERENCES AND BIBLIOGRAPHY R\&B-1

DISTRIBUTION DST-1

ACKNOWLEDGMENTS __ ACK-1

\section{List of Figures}

INT-1. Location of the Western New York Nuclear Service Center INT-2

1-1. Annual Effective Dose Equivalent to the Maximally Exposed Off-Site Individual $1-9$

2-1. Ten-Year Average Gross Alpha and Gross Beta Concentrations in Cattaraugus Creek Downstream of the WVDP at Felton Bridge and Upstream at Background Location Bigelow Bridge

2-2. Ten-Year Average Gross Alpha and Gross Beta Concentrations at Near-Site Ambient Air Sampler AFRSPRD as Compared With Concentrations at Background Air Sampler AFGRVAL, Located 18 Miles $(29 \mathrm{~km})$ From the WVDP

2-3. Ten-Year Trends of Environmental Radiation Levels at Perimeter and Background TLDS

2-4. Wind Frequency and Speed From the On-Site Meteorological Tower (10-m and 60-m Elevations), January 1-December 31, 2008

3-1. Comparison of Doses From Natural and Man-Made Sources to the Dose From 2008 WVDP Effluents

3-2. Air Emissions From Point Sources: Dose Percent by Radionuclide in CY 2008 


\section{List of Figures (concluded)}

3-3. Water Effluents: Dose Percent by Radionuclide in CY 2008 3-8

3-4. All Sources: Dose Percent by Radionuclide in CY 2008 3-8

3-5. Effective Dose Equivalent From Liquid and Airborne Effluents to a Maximally Exposed Individual Residing Near the WVDP_ 3-10

3-6. Collective Effective Dose Equivalent From Liquid and Airborne Effluents to the Population Residing Within 50 Miles $(80 \mathrm{~km})$ of the WVDP

4-1. Geologic Cross Sections of the North and South Plateaus at the WVDP 4-3

4-2. North Plateau Gross Beta Plume: Fourth Quarters 1994, 2002, and December 2008 _-5

4-3 Average Annual Gross Beta Concentrations at Monitoring Wells Centrally Located Within the North Plateau Sr-90 Plume 4-18

4-4. Average Annual Gross Beta Concentrations at Monitoring Wells Near the Leading Edge of the North Plateau Sr-90 Plume _ 4-18

4-5. Average Annual Gross Beta Concentrations at Monitoring Wells Near Former Lagoon 1 __ 4-19

4-6. Average Annual Strontium-90 Concentrations at WNSWAMP __ 4-19

4-7. Average Annual Gross Beta Concentrations at Seeps from the Northeast Edge of the North Plateau _ 4-20

4-8. Concentrations of 1,2-DCE-t, 1,1,1-TCA, 1,1-DCA, and DCDFMeth at Well 8612 in the Sand and Gravel Unit $4-20$

4-9. Concentrations of Tributyl Phosphate at Monitoring Wells Near Former Lagoon 1 in the Sand and Gravel Unit $4-21$

4-10. Average Annual Gross Beta Concentrations at Monitoring Wells Downgradient of the NDA $4-21$

A-1. West Valley Demonstration Project Base Map A-23

A-2. On-Site Surface Water, Drinking Water, and Soil/Sediment Sampling Locations A-24

A-3. On-Site Storm Water Outfalls___ A-25

A-4. Rail Spur Storm Water Outfalls __ A-26

A-5. Off-Site Surface Water and Soil/Sediment Sampling Locations___ A-27

A-6. On-Site Air Monitoring and Sampling Locations ___ A-28

A-7. North Plateau Groundwater Monitoring Network (Includes Wells Used for Water-Level Measurements)

A-8. South Plateau Groundwater Monitoring Network (Includes Wells Used for Water-Level Measurements) A-30

A-9. Biological Sampling Locations ___ A-31

A-10. Location of On-Site Thermoluminescent Dosimeters ___ A-32

A-11. Location of Off-Site Thermoluminescent Dosimeters ___ A-33

A-12. Environmental Sampling Locations More Than 5 Kilometers From the WVDP __ A-34

A-13. U.S. Population by Sector Within 80 Kilometers of the WVDP (2002 Estimate) ___ A-35

A-14. 2008 Geoprobe ${ }^{\circledR}$ Sampling Locations for the North Plateau Background Subsurface Soil Investigation _ A-36

A-15. 2008 Geoprobe ${ }^{\circledR}$ Sampling Locations on the WVDP North Plateau ___ A-37 


\section{List of Tables}

INT-1. Historic Timeline of the WNYNSC and the WVDP INT-3

ECS-1. Compliance Status Summary for the WVDP in CY 2008 ECS-1

ECS-2. National Environmental Policy Act Documents Affecting DOE Activities at the WVDP ECS-11

ECS-3. WVDP Environmental Permits ECS-19

ECS-4. Solid Waste Management Units at the WVDP ECS-22

ECS-5. Summary of Waste Management Activities at the WVDP in CY 2008 ECS-24

ECS-6. Pollution Prevention Progress for FY 2008 ECS-25

ECS-7. Affirmative Procurement Accomplishments for FY 2008 ECS-25

ECS-8. WVDP 2008 Air Quality Noncompliance Episodes ECS-26

ECS-9. Status of EPCRA (SARA Title III) Reporting at the WVDP in 2008 ECS-26

ECS-10. Reportable Chemicals Above EPCRA 312 Threshold Planning Quantities Stored at the WVDP in 2008 ECS-26

ECS-11. WVDP 2008 NPDES/SPDES Permit Noncompliance Episodes ECS-26

ECS-12. WVDP Migratory Bird Nest Depredation Episodes in 2008 ECS-27

1-1. Elements of the Environmental Management System at the WVDP 1-3

1-2. 2008 Radioactivity Releases Versus 10-Year Averages 1-8

1-3. Summary of Crosschecks Completed in 2008 $1-12$

2-1. Total Radioactivity Discharged at Lagoon 3 (WNSP001) in 2008 and Comparison of Concentrations with DOE DCGs

2-2. Total Radioactivity Released at Northeast Swamp (WNSWAMP) in 2008 and Comparison of Concentrations with DOE DCGs

2-3. Total Radioactivity Released at Main Plant Stack (ANSTACK) in 2008 and Comparison of Concentrations with DOE DCGs

2-4. 2008 Comparison of Environmental Monitoring Results with Applicable Limits and Backgrounds $2-8$

2-5. WVDP 2008 Monthly Precipitation Totals Compared With 10-Year Monthly Averages $2-12$

2-6. 2008 Comparison of Radiological Results From Special Geoprobe ${ }^{\circledR}$ Subsurface Soil Samples on the North Plateau With Background Results

3-1. Potential Exposure Pathways From the WVDP to the Local Off-Site Population

3-2. Summary of Annual Effective Dose Equivalents to an Individual and Population from WVDP Releases in 2008

3-3. WVDP Radiological Dose and Release Summary

3-4. 2008 Evaluation of Dose to Aquatic and Terrestrial Biota 3-13

4-1. Summary of Hydrogeology at the WVDP

4-2. WVDP Groundwater Monitoring Network Sorted by Geologic Unit 4-7

4-3. WVDP Groundwater Sampling and Analysis Agenda 4-8

4-4. WVDP 2008 Groundwater Monitoring Overview by Geographic Area ___ 4-8

4-5. $\quad$ WVDP 2008 Groundwater Monitoring Overview by Purpose 4-8 


\section{List of Tables (concluded)}

4-6. Maximum Concentrations of Radiological Parameters in WVDP Wells During 2008 4-9

4-7. 2008 Maximum Concentrations $(\mu \mathrm{Ci} / \mathrm{mL})$ of Radionuclides in Groundwater at the WVDP 4-10

4-8. Summary of Maximum Concentrations of Organic Constituents in Select WVDP Groundwater Wells During 2008

4-9. Metals Detected Above Site-Specific Groundwater Screening Levels During Special Sampling Events in 2005, 2007, and 2008

A-1. WVDP Environmental Program Drivers and Sampling Rationale A-2

UI-1. Unit Prefixes Used in This ASER UI-4

UI-2. Units of Measure Used in This ASER UI-5

UI-3. Conversion Factors Used in This ASER UI-5

UI-4. U.S. Department of Energy Derived Concentration Guides for Inhaled Air or Ingested Water $(\mu \mathrm{Ci} / \mathrm{mL})$ UI-8 


\section{TABLE OF CONTENTS FOR APPENDICES B THROUGH I (CD ONLY)}

\section{List of Tables}

APPENDIX B-1. SUMMARY OF WATER LIMITS, GUIDELINES, AND STANDARDS B-1

B-1A. West Valley Demonstration Project State Pollutant Discharge Elimination System Sampling Program B-1

B-1B. New York State Water Quality Standards and Guidelines B-4

B-1C. New York State Department of Health/U.S. Environmental Protection Agency Potable Water MCLs, MCLGs, and Raw Water Standards B-6

B-1D. U.S. Department of Energy Derived Concentration Guides in Ingested Water B-7

B-2A. Comparison of 2008 Lagoon 3 (WNSP001) Liquid Effluent Radioactivity Concentrations With U.S. Department of Energy Guidelines B-9

B-2B. 2008 SPDES Results for Outfall 001 (WNSP001): Water Quality ___ B-10

B-2C. 2008 SPDES Results for Outfall 001 (WNSP001): Metals _ B-12

B-2D. 2008 SPDES Results for Outfall 007 (WNSP007): Water Quality and Iron ___ B-13

B-2E. 2008 SPDES Results for Sums of Outfalls 001, 007, 008, and 116: Water Quality ___ B-14

B-2F. 2008 Annual, Semiannual, and Quarterly SPDES Results for Outfall 001 (WNSP001):

Metals, Organics, and Water Quality

B-2G. 2008 SPDES Action Level Requirement Monitoring Results for Outfalls 001, 007, and 008: Metals, Organics, and Water Quality B-16

B-2H. 2008 SPDES Results for Outfall 01B (WNSP01B): Water Quality B-17

B-2I. 2008 SPDES Results for Outfall 008 (WNSP008): Water Quality B-17

B-2J. 2008 Results for Sewage Treatment Outfall (WNSP007) B-17

APPENDIX B-3. SPDES-PERMITTED STORM WATER OUTFALL DISCHARGE DATA B-19

B-3A. 2008 Storm Water Discharge Monitoring Data for Outfall Group 1: Storm Water Outfall S04 B-19 2008 Storm Water Discharge Monitoring Data for Outfall Group 1: Storm Water Outfall S04 B-20

B-3B. 2008 Storm Water Discharge Monitoring Data for Outfall Group 2: Storm Water Outfall S06 B-21 2008 Storm Water Discharge Monitoring Data for Outfall Group 2: Storm Water Outfall S33

B-3C. 2008 Storm Water Discharge Monitoring Data for Outfall Group 3: Storm Water Outfall S09 B-23 2008 Storm Water Discharge Monitoring Data for Outfall Group 3: Storm Water Outfall S12 B-24

B-3D. 2008 Storm Water Discharge Monitoring Data for Outfall Group 4: Storm Water Outfall S34 B-25 2008 Storm Water Discharge Monitoring Data for Outfall Group 4: Storm Water Outfall S34 B-26

B-3E. 2008 Storm Water Discharge Monitoring Data for Outfall Group 5: Storm Water Outfall S28 B-27 2008 Storm Water Discharge Monitoring Data for Outfall Group 5: Storm Water Outfall S14 B-28 


\section{TABLE OF CONTENTS FOR APPENDICES B THROUGH I (CD ONLY) (continued)}

\section{List of Tables (continued)}

APPENDIX B-3 (concluded)

B-3F. 2008 Storm Water Discharge Monitoring Data for Outfall Group 6: Storm Water Outfall S36 B-29 2008 Storm Water Discharge Monitoring Data for Outfall Group 6: Storm Water Outfall S37 B-30

B-3G. 2008 Storm Water Discharge Monitoring Data for Outfall Group 7: Storm Water Outfall S20 B-31 2008 Storm Water Discharge Monitoring Data for Outfall Group 7: Storm Water Outfall S20 B-32

B-3H. 2008 Storm Water Discharge Monitoring Data for Outfall Group 8: Storm Water Outfall S27 B-33 2008 Storm Water Discharge Monitoring Data for Outfall Group 8: Storm Water Outfall S35 B-34

B-4A. 2008 Radioactivity and pH in Surface Water at Facility Yard Drainage (WNSP005) B-35

B-4B. 2008 Radioactivity in Surface Water at French Drain (WNSP008) B-35

B-4C. 2008 Radioactivity in Surface Water at the North Swamp (WNSW74A) B-36

B-4D. 2008 Radioactivity in Surface Water at the Northeast Swamp (WNSWAMP) B-37

B-4E. 2008 Radioactivity in Surface Water at Storage and Disposal Area Drainage (WNNDADR) B-37

B-5A. 2008 Radioactivity and pH in Surface Water Downstream of the WVDP in Cattaraugus Creek at Felton Bridge (WFFELBR)

B-5B. 2008 Water Quality of Surface Water Downstream of the WVDP in Buttermilk Creek at Thomas Corners Bridge (WFBCTCB)

B-5C. 2008 Radioactivity in Surface Water Downstream of the WVDP at Franks Creek (WNSP006)

B-5D. 2008 Radioactivity and pH in Surface Water at Erdman Brook (WNERB53) B-42

B-5E. 2008 Radioactivity and pH in Surface Water at Franks Creek East of the SDA (WNFRC67) B-43

APPENDIX B-6. POTABLE WATER (DRINKING WATER) DATA B-45

B-6A. 2008 Water Quality Results in Potable Water at the WVDP B-45

B-6B. 2008 Water Quality Results in Utility Room Potable Water (WNDNKUR) B-46

B-6C. 2008 Water Quality Results in Utility Room Raw (Untreated) Water (WNURRAW) B-46

B-6D. 2008 Biological and Chlorine Results in Various Site Tap Water From Locations B-47

B-6E. 2008 Nitrate Results in the Utility Room Raw Tap Water B-47

B-6F. 2008 Copper and Lead Results From On-Site Tap Water Locations at the WVDP B-47 


\section{TABLE OF CONTENTS FOR APPENDICES B THROUGH I (CD ONLY) (continued)}

\section{List of Tables (continued)}

APPENDIX C. SUMMARY OF AIR MONITORING DATA C-1

C-1. 2008 Effluent Airborne Radioactivity at Main Stack (ANSTACK) C-1

C-2. 2008 Effluent Airborne Radioactivity at Vitrification System HVAC (ANVITSK) C-2

C-3. 2008 Effluent Airborne Radioactivity at 01-14 Building (ANCSSTK) $\mathrm{C}-2$

C-4. $\quad 2008$ Effluent Airborne Radioactivity at Contact Size-Reduction Facility (ANCSRFK) C-3

C-5. 2008 Effluent Airborne Radioactivity at Supernatant Treatment System (ANSTSTK) C-3

C-6. 2008 Effluent Airborne Radioactivity at Container Sorting and Packaging Facility (ANCSPFK) C-4

C-7. 2008 Effluent Airborne Radioactivity at Outdoor Ventilation Enclosures/Portable Ventilation Units C-4

C-8. $\quad 2008$ Effluent Airborne Radioactivity at Remote-Handled Waste Facility (ANRHWFK) C-5

C-9. 2008 Ambient Airborne Radioactivity at Background Great Valley Location (AFGRVAL) C-5

D-1. 2007/2008 Indicator Results From the Sand and Gravel Unit D-2

D-2. 2007/2008 Indicator Results From the Lavery Till-Sand Unit D-7

D-3. 2007/2008 Indicator Results From the Weathered Lavery Till Unit D-8

D-4. 2007/2008 Indicator Results From the Unweathered Lavery Till Unit D-9

D-5. 2007/2008 Indicator Results From the Kent Recessional Sequence D-10

D-6. 2007/2008 Results for Metals in Groundwater D-11

D-7. 2007/2008 Radioactivity in Groundwater From Selected Monitoring Locations D-15

D-8. Practical Quantitation Limits D-17

APPENDIX E. SUMMARY OF BIOLOGICAL DATA E-1

E-1. 2008 Radioactivity Concentrations in Milk E-1

E-2. 2008 Radioactivity Concentrations in Venison $\mathrm{E}-2$

E-3. 2008 Radioactivity Concentrations in Food Crops $\mathrm{E}-2$

E-4. 2008 Radioactivity Concentrations in Edible Portions of Fish From Cattaraugus Creek $\mathrm{E}-2$ 


\section{TABLE OF CONTENTS FOR APPENDICES B THROUGH I (CD ONLY) (continued)}

\section{List of Tables (continued)}

APPENDIX F. SPECIAL SAMPLING IN 2008 TO CHARACTERIZE SUBSURFACE SOIL AND GROUNDWATER WITHIN THE NORTH PLATEAU PLUME

APPENDIX F-1. GEOPROBE ${ }^{\circledR}$ SUBSURFACE SOIL AND GROUNDWATER BORING LOCATION AND DEPTH

SUMMARY

F-1A. Geoprobe ${ }^{\circledR}$ Subsurface Soil and Groundwater Boring Location and Depth Summary

F-2A. Average and Maximum Background Concentrations for Radiological Constituents in Subsurface Soil F-7

F-2B. Average and Maximum Background Concentrations for Radiological Constituents in Groundwater F-8

F-2C. Site-Specific Soil Screening Levels for Metals Concentrations in North Plateau Soils

F-2D. Groundwater Screening Levels for Metals in North Plateau S\&G Unit F-10

F-2E. Soil Cleanup Objectives and Levels

F-2F. Screening Concentrations for Contaminated Sediment F-12

F-2G. Screening Thresholds for In-Water and Riparian Management of Sediment and Dredge Material F-13

F-2H. Radionuclide Comparison Values for Soils F-13

APPENDIX F-3. RADIOLOGICAL RESULTS FOR 2008 SUBSURFACE SOIL AND GROUNDWATER FROM THE WVDP NORTH PLATEAU

F-3A. Comparison of Radiological Concentrations in Subsurface Soil With Background F-15

F-3B. Comparison of Radiological Concentrations in Groundwater With Background $F-30$

F-3C. Concentration Ranges of Radiological Constituents in 2008 Geoprobe ${ }^{\circledR}$ Soil Samples F-35

F-3D. Concentration Ranges of Radiological Constituents in 2008 Geoprobe ${ }^{\circledR}$ Groundwater Samples F-36

F-3E. Maximum Radiological Concentrations in Groundwater From the 2008 North Plateau Geoprobe ${ }^{\circledR}$ Characterization Program F-37 


\section{TABLE OF CONTENTS FOR APPENDICES B THROUGH I (CD ONLY) (concluded)}

\section{List of Tables (concluded)}

APPENDIX F-4. NONRADIOLOGICAL RESULTS FOR 2008 SUBSURFACE SOIL AND GROUNDWATER FROM THE WVDP NORTH PLATEAU

F-4A. Metals Results for 2008 Geoprobe ${ }^{\circledR}$ Soil Samples

F-4B. Metals Detected in 2008 Geoprobe $^{\circledR}$ Soil Samples Above Site-Specific Screening Levels F-51

F-4C. Metals Results for 2008 Geoprobe ${ }^{\circledR}$ Groundwater Samples F-52

F-4D. Metals Detected in 2008 Geoprobe ${ }^{\circledR}$ Groundwater Samples Above Groundwater Screening Levels $\mathrm{F}-55$

G-1. Summary of 2008 Semiannual Averages of Off-Site TLD Measurements G-1

G-2. Summary of 2008 Semiannual Averages of On-Site TLD Measurements G-2

H-1. Crosscheck Sample Comparisons From the DOE Mixed Analyte Performance Evaluation Program; Study 18, February 2008 $\mathrm{H}-1$

H-2. Crosscheck Sample Comparisons From the DOE Mixed Analyte Performance Evaluation Program; Study 19, June 2008

H-3. Comparisons of Results From Crosscheck Samples Analyzed for Water Quality Parameters as Part of the EPA's 2008 Discharge Monitoring Report - Quality Assurance Study 28 (August 2008) for the National Pollutant Discharge Elimination System 


\section{Purpose of This Report}

The Annual Site Environmental Report for the West Valley Demonstration Project (WVDP or Project) is published to provide information about environmental conditions at the WVDP to members of the public living near the site, to the United States (U.S.) Department of Energy (DOE) Headquarters, and to other interested stakeholders. In accordance with DOE Order 231.1A, "Environment, Safety, and Health Reporting," this report summarizes calendar year (CY) 2008 environmental monitoring data so as to describe the performance of the WVDP's environmental management system (EMS), confirm compliance with standards and regulations, and highlight important programs. Activities at the WVDP are being conducted in cooperation with the New York State Energy Research and Development Authority.

\section{Major Site Programs}

The WVDP is located on the site of a former commercial nuclear fuel reprocessing plant, which was shut down in 1976. In 1980, Public Law 96-368 (the WVDP Act) was passed, which authorized the DOE to demonstrate a method for solidifying 600,000 gallons (2.3 million liters) of liquid high-level radioactive waste (HLW) that remained at the West Valley site. Vitrification of the HLW, begun in 1996, was completed in September 2002. Activities for decontaminating and dismantling the facilities and for managing and disposing of wastes were then initiated and continued through CY 2008. The major activities that occurred in 2008 are described below.

Safety Emphasis. By the end of 2008, WVDP employees achieved 1.24 million work hours without a losttime work accident or illness. Radiological safety was maintained with no reportable contamination incidents while conducting complicated, hazardous work in a number of radiological areas, including the main plant process building (MPPB).

MPPB. By the end of CY 2008, fuel processing equipment and source contamination were removed from approximately $75 \%$ of the MPPB's 61 high-hazard cells and operating aisles, including residual tanks, ves- sels, and process piping. The product purification cell (north) was emptied. Equipment removal and decontamination was completed in the miniature cell, the upper warm aisle, and the acid recovery cell pump room. Dismantlement and decontamination continues in the acid recovery cell and the hot acid cell.

Waste Management. In 2008, additional remotehandled waste processing capability for processing large and high-dose waste containers was established in the former vitrification facility. A total of 62,500 cubic feet of low-level waste (LLW) and 21,400 cubic feet of transuranic waste were processed, packaged, and/or shipped. Totals include both contacthandled and remote-handled waste. All shipments in 2008 were by truck.

Balance of Site Facilities. Three unneeded site facilities were demolished and removed and two were prepared for demolition. Five hardstands were cleared of excess materials.

\section{Key Initiatives}

Environmental Performance Indicators. The WVDP has been recognized by the U.S. Environmental Protection Agency (EPA) as a charter member of the Performance Track (P-Track) Program for implementation of its EMS.

The purpose of the P-Track program was to identify and address opportunities to improve environmental performance. West Valley Environmental Services (WVES) renewed its application in 2007.

The commitments and the 2008 annual reporting accomplishments were as follows:

- to reduce total non-transportation energy usage by $5 \%$ : total energy usage was reduced by $36.1 \%$ in CY 2008;

- to reduce amount of liquid nitrogen used in the waste tank farm by $10 \%$ : liquid nitrogen usage was reduced by $100 \%$ in CY 2008 ; 
- to reduce amount of resins used for the treatment of radiologically contaminated wastewater generated by plant operations by $10 \%$ : resin usage was reduced by $25.6 \%$ in $\mathrm{CY} 2008$; and

- to reduce amount of sulfur oxide $\left(\mathrm{SO}_{\mathrm{x}}\right)$ air emissions from non-transportation purposes by $10 \%$ : $\mathrm{SO}_{\mathrm{x}}$ emissions were reduced by $64.3 \%$ in CY 2008.

The EPA discontinued this program on March 16, 2009.

Pollution Prevention/Waste Minimization. In 2008, the WVDP's long-term waste minimization and pollution prevention program accomplished the following:

- Recycled more than 251 tons (228 metric tons) of materials;

- Transferred a 7-ton (6.35-metric ton) leaded-glass window back to the manufacturer for reuse;

- Transferred $\$ 1,750,000$ worth of excess materials for reuse or resale; and

- Purchased more than $\$ 135,000$ of environmentally preferable products.

\section{Environmental Management System}

The WVDP EMS satisfies the requirements of DOE Order 450.1A, "Environmental Protection Program," and is a key part of the WVDP Integrated Safety Management System. In 2008, WVDP employees continued to demonstrate their commitment to an all-inclusive approach to safety, coordinating the EMS with other safety management and work planning processes through the integrated environmental, health, and safety management program.

Compliance. Management at the WVDP continued to provide strong support for environmental compliance in 2008. Requirements and guidance from applicable state and federal statutes, executive orders, DOE orders, and standards are integrated into the Project's compliance program. In CY 2008:

- No notices of violation or inspection findings from any environmental regulatory agencies were received.

- Inspections by the New York State Department of Environmental Conservation and the local depart- ment of health verified Project compliance with the applicable environmental and health regulations.

- Waste management areas at the site were monitored in compliance with the Resource Conservation and Recovery Act $\S 3008(\mathrm{~h})$ Administrative Order on Consent.

- Project representatives met requirements of the Emergency Planning and Community Right-to-Know Act by collecting information about hazardous materials used at the Project and making this information available to the local community.

- No exceedances to State Pollutant Discharge Elimination System (SPDES) permit limits or to the EPA's National Emission Standards for Hazardous Air Pollutants (NESHAP) dose standard were noted in 2008.

Environmental Monitoring. As part of the EMS, environmental monitoring was continued on and near the site to detect and evaluate changes in the environment resulting from Project (or pre-Project) activities and to assess the effect of any such changes on the environment or human population. Within the environmental monitoring program, airborne and waterborne effluents were sampled and environmental surveillance of the site and nearby areas was conducted.

- Radiological Releases

In 2008, the WVDP maintained six NESHAP permits for release of radiological airborne emissions. The primary controlled air emission point at the WVDP is the MPPB ventilation stack.

Waterborne releases were from two primary sources. In 2008, treated process water was released in seven batches from lagoon 3, totaling approximately 12.7 million gallons (48.1 million liters). The other primary source is from a wellcharacterized seepage on the north plateau of the WVDP that is contaminated with strontium-90 from pre-WVDP operations. Radiological concentrations and flow from north plateau seepage were closely monitored.

\section{- Estimated Dose}

In 2008, the estimated dose to a maximally exposed off-site individual (MEOSI) from airborne 
emissions at the WVDP was 0.0011 millirem (mrem) (0.000011 millisievert [mSv]), about $0.011 \%$ of the 10 -mrem NESHAP standard. Estimated dose from waterborne sources in 2008 was about 0.064 mrem (0.00064 mSv), with 0.019 mrem (0.00019 $\mathrm{mSv}$ ) attributable to liquid effluent releases and 0.044 mrem $(0.00044 \mathrm{mSv})$ attributable to the north plateau drainage.

Total estimated dose to the MEOSI from both airborne and waterborne sources in 2008 was 0.065 mrem $(0.00065 \mathrm{mSv})$, about $0.065 \%$ of the annual 100-mrem DOE standard. In comparison, the average dose to a member of the public from natural background sources is 295 mrem per year.

Estimated dose to the population from both air and water within a 50-mile (80-kilometer) radius of the WVDP from DOE activities in 2008 was 0.28 person-rem (0.0028 person-Sv). This same population would have received approximately 497,000 person-rem from natural background radiation in 2008.

\section{- Dose to Biota}

An evaluation of dose to biota for CY 2008 concluded that populations of aquatic and terrestrial biota (both plants and animals) are not being exposed to doses in excess of the existing DOE dose standard for native aquatic animal organisms (1 $\mathrm{rad} /$ day) nor the recommended thresholds for terrestrial animals (0.1 rad/day) and plants (1 rad/ day).

\section{- Nonradiological Releases}

Nonradiological releases from Project wastewater and storm water monitoring points were measured under the site's SPDES permit. In 2008, no exceedances of any permit limits occurred. However, during the month of January 2009, the daily maximum permit limit of $0.30 \mathrm{mg} / \mathrm{L}$ for total iron for the sum of outfalls was exceeded. Site personnel are currently working with NYSDEC on a permit renewal that will include updated iron discharge monitoring and compliance limits.

North Plateau Characterization. Additional subsurface soil and groundwater samples were collected in the summer and fall of 2008 to enhance the characterization of chemical and radiological constituents in soil and water within the contaminated groundwater plume beneath and downgradient of the MPPB.
The Nuclear Regulatory Commission-Licensed Disposal Area (NDA). Work was completed to stabilize the inactive landfill to prevent infiltration from surface water and groundwater. A trench was excavated along two sides of the NDA and backfilled with a soil and clay mixture to form an impermeable subsurface barrier to infiltration. The entire landfill was then resurfaced and covered with an impermeable geomembrane.

Quality Assurance. In 2008, implementation of a quality assurance program for activities supporting the environmental monitoring and groundwater monitoring programs continued at the WVDP. As part of this ongoing effort, on-site and subcontract laboratories that analyze WVDP environmental samples participated in independent radiological and nonradiological constituent performance evaluation studies. In these studies, test environmental samples with concentrations known by the testing agency, but unknown by the laboratory, were analyzed. Of 290 performance evaluation analyses conducted by or for the WVDP, $97.9 \%$ fell within acceptance limits.

Several inspections, audits, and assessments of components of the environmental monitoring program were conducted in 2008. Although actions were recommended to improve the program, nothing was found that would compromise the data quality in this report or the environmental monitoring program in general.

\section{Conclusion}

In addition to demonstrating compliance with environmental regulations and directives, evaluation of data collected in 2008 continued to indicate that WVDP activities pose no threat to public health or safety, or to the environment. 
This page intentionally left blank 


\section{Site Location}

The West Valley Demonstration Project (WVDP or Project) is located in western New York State, about 30 miles (50 kilometers [km]) south of Buffalo, New York (Fig. INT-1). The WVDP facilities occupy a security-fenced area of about 167 acres (68 hectares [ha]) within the 3,338-acre (1,351 ha) Western New York Nuclear Service Center (WNYNSC) located primarily in the town of Ashford in northern Cattaraugus County. The security-fenced area is specifically referred to as the Project premises.

\section{General Environmental Setting}

Climate. Although extremes of $98.6^{\circ} \mathrm{F}\left(37^{\circ} \mathrm{C}\right)$ and $-43.6^{\circ} \mathrm{F}\left(-42^{\circ} \mathrm{C}\right)$ have been recorded in western New York, the climate is moderate, with an average annual temperature $(1971-2000)$ of $48^{\circ} \mathrm{F}\left(8.9^{\circ} \mathrm{C}\right)$. Precipitation is markedly influenced by Lake Erie to the west and, to a lesser extent, by Lake Ontario to the north. Regional winds are generally from the west and south at about 9 miles per hour (4 meters/second).

Ecology. The WNYNSC lies within the northern deciduous forest biome, and the diversity of its vegetation is typical of the region. Equally divided between forest and open land, the site provides a habitat especially attractive to white-tailed deer and various indigenous migratory birds, reptiles, and small mammals. No species on the federal endangered species list are known to reside on the WNYNSC.

Geology and Hydrology. The Project lies on New York State's Allegheny Plateau at an average elevation of about 1,300 feet ( 400 meters). The underlying geology includes a sequence of glacial sediments above shale bedrock. The Project is drained by three small streams (Franks Creek, Quarry Creek, and Erdman Brook) and is divided by a stream valley (Erdman Brook) into two general areas: the north plateau and the south plateau.

Franks Creek, which receives drainage from Erdman Brook and Quarry Creek, flows into Buttermilk Creek, which enters Cattaraugus Creek and leaves the WNYNSC. (See Figs. A-1 and A-5.) Cattaraugus Creek ultimately drains into Lake Erie, to the northwest.

\section{Relevant Demographics}

Although several roads and a railway approach or pass through the WNYNSC, the public is prohibited from accessing the WNYNSC. A limited public deer hunting program managed by the New York State Energy Research and Development Authority is conducted on a year-to-year basis in designated areas on the WNYNSC. No public access is allowed on the WVDP Project premises.

Land near the WNYNSC is used primarily for agriculture and arboriculture. Downstream of the WNYNSC, Cattaraugus Creek is used locally for swimming, canoeing, and fishing. Although some water is taken from the creek to irrigate nearby golf course greens and tree farms, no public drinking water is drawn from the creek before it flows into Lake Erie. Water from Lake Erie is used as a public drinking water supply.

The communities of West Valley, Riceville, Ashford Hollow, and the village of Springville are located within approximately 5 miles $(8 \mathrm{~km})$ of the Project. The nearby population, approximately 9,200 residents within 6.2 miles $(10 \mathrm{~km})$ of the Project, relies largely on an agricultural economy. No major industries are located within this area. The WVDP is one of the largest employers in Cattaraugus County.

\section{Historic Timeline of the WNYNSC and the WVDP}

The following summary, presented in Table INT-1, depicts a historic timeline for the WNYNSC and the WVDP beginning with the establishment of the WNYNSC as a commercial nuclear fuel reprocessing facility, to the creation of the WVDP, to the current Project mission. The summary includes significant legal directives, major activities and accomplishments.

A reader opinion survey has been inserted in this report. If it is missing, please contact the WVDP Communications Department at (716) 942-2152. Additional Project information is available on the internet at http://www.wv.doe.gov. 
FIGURE INT-1

Location of the Western New York Nuclear Service Center

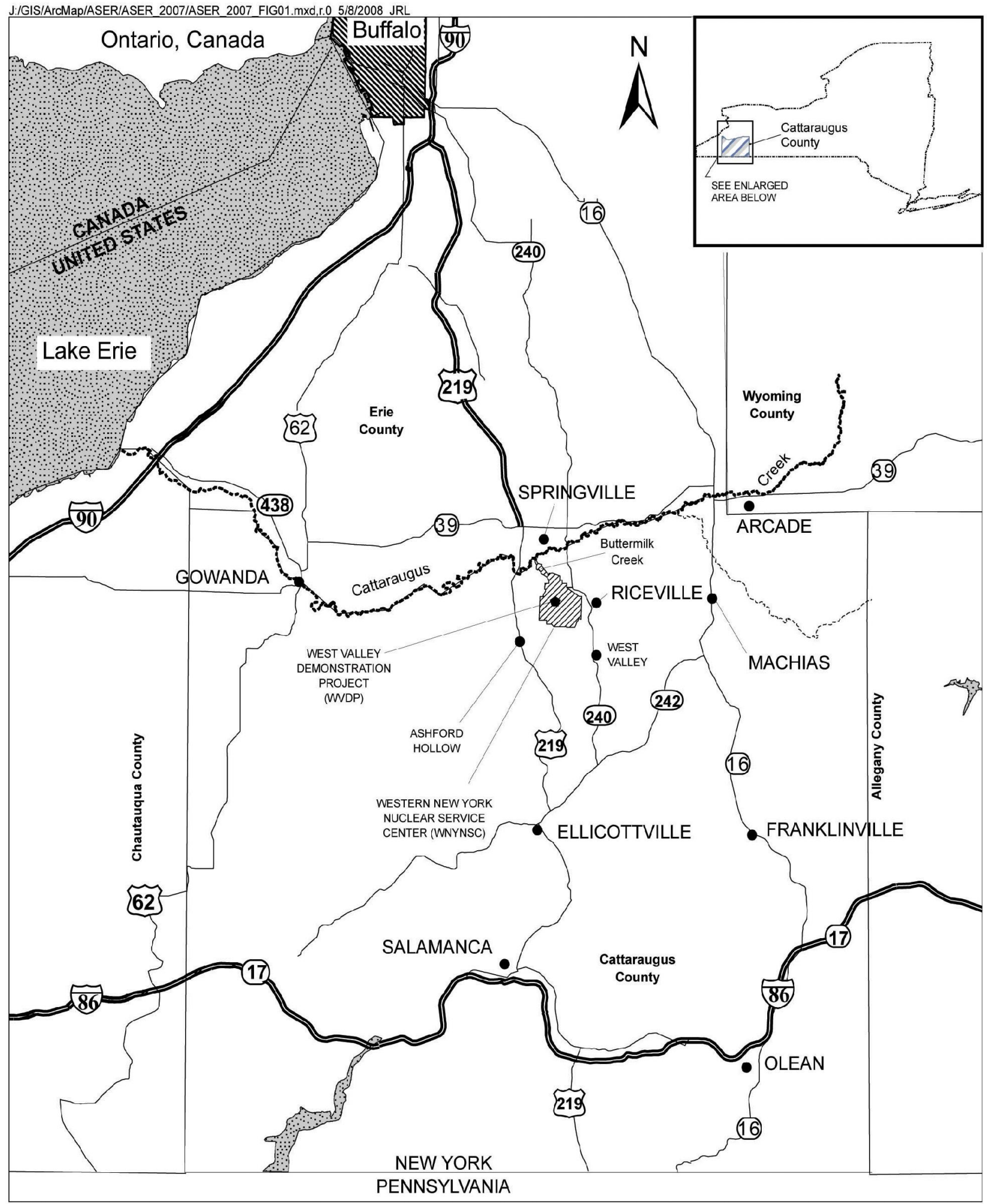


TABLE INT-1

Historic Timeline of the WNYNSC and the WVDP

\begin{tabular}{|c|c|}
\hline Year & \\
\hline 1954 & e Federal Atomic Energy Act promoted commercialization of reprocessing spent nu \\
\hline 1959 & ew York State (NYS) established the Office of Atomic Development (OAD) to coordinate the atomic industry. \\
\hline 1961 & $\begin{array}{l}\text { The NYS OAD acquired 3,345 acres (1,354 hectares) of land in Cattaraugus County, Town of Ashford (near West Valley), } \\
\text { in western New York and established the Western New York Nuclear Service Center (WNYNSC). }\end{array}$ \\
\hline 1962 & $\begin{array}{l}\text { Davison Chemical Company established Nuclear Fuels Services, Inc. (NFS) as a nuclear fuel reprocessing company, and } \\
\text { reached an agreement with NYS to lease the WNYNSC (also referred to as "the Center"). }\end{array}$ \\
\hline 1966 & $\begin{array}{l}\text { NFS constructed and operated the commercial nuclear fuel reprocessing facility at the WNYNSC from } 1966 \text { to } 1972 . \\
\text { NFS processed } 640 \text { metric tons of spent reactor fuel at the facility, generating 660,000 gallons ( } 2.5 \text { million liters) of } \\
\text { highly radioactive liquid waste. NFS operated a 5-acre landfill, the "U.S. Nuclear Regulatory Commission (NRC)-licensed } \\
\text { disposal area (NDA)" for disposal of waste generated from the reprocessing operations. In addition, a 15-acre } \\
\text { commercial disposal area, the "state-licensed disposal area (SDA)" regulated by NYS agencies, under delegation of } \\
\text { authority from the NRC, accepted low-level radioactive waste (LLW) from operations at the Center and from off-site } \\
\text { facilities from } 1963 \text { until } 1975 .\end{array}$ \\
\hline 1972 & $\begin{array}{l}\text { In 1972, while the plant was closed for modifications, more rigorous regulatory requirements were imposed upon fuel } \\
\text { reprocessing facilities. NFS determined the costs to meet regulatory requirements of spent nuclear fuel reprocessing } \\
\text { were not economically feasible. NFS notified the New York State Energy Research and Development Authority } \\
\text { (NYSERDA) in } 1976 \text { that they would discontinue reprocessing and would not renew the lease that would expire at the } \\
\text { end of 1980. }\end{array}$ \\
\hline 1975 & $\begin{array}{l}\text { Water infiltrated into the SDA trenches and waste burial operations ceased. Between } 1975 \text { and 1981, NFS pumped, } \\
\text { treated, and released liquids to the adjacent stream. Redesigning the covers reduced, but did not eliminate, water } \\
\text { accumulation in the trenches. }\end{array}$ \\
\hline 1980 & $\begin{array}{l}\text { Before discontinuing fuel reprocessing operations in 1975, NFS had accepted } 750 \text { spent fuel assemblies which } \\
\text { remained in storage in the on-site fuel receiving and storage (FRS) area. In 1980, } 625 \text { of those assemblies were } \\
\text { returned to the utilities that owned them. }\end{array}$ \\
\hline 1980 & $\begin{array}{l}\text { The United States (U.S.) Congress passed Public Law 96-368, the West Valley Demonstration Project Act (WVDP Act), } \\
\text { requiring the U.S. Department of Energy (DOE) to be responsible for solidifying the liquid high-level waste (HLW) stored } \\
\text { in underground tanks, disposing of the waste created by solidification, and decontaminating and decommissioning the } \\
\text { facilities used during the process. }\end{array}$ \\
\hline 1980 & $\begin{array}{l}\text { Per the WVDP Act, the DOE entered into a Cooperative Agreement with NYSERDA that established the framework for } \\
\text { cooperative implementation of the WVDP Act. Under the agreement, the DOE has exclusive use and possession of a } \\
\text { portion of the Center known as the Project Premises (approximately } 167 \text { acres). A supplement to the Cooperative } \\
\text { Agreement (1981 amendment) between the two agencies set forth special provisions for the preparation of a joint } \\
\text { Environmental Impact Statement (EIS). }\end{array}$ \\
\hline 1981 & $\begin{array}{l}\text { The DOE and the NRC entered into a Memorandum of Understanding that established specific agency responsibilities } \\
\text { and arrangements for informal review and consultation by the NRC. Because NYSERDA holds the license and title to the } \\
\text { West Valley site, the NRC put the technical specifications of the license (CSF-1) in abeyance to allow the DOE to carry } \\
\text { out the responsibilities of the WVDP Act. }\end{array}$ \\
\hline 1982 & $\begin{array}{l}\text { West Valley Nuclear Services (WVNS), a Westinghouse subsidiary, was chosen by the DOE to be the management and } \\
\text { operating contractor. WVNS commenced operations at the WVDP on February } 28,1982 .\end{array}$ \\
\hline 1983 & $\begin{array}{l}\text { In 1983, NYSERDA assumed management responsibility for the SDA and focused efforts to minimize infiltration of } \\
\text { water into the trenches. In the 1990s, installation of a geomembrane cover over the entire SDA and an underground } \\
\text { barrier wall were successful in eliminating increases in trench water levels. }\end{array}$ \\
\hline 1983 & The DOE selected the vitrification (VIT) process as the preferred method for solidifying the HLW into glass. \\
\hline 1984 & Nonradioactive testing of a full-scale VIT system was conducted from 1984-1989. \\
\hline 1984 & $\begin{array}{l}\text { NFS entered into an agreement with the DOE in which the DOE assumed ownership of the remaining } 125 \text { fuel } \\
\text { assemblies in the FRS pool and the responsibility for their removal. }\end{array}$ \\
\hline
\end{tabular}




\section{TABLE INT-1 (continued) Historic Timeline of the WNYNSC and the WVDP}

\begin{tabular}{|c|c|}
\hline Year & Activity \\
\hline 1986 & $\begin{array}{l}\text { A large volume of radioactive, non-high-level waste would result from WVDP activities. Disposal of most of this waste } \\
\text { was evaluated in an Environmental Assessment (DOE/EA-0295, April 1986), and a finding of no significant impact was } \\
\text { issued. Consistent with a settlement agreement, the DOE temporarily stored the waste on site until disposal } \\
\text { alternatives are determined under subsequent EISs. }\end{array}$ \\
\hline 1987 & $\begin{array}{l}\text { A decision to potentially dispose of LLW at the Project led to a legal disagreement between the DOE and the Coalition } \\
\text { on West Valley Nuclear Wastes and the Radioactive Waste Campaign. It was resolved by a Stipulation of Compromise } \\
\text { which states that LLW disposal at the site and the potential effects of erosion at the site must be included in a } \\
\text { comprehensive EIS. }\end{array}$ \\
\hline 1988 & $\begin{array}{l}\text { In December 1988, the DOE and NYSERDA issued a Notice of Intent in the Federal Register to prepare an EIS in } \\
\text { accordance with Section 102(2)(C) of the National Environmental Policy Act and Section 8-0109 of the New York State } \\
\text { Environmental Quality Review Act. }\end{array}$ \\
\hline 1988 & $\begin{array}{l}\text { To prepare for VIT, the integrated radwaste treatment system was constructed to process the liquid supernatant from } \\
\text { the underground HLW tanks by removing most of the radioactivity in the supernatant, concentrating the liquid, and } \\
\text { blending it with cement. The HLW sludge layer was then washed to remove soluble salts. The water containing the salts } \\
\text { was also stabilized into cement. About } 20,000 \text { drums of cement-stabilized LLW were stored in the aboveground drum } \\
\text { cell. The process was completed in } 1995 \text {. }\end{array}$ \\
\hline 1990 & $\begin{array}{l}\text { Organic solvent waste was observed in a groundwater monitoring well immediately downgradient of the NDA in } 1983 . \\
\text { Following characterization of the area, an interceptor trench bordering the northeast and northwest boundaries of the } \\
\text { NDA and a liquid pretreatment system (LPS) were built in 1990-1991. The trench was designed to collect liquid that } \\
\text { might migrate from the NDA and the LPS was designed to recover free organic product (if any) from the recovered } \\
\text { liquid. To date, no organic product has been detected in the interceptor trench water; therefore, the water has been } \\
\text { pumped and treated through the LLW treatment system. }\end{array}$ \\
\hline 1991 & $\begin{array}{l}\text { The NYS Department of Environmental Conservation (NYSDEC) was authorized by the U.S. Environmental Protection } \\
\text { Agency (EPA) to administer the Resource Conservation and Recovery Act (RCRA) hazardous waste program. In 1991, a } \\
\text { RCRA Part A Permit Application for the WVDP was filed with NYSDEC for storage and treatment of hazardous wastes. }\end{array}$ \\
\hline 1992 & $\begin{array}{l}\text { In 1992, the DOE and NYSERDA entered into a RCRA } \S 3008(\mathrm{~h}) \text { Administrative Order on Consent (Consent Order) with } \\
\text { NYSDEC and the EPA. The Consent Order pertained to management of hazardous waste and/or hazardous constituents } \\
\text { from solid waste management units at the WVDP. It also required the DOE and NYSERDA to perform a RCRA Facility } \\
\text { Investigation at the WNYNSC to determine if there had been a release or if there was a potential for a release of RCRA } \\
\text { hazardous constituents. }\end{array}$ \\
\hline 1993 & $\begin{array}{l}\text { In 1993, gross beta activity in excess of } 1.0 \mathrm{E}-06 \mu \mathrm{Ci} / \mathrm{mL} \text { (the applicable DOE Derived Concentration Guide for strontium- } \\
90 \text { ) was detected in surface water on the north plateau, in the vicinity of sampling location WNSWAMP. The gross beta } \\
\text { radioactivity was determined to be strontium-90. }\end{array}$ \\
\hline 1994 & $\begin{array}{l}\text { Extensive subsurface investigations delineated the extent of the strontium-90 plume and determined that the plume } \\
\text { originated beneath the southwest corner of the main plant process building (MPPB) during NFS operations and } \\
\text { migrated toward the northeast quadrant of the north plateau. A second lobe of contamination was attributed to the } \\
\text { area of former lagoon 1, which was backfilled in } 1984 \text {. }\end{array}$ \\
\hline 1995 & $\begin{array}{l}\text { In 1995, a groundwater recovery system consisting of three wells was installed on the north plateau to extract and } \\
\text { treat the strontium-90-contaminated groundwater to minimize plume advancement. In 1999, a pilot-scale permeable } \\
\text { treatment wall was constructed to test this passive in-situ remediation technology. }\end{array}$ \\
\hline 1995 & $\begin{array}{l}\text { The vitrification building shielding was installed in 1991, the slurry-fed ceramic melter was assembled in 1993, and the } \\
\text { remaining major components were installed and tested by the end of 1994. In 1995, the vitrification facility was } \\
\text { completed, fully tested, and "cold operations" began. }\end{array}$ \\
\hline 1996 & $\begin{array}{l}\text { The DOE and NYSERDA issued a Draft Environmental Impact Statement (DEIS) for Completion of the WVDP and Closure } \\
\text { or Long-Term Management of the WNYNSC. After issuance of the DEIS, the Citizen Task Force was convened to provide } \\
\text { additional stakeholder input regarding the WVDP/WNYNSC closure process. }\end{array}$ \\
\hline
\end{tabular}




\section{TABLE INT-1 (continued) Historic Timeline of the WNYNSC and the WVDP}

\begin{tabular}{|c|c|}
\hline Year & Activity \\
\hline 1996 & $\begin{array}{l}\text { Vitrification operations began in } 1996 \text { and continued into 2002, producing a total of } 275 \text { 10-foot-tall stainless-steel } \\
\text { canisters of hardened radioactive glass containing more than } 12.2 \text { million cesium/strontium curies. The glass melter } \\
\text { was shut down in September } 2002 \text {. }\end{array}$ \\
\hline 1996 & $\begin{array}{l}\text { NYSDEC and the DOE entered into an Order on Consent negotiated under the Federal Facilities Compliance Act for } \\
\text { handling, storage, and treatment of mixed wastes at the WVDP. }\end{array}$ \\
\hline 1996 & $\begin{array}{l}\text { The Seneca Nation of Indians Cooperative Agreement was signed in } 1996 \text { to foster government-to-government } \\
\text { relationships between the Seneca Nation and the U.S. government, as represented by the DOE. }\end{array}$ \\
\hline 1999 & $\begin{array}{l}\text { Vitrification expended materials processing was initiated to begin processing unserviceable equipment from the VIT } \\
\text { facility. This success helped in developing a remote-handled waste facility (RHWF) to process large-scale, highly } \\
\text { contaminated equipment excessed during decontamination and decommissioning activities. }\end{array}$ \\
\hline 2000 & Restructuring of the work force began. Construction of the RHWF began. \\
\hline 2001 & $\begin{array}{l}\text { The } 125 \text { spent fuel assemblies that remained in storage at the WVDP since } 1975 \text { were prepared for transport to the } \\
\text { Idaho National Engineering and Environmental Laboratory (INEEL). Two significantly contaminated areas in the MPPB, } \\
\text { the process mechanical cell and the general purpose cell, were decontaminated. }\end{array}$ \\
\hline 2001 & $\begin{array}{l}\text { The DOE published formal notice in the Federal Register (66 FR 16447) to split the EIS process into (1) the WVDP Waste } \\
\text { Management EIS, and (2) the Decommissioning and/or Long-Term Stewardship EIS at the WVDP and the WNYNSC. }\end{array}$ \\
\hline 2002 & $\begin{array}{l}\text { The NRC issued "Decommissioning Criteria for the West Valley Demonstration Project (M-32) at the West Valley Site; } \\
\text { Final Policy Statement" (67 FR 5003). }\end{array}$ \\
\hline 2003 & The remaining 125 spent fuel assemblies were shipped to INEEL, allowing for decontamination of the FRS to begin. \\
\hline 2004 & $\begin{array}{l}\text { The RHWF became operational. Major decontamination efforts continued and more than 104,000 cubic feet of LLW } \\
\text { were safely shipped for off-site disposal. Footprint reduction began as } 20 \text { office trailers were removed. The Title 6, New } \\
\text { York State Official Compilation of Codes, Rules, and Regulations (6 NYCRR) RCRA Part 373-2 Permit Application was } \\
\text { submitted to NYSDEC. }\end{array}$ \\
\hline 2005 & $\begin{array}{l}\text { In June 2005, the DOE published its final decision on the "WVDP Waste Management Environmental Impact Statement } \\
\text { ( } 68 \text { FR 26587)." The DOE implemented the preferred alternative for the management of WVDP LLW and mixed LLW. } \\
\text { The decision on transuranic waste was deferred, and the HLW canisters will remain in on-site storage until they can be } \\
\text { shipped to a repository. }\end{array}$ \\
\hline 2005 & $\begin{array}{l}\text { In November 2005, the WVDP was downgraded to a Category } 3 \text { nuclear facility, marking the first time in the site's } \\
\text { history that it has been designated the least of the three DOE nuclear facility designations. The categorization is based } \\
\text { on amounts, types, and configuration of the nuclear materials stored and their potential risks. Site footprint reduction } \\
\text { activities escalated and more than } 300,000 \text { cubic feet of LLW were shipped off site for disposal. }\end{array}$ \\
\hline 2006 & $\begin{array}{l}\text { An Environmental Assessment (DOE/EA-1552) evaluating the proposed decontamination, demolition, and removal of } \\
36 \text { facilities was issued. Eleven of the } 36 \text { structures were removed by the end of } 2006 \text {, and about } 400,000 \text { cubic feet of } \\
\text { various waste types were shipped off site for disposal. }\end{array}$ \\
\hline 2006 & $\begin{array}{l}\text { The DOE-WVDP office initiated a collaborative, consensus-based team process, referred to as the "Core Team," that } \\
\text { involves NYSERDA, the EPA, the New York State Department of Health, the NRC, and NYSDEC. This team brings } \\
\text { individuals with decision-making authority together to resolve challenging issues surrounding the WVDP EIS process } \\
\text { and to make recommendations to move the Project toward an "Interim End-State" prior to issuance of the "Final EIS } \\
\text { for the Decommissioning and/or Long-Term Stewardship at the WVDP and the WNYNSC." }\end{array}$ \\
\hline 2007 & $\begin{array}{l}\text { Demolition and removal of four more structures identified under the DOE/EA-1552 was completed. On June 29, 2007, } \\
\text { the DOE awarded West Valley Environmental Services LLC a four-year contract (Contract DE-AC30-07CC30000) to } \\
\text { conduct the next phase of cleanup operations at the WVDP. The remaining drums of cemented LLW in the Drum Cell } \\
\text { were packaged and shipped to the Nevada Test Site for disposal. }\end{array}$ \\
\hline
\end{tabular}


TABLE INT-1 (concluded)

Historic Timeline of the WNYNSC and the WVDP

\begin{tabular}{|c|l|}
\hline Year & \multicolumn{1}{c|}{ Activity } \\
\hline $2007-$ & $\begin{array}{l}\text { An interim measure (IM) to minimize water infiltration into the NDA was initiated in 2007 with site surveys and } \\
\text { core borings. In 2008, a trench was excavated along two sides of the NDA. The trench was backfilled with soil and } \\
\text { clay to form the slurry wall - an impermeable subsurface barrier to infiltration. The entire landfill was covered } \\
\text { with an impermeable geomembrane cover. }\end{array}$ \\
\hline 2008 & $\begin{array}{l}\text { Additional subsurface soil and groundwater samples were collected in the summer and fall of } 2008 \text { to enhance } \\
\text { the characterization of chemical and radiological constituents in soil and water within the contaminated } \\
\text { groundwater plume beneath and downgradient of the MPPB. }\end{array}$ \\
\hline 2008 & $\begin{array}{l}\text { The revised DEIS for Decommissioning and/or Long-Term Stewardship at the WVDP and WNYNSC was issued in } \\
\text { December 2008 for a six-month public review period through June 8, 2009, which was later extended through } \\
\text { September 8, 2009. At the same time, the Proposed Phase 1 Decommissioning Plan for the WVDP was made } \\
\text { available to the public. }\end{array}$ \\
\hline
\end{tabular}




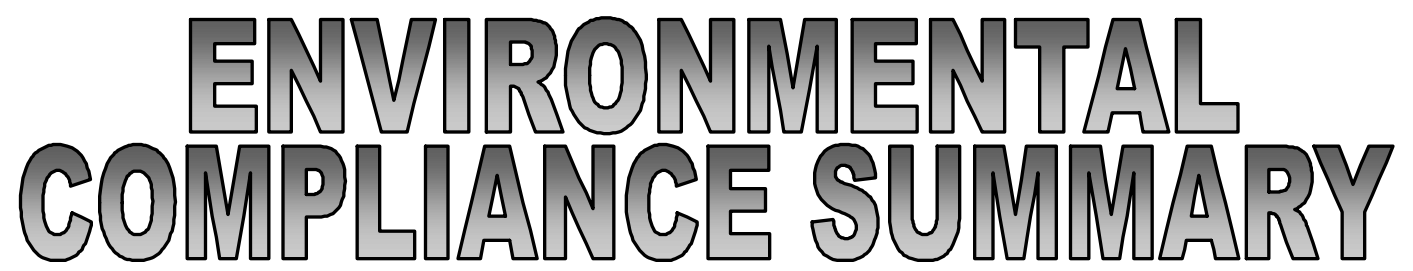

\section{Compliance Program}

The United States (U.S.) Department of Energy (DOE) is currently focusing on several goals at the West Valley Demonstration Project (WVDP or Project) to support completion of the requirements identified in the WVDP Act (Public Law 96-368).

Activities at the WVDP are regulated by various federal and state public, worker, and environmental protection laws. These laws are administered primarily by the U.S. Environmental Protection Agency (EPA), the U.S. Fish and Wildlife Service, the U.S. Army Corps of Engineers, the New York State Department of Environmental Conservation (NYSDEC), and the New York State Department of Health (NYSDOH) through programs and regulatory requirements for permitting, reporting, inspecting, self-monitoring, and auditing.

The EPA, NYSDEC, and DOE have established standards for effluents that are intended to protect human health, safety, and the environment. The DOE applies to the EPA for permits to release limited amounts of radiological constituents to the air and applies to NYSDEC for permits to release limited amounts of nonradiological constituents to the air and water, in concentrations determined to be safe for humans and the environment. In general, the permits describe release points, specify management and reporting requirements, list discharge limits on those pollutants likely to be present, and define the sampling and analysis regimen. Releases of radiological constituents in water are subject to the requirements in DOE Orders 450.1A (Environmental Protection Program) and 5400.5 (Radiation Protection of the Public and the Environment). A summary of permits is found in Table ECS-3. (See the compliance tables at the end of this chapter.) No releases above allowable permit or regulatory limits occurred in 2008.

\section{Compliance Status}

Table ECS-1 describes the WVDP's compliance status with applicable environmental statutes, DOE directives, executive orders, and state laws and regulations applicable to the Project activities.

\section{Compliance Status Summary for the WVDP in CY 2008}

\begin{tabular}{|l|l|l|}
\hline \multicolumn{1}{|c|}{ Citation } & \multicolumn{1}{c|}{\begin{tabular}{c}
\multicolumn{1}{c|}{ Environmental Statute, } \\
DOE Directive, Executive Order, Agreement
\end{tabular}} & \multicolumn{1}{c|}{\begin{tabular}{c}
\multicolumn{1}{c|}{ SVDP Compliance } \\
Status
\end{tabular}} \\
\hline $\begin{array}{l}\text { 42 United States } \\
\text { Code (USC) §2011 } \\
\text { et seq. }\end{array}$ & $\begin{array}{l}\text { The Atomic Energy Act (AEA) of 1954 was enacted to } \\
\text { assure the proper management of source, special } \\
\text { nuclear, and by-product materials. The AEA and the } \\
\text { statutes that amended it delegate the control of } \\
\text { nuclear energy primarily to the Department of Energy } \\
\text { (DOE), the Nuclear Regulatory Commission (NRC), and } \\
\text { the Environmental Protection Agency (EPA). }\end{array}$ & $\begin{array}{l}\text { See discussions of the West Valley Demonstration } \\
\text { Project (WVDP) Act and of DOE Orders 435.1, } \\
\text { 450.1A, and 5400.5. }\end{array}$ \\
\hline $\begin{array}{l}\text { Public Law } \\
\text { 96-368 }\end{array}$ & $\begin{array}{l}\text { The WVDP ACT of 1980 authorized the DOE to carry } \\
\text { out a high-level liquid nuclear waste demonstration } \\
\text { project at the Western New York Nuclear Service } \\
\text { Center (WNYNSC [the Center]) in West Valley, New } \\
\text { York. }\end{array}$ & $\begin{array}{l}\text { The DOE is focusing on goals that will lead to } \\
\text { completion of responsibilities listed in the WVDP Act. }\end{array}$ \\
\hline
\end{tabular}


TABLE ECS-1 (continued)

Compliance Status Summary for the WVDP in CY 2008

\begin{tabular}{|c|c|c|}
\hline Citation & $\begin{array}{c}\text { Environmental Statute, } \\
\text { DOE Directive, Executive Order, Agreement }\end{array}$ & $\begin{array}{l}\text { WVDP Compliance } \\
\text { Status }\end{array}$ \\
\hline \begin{tabular}{|l|} 
Cooperative \\
Agreement \\
between the DOE \\
and the New York \\
State Energy \\
Research and \\
Development \\
Authority \\
(NYSERDA) \\
\end{tabular} & $\begin{array}{l}\text { The Cooperative Agreement Between the DOE and } \\
\text { NYSERDA on the WNYNSC established a cooperative } \\
\text { framework for implementation of the Project, } \\
\text { effective October 1980, as amended in September } \\
1981 .\end{array}$ & $\begin{array}{l}\text { The agreement arranged lease of the Project } \\
\text { premises to the DOE in order to carry out } \\
\text { responsibilities under the WVDP Act. The } \\
\text { supplemental agreement defined special provisions } \\
\text { for the preparation of a joint Environmental Impact } \\
\text { Statement (EIS). }\end{array}$ \\
\hline $\begin{array}{l}\text { WVDP } \\
\text { Memorandum of } \\
\text { Understanding } \\
\text { (MOU) between } \\
\text { the DOE and the } \\
\text { NRC }\end{array}$ & $\begin{array}{l}\text { The } 1981 \mathrm{MOU} \text {, mandated by the WVDP Act, } \\
\text { established procedures for review and consultation by } \\
\text { the NRC with respect to activities conducted at the } \\
\text { WNYNSC by the DOE under the WVDP Act. The } \\
\text { agreement encompassed development, design, } \\
\text { construction, operation, and decontamination and } \\
\text { decommissioning activities associated with the Project } \\
\text { as described in the WVDP Act. Under the WVDP Act, } \\
\text { and to satisfy committments made to the NRC, the } \\
\text { DOE was required to prepare a decommissioning plan } \\
\text { for the Project and submit it to the NRC for review. }\end{array}$ & $\begin{array}{l}\text { The NRC was authorized through the WVDP Act to } \\
\text { prescribe decommissioning criteria for the WVDP. In } \\
\text { 2002, the NRC issued "Decommissioning Criteria for } \\
\text { the WVDP (M-32) at the West Valley Site; Final Policy } \\
\text { Statement" (67 Federal Register [FR] 5003). NRC } \\
\text { representatives visited the WVDP in January, August, } \\
\text { and December } 2008 \text { to ensure that activities were } \\
\text { performed in accordance with requirements of } \\
\text { established programs. The "Phase } 1 \\
\text { Decommissioning Plan for the West Valley } \\
\text { Demonstration Project" was prepared by the DOE } \\
\text { persuant to its statutory obligations for } \\
\text { decontamination and decommissioning of the WVDP } \\
\text { under the WVDP Act. This plan was submitted to the } \\
\text { NRC in December } 2008 \text { and an update submitted in } \\
\text { March } 2009 .\end{array}$ \\
\hline DOE C & $\begin{array}{l}\text { DOE Order 231.1A, Environment, Safety, and Health } \\
\text { Reporting, was issued to ensure timely collection, } \\
\text { reporting, analysis, and dissemination of information } \\
\text { on environment, safety, and health issues as required } \\
\text { by law or regulations or as needed to ensure that the } \\
\text { DOE and National Nuclear Security Administration are } \\
\text { kept fully updated about events that could adversely } \\
\text { affect the health and safety of the public or the } \\
\text { workers, the environment, the intended purpose of } \\
\text { DOE facilities, or the DOE's credibility. }\end{array}$ & $\begin{array}{l}\text { This WVDP Annual Site Environmental Report (ASER) } \\
\text { is prepared and submitted annually to DOE } \\
\text { Headquarters, regulatory agencies, and interested } \\
\text { stakeholders in compliance with DOE Order 231.1A. }\end{array}$ \\
\hline DOE & $\begin{array}{l}\text { DOE Order 5400.5, Radiation Protection of the Public } \\
\text { and the Environment, established standards for DOE } \\
\text { operations and DOE contractors to ensure that (1) } \\
\text { operations are conducted to limit radiation exposure } \\
\text { to members of the public pursuant to limits } \\
\text { established in the Order, (2) potential exposures to } \\
\text { members of the public are as low as reasonably } \\
\text { achievable, (3) routine and nonroutine releases are } \\
\text { monitored and dose to the public is addressed, and (4) } \\
\text { the environment is protected from radioactive } \\
\text { contamination to the extent practicable. }\end{array}$ & $\begin{array}{l}\text { This ASER summarizes radiological estimates of dose } \\
\text { to the public and the environment, and compares } \\
\text { these values with release and dose standards } \\
\text { established by this Order. In } 2008 \text {, estimated doses } \\
\text { from airborne and waterborne releases to the } \\
\text { maximally exposed off-site individual (MEOSI) were } \\
0.065 \% \text { of the } 100 \text {-millirem (mrem) standard, and } \\
\text { about } 0.022 \% \text { of natural background radiation. Refer } \\
\text { to Chapter } 3 \text {, "Dose Assessment," for further } \\
\text { discussion. }\end{array}$ \\
\hline
\end{tabular}


TABLE ECS-1 (continued) Compliance Status Summary for the WVDP in CY 2008

\begin{tabular}{|c|c|c|}
\hline Citation & $\begin{array}{c}\text { Environmental Statute, } \\
\text { DOE Directive, Executive Order, Agreement }\end{array}$ & $\begin{array}{l}\text { WVDP Compliance } \\
\text { Status }\end{array}$ \\
\hline DOE Order 435.1 & $\begin{array}{l}\text { DOE Order 435.1, Radioactive Waste Management, } \\
\text { was issued in } 1999 \text { to ensure that all DOE radioactive } \\
\text { waste is managed in a manner that protects the } \\
\text { public, the environment and workers, and complies } \\
\text { with applicable state, federal and local laws and } \\
\text { regulations. Under the Order, sites that manage } \\
\text { radioactive waste are required to develop, document, } \\
\text { implement, and maintain a site-wide radioactive } \\
\text { waste management program which includes actions to } \\
\text { minimize radioactive waste generation. }\end{array}$ & $\begin{array}{l}\text { The WVDP maintains program documentation } \\
\text { separately for each waste type. Management of high- } \\
\text { level waste was conducted in accordance with the } \\
\text { "WVDP Waste Acceptance Manual;" Transuranic } \\
\text { (TRU) waste was managed in accordance with the } \\
\text { "TRU Waste Management Program Plan;" low-level } \\
\text { waste (LLW) was managed as summarized in the } \\
\text { "LLW Management Program Plan;" and the } \\
\text { radioactive component of mixed LLW was managed } \\
\text { as summarized in the "Site Treatment Plan (STP) } \\
\text { Fiscal Year } 2008 \text { Update." }\end{array}$ \\
\hline DOE Order $450.1 \mathrm{~A}$ & $\begin{array}{l}\text { DOE Order 450.1A, Environmental Protection } \\
\text { Program, June 4, } 2008 \text { replaced DOE Order 450.1. The } \\
\text { Order required implementing an environmental } \\
\text { management system (EMS) to conduct work at DOE } \\
\text { sites to protect air, water, land, and other natural and } \\
\text { cultural resources impacted by DOE operations. The } \\
\text { DOE is required to conduct environmental effluent } \\
\text { and surveillance monitoring to support the WVDP's } \\
\text { integrated safety management system (ISMS), to } \\
\text { ensure early identification of, and appropriate } \\
\text { response to, potential adverse environmental impacts } \\
\text { associated with operations. Sites must have a formal } \\
\text { third party audit of the EMS, identified findings must } \\
\text { be tracked to completion, and a "Declaration of Full } \\
\text { Implementation" must be submitted to DOE- } \\
\text { Headquarters every three years. }\end{array}$ & $\begin{array}{l}\text { Since 1999, an EMS has been implemented via } \\
\text { policies and procedures that provide an integrated } \\
\text { site safety management program to accomplish work } \\
\text { through proactive management, environmental } \\
\text { stewardship, and integrating appropriate } \\
\text { technologies across all Project functions. The EMS is } \\
\text { an important part of the ISMS at the WVDP. West } \\
\text { Valley Environmental Services (WVES) conducted an } \\
\text { annual ISMS/EMS effectiveness review (self- } \\
\text { assessment) during August } 12 \text { through August 22, } \\
\text { 2008. A formal third party audit of the EMS was } \\
\text { conducted on May } 18-20,2009 \text { by a qualified party } \\
\text { outside the control of the WVES EMS. On June 11, } \\
2009, \text { consistent with the requirements of DOE } \\
\text { Order } 450.1 \text {, WVES submitted to the DOE a } \\
\text { declaration that the WVES EMS at the WVDP is fully } \\
\text { implemented. Refer to Chapter } 1 \text {, "Environmental } \\
\text { Management System," for further discussion. }\end{array}$ \\
\hline $\begin{array}{l}\text { Title } 10 \text { Code of } \\
\text { Federal } \\
\text { Regulations (10 } \\
\text { CFR) Part 830, } \\
\text { Subpart A } \\
\end{array}$ & $\begin{array}{l}10 \text { CFR Part } 830 \text {, Nuclear Safety Management, } \\
\text { Subpart A, Quality Assurance Requirements provides } \\
\text { the quality assurance (QA) program policies and } \\
\text { requirements applicable to activities at the WVDP. }\end{array}$ & $\begin{array}{l}\text { A QA program that provides a consistent system for } \\
\text { collecting, assessing, and documenting data } \\
\text { pertaining to radionuclides in the environment is } \\
\text { implemented at the WVDP. }\end{array}$ \\
\hline $\begin{array}{l}42 \text { USC } § 4321 \text { et } \\
\text { seq. }\end{array}$ & $\begin{array}{l}\text { The National Environmental Policy Act (NEPA), of } \\
1969 \text { and as amended in 1970, established a national } \\
\text { policy to ensure that protection of the environment is } \\
\text { included in federal planning and decision-making. The } \\
\text { President's Council on Environmental Quality } \\
\text { established a screening system of analyses and } \\
\text { documentation that requires each proposed action to } \\
\text { be categorized according to the extent of its potential } \\
\text { environmental impact. }\end{array}$ & $\begin{array}{l}\text { DOE-WVDP has prepared various documents which } \\
\text { describe potential environmental effects associated } \\
\text { with proposed site activities. The level of } \\
\text { documentation depends upon whether the action } \\
\text { constitutes a major federal action significantly } \\
\text { affecting the quality of the human environment } \\
\text { within the meaning of NEPA. Draft documents are } \\
\text { then issued for public comment, as appropriate. } \\
\text { Based on the analyses presented, and considering } \\
\text { regulatory agency and public input, the DOE will } \\
\text { determine the preferred alternative and issue a } \\
\text { record of decision regarding the action. Refer to text } \\
\text { later in this chapter for further discussion of NEPA } \\
\text { activities. }\end{array}$ \\
\hline
\end{tabular}


TABLE ECS-1 (continued)

Compliance Status Summary for the WVDP in CY 2008

\begin{tabular}{|c|c|c|}
\hline Citation & $\begin{array}{c}\text { Environmental Statute, } \\
\text { DOE Directive, Executive Order, Agreement }\end{array}$ & $\begin{array}{l}\text { WVDP Compliance } \\
\text { Status }\end{array}$ \\
\hline \begin{tabular}{|l|} 
Title 6 of the \\
Official \\
Compilation of \\
Codes, Rules, and \\
Regulations of the \\
State of New York \\
(6 NYCRR) Part \\
617 New York \\
State (NYS) \\
Environmental \\
Conservation Law \\
(ECL)
\end{tabular} & $\begin{array}{l}\text { The NY State Environmental Quality Review (SEQR) } \\
\text { Act, enacted in September 1976, requires adequate } \\
\text { environmental review and assessment of whether a } \\
\text { proposed action has the potential to have a significant } \\
\text { environmental impact, prior to a decision regarding } \\
\text { the action. Where a project involves both NYS and } \\
\text { federal approvals, it is preferred to coordinate the } \\
\text { SEQR and NEPA processes. }\end{array}$ & $\begin{array}{l}\text { The SEQR process is an action-forcing statute that } \\
\text { requires state agencies to incorporate environmental } \\
\text { considerations directly into their decision-making, } \\
\text { and where necessary, to modify that action to } \\
\text { mitigate adverse environmental effects. Although } \\
\text { the NEPA federal procedural statute requires } \\
\text { documentation of the decision-making process, it } \\
\text { does not require that environmental considerations } \\
\text { be elevated above other factors. Efforts are being } \\
\text { made at the WVDP to effectively coordinate } \\
\text { information to utilize the federal EIS process to make } \\
\text { the required SEQR findings. }\end{array}$ \\
\hline $\begin{array}{l}42 \text { USC } \$ 6901 \text { et } \\
\text { seq ., and NYS ECL }\end{array}$ & $\begin{array}{l}\text { The Resource Conservation and Recovery Act (RCRA) } \\
\text { of } 1976 \text { and the NYS Solid Waste Disposal Act (NYS } \\
\text { ECL Article } 27 \text { [Title 9]) govern the generation, storage, } \\
\text { handling, and disposal of hazardous wastes and } \\
\text { closure of systems that handle these wastes. RCRA } \\
\text { was enacted to ensure that hazardous wastes are } \\
\text { managed in a way that protects human health, safety, } \\
\text { and the environment. }\end{array}$ & $\begin{array}{l}\text { Generation, storage, handling, treatment and } \\
\text { disposal of hazardous waste, and closure of systems } \\
\text { that handle hazardous waste at the WVDP, are } \\
\text { conducted in accordance with the RCRA Part A } \\
\text { Permit Application. The New York State Department } \\
\text { of Environmental Conservation (NYSDEC) performed } \\
\text { a hazardous waste compliance inspection of the } \\
\text { WVDP facilities on March 31, } 2008 \text { and reported no } \\
\text { violations of NYS hazardous waste regulations. A } \\
\text { detailed discussion of calendar year (CY) } 2008 \text { RCRA } \\
\text { activities is presented later in this chapter. }\end{array}$ \\
\hline $\begin{array}{l}\text { ient to } 42 \\
51\end{array}$ & $\begin{array}{l}\text { The Federal Facilities Compliance Act (FFCA) of } 1992 \\
\text { (an amendment to RCRA) requires DOE facilities to } \\
\text { prepare an STP for treating mixed waste inventories to } \\
\text { meet land disposal restrictions and to update the plan } \\
\text { (i.e., annually) to account for changes in mixed waste } \\
\text { inventories, capacities, and treatment technologies. } \\
\text { The DOE entered into a Consent Order with NYSDEC } \\
\text { for the WVDP in } 1996 .\end{array}$ & $\begin{array}{l}\text { The WVDP STP fiscal year (FY) 2008, revised in } \\
\text { February 2009, consists of two volumes, the } \\
\text { background volume and the plan volume. The FFCA } \\
\text { requires completing milestones identified in the plan } \\
\text { volume. The FY } 2008 \text { Plan identified five proposed } \\
\text { milestones for waste streams managed under the } \\
\text { WVDP STP, all of which were completed by } \\
\text { September } 30,2008 \text {. }\end{array}$ \\
\hline $\begin{array}{l}\text { Docket No. II } \\
\text { RCRA 3008(h) 92- } \\
0202\end{array}$ & $\begin{array}{l}\text { The DOE and NYSERDA entered into the RCRA } \\
\text { \$3008(h) Administrative Order on Consent (the } \\
\text { Consent Order) with the EPA and NYSDEC in March } \\
\text { 1992. The Consent Order pertains to management of } \\
\text { RCRA corrective actions in association with hazardous } \\
\text { waste and/or hazardous constituents from solid waste } \\
\text { management units at the WNYNSC. The EPA is the } \\
\text { lead agency. }\end{array}$ & $\begin{array}{l}\text { Written procedures and site activities are compliant } \\
\text { with the Consent Order. In accordance with the } \\
\text { Consent Order, the DOE submits quarterly reports to } \\
\text { the EPA and NYSDEC that summarize all RCRA } \\
\S 3008 \text { (h) activities and progress conducted at the } \\
\text { WVDP for the representative quarter. A detailed } \\
\text { discussion of CY } 2008 \text { activities is presented later in } \\
\text { this chapter. }\end{array}$ \\
\hline $\begin{array}{l}\text { RCRA } 3016 \\
\text { Statute }\end{array}$ & $\begin{array}{l}\text { The RCRA } 3016 \text { Statute applies to all Federal } \\
\text { hazardous waste facilities currently owned or } \\
\text { operated by the government. It requires that facility } \\
\text { hazardous waste information be submitted to the EPA } \\
\text { and authorized states. }\end{array}$ & $\begin{array}{l}\text { Contract \# DE-AC30-07CC30000, Section J, Item } 11 \\
\text { requires that WVDP facility hazardous waste } \\
\text { activities be reported biennially to NYSDEC. This } \\
\text { report was submitted in December } 2007 .\end{array}$ \\
\hline
\end{tabular}


TABLE ECS-1 (continued) Compliance Status Summary for the WVDP in CY 2008

\begin{tabular}{|c|c|c|}
\hline Citation & $\begin{array}{c}\text { Environmental Statute, } \\
\text { DOE Directive, Executive Order, Agreement }\end{array}$ & $\begin{array}{l}\text { WVDP Compliance } \\
\text { Status }\end{array}$ \\
\hline $\begin{array}{l}\text { NYS Navigation } \\
\text { Law and NYS ECL }\end{array}$ & $\begin{array}{l}\text { NYS ECL Article } 17 \text { (Titles } 10 \text { and 17), } 6 \text { NYCRR 612-614 } \\
\text { and Parts 595-599, and } 6 \text { NYCRR Subpart 360-14 } \\
\text { regulate design, operation, inspection, maintenance, } \\
\text { and closure of aboveground and underground bulk } \\
\text { petroleum and bulk chemical storage tanks. They also } \\
\text { regulate spill reporting and cleanup. Under terms of a } \\
1996 \text { agreement, amended in 2005, the DOE is not } \\
\text { required to report a spill of petroleum product onto an } \\
\text { impervious surface if the spill is less than } 5 \text { gallons and } \\
\text { is cleaned up within two hours of discovery. }\end{array}$ & $\begin{array}{l}\text { The last chemical bulk storage tank at the WVDP was } \\
\text { closed under these regulations in } 2006 \text {. There remain } \\
9 \text { registered petroleum bulk storage tanks (eight } \\
\text { aboveground and one underground) that are } \\
\text { periodically inspected and maintained. Tank No. FO- } \\
\text { D-11, a bulk diesel fuel storage tank, was } \\
\text { permanently closed in September } 2008 \text {. Spills are } \\
\text { reported and cleaned up in accordance with written } \\
\text { policies and procedures. There were two spills of } \\
\text { petroleum product of approximately } 1 \text { quart each } \\
\text { during the second and third quarters of } 2008 \text {. These } \\
\text { quantities did not require immediate notification to } \\
\text { NYSDEC, and were reported in quarterly reports. }\end{array}$ \\
\hline $\begin{array}{l}\text { Executive Order } \\
\text { (E.O.) } 13423\end{array}$ & $\begin{array}{l}\text { E.O. 13423, Strengthening Federal Environmental, } \\
\text { Energy, and Transportation Management, issued in } \\
\text { January 2007, replaced several executive orders } \\
\text { known as the Greening the Government Executive } \\
\text { Orders (including E.O. } 13101 \text { and E.O. 13148). The } \\
\text { Order did not rescind any of the requirements found } \\
\text { in the earlier orders, but updated previous goals and } \\
\text { their baselines and added new initiatives. The Order } \\
\text { set goals in areas of energy efficiency, renewable } \\
\text { energy, acquisition, toxics reduction, recycling, } \\
\text { sustainable buildings, electronics stewardship, and } \\
\text { water conservation. }\end{array}$ & $\begin{array}{l}\text { Waste minimization, pollution prevention, recycling, } \\
\text { and affirmative procurement objectives are achieved } \\
\text { in accordance with the WVDP "Waste Minimization } \\
\text { Pollution Prevention Awareness Plan." (See Tables } \\
\text { ECS-6 and 7.) The WVDP renewed the EPA National } \\
\text { Environmental Performance Track Program } \\
\text { membership in 2007, and committed to four new } \\
\text { goals to reduce the following; (1) total non- } \\
\text { transportation energy by 5\%, (2) liquid nitrogen use } \\
\text { by } 10 \%,(3) \text { resins used for treatment of } \\
\text { radiologically contaminated wastewater by } 10 \% \text {, and } \\
\text { (4) sulfur oxide (SO } \text { S }_{\text {) air emissions from non- }} \\
\text { transportation purposes by } 10 \% \text {. The goals are to } \\
\text { meet or exceed these commitments by the end of } \\
2009, \text { compared with } 2006 \text { as the baseline. The EPA } \\
\text { discontinued this program in March, } 2009 \text {. The } \\
\text { WVES EMS procedure was revised in CY } 2009 \text { to } \\
\text { incorporate the new requirements of this Order. } \\
\end{array}$ \\
\hline $\begin{array}{l}42 \text { USC } \S 7401 \text { et } \\
\text { seq.; } 40 \text { CFR 61, } \\
\text { Subpart H; and } \\
6 \text { NYCRR Chapter } \\
\text { 3, Air Resources }\end{array}$ & $\begin{array}{l}\text { The Clean Air Act of } 1970 \text { and the NYS ECL regulate } \\
\text { the release of air pollutants through permits and air } \\
\text { quality limits. Emissions of radionuclides are regulated } \\
\text { by the EPA via the National Emission Standards for } \\
\text { Hazardous Air Pollutants (NESHAP) regulations. } \\
\text { Nonradiological emissions are permitted under } 6 \\
\text { NYCRR Part 201-4 (Minor Facility Registrations). }\end{array}$ & $\begin{array}{l}\text { During CY } 2008 \text {, the DOE maintained six NESHAP } \\
\text { permits for radiological emissions and one Air Facility } \\
\text { Registration Certificate for nonradiological emissions } \\
\text { at the WVDP. An annual NESHAP Report } \\
\text { summarizing radiological emissions and estimating } \\
\text { dose is submitted to the EPA. Estimated dose from } \\
\text { radiological air emissions to the MEOSI in } 2008 \text { was } \\
0.011 \% \text { of the } 10 \text {-millirem Subpart H standard. Refer } \\
\text { to Chapter } 3 \text {, "Dose Assessment," for discussion. In } \\
\text { February 2009, the DOE submitted to the EPA a } \\
\text { request for approval to proceed with demolition of } \\
\text { the WVDP main plant process building (MPPB), after } \\
\text { shutting down the MPPB ventilation system, and to } \\
\text { implement a program of environmental } \\
\text { measurements to document compliance with } \\
\text { radiological NESHAP requirements. Refer to the } \\
\text { "Environmental Issues" section at the end of this } \\
\text { chapter for a discussion. In CY } 2008 \text {, two utility } \\
\text { steam boilers were responsible for nonradiological } \\
\text { emissions of nitrogen oxides at } 3.1 \% \text { of the capping } \\
\text { limit for maintaining the registration certificate, and } \\
\text { SO at } 0 \% \text { of the capping limit. }\end{array}$ \\
\hline
\end{tabular}


TABLE ECS-1 (continued)

Compliance Status Summary for the WVDP in CY 2008

\begin{tabular}{|c|c|c|}
\hline Citation & $\begin{array}{c}\text { Environmental Statute, } \\
\text { DOE Directive, Executive Order, Agreement }\end{array}$ & $\begin{array}{l}\text { WVDP Compliance } \\
\text { Status }\end{array}$ \\
\hline $\begin{array}{l}33 \text { USC } \$ 1251 \text { et } \\
\text { seq. and NYS ECL }\end{array}$ & $\begin{array}{l}\text { The Federal Water Pollution Control Act of } 1977 \\
\text { (Clean Water Act [CWA]) and NYS ECL (Article } 17 \\
\text { [Title 8]) seek to improve surface water quality by } \\
\text { establishing standards and a system of permits. } \\
\text { Wastewater and storm water discharges are regulated } \\
\text { by NYSDEC through the State Pollutant Discharge } \\
\text { Elimination System (SPDES) permit. Discharges of fill } \\
\text { material are regulated through permits issued by the } \\
\text { U.S. Army Corps of Engineers (USACE) and water } \\
\text { quality certifications issued by NYSDEC. }\end{array}$ & $\begin{array}{l}\text { Monthly SPDES Discharge Monitoring Reports are } \\
\text { submitted to NYSDEC. SPDES-permitted storm water } \\
\text { monitoring was successfully completed during } 2008 \\
\text { by sampling the eight drainage basins during } \\
\text { qualifying storm events. During 2008, no SPDES } \\
\text { permit exceedances occurred. However, during the } \\
\text { month of January, 2009, the daily maximum permit } \\
\text { limit of } 0.30 \mathrm{mg} / \text { L for total iron for the sum of the } \\
\text { outfalls was exceeded. Site personnel are currently } \\
\text { working with NYSDEC on a permit renewal that will } \\
\text { include updated iron discharge monitoring and } \\
\text { compliance limits. Refer to Chapter 2, } \\
\text { "Environmental Monitoring," for further discussion. }\end{array}$ \\
\hline E.O. 1 & $\begin{array}{l}\text { E.O. 11990, Protection of Wetlands, directed federal } \\
\text { agencies to avoid, where possible, impacts (e.g., } \\
\text { destruction, modification, or new construction) that } \\
\text { would adversely effect wetlands wherever there is a } \\
\text { practical alternative. Activities in wetlands are } \\
\text { regulated by the USACE and NYSDEC permits. The } \\
\text { wetlands on the WVDP are subject to regulation under } \\
\text { Section } 404 \text { of the CWA. }\end{array}$ & $\begin{array}{l}\text { Wetlands are periodically identified, delineated, and } \\
\text { mapped on the WVDP. In 2006, the USACE } \\
\text { performed a field assessment of a wetland } \\
\text { delineation report and confirmed that } 34.09 \text { acres of } \\
\text { wetlands, subject to federal jurisdiction, exist within } \\
\text { and adjacent to the WVDP. A wetland complex of } \\
17.3 \text { acres is subject to NYSDEC jurisdiction. During } \\
2006-2007 \text {, a re-delineation was done to determine } \\
\text { if any portion of the live-fire range (LFR) on the } \\
\text { WNYNSC property fell within a } 100-\text { foot buffer of any } \\
\text { adjacent wetlands and to locate a new storm water } \\
\text { outfall in the basin area. Adjacent to the LFR, a new } \\
\text { wetland of } 0.09 \text { acres was identified that is } \\
\text { hydrologically connected to the NYSDEC } \\
\text { jurisdictional wetlands. There were no activities in } \\
\text { the wetlands or buffer areas during } 2008 \text {. }\end{array}$ \\
\hline $\begin{array}{l}42 \text { USC §9601 et } \\
\text { seq. }\end{array}$ & $\begin{array}{l}\text { The Comprehensive Environmental Response, } \\
\text { Compensation, and Liability Act of } 1980 \text { (CERCLA, } \\
\text { including the Superfund Amendments and } \\
\text { Reauthorization Act of } 1986 \text { [SARA]) provided the } \\
\text { regulatory framework for remediation of releases of } \\
\text { hazardous substances and remediation of inactive } \\
\text { hazardous waste disposal sites. }\end{array}$ & $\begin{array}{l}\text { Based on the results of a Preliminary Assessment } \\
\text { Report prepared for the DOE, it was determined that } \\
\text { the WVDP did not qualify for listing on the national } \\
\text { priorities list. Therefore, no further investigation } \\
\text { pursuant to CERCLA was warranted. However, if a } \\
\text { hazardous substance spill exceeds a reportable } \\
\text { quantity, CERCLA reporting requirements may be } \\
\text { triggered. }\end{array}$ \\
\hline $\begin{array}{l}42 \text { USC } \S 11001 \text { et } \\
\text { seq. }\end{array}$ & $\begin{array}{l}\text { The Emergency Planning and Community Right-to- } \\
\text { Know Act (EPCRA) of } 1986 \text { (also known as SARA Title } \\
\text { III) was designed to create a working partnership } \\
\text { between industry, business, state and local } \\
\text { government, and emergency response representatives } \\
\text { to help local communities protect public health, } \\
\text { safety, and the environment from chemical hazards. }\end{array}$ & $\begin{array}{l}\text { Chemical inventories for the WVDP are reported } \\
\text { quarterly under EPCRA as appropriate. There were } \\
\text { no releases of hazardous substances in } 2008 \text { that } \\
\text { triggered release notifications under EPCRA. No new } \\
\text { chemicals exceeded their threshold planning } \\
\text { quantities. Refer to Tables ECS-9 and ECS-10 at the } \\
\text { end of this chapter. }\end{array}$ \\
\hline $\begin{array}{l}42 \text { USC } \S 300 f \text { et } \\
\text { seq. }\end{array}$ & $\begin{array}{l}\text { The Safe Drinking Water Act of } 1974 \text { requires that } \\
\text { each federal agency operating or maintaining a public } \\
\text { water system must comply with all federal, state, and } \\
\text { local requirements regarding safe drinking water. } \\
\text { Compliance in New York State is verified by oversight } \\
\text { of the New York State Department of Health } \\
\text { (NYSDOH), through NYS Public Health law, and the } \\
\text { Cattaraugus County Department of Health. }\end{array}$ & $\begin{array}{l}\text { The WVDP drinking water plant is considered a Class } \\
\text { "C" system. All CY } 2008 \text { results from analyses of } \\
\text { drinking water were reported within limits to the } \\
\text { Cattaraugus County Health Department (CCHD). The } \\
\text { CCHD performed an inspection of the treatment and } \\
\text { distribution system on March } 17,2009 \text {, during which } \\
\text { backflow prevention device testing documentation } \\
\text { was verified. No concerns were identified. }\end{array}$ \\
\hline
\end{tabular}




\begin{tabular}{|c|c|c|}
\hline \multicolumn{3}{|c|}{$\begin{array}{l}\text { TABLE ECS-1 (continued) } \\
\text { Compliance Status Summary for the WVDP in CY } 2008\end{array}$} \\
\hline Citation & $\begin{array}{c}\text { Environmental Statute, } \\
\text { DOE Directive, Executive Order, Agreement }\end{array}$ & $\begin{array}{l}\text { WVDP Compliance } \\
\text { Status }\end{array}$ \\
\hline 10 CFR 851 & $\begin{array}{l}10 \text { CFR } 851 \text { "Worker Safety and Health Program" of } \\
2006 \text { requires DOE contractors to provide their } \\
\text { workers with a safe and healthful workplace. To } \\
\text { accomplish this objective, the rule established } \\
\text { program requirements specific to management } \\
\text { responsibilities, worker rights, hazard identification } \\
\text { and prevention, safety health standards, required } \\
\text { training, recordkeeping, and reporting. }\end{array}$ & $\begin{array}{l}\text { WVES personnel revise procedures and programs to } \\
\text { maintain requirements to comply with } 10 \text { CFR } 851 \text {. } \\
\text { Any proposed modification, addition, or deletion } \\
\text { that may invalidate a portion of the worker health } \\
\text { and safety program at the WVDP must be approved } \\
\text { by DOE-WVDP. }\end{array}$ \\
\hline $\begin{array}{l}15 \text { USC } \$ 2601 \text { et } \\
\text { seq ., and } 12 \\
\text { NYCRR Part } 56\end{array}$ & $\begin{array}{l}\text { The Toxic Substances Control Act of } 1976 \text { regulates } \\
\text { the manufacture, processing and distribution of } \\
\text { chemicals, including asbestos-containing material } \\
\text { (ACM) and polychlorinated biphenyls (PCBs). Effective } \\
\text { September 2006, the New York State Department of } \\
\text { Labor (NYSDOL) significantly revised the asbestos } \\
\text { regulations, cited in } 12 \text { NYCRR Part } 56 .\end{array}$ & $\begin{array}{l}\text { Due to regulation changes, operating procedures } \\
\text { were revised, special training for asbestos workers } \\
\text { was conducted, and the WVDP applied for and was } \\
\text { granted site-specific variances. During 2008, all ACM } \\
\text { activities were managed in accordance with the site } \\
\text { "Asbestos Management Plan" and activities were } \\
\text { completed by personnel certified by NYSDOL. Refer } \\
\text { to Table ECS-5 for a summary of asbestos waste } \\
\text { management activities. Management of PCBs was } \\
\text { done in accordance with the WVDP "PCB and PCB- } \\
\text { Contaminated Material Management Plan." The } \\
\text { WVDP operators maintain an annual document log } \\
\text { that details PCB use and changes in storage or } \\
\text { disposal status. }\end{array}$ \\
\hline $\begin{array}{l}7 \text { USC } \$ 136 \text { et } \\
\text { seq. }\end{array}$ & $\begin{array}{l}\text { The Federal Insecticide, Fungicide, and Rodenticide } \\
\text { Act of } 1996 \text { and NYS ECL provided for EPA and } \\
\text { NYSDEC control of pesticide distribution, sale, and use. }\end{array}$ & $\begin{array}{l}\text { Chemical pesticides are applied at the WVDP only } \\
\text { after alternative methods are evaluated by trained } \\
\text { and NYSDEC-certified professionals and determined } \\
\text { to be unfeasible. In } 2008 \text {, approximately } 400 \text { pounds } \\
\text { of a NYSDEC-registered biocide was added to the } \\
\text { cooling water system. Control is necessary to } \\
\text { minimize the potential for system damage due to } \\
\text { algal buildup and the potential for worker exposure } \\
\text { to waterborne pathogens such as Legionella. }\end{array}$ \\
\hline $\begin{array}{l}\text { NYS ECL, Article } \\
15, \text { Title } 5 \text {, et seq }\end{array}$ & $\begin{array}{l}\text { NYS ECL, Article 15, Title 5, Protection of Water } \\
\text { regulates the safety of dams and other surface water } \\
\text { impounding structures, including construction, } \\
\text { inspection, operation, maintenance and modification } \\
\text { of these structures. }\end{array}$ & $\begin{array}{l}\text { Two surface water impounding dam structures on } \\
\text { the WNYNSC were inspected on September } 29, \\
\text { 2008. The routine inspection identified actions to } \\
\text { perform maintenance on the staff gauges and to } \\
\text { clear debris. }\end{array}$ \\
\hline $\begin{array}{l}\text { NYS Public Health } \\
\text { Law }\end{array}$ & $\begin{array}{l}\text { Public Health Law, Article } 5 \text { (Laboratories), Section } \\
502 \text { (Environmental Laboratories, Examinations, and } \\
\text { Certificates of Approval) }\end{array}$ & $\begin{array}{l}\text { The WVDP Environmental Laboratory (the URS } \\
\text { Corporation Laboratory) is certified by NYSDOH for } \\
\text { certain radiological and nonradiological constituents } \\
\text { in potable and nonpotable water, as well as for } \\
\text { asbestos in solids. }\end{array}$ \\
\hline $\begin{array}{l}49 \text { CFR Part 172, } \\
\text { and } 6 \text { NYCRR Part } \\
364.9\end{array}$ & $\begin{array}{l}6 \text { NYCRR Part } 364.9 \text { regulates handling and storage of } \\
\text { potentially infectious regulated medical waste. } 49 \text { CFR } \\
\text { Part } 172 \text {, Subpart H regulates transportation safety } \\
\text { and disposal of regulated medical waste at a licensed } \\
\text { facility. }\end{array}$ & $\begin{array}{l}\text { The on-site health services office is registered with } \\
\text { NYS as a "Small Quantity Generator" of regulated } \\
\text { medical waste. Medical services generate potentially } \\
\text { infectious medical wastes that are securely stored in } \\
\text { approved biohazard containers and are handled and } \\
\text { controlled by authorized personnel. }\end{array}$ \\
\hline
\end{tabular}


TABLE ECS-1 (concluded) Compliance Status Summary for the WVDP in CY 2008

\begin{tabular}{|c|c|c|}
\hline Citation & $\begin{array}{c}\text { Environmental Statute, } \\
\text { DOE Directive, Executive Order, Agreement }\end{array}$ & $\begin{array}{l}\text { WVDP Compliance } \\
\text { Status }\end{array}$ \\
\hline $\begin{array}{l}16 \text { USC } \S 703 \text { et } \\
\text { seq. , and } 6 \\
\text { NYCRR Part } 175\end{array}$ & $\begin{array}{l}\text { The Migratory Bird Treaty Act of } 1918 \text { implemented } \\
\text { various treaties and conventions between the U.S. and } \\
\text { foreign countries for the protection of migratory birds. } \\
\text { Under the Act, taking, killing, or possessing migratory } \\
\text { birds is unlawful. (See also } 6 \text { NYCRR Part 175, Special } \\
\text { Licenses and Permits - Definitions and Uniform } \\
\text { Procedures.) }\end{array}$ & $\begin{array}{l}\text { The DOE maintains, and complies with, a NYSDEC } \\
\text { Division of Fish and Wildlife Bird Depredation License } \\
\text { and a U.S. Fish and Wildlife Bird Depredation Permit } \\
\text { for the WVDP. }\end{array}$ \\
\hline $\begin{array}{l}16 \text { USC } \S 1531 \text { et } \\
\text { seq. , and } 6 \\
\text { NYCRR Part } 182\end{array}$ & $\begin{array}{l}\text { The Endangered Species Act of } 1973 \text { provided for the } \\
\text { conservation of endangered and threatened species of } \\
\text { fish, wildlife, and plants. (See also } 6 \text { NYCRR Part 182, } \\
\text { Endangered and Threatened Species of Fish and } \\
\text { Wildlife; Species of Special Concern.) }\end{array}$ & $\begin{array}{l}\text { Several ecological surveys of the WNYNSC premises } \\
\text { have been conducted. Except for "occasional } \\
\text { transient individuals," no plant or animal species } \\
\text { protected under the Endangered Species Act are } \\
\text { known to reside at the Center. }\end{array}$ \\
\hline 16 USC §470 & $\begin{array}{l}\text { The National Historic Preservation Act of } 1966 \\
\text { established a program for the preservation of historic } \\
\text { properties throughout the nation. }\end{array}$ & $\begin{array}{l}\text { Surveys have been conducted of the WNYNSC for } \\
\text { historic and archaeological sites. Surveys revealed } \\
\text { American Indian and historic homestead artifacts, } \\
\text { consistent with surrounding areas. }\end{array}$ \\
\hline E.O. 11988 & $\begin{array}{l}\text { E.O. 11988, Floodplain Management, was issued to } \\
\text { avoid adverse impacts associated with the occupancy } \\
\text { and modification of floodplains and to avoid direct or } \\
\text { indirect support of floodplain development wherever } \\
\text { there is a practicable alternative. }\end{array}$ & $\begin{array}{l}\text { No activities were performed during } 2008 \text { at the } \\
\text { WVDP that would develop or be adversely impacted } \\
\text { by the } 100 \text {-year floodplain within the premises. }\end{array}$ \\
\hline \begin{tabular}{|l|} 
Stipulation \\
Pursuant to NYS \\
ECL Section 17- \\
0303 , and Section \\
176 of the \\
Navigation Law
\end{tabular} & $\begin{array}{l}\text { In accordance with Stipulation No. R9-4756-99-03, } \\
\text { dated March 1999, the DOE agreed to install a soil } \\
\text { bioventing system to remediate petroleum } \\
\text { contaminated soils in the warehouse underground } \\
\text { tank site (NYSDEC Spill number } 9708617) \text {. The } \\
\text { remediation plan was to construct a bioventing } \\
\text { system, operate it for two calendar years, assess } \\
\text { performance, and report to NYSDEC. }\end{array}$ & $\begin{array}{l}\text { The system stimulated natural in-situ biodegradation } \\
\text { of petroleum hydrocarbons in the soil by providing } \\
\text { abundant oxygen to existing microorganisms. After } \\
\text { reviewing soil and water sampling, analyses, and } \\
\text { evaluations, NYSDEC determined that no further } \\
\text { remediation was required. Final disposition of this } \\
\text { area is pending decision in the Decommissioning } \\
\text { and/or Long-Term Stewardship EIS for the WVDP and } \\
\text { the WNYNSC. }\end{array}$ \\
\hline 6 NYCRR 360 & $\begin{array}{l}\text { NYS ECL Solid Waste Management Facility } \\
\text { Regulations define requirements for closure of } \\
\text { nonradioactive solid waste disposal facilities in a } \\
\text { manner that protects the environment. }\end{array}$ & $\begin{array}{l}\text { In 1986, an engineering closure plan was submitted } \\
\text { to and approved by NYSDEC for the construction and } \\
\text { demolition debris landfill (CDDL). The closure was } \\
\text { performed in accordance with landfill closure } \\
\text { regulatory requirements specified in the approved } \\
\text { closure plan. The plan also requires post-closure } \\
\text { perpetual maintenance and annual reporting in this } \\
\text { ASER. The CDDL cover was inspected in May and } \\
\text { September } 2008 \text { for integrity and bare areas and the } \\
\text { culverts were inspected for erosion and silting. All } \\
\text { areas were found to be in good condition. }\end{array}$ \\
\hline
\end{tabular}




\section{Accomplishments and Highlights at the WVDP}

West Valley Environmental Services (WVES) operated the WVDP in a safe manner that continued to be protective of the public, its workers, and the environment throughout 2008. The projects were carried out in accordance with applicable permits and licenses with no regulatory notices of noncompliance. The following accomplishments contributed to major progress in support of completion of the requirements identified in the WVDP Act.

Safety Emphasis. Collectively, the WVDP's workforce achieved 1.24 million work hours without a lost-time work accident or illness and worked 85 consecutive weeks without a lost-time work injury or illness by the end of 2008. The WVDP had 11 first-aid incidents and one recordable injury in 2008. The site's excellent safety performance earned the WVDP one of the best Total Recordable Case Rate records in the DOE's Environmental Management complex in 2008. Radiological safety was maintained with no reportable contamination incidents while conducting complicated, hazardous work in a number of radiological areas, including main plant process building (MPPB) dismantlement activities. There were no nuclear safety program violations, maintaining full Technical Safety Requirement compliance.

Main Plant Process Building. The fuel processing equipment has been removed from approximately $75 \%$ of the MPPB's 61 high-hazard cells and operating aisles. Work was focused on removing residual tanks, vessels, and process piping; removing source contamination; and fixing surface contamination in place. The product purification cell-north was emptied and equipment removal and decontamination was essentially completed in three other locations: the miniature cell, upper warm aisle, and acid recovery cell (ARC) pump room. Dismantlement and decontamination continues in the ARC and the hot acid cell.

Radioactive Waste Management. During 2008, WVES continued processing and shipping stored radioactive waste off site for disposal. During 2008, additional remote-handled waste processing ability was established in the former vitrification facility for large and high-dose waste containers. A total of 62,500 cubic feet of low-level waste and 21,400 cubic feet of transuranic waste were processed. All shipments in 2008 were by truck. Refer to Table ECS- 5 for a breakdown of waste volumes (by classification) processed and shipped during calendar year (CY) 2008.
Balance of Site Facilities. Reducing unneeded site facilities continues to be a priority. Five hardstands (outdoor equipment laydown areas) were cleared of excess materials during 2008 and five facilities were prepared for demolition. Three of the five facilities (the old counting lab, the vit diesel tank building, and the emergency vehicle shelter) were demolished and removed.

\section{Special Projects:}

- A cap and a slurry wall were installed on the Nuclear Regulatory Commission (NRC)-licensed disposal area (NDA) as an Interim Measure (IM) under the Resource Conservation and Recovery Act (RCRA), in 2008.

See discussion later in this chapter under "RCRA $\S 3008(\mathrm{~h})$ Administrative Order on Consent," "Interim Measure."

- Additional sampling was conducted in 2008 (1) to determine background concentrations of metals in subsurface soil from the north plateau and (2) to better characterize concentrations of chemical and radiological constituents in subsurface soil and groundwater in the strontium-90 plume.

See discussions in Chapter 2 under "Special Monitoring" and Chapter 4 under "Strontium-90 Plume Characterization and Remediation Activities Performed in 2008."

\section{National Environmental Policy Act (NEPA)}

NEPA requires the DOE to consider the overall environmental effects of its proposed actions. Draft documents are prepared that describe potential environmental effects associated with proposed Project activities. The level of evaluation and documentation depends upon whether the action constitutes a major federal action significantly affecting the quality of the human environment within the meaning of NEPA. The categories of documentation include categorical exclusions (CXs), environmental assessments (EAs) and environmental impact statements (EISs).

CXs document actions that, by their nature, will not have a significant effect on the environment. EAs are used to evaluate the extent to which a proposed action, not categorically excluded, will affect the environment. 
Based on the analyses presented in an EA and considering regulatory agency, stakeholder, and public comment, the DOE may determine that the proposed action is not a major federal action significantly affecting the quality of the human environment within the meaning of NEPA. As a result, the DOE may issue a notice indicating the finding of no significant impact and therefore would not be required to prepare an EIS.

If a proposed action has the potential for significant environmental effects, an EIS would be prepared that describes proposed alternatives to an action and explains the effects of each. Based on the analyses presented, and considering regulatory agency and public input, the DOE will determine the preferred alternative and issue a record of decision (ROD) regarding the action.

Since the Project began, a number of proposed site activities have warranted environmental impact evaluations. The WVDP NEPA history is summarized in Table ECS-2. Decisions resulting from the final EISs and associated RODs and EAs facilitate ongoing waste management and remediation activities at the Project.

\section{Waste Tank Farm (WTF) Tank and Vault Drying System} (CX). In early 2009, the need for a CX (from a NEPA perspective) of a new system to eliminate moisture from in and around the former high-level waste tanks was documented. This system will help to eliminate the potential for migration of contaminants from the tanks. Implementation of the proposed system would not impact any EIS alternative under consideration.

The Draft EIS and the WVDP Core Team. The "EIS for the Decommissioning and/or Long-Term Stewardship at the WVDP and the WNYNSC," evaluating different scenarios for completing the DOE's mission at the Project, had been stalled for several years as involved agencies struggled with many of the difficult issues that the WVDP presents. The DOE and New York State Energy Research and Development Authority (NYSERDA) are joint lead agencies on this EIS, and the EPA, NRC, and NYSDEC are cooperating agencies. NYSDOH is an involved agency under SEQRA. In September 2005, the DOE released a revised internal multi-agency pre-decisional draft. After agency reviews, a large number of comments on the pre-decisional draft were received. These comments addressed a wide range of technical issues and challenges.
In August 2006, in an effort to continue progress toward Project completion, the DOE-WVDP requested that the NRC, the EPA, NYSDOH, NYSDEC, and NYSERDA (i.e., Core Team) participate in a collaborative process to resolve technical issues and make recommendations associated with the draft Decommissioning and/or Long-Term Stewardship EIS. The WVDP Core Team was formed in November 2006. The Core Team approach is a formalized, consensus-based process in which those individuals with decision-making authority work together to reach agreement on how to address key technical issues. Equally important, the Core Team worked to ensure that technical support staff were involved and communicating effectively throughout the process and that stakeholders were informed of the Core Team progress.

The Core Team met regularly to evaluate site challenges and make recommendations to move the focus of the Project forward. In early 2008, the Core Team proposed a preferred alternative for the Draft Decommissioning EIS that would be implemented in two phases (phased decisionmaking).

On December 5, 2008, the DOE issued a notice of availability in the Federal Register for the "Revised Draft Environmental Impact Statement for Decommissioning and/or Long-Term Stewardship at the West Valley Demonstration Project and Western New York Nuclear Service Center" (DOE/EIS-0226-D [Revised], referred to as the Decommissioning EIS). This began the six-month public review and comment period. The draft Decommissioning EIS evaluates the range of reasonable alternatives for decommissioning and/ or long-term stewardship of the facilities at the WVDP and the Center. This draft is a revision of the 1996 draft EIS, and it proposes the preferred alternative that was recommended by the Core Team to be implemented in two phases.

Phase 1 decommissioning would include removal of a number of the major facilities at the WVDP: relocation of the high-level radioactive waste (HLW) canisters in a configuration for future shipment, demolition of the MPPB, removal of the contaminated soil under the MPPB (i.e., the source area of the north plateau groundwater plume contamination), and the removal of the low-level waste treatment facility and lagoons. After completion of Phase 1 activities, the following facilities/areas/materials would remain: (1) the waste tank farm, (2) the NDA and the statelicensed disposal area, (3) HLW solidified in waste canisters, (4) the remaining portion of the contaminated north plateau groundwater plume, (5) areas of 
TABLE ECS-2

National Environmental Policy Act (NEPA) Documents Affecting DOE Activities at the WVDP

\begin{tabular}{|c|c|c|}
\hline Year & Action & Outcome \\
\hline 1982 & $\begin{array}{l}\text { The final Environmental Impact Statement (EIS) } \\
\text { and associated Record of Decision (ROD) were } \\
\text { issued outlining the actions the United States } \\
\text { Department of Energy (DOE) proposed for } \\
\text { solidification of the liquid high-level waste (HLW) } \\
\text { contained in the underground tanks (DOE-EIS- } \\
0081 \text { ). }\end{array}$ & $\begin{array}{l}\text { The first phase of the West Valley Demonstration } \\
\text { Project (WVDP) Act, completed in September 2002, } \\
\text { removed the HLW from the tanks and immobilized } \\
\text { it into borosilicate glass through vitrification. The } \\
\text { glass canisters remain on site in storage. }\end{array}$ \\
\hline 1988 & $\begin{array}{l}\text { The DOE and the New York State Energy Research } \\
\text { and Development Authority (NYSERDA) published } \\
\text { a Notice of Intent (NOI) to prepare the EIS for } \\
\text { Completion of the WVDP and Closure or Long- } \\
\text { Term Management of the Facilities at the Western } \\
\text { New York Nuclear Service Center (WNYNSC). }\end{array}$ & The draft EIS was issued $\mathrm{i}$ \\
\hline 1996 & $\begin{array}{l}\text { The DOE and NYSERDA issued the "Draft EIS for } \\
\text { the Completion of the WVDP and Closure or Long- } \\
\text { Term Management of the Facilities at the } \\
\text { WNYNSC" (DOE/EIS-0226-D). }\end{array}$ & $\begin{array}{l}\text { The draft EIS was issued without a preferred } \\
\text { alternative for a six-month review and comment } \\
\text { period. After issuance of the draft EIS, and despite } \\
\text { long negotiations, the DOE and NYSERDA were } \\
\text { unable to reach an agreement on the future course } \\
\text { of action for closure at the Center (see Government } \\
\text { Accounting Office, 2001). }\end{array}$ \\
\hline 1997 & $\begin{array}{l}\text { Following issuance of the draft } 1996 \text { EIS, NYSERDA } \\
\text { and the DOE formed a stakeholder advisory group } \\
\text { (the West Valley Citizen Task Force [CTF]) to } \\
\text { provide additional input to the public comment } \\
\text { process required by NEPA. }\end{array}$ & $\begin{array}{l}\text { The CTF mission is to provide stakeholder input to } \\
\text { decision-making for development of a closure } \\
\text { option for the WVDP and the WNYNSC. The mission } \\
\text { has expanded to future site use, long-term } \\
\text { stewardship, and regulatory issues. }\end{array}$ \\
\hline 1997 & $\begin{array}{l}\text { The DOE Headquarters issued the "Final Waste } \\
\text { Management Programmatic EIS," (WM PEIS } \\
\text { [DOE/EIS-0200F]) to evaluate nationwide } \\
\text { management and siting alternatives for } \\
\text { treatment, storage, and disposal of five types of } \\
\text { radioactive and hazardous waste. }\end{array}$ & $\begin{array}{l}\text { The EIS was issued with the intent to issue a } \\
\text { separate ROD for each type of waste generated, } \\
\text { stored, or buried over the next } 20 \text { years at } 54 \text { sites } \\
\text { in the DOE complex. }\end{array}$ \\
\hline 1999 & $\begin{array}{l}\text { The DOE issued a ROD for nationwide } \\
\text { management of HLW,Vol. 64, Federal Register } \\
\text { (FR), p. } 46661 \text { (64 FR 46661) }\end{array}$ & $\begin{array}{l}\text { The ROD specified that WVDP-vitrified HLW will } \\
\text { remain in storage on site until it is accepted at a } \\
\text { geologic repository. }\end{array}$ \\
\hline 2000 & $\begin{array}{l}\text { The DOE issued a ROD for nationwide } \\
\text { management of low-level waste (LLW) and mixed } \\
\text { LLW (65 FR 10061). }\end{array}$ & $\begin{array}{l}\text { The Hanford site in Washington State and the } \\
\text { Nevada Test Site were designated as national DOE } \\
\text { disposal sites for LLW and mixed LLW. }\end{array}$ \\
\hline 2001 & $\begin{array}{l}\text { The DOE published an NOI (66 FR 16447) formally } \\
\text { announcing its rescoping plan and preparation of } \\
\text { the waste management EIS for the WVDP. }\end{array}$ & $\begin{array}{l}\text { The rescoping plan split the scope of the } 1996 \\
\text { WVDP Draft EIS into two phases: (1) near-term } \\
\text { waste management decision-making and (2) final } \\
\text { decommissioning and/or long-term stewardship } \\
\text { decision-making. }\end{array}$ \\
\hline 2003 & $\begin{array}{l}\text { The DOE issued a notice of availability of the } \\
\text { “WVDP Draft Waste Management EIS" (68 FR } \\
\text { 26587). }\end{array}$ & $\begin{array}{l}\text { The draft EIS presented alternatives for near-term } \\
\text { management of WVDP LLW, mixed LLW, } \\
\text { transuranic (TRU) waste, and HLW. }\end{array}$ \\
\hline
\end{tabular}


TABLE ECS-2 (concluded)

National Environmental Policy Act (NEPA) Documents Affecting DOE Activities at the WVDP

\begin{tabular}{|c|c|c|}
\hline Year & Action & Outcome \\
\hline 2003 & \begin{tabular}{|l|} 
The DOE, in cooperation with NYSERDA, issued an \\
NOI (68 FR 12044) to issue an EIS for \\
"Decontamination and/or Long-Term Stewardship \\
at the WVDP and the WNYNSC."
\end{tabular} & $\begin{array}{l}\text { As a result of comments during the scoping process } \\
\text { and the complexity of issues relating to long-term } \\
\text { agency responsibility, this EIS was delayed (DOE-EIS- } \\
0226-\mathrm{R} \text { ). }\end{array}$ \\
\hline 2005 & $\begin{array}{l}\text { The DOE issued a ROD, based on alternative A, for } \\
\text { the "WVDP Waste Management EIS (WVDP WM } \\
\text { EIS-0337)" (70 FR 35073). }\end{array}$ & $\begin{array}{l}\text { As a result, the HLW canisters remain in storage on } \\
\text { site until transfer to a geologic repository, the } \\
\text { decision on TRU waste would be deferred until } \\
\text { certification is obtained from the Waste Isolation } \\
\text { Pilot Plant in Carlsbad, New Mexico, and LLW and } \\
\text { mixed LLW would be shipped off site according to } \\
\text { the ROD for nationwide management of LLW and } \\
\text { mixed LLW. }\end{array}$ \\
\hline 2005 & $\begin{array}{l}\text { On August 26, 2005, the Coalition on West Valley } \\
\text { Nuclear Wastes (the Coalition [a citizens group]) } \\
\text { filed a complaint in the U.S. District Court, } \\
\text { Western District of New York, against the DOE } \\
\text { regarding the NEPA process at the WVDP. The } \\
\text { Coalition contended that the DOE's rescoping plan } \\
\text { to split the } 1996 \text { draft WVDP EIS violated NEPA } \\
\text { and the Stipulation of Compromise. The Coalition } \\
\text { also sought a declaration that the DOE is not } \\
\text { empowered to reclassify waste at the WVDP using } \\
\text { the "waste incidental to reprocessing " } \\
\text { determination. }\end{array}$ & $\begin{array}{l}\text { On September, 28, 2007, the U.S. District Court, } \\
\text { Western District of New York ruled to dismiss the } \\
\text { complaint in its entirety. Refer to Case 1:05-cv- } \\
\text { 00614-JTC, Document 41, filed September 28, } 2007 \\
\text { for the ruling. }\end{array}$ \\
\hline 2006 & $\begin{array}{l}\text { An Environmental Assessment (EA) (DOE/EA-1552) } \\
\text { evaluated the proposed decontamination, } \\
\text { demolition, and removal of select facilities at the } \\
\text { site. A finding of no significant impact (FONSI) } \\
\text { was issued. }\end{array}$ & $\begin{array}{l}\text { The EA, with the associated FONSI, cleared the way } \\
\text { for removal of } 36 \text { facilities that are (or in the next } \\
\text { four years will be) no longer required to support } \\
\text { activities at the WVDP. }\end{array}$ \\
\hline 2007 & $\begin{array}{l}\text { DOE issued an NOI to prepare an EIS for the } \\
\text { disposal of Greater-Than-Class-C LLW (72 FR } \\
40135) \text {. }\end{array}$ & $\begin{array}{l}\text { Nine scoping meetings were held and the scoping } \\
\text { comment period ended in September 2007. The } \\
\text { Draft EIS has not been issued. }\end{array}$ \\
\hline 2008 & $\begin{array}{l}\text { The DOE issued a notice of availability for the } \\
\text { Revised Draft Environmental Impact Statement for } \\
\text { Decommissioning and/or Long-Term Stewardship } \\
\text { at the West Valley Demonstration Project and } \\
\text { Western New York Nuclear Service Center } \\
\text { (DOE/EIS-0226-D [Revised]) (73 FR 74160). }\end{array}$ & $\begin{array}{l}\text { The draft EIS evaluates the range of reasonable } \\
\text { alternatives for decommissioning and/or long-term } \\
\text { stewardship of the facilities at the Center. This EIS is } \\
\text { a revised draft of the } 1996 \text { Cleanup and Closure } \\
\text { Draft EIS. The draft EIS was distributed December } 5, \\
2008 \text { for a six-month public review period, which } \\
\text { was later extended three months through } \\
\text { September } 8,2009 \text {. }\end{array}$ \\
\hline
\end{tabular}


low-level surface contamination, and (6) waste without off-site disposal options.

A decommissioning decision (Phase 2 ) for the remaining facilities/areas would be made no later than 30 years after the Phase 1 ROD. This approach assumes that Phase 1 will be complete in 2011. The 30-year time frame would support achieving residual radioactivity levels less than the cleanup goals and would ensure that dose criteria of 10 CFR 20.1402 would be met in 2041 and any time thereafter. The derived concentration guideline levels and associated cleanup goals for strontium-90 and cesium-137 incorporate a 30-year decay period from 2011.

Phase 1 Decommissioning Plan for the West Valley Demonstration Project. On December 5, 2008, the DOE issued the proposed "Phase 1 Decommissioning Plan for the West Valley Demonstration Project, West Valley, NY" (73 Federal Register [FR] 74162). In December 2008, the DOE transmitted the "Phase 1 Decommissioning Plan for the West Valley Demonstration Project" (Rev. 0) to the NRC for review. On March 16, 2009, the DOE submitted revision 1 of the plan, which incorporated additional information, to the NRC. On March 20, 2009, the NRC determined that the document was sufficiently complete to warrant a technical review.

The plan was prepared pursuant to statutory obligations required under the WVDP Act and to satisfy commitments made to the NRC in 1981 under the DOE/NRC memorandum of understanding, and again in 2003. The plan addressed phase 1 of the two phases of the proposed WVDP decommissioning approach based on the preferred alternative in the Draft Environmental Impact Statement for Decommissioning and/or Long-Term Stewardship at the WVDP and the WNYNSC. If changes to that document occur during the course of the NEPA process that affect this plan, such as changes to the preferred alternative, or if a different approach is selected in the ROD, this plan will be revised as necessary to reflect the changes.

\section{Resource Conservation and Recovery Act}

RCRA and its implementing regulations govern the life cycle of hazardous waste from "cradle-to-grave" and mandate that generators take responsibility for ensuring the proper treatment, storage, and ultimate disposal of their wastes.

The EPA is responsible for issuing guidelines and regulations for the proper management of solid and hazardous waste (including mixed [radioactive and hazardous] waste). In New York, the EPA has delegated the authority to issue permits and enforce these regulations to NYSDEC. In addition, the U.S. Department of Transportation is responsible for issuing guidelines and regulations for labeling, packaging, and spill reporting for hazardous and mixed wastes while in transit.

Hazardous Waste Permitting. A hazardous waste permit is required for facilities that treat or store large quantities of hazardous waste for more than 90 days or dispose of hazardous waste at the facility. In 1984, the DOE notified the EPA of hazardous waste activities at the WVDP and identified the DOE as a generator of hazardous waste.

RCRA Part A Permit Application. In 1990, to comply with Title 6 of the Official Compilation of Codes, Rules, and Regulations of the State of New York (6 NYCRR) Part 373-3, a RCRA Part A (i.e., Interim Status) Permit Application for the WVDP was filed with NYSDEC for storage and treatment of hazardous and mixed wastes. The WVDP has operated under interim status ever since. Facility operations are limited to those described in the RCRA Part A Permit Application and must comply with the interim status regulations; therefore, it must be revised prior to changes to the Project's waste management operations. February 2008 and December 2008 revisions of the RCRA Part A Permit Application are currently under NYSDEC review.

In accordance with the RCRA Part A Permit, the DOE prepared closure plans for the hazardous waste management units at the WVDP. The closure plans were transmitted to NYSDEC in anticipation of closure activities, and are revised as appropriate to address NYSDEC comments or changes in activities. In 2006, the DOE initiated clean closure of two units. Activities included NYSDEC notification of the closure schedule, removal of the waste, and decontamination of the impacted areas. As specified in the interim waste storage facility (IWSF) closure plan, clean closure confirmation sampling and analysis were performed and results were evaluated for presentation in a closure certification report. Once NYSDEC approved the IWSF closure plan in April 2008, the closure certification report was submitted and subsequently approved.

The closure plan was also submitted to and approved by NYSDEC for the lag storage building (LSB), and clean closure of the unit was performed under interim status. Clean closure confirmation sampling and analyses were performed, as specified in the closure plan, and results were evaluated for presen- 
tation in the closure certification report. NYSDEC approved the closure certification report for the LSB on July 16, 2009.

A third unit, the lag storage area (LSA) \#1 (a unit that was not used for the management of hazardous or mixed waste) was also demolished. A correspondence was transmitted to NYSDEC that documented the waste management history of the unit and requested removal from the RCRA Part A Permit Application. NYSDEC approved the closure certification report in August 2008.

6 NYCRR Part 373-2 Permit Application. In 2003, NYSDEC made an official request for the submittal of a 6 NYCRR Part 373-2 Permit Application (i.e., Part B) for the WVDP. The complete 6 NYCRR Part 373-2 Permit Application was transmitted to NYSDEC in December 2004. This application included RCRA closure plans for all interim status units that continued to be managed in accordance with the 6 NYCRR Part 373-3 Permit Application. The permit application remains in review with NYSDEC.

RCRA §3008(h) Administrative Order on Consent. Section 3008(h) of RCRA authorizes the EPA to issue an order requiring corrective action to protect human health or the environment if there has been a release of hazardous waste or hazardous constituents to the environment from an interim status facility. The DOE and NYSERDA entered into a RCRA $\S 3008(\mathrm{~h})$ Administrative Order on Consent (the Consent Order) with NYSDEC and the EPA in March 1992.

- RCRA Facility Investigation (RFI)

The Consent Order required NYSERDA and the DOE's WVDP office to conduct RFIs (unit-specific environmental investigation) at solid waste management units (SWMUs) to determine if there had been a release or if there were a potential for release of RCRAregulated hazardous constituents from SWMUs.

Because many SWMUs are contiguous, or so close together as to make their separate monitoring impractical, many SWMUs have been grouped into larger units, referred to as super SWMUs (SSWMUs). This terminology is unique to the WVDP, and is not an official regulatory term. Descriptions of the SSWMUs, with the associated constituent SWMUs, as well as the individual SWMUs, are presented in Table ECS-4. Figures A-7 and A-8 in Appendix A show the locations of the WVDP SSWMUs. The final RFI reports were submit- ted in 1997, completing the investigative activities associated with the Consent Order. No corrective actions were required at that time as a result of the RFIs.

Groundwater monitoring, as recommended in the RFI reports and approved by the EPA and NYSDEC, continued during 2008 in compliance with the requirements of the Consent Order. The groundwater monitoring results and the groundwater program at the WVDP are discussed in Chapter 4 "Groundwater Protection Program."

- Current Conditions Report

Pursuant to a request from NYSDEC, a report entitled "West Valley Demonstration Project Solid Waste Management Unit Assessment and Current Conditions Report" was submitted in November 2004. This report summarized the historic activities at individual SWMUs through the RFI activities and provided environmental monitoring data and information on site activities performed since the completion of the RFI reports.

- Corrective Measures Study (CMS)

In 2004, NYSDEC requested Corrective Measures Studies to be performed on six specific SWMUs at the WVDP. The six SWMUs were:

- NDASWMU \#2;

- NDA Interceptor Trench SWMU \#23;

- Demineralizer Sludge Ponds SWMU \#5;

- Lagoon 1 SWMU \#3;

- Construction Demolition \& Debris Landfill SWMU\#1; and

- $\quad$ The Low-Level Waste Treatment Facility SWMU \#17, \#17a, \& \#17b.

The CMS Work Plan was provided to NYSDEC and the draft reports are in internal review with the DOE, pending the outcome of the EIS process.

- Interim Measures (IM)

NRC NDA Cap - The NDA has been identified as SWMU \#9, regulated under the Consent Order. As a result of the "CMS Work Plan for Select SWMUs" and in response to Core Team comments on the work plan, the DOE evaluated engineering controls to improve the integrity of the NDA cap. Pursuant to Section VI, paragraph 7 of the Consent Order, the DOE implemented an IM to ensure a minimum 
four-foot-thick earthen cap, minimize the potential release of impacted groundwater from the NDA, and minimize water infiltration into the NDA until the final disposition of the NDA is determined and can be implemented.

Prior to inception of the NDA IM construction activities, a site visit of the NDA was completed by representatives of the DOE and the NRC to verify site conditions and to discuss the NDA cover system and erosion protection design. Soil boring tests were completed in late 2007. Field activities included excavation of a 950-foot-long trench along two sides of the disposal area. The trench was backfilled with a soil and clay mixture (slurry wall) that formed an impermeable barrier against lateral groundwater infiltration. The second part of the two-phase project involved resurfacing the entire surface of the approximately seven-acre landfill with added soils, re-grading, compaction, and application of an impermeable geomembrane cover. The action falls within the scope and intent of the CX for small-scale, short-term cleanup actions, described in 10 Code of Federal Regulations $\S 1021$, Subpart D, Appendix B, B6.1. The work was completed in the 2008 construction season.

Storm Water Runoff at the NDA - To evaluate storm water discharges associated with construction activities for capping of the NDA and installation of the slurry wall, a supplement to the existing sitewide "Storm Water Pollution Prevention Plan" (SWPPP) was prepared. The plan's intent was to identify potential sources of pollution in storm water runoff at the construction site, and to develop practices to limit potential impacts from runoff. Because this is an IM conducted under the Consent Order, NYSDEC determined that the SWPPP met the substantiative requirements of the state pollutant discharge elimination system (SPDES) general permit for storm water discharges from construction activities. Upon NYSDEC concurrence with the SWPPP, the document was incorporated into the RCRA Interim Measure Work Plan that was submitted to NYSDEC for review and approval.

Storm water management training was provided to construction personnel, and erosion and sediment control structures were installed, prior to the initiation of construction activities. Pre-construction and post-construction SWPPP inspections were performed as well as weekly inspections, and inspections following any rainfall event of 0.5 inches or more. As a result of the SWPPP training, routine inspections, and diligence of individuals involved in the day-to-day operations, potential impacts from storm water runoff during construction activities were minimized. Field geotechnical and environmental monitoring personnel frequently identified storm water quality and erosion concerns before they occurred. This enabled maintenance and modifications to erosion and sediment controls to be performed before potential problems could contribute to water quality degradation in downstream waterways.

Refer to Chapter 4, "Groundwater Protection Program," for a discussion of groundwater in the vicinity of the NDA.

\section{- Quarterly Reporting to the EPA and NYSDEC}

In accordance with the Consent Order, the DOE transmits a quarterly progress report to the EPA and NYSDEC that summarizes all Consent Order activities conducted at the WVDP for the previous quarter. The summary includes progress and accomplishments, contacts with local community interest groups and regulatory agencies, changes to personnel, projected future work activities, and an inventory of mixed waste that was generated from decontamination activities during the reporting period.

Hazardous Waste Management. Under RCRA, hazardous wastes at the WVDP are managed in accordance with 6 NYCRR Parts 370-374 and 376. Hazardous and mixed waste activities are reported to NYSDEC annually in the WVDP's Annual Hazardous Waste Report, which specifies the quantities of waste generated, treated, and/or disposed of, and identifies the treatment, storage, and disposal facilities used. The Annual Hazardous Waste Report for 2008 was submitted to NYSDEC in February 2009.

Additional reports are submitted each year to document hazardous waste reduction efforts. Pursuant to Article 27, Section 0908 of New York State Environmental Conservation Law, an annual update of the WVDP's Hazardous Waste Reduction Plan must be submitted to NYSDEC. The updates are submitted in two forms which differ slightly in scope. The plan is updated biennially to reflect changes in the types and amounts of hazardous wastes generated at the WVDP. The biennial update to the Hazardous Waste Reduction Plan for calendar year (CY) 2008 was submitted to NYSDEC on June 24, 2009. Every other year, the Annual Status Report, essentially an abbreviated version of the biennial update, is 
submitted. The CY 2007 Annual Status Report for the Hazardous Waste Reduction Program was submitted to NYSDEC on June 25, 2008.

Mixed Waste Management. Mixed waste was managed according to the "Site Treatment Plan," prepared by the DOE under requirements of the Federal Facilities Compliance Act, an amendment to RCRA. The plan describes the development of treatment capabilities and technologies for treating mixed waste. The fiscal year (FY) 2008 update brought the waste stream inventory and treatment information current to the end of FY 2008. There were five proposed milestones, and all were completed by the end of September 2008. If acceptable treatment or handling options were not available for a specific waste stream, an alternate schedule was prepared. During 2008, 3,038 cubic feet ( 86 cubic meters) of mixed waste was shipped off site for disposal. (See Table ECS-5.)

Nonhazardous, Regulated Waste Management. Nonradioactive, nonhazardous material was shipped off site to solid waste management facilities in 2008. Certain components of this waste (lead-acid batteries and spent lamps [universal wastes]) were reclaimed or recycled at off-site, authorized reclamation and recycling facilities. Digested sludge from the site sanitary and industrial wastewater treatment facility was shipped to the Buffalo Sewer Authority for disposal. Sanitary treated wastewater was routinely sampled and discharged to Erdman Brook in compliance with the WVDP's SPDES permit. Quantities of nonhazardous wastes handled in 2008 are summarized in Table ECS-5.

Waste Minimization and Pollution Prevention. Waste minimization and pollution prevention objectives are summarized under Executive Order 13423 in Table ECS1. WVES submits an annual pollution prevention report to the DOE summarizing recycling and waste generation information. See Table ECS-6, "Pollution Prevention Progress for FY 2008;" Table ECS-7, "Affirmative Procurement Accomplishments for FY 2008;" and Chapter 1, "Environmental Management System."

\section{Environmental Issues}

Unplanned Releases. No unplanned releases of pollutants or hazardous substances, radiological or nonradiological, from the WVDP occurred in 2008.

Request to EPA to Use Environmental Measurements for National Emission Standards for Hazardous Air Pollutants (NESHAP) Compliance. Radiological NESHAP compliance at the WVDP is currently demonstrated by (1) measuring (and/or estimating) radiological emissions in air released from the site during the calendar year of interest and (2) using EPA-approved computer models to estimate the dose to the maximally exposed off-site individual. This method is referred to as the "measure and model" approach, and is most suitable for point sources of air emissions such as stacks or ducts. Resulting dose estimates for the WVDP have always been far below the 10-mrem/year compliance standard. (See Chapter 3 for a discussion of dose assessment methodology.)

NESHAP regulations in 40 CFR 61 allow (with prior EPA approval) for use of an alternate method of demonstrating compliance by measuring environmental concentrations of airborne radionuclides at critical receptor locations. As facilities continue to be closed at the WVDP, the relative importance of diffuse (nonpoint) sources to dose estimates will increase as the number of point sources suitable for emission measurements decrease. Therefore, the measuring/ modeling approach for demonstrating compliance will become less representative of total WVDP emissions, and the alternative approach of environmental air sampling will become the more appropriate method.

In June 2007, the DOE submitted a plan to the EPA for approval to use environmental air measurements for demonstrating NESHAP compliance at the WVDP. In February 2009, the DOE submitted to the EPA a request for approval to proceed with demolition of the MPPB (after shutting down the MPPB ventilation system) and submitted an updated plan for implementing a program of environmental measurements to document NESHAP compliance. The plan includes a one-year period of using both the "measure and model" and the environmental measurement approaches to confirm compliance. On July 9, 2009, the EPA granted interim conditional approval for 24 months. During this period, an ambient air monitoring network around the site will be set up. Once the network is demonstrated to be satisfactory for demonstrating NESHAP compliance and all other EPA conditions are met, final approval may be granted.

Lagoon 3 Embankment Inspections. The lagoon 3 embankment was constructed in the 1960 s to manage waters from operation of the low-level wastewater treatment facility (LLWTF, now the LLW2). In 1991, surface erosion and surface soil movement was observed. A stability evaluation, conducted by Empire Soils Investigation, Inc., concluded that overall glo- 
bal or deep-seated stability of the slope was adequate and that the observed soil movement was shallow. Five test borings were installed (piezometers and inclinometers) to provide continued monitoring. During 1998, one inclinometer became unreadable and observations included surface movement in the slope, settlement, new tension cracks, and stair movement/distortion. In 2005, WVNSCO retained a NYSlicensed Professional Engineer (PE) from Empire GEO-Services, Inc. to perform a slope stability analysis which generally agreed with the original (1991) safety analysis.

Slope stability analysis demonstrates that numerous factors determine the overall stability of the slope, the major factors being: soils strength parameters, elevation of the groundwater, and the steepness of the slope. The most likely mode of slope movement at the site consists of shallow surface failures resulting from the upper portion of the indigenous soils becoming saturated from rainfall and surface waters. As a result, the lagoon 3 embankment and surrounding roadway have been inspected semiannually for stability by measuring and/or observing:

- Well and lagoon depth and elevation; and

- Conditions of the interior and exterior slopes for cracks, erosion, sliding, animal burrows, standing water, or surface seepage.

If necessary, actions for further investigation or repair are identified.

The groundwater and surface water depths and elevations are compared to pre-determined "trigger elevation levels" in an effort to maintain a calculated minimum safety factor. These triggers, if exceeded, would require the lagoon to be held at less than $60 \%$ capacity. On March 11, 2008, a trigger action elevation level was exceeded for one of the sampled wells. It was determined that a surface slope movement occurred that resulted in a break of the piezometer (well B-2/W-2) approximately 10 feet in depth from the ground elevation. Water at the break point was entering the piezometer and filled it to above the trigger level exceedance point. Follow-up actions were implemented per the standard operating procedure to close the lagoon 3 road and to maintain a water level in lagoon 3 at less than $60 \%$ capacity. Currently the lagoon slopes and roadway are inspected monthly, and the observations and measurements undergo an engineering evaluation to monitor potential changes and initiate corrective actions or repairs if required.

Proposed Congressional Legislation. In mid-2005, proposed legislation addressing the long-term responsibility for the WVDP was introduced into the U.S. House of Representatives by Congressmen Kuhl, Boehlert, Reynolds, and Higgins, and a companion bill was introduced into the U.S. Senate by Senators Schumer and Clinton. The bill, entitled "West Valley Remediation Act of 2005," included provisions for federal (DOE) takeover of the responsibility for the WVDP and the entire WNYNSC from the current owner, the state of New York. The legislation directed the DOE to complete and issue a draft of the site's decommissioning and long-term stewardship EIS within two years of enactment of the law. The bill also included a provision for minimum funding levels and prohibited any new waste from being transported to West Valley.

In 2007, the bills were reintroduced in the U.S. Senate and House of Representatives as S.81, and H.R.2476, each entitled the "West Valley Remediation Act of 2007," respectively. This proposed legislation remained in committee in both houses of Congress throughout 2008.

NYSERDA Files Suit to Determine Federal Responsibilities at the West Valley Site. On December 11, 2006, the NYSERDA Board of Directors voted to authorize legal action against the DOE over issues related to ongoing cleanup responsibilities at the West Valley site. A legal complaint was filed in U.S. District Court in Buffalo on behalf of New York State against the federal government regarding the cleanup at West Valley. NYSERDA is a plaintiff in the lawsuit, along with the state of New York and NYSDEC. New York is suing the U.S. government to clarify federal responsibilities for the West Valley site.

Since the end of 2007, the litigation has been stayed pending the outcome of discussions between the parties regarding respective cleanup responsibilities.

\section{Project Assessment Activities in 2008}

Throughout CY 2008, assessments were conducted through the Integrated Assessment Program (IAP) at the WVDP. This program effectively complies with applicable DOE directives, regulations, standards, and integrated safety management system requirements. The IAP applies to all disciplines including, but not limited to, safety and health, operations, maintenance, 
environmental protection, quality, decontamination and decommissioning, HLW activities, emergency management, business processes, and management. During CY 2008, there were 77 formal surveillances, assessments, and audits performed. In addition, inspections, reviews, and oversight activities are routinely conducted to evaluate performance, reduce risk, and identify improvement opportunities.

The local DOE Project office and other agencies with responsibilities for the WVDP also independently reviewed various aspects of the environmental and waste management programs. At the conclusion of the reporting period, there were no outstanding issues that had not been satisfactorily addressed. Overall results reflected continuing, well-managed environmental programs at the WVDP. 
TABLE ECS-3

WVDP Environmental Permits

\begin{tabular}{|c|c|c|c|c|}
\hline $\begin{array}{c}\text { Permit Name and } \\
\text { Number }\end{array}$ & $\begin{array}{c}\text { Agency/Permit } \\
\text { Type }\end{array}$ & Description & 2008 Changes & Status \\
\hline $\begin{array}{l}\text { West Valley } \\
\text { Demonstration Project } \\
\text { (WVDP) Resource } \\
\text { Conservation and } \\
\text { Recovery Act (RCRA) } \\
\text { Part A Permit } \\
\text { Application (United } \\
\text { States [U.S.] } \\
\text { Environmental } \\
\text { Protection Agency } \\
\text { [EPA] ID } \\
\text { \#NYD980779540) }\end{array}$ & $\begin{array}{l}\text { New York State } \\
\text { Department of } \\
\text { Environmental } \\
\text { Conservation } \\
\text { (NYSDEC)/ } \\
\text { Hazardous } \\
\text { Waste }\end{array}$ & $\begin{array}{l}\text { Provides interim status } \\
\text { under RCRA for } \\
\text { treatment and storage } \\
\text { of hazardous waste. }\end{array}$ & $\begin{array}{l}\text { The U.S. Department of } \\
\text { Energy (DOE) is currently } \\
\text { operating under the June } \\
2001 \text { NYSDEC-approved } \\
\text { RCRA Part A Permit } \\
\text { Application. Revisions to } \\
\text { the RCRA Part A Permit } \\
\text { Application were } \\
\text { submitted to NYSDEC for } \\
\text { review during } 2008 \text { on } \\
\text { February } 14 \text { and December } \\
\text { 18. NYSDEC approval is } \\
\text { pending. }\end{array}$ & \begin{tabular}{|l|} 
A RCRA Part 373-2 \\
Permit (i.e., Part B) \\
Application was \\
submitted to NYSDEC \\
on December 23, 2004.
\end{tabular} \\
\hline $\begin{array}{l}\text { Air Facility Registration } \\
\text { Certificate } \\
(9-0422-00005 / 00099)\end{array}$ & $\begin{array}{l}\text { NYSDEC/Air } \\
\text { Emissions }\end{array}$ & $\begin{array}{l}\text { Certificate caps nitrogen } \\
\text { oxide }\left(\mathrm{NO}_{\mathrm{x}}\right) \text { and sulfur } \\
\text { oxide }\left(\mathrm{SO}_{\mathrm{x}} \text { emissions }\right. \\
\text { from } 2 \text { boilers. }\end{array}$ & None & No expiration date. \\
\hline $\begin{array}{l}\text { Slurry-fed ceramic } \\
\text { melter (modification } \\
\text { to WVDP-687-01) } \\
\text { process building } \\
\text { ventilation }\end{array}$ & $\begin{array}{l}\text { EPA/National } \\
\text { Emission } \\
\text { Standards for } \\
\text { Hazardous Air } \\
\text { Pollutants } \\
\text { (NESHAP) } \\
\end{array}$ & $\begin{array}{l}\text { Slurry-fed ceramic } \\
\text { melter radionuclide } \\
\text { emissions - main plant } \\
\text { stack modified February } \\
18,1997 .\end{array}$ & None & \begin{tabular}{|l|} 
Permit approved \\
February $18,1997$. No \\
expiration date.
\end{tabular} \\
\hline $\begin{array}{l}\text { Vitrification Facility } \\
\text { Heating, Ventilation, } \\
\text { and Air-Conditioning } \\
\text { (HVAC) System (no } \\
\text { permit number) }\end{array}$ & EPA/NESHAP & $\begin{array}{l}\text { Vitrification facility } \\
\text { HVAC system for } \\
\text { radionuclide emissions }\end{array}$ & None & \begin{tabular}{|l|} 
Permit approved \\
February $18,1997$. No \\
expiration date.
\end{tabular} \\
\hline $\begin{array}{l}\text { 01-14 Building } \\
\text { Ventilation System } \\
\text { (WVDP-187-01) }\end{array}$ & EPA/NESHAP & $\begin{array}{l}\text { Liquid waste treatment } \\
\text { system ventilation of } \\
\text { radionuclide emissions } \\
\text { in the } 01-14 \text { building. }\end{array}$ & None & $\begin{array}{l}\text { Issued October 5, } \\
\text { 1987. Modified May } \\
\text { 25, 1989. No } \\
\text { expiration date. }\end{array}$ \\
\hline $\begin{array}{l}\text { Contact Size- } \\
\text { Reduction Facility } \\
\text { (WVDP-287-01) }\end{array}$ & EPA/NESHAP & $\begin{array}{l}\text { Contact size-reduction } \\
\text { and decontamination } \\
\text { facility radionuclide } \\
\text { emissions }\end{array}$ & None & $\begin{array}{l}\text { Issued October 5, } \\
\text { 1987. No expiration } \\
\text { date. }\end{array}$ \\
\hline $\begin{array}{l}\text { Supernatant } \\
\text { Treatment } \\
\text { System/Permanent } \\
\text { Ventilation System } \\
\text { (WVDP-387-01) } \\
\end{array}$ & EPA/NESHAP & $\begin{array}{l}\text { Supernatant treatment } \\
\text { system ventilation for } \\
\text { radionuclide emissions }\end{array}$ & None & $\begin{array}{l}\text { Modified January 1, } \\
\text { 1997. No expiration } \\
\text { date. }\end{array}$ \\
\hline
\end{tabular}

Note: Permit and license expiration dates are current as of September 2009. 
TABLE ECS-3 (continued)

WVDP Environmental Permits

\begin{tabular}{|c|c|c|c|c|}
\hline $\begin{array}{c}\text { Permit Name and } \\
\text { Number }\end{array}$ & $\begin{array}{c}\text { Agency/Permit } \\
\text { Type }\end{array}$ & Description & 2008 Changes & Status \\
\hline $\begin{array}{l}\text { Outdoor Ventilated } \\
\text { Enclosures } \\
\text { (WVDP-587-01) }\end{array}$ & EPA/NESHAP & $\begin{array}{l}\text { Fifteen portable } \\
\text { ventilation units for } \\
\text { removal of } \\
\text { radionuclides. }\end{array}$ & $\begin{array}{l}\text { Since } 2007 \text { EPA approval to } \\
\text { expand usage of PVUs from } \\
10 \text { to } 15, \text { the DOE tracks } \\
\text { usage on the basis of } \\
\text { annual cumulative } \\
\text { estimated dose. }\end{array}$ & $\begin{array}{l}\text { Issued December } 22, \\
\text { 1987. Permit } \\
\text { modification issued on } \\
\text { December } 10,2007 . \\
\text { No expiration date. }\end{array}$ \\
\hline $\begin{array}{l}\text { State Pollutant } \\
\text { Discharge Elimination } \\
\text { System (SPDES) } \\
\text { (NY0000973) }\end{array}$ & NYSDEC/Water & $\begin{array}{l}\text { Monitors discharges to } \\
\text { surface waters from } \\
\text { various on-site sources. }\end{array}$ & $\begin{array}{l}\text { An amended permit went } \\
\text { into effect on September 1, } \\
\text { 2006. A revised } \\
\text { application for SPDES } \\
\text { Permit modifications was } \\
\text { submitted to NYSDEC in } \\
\text { September and December } \\
2008 .\end{array}$ & $\begin{array}{l}\text { Although the current } \\
\text { permit expired on } \\
\text { February 1, 2009, } \\
\text { NYSDEC notified the } \\
\text { DOE that the current } \\
\text { permit will remain in } \\
\text { effect after the } \\
\text { expiration date under } \\
\text { the provisions of the } \\
\text { State Administrative } \\
\text { Procedure Act. }\end{array}$ \\
\hline $\begin{array}{l}\text { New York State } \\
\text { Department of Health } \\
\text { (NYSDOH) } \\
\text { Environmental } \\
\text { Laboratory Approval } \\
\text { Program (ELAP) } \\
\text { Certification to URS } \\
\text { Corporation, Lab ID } \\
\text { \#10474 } \\
\text { EPA Lab Code } \\
\text { NY01259 }\end{array}$ & $\begin{array}{l}\text { NYSDOH/ELAP } \\
\text { certification }\end{array}$ & $\begin{array}{l}\text { Certification of the } \\
\text { Environmental } \\
\text { Laboratory for the } \\
\text { analysis of potable and } \\
\text { nonpotable water } \\
\text { samples for specific } \\
\text { radiological and } \\
\text { nonradiological } \\
\text { constituents and for } \\
\text { asbestos in friable } \\
\text { material. }\end{array}$ & $\begin{array}{l}\text { Certification was } \\
\text { transferred from West } \\
\text { Valley Nuclear Services } \\
\text { (WVNSCO) to URS } \\
\text { Corporation in April } 2006 . \\
\text { The certificate was revised } \\
\text { to remove total suspended } \\
\text { solids from the permit. } \\
\text { The change became } \\
\text { efffective in February, } \\
2009 .\end{array}$ & $\begin{array}{l}\text { Certification renewed } \\
\text { on April 1, } 2009 . \\
\text { Certification expires } \\
\text { April 1, } 2010 .\end{array}$ \\
\hline $\begin{array}{l}\text { Buffalo Pollutant } \\
\text { Discharge Elimination } \\
\text { System (09-05-TR096) }\end{array}$ & $\begin{array}{l}\text { Buffalo Sewer } \\
\text { Authority/ } \\
\text { sanitary sewage } \\
\text { sludge disposal }\end{array}$ & $\begin{array}{l}\text { Permit issued to hauler } \\
\text { of waste from the } \\
\text { wastewater treatment } \\
\text { facility. }\end{array}$ & $\begin{array}{l}\text { Hauler renewed permit in } \\
\text { June } 2009 .\end{array}$ & $\begin{array}{l}\text { Permit expires } \\
\text { June } 30,2010 .\end{array}$ \\
\hline $\begin{array}{l}\text { Chemical Bulk Storage } \\
\text { (CBS) (\#9-000158) }\end{array}$ & $\begin{array}{l}\text { NYSDEC/ } \\
\text { regulated CBS } \\
\text { tanks }\end{array}$ & $\begin{array}{l}\text { Registration of bulk } \\
\text { storage tanks used for } \\
\text { listed hazardous } \\
\text { chemicals. }\end{array}$ & $\begin{array}{l}\text { As of May 2006, the WVDP } \\
\text { no longer has tanks } \\
\text { regulated under chemical } \\
\text { bulk storage regulations } \\
\text { (Title } 6 \text { of the New York } \\
\text { State Official Compilation } \\
\text { of Codes, Rules, and } \\
\text { Regulations, Parts } \\
595-599 \text { ) }\end{array}$ & $\begin{array}{l}\text { If regulated CBS tanks } \\
\text { are needed in the } \\
\text { future, a permit } \\
\text { application will be } \\
\text { submitted under the } \\
\text { existing CBS } \\
\text { Registration. }\end{array}$ \\
\hline
\end{tabular}

Note: Permit and license expiration dates are current as of September 2009. 
TABLE ECS-3 (concluded)

WVDP Environmental Permits

\begin{tabular}{|c|c|c|c|c|}
\hline $\begin{array}{c}\text { Permit Name and } \\
\text { Number }\end{array}$ & $\begin{array}{c}\text { Agency/Permit } \\
\text { Type }\end{array}$ & Description & 2008 Changes & Status \\
\hline $\begin{array}{l}\text { Petroleum Bulk } \\
\text { Storage (\#9-008885) }\end{array}$ & $\begin{array}{l}\text { NYSDEC/ } \\
\text { petroleum bulk } \\
\text { storage tank } \\
\text { registration }\end{array}$ & $\begin{array}{l}\text { Registration of bulk } \\
\text { storage tanks used for } \\
\text { petroleum. }\end{array}$ & $\begin{array}{l}\text { Diesel fuel tank FO-D-11 } \\
\text { was permanently closed } \\
\text { and removed from the } \\
\text { license. }\end{array}$ & $\begin{array}{l}\text { License expires } \\
\text { September 2, } 2011 .\end{array}$ \\
\hline $\begin{array}{l}\text { Asbestos-Handling } \\
\text { License } \\
\text { WVES \#33657 }\end{array}$ & $\begin{array}{l}\text { New York State } \\
\text { Department of } \\
\text { Labor } \\
\text { (NYSDOL)/ } \\
\text { asbestos } \\
\text { handling and } \\
\text { sampling } \\
\text { activities }\end{array}$ & $\begin{array}{l}\text { WVES maintains the } \\
\text { asbestos-handling } \\
\text { license and specific } \\
\text { variances for asbestos } \\
\text { handling and } \\
\text { monitoring. }\end{array}$ & $\begin{array}{l}\text { License was transferred } \\
\text { from WVNSCO to WVES } \\
\text { and renewed in September } \\
2008 .\end{array}$ & $\begin{array}{l}\text { License expires on } \\
\text { September } 30,2009 ; \\
\text { each variance has a } \\
\text { unique expiration date. }\end{array}$ \\
\hline $\begin{array}{l}\text { Bird Depredation } \\
\text { License (32) }\end{array}$ & $\begin{array}{l}\text { NYSDEC/ } \\
\text { Division of Fish } \\
\text { and Wildlife }\end{array}$ & $\begin{array}{l}\text { State license for the } \\
\text { removal of nests of } \\
\text { migratory birds. }\end{array}$ & $\begin{array}{l}\text { License was renewed on } \\
\text { October } 8,2008 .\end{array}$ & $\begin{array}{l}\text { License expires on } \\
\text { October 30, } 2009 .\end{array}$ \\
\hline $\begin{array}{l}\text { Bird Depredation } \\
\text { Permit } \\
(\text { MB747595-0) }\end{array}$ & $\begin{array}{l}\text { U.S. Fish and } \\
\text { Wildlife Service }\end{array}$ & $\begin{array}{l}\text { Federal permit for the } \\
\text { limited taking of } \\
\text { migratory birds and } \\
\text { active bird nests. }\end{array}$ & $\begin{array}{l}\text { Permit was renewed on } \\
\text { October } 8,2008 .\end{array}$ & $\begin{array}{l}\text { Permit expires } \\
\text { September 30, } 2009 .\end{array}$ \\
\hline
\end{tabular}

Note: Permit and license expiration dates are current as of September 2009. 
TABLE ECS-4

Solid Waste Management Units at the WVDP

\begin{tabular}{|c|c|c|}
\hline \multicolumn{3}{|c|}{ WVDP RCRA SSWMUs and Constituent SWMUs Identified in the RFI } \\
\hline SSWMU & SWMU \# & Constituent SWMUs \\
\hline $\begin{array}{l}\text { SSWMU \#1 - Low-Level } \\
\text { Waste Treatment Facilities } \\
\text { (LLWTF) }\end{array}$ & $\begin{array}{l}3,4,17,17 a \\
\text { and } 17 b\end{array}$ & $\begin{array}{l}\text { Former Lagoon } 1 \\
\text { LLWTF and LLWTF Lagoons 2, 3, 4, and } 5 \\
\text { Neutralization pit and interceptors }\end{array}$ \\
\hline $\begin{array}{l}\text { SSWMU \#2 - Miscellaneous } \\
\text { Small Units }\end{array}$ & $\begin{array}{l}5,6,7, \text { and } \\
10\end{array}$ & $\begin{array}{l}\text { Demineralizer sludge ponds, and solvent dike } \\
\text { Effluent mixing basin } \\
\text { Waste paper incinerator }\end{array}$ \\
\hline $\begin{array}{l}\text { SSWMU \#3 - Liquid Waste } \\
\text { Treatment System (LWTS) }\end{array}$ & $\begin{array}{l}18,22, \text { and } \\
18 a-\text { Sealed } \\
\text { Rooms }\end{array}$ & $\begin{array}{l}\text { LWTS } \\
\text { Cement solidification system } \\
\text { Sealed Rooms in the main plant process building }\end{array}$ \\
\hline $\begin{array}{l}\text { SSWMU \#4 - High-Level } \\
\text { Waste (HLW) Storage and } \\
\text { Processing Area }\end{array}$ & $\begin{array}{l}12 / 12 a, 13 \\
19, \text { and } 20\end{array}$ & $\begin{array}{l}\text { HLW vitrification facility and HLW tank farm } \\
\text { Vitrification test facility waste storage areas } \\
\text { Supernatant treatment system }\end{array}$ \\
\hline $\begin{array}{l}\text { SSWMU \#5 - Maintenance } \\
\text { Shop Leach Field }\end{array}$ & 8 & Maintenance shop leach field \\
\hline $\begin{array}{l}\text { SSWMU \#6 - Low-Level } \\
\text { Waste Storage Area }\end{array}$ & $\begin{array}{l}9 / 9 a, 15, \text { and } \\
16 / 16 a\end{array}$ & $\begin{array}{l}\text { Lag storage (LSA \#1 and \#2 Hardstands) } \\
\text { Lag storage building, Lag storage extension and Lag storage Addition } \\
\text { (LSA \#3 and \#4) }\end{array}$ \\
\hline $\begin{array}{l}\text { SSWMU \#7 - Chemical } \\
\text { Process Cell (CPC) Waste } \\
\text { Storage Area }\end{array}$ & 14 & CPC waste storage area \\
\hline $\begin{array}{l}\text { SSWMU \#8 - Construction } \\
\text { and Demolition Debris Landfill } \\
\text { (CDDL) }\end{array}$ & 1 & Construction and demolition debris landfill \\
\hline $\begin{array}{l}\text { SSWMU \#9 - NRC-Licensed } \\
\text { Disposal Area (NDA) }\end{array}$ & $\begin{array}{l}\text { 2, 11/11a, 23, } \\
\text { and } 39\end{array}$ & $\begin{array}{l}\text { NDA } \\
\text { Kerosene tanks and NDA container storage area } \\
\text { Trench interceptor project and staging area for NDA }\end{array}$ \\
\hline $\begin{array}{l}\text { SSWMU \#10 - Integrated } \\
\text { Radwaste Treatment System } \\
\text { (IRTS) }\end{array}$ & 21 & IRTS drum cell \\
\hline $\begin{array}{l}\text { SSWMU \#11 - New York State } \\
\text { Licensed Disposal Area (SDA) }\end{array}$ & NA & $\begin{array}{l}\text { The SDA is a closed radioactive waste landfill that is contiguous with } \\
\text { the Project premises and is owned and managed by the New York } \\
\text { State Energy Research and Development Authority. For more } \\
\text { information, see their website at www.nyserda.org. }\end{array}$ \\
\hline $\begin{array}{l}\text { SSWMU \#12 - Hazardous } \\
\text { Waste Storage Lockers }\end{array}$ & 24 & Hazardous waste storage lockers 1 to 4 \\
\hline
\end{tabular}

Note: The WVDP RCRA SWMUs and SSWMUs are discussed under "RCRA $\S 3008(\mathrm{~h})$ Administrative Order on Consent" on p. ECS-14. 
TABLE ECS-4 (concluded)

Solid Waste Management Units at the WVDP

\begin{tabular}{|c|c|c|}
\hline \multicolumn{3}{|c|}{ WVDP RCRA Individual SWMUs Not Associated with an SSWMU } \\
\hline \multirow{23}{*}{ Individual SWMUs } & 25 & $\begin{array}{l}\text { Inactive scrap metal landfill adjacent to bulk storage warehouse } \\
\text { (NYSERDA SWMU) }\end{array}$ \\
\hline & 26 & Subcontractor maintenance area \\
\hline & 27 & Fire brigade training area \\
\hline & 28 & Vitrification hardstand \\
\hline & 29 & Industrial waste storage area \\
\hline & 30 & Cold hardstand area near the CDDL \\
\hline & 31 & NDA trench soil container area \\
\hline & 32 & Old sewage treatment facility \\
\hline & 33 & Existing sewage treatment facility \\
\hline & 34 & Storage locations for well purge water \\
\hline & 35 & Construction and demolition area \\
\hline & 36 & Old school house septic system \\
\hline & 37 & Contact size-reduction facility \\
\hline & 38 & Drum super compactor \\
\hline & 39 & Staging area for the NDA \\
\hline & 40 & Satellite Accumulation Areas and 90-day storage areas \\
\hline & 41 & Designated roadways \\
\hline & 42 & Product storage area \\
\hline & 43 & Warehouse extension staging area \\
\hline & 44 & $\begin{array}{l}\text { Fuel receiving and storage area; high-intensity container and } \\
\text { SUREPAK }{ }^{\mathrm{TM}} \text { staging area }\end{array}$ \\
\hline & 45 & Breach in laundry wastewater line \\
\hline & 46 & Vitrification vault and empty container hardstand \\
\hline & 47 & Remote-handled waste facility \\
\hline
\end{tabular}

Note: The WVDP RCRA SWMUs and SSWMUs are discussed under “RCRA $§ 3008(\mathrm{~h})$ Administrative Order on Consent" on p. ECS-14. 
TABLE ECS-5

Summary of Waste Management Activities at the WVDP in CY 2008

\begin{tabular}{|c|c|c|c|}
\hline $\begin{array}{c}\text { Waste Description/ } \\
\text { Facility }\end{array}$ & $\begin{array}{l}\text { Type of Project } \\
\text { Generating Waste }\end{array}$ & $\begin{array}{l}\text { Quantity } \\
\text { in } 2008\end{array}$ & Discussion \\
\hline $\begin{array}{l}\text { Low-level waste } \\
\text { (LLW) }\end{array}$ & $\begin{array}{l}\text { Waste disposition and } \\
\text { shipping }\end{array}$ & $\begin{array}{c}62,500 \text { cubic feet }\left(\mathrm{ft}^{3}\right) \\
\left(1,770 \text { cubic meters }\left[\mathrm{m}^{3}\right]\right)\end{array}$ & $\begin{array}{l}\text { Waste processed, packaged, and /or } \\
\text { shipped }\left(34,700 \mathrm{ft}^{3}\left[982 \mathrm{~m}^{3}\right] \text { shipped }\right)\end{array}$ \\
\hline Mixed LLW & $\begin{array}{l}\text { Waste management } \\
\text { according to the Site } \\
\text { Treatment Plan }\end{array}$ & $\begin{array}{l}3,038 \mathrm{ft}^{3} \\
\left(86 \mathrm{~m}^{3}\right)\end{array}$ & $\begin{array}{l}\text { Waste processed, packaged, and } \\
\text { shipped }\end{array}$ \\
\hline \begin{tabular}{|l} 
Transuranic waste \\
$(\mathrm{TRU})$
\end{tabular} & Waste processing & $\begin{array}{l}21,400 \mathrm{ft}^{3} \\
\left(607 \mathrm{~m}^{3}\right)\end{array}$ & TRU waste processed (none shipped) \\
\hline Hazardous Waste & $\begin{array}{l}\text { Waste management } \\
\text { according to the Resource } \\
\text { Conservation Recovery Act } \\
\text { Part A Permit }\end{array}$ & $\begin{array}{c}150 \mathrm{ft}^{3} \\
\left(4.25 \mathrm{~m}^{3}\right)\end{array}$ & $\begin{array}{l}\text { Waste processed, packaged, and } \\
\text { shipped }\end{array}$ \\
\hline $\begin{array}{l}\text { Radiological } \\
\text { wastewater from } \\
\text { the low-level liquid } \\
\text { waste treatment } \\
\text { facility (LLW2 } \\
\text { [WNSP001]) }\end{array}$ & $\begin{array}{l}\text { NYSDEC regulates point- } \\
\text { source liquid effluent } \\
\text { discharges of treated process } \\
\text { wastewater through the } \\
\text { State Pollutant Discharge } \\
\text { Elimination System (SPDES) } \\
\text { Permit for the WVDP. }\end{array}$ & $\begin{array}{c}\text { About } 12,700,000 \text { gallons } \\
(48,100,000 \text { liters })\end{array}$ & $\begin{array}{l}\text { During } 2008 \text {, seven batches of } \\
\text { wastewater were processed through } \\
\text { the LLW2. There were no effluent limit } \\
\text { exceptions to the requirements in the } \\
\text { SPDES permit. }\end{array}$ \\
\hline \begin{tabular}{|l|} 
Treated sewage and \\
industrial \\
wastewaters \\
(WNSP007) \\
\end{tabular} & $\begin{array}{l}\text { Wastewater processing, } \\
\text { discharge }\end{array}$ & $\begin{array}{l}4,600,000 \text { gallons } \\
(17,400,000 \text { liters })\end{array}$ & $\begin{array}{l}\text { The wastewater treatment facility } \\
\text { (WWTF) treated sanitary wastewater } \\
\text { that was discharged through WNSP007 } \\
\text { in } 2008 .\end{array}$ \\
\hline $\begin{array}{l}\text { North plateau } \\
\text { groundwater } \\
\text { recovery system } \\
\text { (NPGRS) }\end{array}$ & $\begin{array}{l}\text { Pump and treat strontium-90 } \\
\text { (Sr-90) contaminated } \\
\text { groundwater }\end{array}$ & $\begin{array}{r}3,600,000 \text { gallons } \\
(14,000,000 \text { liters })\end{array}$ & $\begin{array}{l}\text { The NPGRS operated to recover } \\
\text { groundwater from an area near the } \\
\text { leading edge of the Sr-90 plume on the } \\
\text { north plateau. Water was treated by } \\
\text { ion exchange to remove Sr-90, then } \\
\text { transferred to the LLW2. }\end{array}$ \\
\hline $\begin{array}{l}\text { Nuclear Regulatory } \\
\text { Commission - } \\
\text { Licensed Disposal } \\
\text { Area groundwater } \\
\text { interceptor trench } \\
\end{array}$ & $\begin{array}{l}\text { Interceptor trench } \\
\text { (WNNDATR) and } \\
\text { groundwater pre-treatment }\end{array}$ & $\begin{array}{l}717,000 \text { gallons } \\
(2,710,000 \text { liters })\end{array}$ & $\begin{array}{l}\text { Groundwater was pumped and } \\
\text { transferred to the LLW2. No n- } \\
\text { dodecane or tributyl phosphate were } \\
\text { encountered in 2008. No pre- } \\
\text { treatment was necessary. }\end{array}$ \\
\hline $\begin{array}{l}\text { Sanitary and } \\
\text { industrial } \\
\end{array}$ & Cleanup-stabilization & $\begin{array}{c}426.3 \text { tons } \\
\text { (386.7 metric tons) }\end{array}$ & $\begin{array}{l}\text { Cleanup stabilization waste disposed as } \\
\text { trash. }\end{array}$ \\
\hline $\begin{array}{l}\text { Digested sanitary } \\
\text { sludge }\end{array}$ & Waste shipping and disposal & $\begin{array}{l}40,000 \text { gallons } \\
(151,000 \text { liters })\end{array}$ & $\begin{array}{l}\text { Digested sludge from the WWTF was } \\
\text { shipped to the Buffalo Sewer Authority } \\
\text { for disposal. }\end{array}$ \\
\hline Asbestos & $\begin{array}{l}\text { Asbestos management and } \\
\text { abatement }\end{array}$ & $\begin{array}{l}390 \text { square feet of vessel } \\
\text { insulation }\end{array}$ & $\begin{array}{l}\text { Asbestos was removed from tanks } \\
\text { inside the acid recovery cell in the mair } \\
\text { plant process building. }\end{array}$ \\
\hline
\end{tabular}


TABLE ECS- 6

Pollution Prevention Progress for FY 2008

\begin{tabular}{|c|c|}
\hline Recycled Materials & 2008 Quantity (tons/metric tons) \\
\hline Office and mixed paper & 16.4 tons (14.9 metric tons) \\
\hline Corrugated cardboard & 4.49 tons ( 4.07 metric tons) \\
\hline Stainless steel & 11.2 tons (10.2 metric tons) \\
\hline Iron & 45.9 tons ( 41.6 metric tons) \\
\hline Aluminum cans & 0.09 tons ( 0.08 metric tons) \\
\hline Toner cartridges & 0.76 tons ( 0.69 metric tons) \\
\hline Batteries & 3.51 tons ( 3.18 metric tons) \\
\hline Concrete & 165 tons (150 metric tons) \\
\hline Fluorescent bulbs & 0.54 tons ( 0.49 metric tons) \\
\hline Plastic & 0.15 tons ( 0.13 metric tons) \\
\hline Styrofoam & 0.010 tons ( 0.009 metric tons) \\
\hline Wood pallets & 2.26 tons ( 2.05 metric tons) \\
\hline Electronics (electronics reuse \& recycling campaign) & 1.34 tons (1.22 metric tons) \\
\hline \multicolumn{2}{|c|}{ Other Accomplishments - Transfer or Sale of Excess Material } \\
\hline $\begin{array}{l}\text { Transfered vit test facility mock-up area, radiologically } \\
\text { clean, leaded glass shield window back to manufacturer } \\
\text { for reuse as opposed to disposal as a hazardous material. }\end{array}$ & $\begin{array}{l}\text { The window weighed } 7 \text { tons ( } 6.35 \text { metric tons), with an } \\
\text { estimated cost avoidance of } \$ 15,000\end{array}$ \\
\hline $\begin{array}{l}\text { Excess materials transferred for reuse to other DOE } \\
\text { facilities, federal and state agencies, DOE-sponsored } \\
\text { programs, public auctions and sales }\end{array}$ & $\begin{array}{l}\$ 1,750,000 \text { worth of excess materials (based upon } \\
\text { estimated and/or actual acquisition costs) }\end{array}$ \\
\hline
\end{tabular}

TABLE ECS-7

Affirmative Procurement Accomplishments for FY 2008

\begin{tabular}{|l|c|}
\multicolumn{1}{|c|}{ Environmentally Preferable Products } & Amount Purchased \\
\hline Plastic envelopes & $\$ 1,001$ \\
\hline Plastic trash bags & $\$ 70,975$ \\
\hline Printer ribbons & $\$ 1,410$ \\
\hline Toner cartridges & $\$ 7,022$ \\
\hline Sanitary tissue products & $\$ 25,146$ \\
\hline Paperboard and packaging products & $\$ 846$ \\
\hline Uncoated printing papers & $\$ 27,309$ \\
\hline Re-refined lubricating oil & $\$ 663$ \\
\hline Bristols (file folders, card stock, tags) & $\$ 25$ \\
\hline Newsprint & $\$ 102$ \\
\hline Park benches and picnic tables & $\$ 777$ \\
\hline
\end{tabular}


TABLE ECS-8

WVDP 2008 Air Quality Noncompliance Episodes

\begin{tabular}{|l|c|c|c|c|}
\hline \multicolumn{1}{|c|}{ Permit Type } & Facility & Parameter & Date(s) Exceeded & $\begin{array}{c}\text { Description/ } \\
\text { Solutions }\end{array}$ \\
\hline EPA NESHAP & All & All & None & None \\
\hline NYSDEC Air & All & All & None & None \\
\hline
\end{tabular}

Note: There were no episodes of noncompliance in 2008.

TABLE ECS-9

Status of EPCRA (SARA Title III) Reporting at the WVDP in 2008

\begin{tabular}{|l|l|l|}
\hline \multicolumn{1}{|c|}{ EPCRA Section } & \multicolumn{1}{|c|}{ Description of Reporting } & \multicolumn{1}{c|}{ Submission to EPA } \\
\hline EPCRA 302-303 & Planning Notification & Not Required \\
\hline EPCRA 304 & Extremely Hazardous Substance Release Notification & Not Required \\
\hline EPCRA 311 & Material Safety Data Sheet & Not Required \\
\hline EPCRA 312 & Hazardous Chemical Inventory & Required \\
\hline EPCRA 313 & Toxic Release Inventory Reporting & Not Required \\
\hline
\end{tabular}

TABLE ECS-10

Reportable Chemicals Above EPCRA 312 Threshold Planning Quantities (TPQ) Stored at the WVDP in 2008

\begin{tabular}{|l|l|l|}
\hline \multicolumn{2}{|c|}{ Chemicals Stored at the WVDP in 2008 Above TPQ } \\
\hline Diesel fuel \#2 & lon-exchange media & Sulfuric acid \\
\hline Gasoline & Sodium hydroxide & Lead-acid batteries \\
\hline Oils - various grades & NA & NA \\
\hline
\end{tabular}

Note: The liquid nitrogen tank was emptied in August 2007, but remains available for future use.

TABLE ECS-11

WVDP 2008 NPDES/SPDES ${ }^{a}$ Permit Noncompliance Episodes

\begin{tabular}{|l|c|c|c|c|c|c|}
\hline Permit Type & Outfall(s) & Parameter & $\begin{array}{c}\text { No. of Permit } \\
\text { Exceptions }\end{array}$ & $\begin{array}{c}\text { No. of Samples } \\
\text { Taken }\end{array}$ & $\begin{array}{c}\text { No. of } \\
\text { Compliant } \\
\text { Samples }\end{array}$ & $\begin{array}{c}\text { Percent } \\
\text { Compliant } \\
\text { Samples }\end{array}$ \\
\hline SPDES & All & All & 0 & 1,669 & 1,669 & $100 \%$ \\
\hline
\end{tabular}

a Radionuclides are not regulated under the site's SPDES permit. However, special requirements in the permit specify that the concentration of radionuclides in the discharge is subject to requirements of DOE Order 5400.5 . 
TABLE ECS-12

WVDP Migratory Bird Nest Depredation Episodes in 2008

\begin{tabular}{|l|l|c|c|}
\hline \multicolumn{1}{|c|}{ Permit/License Type } & Parameter & $\begin{array}{c}\text { Permit/License } \\
\text { Limit }\end{array}$ & $\begin{array}{c}\text { Total Removed } \\
\text { in 2008 }\end{array}$ \\
\hline $\begin{array}{l}\text { U.S. Fish and Wildlife - } \\
\text { Bird Depredation Permit }\end{array}$ & Removal of Active Barn Swallow Nests & 15 & 0 \\
\hline $\begin{array}{l}\text { U.S. Fish and Wildlife - } \\
\text { Bird Depredation Permit }\end{array}$ & Removal of Active American Robin Nests & 15 & 0 \\
\hline $\begin{array}{l}\text { U.S. Fish and Wildlife - } \\
\text { Bird Depredation Permit }\end{array}$ & Removal of Active Eastern Phoebe Nests \\
\hline $\begin{array}{l}\text { U.S. Fish and Wildlife - } \\
\text { Bird Depredation Permit }\end{array}$ & Removal of Active Canada Goose Nests & 5 & 1 \\
\hline $\begin{array}{l}\text { NYSDEC - Bird Depredation } \\
\text { License }\end{array}$ & Removal of Inactive Migratory Bird Nests & Not limited & 0 \\
\hline
\end{tabular}


This page intentionally left blank 


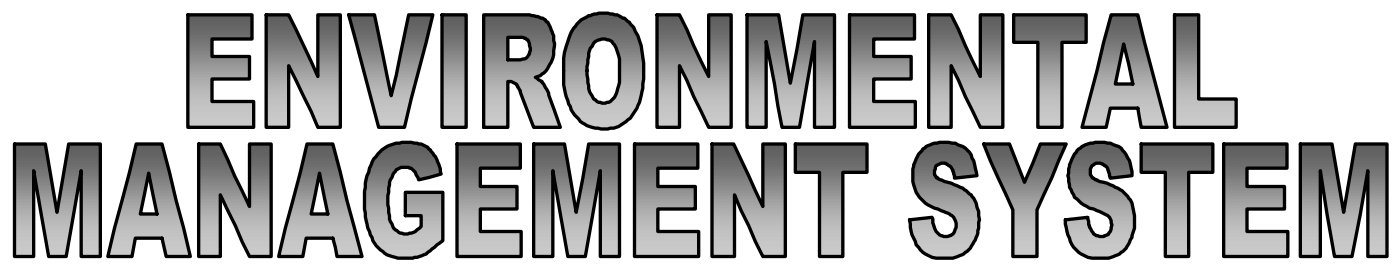

\section{Integrated Safety Management System (ISMS) Implementation}

A plan to integrate environmental, safety, and health (ES\&H) management programs at the West Valley Demonstration Project (WVDP or Project) was developed and initiated in 1998. Implementation of an ISMS at the WVDP was verified by the United States (U.S.) Department of Energy (DOE) in November 1998. Environmental subject matter experts routinely participate in a site-wide work review group to review work plans, identify ES\&H concerns, and specify practices that ensure work is performed safely. For the purposes of this policy, the term "safety" includes environmental, radiological, industrial/chemical, and nuclear safety and health and encompasses the public, workers, and the environment.

\section{Environmental Management System (EMS)}

During the development of the ISMS, EMS was identified as an integral part of the ISMS. The WVDP EMS satisfies the requirements of DOE Order 450.1A, "Environmental Protection Program." On June 4, 2008, the Deputy Secretary approved DOE Order 450.1A which revised the previous DOE Order 450.1 to incorporate and implement the new requirements of Executive Order (E.O.) 13423, Strengthening Federal Environmental, Energy, and Transportation Management (issued in January 2007) and instructions for implementing the Order. As a result, there are four new requirements for an EMS:

- An EMS is to reflect the EMS elements and framework found in International Organization for Standardization (ISO) 14001:2004, Environmental Management Systems, and serve as the primary management approach for addressing the environmental aspects of agency operations and activities, including energy and transportation functions.

- An EMS shall include specified compliance management elements, including an environmental compliance audit program that identifies compliance needs and possible root causes of non-compliance.
- An EMS shall include site-specific goals and targets that contribute to the achievement of DOE sustainable environmental stewardship goals and energy transportation goals.

- Each EMS must have a formal audit by a qualified party outside the control or scope of the EMS before declaring initial implementation of the EMS, and every three years thereafter.

In compliance with the fourth requirement, an independent third party audit of the EMS was conducted in May 2009. As a result of this audit, on June 11, 2009, WVES submitted a declaration to the DOE-WVDP that the EMS at the WVDP is fully implemented, consistent with the requirements of DOE 450.1A.

There are challenges at the WVDP to meet the new sustainability practices in E.O. 13423, as the WVDP is currently into the closure portion of its life cycle. The goals and objectives of E.O. 13423 have been evaluated using the graded approach that takes into consideration that all buildings and infrastructure will be demolished in the coming years. Another challenge is to ensure that subcontractors perform work in accordance with the site's EMS. This was accomplished through submittal and review of detailed work documents by environmental affairs personnel. Yet another challenge has been to ensure the subcontractor "way of thinking" about environmental safety culture is consistent with the site's EMS. This has been accomplished through enhanced communication of safety expectations, hazard recognition, and assignment of a safety department member as a subcontractor point of contact.

The Project's EMS provides the basic policy and direction for work at the WVDP through procedures that support proactive management, environmental stewardship, and the integration of appropriate technologies throughout all aspects of work. The environmental monitoring program is an important component of the EMS and accomplishment of its mission.

As the Western New York Nuclear Service Center is no longer an active nuclear fuel reprocessing facility, the environmental monitoring program at the WVDP fo- 
cuses on measuring radioactivity and chemical constituents associated with the aged residual by-products of former Nuclear Fuel Services Inc. operations, the Project's former high-level radioactive waste (HLW) treatment operations, and the current operations for management of HLW, transuranic waste, and low-level radioactive waste (LLW). On June 29, 2007. West Valley Environmental Services LLC (WVES) was awarded the WVDP Interim End-State Contract (Contract DEAC30-07CC30000) that includes in its scope waste disposition, decontamination, deactivation, disposition of facilities, and infrastructure/landlord activities.

Elements of the WVDP EMS implementation are summarized in Table 1-1.

The Project's ISMS and EMS policies are integrated into all aspects of work at the WVDP. The following sections depict accomplishments at the WVDP associated with specific 2008 EMS activities.

\section{Environmental Policy}

Activities at the WVDP during 2008 were conducted in full compliance with applicable environmental statutes, DOE directives, executive orders, and state laws and regulations. Refer to Table ECS-1, "Compliance Status Summary for the WVDP in CY 2008," for details.

\section{Environmental Aspects and Impacts}

Since the Project work scope currently encompasses waste disposition, decontamination, deactivation, disposition of facilities, and infrastructure reduction, the significant environmental aspects of current site activities are related to decommissioning and demolition activities. For each facility or structure that is under consideration for demolition, the base environmental aspects have been identified. These aspects are addressed during work planning with the assistance of the Hazard Control Specialists. In addition, before a building may be demolished, a Demolition Readiness Checklist which captures many of these environmental aspects, must be completed.

\section{Legal and Other Requirements}

Requirements contained in DOE orders and directives are incorporated into the WVDP Interim End-State Contract with WVES as specific terms and conditions. The WVES Environmental Affairs (EA) Department conducts environmental regulatory reviews to identify, evaluate, and document changes to applicable environmental regulations. Items that have an effect upon compliance activities at the WVDP are communicated to EA and other Project personnel.

\section{Objectives and Targets}

National Environmental Performance Track. In 2000, the U.S. Environmental Protection Agency (EPA) recognized the WVDP as a charter member of the Performance Track (P-Track) Program for implementation of its EMS. The focus of the P-Track was to ensure that the EMS has sufficient programs in place to perform effectively, and to identify and address opportunities to improve environmental performance.

The WVDP completed two three-year rounds of environmental commitments under the EPA P-Track. Using calendar year (CY) 2000 as a baseline, the WVDP accomplished four initial commitments from CYs 2001 through 2003. Next, using CY 2003 as a baseline, the WVDP accomplished three additional performance goals from 2004 through 2006. WVES renewed its application to the program by identifying four new commitments to be accomplished in 2007 through 2009, with 2006 as the baseline. Annual reports to the EPA summarizing progress toward achieving these commitments included topics such as results from EMS audits, issues and corrective actions, reporting, and public outreach.

The EPA made the decision to halt this program on March 16, 2009. Even so, WVES, in conjunction with the DOE, submitted the P-Track annual perfomance report for 2008 to the EPA in March 2009 to demonstrate the WVDP's progress toward its performance commitments and to preserve the data in the EPA's database. The 2008 goals, and progress toward achieving these goals, were as follows:

- to reduce total non-transportation energy usage by $5 \%$ : total energy used was reduced by $36.1 \%$ in CY 2008;

- to reduce the amount of liquid nitrogen used in the waste tank farm by $10 \%$ : liquid nitrogen usage was reduced by $100 \%$ in CY 2008 ;

- to reduce the amount of resins used for the treatment of radiologically contaminated wastewater generated by plant operations by $10 \%$ : resin usage was reduced by $25.6 \%$ in CY 2008; and

- to reduce the amount of $\mathrm{SO}_{\mathrm{x}}$ air emissions from non-transportation sources by $10 \%$ : $\mathrm{SO}_{\mathrm{x}}$ emissions were reduced by $64.3 \%$ in CY 2008. 
TABLE 1-1

Elements of the Environmental Management System (EMS) at the WVDP

\begin{tabular}{|c|c|}
\hline EMS Element & WVDP Implementation \\
\hline Environmental Policy & $\begin{array}{l}\text { The environmental policy at the West Valley Demonstration Project (WVDP) is to conduct } \\
\text { all activities, including design, construction, testing, startup, commissioning, operation, } \\
\text { maintenance, and decontamination and decommissioning in a manner appropriate to the } \\
\text { nature, scale, and environmental impacts of these activities. West Valley Environmental } \\
\text { Services LLC (WVES) is committed to full compliance with applicable federal and New } \\
\text { York State laws and regulations for the protection of the environment, continual } \\
\text { improvement, the prevention and/or minimization of pollution, and public outreach, } \\
\text { including stakeholder involvement. }\end{array}$ \\
\hline $\begin{array}{l}\text { Environmental Aspects } \\
\text { and Impacts }\end{array}$ & $\begin{array}{l}\text { When operations have an environmental aspect, WVES implements the EMS to minimize } \\
\text { or eliminate any adverse potential impact. Implementation of an EMS is a prerequisite for } \\
\text { the United States (U.S.) Environmental Protection Agency (EPA) National Environmental } \\
\text { Performance Track (P-Track) awarded by the EPA to the WVDP. Using the EMS, WVDP } \\
\text { employees evaluate operations, identify the aspects of operations that can impact the } \\
\text { environment, and determine those impacts that are significant. The following operational } \\
\text { aspects have been determined to have the potential to affect the environment: } \\
\text { - Waste generation, management, and decontamination activities; } \\
\text { - Atmospheric emissions and liquid effluents; } \\
\text { - Storage or use of chemicals and radioactive materials; } \\
\text { - Natural resource usage and noise disturbance; and } \\
\text { - Disturbances to soil and to endangered species/protected habitats. }\end{array}$ \\
\hline $\begin{array}{l}\text { Legal and Other } \\
\text { Requirements }\end{array}$ & $\begin{array}{l}\text { WVES has implemented an environmental regulatory review and assessment process to } \\
\text { deliver WVDP-level requirements and guidance to all staff. New or revised requirements } \\
\text { (e.g., new regulations) are analyzed to determine their applicability to the WVDP and to } \\
\text { identify whether actions are required to achieve compliance. This may involve developing } \\
\text { or revising WVDP documents or operating procedures, implementing administrative } \\
\text { controls, providing training, installing engineered controls, or increasing monitoring. }\end{array}$ \\
\hline Objectives and Targets & $\begin{array}{l}\text { The performance-based management system is designed to develop, align, balance, and } \\
\text { implement the strategic objectives for the WVDP, including environmental objectives. } \\
\text { Objectives and targets are developed by calendar year (CY). For the three-year period of } \\
\text { CY } 2007-2009, \text { WVES defined four commitments under the EPA P-Track. These } \\
\text { commitments, and progress toward achieving the objectives, are presented later in this } \\
\text { chapter. }\end{array}$ \\
\hline $\begin{array}{l}\text { Environmental } \\
\text { Management Program }\end{array}$ & $\begin{array}{l}\text { A pollution prevention program to conserve resources and minimize waste generation is } \\
\text { implemented at the WVDP. The budgeting system is designed to ensure that priorities are } \\
\text { balanced and that resources essential to the implementation and control of the EMS are } \\
\text { provided. }\end{array}$ \\
\hline $\begin{array}{l}\text { Structure and } \\
\text { Responsibility }\end{array}$ & $\begin{array}{l}\text { All employees at the WVDP have specific roles and responsibilities in key areas, including } \\
\text { environmental protection. Environmental and waste management technical support } \\
\text { personnel assist the line organization with their environmental responsibilities. }\end{array}$ \\
\hline $\begin{array}{l}\text { Training, Awareness, } \\
\text { and Competence }\end{array}$ & $\begin{array}{l}\text { Training on EMS requirements has been provided to staff whose responsibilities include } \\
\text { environmental protection. The training program includes general environmental } \\
\text { awareness for all employees, regulatory compliance training for select staff, and specific } \\
\text { courses for managers, internal assessors, EMS implementation teams, and operations } \\
\text { personnel whose work can impact the environment. }\end{array}$ \\
\hline
\end{tabular}


TABLE 1-1 (concluded)

Elements of the Environmental Management System (EMS) at the WVDP

\begin{tabular}{|c|c|}
\hline EMS Element & WVDP Implementation \\
\hline $\begin{array}{l}\text { Communication and } \\
\text { Community } \\
\text { Involvement }\end{array}$ & $\begin{array}{l}\text { The WVDP representatives continue to improve internal and external communications on } \\
\text { environmental issues. Communications with the local stakeholders include monthly } \\
\text { meetings with the Citizen Task Force and meeting with the general public on a quarterly } \\
\text { basis. Project information, including this entire Annual Site Environmental Report, is } \\
\text { available on the internet at http://www.wv.doe.gov. Notable community involvement } \\
\text { activities included participation in the United Way Day of Caring, supporting local food } \\
\text { banks, and the mentoring program with local schools. }\end{array}$ \\
\hline EMS Documentation & $\begin{array}{l}\text { Comprehensive, up-to-date environmental policies are written to describe the EMS. } \\
\text { These procedures and manuals inform staff how to control processes and perform work } \\
\text { at the WVDP in a manner that protects the environment. }\end{array}$ \\
\hline Document Control & $\begin{array}{l}\text { A comprehensive electronic document control system to ensure the effective } \\
\text { management of procedural documents is maintained. When facilities require additional } \\
\text { procedures to control their work, document-control protocols are implemented to } \\
\text { ensure that workers have access to the current version of procedures. }\end{array}$ \\
\hline Operational Control & $\begin{array}{l}\text { Operations are evaluated for the adequacy of current controls to prevent impacts to the } \\
\text { environment. As needed, additional administrative or engineered controls are identified } \\
\text { and plans for upgrades and improvements are developed and implemented. }\end{array}$ \\
\hline $\begin{array}{l}\text { Emergency } \\
\text { Preparedness and } \\
\text { Response }\end{array}$ & $\begin{array}{l}\text { An emergency preparedness and response program with specialized staff provides timely } \\
\text { response to hazardous material releases or other environmental emergencies. This } \\
\text { program includes procedures for preventing, as well as responding to, emergencies. }\end{array}$ \\
\hline $\begin{array}{l}\text { Monitoring and } \\
\text { Measurement }\end{array}$ & $\begin{array}{l}\text { Liquid effluent and air-emission monitoring helps ensure the effectiveness of controls, } \\
\text { adherence to regulatory requirements, and timely identification and implementation of } \\
\text { corrective measures. A comprehensive, sitewide environmental monitoring program is in } \\
\text { place at the WVDP. Results are reported to regulatory agencies and summarized in this } \\
\text { ASER. In addition, monitoring data are assessed for adverse trends to determine site } \\
\text { performance, impacts from site conditions, and the need for preventative or corrective } \\
\text { measures. }\end{array}$ \\
\hline $\begin{array}{l}\text { Nonconformance and } \\
\text { Corrective and } \\
\text { Preventive Actions }\end{array}$ & $\begin{array}{l}\text { The WVDP employees continue to implement processes that identify and correct } \\
\text { problems. This includes a lessons learned program to prevent recurrences, robust self- } \\
\text { assessment and environmental assessment programs, and an electronic action tracking } \\
\text { system. }\end{array}$ \\
\hline Records & $\begin{array}{l}\text { EMS-related records, including audit and training records, are maintained to ensure } \\
\text { integrity, facilitate retrieval, and protection from loss. }\end{array}$ \\
\hline EMS Audit & $\begin{array}{l}\text { To periodically verify that the EMS is operating as intended, assessments are conducted } \\
\text { by the DOE and its contractors. These assessments are designed to ensure that } \\
\text { nonconformances are identified and addressed. In addition, compliance with regulatory } \\
\text { requirements is verified through routine inspections, operational evaluations, and } \\
\text { periodic assessments and self-assessments. }\end{array}$ \\
\hline Management Review & $\begin{array}{l}\text { In addition to audits, a management review process has been established to involve top } \\
\text { management in the overall assessment of environmental performance, the EMS, and } \\
\text { progress toward achieving environmental goals. This review also identifies, as necessary, } \\
\text { the need for changes to and continual improvement of the EMS. }\end{array}$ \\
\hline
\end{tabular}




\section{Environmental Management Program}

An environmental management program is a key element to the successful implementation of an EMS. An integral part of the WVDP environmental management program is the "Waste Minimization and Pollution Prevention Awareness Plan" (WMin/P2). The plan established the strategic framework for integrating waste minimization and pollution prevention into waste generation and reduction activities, the procurement of recycled products, the reuse of existing products, and the use of methods that conserve energy. The program is a comprehensive and continual effort to prevent or minimize pollution, with the overall goals of reducing health and safety risks, and protecting the environment. Refer to the EPA PTrack progress described above. Also refer to the Environmental Compliance Summary Table ECS-6, "Pollution Prevention Progress for fiscal year (FY) 2008," and Table ECS-7, "Affirmative Procurement Accomplishments for FY 2008."

\section{Training, Awareness, and Competence}

Human performance/behavior-based safety (HP/BBS) training is conducted across the site. Project personnel are trained to HP/BBS concepts and practices, and HP/BBS observer technique training is provided for safety department and safety observers. Self-assessment activities are also stressed as a mechanism for evaluating, improving, and maintaining worker safety. WVES operated the WVDP throughout 2008 in a safe manner that was protective of its workers, the public, and the environment.

- WVES achieved 1.24 million work hours without a lost-time work accident or illness. By the close of 2008, collectively, the WVDP's workforce had worked 85 consecutive weeks without a lost-time work injury or illness. The WVDP had 11 first-aid incidents and one recordable injury in 2008.

- The site's excellent safety performance earned the WVDP one of the best Total Recordable Case Rate records in the DOE's Environmental Management complex in 2008.

- WVES earned the URS Washington Division President's Award for Safety in 2008, for achieving one million work hours without a lost time work injury in one year.

- Radiological safety at the site was carried out with no reportable contamination incidents while con- ducting complicated, hazardous work in a number of radiological areas, including main plant process building (MPPB) dismantlement activities, waste processing, waste shipping, and special projects.

- All environmental deliverables were on or ahead of schedule with no regulatory notices of noncompliance and no nuclear safety program violations, including full Technical Safety Requirement compliance.

Voluntary Protection Program (VPP) STAR Status. In May 2000, West Valley Nuclear Services Company (WVNSCO) received its first certification of the WVDP as a VPP STAR Site for recognition of excellent worker safety and health programs. During the conclusion of a triennial recertification visit by the DOE-VPP Team on June 26, 2008 the decision was made to retire the WVNSCO STAR on the basis that WVES was a new company, therefore ineligible for recertification under the original WVNSCO STAR. WVES was assigned an interim STAR and has subsequently submitted an application. WVES is awaiting a certification visit by the DOE-VPP Team.

10 Code of Federal Regulations (CFR) 851, "Worker Safety and Health Program." 10 CFR 851 became effective in February 2007, with full implementation at the WVDP by May, 2007. The law superseded DOE Order 440.1A, "Worker Protection Management for DOE Federal and Contractor Employees," which directed compliance with specific Occupaton Safety and Health (OSHA) requirements.

Similar to OSHA, the rule established the framework for an effective worker safety and health program to provide DOE contractor workers with a safe and healthful workplace in which workplace hazards are abated, controlled or otherwise mitigated in a matter that provides reasonable assurance that workers are adequately protected from identified hazards. To accomplish this objective, the law established program requirements specific to management responsibilities, worker rights, hazard identification and prevention, safety and health standards, required training, recordkeeping and reporting.

In compliance, WVES personnel revised procedures and programs to comply with 10 CFR 851 , and issued the "WVDP Worker Safety and Health Plan" for DOE approval. Any modification, addition, or deletion that could invalidate a portion of the worker health and safety program requires approval by the DOE. The 
significant impacts to the workforce are: (1) WVES is subject to inspection by the DOE and can be cited and fined for any violation, (2) fire protection inspection frequencies increased to weekly or monthly from the current schedule, (3) WVDP-310, Addendum 1, "WVDP Worker Safety and Health Plan," was developed, which describes how the WVDP complies with 10 CFR 851, and (4) violations to 10 CFR 851 are tracked.

Any person working at the WVDP who has a personal photo badge allowing unescorted access to administrative areas of the site receives general employee training that covers health and safety, emergency response, and environmental compliance issues. All visitors to the WVDP receive a site-specific briefing on safety and emergency procedures.

Hazardous waste operations and emergency response regulations require that employees at treatment, storage, and disposal facilities receive training appropriate to their job function and responsibilities. The WVDP environmental, health, and safety training matrix identifies the specific training requirements for such employees.

Training programs include, but are not limited to:

- 24-hour/40-hour hazardous waste operations;

- emergency spill-response training;

- decontamination techniques;

- waste minimization and pollution prevention;

- the WVDP environmental management program;

- radiation hazards and warnings;

- dosimetry and respiratory protection;

- medical emergency response training; and

- electrical safety and fire protection.

Training programs have evolved into a comprehensive curriculum of knowledge and skills necessary to maintain the health and safety of employees and ensure the continued compliance of the WVDP with applicable regulations and requirements.

Safety-Trained Supervisor (STS) Program. Since November 2003, WVNSCO/WVES has maintained an STS certification program whereby employees complete an extensive program to become safety-certified. Certification and renewal requirements include at least 30 hours of safety-related training and successful completion of a certification exam. Standards, established by the Council on Certification of Health, Environmental, and Safety Technologists, ensure that certified individuals have a broad under- standing of industrial safety. The benefits at the site include increased safety awareness among employees, an improved site safety culture, and increased confidence when dealing with safety and health matters during the planning and field phases of work. Currently there are 63 certified WVES safety-trained supervisors at the WVDP.

\section{Communication and Community Involvement}

On December 5, 2008, the DOE issued a notice of public availability for the draft Environmental Impact Statement (EIS) for Decommissioning and/or Long-Term Stewardship at the West Valley Demonstration Project and the Western New York Nuclear Service Center (DOE-EI0226-D [Revised]) (referred to as the draft Decommissioning EIS). This notice of availability began the six-month public review and comment period. With the issuance of the draft Decommissioning EIS, subject matter experts from the WVDP continued to improve communications regarding environmental issues related to the site. In addition to regularly scheduled meetings with the Citizens' Task Force and the quarterly meetings to other public stakeholders, site representatives participated in numerous briefings and presentations regarding the Draft Decommissioning EIS.

Representatives from the WVDP also continued to support community-based efforts through volunteer involvement in organizations and non-profit and charitable causes.

\section{Operational Control}

U.S. Nuclear Regulatory Commision (NRC)-Licensed Disposal Area (NDA) Interceptor Trench and Pretreatment System. Radioactively contaminated ndodecane, in combination with tributyl phosphate (TBP), was discovered in groundwater at the northern boundary of the NDA in 1983, shortly after the DOE assumed control of the WVDP. To mitigate subsurface migration of this radioactive organic mixture, an interceptor trench and liquid pre-treatment system (LPS) were installed.

As in previous years, $\mathrm{n}$-dodecane/TBP contamination was not detected in the trench water; therefore, no water was treated by the LPS in 2008. Approximately 717,000 gallons $(2,710,000$ liters $)$ of radiologically contaminated water were pumped and transferred from the interceptor trench to the low-level waste treatment facility (LLW2) during CY 2008. Refer to the 
"Environmental Compliance Summary" for a discussion of the interim measure to construct a cap over the NDA and discussion of the installation of the slurry wall upgradient of the NDA. Refer also to Chapter 4, "Groundwater Protection Program," under "Groundwater Sampling Observations on the South Plateau: Weathered Lavery Till and the NDA" for a discussion of results of surface and groundwater monitoring in the vicinity of the NDA.

Process Sewer Integrity Evaluation. Video inspection of camera-accessible process sewer lines was initiated in 2003, and a breach was identified in a tributary line allowing laundry wastewater to discharge to subsurface soil. Wastewater from the laundry was immediately directed through an alternate pipeline to the LLW2, and the breached line was taken out of service. Following full investigations and reporting to the New York State Department of Environmental Conservation (NYSDEC), a New York State-licensed professional engineer (PE) performed an integrity evaluation of the process sewer system and prepared a final report that identified actions to be implemented. The initial recommendations of the PE have been completed. The final recommendation, to perform routine cleaning and reinspection of accessible main service lines and operational clean-out risers, is in the planning stages for completion by November 2009.

\section{Emergency Preparedness and Response}

During 2008, quarterly exercises were conducted to evaluate the ability to activate and declare the emergency operations center and the technical support center "operational" in a timely manner. The exercises are performed to ensure that all members of the emergency response organization (ERO) respond in accordance with site emergency response procedures in the event of health, safety, or environmental emergencies.

On August 26, 2008, off-site emergency response organization personnel attended the annual WVDP offsite emergency responders training. The training content included: (1) an overview of the WVDP and the state disposal area; (2) the WVDP incident command structure and response program; (3) review of potential site hazards, including radiological response; and (4) changes associated with the new WVES contract. Organizations invited included surrounding fire departments, hazmat response teams, medical centers, law enforcement, and NYSDEC.
On September 22, 2008, a triennial emergency exercise (TRIEX 2008) was conducted at the WVDP to assess the WVDP ERO communication and interface with off-site organizations, and the WVDP emergency management plan and implementation procedures. The exercise was conducted with observers and evaluators and included participation from over 60 individuals, both internal and external to the WVDP. Organizations participating in the exercise included WVES ERO, WVDP participating organizations, DOE-Headquarters, DOE-WVDP office, Cattaraugus County Emergency Services, Cattaraugus County sheriff, and Bertrand Chaffee Hospital. Thirteen objectives were evaluated during the exercise. Several of them were developed to address emergency communications. Upon evaluation of the TRIEX, all 13 exercise objects were "met," with improvement items identified. Improvement items with respect to radiation safety control of contaminated areas and communication among emergency response groups were incorporated into a corrective action plan.

\section{Environmental Monitoring and Measurement}

Human beings are exposed to radioactivity from site activities primarily through air, water, and food. All three potential exposure pathways are monitored at the WVDP, but air and surface water pathways are the two primary means by which radioactive material can move off site.

The on-site and off-site monitoring program at the WVDP includes measuring the concentration of alpha and beta radioactivity, conventionally referred to as "gross alpha" and "gross beta," in air and water effluents. Measuring the total alpha and beta radioactivity from key locations produces a comprehensive picture of on-site and off-site levels of radioactivity from all sources. Frequent updating and tracking of the gross radioactivity in effluents is required to maintain acceptable operations.

More-detailed measurements are also made for specific radionuclides. The radionuclides monitored at the Project are those that might produce relatively higher doses or that are most abundant in air and water effluents. Because man-made sources of radiation at the Project have been decaying for more than 35 years, the monitoring program does not routinely include short-lived radionuclides, that is, isotopes with a half-life of less than two years, which would be present at less than $1 / 100,000$ of the original radioactivity levels. 
The WVDP monitoring program includes monitoring wastewater discharges and storm water for nonradiological water quality and chemical constituents. See Appendix A for the schedule of sample locations and analytical requirements and Chapter 2 for a discussion of nonradiological program information.

Environmental Management of Wastewater. Water containing radioactive material from site process operations is collected and treated in the LLW2, which includes the LLW treatment building and associated holding lagoons.

Treated process water is held, sampled, and analyzed before its release through a New York State Pollutant Discharge Elimination System (SPDES)-permitted outfall. In 2008, about 12.7 million gallons (48.1 million liters) of water were treated in the LLW2 system and discharged through outfall 001, the lagoon 3 weir. Table 1-2 summarizes the estimated releases of radioactivity in the 2008 discharge waters, as compared to the previous 10-year average. (Also, see Table 2-1 in Chapter 2.) Note that releases of tritium activity through outfall 001 were below the 10-year average, however releases of gross alpha and beta activity were higher.

TABLE 1-2

2008 Radioactivity Releases Versus 10-Year Averages $^{a}$

\begin{tabular}{|l|c|c|c|}
\hline Radionuclide & $\begin{array}{c}\text { 10-Year } \\
\text { Average } \\
\text { Curies }\end{array}$ & $\begin{array}{c}\text { 2008 } \\
\text { Curies }\end{array}$ & $\begin{array}{c}\text { \% of } \\
\text { 10-Year } \\
\text { Average }\end{array}$ \\
\hline \multicolumn{4}{|c|}{ Aqueous Discharge LLW2 } \\
\hline Tritium & 0.12 & 0.047 & $40 \%$ \\
\hline $\begin{array}{l}\text { Gross Alpha } \\
\text { and Beta }\end{array}$ & 0.016 & 0.018 & $116 \%$ \\
\hline \multicolumn{4}{|c|}{ Airborne Discharge ANSTACK } \\
\hline Tritium & 0.016 & 0.0018 & $11 \%$ \\
\hline lodine-129 & 0.00093 & 0.000021 & $2.3 \%$ \\
\hline \multicolumn{4}{|c|}{ Particulate } \\
\hline $\begin{array}{l}\text { Gross Alpha } \\
\text { and Beta }\end{array}$ & 0.00020 & 0.000013 & $6.4 \%$ \\
\hline
\end{tabular}

a All numbers were rounded to two significant digits after calculations were complete. Percentages based on the above total curie values may not exactly match those in the table.
Effective operation of the site wastewater treatment facilities is indicated by compliance with the applicable discharge limits regulated by the SPDES permit. Approximately 60 chemical and water quality constituents are monitored regularly. The analytical results are reported to NYSDEC via monthly Discharge Monitoring Reports, required under the SPDES program. There were no SPDES effluent limit exceptions for chemical constituents during 2008. Historical limit exceptions are discussed in previous Annual Site Environmental Reports (ASERs). Although the goal of the LLW2 and sanitary wastewater treatment facility operations is to maintain effluent water quality consistently within the permit requirements, if SPDES permit limit exceptions occur, the exceptions are evaluated to determine their cause and to identify corrective measures.

- North Plateau Groundwater Recovery System (NPGRS)

The NPGRS operated throughout 2008, recovering groundwater from an area within the eastern lobe of the strontium-90 plume on the north plateau. Approximately 3.6 million gallons (14.0 million liters) were recovered during 2008. For a moredetailed discussion of the plume and the NPGRS, see "Strontium-90 Plume Characterization and Remediation Activities" in Chapter 4.

Environmental Management of Airborne Emissions. During operations, ventilated air from the various WVDP facilities is continuously sampled for radioactivity in gases and particulate matter. Ventilated air is monitored and an alarm is activated if particulate matter radioactivity increases above preset levels. Samples are analyzed in the laboratory for the specific radionuclides that are present in the radioactive materials being handled in the facilities. (See "Radiological Air Emissions" in Chapter 2.)

Ventilation air through facilities undergoing radioactive material cleanup passes through high-efficiency filters before being released to the atmosphere. The filters are generally more effective for particulate matter than for gaseous radioactivity. For this reason, facility air treatment tends to remove a lesser percentage of gaseous radioactivity (e.g., tritium and iodine-129) than radioactivity associated with particulate matter (e.g., strontium-90 and cesium-137). However, gaseous radionuclide emissions still remain so far below the most restrictive regulatory limits for public safety that additional treatment technologies beyond those already provided are not necessary. 
Table 1-2 shows the gaseous and particulate matter radioactivity emissions from the main plant (location ANSTACK) in 2008 compared to averages from the previous 10 -year period. These 2008 values are low in comparison with the 10-year average that includes several years when the vitrification system was operating.

\section{Environmental Performance Measures}

Performance measures can be used to evaluate effectiveness, quality, timeliness, safety, or other areas that reflect achievements related to organization or process goals, and can be used as tools to identify the need to institute changes.

Dose Assessment. As an overall assessment of Project activities and the effectiveness of the as-low-as-reasonably-achievable policy, the low potential radiological dose to the maximally exposed off-site individual is an indicator of well-managed radiological operations.

The relative dose equivalents for radiological air emissions, liquid effluent discharges, and other liquid releases (such as swamp drainage) from 1999 through 2008 are graphed on Figure 1-1. Note that, when summed, the total is well below the DOE standard of 100 mrem per year. The consistently low effluent results indicate that radiological activities at the site are well-controlled. (See also Table 3-2 in Chapter 3, "Dose Assessment.")

Groundwater Monitoring. The groundwater program is implemented at the WVDP according to DOE Order 450.1A and Resource Conservation and Recovery Act (RCRA) §3008(h) Administrative Order on Consent requirements, as approved by NYSDEC and the EPA. Monitoring continued during 2008. Refer to Chapter 4, "Groundwater Protection Program," for details.

Environmental Management of Radiation Exposure. Environmental radiation is measured with thermoluminescent dosimeters (TLDs) at on-site and off-site locations. See Figures A-10 through A-12 for the locations of on-site and off-site TLD monitoring points. Although exposure rates at most on-site locations in 2008 were elevated with respect to background, results from perimeter TLDs that would be more representative of exposure to the public were statistically indistinguishable from background results. (See "Environmental Radiation" in Chapter 2.)

\section{Quality Assurance (QA) Program}

The QA program at the WVDP provides for and documents consistency, precision, and accuracy in collecting and analyzing environmental samples and in interpreting and reporting environmental monitoring data. Under contract with the DOE, WVES imple-

FIGURE 1-1

Annual Effective Dose Equivalent to the Maximally Exposed Off-Site Individual

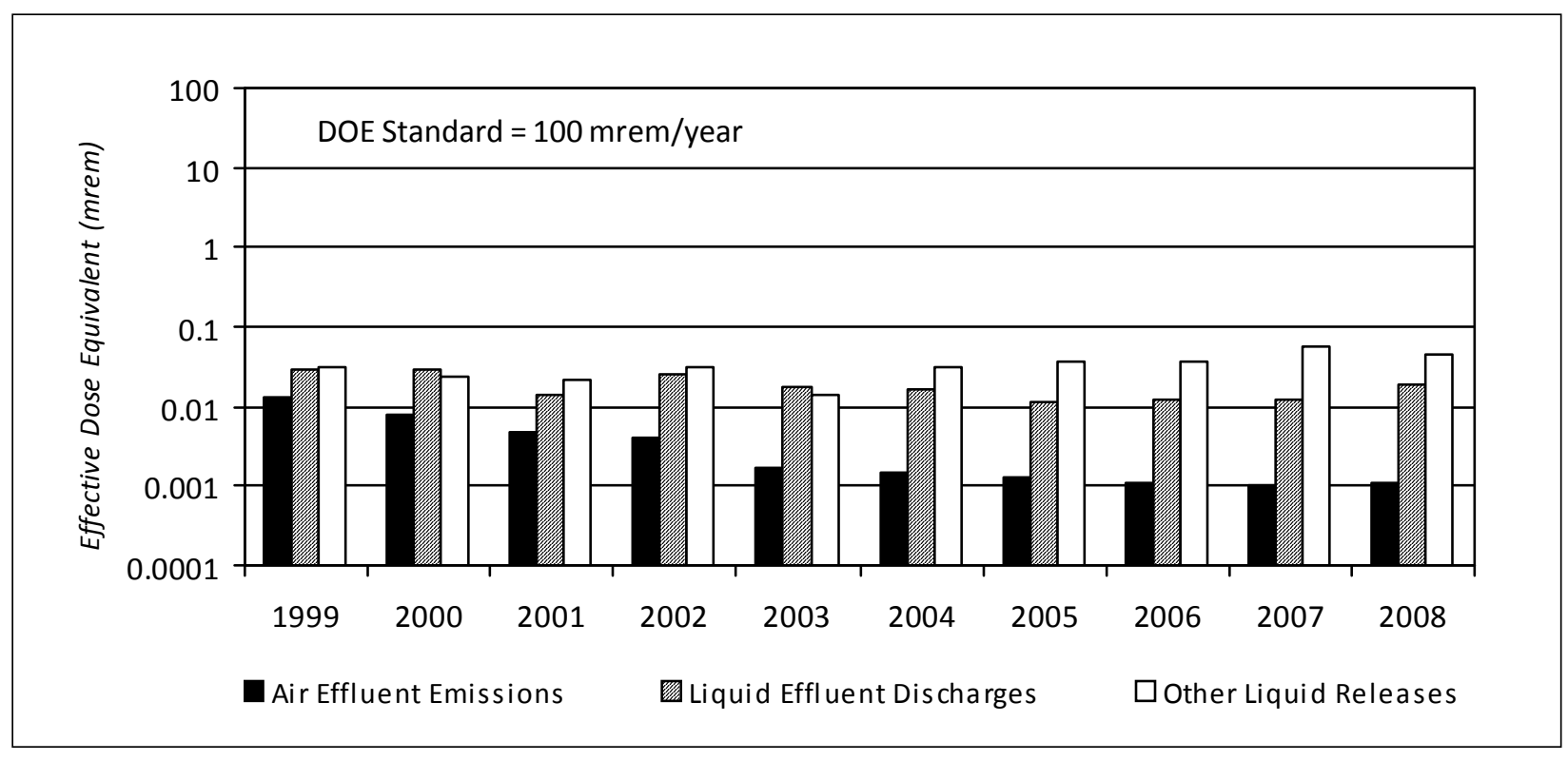


ments the QA program at the WVDP. Subcontractor laboratories providing analytical services for the environmental monitoring program are contractually required to maintain a QA program consistent with WVES requirements.

10 CFR Part 830, Subpart A, "Quality Assurance Requirements," Section 830.122, "Quality Assurance Criteria," and DOE Order 414.1C, "Quality Assurance" (DOE, 2005), document the QA program policies and requirements applicable to activities at the WVDP. The WVDP QA program serves to implement the DOE Order 450.1A requirement to provide "assurance that analytical work for environmental and effluent monitoring supports data quality objectives, using a documented approach for collecting, assessing, and reporting environmental data." The integrated QA program also incorporates the requirements from the consensus standard "Quality Assurance Program Requirements for Nuclear Facilities" (American Society of Mechanical Engineers NQA-1, 1989). Controlled documents specific to the WVDP are used to implement the integrated QA program.

General areas addressed by the QA program include the following:

Responsibility. Responsibilities for overseeing, managing, and conducting an activity must be clearly defined. Personnel who verify that an activity has been completed correctly must be independent of those who performed it. Managers of programs, projects, and tasks at the WVDP are responsible for ensuring that $Q A$ requirements applicable to activities under their cognizance are implemented.

Planning. Work activities must be planned beforehand, the plan followed, and activities documented. Purchases of quality-affecting equipment or items must be planned, specified precisely, and verified for correctness upon receipt.

Training. Anyone performing an activity in support of the WVDP environmental monitoring program must be trained in the appropriate procedures and qualified accordingly before carrying out the activity.

Control of Design, Procedures, Items, and Documents. Any activity, equipment, or construction must be clearly described or defined and tested. Changes in the design must be tested and documented. Procedures must clearly state how activities will be conducted. New procedures must be developed each time an activity is added to the monitoring program. Pro- cedures are reviewed periodically, updated when necessary, and are controlled so that only approved and current procedures are used.

Equipment or particular items affecting the quality of environmental data must be identified, inspected, calibrated, and tested before use. Calibration status must be clearly indicated. Items that do not conform to requirements must be identified as nonconforming and segregated so as to prevent inadvertent use.

Corrective Action. Conditions adverse to quality must be promptly identified, a corrective action planned, responsibility assigned, and the problem remedied.

Documentation. Records of all activities must be kept to verify what was done and by whom. Records must be clearly traceable to an item or activity. Records such as field data sheets, chain-of-custody forms, requests for analysis, sample shipping documents, sample logs, data packages, training records, and weather measurements, in addition to other records in both paper and electronic form, are maintained as documentation for the environmental monitoring program.

\section{Quality Control (QC)}

The QC practices, an integral part of the WVDP QA program, are used to ensure that samples are collected and analyzed in a consistent and repeatable manner. QC methods are applied both in the field and in the laboratory.

Field QC. Procedures are defined for collecting each type of sample, such as surface water, groundwater, soil, and air. Trained Environmental Laboratory (ELAB) field personnel collect the samples. Field sampling locations are clearly marked to ensure that routine samples are collected in the same location each time. Collection equipment that remains in the field is routinely inspected, calibrated, and maintained, and automated sampling stations are kept locked to prevent tampering. Samples are collected into certified pre-cleaned containers of an appropriate material and capacity. Containers are labeled with information about the sample, such as date and time of collection, sample collection personnel, and special field conditions. Collection information is documented and kept as part of the sample record.

Chain-of-custody documentation is maintained so as to trace sample possession from time of collection through analysis. Samples are stored in a locked, secure location before analysis or shipping. Samples 
sent off site for analysis are accompanied by an additional chain-of-custody form. Subcontract laboratories are required by contract to maintain internal chain-of-custody records and to store the samples under secure conditions.

Special field QC samples are collected and analyzed to assess the sampling process. Duplicate field samples are used to assess sample homogeneity and sampling precision. Field and trip blanks (laboratorydeionized water in sample containers) are used to detect contamination potentially introduced during sampling or shipping. Environmental background samples (samples of air, water, vegetation, venison, and milk taken from locations remote from the WVDP) are collected and analyzed to provide baseline information for comparison with on-site or near-site samples so that site influences can be evaluated.

Laboratory QC. In 2008, samples were collected by personnel from the URS ELAB. On-site analyses were performed at the ELAB or the Wastewater Treatment Facility Laboratory. Off-site analyses were performed by General Engineering Laboratories (GEL, in Charleston, South Carolina), TestAmerica Laboratories, Inc. (TestAmerica, formerly Severn Trent Laboratories, in Buffalo, New York), and AREVA NP Inc. (AREVA, in Westborough, Massachusetts). As samples were collected, shipped, and analyzed, chain-of-custody documentation was maintained to track sample possession from time of collection through analysis and data reporting. All laboratories are required to maintain relevant certifications, to participate in applicable crosscheck programs, and to maintain a level of QC as defined in their contracts.

To analyze environmental samples originating from the state of New York, both on-site and subcontract analytical laboratories are required to maintain the relevant New York State Department of Health (NYSDOH) Environmental Laboratory Approval Program (ELAP) certification.

Laboratory QC practices specific to each analytical method are described in approved references or procedures. QC practices include proper training of analysts, maintaining and calibrating measuring equipment and instrumentation, and routinely processing laboratory QC samples such as standards and spikes (to assess method accuracy), duplicates and replicates (to assess precision), and blanks (to assess the possibility of contamination). Standard reference materials (materials with known quantities or concentrations of constituents of interest) traceable to the National Institute of Standards and Technology are used to calibrate counting and test instruments and to monitor their performance.

Crosschecks. Crosscheck samples (performance evaluation samples) contain a concentration of a constituent of interest known to the agency conducting the crosscheck, but unknown to the participating laboratory. Crosscheck programs provide an additional means of testing accuracy of environmental measurements. Subcontract laboratories are required to perform satisfactorily on crosschecks, defined as having at least $80 \%$ of reported results falling within control limits. Crosscheck results that fall outside of control limits are addressed by formal corrective actions to determine any conditions that could adversely affect sample data and to ensure that actual sample results are reliable.

The WVDP participates in formal crosscheck programs for both radiological and nonradiological analyses.

\section{- Radiological Crosschecks}

Organizations performing radiological analyses as part of effluent or environmental monitoring are encouraged by the DOE to participate in formal crosscheck programs to test the quality of environmental measurements being reported to the DOE by its contractors. Crosscheck samples for radiological constituents are analyzed on site by the ELAB and off site by GEL. In 2008, the WVDP participated in the DOE Radiological Environmental Sciences Laboratory Mixed Analyte Performance Evaluation Program (MAPEP). Results are listed in Appendix $\mathrm{H}^{\text {cor }}$.

\section{- Nonradiological Crosschecks}

As a SPDES Permittee, the WVDP is required to participate in the EPA Discharge Monitoring Report QA performance evaluation studies for the National Pollutant Discharge Elimination System. Samples from this program are analyzed both on site and by subcontract laboratories. In addition, subcontract laboratories performing nonradiological analyses of samples that contain radiological contamination participate in the DOE MAPEP program. This mixed analyte program provides performance evaluation samples for both radiological and nonradiological constituents. 
In 2008, nonradiological crosschecks were analyzed by the WVDP Wastewater Treatment Facility Laboratory, the ELAB, GEL, and TestAmerica. Results are summarized in Appendix $\mathrm{H}^{\mathbf{C D}}$.

Results for 2008 from all laboratories that analyzed samples from the WVDP monitoring program are summarized in Table 1-3. As presented, $97.9 \%$ of the crosschecks performed in 2008 were acceptable.

TABLE 1-3

Summary of Crosschecks Completed in 2008

\begin{tabular}{|l|c|c|c|}
\hline \multicolumn{1}{|c|}{ Type } & $\begin{array}{c}\text { Number } \\
\text { Reported }\end{array}$ & $\begin{array}{c}\text { Number } \\
\text { Within } \\
\text { Acceptance } \\
\text { Limits }\end{array}$ & $\begin{array}{c}\text { Percent } \\
\text { Within } \\
\text { Limits }\end{array}$ \\
\hline Radiological & 92 & 91 & $98.9 \%$ \\
\hline Nonradiological & 198 & 193 & $97.5 \%$ \\
\hline \hline All types & 290 & 284 & $97.9 \%$ \\
\hline
\end{tabular}

\section{Data Management}

The Environmental Laboratory Information Management System (LIMS) is a database system used at the WVDP for establishing sample identification number, maintaining the sample data log, tracking samples, managing field and analytical data, and recording status and results of data validation. The LIMS is used as a controlled-source database for generating reports and statistical evaluations of data sets to support environmental surveillance activities. Subcontract laboratories are requested to provide data in electronic format for direct entry into the LIMS by WVDP personnel.

All software packages used to generate data are verified and validated before use. All analytical data produced in the ELAB at the bench level are reviewed and signed off by a qualified person other than the one who performed the analysis. A similar in-house review is contractually required from subcontractor laboratories.

\section{Data Verification and Validation}

Data validation is the process by which analytical data from both on-site and off-site laboratories are reviewed to verify proper documentation of sample processing and data reporting, and to determine the quality and usability of the data. A graded approach is applied that, based upon data quality objectives, dictates the rigor of review of the documentation associated with sample collection and/or sample analysis. In the WVDP environmental program, each data point is validated per approved standard procedures before it is assigned approval status and made ready for data assessment.

\section{Data Assessment and Reporting}

Validated analytical data, field information, and historical project data are integrated and evaluated to determine whether the constituents of interest are actually present and, if so, at what concentrations. Data problems identified at this level are investigated and appropriately resolved.

Data from the environmental monitoring program are then evaluated to assess the effect, if any, of the site operations and activities on the environment and the public. Data from each sampling location are compared with historical results from the same location, with comparable background measurements, and (if applicable) with regulatory limits or guidance standards. Standard statistical methods are used to evaluate the data.

Before each technical report is issued, the final document is comprehensively reviewed by one or more persons who are knowledgeable in the technical aspects of the work.

\section{Audits and Assessments}

Audits and assessments are conducted to verify compliance with, and effectiveness of, all aspects of the QA program, and to verify programmatic and functional compliance with site procedures, applicable local, state, and federal environmental regulations, and applicable DOE Directives. The WVDP environmental monitoring program is audited by external agencies and evaluated using internal self-assessments and audits. An audit or assessment provides for objective and independent review of site functions to determine if they are operating within regulatory, programmatic, and procedural parameters. The focus and/or topics of an audit or assessment are selected from specific criteria taken from the protocol, procedure, or regulation against which the function is to be evaluated.

During an audit or assessment, a "finding" is a noncompliance of a program element or a requirement of a specification, procedure, or commitment. Findings that may be considered immediately dangerous or involve any direct violation of a regulation, WVDP policy or procedure, DOE Order, or conduct of opera- 
tions requirement must be brought to the immediate attention of the cognizant site manager. Such conditions require corrective action and are to be fixed immediately and documented within the assessment. An "observation" is a condition that, if left uncorrected, could lead to a "finding." It may indicate the potential for violating regulations or requirements or an opportunity to improve an existing compliant condition or procedure. Such conditions also require corrective action. If a finding or an observation cannot be fixed before the issuance of the assessment report, an Issue Report (IR) is initiated to document the condition that needs to be addressed, the required corrective action, and the timeline for completing the corrective action. IRs are tracked to closure in the WVDP open items tracking system. A "recommended action" may be identified to improve a program. "Good practices" (noteworthy practices) are identified when actions are above and beyond those required by procedural compliance.

WVES Surveillance. On March 27, 2008, WVES QA performed a follow-up surveillance to an external audit (EA-07-02) that was performed in the ELAB on December 3-4, 2007. The follow-up surveillance was performed to document review of records (i.e., field records, in-process records, shipping files, and logbooks) and to verify compliance with requirements to properly document corrections or changes to original hard copy records. Objective evidence was reviewed and personnel were interviewed to verify that appropriate methods for making changes to quality records were being implemented. The surveillance results were satisfactory.

WVES QA Audit of the ELAB. The WVES QA department conducted an audit of the URS ELAB on December 15 through 17, 2008. The ELAB audit focused on specific NQA-1-1989 elements, as well as National Environmental Laboratory Accreditation Conference (NELAC) and ELAP requirements. Compliance with relevant requirements from the WVDP Quality Management Manual and the WVDP ELAP Quality Manual was assessed. Within the scope of the audit, one commendable practice was identified by the audit team with regard to the LIMS, utilized in the ELAB. Two observations were also noted during the audit. One observation cited two instances where a section of a "Sampling Worksheet/Internal Chain-of-Custody" form was left blank instead of entering an "NA" in the space to indicate not applicable. This was satisfied during the audit and required no further action. The second observation identified a mismatch between actual practices and the "Records Inventory \& Dis- position Schedule" (RIDS) for the ELAB. A review and revision of RIDS for the ELAB was undergoing evaluation. No further action was required.

WVES QA Surveillance of ELAB Storm Water Monitoring. On April 28, 2008, WVES QA personnel performed a field surveillance of ELAB personnel collecting storm water during a rain event. Field notebook documentation and timed-interval sample collection was observed. On June 24, 2008, a follow-up surveillance was performed to ensure that storm water was collected and reported in accordance with the "Monitoring Plan for Storm Water Discharges at the WVDP" that implements requirements of the SPDES permit. Objectives of the surveillance were to observe sampling and to verify the integrity of the required regulatory information collected or generated through the execution of the storm water plan. All results of the surveillance were satisfactory.

WVES QA Department Off-Site Audit of the Bioassay Program. On November 18-19, 2008, the WVES QA Department conducted an audit of the off-site laboratory, GEL, that analyzes radiobioassay samples for the WVDP. The audit focused on quality assurance and technical programs, as well as compliance with contractual requirements of the contract. Within the scope of the audit, one finding was identified for which a response was required within 30 days stating remedial and preventative action. The finding identified lack of objective evidence of training for one of the technicians directly related to responsibility essential to the job. This was classified as a finding, as there have been issues related to training during the last three audits at GEL. The response was received from GEL in a timely fashion and the resolution was received and approved by WVES.

ISMS and QA Program Assessment. During 2008, WVES conducted an annual effectiveness review (self-assessment), which included both a program review and a focused field assessment. A declaration was submitted to DOE-WVDP on October 7, 2008, concluding that the ISMS program is well-documented and effectively functioning. The program review included not only ISMS, but also EMS and QA program effectiveness and concluded that the systems are upto-date, meet applicable standards, and are effectively implemented.

The effective integration of EMS, QA, and worker safety and health programs into ISMS was evaluated through both WVES and DOE oversight and self-assessment, multiple DOE-WVDP and DOE-HQ reviews, 
two DOE audits of the WVES QA program, and URS Washington Division corporate assessments of ISMS and QA. Areas for improvement were identified and the resulting recommendations are being tracked to closure in the open items tracking system.

A review of corrective actions completed in fiscal year 2008 related to independent assessment of EMS and QA was conducted and all recommendations have been satisfied. No significant programmatic trends in any of these programs have been indicated through this process.

DOE Audit of WVDP QA Programs. During the week of July 22-25, 2008, the DOE Office of Standards and Quality Assurance (EM-64) conducted an independent audit of the WVES and DOE/WVDP quality assurance programs. The audit focused on quality programs for the solid waste and tank waste stabilization and disposition services, as well as controls applied to WVDP decontamination and demolition activities. The audit team concluded that the design control process is well implemented by WVES with respect to integration with field efforts, document control, and records management programs. Record retention on site and retrieval of records from the off-site storage facility were adequate; however, the team suggested that it may be preferable to retain records on site for longer periods before transferring to the storage facility.

The team observed that training and qualification and corrective actions programs are well implemented, and concluded that the QA program is well documented and well implemented by WVES at the WVDP.

DOE Audit of WVES Environmental Programs. WVES Environmental Programs were audited by DOE-WVDP from November 17-24, 2008. Specific elements evaluated were: contractor requirements of DOE 450.1A; the air-effluent-source monitoring program; the formality of environmental programs; program evlauation, reporting, and corrective action; environmental management and risk; waste management planning, recordkeeping, and tracking; waste management monitoring; and contingency planning. Results of this audit were formally submitted to WVES on December 18, 2008. Six findings and five comments (comments are synonymous to WVES observations) were reported.

Two findings pertained to Environmental Management (EM) requirements: failures to perform envi- ronmental regulatory reviews and distribute change summaries; and failures to perform environmental program assessments as part of the WVES Integrated Assessment Program. The one comment applicable to EM suggested the need for implementation of a tracking system for regulatory and other environmental reports and their submittal deadlines.

Four findings pertained to Waste Management (WM) requirements: failures to store, post storage areas, train employees, and perform inspections; failures to maintain procedures current administratively; failures to inspect all 90-day storage areas every week; and failures to ensure the removal of waste with a path for disposal from the site. The four comments applicable to WM: recommended the establishment or improvement of procedures to better define terminology in procedures; recommended a description of the inspection of storage containers to verify their being in good condition; identified the need for a formal evaluation to document that containers or tanks in the 90-day storage area do not exceed the site limits of 8,800 gallons; and recommended the need for improved organization of the RCRA inspection records located in the shipping depot for 2005, 2006, and 2007.

Except for the above findings, implementation of the evaluated activities were determined to be effective and in compliance with applicable requirements. WVES submitted a response on February 5, 2009, listing completed and ongoing corrective actions. Corrective actions are being tracked to completion in the open items tracking system.

Lessons Learned. Lessons learned data from audits, appraisals, and self-assessments are shared internally and externally through the WVDP lessons learned program. The WVDP maintains this system to promote the recurrence of desirable events and to minimize the recurrence of undesirable events.

Summary. Although areas for improvement were identified in the course of audits and assessments, nothing was found that would compromise the quality of the data in this report or the environmental monitoring program in general.

\section{Changes in the 2008 Environmental Monitoring Program}

Over the last few years, activities on site have focused on dismantlement and decontamination of facilities, demolition of unnecessary structures, and 
processing and shipping of waste. Hazardous materials on site are being reduced, as are potential pollutant sources. In late 2007 the environmental monitoring program was thoroughly evaluated and changes were identified to streamline the program in response to changing Project activities.

Each sampling location was evaluated on several bases: (1) regulatory requirements or other drivers, (2) pathways and hazard conditions, (3) a statistical evaluation of up to 16 years of monitoring data at each location, and (4) a determination of the need for additional data and/or ongoing monitoring for each constituent. The evaluations indicated that the frequency of sampling and the number of constituents at some locations could be reduced without any reduction in the quality of the environmental monitoring program. As a result, sampling at several locations was discontinued altogether, frequency of sampling at other locations was cut back, and the number of constituents monitored at some locations was reduced.

Environmental monitoring program modifications were implemented in January of 2008. The maps in Appendix A have been color-coded to show those locations at which sampling has remained unchanged, and those locations at which sampling has been modified. Specific program changes in CY 2008 at each location, with the rationale for the change, are summarized in Appendix A. 
This page intentionally left blank 


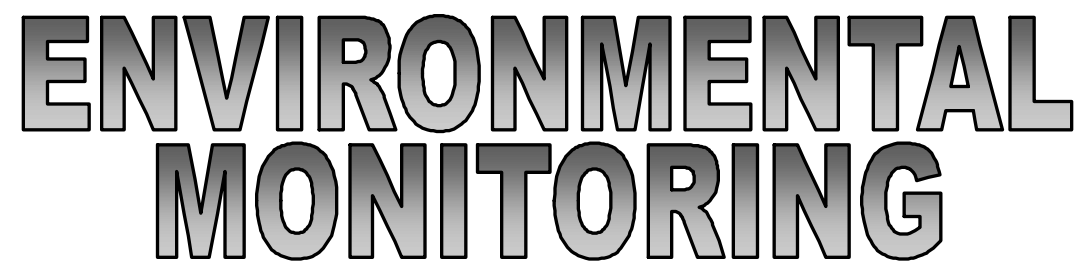

\section{Monitoring Program}

The goal of the West Valley Demonstration Project (WVDP or Project) environmental monitoring program is to ensure that public health and safety and the environment continue to be protected with respect to releases from site activities. To achieve this goal, possible exposure pathways are monitored.

The primary focus of the monitoring program is on surface water and air pathways, as these are the principal means by which potential contaminants are transported off site. Samples are collected from water, air, and other environmental media and measured for radiological and nonradiological constituents. A description of and schedule for the sampling program at each location and discussion of the environmental monitoring program drivers and rationale are presented in Appendix A, as well as maps showing the 2008 sampling locations. In accordance with United States (U.S.) Department of Energy (DOE) Order $450.1 \mathrm{~A}$, the monitoring program includes both effluent monitoring and environmental surveillance.

Effluent Monitoring. Liquid effluents and air emissions are monitored by collecting samples at locations on site where radioactivity or chemical pollutants are (or might be) released. Release points include discharge outfalls, storm water outfalls, site drainage points, and plant ventilation stacks. The WVDP maintains required permits and/or certificates from regulatory agencies applicable to releases to air and water, as listed in Table ECS-3.

Environmental Surveillance. Surface water, drinking water, air, sediment, soil, venison, fish, and milk are collected at locations where the highest concentrations of transported contaminants might be expected. Samples are also collected at remote locations to provide background data for comparison with data from on-site and near-site samples. Direct radiation is monitored on site, at the site perimeter, in nearby communities, and at a remote background location.

Data Evaluation. Data are assessed to determine whether the constituents of interest are present and, if so, at what concentrations. Data from each sam- pling location are compared with regulatory or guidance limits (if applicable) to determine if any limits have been exceeded. Guidance levels for radiological constituents in air and water are listed in Table UI-4 in the "Useful Information" section of this report. Regulatory limits for nonradiological constituents in discharges to surface water, additional water quality standards and potable water standards are listed in Appendix B-1 ${ }^{\mathrm{m}}$. Guidance levels for soil and sediment are listed in Appendix $\mathrm{F}-2^{\mathrm{GD}}$.

Data from near-site locations are compared with background concentrations using standard statistical methods as a means of assessing possible site impacts to the environment. Results from each location are also compared with historical data from that location to determine if any trends, such as increasing concentrations of a constituent, are occurring. If indicated, follow-up actions are evaluated and implemented as warranted.

\section{Effluent Monitoring}

Liquid Effluents. The Project is drained by several small streams. Franks Creek enters from the south and receives drainage from the south plateau. As it flows northward, Franks Creek is joined by Erdman Brook, which receives effluent from the low-level waste treatment facility (LLW2). After leaving the Project at the site security fence, Franks Creek receives drainage from the north and northeast swamp areas on the north plateau and from Quarry Creek. Franks Creek then flows into Buttermilk Creek, which, after flowing northward through the Western New York Nuclear Service Center (WNYNSC), enters Cattaraugus Creek and leaves the WNYNSC. (See maps on Figs. A-2 and A-5.)

- Radiological Releases

Two locations, the lagoon 3 weir at outfall 001 (WNSP001 on Fig. A-2) and a natural drainage from the northeast swamp (monitoring point WNSWAMP on Fig. A-2), are the primary sources of radionuclide releases to surface waters. (Note that two other liquid release points, the sewage treatment outfall [point WNSP007] and another drainage 
point on the north plateau [the north swamp, point WNSW74A] are also evaluated each year. Releases from these points are minor and are not included in this discussion. However, they are addressed in Chapter 3, Dose Assessment.)

The discharge through the lagoon 3 weir at outfall 001 into Erdman Brook is the primary controlled point source of liquid release from the Project. Seven batch releases totaling about 12.7 million gallons (48.1 million liters) were discharged from WNSP001 in 2008. Drainage from the northeast swamp in calendar year (CY) 2008 was estimated to be approximately 30.7 million gallons (116 million liters). Estimates of curies released from these two sources in 2008 and average radionuclide concentrations are summarized in Tables 2-1 and 2-2.

DOE Order 5400.5 defines derived concentration guides (DCGs) as radionuclide concentrations that, under conditions of continuous exposure for one year by one exposure mode, would result in an effective dose equivalent of 100 millirem (1 millisievert). These DCGs are applicable only at locations where mem-

TABLE 2-1

Total Radioactivity Discharged at Lagoon 3 (WNSP001) in 2008 and Comparison of Concentrations with DOE DCGs

\begin{tabular}{|c|c|c|c|c|c|}
\hline Isotope ${ }^{a}$ & $\begin{array}{l}\text { Discharge } \\
\text { Activity }^{b} \\
\text { (Ci) }\end{array}$ & $\begin{array}{c}\text { Radioactivity }^{C} \\
\text { (Becquerels) }\end{array}$ & $\begin{array}{c}\text { Average } \\
\text { Concentration } \\
(\mu \mathrm{Ci} / \mathrm{mL})\end{array}$ & $\begin{array}{c}D C G^{d} \\
(\mu \mathrm{Ci} / \mathrm{mL})\end{array}$ & $\begin{array}{c}\text { Ratio of } \\
\text { Concentration } \\
\text { to DCG } \\
\end{array}$ \\
\hline Gross Alpha & $9.20 \pm 1.04 \mathrm{E}-04$ & $3.40 \pm 0.38 \mathrm{E}+07$ & $1.91 \pm 0.22 \mathrm{E}-08$ & $N A^{e}$ & $\mathrm{NA}$ \\
\hline Gross Beta & $1.71 \pm 0.03 \mathrm{E}-02$ & $6.34 \pm 0.10 \mathrm{E}+08$ & $3.56 \pm 0.06 \mathrm{E}-07$ & $N A^{e}$ & $\mathrm{NA}$ \\
\hline $\mathrm{H}-3$ & 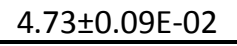 & $1.75 \pm 0.03 E+09$ & $9.83 \pm 0.19 E-07$ & $2 \mathrm{E}-3$ & 0.0005 \\
\hline C-14 & $2.23 \pm 5.73 \mathrm{E}-04$ & $0.82 \pm 2.12 E+07$ & $0.46 \pm 1.19 E-08$ & $7 \mathrm{E}-5$ & $<0.0002$ \\
\hline K-40 & $0.58 \pm 1.04 \mathrm{E}-03$ & $2.16 \pm 3.84 \mathrm{E}+07$ & $1.21 \pm 2.16 \mathrm{E}-08$ & $\mathrm{NA}^{f}$ & NA \\
\hline Co-60 & $-0.03 \pm 3.55 E-05$ & $-0.01 \pm 1.31 \mathrm{E}+06$ & $-0.06 \pm 7.37 \mathrm{E}-10$ & $5 \mathrm{E}-6$ & $<0.0002$ \\
\hline Sr-90 & $6.89 \pm 0.09 E-03$ & $2.55 \pm 0.03 E+08$ & $1.43 \pm 0.02 \mathrm{E}-07$ & $1 \mathrm{E}-6$ & 0.143 \\
\hline Tc-99 & $7.66 \pm 0.49 E-04$ & $2.84 \pm 0.18 \mathrm{E}+07$ & $1.59 \pm 0.10 \mathrm{E}-08$ & $1 \mathrm{E}-4$ & 0.0002 \\
\hline I-129 & $2.02 \pm 1.85 \mathrm{E}-05$ & $7.48 \pm 6.85 E+05$ & $4.21 \pm 3.85 E-10$ & $5 \mathrm{E}-7$ & 0.0008 \\
\hline Cs-137 & $3.87 \pm 0.11 \mathrm{E}-03$ & $1.43 \pm 0.04 \mathrm{E}+08$ & $8.06 \pm 0.23 E-08$ & $3 E-6$ & 0.0269 \\
\hline $\mathrm{U}-\mathbf{2 3 2 ^ { g }}$ & $3.85 \pm 0.13 E-04$ & $1.42 \pm 0.05 \mathrm{E}+07$ & $8.00 \pm 0.28 \mathrm{E}-09$ & $1 \mathrm{E}-7$ & 0.0800 \\
\hline $\mathrm{U}-233 / 234^{g}$ & $2.33 \pm 0.10 \mathrm{E}-04$ & $8.62 \pm 0.38 \mathrm{E}+06$ & $4.84 \pm 0.21 \mathrm{E}-09$ & $5 \mathrm{E}-7$ & 0.0097 \\
\hline U-235/236 ${ }^{g}$ & $1.20 \pm 0.25 \mathrm{E}-05$ & $4.43 \pm 0.91 \mathrm{E}+05$ & $2.49 \pm 0.51 \mathrm{E}-10$ & $5 \mathrm{E}-7^{h}$ & 0.0005 \\
\hline U-238 ${ }^{g}$ & $1.97 \pm 0.10 \mathrm{E}-04$ & $7.30 \pm 0.36 \mathrm{E}+06$ & $4.10 \pm 0.20 \mathrm{E}-09$ & $6 \mathrm{E}-7$ & 0.0068 \\
\hline $\mathrm{Pu}-238$ & $2.63 \pm 0.83 \mathrm{E}-06$ & $9.71 \pm 3.09 E+04$ & $5.46 \pm 1.73 \mathrm{E}-11$ & $4 \mathrm{E}-8$ & 0.0014 \\
\hline Pu-239/240 & $2.23 \pm 0.71 \mathrm{E}-06$ & $8.26 \pm 2.63 E+04$ & $4.64 \pm 1.48 \mathrm{E}-11$ & $3 \mathrm{E}-8$ & 0.0015 \\
\hline Am-241 & $5.38 \pm 1.49 E-06$ & $1.99 \pm 0.55 E+05$ & $1.12 \pm 0.31 \mathrm{E}-10$ & $3 \mathrm{E}-8$ & 0.0037 \\
\hline \multicolumn{5}{|l|}{ Sum of Ratios } & 0.28 \\
\hline
\end{tabular}

Note: Radiological measurements are expressed as a result term plus or minus ( \pm ) an uncertainty term. Result terms may be positive or negative. If the uncertainty term is larger than the result, the radionuclide was not detected. For more detail, see the "Data Reporting" discussion in the "Useful Information" section.

NA - Not applicable

a Half-lives are listed in Table UI-4.

$b$ Total volume released: $4.81 \mathrm{E}+10 \mathrm{~mL}(1.27 \mathrm{E}+07$ gal)

c 1 curie $(\mathrm{Ci})=3.7 \mathrm{E}+10$ becquerels $(\mathrm{Bq}): 1 \mathrm{~Bq}=2.7 \mathrm{E}-11 \mathrm{Ci}$

$d$ DCGs are listed for reference only. DCGs are applicable at the point at which water is available for ingestion by the public (i.e., at the site boundary) but not to release point concentrations, as might be inferred from their inclusion in this table.

e DOE DCGs do not exist for indicator parameters gross alpha and beta.

$f$ The DCG is not applied to potassium-40 (K-40) activity because of its natural origin.

$g$ Total uranium $(\mathrm{g})=5.39 \pm 0.13 \mathrm{E}+02$; average uranium concentration $(\mu \mathrm{g} / \mathrm{mL})=1.12 \pm 0.03 \mathrm{E}-02$

$h$ The DCG for U-236 is used for this comparison. 
TABLE 2-2

Total Radioactivity Released at Northeast Swamp (WNSWAMP) in 2008 and Comparison of Concentrations with DOE DCGs

\begin{tabular}{|c|c|c|c|c|c|}
\hline Isotope $^{a}$ & $\begin{array}{c}\text { Discharge } \\
\text { Activity }^{b} \\
\text { (Ci) } \\
\end{array}$ & $\begin{array}{c}\text { Radioactivity }^{c} \\
\text { (Becquerels) }\end{array}$ & $\begin{array}{c}\text { Average } \\
\text { Concentration } \\
(\mu \mathrm{Ci} / \mathrm{mL})\end{array}$ & $\begin{array}{c}D_{C G}{ }^{d} \\
(\mu C i / m L) \\
\end{array}$ & \begin{tabular}{|c|} 
Ratio of \\
Concentration to \\
DCG
\end{tabular} \\
\hline Gross Alpha & $0.27 \pm 1.34 \mathrm{E}-04$ & $0.98 \pm 4.95 \mathrm{E}+06$ & $0.23 \pm 1.15 \mathrm{E}-09$ & $N A^{e}$ & $\mathrm{NA}$ \\
\hline Gross Beta & $5.24 \pm 0.05 E-01$ & $1.94 \pm 0.02 E+10$ & $4.51 \pm 0.04 \mathrm{E}-06$ & $\mathrm{NA}^{e}$ & NA \\
\hline $\mathrm{H}-3$ & $4.22 \pm 1.85 \mathrm{E}-03$ & $1.56 \pm 0.69 E+08$ & $3.63 \pm 1.59 \mathrm{E}-08$ & $2 \mathrm{E}-03$ & $<0.0001$ \\
\hline C-14 & $-2.15 \pm 2.97 \mathrm{E}-03$ & $-0.80 \pm 1.10 \mathrm{E}+08$ & $-1.85 \pm 2.55 \mathrm{E}-08$ & 7E-05 & $<0.0004$ \\
\hline Sr-90 & $2.86 \pm 0.02 E-01$ & $1.06 \pm 0.01 E+10$ & $2.46 \pm 0.01 \mathrm{E}-06$ & $1 \mathrm{E}-06$ & 2.46 \\
\hline $1-129$ & $-1.00 \pm 6.30 \mathrm{E}-05$ & $-0.37 \pm 2.33 \mathrm{E}+06$ & $-0.86 \pm 5.42 E-10$ & $5 E-07$ & $<0.0011$ \\
\hline Cs-137 & $1.22 \pm 0.88 \mathrm{E}-04$ & $4.52 \pm 3.26 E+06$ & $1.05 \pm 0.76 \mathrm{E}-09$ & $3 \mathrm{E}-06$ & 0.0004 \\
\hline $\mathrm{U}-232^{f}$ & $2.04 \pm 5.75 \mathrm{E}-06$ & $0.76 \pm 2.13 \mathrm{E}+05$ & $1.76 \pm 4.95 \mathrm{E}-11$ & $1 \mathrm{E}-07$ & $<0.0005$ \\
\hline $\mathrm{U}-233 / 234^{f}$ & $2.36 \pm 0.87 \mathrm{E}-05$ & $8.74 \pm 3.23 \mathrm{E}+05$ & $2.03 \pm 0.75 \mathrm{E}-10$ & $5 \mathrm{E}-07$ & 0.0004 \\
\hline $\mathrm{U}-235 / 236^{f}$ & $3.04 \pm 4.96 \mathrm{E}-06$ & $1.13 \pm 1.83 \mathrm{E}+05$ & $2.62 \pm 4.26 \mathrm{E}-11$ & $5 \mathrm{E}-07^{\mathrm{g}}$ & $<0.0001$ \\
\hline U-238 & $1.87 \pm 0.75 \mathrm{E}-05$ & $6.91 \pm 2.78 \mathrm{E}+05$ & $1.61 \pm 0.65 \mathrm{E}-10$ & $6 \mathrm{E}-07$ & 0.0003 \\
\hline Pu-238 & $0.17 \pm 4.91 \mathrm{E}-06$ & $0.06 \pm 1.82 E+05$ & $0.14 \pm 4.22 \mathrm{E}-11$ & $4 \mathrm{E}-08$ & $<0.0011$ \\
\hline $\mathrm{Pu}-239 / 240$ & $3.02 \pm 4.89 \mathrm{E}-06$ & $1.12 \pm 1.81 \mathrm{E}+05$ & $2.60 \pm 4.20 \mathrm{E}-11$ & $3 \mathrm{E}-08$ & $<0.0014$ \\
\hline Am-241 & $1.20 \pm 1.70 \mathrm{E}-06$ & $4.44 \pm 6.28 \mathrm{E}+04$ & $1.03 \pm 1.46 \mathrm{E}-11$ & $3 \mathrm{E}-08$ & $<0.0005$ \\
\hline \multicolumn{5}{|l|}{ Sum of Ratios } & 2.47 \\
\hline
\end{tabular}

Note: Radiological measurements are expressed as a result term plus or minus $( \pm)$ an uncertainty term. Result terms may be positive or negative. If the uncertainty term is larger than the result, the radionuclide was not detected. For more detail, see the "Data Reporting" discussion in the "Useful Information" section.

Note: The average $\mathrm{pH}$ at this location was 7.64 S.U.

NA - Not applicable

a Half-lives are listed in Table UI-4.

$b$ Total volume released: $1.16 \mathrm{E}+11 \mathrm{~mL}(3.07 \mathrm{E}+07$ gal)

c 1 curie $(\mathrm{Ci})=3.7 \mathrm{E}+10$ becquerels $(\mathrm{Bq}): 1 \mathrm{~Bq}=2.7 \mathrm{E}-11 \mathrm{Ci}$

$d$ DCGs are listed for reference only. DCGs are applicable at the point at which water is available for ingestion by the public (i.e., at the site boundary) but not to release point concentrations, as might be inferred from their inclusion in this table.

e DOE DCGs do not exist for indicator parameters gross alpha and beta.

$f$ Total uranium $(\mathrm{g})=3.28 \pm 0.17 \mathrm{E}+01$; average uranium concentration $(\mu \mathrm{g} / \mathrm{mL})=2.82 \pm 0.15 \mathrm{E}-04$

$g$ The DCG for U-236 is used for this comparison.

bers of the public could be exposed to effluents containing contaminants. DCGs for radionuclides measured at the WVDP are listed in Table UI-4. Note that DCGs are not used for dose assessment. Methods for estimating dose from the liquid pathway are discussed in Chapter 3.

To evaluate each of the releases with respect to the DCGs, each annual average radionuclide concentration was divided by its respective DCG and the ratios from all nuclides were summed. As a DOE policy, the sum of the ratios (also called the "sum of fractions") should not exceed 1.0. That is, the sum of percentages should not exceed $100 \%$. Tables $2-1$ and $2-2$ list the sum of ratios for each release point.
The sum of ratios for the release from WNSP001 in 2008 was approximately 0.28 , below the 1.0 criterion. However, the sum of ratios from WNSWAMP was 2.47, above the DOE Order 5400.5 criterion. As in 2007 , the elevated sum of ratios was almost entirely attributable to strontium-90. Note that even though the sum of ratios in 2008 (2.47) was higher than that in 2007 (1.57), total strontium-90 curies released in 2008 were actually less than those released in 2007 (about 0.286 in 2008 versus about 0.343 in 2007) because water flow was less.

Drainage at this point largely consists of emergent groundwater. Elevated gross beta concentrations were first noted at this location in 1993. Subsequent 
investigations delineated a plume of strontium-90 contaminated groundwater on the north plateau. Annualized average strontium-90 concentrations, which first exceeded the strontium-90 DCG (1E-06 $\mu \mathrm{Ci} / \mathrm{mL}$ ) in 1995 , continued to exceed the DCG through 2008. (See Fig. 4-6 in Chapter 4, "Groundwater Protection Program.") Ongoing activities to characterize and remediate the strontium-90 groundwater plume are discussed in Chapter 4.

Even though waters with elevated strontium-90 concentrations drain from WNSWAMP into Franks Creek, then into Buttermilk Creek, and ultimately into Cattaraugus Creek, concentrations of strontium-90 and gross beta in water collected from Cattaraugus Creek downstream of the WVDP at the first point of public access continue to show little or no difference from background concentrations. (See Table B$5 \mathrm{~A}$ in Appendix B-5 ${ }^{\text {(D) }}$.)

State Pollutant Discharge Elimination System (SPDES) Permit-Required Monitoring. Liquid discharges from the WVDP are regulated for nonradiological constituents under a SPDES permit, as identified in Table ECS3. The permit identifies compliance points from which liquid effluents are released to Erdman Brook (Fig. A2), identifies 20 storm water outfalls (Figs. A-3 and A-4) and specifies the sampling and analytical requirements for each. One additional storm water locations is being added to the permit. This additional storm water runoff location, designated as location WNSO43, was identified in 2006 near a wetland near the Live-Fire Range on the WNYNSC and was characterized in 2007.

The conditions and requirements of the SPDES permit are summarized in Appendix B-1 ${ }^{\text {ED }}$. The permit identifies 25 outfalls and compliance points with monitoring requirements and discharge limits. The monitored outfalls include:

- outfall 001 (monitoring point WNSP001), discharge from the LLW2

- outfall 007 (monitoring point WNSP007), discharge from the sanitary and industrial wastewater treatment facility

- outfall 008 (monitoring point WNSP008), a groundwater french drain around the perimeter of the lowlevel waste treatment facility storage lagoons (closed in May 2001 but still on the permit)
- outfall 116 (pseudo-monitoring point WNSP116), a location in Franks Creek that represents the confluence of outfalls WNSP001, WNSP007, and WNSP008, as well as storm water runoff, groundwater seepage, and augmentation water. Samples from upstream sources are used to calculate total dissolved solids at this location and to demonstrate compliance with the SPDES permit limit for this parameter. (Outfall 116 is referred to as a "pseudo-monitoring" point on the SPDES permit.)

- outfall 01B (monitoring point WNSP01B), an internal monitoring point for the liquid waste treatment system evaporator effluent, being monitored for flow and total mercury.

- 20 storm water discharge outfalls that also receive flows from other minor sources, such as fire hydrant testing and groundwater seepage, being monitored on a rotational basis. The objectives of SPDES permit requirements for monitoring storm water runoff are to determine (1) the levels of water quality and specific chemicals in storm water discharges from specified locations on the WVDP, (2) the amount of rainfall, (3) duration of the storm event, and (4) the resulting flow at the outfalls. The 20 storm water outfalls at the WVDP are grouped into eight representative drainage basins that could potentially be influenced by industrial or construction activity runoff. One representative outfall for each of the eight outfall groups listed in Appendix A must be sampled on a semiannual basis.

The SPDES permit specifies the following conditions for a qualifying storm water event eligible for monitoring: (1) a period of 72 hours between the monitored event and the previous measurable event of 0.1 inches of precipitation; (2) a total rainfall of more than 0.1 inch; (3) resultant storm discharge at the outfall.

Appendix B-2 $2^{\text {Gov }}$ presents process effluent data with SPDES permit limits provided for comparison with these data. Appendix B- ${ }^{\text {(tD. }}$ presents storm water runoff monitoring data for outfalls designated in the WVDP SPDES permit.

All samples were collected and analyzed in accordance with the permit in CY 2008, and no SPDES effluent limits were exceeded. However, during the month of January 2009, the daily maximum permit limit of $0.30 \mathrm{mg} /$ $L$ for total iron for the sum of outfalls was exceeded. Site personnel are currently working with NYSDEC on a permit renewal that will include updated iron discharge monitoring and compliance limits. 
Radiological Air Emissions. Federal law allows air containing small amounts of radioactivity to be released from plant ventilation stacks during normal operations. The releases must meet dose criteria specified in the National Emission Standards for Hazardous Air Pollutants (NESHAP) regulations to ensure that public health and safety and the environment are protected. At the WVDP, radiological releases are measured and/or estimated from six permitted emission points (see Table ECS-3), five non-permitted points, and three diffuse sources (wastewater storage lagoons, stored waste containers, and demolition activities). Sampling locations for air emissions are shown in Appendix A on Figure A-6. Releases are evaluated and reported to the U.S. Environmental Protection Agency (EPA) in an annual NESHAP report.

Measured radionuclide concentrations in air are also compared with DOE DCGs. Unlike NESHAP dose criteria, the DOE DCGs are expressed in units of microcuries per milliliter $(\mu \mathrm{Ci} / \mathrm{mL})$ and can be directly compared with measurements from the monitoring program. Although the DOE DCGs are applicable only where the public may breathe air containing radionuclides, the DCGs are used at the WVDP as a tool for evaluating airborne emissions at the point of release. DCGs for radionuclides of interest at the WVDP are found in Table UI-4 in the "Useful Information" section at the end of this report. When only gross alpha and beta measurements are available, activity is assumed to come from americium-241 and strontium-90, respectively, because the DCGs for these radionuclides are the most limiting for major particulate emissions at the WVDP.

Ventilation and Emission Systems. The exhaust from each EPA-permitted ventilation system is continuously filtered and the permanent systems are monitored as air is released to the atmosphere. Because radionuclide concentrations in air emissions are quite low, a large volume of air must be sampled to measure the quantities of radionuclides released from the facility. Emissions are sampled for radioactivity in both particulate forms (e.g., strontium-90 and americium-241) and gaseous forms (e.g., tritium and iodine-129). The total release of each radionuclide varies from year to year in response to changing site activities. For instance, releases of iodine-129 dropped sharply after vitrification was completed. Over the years, annual calculated dose from air emissions at the WVDP has remained a small fraction of the NESHAP standard. (See "Predicted Dose From Airborne Emissions" in Chapter 3.)

\section{- The Main Plant Ventilation Stack}

The primary controlled air emission point at the WVDP is the main plant process building (MPPB) ventilation stack, monitoring location code ANSTACK, which vents to the atmosphere at a height of 208 feet (ft) (63.4 meters [m]). This stack has historically released ventilation exhaust from several facilities, including the liquid waste treatment system, the analytical laboratories, and off-gas from the former vitrification system. In 2008, the main plant stack continued to release ventilation exhaust from a variety of main plant spaces.

Total curies released from the main stack in 2008 are listed in Table 2-3, together with annual averages, maxima, and a comparison of average isotopic concentrations with the applicable DCGs. The sum of fractions for radiological concentrations from ANSTACK was 0.028 , far below the DOE guideline of 1.0. Airborne concentrations from the stack to the site boundary were further reduced by dispersion. Results from air samples taken near the site boundary confirm that WVDP operations had no discernible effect on off-site air quality. (See "Ambient Air," later in this chapter.)

- Other On-Site Air Sampling Systems

Sampling systems similar to those of the MPPB are used to monitor airborne effluents from the former vitrification heating, ventilation, and airconditioning system (ANVITSK), the 01-14 building ventilation stack (ANCSSTK), the contact size-reduction facility ventilation stack (ANCSRFK), the supernatant treatment system ventilation stack (ANSTSTK), the container sorting and packaging facility ventilation stack (ANCSPFK), and the remote-handled waste facility (ANRHWFK) (Fig. A-6).

Permitted portable outdoor ventilation enclosures (OVEs) are used to provide the ventilation necessary for the safety of personnel working with radioactive materials in areas outside permanently ventilated facilities or in areas where permanent ventilation must be augmented. Air samples from OVEs are collected continuously while emission points are discharging, and data from these portable ventilation units are included in annual evaluations of airborne emissions.

Appendix $\mathrm{C}^{\mathrm{GD}}$ presents total radioactivity released for specific radionuclides at each of the on-site 
TABLE 2-3

Total Radioactivity Released at Main Plant Stack (ANSTACK) in 2008 and Comparison of Concentrations with DOE DCGs

\begin{tabular}{|c|c|c|c|c|c|c|}
\hline Isotope $e^{a}$ & $\mathbf{N}$ & $\begin{array}{c}\text { Total } \\
\text { Activity Released }^{b} \\
\text { (Ci) }\end{array}$ & $\begin{array}{c}\text { Average } \\
\text { Concentration } \\
(\mu \mathrm{Ci} / \mathrm{mL})\end{array}$ & $\begin{array}{c}\text { Maximum } \\
\text { Concentration } \\
(\mu \mathrm{Ci} / \mathrm{mL})\end{array}$ & $\begin{array}{c}D C G^{c} \\
(\mu C i / m L)\end{array}$ & $\begin{array}{c}\text { Ratio of } \\
\text { Concentration } \\
\text { to DCG }\end{array}$ \\
\hline Gross Alpha & 26 & $4.61 \pm 0.56 \mathrm{E}-07$ & $6.20 \pm 0.75 \mathrm{E}-16$ & $1.47 \mathrm{E}-15$ & -- & -- \\
\hline Gross Beta & 26 & $1.24 \pm 0.02 \mathrm{E}-05$ & $1.67 \pm 0.03 \mathrm{E}-14$ & $8.28 \mathrm{E}-14$ & -- & -- \\
\hline $\mathrm{H}-3$ & 26 & $1.79 \pm 0.04 \mathrm{E}-03$ & $3.36 \pm 0.22 \mathrm{E}-14$ & $7.34 \mathrm{E}-12$ & $1 \mathrm{E}-07$ & $<0001$ \\
\hline Co-60 & 2 & $0.44 \pm 6.95 E-08$ & $0.60 \pm 9.34 \mathrm{E}-17$ & $<1.42 \mathrm{E}-16$ & $8 \mathrm{E}-11$ & $<0001$ \\
\hline Sr-90 & 2 & $2.46 \pm 0.25 \mathrm{E}-06$ & $3.31 \pm 0.33 \mathrm{E}-15$ & $4.00 \mathrm{E}-15$ & $9 \mathrm{E}-12$ & 0.0003 \\
\hline I-129 & 2 & $2.10 \pm 0.12 E-05$ & $2.83 \pm 0.17 \mathrm{E}-14$ & $3.53 \mathrm{E}-14$ & $7 \mathrm{E}-11$ & 0.0004 \\
\hline Cs-137 & 2 & $4.77 \pm 0.24 \mathrm{E}-06$ & $6.42 \pm 0.32 \mathrm{E}-15$ & $6.93 \mathrm{E}-15$ & $4 \mathrm{E}-10$ & $<0.0001$ \\
\hline Eu-154 & 2 & $-0.46 \pm 1.60 \mathrm{E}-07$ & $-0.62 \pm 2.15 E-16$ & $<2.98 \mathrm{E}-16$ & $5 \mathrm{E}-11$ & $<0.0001$ \\
\hline $\mathrm{U}-232^{d}$ & 2 & $1.00 \pm 2.70 \mathrm{E}-09$ & $1.35 \pm 3.63 \mathrm{E}-18$ & $<5.30 \mathrm{E}-18$ & $2 \mathrm{E}-14$ & $<0.0002$ \\
\hline $\mathrm{U}-233 / 234^{d}$ & 2 & $1.68 \pm 0.59 E-08$ & $2.26 \pm 0.78 \mathrm{E}-17$ & $2.34 \mathrm{E}-17$ & $9 \mathrm{E}-14$ & 0.0003 \\
\hline $\mathrm{U}-235 / 236^{d}$ & 2 & $3.11 \pm 2.64 \mathrm{E}-09$ & $4.18 \pm 3.55 E-18$ & $<4.70 \mathrm{E}-18$ & $1 \mathrm{E}-13$ & $<0.0001$ \\
\hline $\mathrm{U}-238^{d}$ & 2 & $1.15 \pm 0.49 \mathrm{E}-08$ & $1.55 \pm 0.66 \mathrm{E}-17$ & $1.53 \mathrm{E}-17$ & $1 \mathrm{E}-13$ & 0.0002 \\
\hline Pu-238 & 2 & $4.39 \pm 1.22 \mathrm{E}-08$ & $5.90 \pm 1.64 \mathrm{E}-17$ & $5.97 \mathrm{E}-17$ & $3 \mathrm{E}-14$ & 0.0020 \\
\hline $\mathrm{Pu}-239 / 240$ & 2 & $1.15 \pm 0.19 \mathrm{E}-07$ & $1.54 \pm 0.26 \mathrm{E}-16$ & $1.47 \mathrm{E}-16$ & $2 \mathrm{E}-14$ & 0.0077 \\
\hline Am-241 & 2 & $2.58 \pm 0.35 \mathrm{E}-07$ & $3.46 \pm 0.47 \mathrm{E}-16$ & $3.51 \mathrm{E}-16$ & $2 \mathrm{E}-14$ & 0.0173 \\
\hline \multicolumn{6}{|l|}{ Sum of Ratios } & 0.028 \\
\hline
\end{tabular}

$\mathrm{N}$ - Number of samples

-- - DCGs are not specified for gross alpha and beta activity.

a Half-lives are listed in Table UI-4.

b Total volume released at 50,000 cfm $=7.44 \mathrm{E}+14 \mathrm{~mL} /$ year.

c DCGs are listed for reference only. DCGs are applicable at the point at which air could be inhaled by the public (i.e., at the site boundary) but not to release point concentrations, as might be inferred from their inclusion in this table.

${ }^{d}$ Total uranium $(\mathrm{g})=3.78 \pm 0.09 \mathrm{E}-02 ;$ average $=5.08 \pm 0.12 \mathrm{E}-11 \mu \mathrm{g} / \mathrm{mL}$

air sampling locations, with the exception of ANCSRFK, which did not operate in 2008 because no activities have been taking place in the facility since 2005 , and the ventilation has been turned off.

No results exceeding the DOE DCGs were noted at any of the air emission sampling locations. Most results showed no detectable radioactivity.

- Nonradiological Air Emissions

Nonradiological air emissions at the WVDP are regulated under an air facility registration certificate that includes a cap, which limits the nitrogen and sulfur oxide emissions from the facility to 99 tons per year. (See Table ECS-3.) The WVDP certificate applies $50 \%$ of the capping limit (i.e., 49.5 tons) for each. Two site utility steam boilers are left as the only remaining sources of nitrogen and sulfur oxides. During CY 2008, approximately 1.5 tons of nitrogen oxides were emitted from these units, about $3.1 \%$ of the 49.5 -ton capping limit. No sulfur dioxide was emitted in 2008.

\section{Environmental Surveillance}

Surface Water. On-site surface water drainage is routinely sampled at several points on the north and south plateaus, as shown in Appendix A, Figure A-2. Monitoring points are sited at locations where releases from possible source areas on the south and north plateaus could be detected.

Appendices B- $4^{\mathrm{CD}}$ through B- $6^{\mathrm{CD}}$ present data for subsurface drainage water, contained water, ambient surface water, and potable water monitoring locations. 
Also provided for side-by-side comparison with these data are reference values, where available, including background ambient water monitoring data and/or pertinent ambient water quality standards, guidelines, or maximum contaminant levels (MCLs).

Radiological and nonradiological results from surface water samples were compared with applicable water quality standards and guidelines. Results from on-site and downstream locations on Franks and Buttermilk Creeks were also compared with results from the background location on Buttermilk Creek (WFBCBKG), upstream of the WVDP. Results from Cattaraugus Creek near Felton Bridge (sampling point WFFELBR), were compared with historical results from the Cattaraugus Creek background at Bigelow Bridge (former sampling point WFBIGBR). Locations with results exceeding applicable limits and those with results statistically greater than background values are summarized in Table 2-4.

- South Plateau

Two inactive underground radioactive waste disposal areas, the Nuclear Regulatory Commission (NRC)-licensed disposal area (NDA) and the New York State-licensed disposal area (SDA) lie on the south plateau. These disposal sites are possible sources of contaminants to surface water. Also located on the south plateau is the drum cell, formerly used to store approximately 20,000 drums of processed low-level radioactive waste. During 2007, shipment of drums to an off-site facility was completed and the drum cell is now empty. Areas of the south plateau are being used to store radioactive vessels removed from site facilities and to temporarily store radioactive waste containers and stage them for shipment.

At the NDA interceptor trench, samples are collected from a sump at the lowest point in the collection trench system that intercepts groundwater from the northeastern and northwestern sides of the NDA (interceptor trench at sampling point WNNDATR). Water collected underground at this location is pumped to the LLW2 for treatment prior to discharge at outfall WNSP001. If contamination were to migrate through the NDA, it would most likely be first detected at the interceptor trench.

Surface water drainage downstream of the NDA is also monitored at point WNNDADR and at Erdman Brook (point WNERB53), before it joins with drainage from the MPPB and lagoon areas. Some drain- age from western and northwestern portions of the SDA is also captured at these sampling points.

Although strontium-90 and associated gross beta results at all three locations were elevated with respect to background concentrations from Buttermilk Creek (WFBCBKG), all were below the strontium-90 DCG. Residual soil contamination from past waste burial activities is thought to be the source of the strontium-90 activity. The NDA is thought to be the predominant source of gross beta activity observed at WNNDATR.

Tritium concentrations have generally decreased over time at both WNNDATR and WNNDADR. Because the half-life of tritium is slightly longer than 12 years, decreasing tritium concentrations may be partially attributable to radioactive decay.

North of the SDA, Franks Creek is sampled to monitor drainage downstream of the drum cell and the eastern and southern borders of the SDA (point WNFRC67, on Fig. A-2). In 2008, radionuclide concentrations at this point were indistinguishable from background.

- North Plateau

Besides the effluent and drainage locations discussed earlier in the liquid effluents section, an additional location on the north plateau is sampled to monitor drainage and groundwater seepage on the east side of the MPPB (point WNSP005). As was noted at the northeast swamp location (WNSWAMP), gross beta and strontium-90 concentrations also exceeded background at locations WNSW74A and WNSP005.

On the north plateau, possible sources of contamination that could affect surface water include the high-level waste tanks, process buildings, the lagoon system associated with the LLW2, and facilities for handling and storing wastes.

\section{- Off-Site Surface Water}

Surface water samples are collected at three offsite locations, one upstream background location and one downstream location on Buttermilk Creek and one downstream location on Cattaraugus Creek. Sampling locations are shown on Fig. A-5. Results are presented in Appendix B- $5^{\text {CDD }}$. 
TABLE 2-4

2008 Comparison of Environmental Monitoring Results with Applicable Limits and Backgrounds

\begin{tabular}{|c|c|c|c|c|}
\hline Sample Type & $\begin{array}{l}\text { Number of } \\
\text { Sampling } \\
\text { Locations }\end{array}$ & $\begin{array}{l}\text { Locations with } \\
\text { Results Greater than } \\
\text { Applicable Limits or } \\
\text { Screening Levels } \\
\text { (Constituent) }\end{array}$ & \begin{tabular}{|} 
Number of \\
Locations with \\
Results Greater \\
Than \\
Background
\end{tabular} & $\begin{array}{c}\text { Locations with Results Statistically Greater } \\
\text { than Background (Constituent) }\end{array}$ \\
\hline \multicolumn{5}{|l|}{ Air (1 background location) } \\
\hline On-site air emission points & 7 & 0 & 4 & $\begin{array}{l}\text { ANSTACK (H-3, Sr-90, I-129, Cs-137, Pu-238, } \\
\text { Pu-239/240, Am-241); } \\
\text { ANSTSTK (I-129); } \\
\text { ANCSPFK (I-129); } \\
\text { ANVITSK (I-129) }\end{array}$ \\
\hline \multicolumn{5}{|c|}{ Surface water (2 background locations, one on Buttermilk Creek and one [historical] on Cattaraugus Creek) } \\
\hline On-site controlled effluents & 2 & 0 & 2 & $\begin{array}{l}\text { WNSP001 (Gross alpha, Gross beta, } \\
\mathrm{H}-3, \mathrm{Sr}-90, \mathrm{Tc}-99, \mathrm{Cs}-137, \mathrm{U}-232, \\
\mathrm{U}-233 / 234, \mathrm{U}-235 / 236, \mathrm{U}-238, \\
\mathrm{Pu}-238, \mathrm{Pu}-239 / 240, \mathrm{Am}-241, \text { bromide, } \mathrm{SO}_{4}, \\
\mathrm{NO}_{3}-\mathrm{N}, \text { oil \& grease, total B, dissolved Cu, } \\
\text { total Sb, total dissolved solids [TDS]); } \\
\text { WNSP007 (Gross beta) }\end{array}$ \\
\hline On-site surface water & 7 & $\begin{array}{l}\text { WNSWAMP (Sr-90); } \\
\text { WNSP006 (TDS) }\end{array}$ & 6 & $\begin{array}{l}\text { WNSP006 (Gross beta, Sr-90, Cs-137, U-232, } \\
\text { U-233/234, U-238); } \\
\text { WNSP005 (Gross beta, Sr-90); } \\
\text { WNSWAMP (Gross beta, Sr-90); } \\
\text { WNSW74A (Gross beta, Sr-90); } \\
\text { WNNDADR (Gross beta, H-3, Sr-90); } \\
\text { WNERB53 (Gross beta, Sr-90) }\end{array}$ \\
\hline Off-site surface water & 2 & WFBCTCB (total Fe ${ }^{b}$ ) & 2 & $\begin{array}{l}\text { WFBCTCB (Gross beta); } \\
\text { WFFELBR (Gross beta) }\end{array}$ \\
\hline \multicolumn{5}{|c|}{ Drinking water ( 2 background locations, one on site and one off site) } \\
\hline On-site drinking water & 1 & 0 & 0 & None \\
\hline \multicolumn{5}{|l|}{ Soil (1 background location) } \\
\hline Off-site soil & 5 & NS & NS & NS \\
\hline \multicolumn{5}{|c|}{ Sediment ( 2 background locations, one on Buttermilk Creek and one [historical] on Cattaraugus Creek) } \\
\hline On-site sediment/soil & 3 & NS & NS & NS \\
\hline Off-site sediment & 3 & NS & NS & NS \\
\hline \multicolumn{5}{|c|}{ Biologicals (3 background deer; 1 background per matrix for remainder) } \\
\hline Fish & 2 & NA & NS & NS \\
\hline Milk & 1 & NA & 0 & None \\
\hline Deer & 3 & NA & 0 & None \\
\hline Vegetables/fruits & 3 & NA & NS & NS \\
\hline \multicolumn{5}{|c|}{ Environmental dosimetry (1 background) } \\
\hline On-site, near facilities & 8 & NA & 3 & DNTLDs \#24, 38, 40 \\
\hline Perimeter & 17 & NA & 0 & None \\
\hline
\end{tabular}

NA - No applicable regulatory, guidance, or screening limits are available for these matrices.

NS - Not sampled in 2008.

a Applicable regulatory, guidance, or screening limits are listed in Table UI-4 (radionuclides in air and water), Appendix B-1 ${ }^{\text {שD }}$ (water) and Appendix F-2 ${ }^{\text {[DT }}$ (soil and sediment).

$b$ Background location WFBCBKG also exceeded the water quality standard for iron. 
- Buttermilk Creek receives surface drainage from the WNYNSC. The background monitoring point is located upstream of the WVDP at Fox Valley Road (WFBCBKG) and the downstream point is located at Thomas Corners Bridge (WFBCTCB), just before Buttermilk Creek enters Cattaraugus Creek.

- Background samples were collected from Cattaraugus Creek at Bigelow Bridge before the point where Buttermilk Creek flows into Cattaraugus Creek. Data from this location from 1991 through 2007 have been used to establish an upstream background. Sampling was discontinued in 2008. Downstream of that point, samples are collected at Felton Bridge (WFFELBR), the first point of public access below the WVDP.

Applicable guidance levels were exceeded at three (of 11) surface water monitoring locations affected by the WVDP in 2008.
The New York State (NYS) Class C and D water quality limit for total iron, 0.3 milligrams per liter (mg/L), was exceeded at location WFBCTCB, with a concentration of $0.39 \mathrm{mg} / \mathrm{L}$. However, the limit was also exceeded at background location WFBCBKG in eight of the 10 years of measurement before sampling for metals was discontinued in 2008. Background results ranged from a low of $0.16 \mathrm{mg} / \mathrm{L}$ to a high of $7.4 \mathrm{mg} / \mathrm{L}$. The NYS Class $C$ water quality limit for total dissolved solids $(500 \mathrm{mg} / \mathrm{L})$ was exceeded at point WNSP006, with a maximum concentration of $555 \mathrm{mg} / \mathrm{L}$. These fluctuating elevated levels of iron and solids are thought to reflect natural variability of stream conditions, not related to activities at the WVDP.

A DOE DCG was exceeded at the northeast swamp (WNSWAMP), where the average strontium-90 concentration was $2.46 \mathrm{E}-06 \mu \mathrm{Ci} / \mathrm{mL}$. (The strontium-90 DCG is $1 \mathrm{E}-06 \mu \mathrm{Ci} / \mathrm{mL}$.)

Consistent with historical data, concentrations of radiological constituents above background values,

FIGURE 2-1
Ten-Year Average Gross Alpha and Gross Beta Concentrations in Cattaraugus Creek Downstream of the WVDP at Felton Bridge and Upstream at Background Location Bigelow Bridge

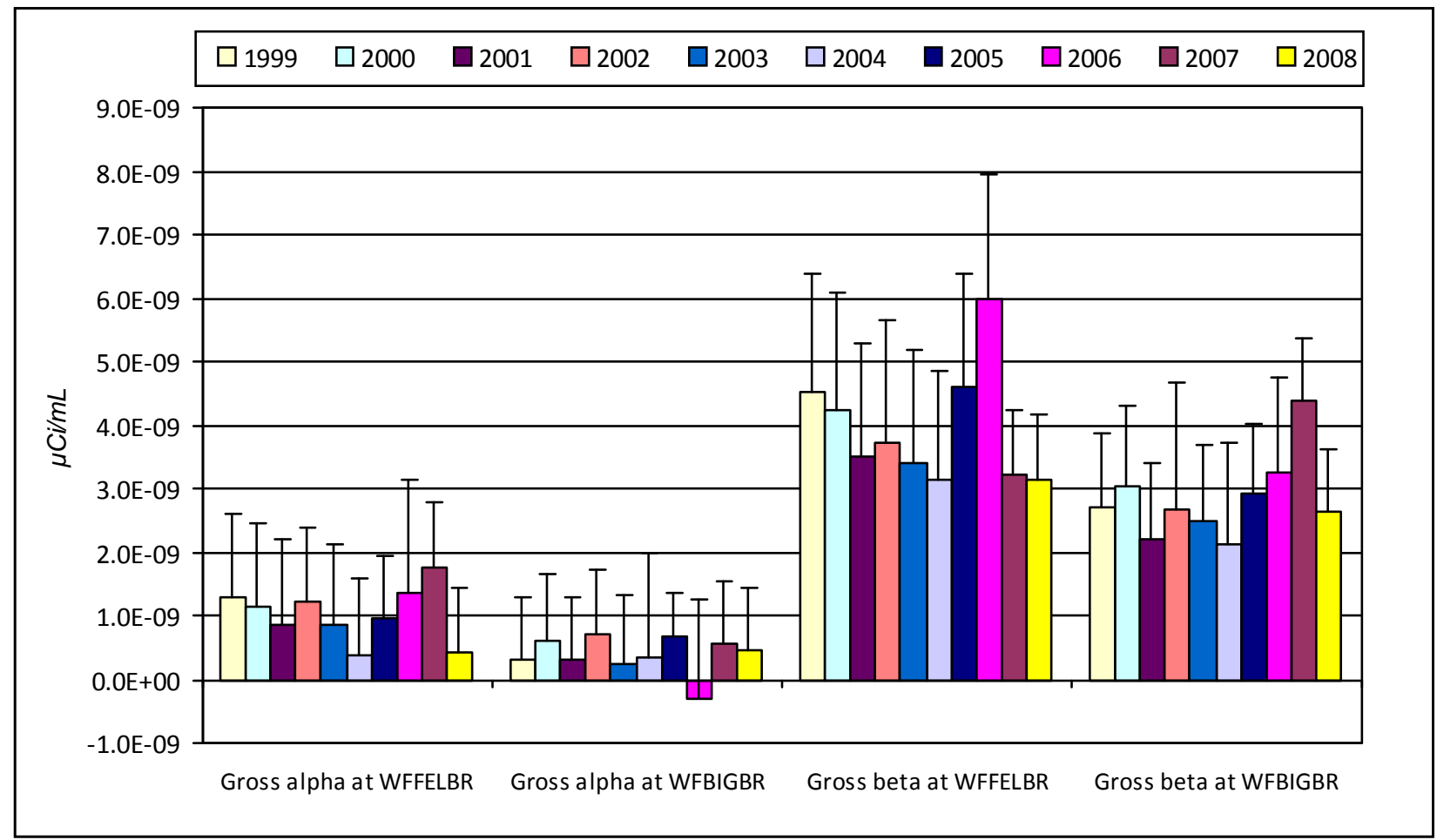

Note: All tritium averages were non-detects, so tritium was not included in this plot. The upper limit of the uncertainty term for the result is indicated with each point. Sampling at WFBIGBR was discontinued in 2007, so the 10-year averages for 1999-2007 were plotted for 2008. 
usually gross beta and strontium-90, were noted at several on-site surface water monitoring locations. However, results from samples taken downstream at the first point of public access were statistically indistinguishable from background or, as with gross beta concentrations, only slightly higher than background, indicating little Project influence downstream.

See Figure 2-1 for a plot comparing average gross alpha and gross beta concentrations in Cattaraugus Creek at WFFELBR with those at historical background point WFBIGBR over the last 10 years. Although relative concentrations vary from year to year, in general, downstream results are only slightly higher than background. The highest average gross beta result at WFFELBR over the last 10 years $(5.99 \mathrm{E}-09 \mu \mathrm{Ci} / \mathrm{mL}$ in 2006) was only about $0.6 \%$ of the DOE DCG for strontium-90 (1E-06 $\mu \mathrm{Ci} / \mathrm{mL})$. The average result in 2008 was about $0.3 \%$ of the DOE DCG.

Drinking Water. Project drinking water (potable water) and utility water is drawn from two on-site surface water reservoirs and is sampled at select locations for both radiological and nonradiological constituents. It is monitored at the distribution entry point (WNDNKUR) and at other site tap water locations to verify compliance with EPA and New York State Department of Health (NYSDOH) regulations. Results from 2008 indicated that no radiological contaminants were found in on-site drinking water and that the Project's drinking water continued to remain below the MCLs and drinking water standards of the EPA, NYSDOH, and the Cattaraugus County Health Department. The results are presented in Appendix B- $6^{\text {[D. }}$.

Ambient Air. In 2008, samples for radionuclides in air were collected at one background location at Great Valley (AFGRVAL), 18 miles (29 kilometers) south of the site. (See Figure A-12.) This location is considered representative of regional air with no potential to be affected by radiological releases from the WVDP.

Until 2008, ambient air was routinely sampled at near-site locations and at locations in nearby communities. Figure 2-2 plots gross alpha and gross beta concentrations in air for a 10 -year period from the

FIGURE 2-2

Ten-Year Average Gross Alpha and Gross Beta Concentrations at Near-Site Ambient Air Sampler AFRSPRD as Compared with Concentrations at Background Air Sampler AFGRVAL, Located 18 Miles $(29 \mathrm{~km})$ from the WVDP

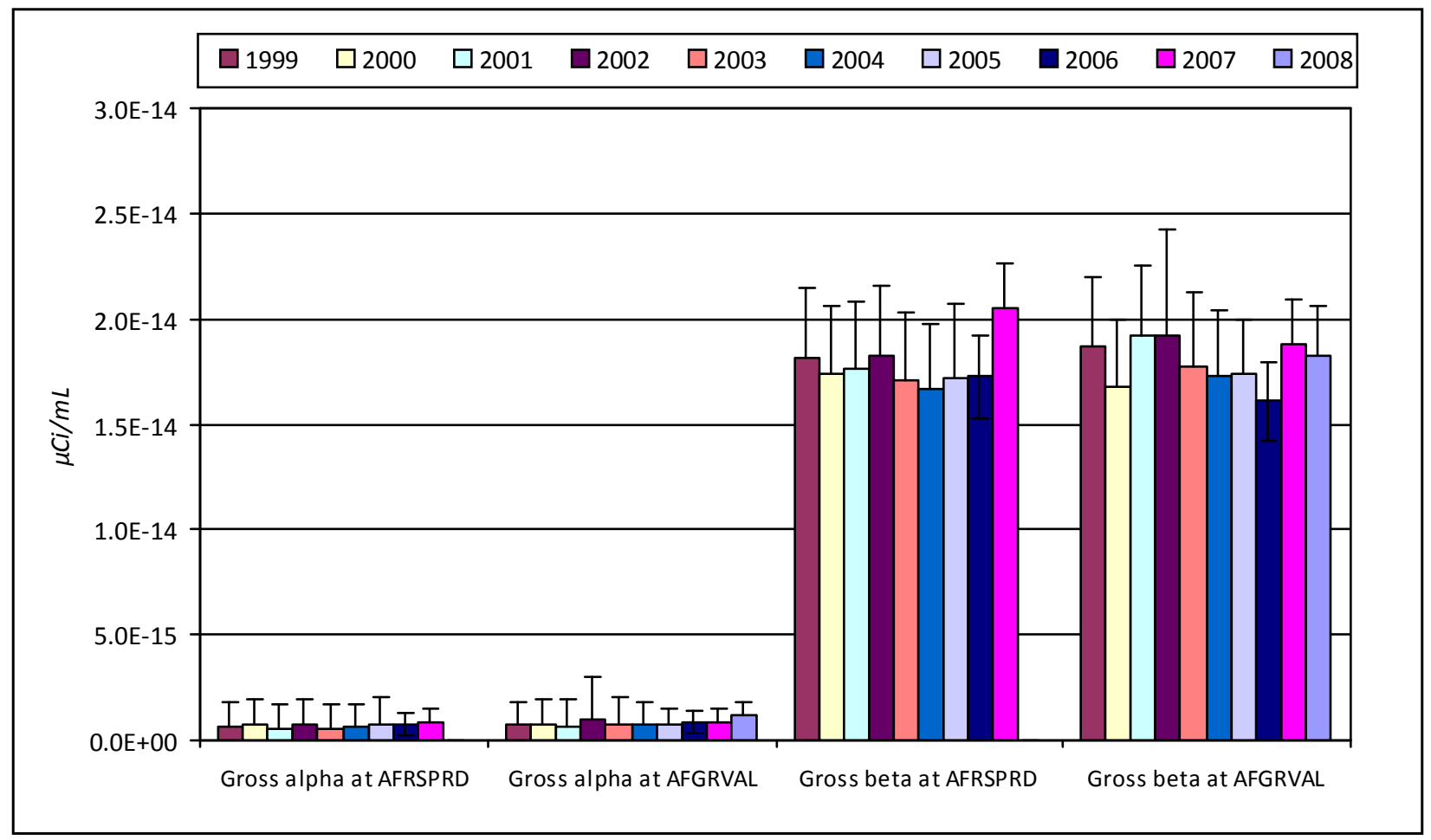

Note: The upper limit of the uncertainty term is plotted with each result. No samples were collected at AFRSPRD in 2008. 
nearest downwind historical sampling point (AFRSPRD) and concentrations from AFGRVAL. (No samples were collected at AFRSPRD in 2008, so only nine years of data for this location are included in Figure 2-2.) Although variability is noted from year to year, results from near-site point AFRSPRD are statistically the same as those from the AFGRVAL background. Results from other historical near-site and community samples have also been statistically indistinguishable from background, suggesting no evidence of adverse site influence on the quality of ambient air.

Sediment and Soil. Airborne particulates may be deposited onto soil by wind or precipitation. Particulate matter in streams can adsorb radiological constituents in liquid effluents and settle on the bottom of the stream as sediment. Soils and sediment may subsequently be eroded or resuspended, especially during periods of high winds or high stream flow. The resuspended particles may provide a pathway for radiological constituents to reach humans either directly via exposure or indirectly through the food pathway. As part of the monitoring program, on-site sediment/ soil samples are collected at three locations on the north plateau where drainage has the potential to be contaminated (SNSP006, SNSWAMP, and SNSW74A on Fig. A-2). Off-site sediment samples are collected at one background location on Buttermilk Creek and at two downstream locations, one on Buttermilk and one on Cattaraugus Creek (SFBCSED, SFTCSED, and SFCCSED, respectively, on Fig. A-5). Soil samples are collected at one background and three former near-site air sampling locations (Figs. A-5 and A-12). All samples are analyzed for radiological constituents. In 2008, frequency of sampling for sediments and soils was dropped to every five years. In accordance with this schedule, no samples were collected in 2008 and the next sampling will be done in 2012 .

Food. Food samples are collected from locations near the site (Fig. A-9) and from remote locations (Fig. A-12). Milk and deer are collected annually. Other food items are collected every five years. Fish and deer are collected during periods when they would normally be taken by sportsmen. Corn, apples, and beans are collected at the time of harvest. Edible portions are analyzed for radionuclides.

No results greater than background were noted in 2008. Data have consistently demonstrated that the Project has little or no effect on local food sources. Dose calculations based on results from food sources have consistently confirmed low dose estimates mod- eled on the basis of results from air and water monitoring. (See Chapter 3, "Dose Assessment.")

Environmental Radiation. Thermoluminescent dosimeters (TLDs) are placed on-site at waste management units, at the site security fence, around the WNYNSC perimeter and the access road, and at a background location remote from the site. These dosimeters directly measure radiation in the environment.

Consistent with historical data, results from TLDs located near on-site facilities on the north plateau in 2008 were generally higher than background results, as shown in Table 2-4. These locations are well within the WNYNSC boundary and are not accessible by the public. Environmental TLD results from the south plateau in 2008, however, were no longer above background, as they had been in 2007 before both the contents of the drum cell and the sodium-bearing waste containers (temporarily stored on the south plateau) were shipped off site.

Results at perimeter locations were statistically the same as results from the background TLDs, indicating no measurable dose from Project activities at these locations. Figure 2-3 presents a graph of annual average exposure rates (in milliroentgen per hour $[\mu \mathrm{R} / \mathrm{hr}])$ over the last 10 years at background and perimeter locations. As can be seen, results at perimeter locations are basically the same as background. In addition, no discernible trends over time are evident. Historical measurements at community locations also showed no difference from background. Sampling at community locations was discontinued in 2008.

Meteorological Monitoring. Meteorological monitoring at the WVDP provides representative and verifiable data that characterize the local climatology. These data are used to assess potential effects of routine and nonroutine releases of airborne radioactivity and to provide input to dispersion models used to calculate dose to off-site residents. An offsite tower, formerly used to characterize regional climatology, was removed in 2008.

The on-site 197-foot (ft) (60-meter [m]) meteorological tower (Figure A-1) continuously monitors wind speed, wind direction, and temperature at both the 197-ft (60-m) and 33-ft (10-m) elevations. Precipitation is also monitored near the Environmental Laboratory. Precipitation in 2008 totaled approximately 44.0 inches (112 centimeter [ $\mathrm{cm}]$ ), about $13 \%$ higher than the 10-year annual average. (See Table 2-5.) 
FIGURE 2-3

Ten-Year Trends of Environmental Radiation Levels at Perimeter and Background TLDs

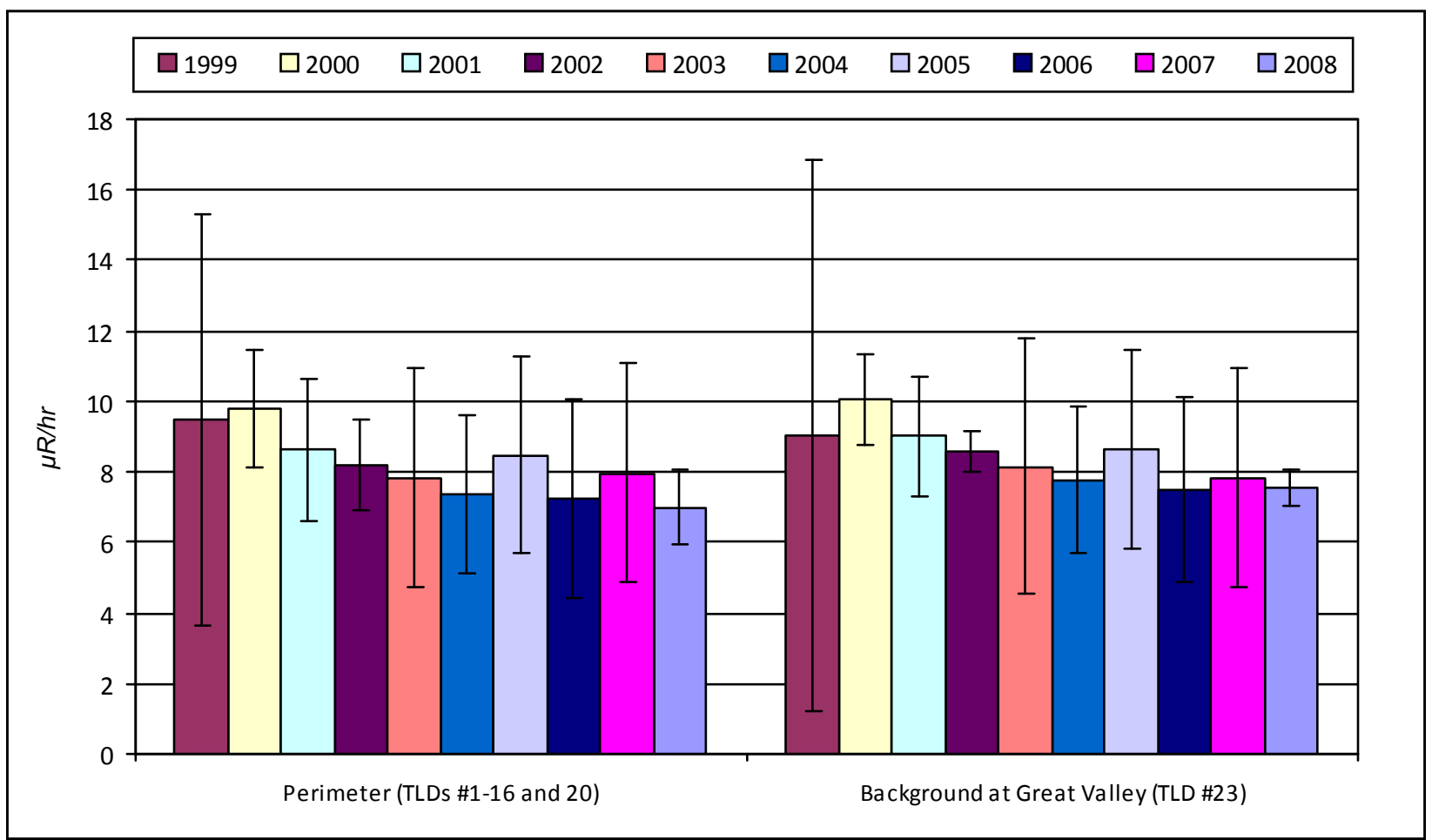

Note: The upper and lower limits of the uncertainty term are plotted with each result.

TABLE 2-5

WVDP 2008 Monthly Precipitation Totals Compared With 10-Year Monthly Averages

\begin{tabular}{|l|c|c|}
\hline \multicolumn{1}{|c|}{ Month } & Monthly Total & $\begin{array}{c}\text { Ten-Year } \\
\text { Monthly } \\
\text { Average (1998 } \\
\text { to 2007) }\end{array}$ \\
\hline January & 2.35 & 2.86 \\
\hline February & 3.73 & 2.17 \\
\hline March & 3.50 & 2.99 \\
\hline April & 2.13 & 3.13 \\
\hline May & 2.35 & 3.04 \\
\hline June & 4.11 & 3.11 \\
\hline July & 6.79 & 3.62 \\
\hline August & 3.74 & 4.00 \\
\hline September & 3.23 & 3.50 \\
\hline October & 4.26 & 3.10 \\
\hline November & 3.05 & 4.13 \\
\hline December & 4.78 & 3.41 \\
\hline Total (inches) & 44.0 & 39.1 \\
\hline (Centimeters) & 111.8 & 99.2 \\
\hline
\end{tabular}

Barometric pressure is measured with instrumentation located in the Environmental Laboratory.

The tower supplies data to the primary digital and analog data acquisition systems located within the Environmental Laboratory. The systems are provided with either uninterruptible or standby power backup in the event of site power failures. In 2008, the onsite system data recovery rate (the time valid data were logged versus the total elapsed time) was $96 \%$. Documentation, such as meteorological system calibration records, site log books, and analog strip charts, is stored in protected archives.

"Wind roses" showing the predominant direction of the wind as measured at the on-site meteorological tower (60-m and 10-m elevations) are shown in Figure 2-4. As shown, wind measurements at the 60-m elevation are predominantly from the west-northwest or south-southeast. Those measured at the 10$m$ elevation are predominantly from the northwest or the south-southeast, apparently influenced by the orientation of the topography around the site. Wind speeds measured at the on-site $10-m$ elevation were the lowest, while those from the $60-\mathrm{m}$ elevation were the highest. 
Because dispersive capabilities of the atmosphere are dependent upon wind speed, wind direction, and atmospheric stability (which includes a function of the difference in temperature between two elevations), these parameters are closely monitored and are available to the emergency response organization at the WVDP. If a release to the air occurred, meteorological data would be used to predict the direction in which the plume would move.

\section{Special Monitoring}

Monitoring may be conducted outside the scope of the routine environmental monitoring program to address topics of environmental interest, or as part of investigations or characterizations. Special monitoring efforts conducted in CY 2008 included sampling of subsurface soil and groundwater chemical and radiological constituents as part of characterization of the north plateau.

Background Concentrations in Subsurface Soil on the North Plateau. In July 2008, subsurface soil samples were collected at five locations upgradient of the north plateau strontium-90 plume. Background samples were collected from various depths, some within the sand and gravel (S\&G) geological unit and some in the deeper unweathered lavery till (ULT). Sampling locations expected to be unaffected by site operations and activities (i.e., locations with no suspected sources of contamination) were chosen. For a map of the locations and a listing of the depths from which samples were taken, see Figure A-14.

The primary focus of the sampling effort was to obtain metals concentrations representative of background for subsurface soil from the north plateau. Although not the primary objective, samples were also collected for analysis of radiological constituents.

Metals results from the S\&G and ULT units were compared and found not to be statistically different from each other. Therefore, data from the two geological units were combined (together with data from a background borehole sampled in 1993) to produce single metals background values for the north plateau. These background values, which were presented in a WVDP report (WVES, February 2009), were used to develop site-specific soil screening levels (SSLS). SSLs were based on both background values and NYSDEC guidance objectives for soil cleanup (NYSDEC, 1994). SSLs for metals concentrations in north plateau subsurface soils are listed in Table F-2C $\mathrm{C}^{\text {[D. }}$.
Radiological results from the background characterization program were used to develop background values for radiological constituents in WVDP subsurface soil as part of preparing the "Phase 1 Decommissioning Plan for the West Valley Demonstration Project" (DOE, March 2009). As seen with metals concentrations, results from the $S \& G$ and ULT geological units for constituents of concern were not statistically different from each other. Therefore, results were combined (with the 1993 borehole data) into single background values for each constituent. Representative subsurface soil backgrounds for radiological constituents are presented in Table F-2A ${ }^{\text {GD }}$.

Sampling of Subsurface Soil on the North Plateau. Subsurface soil on the north plateau was sampled in the summer and fall of 2008 as part of a program to provide additional characterization of chemical and radiological constituents in soil beneath and downgradient of the MPPB. Locations at which Geoprobe ${ }^{\circledast}$ samples were collected are presented in Figure A-15, and subsurface soil data are summarized in Appendix $\mathrm{F}^{\mathrm{CO} \text {. }}$.

Concentrations of chemical constituents were compared with background concentrations in the "West Valley Demonstration Project North Plateau Plume Area Characterization Report" (WVES, April 2009). In general, concentrations of chemical constituents (such as metals) in subsurface soil from the north plateau were not indicative of a release from the MPPB. (See Chapter 4, "Strontium-90 Plume Characterization and Remediation Activities," for a discussion of groundwater results from the north plateau characterization program.)

Radiological constituents that exceeded background concentrations in subsurface soil are summarized by location in Table 2-6. As shown in this table, radiological concentrations exceeding background were found at all sampling points, with highest concentrations underlying and downgradient of the MPPB.

Sampling for Mitigation of the Leading Edge of the Plume. In October and November 2008, subsurface soil and groundwater samples were collected as part of an investigation to provide additional data on the leading edge of the north plateau strontium-90 plume. Physical and hydrological data were also acquired for use in decision-making regarding placement and design of a permeable treatment wall (PTW) and a proposed permeable reactive barrier (PRB) for mitigation of the north plateau plume. For a more detailed discussion, see "Pre-Design Geoprobe ${ }^{\circledR}$ 
TABLE 2-6

2008 Comparison of Radiological Results From Special Geoprobe ${ }^{\circledR}$ Subsurface Soil Samples on the North Plateau With Background Results

\begin{tabular}{|c|c|c|c|}
\hline $\begin{array}{l}\text { Sample } \\
\text { Location }^{a}\end{array}$ & $\begin{array}{l}\text { Number of } \\
\text { Sampling } \\
\text { Locations }\end{array}$ & \begin{tabular}{|c} 
Number of \\
Locations with \\
Results \\
Greater Than \\
Background
\end{tabular} & $\begin{array}{l}\text { Locations with Results Statistically Greater than Background } \\
\text { (Constituent) }\end{array}$ \\
\hline \multicolumn{4}{|c|}{ North Plateau Subsurface Soil (combined data from 6 background locations [Fig. A-14]) } \\
\hline $\begin{array}{l}\text { Inside Main Plant } \\
\text { Process Building }\end{array}$ & 5 & 5 & $\begin{array}{l}\text { GP7508 (Sr-90, Pu-239/240) } \\
\text { GP7608 (Gross beta, H-3, Sr-90, Tc-99, Cs-137, Eu-154, } \\
\text { U-233/234, Pu-238, Pu-239/240, Am-241) } \\
\text { GP7808 (Gross beta, Co-60, Sr-90, Tc-99, Cs-137, Eu-154, } \\
\text { U-233/234, U-235/236, U-238) } \\
\text { GP8008 (Gross beta, Sr-90, Cs-137, U-235/236, Pu-239/240, } \\
\text { Am-241, Cm-243/244) } \\
\text { GP10008 (Gross beta, H-3, Sr-90, I-129, Cs-137, U-233/234, } \\
\text { U-238, Pu-238, Pu-239/240, Am-241) }\end{array}$ \\
\hline $\begin{array}{l}\text { Outside Main } \\
\text { Plant Process } \\
\text { Building }\end{array}$ & 4 & 4 & $\begin{array}{l}\text { GP2908 (Gross alpha, Gross beta, Sr-90, Cs-137, U-232, } \\
\text { U-233/234, U-235/236, U-238, Pu-238, Pu-239/240, Am-241) } \\
\text { GP3008 (Gross beta, Sr-90, Cs-137, U-233/234, U-235/236, } \\
\text { U-238, Am-241) } \\
\text { GP7208 (Gross beta, Sr-90, Tc-99, I-129, Cs-137, U-235/236, } \\
\text { U-238, Pu-239/240, Am-241) } \\
\text { GP10108 (Sr-90, Cs-137, U-233/234, U-235/236, U-238, Pu-238, Pu- } \\
\text { 239/240, Am-241) }\end{array}$ \\
\hline $\begin{array}{l}\text { Downgradient of } \\
\text { Main Plant } \\
\text { Process Building }\end{array}$ & 9 & 9 & $\begin{array}{l}\text { GP8308 (Gross beta, Sr-90, U-233/234, U-235/236, U-238) } \\
\text { GP10208 (Gross beta, Sr-90, Cs-137, U-232, U-233/234, } \\
\text { U-235/236, U-238, Pu-239/240, Am-241) } \\
\text { GP10308 (Gross beta, Sr-90, U-233/234, U-235/236) } \\
\text { GP10408 (Gross beta, Sr-90, U-232, U-233/234, U-235/236, } \\
\text { U-238) } \\
\text { GP10508 (Gross beta, Co-60, Sr-90) } \\
\text { GP10608 (Gross beta, Sr-90, U-233/234, U-235/236, Am-241) } \\
\text { GP10708 (Gross beta, Sr-90, U-235/236, Np-237) } \\
\text { GP10808 (Sr-90, Cs-137, U-233/234, U-238, Am-241) } \\
\text { GP10908 (Gross beta, Sr-90, U-232, U-238) }\end{array}$ \\
\hline
\end{tabular}

Note: No guideline levels specific to radionuclides in subsurface soil are currently available. Dose-based Derived Concentration Guideline Levels specific to radionuclides in subsurface soil at the WVDP have been proposed in the draft Phase I Decommissioning Plan for the West Valley Demonstration Project (March 2009).

${ }^{a}$ MPPB and downgradient sampling locations are shown on Fig. A-15. 
Investigation for Mitigation of the Leading Edge of the North Plateau Strontium-90 Plume" in Chapter 4.

\section{Monitoring Program Changes}

Over the last few years, site activities have focused on dismantlement and decontamination of facilities, demolition of unnecessary structures, and processing and shipping of waste. Hazardous materials and potential pollutant sources on site are being reduced. In late 2007, the environmental monitoring program was thoroughly evaluated and changes were identified to streamline the program in response to changing site activities.

Each sampling location was evaluated on several bases: (1) regulatory requirements or legal drivers on which sampling is based, (2) current exposure pathways and hazard conditions, (3) a statistical evaluation of up to 16 years of monitoring data at each location, and (4) a determination of the need for additional data and/or ongoing monitoring for each constituent. As a result, the sampling frequency at some locations was reduced and/or the number of analytical constituents adjusted. At several locations, sampling was discontinued altogether.

Environmental monitoring program modifications were implemented in January of 2008. Specific program changes in CY 2008 at each location, with the rationale for the change, are summarized in Appen$\operatorname{dix} A$. The maps in Appendix A have been color-coded to show those locations at which sampling has remained unchanged and those locations at which sampling has been reduced.

\section{Summary}

In 2008, no monitoring results exceeded regulatory limits. As in the past, although concentrations of certain radiological and nonradiological constituents from samples collected within the security fence exceeded background or screening concentrations, few results from near-site or downstream locations accessible to the public did.

Monitoring results from CY 2008 continued to demonstrate minimal or no adverse effects of the WVDP on the surrounding environment and confirmed the effectiveness of radiological control measures practiced at the WVDP. 
FIGURE 2-4

Wind Frequency and Speed from the On-Site Meteorological Tower (10-m and 60-m Elevations) January 1-December 31, 2008

Key:

Numbers indicate sector mean wind speed.

Sectors are directions from which the wind is blowing.

Wind Speed Range (m/sec)
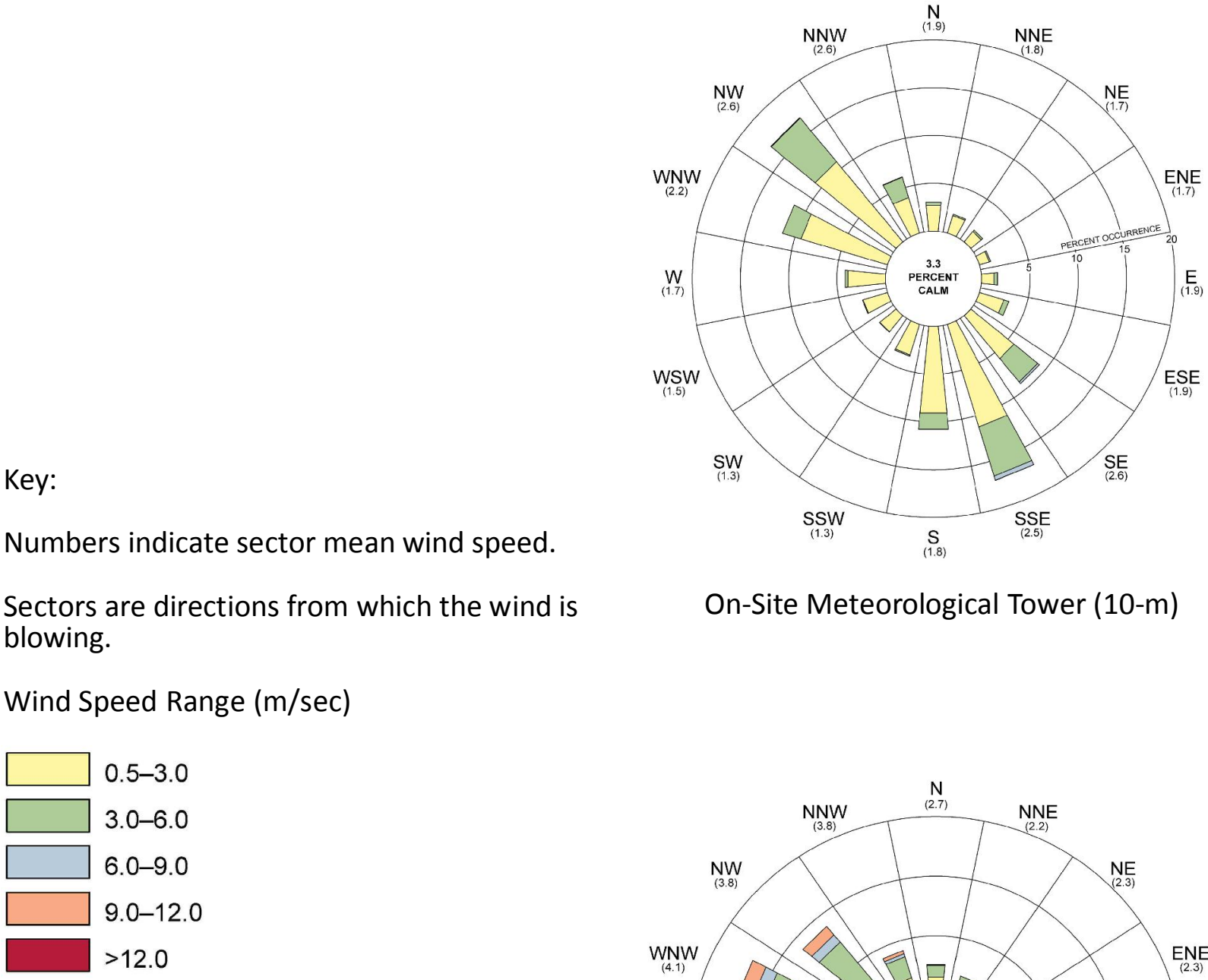

On-Site Meteorological Tower (10-m)

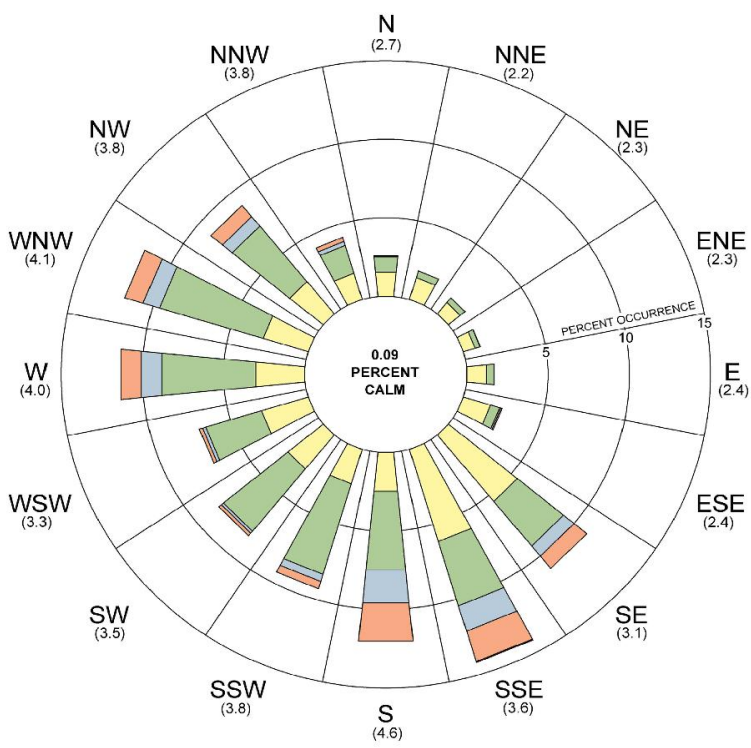

On-Site Meteorological Tower (60-m) 


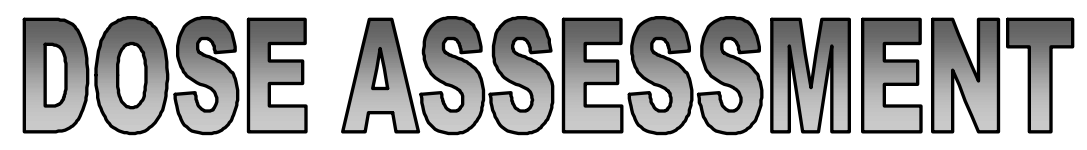

\section{Sources of Radiation at the West Valley Demonstration Project (WVDP)}

Members of the public are routinely exposed to natural and man-made sources of ionizing radiation. An individual living in the United States (U.S.) is estimated to receive an average annual effective dose equivalent (EDE) of about 360 millirem (mrem) (3.6 millisieverts [mSv]) (National Council on Radiation Protection and Measurements Report 93, 1987). (See the "Useful Information" Section at the end of this report for discussions of ionizing radiation. See the inset on p. 3-3 for discussions of "Radiation Dose" and "Units of Dose Measurement.")

Most of the radiation dose to a member of the public, about $295 \mathrm{mrem} / \mathrm{year}$, is from natural background sources of cosmic and terrestrial origin (Fig. 3-1). The remainder, about $65 \mathrm{mrem} /$ year, is from man-made sources, including diagnostic and therapeutic x-rays, nuclear medicine, consumer products such as cigarettes and smoke detectors, fallout from nuclear weapons tests, and effluents from nuclear facilities.
Radioactive materials at the WVDP are residues from the commercial reprocessing of nuclear fuel by a former site operator in the 1960s and early 1970s. Each year, very small quantities of the radioactive materials remaining at the WVDP are released to the environment. Emissions and effluents are strictly controlled so that release quantities are kept as low as reasonably achievable (ALARA).

\section{Exposure Pathways}

An exposure pathway consists of a route for contamination to be transported by an environmental medium from a source to a receptor. Table 3-1 summarizes the potential exposure pathways to the local off-site population and describes the rationale for including or excluding each pathway when calculating dose from the WVDP.

Potential exposure pathways that are considered include: inhalation of gases and particulates, ingestion of locally grown food products and game, and

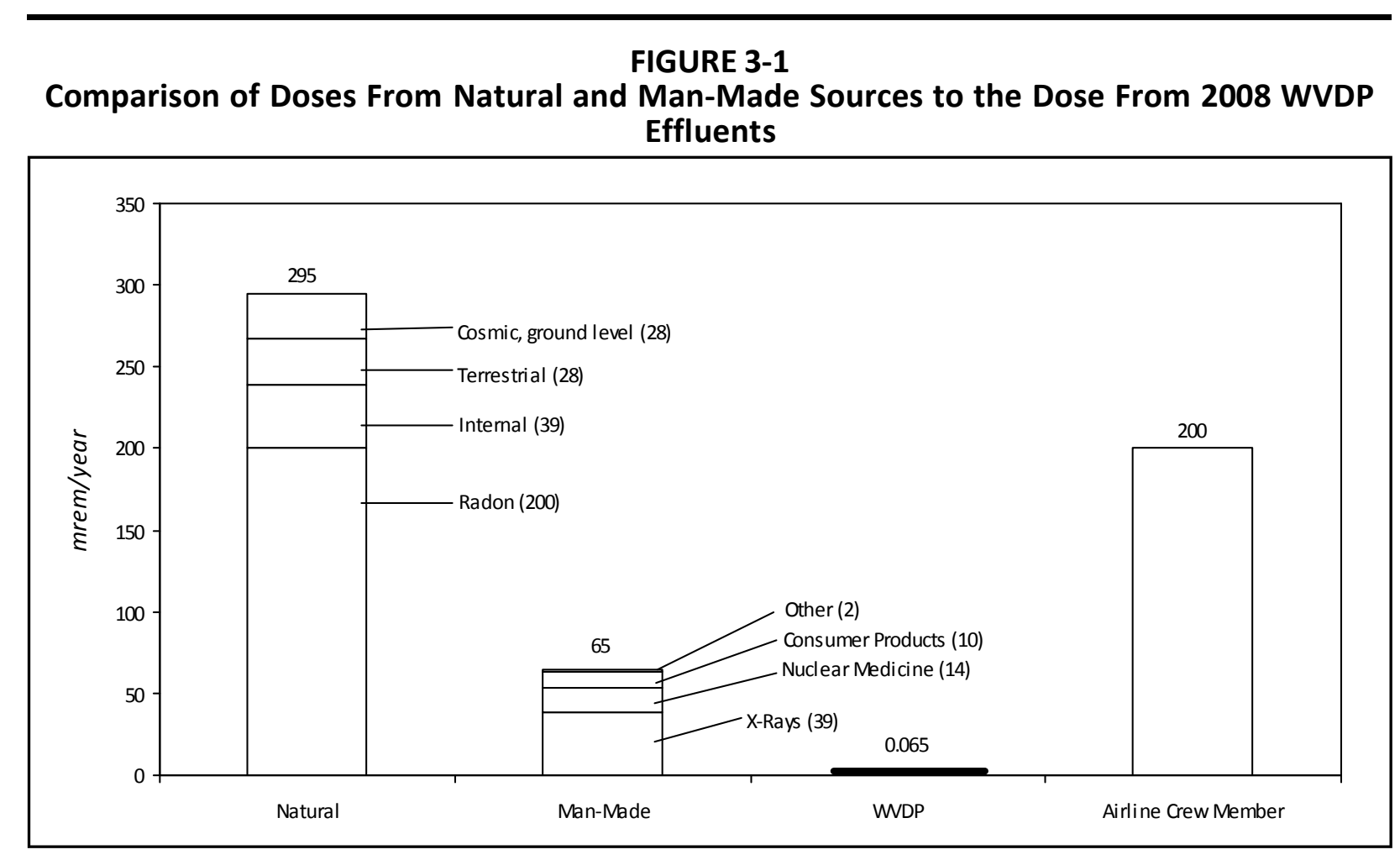


TABLE 3-1

Potential Exposure Pathways from the WVDP to the Local Off-Site Population

\begin{tabular}{|c|c|}
\hline $\begin{array}{l}\text { Exposure Pathway and Transporting } \\
\text { Medium }\end{array}$ & Reason for Including/Excluding \\
\hline $\begin{array}{l}\text { Inhalation of gases and particulates in air } \\
\text { (included) }\end{array}$ & $\begin{array}{l}\text { Off-site transport of contaminants from stacks, vents, diffuse sources, } \\
\text { or resuspended particulates from soil or water. }\end{array}$ \\
\hline $\begin{array}{l}\text { Ingestion of vegetables, cultivated crops, } \\
\text { venison, milk, and fish (included) }\end{array}$ & $\begin{array}{l}\text { Local agricultural products irrigated with potentially contaminated } \\
\text { surface or groundwater; airborne deposition on leaves and uptake of } \\
\text { deposited contaminants; venison and milk from animals that have } \\
\text { inhaled or ingested contaminants; fish that have been exposed to or } \\
\text { ingested contaminants in surface water and sediment. }\end{array}$ \\
\hline $\begin{array}{l}\text { Ingestion of surface and groundwater } \\
\text { (excluded) }\end{array}$ & $\begin{array}{l}\text { No documented use of local surface water or downgradient } \\
\text { groundwater wells as drinking water by local residents. }\end{array}$ \\
\hline $\begin{array}{l}\text { External exposure to radiation from } \\
\text { particulates and gases directly from air or } \\
\text { surface water or indirectly from surface } \\
\text { deposition (included) }\end{array}$ & $\begin{array}{l}\text { Transport of air particulates and gases to off-site receptors; transport } \\
\text { of contaminants in surface water and direct exposure when swimming } \\
\text { wading, boating, or fishing. }\end{array}$ \\
\hline
\end{tabular}

exposure to external penetrating radiation emitted from contaminated materials. Drinking water is not considered a pathway from the WVDP because surveys have determined that no public water supplies are drawn from downstream Cattaraugus Creek before Lake Erie or from groundwater in aquifers potentially affected by the WVDP.

\section{Land Use Survey}

Periodic surveys of local residents provide information about family size, sources of food, and gardening practices. Updated population data from the calendar year (CY) 2000 census was incorporated into WVDP analyses in 2003. Population around the WVDP by sector and distance is presented in Figure A-13. Information from the most recent land use survey, conducted in early 2002, was used to update the locations of the residences nearest to the site. In 2008, a field verification was conducted to confirm the location of the nearest residence in each sector. Also in 2008, the Canadian population within a 50mile (80-kilometer $[\mathrm{km}]$ ) radius of the site (Statistics Canada, 2001) was included in dose calculations. Population information is required when using computer models for annual dose assessments.

\section{Dose Assessment Methodology}

Dose to the public is evaluated using a two-part method consistent with the requirements of the U.S. Department of Energy (DOE) Order 5400.5. First, measurements (and/or estimates) of radionuclide con- centrations in liquid and air released from the Project are assembled from the calendar year of interest. The U.S. Environmental Protection Agency (EPA)- and DOE-approved models are then used to estimate the EDE to the maximally exposed off-site individual (MEOSI) and the collective EDE to the population within a $50-$ mile $(80-\mathrm{km})$ radius.

Second, measurements of radioactivity in food from locations near the WVDP boundaries are taken to corroborate the results from the modeled dose calculations. Samples of vegetables, fruit, milk, venison, and fish from the vicinity of the WVDP are collected and analyzed for radiological constituents. Results are compared with similar measurements from samples collected at background locations far from the WVDP. If any near-site results are higher than background results, dose calculations are performed. These results are used as an independent confirmation of (not added to) the computer-modeled dose estimates (Table 3-2) because the models already take into account contributions from all environmental pathways.

Measurement of Radionuclide Concentrations in Liquid and Air Releases. Because it is difficult to distinguish by direct measurement the small amount of radioactivity originating from the Project or from naturally occurring radiation in the environment, computer codes are used to model the environmental dispersion of radionuclides that originate from onsite monitored ventilation stacks and liquid discharge points. 


\section{Radiation Dose}

The energy released from a radionuclide is eventually deposited in matter encountered along the path of the radiation. The radiation energy absorbed by a unit mass of material is referred to as the absorbed dose. The absorbing material can be either inanimate matter or living tissue.

Alpha particles leave a dense track of ionization as they travel through tissue and thus deliver the most dose per unit path-length. However, alpha particles are not penetrating and must be taken into the body by inhalation or ingestion to cause harm. Beta and gamma radiation can penetrate the protective dead skin layer of the body from the outside, resulting in exposure of the internal organs to radiation.

Because beta and gamma radiations deposit much less energy in tissue per unit path-length relative to alpha radiation, they produce fewer biological effects for the same absorbed dose. To allow for the different biological effects of different kinds of radiation, the absorbed dose is multiplied by a quality factor to yield a unit called the dose equivalent. A radiation dose expressed as a dose equivalent, rather than as an absorbed dose, permits the risks from different types of radiation exposure to be compared with each other (e.g., exposure to alpha radiation compared with exposure to gamma radiation). For this reason, regulatory agencies limit the dose to individuals in terms of total dose equivalent.

\section{Units of Dose Measurement}

The unit for dose equivalent in common use in the U.S. is the rem. The international unit of dose equivalent is the sievert (Sv), which is equal to 100 rem. The millirem (mrem) and millisievert (mSv), used more frequently to report the low dose equivalents encountered in environmental exposures, are equal to onethousandth of a rem or sievert, respectively. Other radioactivity unit conversions are found in the "Useful Information" section at the back of this report.

The effective dose equivalent (EDE), also expressed in units of rem or sievert, provides a means of combining unequal organ and tissue doses into a single "effective" whole body dose that represents a comparable risk probability. The probability that a given dose will result in the induction of a fatal cancer is referred to as the risk associated with that dose. The EDE is calculated by multiplying the organ dose equivalent by the organ-weighting factors developed by the International Commission on Radiological Protection (ICRP) in Publications 26 (1977) and 30 (1979). The weighting factor is a ratio of the risk from a specific organ or tissue dose to the total risk resulting from an equal whole body dose. All organ-weighted dose equivalents are then summed to obtain the EDE.

The dose from internally deposited radionuclides calculated for a fifty-year period following intake is called the fifty-year committed effective dose equivalent (CEDE). The CEDE sums the dose to an individual over fifty years to account for the biological retention of radionuclides in the body. The total EDE for one year of exposure to radioactivity is calculated by adding the CEDE to the dose equivalent from external, penetrating radiation received during the year. Unless otherwise specified, all doses discussed here are total EDE values, which include the CEDE for internal emitters.

A collective population dose is expressed in units of person-rem or person-sievert because the individual doses are summed over the entire potentially exposed population. The average individual dose can therefore be estimated by dividing the collective dose by the population. 
Actual data from air and water release-monitoring samples are collected, together with annual weather measurements and the most recent demographic information. (See Appendices A, $B^{\mathbf{E D}}$, and $C^{\mathbf{E D}}$.) The EDE to the MEOSI and the collective EDE to the population within a 50-mile $(80-\mathrm{km})$ radius are then calculated using conservative DOE- and EPA-approved models to demonstrate compliance with radiation standards. (See the inset on "Radiation Dose" and "Units of Dose Measurement.")

\section{Measurement of Radionuclide Concentrations in Food. The second part of the dose assessment is based on actual radioactivity measurements in samples of foodstuffs grown in the vicinity of the WVDP and the comparison of these values with mea- surements of samples collected from locations well beyond the potential influence of site effluents.}

If any of the near-site food samples contain radionuclide concentrations that are higher than the concentrations in control samples, separate dose calculations are performed to verify that the calculated dose from food is consistent with the dose range estimated by computer modeling. (See "Calculated Dose From Food," later in this chapter.)

These estimates show that the concentrations of radioactivity, whether from sites near or distant from the WVDP, are small - usually near the analytical detection limits - thereby providing additional assurance that operations at the WVDP are not adversely affecting the public. (Biological sampling locations are shown on Figures $A-9$ and $A-12$.)

\section{Dose to the Public}

Each year an estimate is made of the potential radiological dose to the public that is attributable to operations and effluents from the WVDP during that calendar year. Estimates are calculated to confirm that no individual could have received a dose that exceeded the limits for protection of the public, as established by the DOE or the EPA.

Figure 3-1 shows the estimated maximum individual dose from the WVDP in CY 2008 as compared with the average annual dose a U.S. resident receives from man-made and natural background sources. As presented, estimated dose from the WVDP would have contributed a very small amount $(0.065$ mrem [0.00065 mSv]) of the total annual man-made radiation dose to the MEOSI. This is much less than the average dose received from consumer products and is insignificant compared with average dose from natural sources.

Estimated dose from the Project to an off-site resident is also far below the federal standard of 100 mrem allowed from any DOE site operation in a calendar year, confirming that efforts at the WVDP to minimize radiological releases are consistent with the ALARA philosophy of radiation protection.

\section{Predicted Dose From Airborne Emissions}

Airborne emissions of radionuclides are regulated by the EPA under the Clean Air Act and its implementing regulations. DOE facilities are subject to Title 40 of the Code of Federal Regulations (CFR) 61, Subpart $\mathrm{H}$, National Emission Standards for Hazardous Air Pollutants (NESHAP). Subpart H contains the national emission standards for radionuclides other than radon from DOE facilities. The applicable standard is a maximum of 10 mrem (0.1 mSv) EDE to any member of the public in any year.

Releases of airborne radioactive materials in 2008 from stacks and diffuse sources on the WVDP were modeled using the EPA-approved CAP88-PC computer code (Parks, June 1997). This air dispersion code estimates EDEs for the ingestion, inhalation, air immersion, and ground surface pathways. (See "CAP88-PC Computer Code" in the "Useful Information" section.)

Site-specific data for CY 2008 (radionuclide releases in curies per year) were used as input to the CAP88PC code, as were wind data collected from the onsite meteorological tower during 2008 and information from the most recent local population survey. The output from the CAP88-PC code was then used to determine the total EDE from air emissions to the MEOSI and the collective EDE to the population within a $50-$ mile $(80 \mathrm{~km})$ radius of the WVDP. Results are presented in Table 3-2. Although radon is specifically excluded from the NESHAP regulation, an estimate of dose from radon at the WVDP is also included in Table 3-2 for comparison purposes. (For a detailed discussion of radon in air emissions from the WVDP, see the inset on "Radon-220".)

Maximum Dose (Airborne) to an Off-Site Individual. Total curies released to the atmosphere from point sources at the WVDP are summarized in Table 3-3. Based on the nonradon airborne radioactivity released from all site sources during 2008 (i.e., permitted stacks, stacks that do not require permits, and 
nonpoint sources), it was estimated that a person living in the vicinity of the WVDP could have received a total EDE of 0.0011 mrem $(0.000011 \mathrm{mSv})$ from airborne releases. The computer model estimated that this MEOSI, who was assumed to eat only locally produced foods, was located 1.2 mile $(1.9 \mathrm{~km})$ northnorthwest of the site.

The dose from airborne sources is equal to about 2 minutes of natural background radiation received by an average member of the U.S. population, and is well below the 10-mrem (0.1 mSv) NESHAP limit established by the EPA and mandated by DOE Order 5400.5 .

lodine-129, a long-lived radionuclide, has routinely been found in main stack emissions. During the vitrification of high-level waste, iodine-129 releases in- creased because gaseous iodine was not as efficiently removed by the vitrification process off-gas treatment system as were most other radionuclides. As more high-level radioactive waste was removed from the tanks and converted into glass, less waste was available to emit iodine-129 and the total emitted decreased. In 2008, iodine-129 concentrations continued to be back to (or below) pre-vitrification levels. Even so, in 2008, iodine-129 continued to account for the largest proportion of dose to an off-site individual from airborne point source emissions. A comparison of the proportions of dose from various nuclides is presented in Figure 3-2. As shown in this figure, about $94 \%$ of the estimated airborne dose from point sources in 2008 was from iodine-129.

TABLE 3-2

\section{Summary of Annual Effective Dose Equivalents to an Individual and Population From WVDP Releases in 2008}

\begin{tabular}{|c|c|c|}
\hline \multirow[t]{2}{*}{ Exposure Pathways } & \multicolumn{2}{|c|}{ Annual Effective Dose Equivalent } \\
\hline & $\begin{array}{l}\text { Maximally Exposed } \\
\text { Off-Site Individual }^{a} \\
\text { mrem (mSv) }\end{array}$ & $\begin{array}{l}\text { Collective Effective } \\
\text { Dose Equivalent }{ }^{b} \\
\text { person-rem (person-Sv) }\end{array}$ \\
\hline Airborne Releases $^{c}$ & 1.1E-03 (1.1E-05) & $6.9 \mathrm{E}-03(6.9 \mathrm{E}-05)$ \\
\hline \% EPA standard (10 mrem) & $0.011 \%$ & NA \\
\hline Waterborne Releases $^{d}$ & $6.4 \mathrm{E}-02(6.4 \mathrm{E}-04)$ & $2.8 \mathrm{E}-01(2.8 \mathrm{E}-03)$ \\
\hline Effluents only & 1.9E-02 (1.9E-04) & 1.7E-02 (1.7E-04) \\
\hline North plateau drainage & 4.4E-02 (4.4E-04) & $2.6 \mathrm{E}-01(2.6 \mathrm{E}-03)$ \\
\hline Total From All Pathways & $6.5 \mathrm{E}-02(6.5 \mathrm{E}-04)$ & $2.8 \mathrm{E}-01(2.8 \mathrm{E}-03)$ \\
\hline $\begin{array}{l}\% \text { DOE standard (100 mrem) - } \\
\text { air and water combined }\end{array}$ & $0.065 \%$ & NA \\
\hline $\begin{array}{l}\text { \% of natural background } \\
\text { ( } 295 \text { mrem; } 497,000 \text { person-rem) - } \\
\text { received from air and water combined }\end{array}$ & $0.022 \%$ & $0.000057 \%$ \\
\hline Estimated Airborne Radon-220 ${ }^{e}$ & $1.1 \mathrm{E}-02(1.1 \mathrm{E}-04)^{f}$ & 3.7E-01 (3.7E-03) \\
\hline
\end{tabular}

Note: Summed values may not exactly match totals due to rounding.

NA - Not applicable. Numerical regulatory standards are not set for the collective EDE to the population.

$a$ The maximum exposure to air discharges is estimated to occur at a residence 1.2 miles (1.9 km) north-northwest of the main plant process building (MPPB).

$b$ A population of 1.68 million is estimated to reside in the U.S. and Canada within 50 miles (80 km) of the site.

$c$ Releases are from atmospheric nonradon point and diffuse sources. Calculations use CAP88-PC to estimate individual and population doses. EPA and DOE limits for individual airborne dose are the same.

$d$ Estimates are calculated using the methodology described in the WVDP Manual for Radiological Assessment of Environmental Releases at the WVDP (West Valley Nuclear Services Company [WVNSCO], 2003).

$e$ Estimated airborne releases are based on indicator measurements and process knowledge. Dose estimates are calculated using CAP88-PC for the MPPB stack.

$f$ The estimated dose from radon-220 is specifically excluded by rule from NESHAP totals. 


\section{Radon-220}

Radon-220, also known as thoron, is a naturally occurring gaseous decay product of thorium-232 present in the airborne emissions from the WVDP main plant. Radon-220 is also associated with the thorium reduction extraction (THOREX) process-related thorium-232 and uranium-232 in the high-level waste.

As reported in Chapter 2 of the 1996 WVDP Site Environmental Report (WVNSCO and Dames \& Moore, June 1997), thoron levels were observed to increase during startup of the 1996 high-level waste vitrification process. An estimate of the thoron released during each waste concentration cycle was developed and used to determine a theoretical annual release. During the vitrification phase, an average of about 12 curies per day were assumed to have been released. In 2008 , with the vitrification process completed, the average thoron release is conservatively estimated to be about three curies per day.

Although large numbers of curies were released relative to other radionuclides, the calculated dose from thoron is quite small because of its short decay half-life and other characteristics. The NESHAP rule specifically excludes thoron from air emission dose calculations, so a dose estimate using CAP88-PC was calculated separately. The theoretical dose to the MEOSI located $1.2 \mathrm{mi}(1.9 \mathrm{~km})$ north-northwest of the site in 2008 would have been $0.011 \mathrm{mrem}(0.00011 \mathrm{mSv})$, and the collective dose to the population within a 50mile $(80-\mathrm{km})$ radius would have been 0.37 person-rem (0.0037 person-Sv). (See Table 3-2.) These theoretical doses are within the same range as historical doses from the man-made radionuclides found in WVDP effluents.

With vitrification completed, thoron releases have decreased to pre-vitrification levels. The figure presented here provides a relative indication of recent trends in the estimated annual thoron releases.

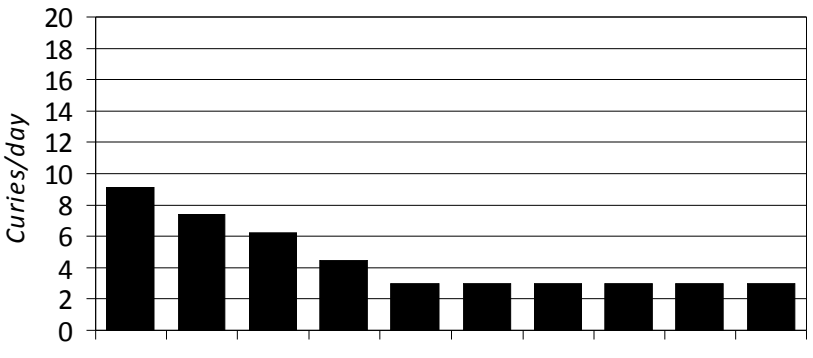

1999200020012002200320042005200620072008 Estimated Radon-220 Releases From the WVDP
Collective Population Dose (Airborne). About $1.68 \mathrm{mil}-$ lion people were estimated to reside in the U.S. and Canada within 50 miles $(80 \mathrm{~km}$ ) of the WVDP. (See Figure A-13.) This population received an estimated 0.0069 person-rem (0.000069 person-Sv) total EDE from radioactive nonradon airborne emissions released from WVDP point and diffuse sources during 2008. The resulting average EDE per individual was $0.0000041 \mathrm{mrem}(0.000000041 \mathrm{mSv})$.

\section{Predicted Dose From Waterborne Releases}

Currently there are no EPA standards establishing limits on the radiation dose to members of the public from liquid effluents, except as applied in 40 CFR Parts 141 and 143, Drinking Water Guidelines (EPA, 1984a; 1984b). Corollary limits for community water supplies are set by the New York State Department of Health (NYSDOH) in the New York State Sanitary Code (Title 10 of the Official Compilation of Codes, Rules, and Regulations of the State of New York 5-
1.52). As indicated in Table 3-1, the only local private residential wells are located upgradient of the WVDP and therefore do not represent a potential source of exposure to radioactivity from Project activities. Cattaraugus Creek is not used as a drinking water supply; therefore, a comparison of estimated doses from this source with the 4-mrem/year (0.04$\mathrm{mSv}$ /year) EPA and NYSDOH drinking water limits is not truly appropriate (although values are well below the drinking water limits). Population dose estimates are based on the presumption that radionuclides are even further diluted in Lake Erie before reaching any municipal water supplies.

Because the Project's liquid effluents eventually reach Cattaraugus Creek, the most important waterborne exposure pathway is the consumption of fish from the creek by local sportsmen and residents. Exposure to external radiation from contamination at the shoreline or in the water is also considered in the model for estimating radiation dose. 
TABLE 3-3

WVDP Radiological Dose and Release Summary

\begin{tabular}{|c|c|c|c|c|c|c|}
\hline \multicolumn{7}{|c|}{ WVDP Radiological Dose Reporting Table CY 2008} \\
\hline \multicolumn{2}{|c|}{$\begin{array}{l}\text { Dose to the } \\
\text { Maximally Exposed } \\
\text { Individual }\end{array}$} & \multirow{2}{*}{$\begin{array}{c}\begin{array}{c}\% \text { of DOE } \\
100-\text { mrem Limit }\end{array} \\
0.065\end{array}$} & \multicolumn{2}{|c|}{$\begin{array}{c}\text { Estimated } \\
\text { Population Dose }\end{array}$} & \multirow{2}{*}{$\begin{array}{c}\text { Population } \\
\begin{array}{c}\text { Within } 50 \text { Miles }^{a} \\
\text { (2000 census) }\end{array} \\
1,684,000\end{array}$} & \multirow{2}{*}{$\begin{array}{c}\begin{array}{c}\text { Estimated Natural } \\
\text { Radiation } \\
\text { Population Dose }\end{array} \\
497,000 \\
\text { person-rem }\end{array}$} \\
\hline $\begin{array}{l}0.065 \\
\text { mrem }\end{array}$ & $\begin{array}{c}0.00065 \\
(\mathrm{mSv})\end{array}$ & & $\begin{array}{c}0.28 \\
\text { person-rem }\end{array}$ & $\begin{array}{c}0.0028 \\
\text { (person-Sv) }\end{array}$ & & \\
\hline
\end{tabular}

WVDP Radiological Atmospheric Emissions ${ }^{b}$ CY 2008 In Curies And Becquerels (Bq)

\begin{tabular}{|c|c|c|c|c|c|c|c|c|c|c|}
\hline Tritium & Kr-85 & $\begin{array}{l}\text { Noble Gases } \\
\left(T_{1 / 2}<40 \mathrm{dy}\right)\end{array}$ & $\begin{array}{c}\text { Short-Lived } \\
\text { Fission and } \\
\text { Activation } \\
\text { Products } \\
\left(\mathrm{T}_{1 / 2}<3 \mathrm{hr}\right)\end{array}$ & $\begin{array}{c}\text { Fission and } \\
\text { Activation } \\
\text { Products } \\
\left(\mathrm{T}_{1 / 2}>3 \mathrm{hr}\right)\end{array}$ & $\begin{array}{c}\text { Total } \\
\text { Radioiodine }\end{array}$ & $\begin{array}{c}\text { Total } \\
\text { Radiostrontium }\end{array}$ & $\begin{array}{c}\text { Total } \\
\text { Uranium }^{c}\end{array}$ & $\begin{array}{c}\text { Total } \\
\text { Plutonium }\end{array}$ & $\begin{array}{c}\text { Total Other } \\
\text { Actinides }\end{array}$ & $\begin{array}{c}\text { Other } \\
\text { (Rn-220) }\end{array}$ \\
\hline $\begin{array}{c}1.79 \mathrm{E}-03 \\
(6.64 \mathrm{E}+07)\end{array}$ & NA & NA & NA & $\begin{array}{c}5.02 \mathrm{E}-06 \\
(1.86 \mathrm{E}+05)\end{array}$ & $\begin{array}{c}2.75 \mathrm{E}-05 \\
(1.02 \mathrm{E}+06)\end{array}$ & $\begin{array}{c}2.46 \mathrm{E}-06 \\
(9.11 \mathrm{E}+04)\end{array}$ & $\begin{array}{c}7.93 \mathrm{E}-08 \\
(2.94 \mathrm{E}+03)\end{array}$ & $\begin{array}{c}1.63 \mathrm{E}-07 \\
(6.01 \mathrm{E}+03)\end{array}$ & $\begin{array}{c}2.57 \mathrm{E}-07 \\
(9.53 \mathrm{E}+03)\end{array}$ & $\begin{array}{c}1.10 \mathrm{E}+03 \\
(4.05 \mathrm{E}+13)\end{array}$ \\
\hline
\end{tabular}

\begin{tabular}{|c|c|c|c|c|c|c|}
\hline \multicolumn{6}{|c|}{ WVDP Liquid Effluent Releases ${ }^{d}$ Of Radionuclide Material - CY 2008 In Curies And Becquerels (Bq) } \\
\hline \multirow{2}{*}{ Tritium } & $\begin{array}{c}\text { Fission and } \\
\text { Activation } \\
\text { Products } \\
\left(\mathrm{T}_{1 / 2}>\mathbf{3} \mathrm{hr}\right)\end{array}$ & $\begin{array}{c}\text { Total } \\
\text { Radioiodine }\end{array}$ & $\begin{array}{c}\text { Total } \\
\text { Radiostrontium }\end{array}$ & Total Uranium ${ }^{e}$ & $\begin{array}{c}\text { Total } \\
\text { Plutonium }\end{array}$ & $\begin{array}{c}\text { Total Other } \\
\text { Actinides }\end{array}$ \\
\hline $5.14 \mathrm{E}-02$ & $8.03 \mathrm{E}-03$ & $<6.82 \mathrm{E}-05$ & $2.93 \mathrm{E}-01$ & $8.91 \mathrm{E}-04$ & $1.05 \mathrm{E}-05$ & $<2.54 \mathrm{E}-05$ \\
$(1.90 \mathrm{E}+09)$ & $(2.97 \mathrm{E}+08)$ & $(<2.53 \mathrm{E}+06)$ & $(1.09 \mathrm{E}+10)$ & $(3.30 \mathrm{E}+07)$ & $(3.88 \mathrm{E}+05)$ & $(<9.41 \mathrm{E}+05)$ \\
\hline
\end{tabular}

Note: There are no known significant discharges of radioactive constituents from the site other than those reported in this table.

NA - Not applicable

a Total population includes the U.S. population from the 2000 census plus the Canadian population residing within a 50-mile $(80-\mathrm{km})$ radius (Statistics Canada, 2001).

$b$ Air releases are from point sources only.

c Total uranium (grams) $=8.79 \mathrm{E}-02$

$d$ Water releases are from both controlled liquid effluent releases and from well-characterized site drainages.

e Total uranium (grams) $=5.88 \mathrm{E}+02$ 
FIGURE 3-2

Air Emissions From Point Sources: Dose Percent by Radionuclide in CY 2008

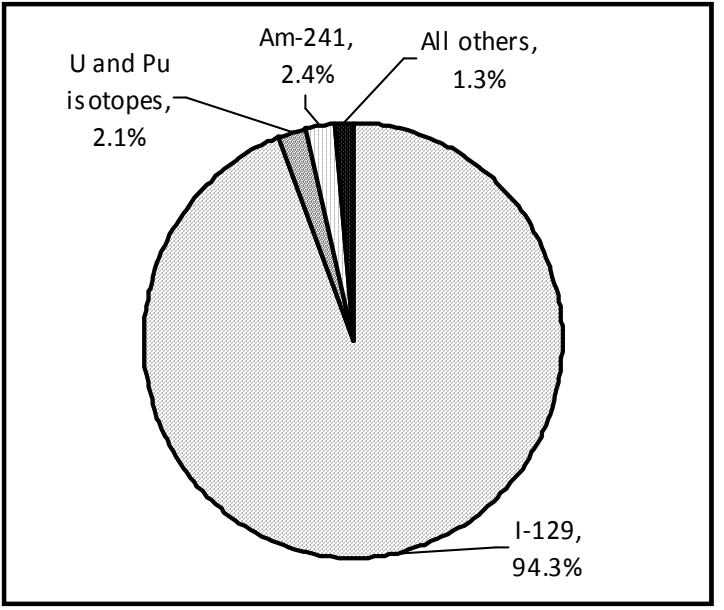

FIGURE 3-3

Water Effluents: Dose Percent by Radionuclide in CY 2008

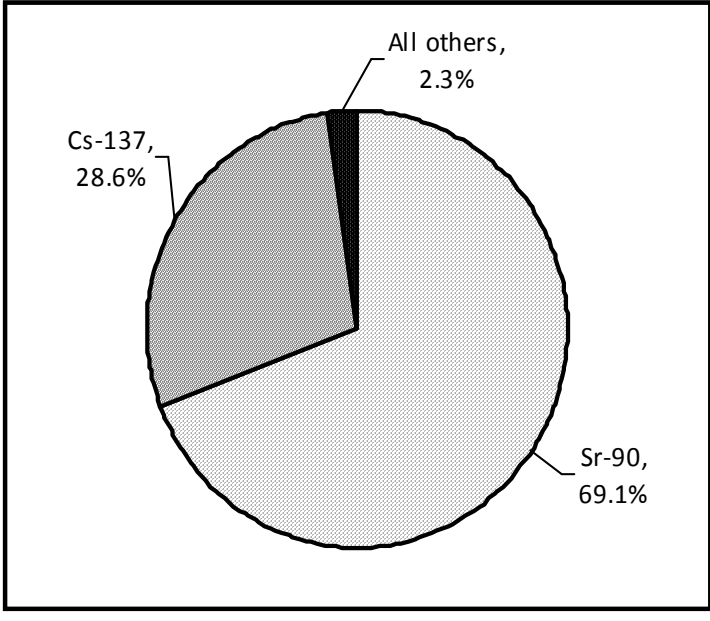

FIGURE 3-4

All Sources: Dose Percent by Radionuclide in CY 2008

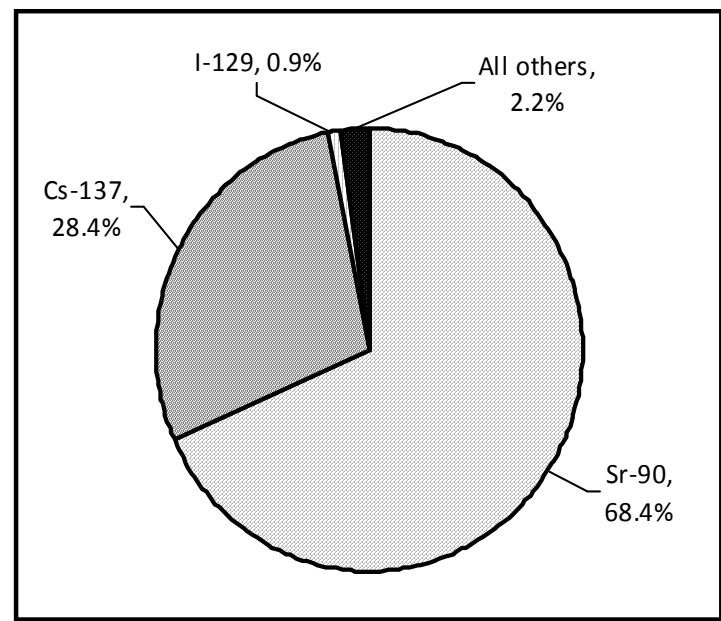


The computer codes GENII version 1.485 (Pacific Northwest Laboratory, 1988), which implements the models in NRC Regulatory Guide 1.109 (U.S. Nuclear Regulatory Commission [NRC], 1977), and LADTAP II (Simpson and McGill, 1980) were used to calculate site-specific unit dose factors (UDFs) for routine waterborne releases and dispersion of these effluents. The UDFs derived from those codes are tabulated in the "WVDP Manual for Radiological Assessment of Environmental Releases at the WVDP" (WVNSCO, 2003).

Seven batches of liquid effluents were released from lagoon 3 (point WNSP001) during 2008. Measurements of the radioactivity discharged in these effluents were combined with the UDFs to calculate the EDE to the MEOSI and the collective EDE to the population living within a $50-$ mile $(80-\mathrm{km})$ radius of the WVDP.

In addition to measurements from WNSP001, radioactivity measurements from sewage treatment facility effluents (WNSP007) were included in the EDE calculations. The french drain at WNSP008, a third release point that is listed in the State Pollutant Discharge Elimination System permit for the WVDP, has been sealed off since 2001 and was therefore not considered a source of discharge in 2008.

Besides the two controlled release points at WNSP001 and WNSP007, water from two natural drainage channels on the north plateau originating on the Project premises contain measurable concentrations of radioactivity: the northeast swamp (WNSWAMP) and north swamp (WNSW74A). Although releases from WNSWAMP and WNSW74A are not considered "controlled" releases, they are well characterized and have been routinely sampled and monitored.

There were no unplanned releases of waterborne radioactivity to the off-site environment in 2008.

Results from monitoring points are included in the EDE calculations for the MEOSI and the collective population. See Figure 3-3 for a comparison of estimated doses attributable to specific waterborne radionuclides. As presented, strontium-90 and cesium-137 account for almost all of the estimated waterborne dose, at $69.1 \%$ and $28.6 \%$, respectively.

Maximum Dose (Waterborne) to an Off-Site Individual. Based on the radioactivity in liquid effluents discharged from the WVDP (lagoon 3 and the sewage treatment plant) during 2008, an off-site individual could have received a maximum EDE of 0.019 mrem (0.00019 mSv). (See Table 3-2.) About $91 \%$ of this dose was from cesium-137. The maximum off-site individual EDE due to drainage from the north plateau was 0.044 mrem ( $0.00044 \mathrm{mSv}$ ). About $97 \%$ of the north plateau dose was attributable to strontium-90.

The combined EDE to the maximally exposed individual from liquid effluents and drainage was 0.064 mrem (0.00064 $\mathrm{mSv})$. This annual dose is very small in comparison to the $295-\mathrm{mrem}$ ( $2.95 \mathrm{mSv}$ ) dose that is received by an average member of the U.S. population from natural background radiation.

Collective Population Dose (Waterborne). As a result of radioactivity released in liquid effluents from the WVDP during 2008, the population living within 50 mile (80 $\mathrm{km}$ ) of the site received an estimated collective EDE of 0.017 person-rem ( 0.00017 person-Sv). The collective dose to the population from the effluents plus the north plateau drainage was 0.28 person-rem $(0.0028$ personSv). The resulting average EDE per individual is 0.00016 mrem ( $0.0000016 \mathrm{mSv})$. This dose is an inconsequential addition to the dose that an average person receives in one year from natural background radiation.

\section{Predicted Dose From All Pathways}

The potential dose to the public from both airborne and liquid effluents released from the Project in 2008 is the sum of the individual dose contributions. (See Table 3-2 and Figure 3-4.) The calculated maximum EDE from all pathways to a nearby resident was 0.065 mrem $(0.00065 \mathrm{mSv})$. This dose is $0.065 \%$ of the $100-$ mrem (1-mSv) annual limit in DOE Order 5400.5. As in past years, CY 2008 results continued to demonstrate WVDP compliance with applicable radiation standards for protection of the public and the environment. As presented in Figure 3-4, the largest proportion of estimated EDE to an off-site individual in 2008 was from strontium-90 via the waterborne pathway.

In CY 2008, the total collective EDE to the population within 50 mile $(80 \mathrm{~km})$ of the site was 0.28 personrem (0.0028 person-Sv), with an average EDE of 0.00017 mrem (0.0000017 mSv) per individual.

Figure 3-5 shows the calculated annual dose to the hypothetical maximally exposed individual over the last 10 years. The estimated doses for 2008 were slightly lower than those in 2007. As shown by this figure, the largest portion is due to waterborne contributions, and is attributed to strontium-90 activity coming from the drainage point location WNSWAMP on the north plateau. 
FIGURE 3-5

Effective Dose Equivalent From Liquid and Airborne Effluents to a Maximally Exposed Individual Residing Near the WVDP

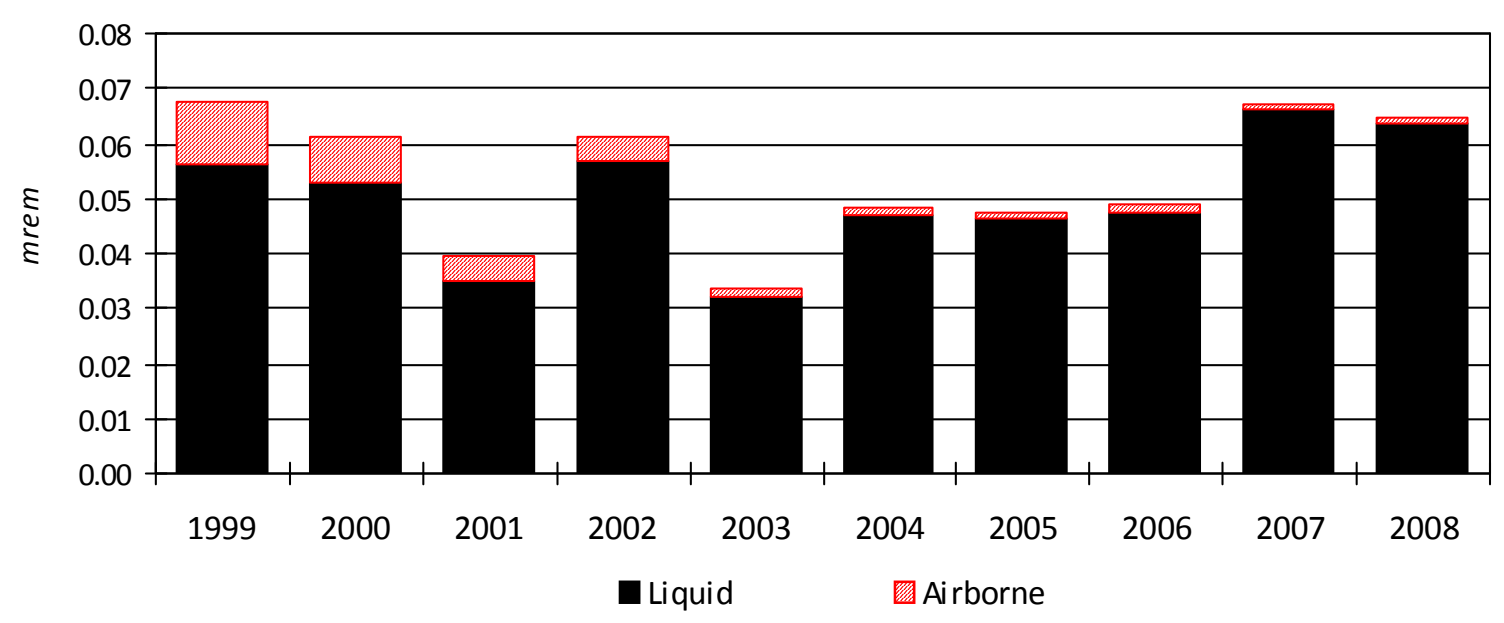

FIGURE 3-6

Collective Effective Dose Equivalent From Liquid and Airborne Effluents to the Population Residing Within 50 Miles $(80 \mathrm{~km})$ of the WVDP

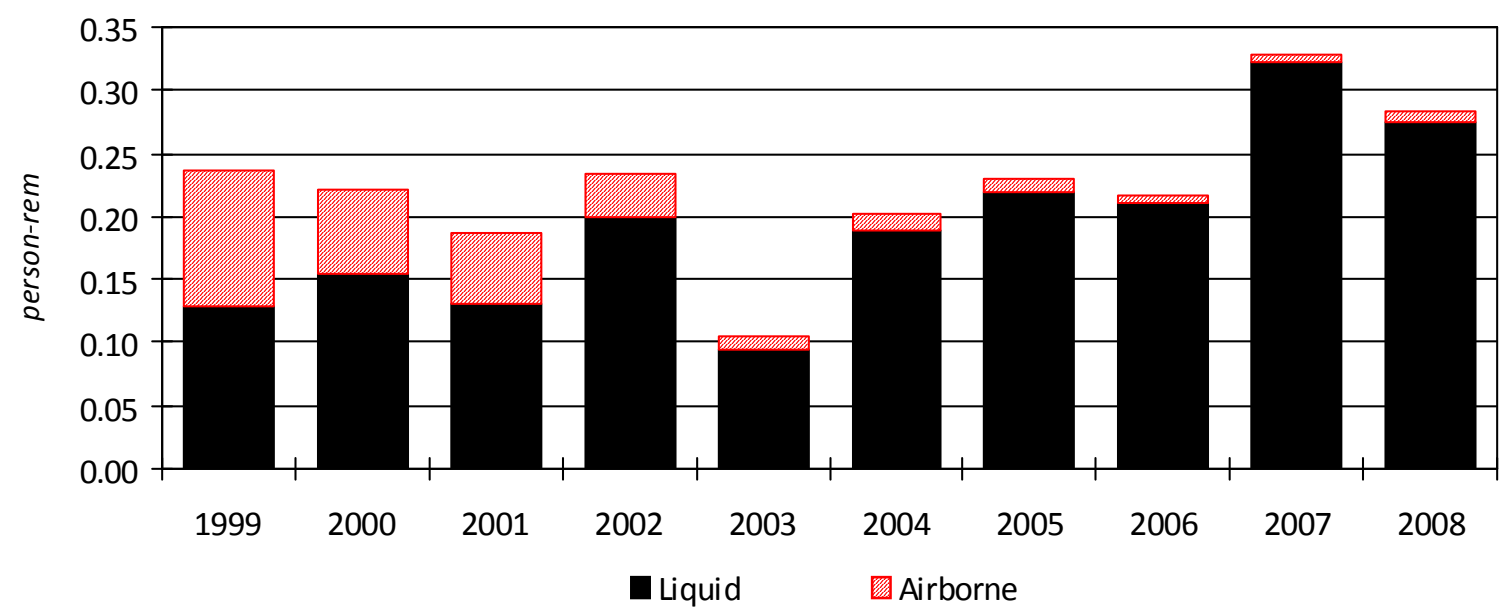


Figure 3-6 shows the collective dose to the population over the last 10 years. The radioactivity in the human pathway represented by these data confirms the continued inconsequential addition to the natural background radiation dose that individuals and the population around the WVDP receive from Project activities.

Calculated Dose From Food. Most radionuclide concentrations in near-site food samples were statistically indistinguishable from concentrations in background samples. Conservative estimates of dose due to consuming near-site deer and milk were about $0.015 \mathrm{mrem} /$ year ( $0.00015 \mathrm{mSv} /$ year). This estimate assumes an individual consumes the maximum quantities of each food item. Food crops and fish were not sampled in 2008. As in 2007, the predominant potential dose from food in 2008 was estimated to be from consumption of venison. These independent estimates confirmed the low modeled dose estimates based on air and water effluents, as summarized in Table 3-2.

\section{Risk Assessment}

Estimates of cancer risk from ionizing radiation have been presented by the National Council on Radiation Protection and Measurements (NCRP) (1987) and the National Research Council's Committee on Biological Effects of Ionizing Radiation (1990).

The NCRP estimates that the probability of fatal cancer occurring is between one and five per 10,000 people who are each exposed to one rem (i.e., a risk coefficient of between 0.0001 and 0.0005 ). DOE guidance has, in the past, recommended using a risk coefficient of 0.0005 (ICRP, 1991) to estimate risk to a MEOSI. Recent DOE guidance recommends using the even more conservative risk coefficient of 0.0006 provided by the Interagency Steering Committee on Radiation Standards (January 2003). The estimated risk to the hypothetical individual residing near the WVDP from airborne and waterborne releases in 2008 was about 4 per 100 million (a risk of $0.00000004)$. This risk is well below the range of 0.000001 to 0.00001 per year considered by the ICRP to be a reasonable risk for any member of the public (ICRP Report Number 26, 1977).

\section{Release of Materials Containing Residual Radioactivity}

The DOE ensures protection of the public and the environment through the implementation of the stan- dards and requirements set forth in DOE Order 5400.5. In addition to discharges to the environment, the release of property containing residual radioactive materials is considered a potential contributor to the dose received by the public.

In 2000, the Secretary of Energy placed a moratorium on the release of volumetrically contaminated metals, and suspended the unrestricted release of metals from radiological areas of DOE facilities for recycling. The moratorium and suspension currently remain in effect.

A graded approach is utilized by the WVDP for the release of equipment and materials to the public for unrestricted use. This approach considers the use of the material, the potential for internal contamination, the location the material was used, and process knowledge of the item(s) to be released. In accordance with WVDP radiological controls manuals and procedures, these criteria are assessed and documented, and the material(s) may be radiologically surveyed to verify the survey results are within the contamination limits presented in DOE Order 5400.5, Figure IV-1. Records of released property are maintained.

Presently there are no approved criteria for releasing WVDP material to the public that may have been contaminated in depth or volume; therefore, no unrestricted release of scrap metal or other material of this type has occurred. Compliance with the Secretary of Energy's suspension of unrestricted release of scrap metal for recycle continues at the WVDP.

The Secretary does encourage efforts to promote reuse and recycling of excess property for use within the DOE complex. These transfers occur only when property is transferred to individuals authorized to use such material.

\section{Dose to Biota}

Radionuclides from both natural and man-made sources may be found in environmental media such as water, sediments, and soils. In the past, it has been assumed that if radiological controls are sufficient to protect humans, other living things are also likely to be sufficiently protected. This assumption is no longer considered adequate, because populations of plants and animals residing in or near these media or taking food or water from these media may be exposed to a greater extent than are humans. For this reason, the DOE prepared a technical standard that provides methods and guidance to be used to 
evaluate doses of ionizing radiation to populations of aquatic animals, riparian animals (i.e., those that live along banks of streams or rivers), terrestrial plants, and terrestrial animals.

Methods in this technical standard, "A Graded Approach for Evaluating Radiation Doses to Aquatic and Terrestrial Biota" (DOE-STD-1153-2002, July 2002), were used in 2008 to evaluate radiation doses to aquatic and terrestrial biota within the confines of the Western New York Nuclear Service Center (WNYNSC), which includes the WVDP. Doses were assessed for compliance with the limit in DOE Order 5400.5 for native aquatic animal organisms (1 rad/ day) and for compliance with the thresholds for terrestrial plants (also $1 \mathrm{rad} /$ day) and for terrestrial animals (0.1 rad/day), as proposed in DOE-STD-11532002. Note that the absorbed dose unit (rad) is used for biota instead of the units used for indicating human risk (rem).

The RESRAD-BIOTA code (May 2006), a calculation tool provided by the DOE for implementing the technical standard, was used to compare existing radionuclide concentration data from environmental sampling with biota concentration guide (BCG) screening values and to estimate upper bounding doses to biota. Data were taken from surface water samples obtained in 2008 and sediments over the most recent five years of sediment sampling (20032007). Soil data from the most recent ten years (19952004) for which special on-site surface soil sampling was conducted and the most recent 10 years of routine on-site surface soil sampling (1998-2007) were used. Differing time periods were used because radionuclide concentrations change more rapidly over time in surface waters than in sediments and soils, as reflected in their sampling frequencies (monthly or quarterly for water, every five years for sediment and soil).

Concentration data for radionuclides in each medium were entered into the RESRAD-BIOTA Code. The value for each radionuclide was automatically divided by its corresponding BCG to calculate a partial fraction for each nuclide in each medium. Partial fractions for each medium were added to produce a sum of fractions.

Exposures from the aquatic pathway may be assumed to be less than the aquatic dose limit from DOE Order 5400.5 if the sum of fractions for the water medium plus that for the sediment medium is less than 1.0. Similarly, exposures from the terrestrial path- way may be assumed to be less than the proposed dose limits for both terrestrial plants and animals if the sum of fractions for the water medium plus that for the soil medium is less than 1.0.

It was found that the isotopes with the highest sums of fractions - the radionuclides that contributed the largest component of both aquatic and terrestrial dose to biota - were strontium-90 and cesium-137. Per guidance in DOE-STD-1153-2002, the populations of organisms most sensitive to strontium-90 and cesium-137 in this evaluation - that is, those most likely to be adversely affected via the aquatic and terrestrial pathways - were determined to be populations of riparian animals (such as the raccoon [aquatic dose]) and terrestrial animals (such as the deer mouse [terrestrial dose]). Populations of both animals are found on the WNYNSC.

In accordance with the graded approach described in DOE-STD-1153-2002, a general screening was first conducted using the maximum radionuclide concentrations from surface waters, sediments, and soils. Maximum radionuclide concentrations exceeded applicable BCG limits for both aquatic and terrestrial evaluations.

As recommended in DOE-STD-1153-2002, a site-specific screening was then done using estimates of average radionuclide concentrations derived from measurements in surface waters, sediments, and soils. Results are summarized in Table 3-4.

At the site-specific screening level, the sums of fractions for the aquatic and terrestrial evaluations were 0.24 and 0.27 , respectively. The sum of fractions for each assessment was less than 1.0, indicating that applicable BCGs were met for both the aquatic and terrestrial evaluations.

Upper bounding doses associated with the aquatic system evaluation were $0.0061 \mathrm{rad} /$ day to an aquatic animal and $0.024 \mathrm{rad} /$ day to a riparian animal, far below the $1 \mathrm{rad} /$ day standard from DOE Order 5400.5 for dose to a native aquatic animal. Upper bounding doses associated with the terrestrial system evaluation were $0.027 \mathrm{rad} /$ day to a terrestrial animal and $0.0025 \mathrm{rad} /$ day to a terrestrial plant, again well below the guidance thresholds ( 0.1 and $1 \mathrm{rad} / \mathrm{day}$, respectively).

It was therefore concluded that populations of aquatic and terrestrial biota (both plants and animals) on the WNYNSC are not being exposed to doses 
TABLE 3-4

2008 Evaluation of Dose to Aquatic and Terrestrial Biota

\begin{tabular}{|c|c|c|c|c|c|c|c|}
\hline \multicolumn{8}{|c|}{ AQUATIC SYSTEM EVALUATION } \\
\hline Nuclide & $\begin{array}{l}\text { Water } \\
\text { BCG }^{a} \\
\text { (pCi/L) }\end{array}$ & $\begin{array}{l}\text { Mean } \\
\text { Water } \\
\text { Value } \\
(p C i / L)\end{array}$ & Ratio & $\begin{array}{l}\text { Sediment } \\
\text { BCG }^{a} \\
(p C i / g)\end{array}$ & $\begin{array}{c}\text { Mean } \\
\text { Sediment } \\
\text { Value } \\
(p C i / g)\end{array}$ & Ratio & $\begin{array}{l}\text { Water and } \\
\text { Sediment Sum } \\
\text { of Fractions }\end{array}$ \\
\hline Cesium-137 & 42.7 & 2.66 & $6.23 \mathrm{E}-02$ & 3,130 & 5.74 & $1.84 \mathrm{E}-03$ & 0.064 \\
\hline Strontium-90 & 279 & 48.2 & $1.73 \mathrm{E}-01$ & 583 & 1.22 & $2.09 \mathrm{E}-03$ & 0.17 \\
\hline All Others & NA & NA & $7.00 \mathrm{E}-04$ & NA & NA & $5.10 \mathrm{E}-04$ & 0.0012 \\
\hline \multicolumn{3}{|c|}{ Sum of Fractions } & $2.36 \mathrm{E}-01$ & & & 4.44E-03 & 0.24 \\
\hline \multicolumn{8}{|c|}{ Estimated upper bounding dose to an aquatic animal = $0.0061 \mathrm{rad} /$ day; to a riparian animal $=0.024 \mathrm{rad} /$ day. } \\
\hline \multicolumn{8}{|c|}{ TERRESTRIAL SYSTEM EVALUATION } \\
\hline Nuclide & $\begin{array}{l}\text { Water } \\
\text { BCG }^{a} \\
\text { (pCi/L) }\end{array}$ & $\begin{array}{l}\text { Mean } \\
\text { Water } \\
\text { Value } \\
\text { (pCi/L) }\end{array}$ & Ratio & $\begin{array}{c}\text { Soil BCG } \\
\quad(p C i / g)\end{array}$ & $\begin{array}{c}\text { Mean Soil } \\
\text { Value } \\
(p C i / g)\end{array}$ & Ratio & $\begin{array}{c}\text { Water and Soil } \\
\text { Sum of } \\
\text { Fractions }\end{array}$ \\
\hline Cesium-137 & 599,000 & 2.66 & $4.44 \mathrm{E}-06$ & 20.8 & 4.64 & $2.23 \mathrm{E}-01$ & 0.22 \\
\hline Strontium-90 & 54,500 & 48.2 & $8.84 \mathrm{E}-04$ & 22.5 & 1.01 & $4.49 \mathrm{E}-02$ & 0.046 \\
\hline All Others & NA & NA & $<1.00 \mathrm{E}-06$ & NA & NA & $1.10 \mathrm{E}-03$ & 0.0011 \\
\hline \multicolumn{3}{|c|}{ Sum of Fractions } & $8.91 \mathrm{E}-04$ & & & $2.69 \mathrm{E}-01$ & 0.27 \\
\hline
\end{tabular}

NA - Not applicable

a The biota concentration guides (BCGs) are calculated values. Except for the sums of fractions and dose estimates, which are rounded to two significant digits, all values are expressed to three significant digits.

in excess of the existing DOE dose standard for native aquatic animals (DOE, February 1990) and the international standards for terrestrial organisms (International Atomic Energy Agency [IAEA], 1992).

\section{Summary}

Tables 3-2, 3-3, and 3-4 summarize radiological dose and release information for CY 2008.

Predictive computer modeling of airborne and waterborne releases resulted in estimated hypothetical doses to the maximally exposed individual that were orders of magnitude below all applicable EPA standards and DOE Orders that place limitations on the release of radioactive materials and dose to individual members of the public. The collective population dose was also assessed and found to be orders of magnitude below the natural background radiation dose. Additionally, estimates indicated that populations of biota at the WVDP are exposed at a fraction of the DOE and IAEA guidelines for dose to biota.
Based on the overall dose assessment, the WVDP was found to be in compliance with applicable effluent radiological guidelines and standards during $\mathrm{CY}$ 2008. 
This page intentionally left blank 


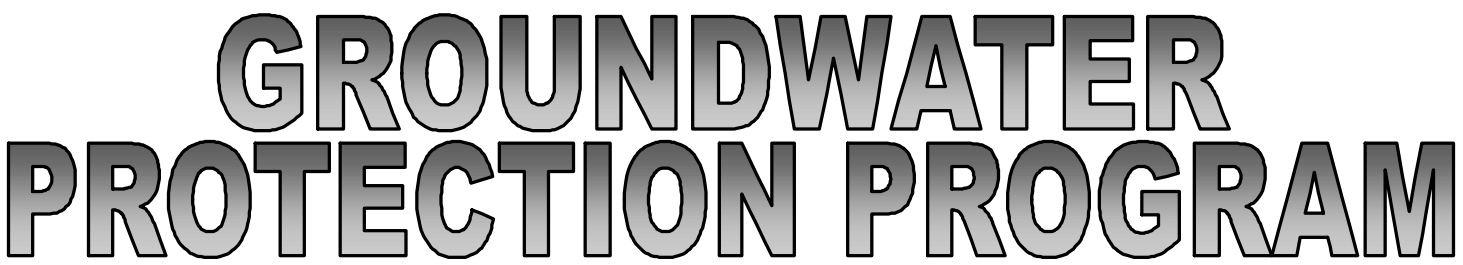

\section{Groundwater Monitoring Program Overview}

Groundwater monitoring at the West Valley Demonstration Project (WVDP or Project) complies with all applicable state and federal regulations and meets the requirements of United States (U.S.) Department of Energy (DOE) Order 450.1A. Groundwater monitoring data are used by site managers to determine baseline groundwater conditions, facilitate early detection of groundwater contamination sources, provide surveillance of existing sources, and provide information for decision-making.

The WVDP's groundwater monitoring program is outlined in the "Groundwater Monitoring Plan" (GMP), which discusses groundwater characterization, the current groundwater sampling agenda, and compliance with long-term monitoring requirements under DOE Orders and the Resource Conservation and Recovery Act (RCRA) §3008(h) Administrative Order on Consent (Consent Order). The "WVDP Groundwater Protection Management Program Plan" documents the Project's approach to the protection of groundwater from on-site activities.

Groundwater from the site is not used for drinking or operational purposes, nor is effluent discharged directly to groundwater. The majority of the site groundwater eventually flows to Cattaraugus Creek and then to Lake Erie. Surveys have determined that no public water supplies are drawn from Cattaraugus Creek, downstream of the WVDP. Upgradient of the site, groundwater is used as a public and private drinking water supply by local residents.

\section{Surface Water Hydrology}

The 167-acre (68-hectare [ha]) Project is located within the Western New York Nuclear Service Center (WNYNSC), which comprises approximately 3,338 acres (1,351 ha) and is located at the northern border of Cattaraugus County. The WNYNSC lies within the watershed of Cattaraugus Creek, which flows northwestward to Lake Erie. Buttermilk Creek, a tributary of Cattaraugus Creek, drains the WNYNSC.
The WVDP is drained by Quarry Creek, Erdman Brook, and Franks Creek, which flow into Buttermilk Creek. (See Figs. A-1 and A-5 in Appendix A.) Erdman Brook bisects the WVDP into the north and south plateaus. The main plant process building (MPPB), waste tanks, and lagoons are located on the north plateau. The drum cell, the U.S. Nuclear Regulatory Commission (NRC)-Licensed Disposal Area (NDA), and the New York State-Licensed Disposal Area (SDA) are located on the south plateau.

\section{Geology}

The WNYNSC is situated upon a layered sequence of glacial-age sediments that fill a steep-sided bedrock valley composed of interbedded shales and siltstones (Rickard, 1975).

The glacial sediments overlying the bedrock consist of a sequence of three glacial tills of Lavery, Kent, and possibly Olean age. The tills are separated by stratified fluvio-lacustrine deposits (silty or silty/ sandy lakebed sediments). On the Project's north plateau, the Lavery till is overlain by a localized coarsegrained alluvial-fluvial deposit (sandy/silty/gravelly streambed sediments). See Table 4-1 for the descriptions and the geographic distribution of these units.

\section{Hydrogeology}

The sediments above the Kent till - the Kent recessional sequence, the weathered and unweathered Lavery till, the intra-Lavery till-sand, and the alluvial sand and gravel - are generally regarded as containing all of the potential routes for contaminant migration from the Project via groundwater. (See Fig. 4-1.) The Kent till has a relatively low permeability and does not provide a pathway for contaminant movement from the WVDP; therefore, it is not discussed here.

Hydrologic conditions of the site are more fully described in "Environmental Information Document, Volume III: Hydrology, Part 4" (West Valley Nuclear Services Co. [WVNSCO], March 1996) and in the "RCRA Facility Investigation Report (RFI) Vol. 1: Introduction and General Site Overview" (WVNSCO and Dames \& Moore, July 1997). 
TABLE 4-1

Summary of Hydrogeology at the WVDP

\begin{tabular}{|c|c|c|c|c|}
\hline Geologic Unit & Description & $\begin{array}{c}\text { Groundwater Flow } \\
\text { Characteristics }\end{array}$ & $\begin{array}{c}\text { Hydraulic } \\
\text { Conductivity }^{a} \\
\end{array}$ & Location \\
\hline $\begin{array}{c}\text { Sand and Gravel; } \\
\text { Thick-Bedded } \\
\text { Unit } \\
\text { (S\&G-TBU) }\end{array}$ & $\begin{array}{l}\text { Silty sand and gravel layer } \\
\text { composed of younger } \\
\text { Holocene alluvial deposits }\end{array}$ & $\begin{array}{l}\text { Flow is generally northeast } \\
\text { across the plateau toward } \\
\text { Franks Creek, with } \\
\text { groundwater near the } \\
\text { northwestern and } \\
\text { southeastern margins flowing } \\
\text { radially outward toward } \\
\text { Quarry Creek and Erdman } \\
\text { Brook }\end{array}$ & $\begin{array}{l}10.5 \text { feet }(\mathrm{ft}) / \text { day) } \\
(3.7 \mathrm{E}-03 \text { centimeters } \\
{[\mathrm{cm}] / \text { second]) or }} \\
126 \text { inches }(\mathrm{in}) / \text { day }\end{array}$ & North plateau \\
\hline $\begin{array}{l}\text { Sand and Gravel; } \\
\text { Slackwater } \\
\text { Sequence } \\
\text { (S\&G-SWS) }\end{array}$ & $\begin{array}{l}\text { Interbedded silty sand and } \\
\text { gravel layers composed of } \\
\text { Pleistocene-age glaciofluvial } \\
\text { deposits partially separated } \\
\text { from the sand and gravel thick } \\
\text { bedded unit by a } \\
\text { discontinuous clay interval }\end{array}$ & $\begin{array}{l}\text { Flow is to the northeast along } \\
\text { gravel layers toward Franks } \\
\text { Creek }\end{array}$ & $\begin{array}{l}21.0 \mathrm{ft} / \mathrm{day} \\
(7 \mathrm{E}-03 \mathrm{~cm} / \mathrm{sec}) \text { or } \\
252 \mathrm{in} / \mathrm{day}\end{array}$ & $\begin{array}{l}\text { Underlies a portion of } \\
\text { the north plateau }\end{array}$ \\
\hline $\begin{array}{l}\text { Weathered } \\
\text { Lavery Till } \\
\text { (WLT) }\end{array}$ & $\begin{array}{l}\text { Upper zone of the Lavery till } \\
\text { which has been exposed at } \\
\text { the ground surface; } \\
\text { weathered and fractured to a } \\
\text { depth of 3-16 ft (0.9-4.9 } \\
\text { meters[m]); brown in color } \\
\text { due to oxidation; contains } \\
\text { numerous desiccation cracks } \\
\text { and root tubes }\end{array}$ & \begin{tabular}{|l} 
Flow has both horizontal and \\
vertical components allowing \\
groundwater to move laterally \\
across the south plateau \\
before moving downward into \\
the unweathered lavery till or \\
discharging to nearby incised \\
stream channels
\end{tabular} & $\begin{array}{l}5 \mathrm{E}-02 \mathrm{ft} / \mathrm{day} \\
(2 \mathrm{E}-05 \mathrm{~cm} / \mathrm{sec}) \text { or } 0.6 \\
\text { in/day; the highest } \\
\text { conductivities are } \\
\text { associated with dense } \\
\text { fracture zones found } \\
\text { within the upper } 7 \mathrm{ft} \\
(2 \mathrm{~m}) \text { of the unit }\end{array}$ & South plateau \\
\hline $\begin{array}{l}\text { Unweathered } \\
\text { Lavery Till } \\
\text { (ULT) }\end{array}$ & $\begin{array}{l}\text { Olive gray silty clay with } \\
\text { intermittent lenses of silt and } \\
\text { sand; ranges up to } 130 \mathrm{ft} \text { ( } 40 \\
\mathrm{~m} \text { ) in thickness }\end{array}$ & $\begin{array}{l}\text { Flow is vertically downward at } \\
\text { a relatively slow rate; unit is } \\
\text { considered an aquitard }\end{array}$ & $\begin{array}{l}2 \mathrm{E}-03 \mathrm{ft} / \mathrm{day} \\
(6.8 \mathrm{E}-07 \mathrm{~cm} / \mathrm{sec}) \text { or } \\
0.02 \mathrm{in} / \mathrm{day}\end{array}$ & $\begin{array}{l}\text { Underlies both the } \\
\text { north and south } \\
\text { plateaus }\end{array}$ \\
\hline $\begin{array}{l}\text { Lavery Till Sand } \\
\text { (LTS) }\end{array}$ & $\begin{array}{l}\text { Thin, sandy unit of limited } \\
\text { areal extent and variable } \\
\text { thickness within the Lavery } \\
\text { till. }\end{array}$ & $\begin{array}{l}\text { Flow is to the east-southeast } \\
\text { toward Erdman Brook }\end{array}$ & $\begin{array}{l}0.26 \mathrm{ft} / \text { day } \\
(9 \mathrm{E}-05 \mathrm{~cm} / \mathrm{sec}) \text { or } \\
3 \mathrm{in} / \text { day }\end{array}$ & $\begin{array}{l}\text { Primarily beneath the } \\
\text { southeastern portion } \\
\text { of the north plateau }\end{array}$ \\
\hline $\begin{array}{l}\text { Kent Recessional } \\
\text { Sequence } \\
\text { (KRS) }\end{array}$ & $\begin{array}{l}\text { Interbedded clay and silty clay } \\
\text { layers locally overlain by } \\
\text { coarser-grained sands and } \\
\text { gravels; pinches out near the } \\
\text { east side of Rock Springs Road }\end{array}$ & $\begin{array}{l}\text { Flow is to the northeast; } \\
\text { recharge from the overlying } \\
\text { till and from bedrock to the } \\
\text { southwest; discharges into } \\
\text { Buttermilk Creek }\end{array}$ & $\begin{array}{l}1.3 \mathrm{E}-02 \mathrm{ft} / \mathrm{day} \\
(4.5-06 \mathrm{~cm} / \mathrm{sec}) \text { or } \\
0.15 \mathrm{in} / \mathrm{day}\end{array}$ & $\begin{array}{l}\text { Underlies most of the } \\
\text { Project, except areas } \\
\text { adjacent to Rock } \\
\text { Springs Road }\end{array}$ \\
\hline
\end{tabular}

${ }^{a}$ Hydraulic conductivities represent an average of testing results from 1991 through 2008. 
FIGURE 4-1

Geologic Cross Sections of the North and South Plateaus at the WVDP

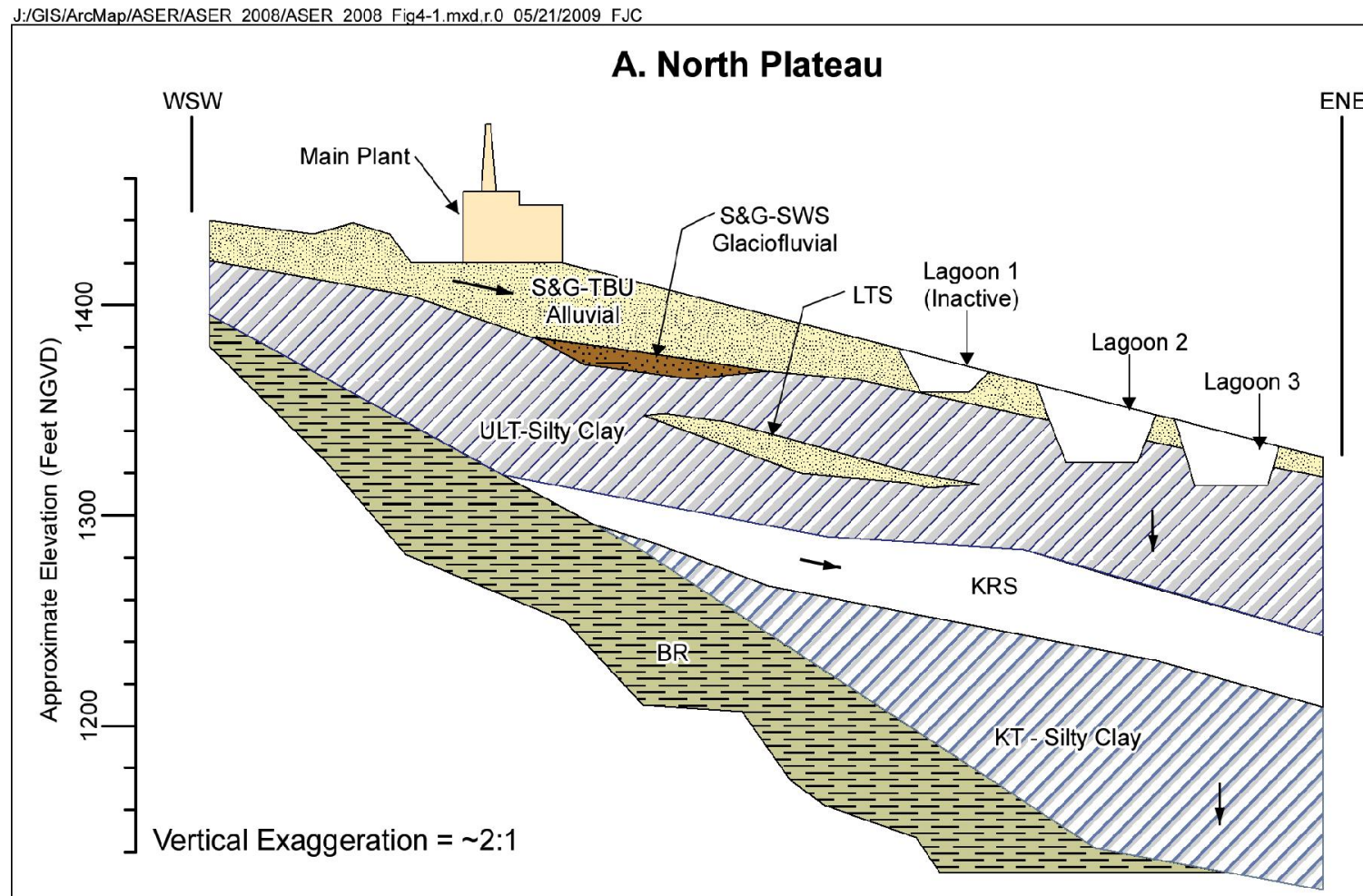

\section{B. South Plateau}

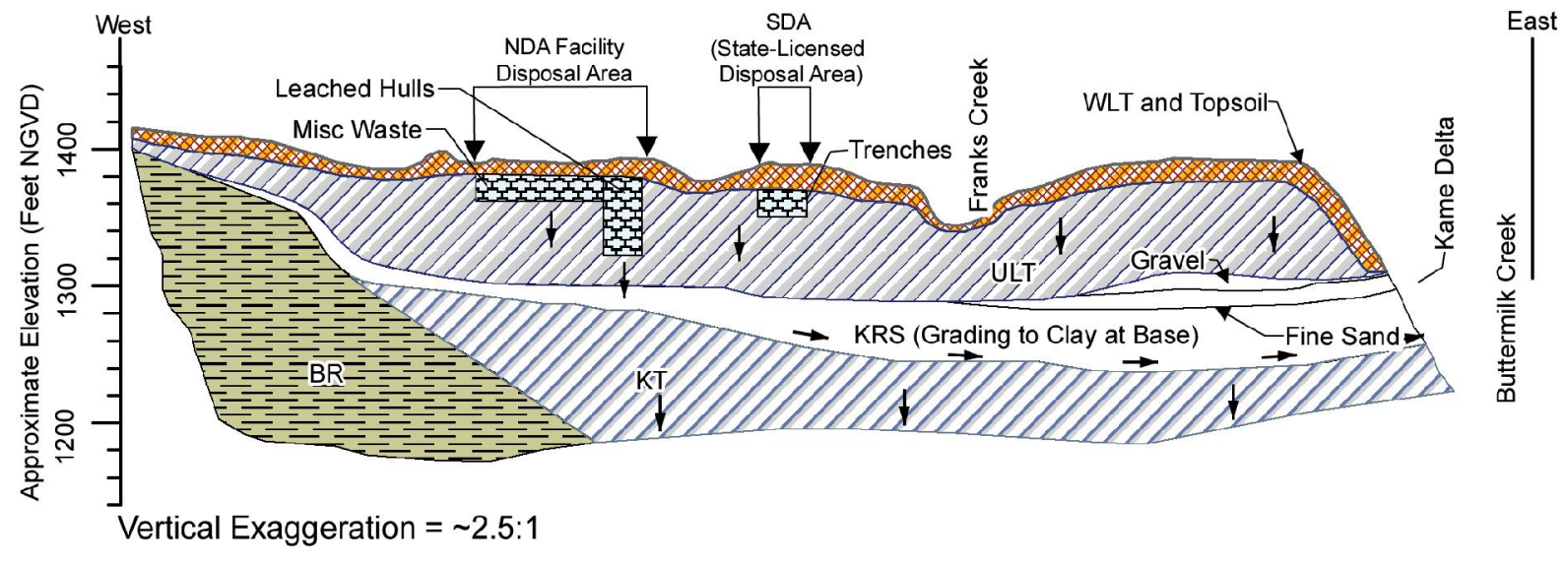

\section{Legend}

\begin{tabular}{llll}
\hline S\&G-TBU & Sand and Gravel - Thick Bedded Unit & KRS & Kent Recessional Sequence \\
S\&G-SWS & Sand and Gravel - Slack Water Sequence & KT & Kent Till \\
LTS & Lavery Till Sand & BR & Shale Bedrock \\
WLT & Weathered Lavery Till & Conceptual Groundwater Flow Direction \\
ULT & Unweathered Lavery Till & (NGVD - National Geodetic Vertical Datum)
\end{tabular}




\section{Routine Groundwater Monitoring Program (GMP)}

GMP Highlights 1982 Through 2008. Program content is dictated by regulatory requirements in conjunction with current operating practices and historical knowledge of previous site activities.

- Groundwater monitoring at the WVDP began in 1982 and continued to expand through 1992 with the addition of new wells, groundwater seep locations, a french drain outfall, and the NDA interceptor trench sump.

- In 1993, monitoring results indicated elevated gross beta activity in groundwater from the sand and gravel (S\&G) unit on the north plateau. Subsequent investigation of this area delineated a plume of contamination originating near the main plant process building (MPPB) extending to the northeast. (See "Groundwater Sampling Observations on the North Plateau" and Figure 4-2 in this chapter for more detail.)

- An RFl expanded characterization program was conducted during 1993 and 1994 to fully assess potential releases of hazardous wastes or constituents from on-site solid waste management units (SWMUs). This investigation, which consisted of two rounds of sampling for a wide range of radiological and chemical parameters, provided valuable information regarding groundwater conditions near each SWMU. Evaluation of these results influenced monitoring program modifications.

- Long-term monitoring needs were the focus of a 1995 groundwater monitoring program evaluation. After a comprehensive assessment, the number of sampling locations was reduced from 91 to 65 and analytical parameters were tailored to each sampling location for a more focused, efficient, and cost-effective program.

- In 1996, several groundwater seep monitoring locations on the northeast edge of the north plateau were added to the monitoring program and the french drain outfall was deleted for groundwater purposes. Five seep locations continue to be monitored.

- Four new groundwater monitoring wells were installed during August 2003 to provide upgradient and downgradient monitoring coverage for the remote-handled waste facility (RHWF).
- In early 2005 , reductions in analytes or sampling frequencies were implemented at 14 monitoring locations.

- In 2007, the GMP was evaluated to reflect current site conditions and activities and to make the program more efficient, and recommendations were made to reduce some analytes and sampling frequency at $\mathbf{2 0}$ monitoring wells and to discontinue sampling at four wells. In addition, after it was confirmed that there were no impacts from site operations on off-site groundwater, monitoring of off-site drinking water wells was discontinued after September 2007. These changes were implemented in 2008.

- Several focused groundwater and subsurface soil investigations that were not part of the GMP were performed in 1994, 1997 and 1998 involving sampling by Geoprobe ${ }^{\circledR}$. New wells and well points were installed in 2000 and 2001 across the north plateau in conjunction with a pilot permeable treatment wall remediation study for the strontium-90 plume.

- During 2008, three subsurface investigations were performed upgradient, within, and downgradient of the strontium-90 plume. Refer to "Strontium-90 Plume Characterization and Remediation Activities in 2008," later in this chapter for more details.

Current Monitoring Well Network. Groundwater is routinely monitored in the six hydrogeologic units described in Table 4-1. (The two sub-units of the S\&G are frequently monitored as one unit since many $S \& G$ well screens are placed across both units.) In 2008, a total of 72 on-site groundwater monitoring locations were sampled. The on-site locations included 66 monitoring wells and well points, five groundwater seepage points, and one sump/manhole. The frequency of monitoring and the constituents measured are a function of regulatory requirements, as well as current operating practices and historical knowledge of previous site activities.

The WVDP groundwater monitoring network is a vital component of the Environmental Protection Program implemented under DOE Order 450.1A. Many of the wells were installed to monitor one or more SWMUs on the WVDP in accordance with the Consent Order. Table 4-2 lists the wells in the network, the super solid waste management units (SSWMUs), the geologic units, and the analytes measured in 2008. This table reflects the changes implemented in early 2008 . Table $4-3$ defines the analyte groups. (See 
FIGURE 4-2

North Plateau Gross Beta Plume: Fourth-Quarter 1994, 2002, and December 2008

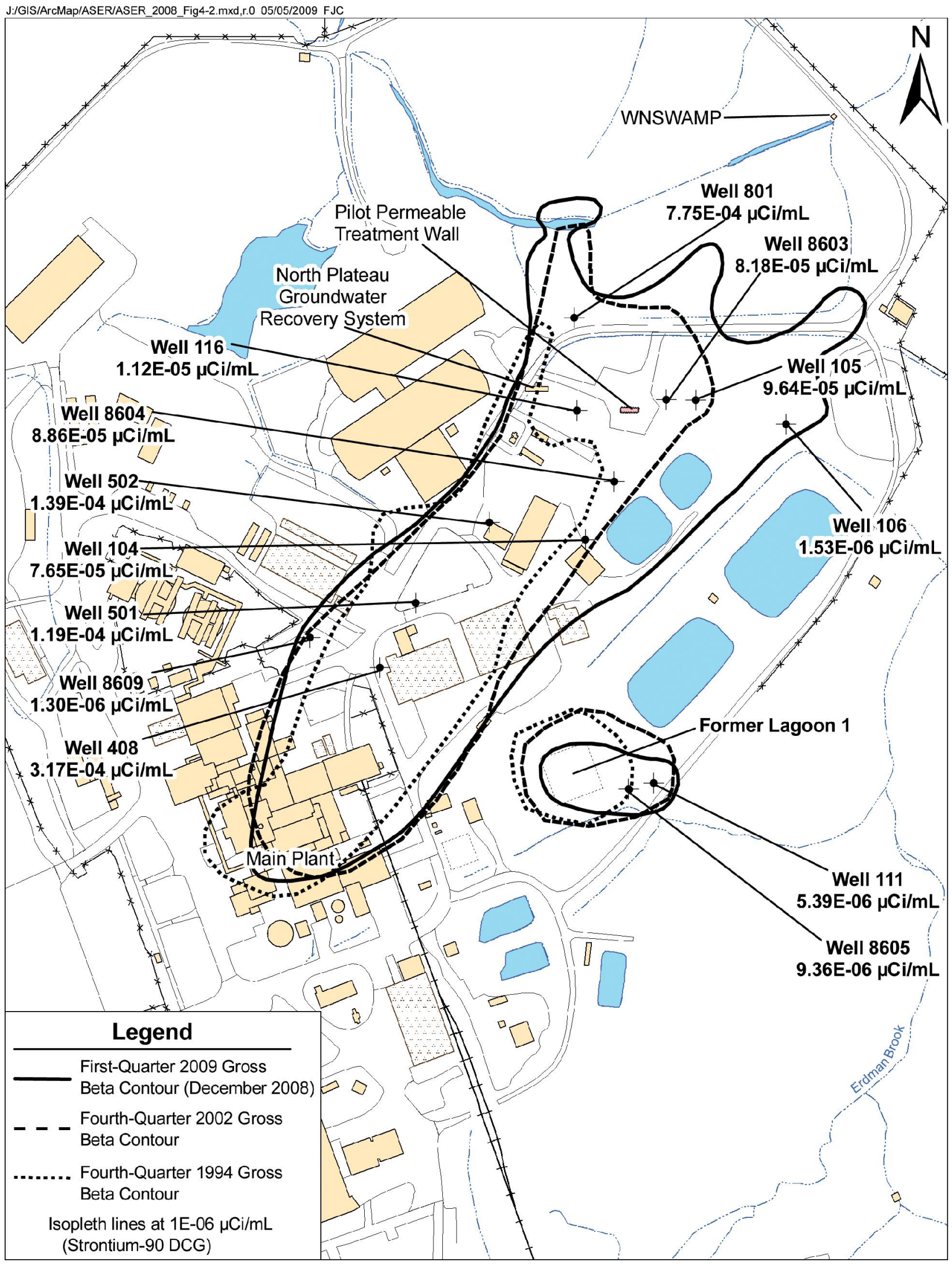


"RCRA $§ 3008(h)$ Administrative Order on Consent" in the "Environmental Compliance Summary.") Tables 4-4 and 4-5 provide an overview of groundwater monitoring during 2008 organized by geographic area and by monitoring purpose.

Groundwater Elevation Monitoring. Potentiometric (water level) data are measured at the monitoring network wells in conjunction with the quarterly analytical sampling schedule. (See Figs. A-7 and A-8 in Appendix A.) Groundwater elevation data are used to produce potentiometric surface maps that delineate groundwater flow directions and gradients. Long-term trend graphs are used to illustrate variations in groundwater elevations over time, such as seasonal fluctuations.

Surface water elevations are also measured on the north plateau where the water table in the sand and gravel unit intersects the ground surface, resulting in standing water. These measurements supplement groundwater elevations measured at nearby monitoring wells to provide data in areas where monitoring well coverage is sparse or nonexistent.

Analytical Trigger Level Evaluation. A computerized data-screening program uses "trigger levels" - preset conservative values for chemical and radiological concentrations and groundwater elevation measurements - to promptly identify anomalies in monitoring results that may require further investigation. The trigger levels are based on regulatory limits, detection limits, or statistically derived values.

\section{Groundwater Sampling Observations on the North Plateau: Sand and Gravel Unit and Strontium-90 Plume}

Gross Beta and the Strontium-90 Plume. In the early 1990 s, elevated gross beta activity was detected in groundwater of the S\&G unit northeast of the MPPB where Nuclear Fuel Services, Inc. reprocessed nuclear fuel (the "Main Plant" on Fig. 4-2). In 1993, elevated gross beta concentrations were detected in surface water near the northeastern edge of the north plateau. Extensive subsurface investigations characterized the plume, which extends from beneath the MPPB to the northeast quadrant of the north plateau. Strontium90 and its daughter product, yttrium-90, were identified as the major isotopic components of the gross beta activity (WVNSCO, 1995). The presumed source of the strontium-90 activity can be traced to soils beneath the southwest corner of the MPPB.
Gross beta activity on the north plateau has been confined to the shallowest hydrologic unit, known as the S\&G unit. The routine GMP network in the S\&G unit on the north plateau includes 32 monitoring wells, three well points, and five groundwater seepage locations.

At the WVDP, DOE derived concentration guides (DCGs) may be used as a reference for evaluating liquid radionuclide effluents. Because there is no DCG for gross beta in liquid effluents, the strontium-90 DCG (1E-06 microcuries per milliliter $[\mu \mathrm{Ci} / \mathrm{mL}]$ ) is used as a conservative basis for comparison where betaemitting radionuclides are detected in groundwater. For the purpose of the following discussions, the strontium-90 DCG is used interchangeably for comparison with either gross beta or strontium-90. (See the "Useful Information" section at the end of this report for a discussion of the DOE DCGs, and Table UI-4 for a list of the DCGs for radionuclides of interest at the WVDP.)

Figure 4-2 shows the outline of the plume, as defined by the strontium-90 DCG, at three intervals spanning fifteen years - 1994, 2002, and 2008. As shown in the figure, although the western boundary of the plume has remained relatively constant since 1994, over time the plume has migrated to the northeast and east, consistent with the direction of groundwater flow in the $S \& G$ unit.

Gross beta concentrations in groundwater in and around the north plateau plume continue to be monitored closely. Gross beta trends pertaining to the plume over the last 10 years are shown in Figures 4-3 through 4-7 at the end of this chapter. With the exception of Figure 4-6, data are plotted on a log scale; therefore, an increase from one unit to the next represents a 10 -fold increase in concentration. The log scale was used so that data from both background locations (with concentrations in the $\mathrm{E}-09 \mu \mathrm{Ci} / \mathrm{mL}$ range) and data from the central plume (with concentrations in the $\mathrm{E}-04 \mu \mathrm{Ci} / \mathrm{mL}$ range, 100,000 times higher than background) could be plotted on the same graphs.

In 2008, the highest gross beta and strontium-90 concentrations in groundwater were seen in the center of the plume immediately downgradient of the MPPB, as shown in Figure 4-2. Maximum concentrations are listed in Table 4-6. Ten-year gross beta trends at the monitoring wells in Figure 4-2 are plotted in Figures 4-3 and 4-4. Well 408 continued to exhibit the highest gross beta concentrations in the plume. While concentrations at most wells were consistent with those in 2007, increases were noted in wells 116 and 106, 
TABLE 4-2

WVDP Groundwater Monitoring Network Sorted by Geologic Unit

\begin{tabular}{|c|c|c|c|c|c|c|c|}
\hline Well ID & SSWMU & $\begin{array}{l}\text { Gradient } \\
\text { Position } \\
\end{array}$ & $\begin{array}{c}\text { Analytical Parameters } \\
\text { (See Table 4-3) }\end{array}$ & Well ID & SSWMU & $\begin{array}{l}\text { Gradient } \\
\text { Position }\end{array}$ & $\begin{array}{c}\text { Analytical Parameters } \\
\text { (See Table 4-3) }\end{array}$ \\
\hline \multicolumn{8}{|c|}{ Sand and Gravel Wells } \\
\hline $103^{a}$ & 1,3 & $D$ & $\mathrm{I}, \mathrm{RI}, \mathrm{V}$ & $801^{a}$ & 8,6 & $U, D$ & $\mathrm{I}, \mathrm{RI}, \mathrm{S}, \mathrm{V}$ \\
\hline 104 & 1 & $\mathrm{C}$ & $\mathrm{I}, \mathrm{RI}$ & 802 & 8 & $\mathrm{D}$ & $\mathrm{I}, \mathrm{RI}, \mathrm{V}$ \\
\hline 105 & 1 & C & $\mathrm{I}, \mathrm{RI}$ & $803^{a}$ & 8 & $\mathrm{D}$ & $\mathrm{I}, \mathrm{RI}, \mathrm{SV}, \mathrm{V}$ \\
\hline 106 & 1 & $\mathrm{D}$ & $\mathrm{I}, \mathrm{RI}$ & $804^{a}$ & 8 & $\mathrm{D}$ & $\mathrm{I}, \mathrm{RI}, \mathrm{V}$ \\
\hline $111^{a}$ & 1 & $\mathrm{D}$ & $\mathrm{I}, \mathrm{RI}, \mathrm{M}, \mathrm{SV}, \mathrm{V}$ & 1302 & $N A^{b}$ & $\mathrm{D}$ & $\mathrm{I}, \mathrm{RI}, \mathrm{M}$ \\
\hline $116^{a}$ & 1,8 & $\mathrm{C}, \mathrm{U}$ & $\mathrm{I}, \mathrm{RI}, \mathrm{V}$ & 1304 & $N A^{b}$ & $U$ & $\mathrm{I}, \mathrm{RI}, \mathrm{M}, \mathrm{R}$ \\
\hline 205 & 2,3 & $\mathrm{D}$ & $\mathrm{I}, \mathrm{RI}$ & 8603 & 8 & $U$ & $\mathrm{I}, \mathrm{RI}$ \\
\hline $301^{a}$ & 3 & $\mathrm{~B}$ & $\mathrm{I}, \mathrm{RI}$ & 8604 & 1 & $\mathrm{C}$ & $\mathrm{I}, \mathrm{RI}$ \\
\hline 302 & 3 & $\mathrm{U}$ & $\mathrm{I}, \mathrm{RI}$ & $8605^{a}$ & 1,2 & $\mathrm{D}$ & $\mathrm{I}, \mathrm{RI}, \mathrm{M}, \mathrm{SV}, \mathrm{V}$ \\
\hline $401^{a}$ & 4,3 & $\mathrm{~B}$ & $\mathrm{I}, \mathrm{RI}, \mathrm{R}$ & $8607^{a}$ & 6,4 & $\mathrm{U}, \mathrm{D}$ & $\mathrm{I}, \mathrm{RI}, \mathrm{V}$ \\
\hline 402 & 4 & $\mathrm{~B}$ & $\mathrm{I}, \mathrm{RI}$ & $8609^{a}$ & $3,4,6$ & $\mathrm{D}, \mathrm{D}, \mathrm{U}$ & $\mathrm{I}, \mathrm{RI}, \mathrm{S}, \mathrm{V}$ \\
\hline 403 & 4 & $\mathrm{U}$ & $\mathrm{I}, \mathrm{RI}$ & $8612^{a}$ & 8 & $\mathrm{D}$ & $\mathrm{I}, \mathrm{RI}, \mathrm{SV}, \mathrm{V}$ \\
\hline $406^{a}$ & 4,6 & $\mathrm{D}, \mathrm{U}$ & $\mathrm{I}, \mathrm{RI}, \mathrm{R}, \mathrm{V}$ & WP-A & $N A^{c}$ & NA & $\mathrm{I}, \mathrm{RI}$ \\
\hline $408^{a}$ & 4,3 & $\mathrm{D}$ & $\mathrm{I}, \mathrm{RI}, \mathrm{R}, \mathrm{V}$ & WP-C & $\mathrm{NA}^{c}$ & NA & $\mathrm{I}, \mathrm{RI}$ \\
\hline $501^{a}$ & 5 & $U$ & $\mathrm{I}, \mathrm{RI}, \mathrm{S}, \mathrm{V}$ & WP-H & $N A^{c}$ & NA & $\mathrm{I}, \mathrm{RI}$ \\
\hline $502^{a}$ & 5 & $\mathrm{D}$ & $\mathrm{I}, \mathrm{RI}, \mathrm{S}, \mathrm{SM}, \mathrm{V}$ & SP04 & $N A^{d}$ & $\mathrm{D}$ & $\mathrm{RI}$ \\
\hline $602 \mathrm{~A}$ & 6 & $\mathrm{D}$ & $\mathrm{I}, \mathrm{RI}$ & SP06 & $\mathrm{NA}^{d}$ & $\mathrm{D}$ & $\mathrm{RI}$ \\
\hline 604 & 6 & $\mathrm{D}$ & $\mathrm{I}, \mathrm{RI}$ & SP11 & $N A^{d}$ & $\mathrm{D}$ & $\mathrm{RI}$ \\
\hline 605 & 6 & $\mathrm{D}$ & $\mathrm{I}, \mathrm{RI}$ & $\mathrm{SP} 12^{a}$ & $N A^{d}$ & $\mathrm{D}$ & $\mathrm{I}, \mathrm{RI}, \mathrm{V}$ \\
\hline $706^{a}$ & 7 & $B$ & $\mathrm{I}, \mathrm{RI}, \mathrm{M}$ & GSEEP $^{a}$ & $N A^{d}$ & $\mathrm{D}$ & $\mathrm{I}, \mathrm{RI}, \mathrm{V}$ \\
\hline \multicolumn{8}{|c|}{ Lavery Till Sand Wells } \\
\hline $204^{a}$ & 2,3 & $\mathrm{D}$ & $\mathrm{I}, \mathrm{RI}$ & 206 & 2 & $\mathrm{C}$ & $\mathrm{I}, \mathrm{RI}$ \\
\hline \multicolumn{8}{|c|}{ Weathered Lavery Till Wells } \\
\hline $906^{a}$ & 9 & $\mathrm{D}$ & $\mathrm{I}, \mathrm{RI}$ & $\operatorname{NDATR}^{a}$ & 9 & $\mathrm{D}$ & $\mathrm{I}, \mathrm{RI}, \mathrm{M}, \mathrm{R}, \mathrm{SV}, \mathrm{V}$ \\
\hline $908^{a}$ & 9 & $\mathrm{D}$ & $\mathrm{I}, \mathrm{RI}$ & $1005^{a}$ & 9,10 & $\mathrm{C}, \mathrm{U}$ & $\mathrm{I}, \mathrm{RI}$ \\
\hline $908 \mathrm{R}^{a}$ & 9 & $B$ & $\mathrm{I}, \mathrm{RI}$ & $1006^{a}$ & 9,10 & C, D & $\mathrm{I}, \mathrm{RI}$ \\
\hline $909^{a}$ & 9 & $\mathrm{D}$ & $\mathrm{I}, \mathrm{RI}, \mathrm{M}, \mathrm{R}, \mathrm{SV}, \mathrm{V}$ & $1008 C^{a}$ & 9,10 & $\mathrm{U}$ & $\mathrm{I}, \mathrm{RI}$ \\
\hline \multicolumn{8}{|c|}{ Unweathered Lavery Till Wells } \\
\hline 107 & 1 & $\mathrm{D}$ & $\mathrm{I}, \mathrm{RI}, \mathrm{V}$ & 707 & 7 & $\mathrm{C}$ & $\mathrm{I}, \mathrm{RI}$ \\
\hline 108 & 1 & $\mathrm{D}$ & $\mathrm{I}, \mathrm{RI}, \mathrm{V}$ & $910^{a}$ & 9 & $\mathrm{D}$ & $\mathrm{I}, \mathrm{RI}$ \\
\hline $110^{a}$ & 1 & $\mathrm{D}$ & $\mathrm{I}, \mathrm{RI}, \mathrm{V}$ & $910 \mathrm{R}^{a}$ & 9 & $\mathrm{D}$ & $\mathrm{I}, \mathrm{RI}$ \\
\hline 405 & 4 & $\mathrm{~B}$ & $\mathrm{I}, \mathrm{RI}, \mathrm{M}$ & 1301 & $N A^{b}$ & $\mathrm{D}$ & $\mathrm{I}, \mathrm{RI}$ \\
\hline 409 & 4 & $\mathrm{D}$ & $\mathrm{I}, \mathrm{RI}$ & 1303 & $\mathrm{NA}^{b}$ & $\mathrm{U}$ & $\mathrm{I}, \mathrm{RI}, \mathrm{M}$ \\
\hline 704 & 7 & $\mathrm{D}$ & $\mathrm{I}, \mathrm{RI}, \mathrm{V}$ & & & & \\
\hline \multicolumn{8}{|c|}{ Kent Recessional Sequence Wells } \\
\hline $901^{a}$ & 4 & $\mathrm{~B}$ & $\mathrm{I}, \mathrm{RI}$ & 1008B & 10 & $\mathrm{U}$ & $\mathrm{I}, \mathrm{RI}$ \\
\hline $902^{a}$ & 9 & $\mathrm{U}$ & $\mathrm{I}, \mathrm{RI}$ & $8610^{a}$ & 9 & $\mathrm{D}$ & $\mathrm{I}, \mathrm{RI}$ \\
\hline $903^{a}$ & 9 & $\mathrm{D}$ & $\mathrm{I}, \mathrm{RI}$ & $8611^{a}$ & 9 & $\mathrm{D}$ & $\mathrm{I}, \mathrm{RI}$ \\
\hline
\end{tabular}

Note: The table reflects monitoring changes that were implemented in January 2008.

Gradient Positions: B (background); C (crossgradient); D (downgradient); U (upgradient)

a Monitoring for certain parameters is required by the RCRA $\S 3008(\mathrm{~h})$ Consent Order.

$b$ Monitor upgradient and downgradient of the RHWF.

c Monitor north and east of the MPPB.

d Monitor groundwater seeping from the edge of the north plateau. 
TABLE 4-3

WVDP Groundwater Sampling and Analysis Agenda

\begin{tabular}{|c|c|}
\hline Analyte Group & Description of Parameters \\
\hline Contamination Indicator Parameters (I) & $\mathrm{pH}$, specific conductance (field measurements) \\
\hline Radiological Indicator Parameters (RI) & Gross alpha, gross beta, tritium \\
\hline Volatile Organic Compounds (V) & $\begin{array}{l}\text { Title } 6 \text { of the New York State Official Compilation of Codes, Rules, } \\
\text { and Regulations ( } 6 \text { NYCRR) Part 373-2 Appendix } 33 \text { Volatile Organic } \\
\text { Compounds (VOCs) }\end{array}$ \\
\hline Semivolatile Organic Compounds (SV) & $\begin{array}{l}6 \text { NYCRR Part 373-2 Appendix } 33 \text { Semivolatile Organic Compounds } \\
\text { (SVOCs) and tributyl phosphate (TBP) }\end{array}$ \\
\hline Groundwater metals (M) & 6 NYCRR Part 373-2 Appendix 33 Metals \\
\hline $\begin{array}{l}\text { Special Monitoring Parameters for early } \\
\text { warning wells (SM) }\end{array}$ & Aluminum, iron, manganese \\
\hline $\begin{array}{l}\text { Radioisotopic Analyses: alpha-, beta-, and } \\
\text { gamma-emitters (R) }\end{array}$ & $\begin{array}{l}\text { Carbon-14, strontium-90, technetium-99, iodine-129, cesium-137, } \\
\text { radium-226, radium-228, uranium-232, uranium-233/234, uranium- } \\
235 / 236 \text {, uranium-238, total uranium. }\end{array}$ \\
\hline Strontium-90 (S) & Strontium-90 \\
\hline
\end{tabular}

TABLE 4-4

WVDP 2008 Groundwater Monitoring Overview by Geographic Area

\begin{tabular}{|l|c|c|c|}
\hline \multicolumn{1}{|c|}{ Number of... } & Total WVDP & North Plateau & South Plateau \\
\hline Monitoring Points Sampled - Analytical & 66 & 51 & 15 \\
\hline Monitoring Points - Water Elevations Only & 52 & 35 & 17 \\
\hline Monitoring Events & 4 & 4 & 4 \\
\hline Analyses & 935 & 749 & 186 \\
\hline Results & 6,004 & 4,745 & 1,259 \\
\hline Percent of Nondetectable Results & $79 \%$ & $78 \%$ & $84 \%$ \\
\hline Water Elevation Measurements & 442 & 312 & 130 \\
\hline
\end{tabular}

TABLE 4-5

WVDP 2008 Groundwater Monitoring Overview by Purpose

\begin{tabular}{|l|c|c|}
\hline \multicolumn{1}{|c|}{ Number of... } & $\begin{array}{c}\text { Regulatory/ } \\
\text { Waste Management }\end{array}$ & Environmental Surveillance \\
\hline Monitoring Points Sampled - Analytical & 35 & 31 \\
\hline Monitoring Points - Water Elevations Only & 0 & 52 \\
\hline Monitoring Events & 4 & 4 \\
\hline Analyses & 612 & 323 \\
\hline Results & 5,087 & 917 \\
\hline Percent of Nondetectable Results & $84 \%$ & $51 \%$ \\
\hline Water Elevation Measurements & 134 & 308 \\
\hline
\end{tabular}


TABLE 4-6

Maximum Concentrations of Radiological Parameters in WVDP Wells During 2008 ${ }^{a}$

\begin{tabular}{|l|c|c|c|c|}
\hline \multirow{2}{*}{ Radionuclide } & \multicolumn{2}{|c|}{ Regulatory/Waste Management } & \multicolumn{2}{c|}{ Environmental Surveillance } \\
\cline { 2 - 5 } & Well ID & $\begin{array}{c}\text { Maximun } \\
\text { Concentration } \\
(\mu \mathrm{Ci} / \mathrm{mL})\end{array}$ & Well ID & $\begin{array}{c}\text { Maximun } \\
\text { Concentration } \\
(\mu \mathrm{Ci} / \mathrm{mL})\end{array}$ \\
\hline Gross Beta & Well 408 & $4.26 \mathrm{E}-04$ & Well 8604 & $1.04 \mathrm{E}-04$ \\
\hline Strontium-90 & Well 408 & $1.64 \mathrm{E}-04$ & Well 8603 & $4.39 \mathrm{E}-05$ \\
\hline Tritium & WNNDATR & $3.15 \mathrm{E}-06$ & WP-C & $3.65 \mathrm{E}-05$ \\
\hline
\end{tabular}

a Includes samples from routinely monitored wells collected from December 2007 to the end of December 2008.

as shown in Figure 4-4. Gross beta concentrations exceeded the strontium-90 DCG throughout 2008 for the monitoring wells within the central portion of the plume, and well 106, at the leading edge of the plume, exceeded the DCG for the first time in 2008.

Results from special Geoprobe ${ }^{\circledR}$ groundwater sampling in 2008 increased the area of monitoring coverage and enhanced definition of the plume's leading edge. (See "Strontium-90 Plume Characterization and Remediation Activities in 2008" later in this chapter.) As shown in Figure 4-2, the leading edge is now characterized as having three small lobes (northern, central, and eastern). The lobes are thought to result from the heterogeneous nature of sediment within the $S \& G$ unit (i.e., the uneven distribution of coarse and fine sediments) which creates preferential pathways for groundwater migration.

Monitoring Near Former Lagoon 1. South of the north plateau plume, elevated gross beta concentrations were also noted in groundwater downgradient of former lagoon 1, which was backfilled in 1984. (See Figure 4-2.) As shown in the 10-year trend graph in Figure 4-5, gross beta concentrations in wells 8605 and 111 are consistently above the strontium-90 DCG and are remaining relatively stable from year to year. The source of the gross beta activity is assumed to be radiologically contaminated materials in the backfill and remaining sediment of former lagoon 1 .

Monitoring at the Northeast Swamp Drainage. Part of the leading edge of the plume is intercepted by a drainage ditch flowing west-to-east across the northern lobe (see Figure 4-2 in this chapter and Figure A2 in Appendix A). Flow rate in this ditch is measured and surface water is sampled for radiological constituents at the WNSWAMP sampling location. As shown in the 10-year trend plot in Figure 4-6, annual average strontium-90 concentrations have been above the strontium-90 DCG for nine of the last 10 years.

Although gross beta and strontium-90 concentrations seasonally fluctuate, measured concentrations in 2008 were all greater than the DCG. The main source of the strontium-90 activity is believed to be groundwater from the north plateau plume seeping into the ditch upstream of WNSWAMP. An estimated 30.7 million gallons (116 million L) of water flowed through this monitoring point in 2008. For additional discussion of monitoring results at WNSWAMP, see "Effluent Monitoring" in Chapter 2 and "Predicted Dose From Waterborne Releases" in Chapter 3.

Monitoring of surface water downstream of the WVDP at the first point of public access, Felton Bridge on Cattaraugus Creek (location WFFELBR), continued to show that strontium-90 concentrations were indistinguishable from historical concentrations from the Cattaraugus Creek background location at Bigelow Bridge (WFBIGBR).

Monitoring at North Plateau Seeps. Groundwater is also monitored along the northeast edge of the north plateau, where it seeps from the steep banks of the stream channels incised by Erdman Brook and Franks Creek. (See Figs. A-2 and A-7 in Appendix A.) Ten-year trends of gross beta concentrations at five seep monitoring points are shown in Figure 4-7. (Annual averages in Figure 4-7 were plotted against surface water backgrounds because water from seepage points may include surface water, and measured concentrations are often lower than groundwater background values.)

Over the last 10 years, gross beta concentrations from points SP12, SP06, and GSEEP have remained relatively stable, with values near, or only slightly above, background concentrations. However, concentrations at point SP11, downstream of surface water 
sampling point WNSWAMP, have steadily increased since 1999. IN 2007 and 2008, concentrations at point SP04 also began increasing, approaching the concentrations in SP11 (about $1.30 \mathrm{E}-07 \mu \mathrm{Ci} / \mathrm{mL}$ ) in 2008. Elevated gross beta activity in the seeps is believed to be attributable to re-infiltration of contaminated plume water that has surfaced upgradient of these locations.

Radioisotopic Sampling Results. In addition to routine sampling of groundwater for gross alpha, gross beta, tritium, and strontium-90 (at specific wells, as indicated in Table 4-2), samples from four groundwater wells in the S\&G unit $(401,406,408$, and 1304) are analyzed for a more extensive list of radionuclides (also indicated in Table 4-2). This list includes carbon-14, technetium-99, iodine-129, cesium-137, radium-226, radium-228, uranium-232, uranium233/234, uranium-235/236, and uranium-238. (Note that radium-226, radium-228, uranium-234, and uranium-238 occur naturally in the environment.)

Historically, all of the above radionuclides except uranium-232 have been detected. In 2008, all but uranium-232 and carbon-14 were detected in groundwater. The maximum concentration of each radionuclide at each location are presented in Table 4-7. Note that wells 401, 405, 706, and 1303 serve as background wells.

On the north plateau, in addition to strontium-90, positive concentrations of uranium-235/236 and technetium-99, and naturally occurring radionuclides radium-226, radium-228, uranium-233/234, and uranium-238 were reported in well 408 , the GMP well closest to the strontium-90 plume source (see Figure 4-2). Concentrations technetium-99 at this well have been decreasing over time, while concentrations of the remaining radionuclides lie within the range of historical results.

Tritium. On the north plateau, elevated tritium concentrations have been observed in isolated areas near the lag storage area, the lag storage hardstand, and adjacent to and downgradient of the lagoon system. Residual tritium activity at these locations is attributed to former operations that occurred as part of nuclear fuel reprocessing. As shown in Table 4-6, the

TABLE 4-7

2008 Maximum Concentrations $\left(\mu \mathrm{Ci} / \mathrm{mL}\right.$ ) of Radionuclides ${ }^{a}$ in Groundwater at the WVDP $^{2}$

\begin{tabular}{|c|c|c|c|c|c|c|c|c|}
\hline Well & TC-99 & $1-129$ & Cs-137 & $R a-226$ & $R a-228$ & $U-233 / 234$ & $U-235 / 236$ & $U-238$ \\
\hline $\begin{array}{l}\text { DOE } \\
\text { DCG }\end{array}$ & $1 E-04$ & $5 E-07$ & $3 E-06$ & NA & $N A$ & $5 E-07$ & $5 E-07^{b}$ & $6 E-07$ \\
\hline \multicolumn{9}{|c|}{ Sand and Gravel } \\
\hline $401^{c}$ & -- & -- & $2.40 \pm 1.88 \mathrm{E}-09$ & $4.00 \pm 0.69 \mathrm{E}-09$ & $8.85 \pm 2.90 \mathrm{E}-10$ & $1.08 \pm 0.83 \mathrm{E}-10$ & -- & $1.07 \pm 1.05 \mathrm{E}-10$ \\
\hline 406 & -- & -- & -- & $1.79 \pm 0.47 \mathrm{E}-09$ & $1.06 \pm 0.12 \mathrm{E}-08$ & $2.34 \pm 1.56 \mathrm{E}-10$ & -- & $2.10 \pm 1.45 \mathrm{E}-10$ \\
\hline 408 & $1.39 \pm 0.29 \mathrm{E}-08$ & -- & - & $8.85 \pm 3.10 \mathrm{E}-10$ & $6.82 \pm 0.60 \mathrm{E}-10$ & $6.94 \pm 2.80 \mathrm{E}-10$ & $1.86 \pm 1.44 \mathrm{E}-10$ & $4.57 \pm 1.73 \mathrm{E}-10$ \\
\hline $706^{c}$ & -- & -- & $5.79 \pm 1.76 \mathrm{E}-10$ & -- & -- & $1.19 \pm 1.00 \mathrm{E}-10$ & -- & $8.29 \pm 8.12 \mathrm{E}-11$ \\
\hline 1302 & -- & -- & -- & -- & -- & $2.32 \pm 1.22 \mathrm{E}-10$ & -- & -- \\
\hline 1304 & -- & -- & -- & $6.49 \pm 2.70 \mathrm{E}-10$ & $1.33 \pm 0.14 \mathrm{E}-08$ & $3.10 \pm 1.48 \mathrm{E}-10$ & -- & $1.32 \pm 0.82 \mathrm{E}-10$ \\
\hline \multicolumn{9}{|c|}{ Weathered Lavery Till } \\
\hline 909 & -- & $9.32 \pm 2.00 \mathrm{E}-09$ & -- & $6.68 \pm 3.26 \mathrm{E}-10$ & -- & $5.00 \pm 1.60 \mathrm{E}-10$ & -- & $4.42 \pm 2.10 \mathrm{E}-10$ \\
\hline NDATR & -- & $1.58 \pm 0.80 \mathrm{E}-09$ & -- & $2.16 \pm 1.35 \mathrm{E}-10$ & $3.23 \pm 0.90 \mathrm{E}-09$ & $1.96 \pm 0.34 \mathrm{E}-09$ & $9.61 \pm 7.81 \mathrm{E}-11$ & $1.62 \pm 0.30 \mathrm{E}-09$ \\
\hline \multicolumn{9}{|c|}{ Unweathered Lavery Till } \\
\hline $405^{c}$ & -- & -- & $2.42 \pm 1.94 \mathrm{E}-09$ & -- & -- & $3.89 \pm 1.56 \mathrm{E}-10$ & -- & $2.93 \pm 1.32 \mathrm{E}-10$ \\
\hline $1303^{c}$ & -- & -- & -- & $3.39 \pm 2.25 \mathrm{E}-10$ & -- & $3.00 \pm 1.30 \mathrm{E}-10$ & $5.66 \pm 5.55 \mathrm{E}-11$ & $1.42 \pm 0.93 \mathrm{E}-10$ \\
\hline
\end{tabular}

Note: "--" indicates that the radionuclide was not positively identified at this location.

a Results for tritium and strontium-90, discussed earlier, are not included in this summary. Routine monitoring locations with no positive detections of additional radionuclides are not listed, nor are sampled radionuclides that were not positively detected at any of the locations. These data are based on routinely monitored groundwater wells.

$b$ DCG for U-236 is used for this comparison.

c Background well 
maximum tritium concentration measured in groundwater from the north plateau in 2008, 3.65E-05 $\mu \mathrm{Ci}$ / $\mathrm{mL}$, was at well point WP-C, downgradient of the main plant (see Figure A-7). This concentration was far below the DOE DCG for tritium of $2.0 \mathrm{E}-03 \mu \mathrm{Ci} / \mathrm{mL}$.

Concentrations of tritium in groundwater at the WVDP have been steadily decreasing, primarily as a result of radioactive decay. (The half-life of tritium is about 12.3 years.) Dilution from surface water infiltration and groundwater recharge is also contributing to the decrease, as is evaporation. Current tritium concentrations in ground water from most monitoring locations on the north plateau are close to or within the range of background values.

Results for Volatile and Semivolatile Organic Compounds (VOCs and SVOCs). In accordance with the Consent Order, select wells within the S\&G unit are monitored for VOCs and SVOCs due to localized concentrations exceeding New York State Department of Environmental Conservation (NYSDEC) Technical and Operational Guidance Series (TOGS 1.1.1), Groundwater Effluent Limitations (Class GA), during the RFI. Currently, the only S\&G monitoring location with consistent positive detections of VOCs is well 8612, located northeast and downgradient of the closed construction and demolition debris landfill (CDDL) at the northeast edge of the north plateau. (See Table 4-8 and Figure A-7 in Appendix A.) Figure 4-8 illustrates concentration ranges of four detected organic compounds at well 8612 . Only two of these VOCs continue to be detected above the TOGS 1.1.1 Class GA; however, these concentrations are steadily decreasing over time. The presence of VOCs in well 8612 is presumed to be the result of wastes buried in the CDDL.

In the recent past (as late as 2007), low levels of benzene, ethyl benzene, toluene, and xylene were also detected in the S\&G unit at well 803 at concentrations less than the quantitation limit and below the TOGS 1.1.1 Class GA Groundwater Effluent Limitations. However, none of these VOCs were detected at well 803 during 2008.

Downgradient of former lagoon 1, the SVOC TBP continued to be detected in groundwater from well 8605 in 2008. However, the concentrations are decreasing when compared to the historic high of 700 micrograms per liter $(\mu \mathrm{g} / \mathrm{L})$ measured in December 1996. TBP was also detected in well 111, located near well 8605 , but at concentrations close to or below the quantitation limit of $10 \mu \mathrm{g} / \mathrm{L}$. (See Fig. 4-9.) Ongoing detection of TBP in this localized area may reflect residual contamination from liquid waste management activities in the former lagoon 1 area during earlier nuclear fuel reprocessing. There is no TOGS 1.1.1 screening criteria established for TBP.

A summary of maximum concentrations of organic compounds detected in WVDP ground water wells for TBP and the VOCs that continue to exceed TOGS 1.1.1 is provided in Table 4-8.

\section{Strontium-90 Plume Characterization and Remediation Activities in 2008}

Near-Term and Long-Term Plume Management Activities. Alternatives for the continued near-term and long-term management of the plume are currently being developed by the DOE. Geoprobe ${ }^{\circledR}$ sampling projects conducted in 2008 obtained additional plume and subsurface characterization data to support the development of these plume management strategies. The proposed strategies include excavation of the subsurface soils in the source area under the MPPB and will include construction of a fullscale permeable treatment wall (PTW) along the lead-

\section{TABLE 4-8 \\ Summary of Maximum Concentrations of Organic Constituents in Select WVDP Groundwater Wells During 2008}

\begin{tabular}{|c|c|c|c|}
\hline \multirow{2}{*}{ Constituent } & \multicolumn{2}{|c|}{$\begin{array}{c}\text { Regulatory/Waste Management } \\
\text { Monitoring Program }\end{array}$} & \multirow{2}{*}{$\begin{array}{c}\text { New York State Groundwater } \\
\text { Effluent Limitations }{ }^{a} \\
\text { Class GA }(\mu g / L)\end{array}$} \\
\hline & $\begin{array}{c}\text { Well with the Highest } \\
\text { Concentration }\end{array}$ & Concentration $(\mu \mathrm{g} / \mathrm{L})$ & \\
\hline 1,2-Dichloroethylene (total) & 8612 & 22 & 5.0 \\
\hline 1,1-Dichloroethane & 8612 & 6.9 & 5.0 \\
\hline Tributyl phosphate & 8605 & 209 & NA \\
\hline
\end{tabular}

NA - Not applicable.

a Source: 6 NYCRR Part 703, Division of Water TOGS 1.1.1, NYS Groundwater Effluent Limitations (Class GA). 
ing edge of the plume, delineated using the $1 \mathrm{E}-06$ $\mu \mathrm{Ci} / \mathrm{mL}$ concentration isopleth. The implementation of these plume management strategies are integral to the starting point of the environmental impact statement (EIS) for the WVDP, to manage and minimize the release of contamination off site while the EIS for the Decommissioning and/or Long-Term Stewardship at the WVDP and the WNYNSC is finalized. The EIS also evaluated other remedial alternatives for the north plateau plume, including removal of all of the subsurface soil and groundwater impacted by the plume (Sitewide Removal Alternative).

During 2008, three subsurface investigations were performed: (1) a Geoprobe ${ }^{\circledR}$ soil investigation to determine background concentrations of radiological and metals constituents in soils from areas of the S\&G and ULT units; (2) a Geoprobe ${ }^{\circledR}$ investigation of radiological, organic, and metals constituents in soils and groundwater from beneath and directly downgradient of the MPPB; and (3) a Geoprobe ${ }^{\circledR}$ investigation to characterize soils and groundwater along the downgradient portions of the strontium-90 plume to obtain data for use in determining remediation strategies to minimize the plume's off-site migration.

North Plateau Metals Background Soils Characterization. In July 2008 , five soil borings were advanced on the north plateau to obtain supplemental background soil data from areas of the north plateau unaffected by site operations and activities. This additional subsurface background soil data for metals was used in evaluations of site soils, including soils from within the strontium-90 plume.

In accordance with the "Sampling and Analysis Plan for Background Subsurface Soil on the North Plateau" (WVNSCO, August 2007), metals data from the five soil borings were evaluated to determine site-specific background concentrations for metals to use for comparison with data from downgradient areas and to aid in site closure activities (see Appendix $\mathrm{F}^{\mathrm{ET}}$. Radioisotopic analyses were also performed on the background soil samples. These data, together with other background sampling locations, were used to establish radiological background values for screening soil samples in the "Phase I Decommissioning Plan for the West Valley Demonstration Project" (DOE, March 2009). Details of this background subsurface soil sampling and analysis characterization effort are provided in the "Special Monitoring" discussion in Chapter 2.
Sampling and Analysis for Source Area Characterization of the North Plateau Plume. Also in July 2008, a Geoprobe ${ }^{\circledR}$ program was initiated to determine whether RCRA-regulated constituents were present in the subsurface soils and groundwater beneath and immediately downgradient of the MPPB. As specified in a sampling plan for the plume area (WVNSCO, August 2007), the resulting data were evaluated relative to background levels and/or to remedial action levels provided in NYSDEC technical guidance. The soil and groundwater samples collected were also analyzed for radiological indicator parameters and selected radioisotopes.

Soil samples collected during this program from the S\&G unit and Lavery till at 18 locations beneath, outside, and downgradient of the MPPB were analyzed for Target Analyte List metals, Target Compound List VOCs, SVOCs, and polychlorinated biphenyls (PCBs), radionuclides, and radiological indicator parameters. Groundwater samples from these same locations were analyzed for Title 6 of the New York Offical Compilation of Codes, Rules, and Regulations ( 6 NYCRR Part 373-2) Appendix 33 metals, VOCs, SVOCs, PCBs, radionuclides, and radiological indicator parameters. Results of the soils and groundwater investigation are discussed in the "WVDP North Plateau Plume Area Characterization Report" (West Valley Environmental services LLC [WVES], 2009). Summarized data are presented in Appendix $\mathrm{F}^{\mathrm{ED}}$.

In addition to the analytical data, the lithologic data were also used to further define the subsurface geology, including the depth and topographic contours of the ULT and the location and extent of the slackwater sequence (SWS) beneath and downgradient of the MPPB.

\footnotetext{
Pre-Design Geoprobe ${ }^{\circledR}$ Investigation for Mitigation of the Leading Edge of the North Plateau Strontium90 Plume. In October 2008, field work to characterize the leading edge of the plume (WVES, October 2008) was initiated with Geoprobe ${ }^{\circledR}$ sampling and the installation of temporary microwells along the leading edge of the strontium-90 plume in the northeastern portion of the Project premises. The objectives were to develop designs for remediation strategies to reduce migration of the downgradient strontium-90 plume, and to reduce the total radioactivity released to surface water and seepage zones downgradient of the swamp ditch. The three main elements of the field work scope included:
} 
- Surface water sample collection, borings, and temporary microwell installation allowing discrete groundwater sampling for downgradient strontium-90 plume characterization;

- Stratigraphic, hydrochemical, and hydraulic data collection to support the PTW design; and

- Ancillary surface water, groundwater, soil, and geotechnical data to investigate potential remedial options in the swamp ditch.

Current objectives are to install a PTW in 2010.

Metals Sampling at Select Wells Within the North Plateau Plume. In July 2005, then again in 2007 and 2008 in anticipation of conducting the Geoprobe ${ }^{\circledR}$ programs discussed above, 12 select groundwater wells were sampled to evaluate the potential metals concentrations within the strontium-90 plume area. Using newly established groundwater background metals concentrations and the TOGS 1.1.1 Groundwater Effluent Limitations, a set of site-specific groundwater metals screening levels (GSLs) were established. (Refer to the "WVDP North Plateau Plume Area Characterization Report" for methodology.) Metals data detected above the GSLs during the special groundwater monitoring well sampling events are shown in Table 4-9.

Fourteen different metals were detected in the unfiltered samples above their corresponding GSLs at eight of the 12 monitored locations. The overwhelming majority of metals detected above GSLs were observed in the deep (WP20D) and shallow (WP20S) well points located south of the fuel receiving and storage facility (FRS). These metals data were reported to NYSDEC along with discussion concerning the construction of the monitoring wells from which the samples were taken. The well points were initially installed as water-level and strontium-90 surveillance points for the north plateau plume monitoring, not to support metals monitoring under the GMP. Therefore, installation of standard-construction replacement wells is planned for CY 2009. Two wells will replace well points WP20D and WP20S near their current locations, and two additional wells will be installed slightly further downgradient of the MPPB, south of the FRS, to supplement downgradient surveillance.

Nickel and chromium were detected at concentrations above the GSLs in GMP wells 104, 301, 408, and 502. These wells are constructed of stainless steel and corrosion of the well screens may attribute to the reported concentrations of these metals. See "Investigation of Chromium and Nickel in the Sand and Gravel Unit and Evaluation of Corrosion in Groundwater Monitoring Wells" later in this chapter.

North Plateau Groundwater Recovery System (NPGRS). In 1995, the NPGRS was installed to minimize the advance of the strontium-90 plume. (See Fig. 4-2.) The NPGRS consists of three wells that extract contaminated groundwater, which is then treated by ion exchange to remove strontium-90. Optimum rates of extraction were obtained with two wells pumping. Treated water is transferred to the lagoon system and is ultimately discharged to Erdman Brook via the New York State Pollutant Discharge Elimination System (SPDES)-permitted outfall.

The NPGRS operated throughout 2008, processing about 3.6 million gallons (14 million liters) of water. The system has extracted and processed approximately 52.9 million gallons (200 million liters) since November 1995.

North Plateau Groundwater Quality Early Warning Monitoring. Early-warning monitoring of water upgradient of the NPGRS is performed because the water that is pumped through the NPGRS is ultimately discharged off site via the SPDES-permitted outfall 001 that discharges from Lagoon 3. Semiannual monitoring results from well 502, located directly upgradient of the NPGRS, can be used to identify metals concentrations in groundwater that may affect compliance with the SPDES-permitted effluent limits. The levels of these metals detected in groundwater from well 502 in CY 2008 were below concentrations likely to affect SPDES permit compliance.

Pilot-Scale PTW. A pilot-scale PTW was constructed in 1999 within the eastern lobe of the strontium-90 plume to test this passive, in-situ remediation technology. The pilot PTW is a 7 -foot by 30 -foot by 25 foot-deep trench that is backfilled with clinoptilolite, a medium selected for its ability to adsorb strontium-90 ions from groundwater. Strontium-90 concentrations are lower in groundwater from wells within the PTW, indicating that strontium-90 is being removed from the water that passes through the wall. However, throughout 2008, strontium-90 concentrations increased in three of the wells within the PTW to levels that may suggest the beginning of some reduction in treatment capacity in that area.

The limited size of the pilot PTW and complex local geology affect the performance of the pilot wall, and 
TABLE 4-9

Metals Detected Above Site-Specific Groundwater Screening Levels (GSLs) During Special Sampling Events in 2005, 2007, and 2008

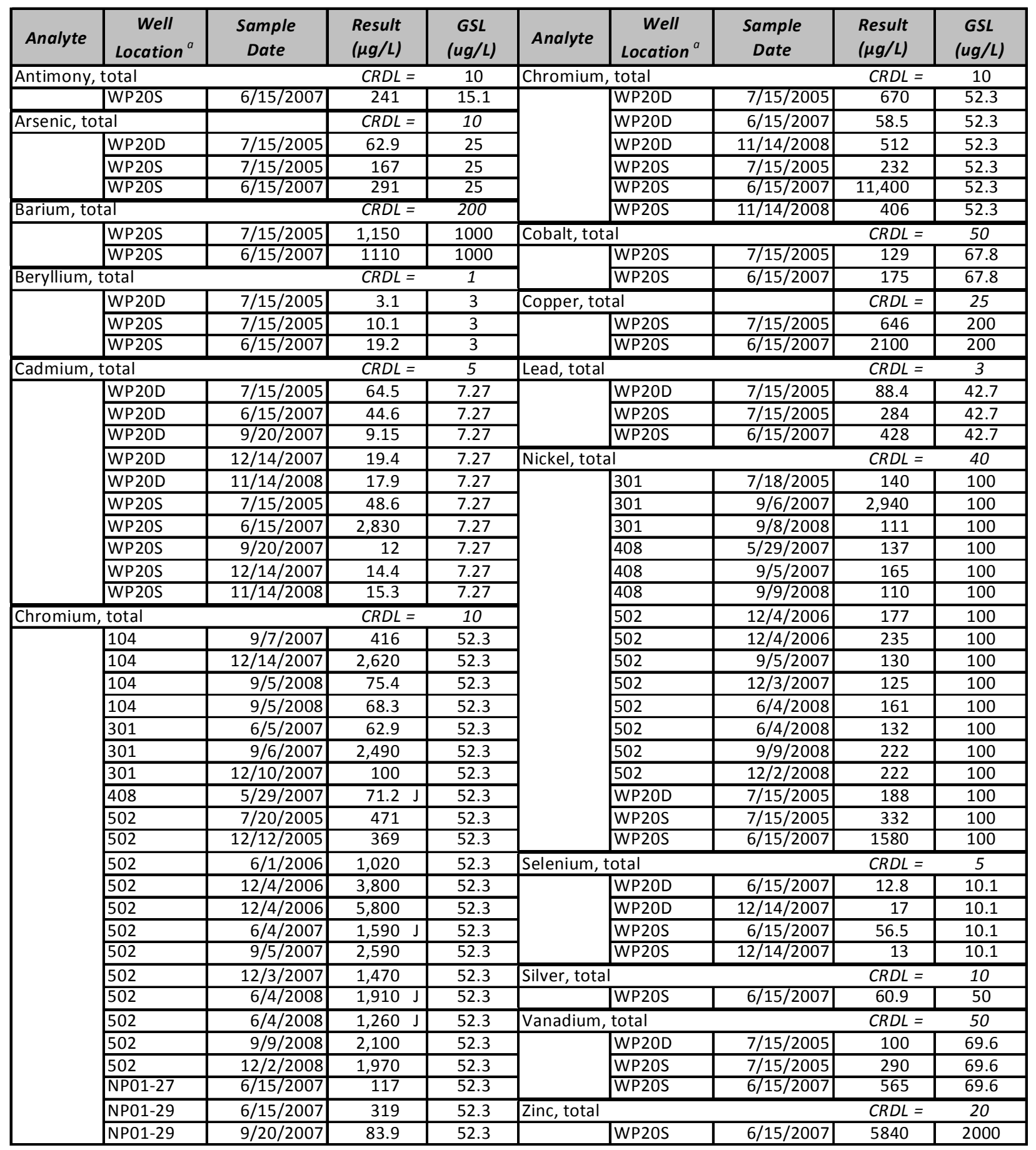

CRDL - Contract-required detection limit

$\mathrm{J}$ - Data are estimated

a Locations sampled as part of these special sampling events include stainless-steel monitoring wells 104, 301, 408, 501, and 502; polyvinyl chloride (PVC) monitoring wells 8609, NP01-17, NP01-22, NP01-27, and NP01-29, and PVC well points WP20S and WP20D. Data from well 502 includes results from routine Groundwater Monitoring Program samples. 
the wall itself may be affecting the pattern of natural groundwater flow in the eastern lobe of the plume. In the 10 years since the installation of the pilot PTW, the plume has continued to migrate past the pilot PTW because the pilot wall only intercepts and treats a small portion of the strontium-90 plume. Nevertheless, the data indicate that the PTW technology is an effective remediation method for strontium-90-contaminated groundwater, and this technology is being implemented as a strontium-90 plume remediation strategy.

\section{Groundwater Sampling Observations on the South Plateau: Weathered Lavery Till and the NDA}

NDA Monitoring. In 1990, a trench system was constructed through the weathered Lavery till (WLT) along the northeast and northwest sides of the NDA to intercept and collect groundwater that was potentially contaminated with a mixture of radioactive $n$-dodecane and TBP. Sampling location WNNDATR is a sump at the lowest point of the interceptor trench. Groundwater is collected at WNNDATR and is transferred to the low-level waste treatment facility for processing. (See also "Interim Measures (IM); NDA Cap" in the Environmental Compliance Summary and "NRC-Licensed Disposal Area [NDA] Interceptor Trench and Pretreatment System" in Chapter 1.) Monitoring results in 2008 detected no TBP in NDA interceptor trench groundwater. Groundwater elevations are monitored quarterly in and around the trench to ensure that an inward gradient is maintained, thereby minimizing outward migration of potentially contaminated groundwater.

Gross beta and tritium concentrations in groundwater from WNNDATR and from WLT well 909, downgradient of WNNDATR (Fig. A-8 in Appendix A), continued to be elevated with respect to concentrations in background monitoring locations on the south plateau. Residual activity from historical site operations in the NDA is the presumed source of this gross beta activity. Similar to the north plateau, strontium-90 is the predominant contributing radioisotope to the gross beta concentrations measured. Gross beta concentrations at WNNDATR have increased with time, with even steeper increases observed from 2005 through 2008. Gross beta concentrations at ULT well 910 became elevated above the DOE DCG at the end of 2007. This was caused by a broken well coupling that was allowing shallow contaminated groundwater, and/or surface water that had been previously identified on the surface of the NDA, to enter the well. Following a hydrogeological evaluation, this well was decommissioned and a replacement well (well 910R) was installed in 2008 to continue monitoring coverage for the ULT in this area.

Replacement well 910R was sampled in December 2008 , and the concentration of gross beta was within the background range. This supports the determination that the high gross beta concentrations seen in decommissioned well 910 were indeed due to the broken coupling allowing shallow waters into the well, rather than from contamination migrating through the ULT.

Tritium concentrations at WNNDATR were slightly lower during 2008 than those in 2007, and overall have decreased since 1994 . Although WNNDATR contained the highest tritium concentration reported in the WVDP regulatory/waste management groundwater monitoring locations, tritium concentrations remain well below the DOE DCG for tritium, 2.0E-03 $\mu \mathrm{Ci} / \mathrm{mL}$ (see Table 4-6). Detections of tritium in the NDA are presumed to be the result of residual activity from former waste burial operations on the south plateau.

At location WNNDATR and well 909 on the south plateau, where monitoring for additional radionuclides continues, low concentrations of iodine-129, radium226 , radium-228, uranium-233/234, uranium-235/ 236 , and uranium-238 were detected. Radionuclide concentrations in groundwater downgradient of the NDA are presumed to be associated with former waste burial operations.

NDA IM. An IM work plan for the NDA was completed under the Consent Order in 2007, with the stated goals being to improve the integrity of the earthen cap and to limit infiltration of groundwater, surface water, and precipitation into the NDA. Construction, completed in December 2008, included the installation of a geosynthetic cap over the NDA, a low-permeability subsurface groundwater cutoff wall (slurry wall) upgradient of the NDA, and surface water drainage diversions. Activities during construction of the cap included addition of new soil to the surface of the NDA prior to installation of the cover to ensure that buried wastes remain covered with a minimum of four feet of soil. As an IM, the design criteria required that the cap and slurry wall be effective for a minimum of 10 years. In addition, 21 piezometers were installed to monitor groundwater elevation differences both upgradient and downgradient of the slurry wall. Early indications suggest that water levels downgradient of the slurry wall have started to de- 
cline. Continued monitoring will demonstrate the effectiveness of the IM.

As part of the NDA IM efforts, two new monitoring wells were installed near the NDA. Well 908R was installed in the WLT west (upgradient) of the new slurry wall to replace well 908 by providing upgradient groundwater monitoring. Because the slurry wall was installed directly upgradient of well 908 , this well can no longer adequately monitor groundwater conditions upgradient of the NDA burial area. Well 910R was installed downgradient of the NDA in the unweathered lavery till (ULT), adjacent to the location of former well 910, which became damaged in late 2007. Well 910 was decommissioned when well 910R was installed. Sampling and monitoring of both new wells was initiated in December 2008.

Refer to Environmental Compliance Summary "Interim Measures" under "RCRA $§ 3008(h)$ Order on Consent" for further discussion of the NDA IM.

\section{Additional Monitoring and Investigations}

\footnotetext{
Groundwater Monitoring Downgradient of the Waste Tank Farm (WTF). The high-level radioactive waste in the underground tanks has been solidified through the vitrification process and the tanks containing residual waste remain in place. In 2005, the NYSDEC requested that the DOE evaluate the current and historical groundwater conditions in the vicinity of the WTF. Throughout waste processing activities, groundwater controls were in place to (1) reduce the upward hydrostatic pressure on the tanks, and (2) to maintain an inward hydraulic gradient toward the tanks, thereby inhibiting any potential leaks from the tanks. The natural inward hydraulic gradient is influenced by periodically pumping a dewatering well (DWW), located outside the vault, that controls the hydrostatic pressure in the immediate vicinity of the tanks.
}

Radioactivity in groundwater in the vicinity of the WTF is routinely monitored and evaluated. Elevated gross beta concentrations in groundwater from well 8607 have been observed since 1994, with the maximum concentration measured in 2005. Gross beta activity has also been observed in the DWW and the tank 8D-2 pan. Radionuclide samples from these locations were collected in 2007 to determine the source(s) of the gross beta activity. After evaluating the radiological results, it was concluded that the gross beta activity in well 8607 is most likely attributed to residual contamination from historical events in and around the WTF (i.e., minor leaks from condensate lines or the WTF underdrain) and is not believed to have originated from the tanks themselves. Monitoring of radionuclides at these sampling points was discontinued in favor of continued indicator parameter sampling, since gross beta results can provide an adequate determination of radioactivity concentrations. Gross beta concentrations at well 8607 continue to decrease from the 2005 maximum.

Investigation of Chromium and Nickel in the S\&G Unit and Evaluation of Corrosion in Groundwater Monitoring Wells. A 1997 and 1998 study of the effect of modifying sampling equipment and methodology on concentrations of chromium and nickel in groundwater samples from the S\&G unit noted that such modifications produced decreases in these concentrations. This finding supported the hypothesis (which is documented in the technical literature) that elevated concentrations of nickel and chromium were not representative of actual groundwater conditions, but were caused by the release of metals from subsurface corrosion of stainless-steel well materials (WVNSCO and Dames \& Moore, June 1998).

To ensure that the integrity of the monitoring wells is maintained, and to ensure that samples representative of actual groundwater conditions are collected, wells are periodically inspected for corrosion. Approximately $75 \%$ of the stainless-steel wells monitoring the $S \& G$ unit were internally inspected for corrosion during 2001. At that time, wells with corrosion were cleaned and reinspected to verify that corrosion had been removed. Since 2001, select wells have been inspected and cleaned when elevated nickel and chromium were observed. An inspection and cleaning project was planned for CY 2007, but was postponed due to equipment problems. This project is rescheduled for CY 2009.

FRS Pool Water Infiltration. During mid-2005, water was found trickling into the empty FRS pool during a quarterly inspection. The water had accumulated to approximately four to six inches. The water is directed by a slope in the floor to a deeper stainlesssteel-lined cask unloading pool (CUP). Analytical data for the FRS CUP water indicate that groundwater seepage is the source of the water. During periods of high precipitation or snow melt, slight seepage has entered along the south wall. Elevated cesium137 concentrations have been observed in water samples collected from the water that has infiltrated 
the FRS pool since the pool was drained. The cesium137 is believed to be from residuals that adhered to the FRS walls when the pool was full. Groundwater seepage into the pool is thought to have dissolved some of the cesium. Because the water does not pose operational or safety concerns, it has been left in the CUP under routine monitoring. Currently, the water level in the CUP is measured daily by facility operators. 
FIGURE 4-3

Average Annual Gross Beta Concentrations

at Monitoring Wells Centrally Located Within the North Plateau Sr-90 Plume

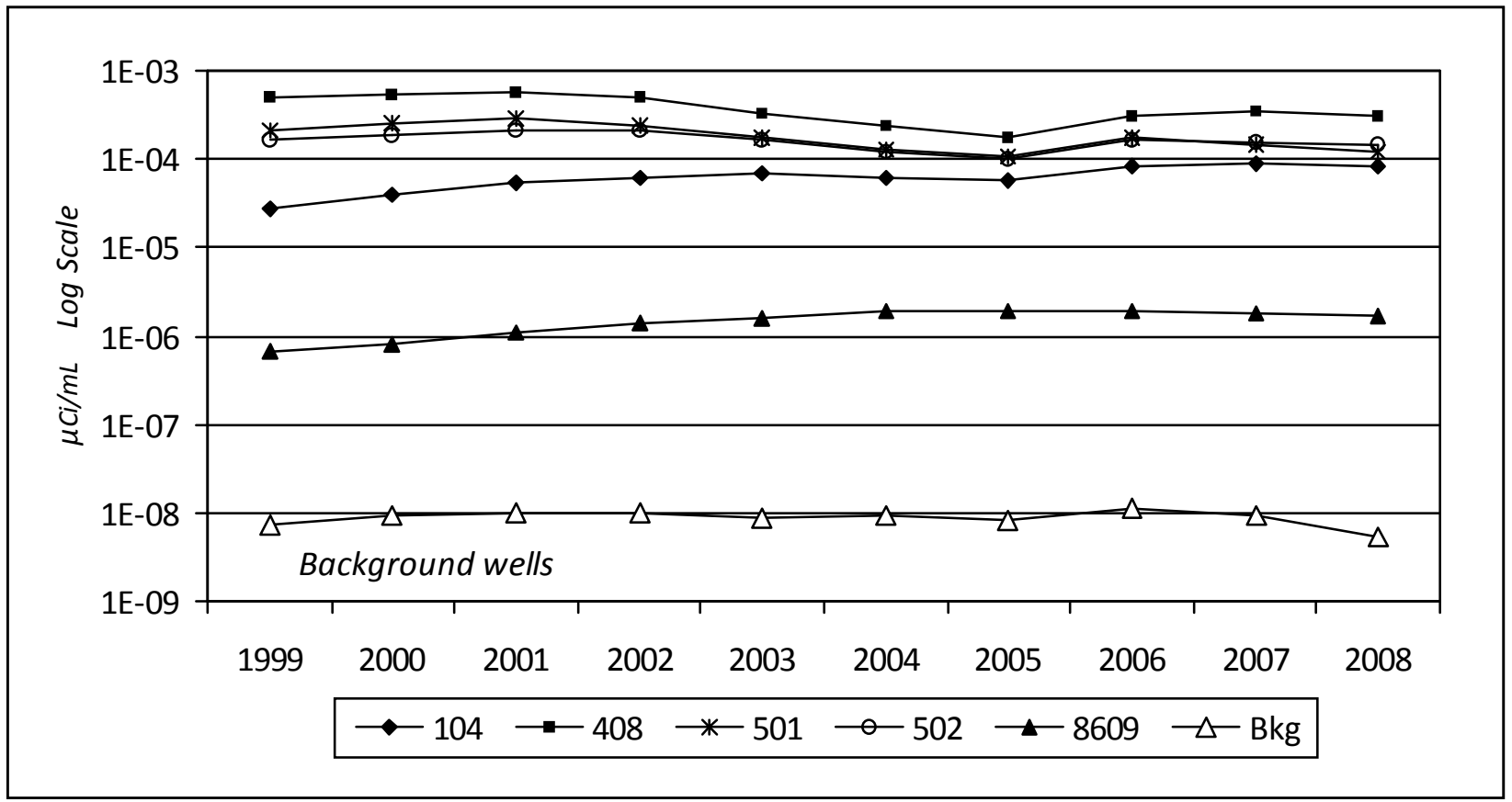

Note: Background wells 301, 401, and 706 are averaged for this comparison.

FIGURE 4-4

Average Annual Gross Beta Concentrations at Monitoring Wells Near the Leading Edge of the North Plateau Sr-90 Plume

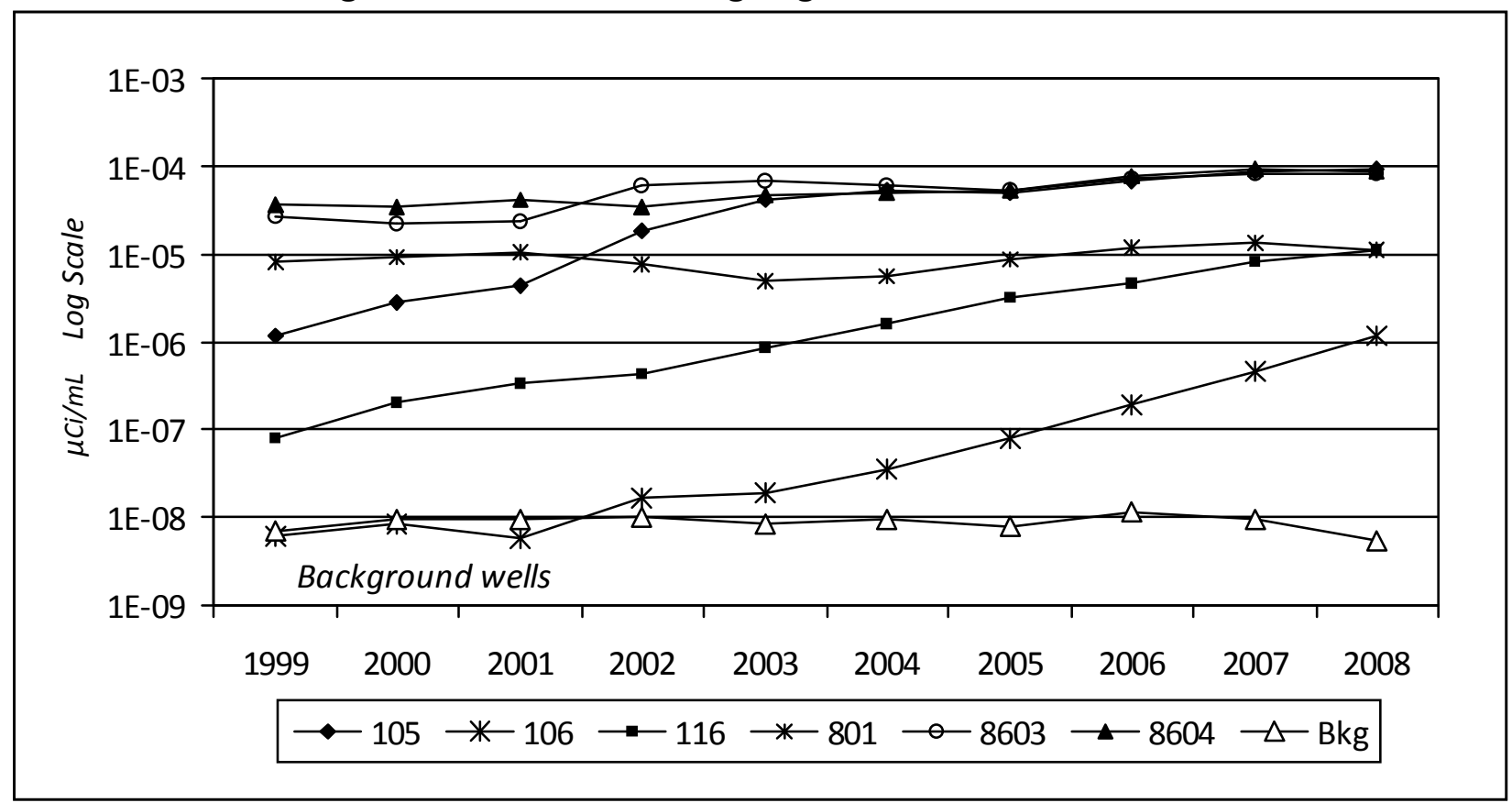

Note: Background wells 301, 401, and 706 are averaged for this comparison. 
FIGURE 4-5

Average Annual Gross Beta Concentrations at Monitoring Wells Near Former Lagoon 1

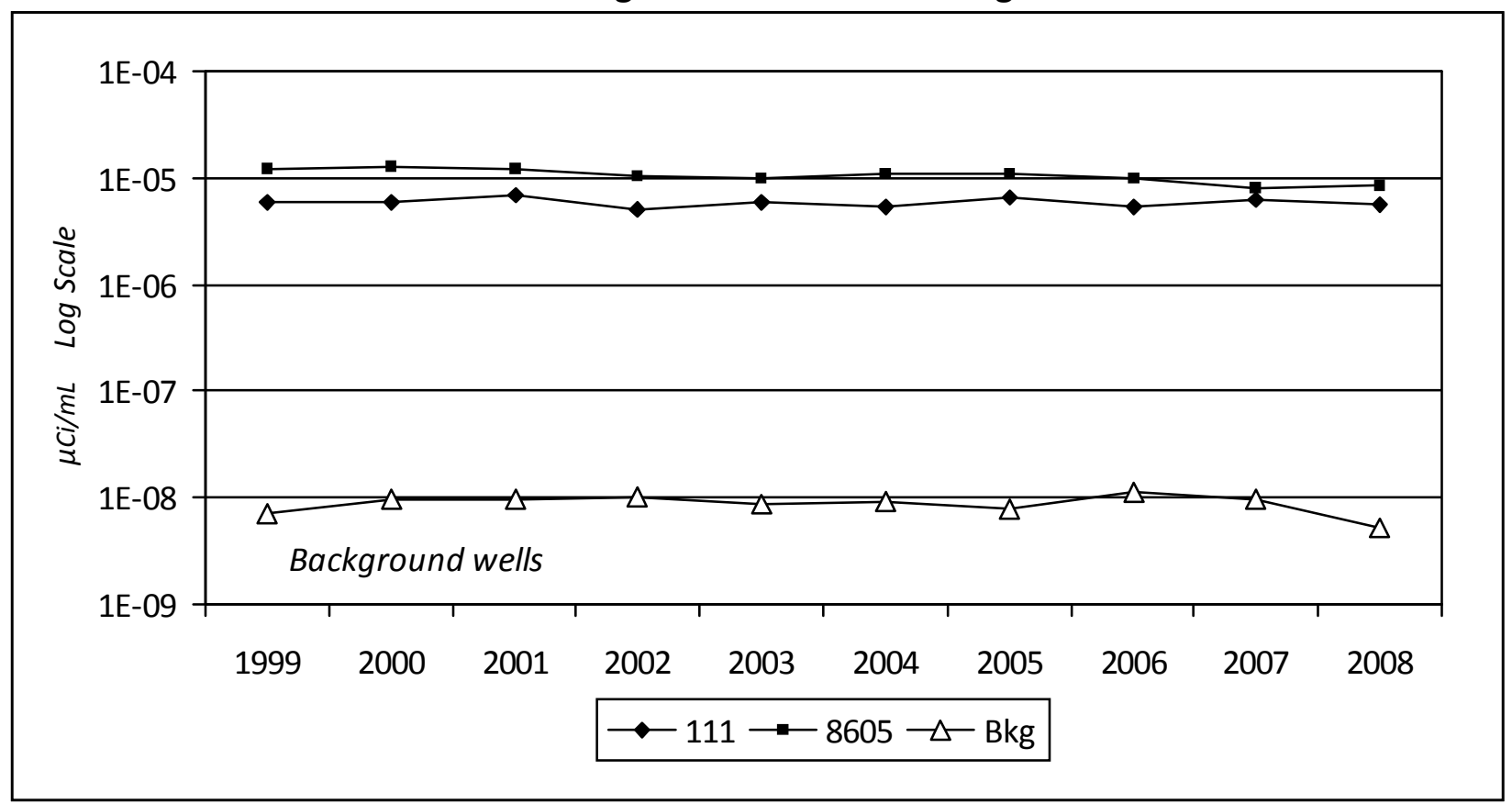

Note: Background wells 301, 401, and 706 are averaged for this comparison.

FIGURE 4-6

Average Annual Strontium-90 Concentrations at WNSWAMP

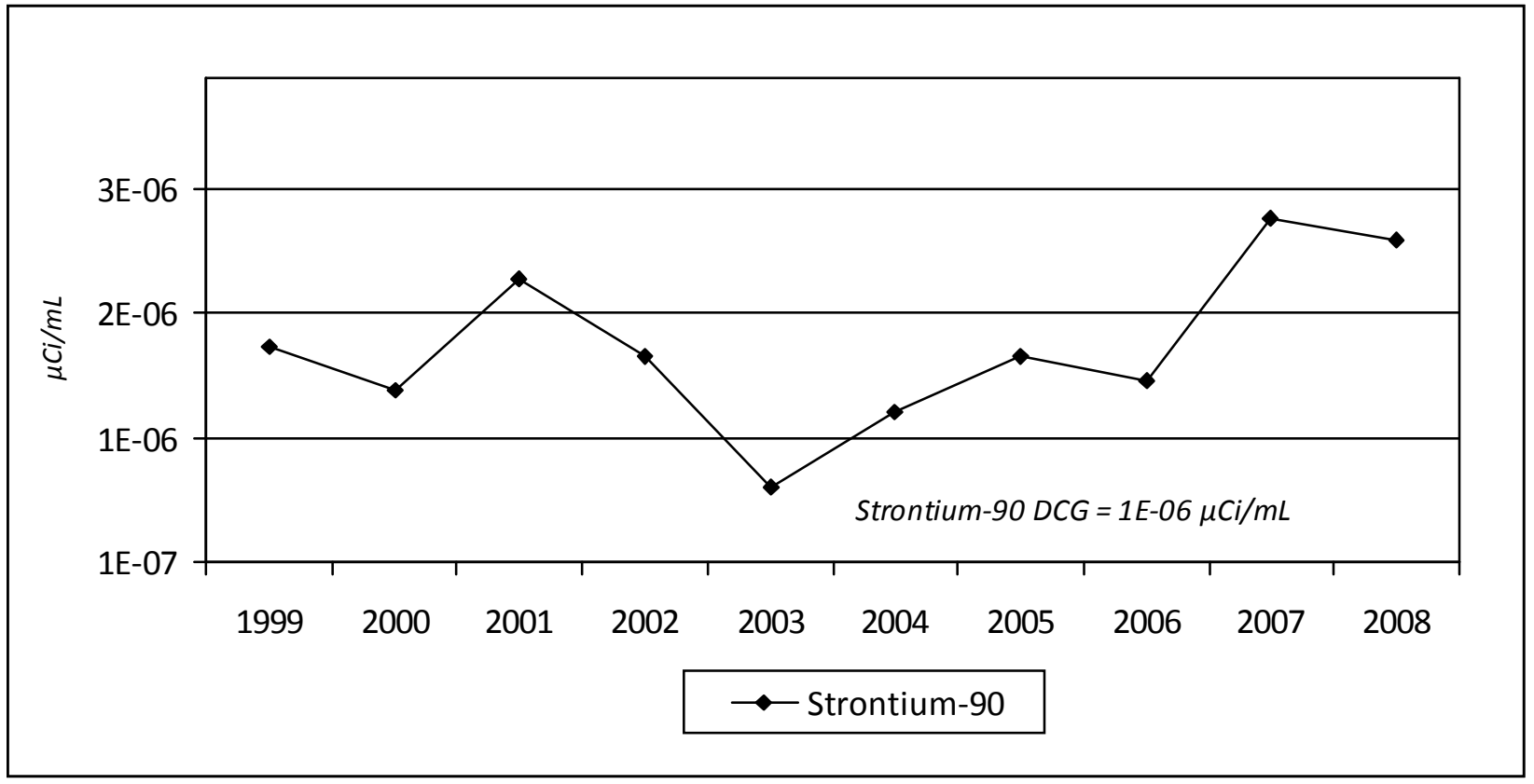

Note: DCGs are used as an evaluation tool for results from on-site locations as part of the routine environmental monitoring program. However, DOE DCGs are applicable only at locations accessible to members of the public. The WNSWAMP location is not accessible to the public. 
FIGURE 4-7

Average Annual Gross Beta Concentrations at Seeps

From the Northeast Edge of the North Plateau

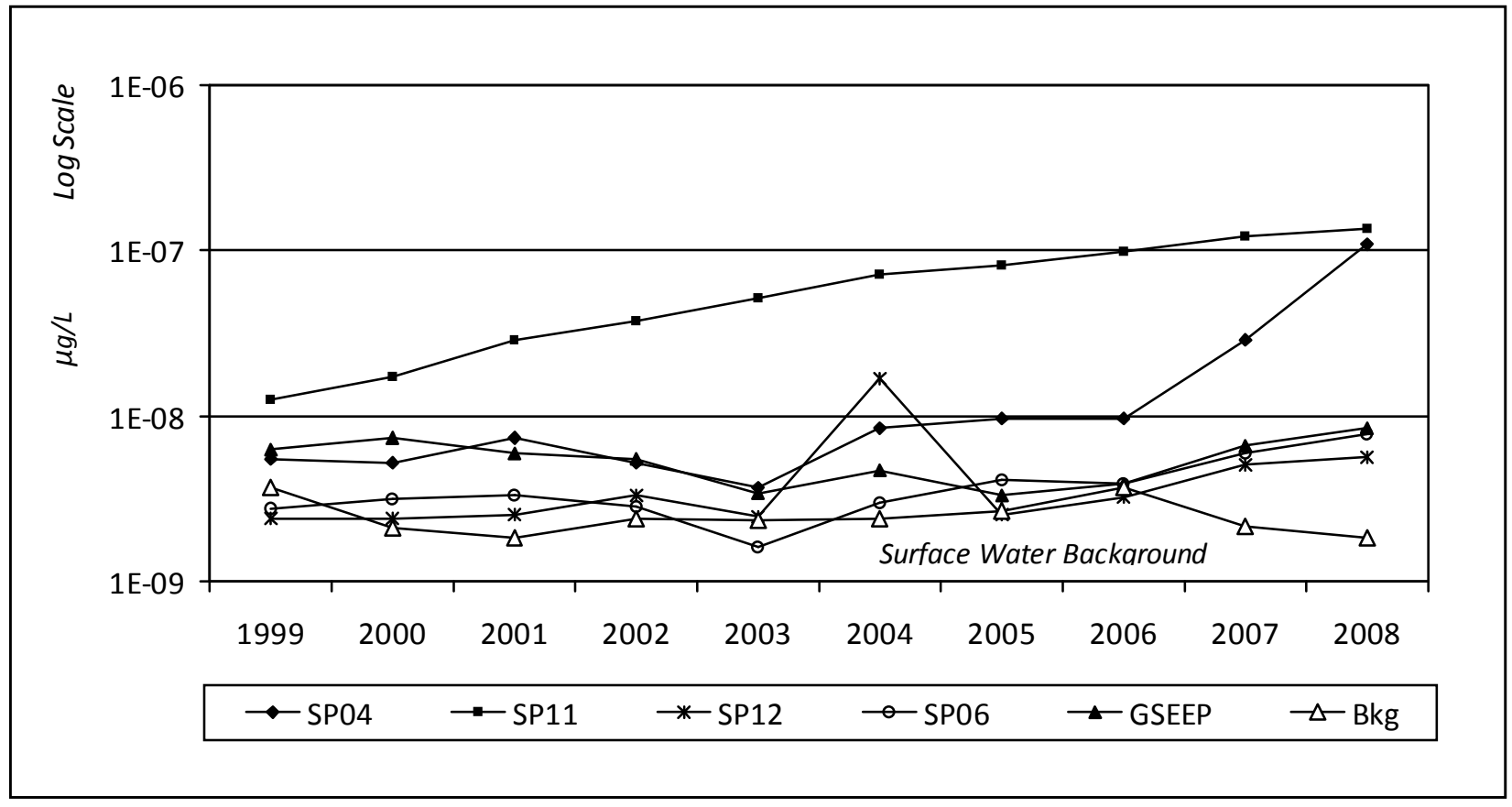

FIGURE 4-8

Concentrations of 1,2-DCE-t, 1,1,1-TCA, 1,1-DCA, and DCDFMeth at Well 8612 in the Sand and Gravel Unit

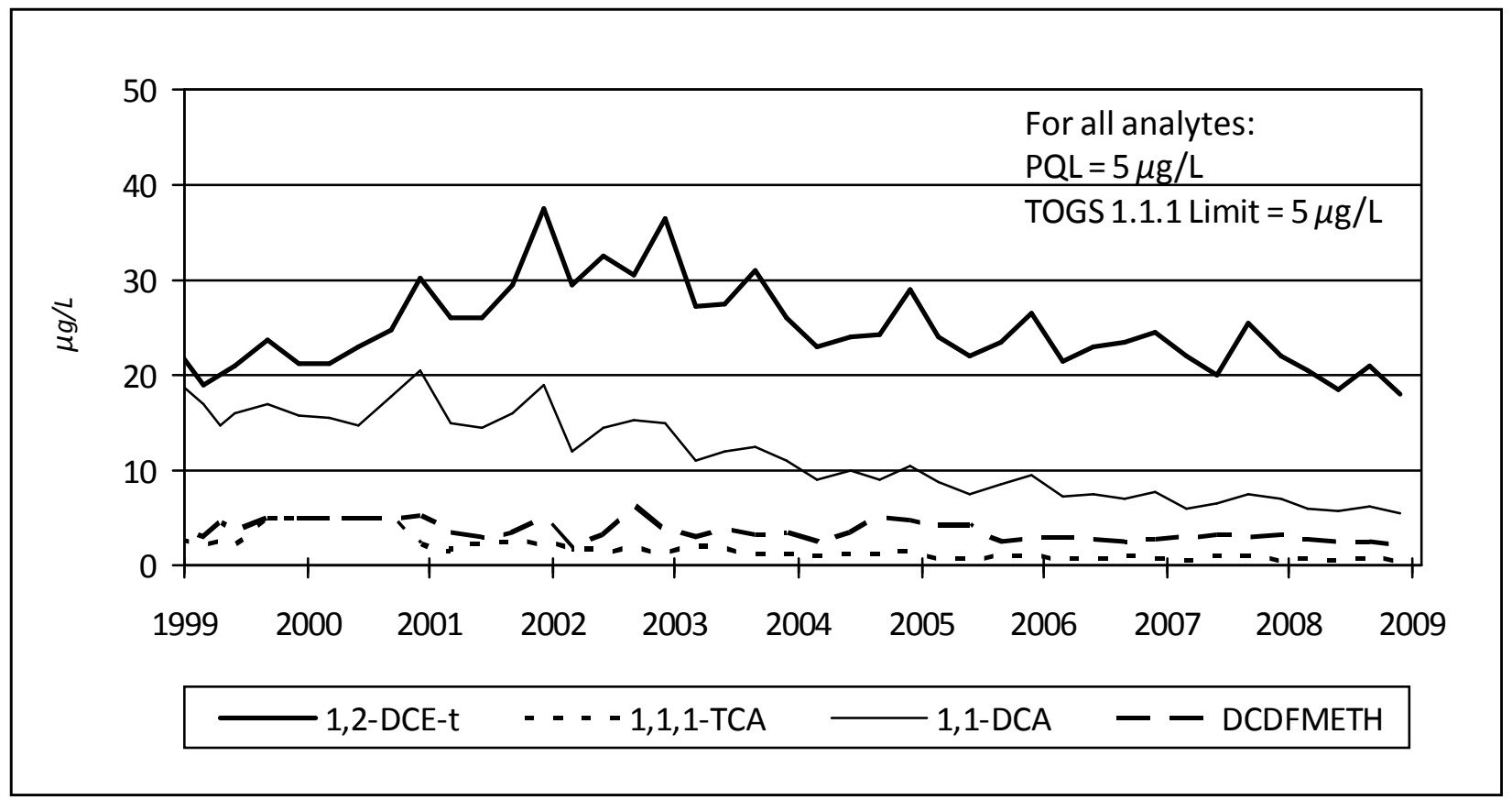


FIGURE 4-9

Concentrations of Tributyl Phosphate at Monitoring Wells Near Former Lagoon 1 in the Sand and Gravel Unit

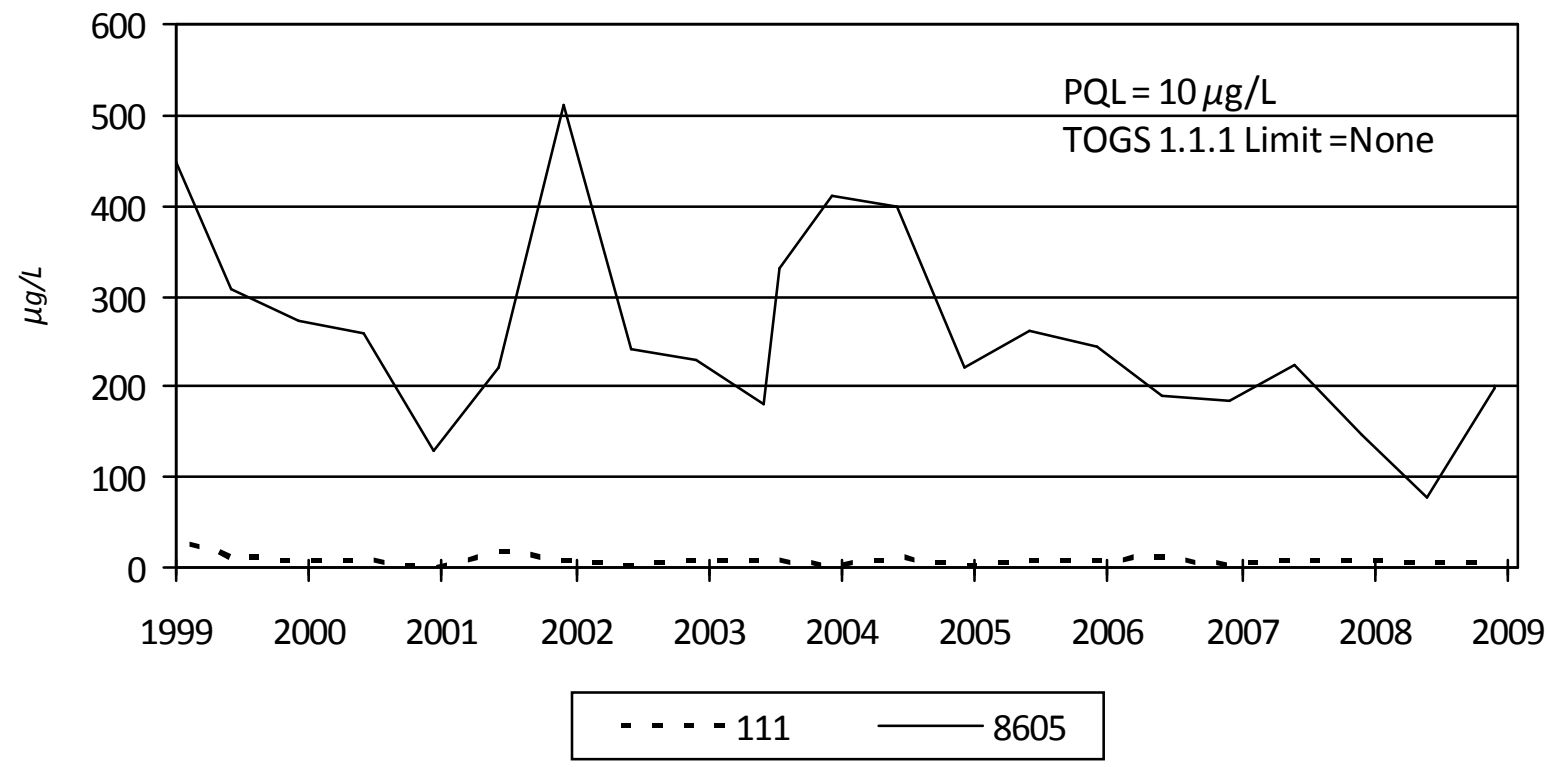

FIGURE 4-10

Average Annual Gross Beta Concentrations at Monitoring Wells Downgradient of the NDA

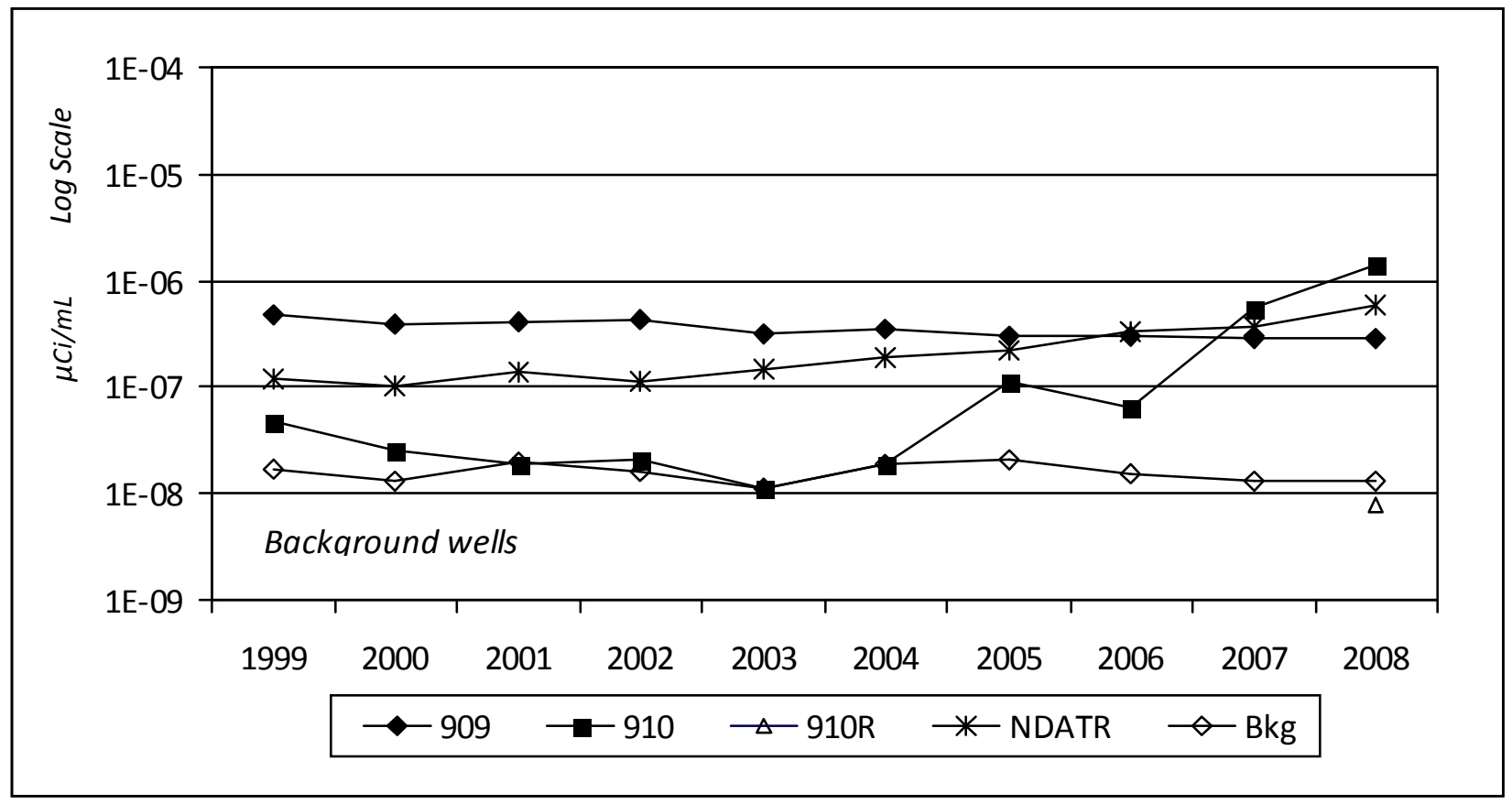


This page intentionally left blank 


\section{APPENDIX A}

\section{Environmental Monitoring Program}

\section{Environmental Monitoring Program Drivers and Sampling Rationale}

The following schedule represents the West Valley Demonstration Project (WVDP) routine environmental monitoring program for 2008. This schedule met or exceeded the requirements of the United States (U.S.) Department of Energy (DOE) Order 450.1A, "Environmental Protection Program," DOE Order 5400.5, "Radiation Protection of the Public and the Environment," and DOE/EH-0173T, "Environmental Regulatory Guide for Radiological Effluent Monitoring and Environmental Surveillance." Specific methods and monitoring program elements were based on DOE/ EP-0096, "A Guide for Effluent Radiological Measurements at DOE Installations," and DOE/EP-0023, "A Guide for Environmental Radiological Surveillance at U.S. Department of Energy Installations." Additional monitoring was mandated by air and water discharge permits (under the National Emission Standards for Hazardous Air Pollutants [NESHAP] regulations in 40 Code of Federal Regulations (CFR) 61, Subpart $H$, and the New York State Pollutant Discharge Elimination System [SPDES], respectively). Specific groundwater monitoring is required by the Resource Conservation and Recovery Act (RCRA) §3008(h) Administrative Order on Consent.

Permits, agreements, and/or programs may require formal reports of monitoring results. Radiological air emissions from the WVDP are reported annually in the NESHAP report to the U.S. Environmental Protection Agency. Nonradiological releases in water effluent and storm water drainage points covered under SPDES permit are reported monthly to the New York State Department of Environmental Conservation (NYSDEC) in a Discharge Monitoring Report. Groundwater monitoring results are reported quarterly to NYSDEC. Annual results from the monitoring program as a whole are evaluated and discussed in this Annual Site Environmental Report (ASER), which is prepared as directed in DOE Order 231.1A, "Environment, Safety, and Health Reporting," and associated guidance.
Table A-1 summarizes programmatic drivers and guidance applicable to each environmental medium measured or sampled as part of the WVDP Environmental Monitoring Program.

\section{Sampling Schedule}

Sampling locations are assigned a specific identifier, the location code, which is used to schedule sampling, track samples, and trace analytical results. This appendix details the sampling schedule conducted at each location in 2008. Changes since the last ASER are summarized on page A-17. Routine sampling locations are shown on Figs. A-2 through A-12. Special 2008 Geoprobe ${ }^{\circledast}$ sampling locations are on Figs. A-14 and A-15. Table headings in the schedule are as follows:

- Sample Location Code. This code describes the physical location where the sample is collected. The code consists of seven or eight characters: The first character identifies the sample medium as Air, Water, Soil/sediment, Biological, or Direct measurement. The second character specifies oNsite or off-site. The remaining characters describe the specific location (e.g., AFGRVAL is Air off-site at GReat VALley). Distances noted at sampling locations are as measured in a straight line from the ventilation stack of the main plant process building on site.

- Sampling Type/Medium. Describes the collection method and the physical characteristics of the medium or sample.

- Collection Frequency/Total Annual Samples. Indicates how often the samples are collected or retrieved and the total number of each type of sample processed in one year.

- Measurements/Analyses. Notes the type of measurement taken from the sampling medium and/or the constituents of interest, and (in some instances) the type of analysis conducted. 
TABLE A-1

WVDP Environmental Program Drivers and Sampling Rationale

\begin{tabular}{|c|c|}
\hline Programmatic Drivers & Sampling Rationale \\
\hline \multicolumn{2}{|c|}{ On-Site Air Emissions (Appendix A, p. A-7) } \\
\hline $\begin{array}{l}40 \text { CFR 61, Subpart H (radiological air } \\
\text { emissions); DOE Order } 450.1 \mathrm{~A}\end{array}$ & $\begin{array}{l}\text { DOE/EH-0173T, Chapter } 3.0 \text { (air effluent monitoring); DOE/EP-0096, } \\
\text { Section } 3.3 \text { (criteria for effluent measurements) }\end{array}$ \\
\hline \multicolumn{2}{|c|}{ Ambient Air (Appendix A, p. A-14 [off-site]) } \\
\hline DOE Order 450.1A & $\begin{array}{l}\text { DOE/EH-0173T, Section 5.7.4 (environmental surveillance, air sampling } \\
\text { locations); DOE/EP-0023, Section } 4.2 .3 \text { (air sampling locations and } \\
\text { measurement techniques) }\end{array}$ \\
\hline \multicolumn{2}{|c|}{ On-Site Liquid Effluents and Storm Water (Appendix A, pp. A-8 through A-11) } \\
\hline $\begin{array}{l}\text { New York State SPDES Permit No. NY } \\
0000973 \text { (nonradiological; specified } \\
\text { points only), DOE Order 450.1A and DOE } \\
\text { Order } 5400.5 \text { (radiological) }\end{array}$ & $\begin{array}{l}\text { DOE/EH-0173T, Section 2.3.3 (sampling locations for effluent } \\
\text { monitoring); New York State Department of Health (NYSDOH) } \\
\text { Environmental Laboratory Approval Program (ELAP) certification for } \\
\text { nonpotable water) }\end{array}$ \\
\hline \multicolumn{2}{|c|}{ Surface Water (Appendix A, pp. A-11 [on-site] and A-14 and A-15 [off-site]) } \\
\hline DOE Order 450.1A & $\begin{array}{l}\text { DOE/EH-0173T, Section } 5.10 .1 \text { (environmental surveillance water } \\
\text { sampling locations and methods); NYSDOH ELAP (Environmental } \\
\text { Laboratory certification for nonpotable water) }\end{array}$ \\
\hline \multicolumn{2}{|c|}{ Potable (Drinking) Water (Appendix A, pp. A-12 [on-site]) } \\
\hline DOE Order 450.1A & $\begin{array}{l}\text { DOE/EH-0173T, Section } 5.10 \text { (basis and guidance for environmental } \\
\text { surveillance, water); NYSDOH ELAP (Environmental Laboratory } \\
\text { certification for nonpotable water) }\end{array}$ \\
\hline \multicolumn{2}{|c|}{ On-Site Groundwater (Appendix A, pp. A-12 and A-13) } \\
\hline $\begin{array}{l}\text { RCRA §3008(h) Order on Consent } \\
\text { (nonradiological); DOE Order 450.1A }\end{array}$ & $\begin{array}{l}\text { DOE/EH-0173T, Section } 5.10 \text { (basis for environmental surveillance, } \\
\text { water); NYSDOH ELAP (Environmental Laboratory certification for } \\
\text { nonpotable water) }\end{array}$ \\
\hline \multicolumn{2}{|c|}{ Soil and Sediment (Appendix A, p. A-13 [on-site and off-site]) } \\
\hline DOE Order 450.1A & $\begin{array}{l}\text { DOE EH-0173T, Sections } 5.9 \text { (environmental surveillance soil sampling } \\
\text { locations and methods) and } 5.12 \text { (sediment sampling locations and } \\
\text { methods) }\end{array}$ \\
\hline \multicolumn{2}{|c|}{ Biological (Appendix A, pp. A-15 and A-16) } \\
\hline DOE Order 450.1A & $\begin{array}{l}\text { DOE/EH-0173T, Sections } 5.8 \text { (environmental surveillance, terrestrial } \\
\text { foodstuffs) and } 5.11 \text { (aquatic foodstuffs) }\end{array}$ \\
\hline \multicolumn{2}{|c|}{ Direct Radiation (Appendix A, p. A-16 [on-site and off-site]) } \\
\hline DOE Order 450.1A & $\begin{array}{l}\text { DOE/EH-0173T, Section } 5.5 \text { (environmental surveillance external } \\
\text { radiation measurement locations and frequency); DOE/EP-0023, Section } \\
4.6 \text { (external radiation) }\end{array}$ \\
\hline
\end{tabular}




\section{Index of Environmental Monitoring Program Sample Points}

Air Effluent and On-Site Ambient Air (Fig. A-6 [p. A-28]) Page

$\begin{array}{lll}\text { ANSTACK } & \text { Main Plant A-7 } \\ \text { ANSTSTK } & \text { Supernatant Treatment System } & \text { A-7 } \\ \text { ANCSSTK } & \text { 01-14 Building } & \text { A-7 } \\ \text { ANCSRFK } & \text { Contact Size-Reduction Facility } & \text { A-7 } \\ \text { ANCSPFK } & \text { Container Sorting and Packaging Facility } & \text { A-7 } \\ \text { ANVITSK } & \text { Vitrification Heating, Ventilation, and Air Conditioning } & \text { A-7 } \\ \text { ANRHWFK } & \text { Remote-Handled Waste Facility } & \end{array}$

Liquid Effluent, On-Site Water, and Storm Water Outfalls (Figs. A-2 through A-4 [pp. A-24 through A-26])

$\begin{array}{lll}\text { WNSP001 } & \text { Lagoon 3 Weir Point } & \text { A-8 } \\ \text { WNSP01B } & \text { A-8 } \\ \text { WNSP116 } & \text { Internal Process Monitoring Point } & \text { A-8 } \\ \text { WNSP007 } & \text { Pseudo-Monitoring Point Outfall 116 A-9 } & \text { A-9 } \\ \text { WNURRAW }^{a} & \text { Sanitary Waste Discharge } & \text { A-9 } \\ \text { WNSP006 } & \text { Utility Room Raw Water } & \text { A-9 }\end{array}$

\section{WNSO-Series Storm Water Outfalls}

GROUP 1

WNSO02

WNSO04

GROUP 2

WNSO06

WNSO33

GROUP 3

WNSO09

WNSO12

GROUP 4

WNSO34

GROUP 5

WNSO14

WNSO17

WNSO28
CPC Waste Storage Area Swale A-9

North Swamp Drainage (WNSW74A) A-9

Northeast Swamp Drainage (WNSWAMP)

A-10

LAG Storage Drainage A-10

Substation

A-10

South Facility Drainage (WNSP005) A-10

Rail Spur Culvert A-10

NDA Service Road Drainage North A-10 NDA Service Road Drainage South A-10

Drum Cell West Road A-10

a Not detailed on map. 


\section{Index of Environmental Monitoring Program Sample Points (continued)}

Liquid Effluent, On-Site Water, and Storm Water Outfalls (Figs. A-2 through A-4) (concluded)

\begin{tabular}{|c|c|c|}
\hline \multicolumn{2}{|l|}{$\underline{\text { GROUP } 6}$} & \multirow[b]{2}{*}{$A-10$} \\
\hline$\overline{\text { WNSO36 }}$ & Live-Fire Range Wetland Drainage & \\
\hline WNSO37 & Pump House Roadway & A-10 \\
\hline WNSO38 & Lake Two Roadway North & A-10 \\
\hline WNSO39 & Lake Two Roadway South. & A-10 \\
\hline WNSO40 & Land Between the Lakes (Pending Removal from Permit) & $\mathrm{A}-10$ \\
\hline WNSO41 & Lake One Roadway & $A-10$ \\
\hline WNSO42 & Pre-Railroad Spur Wetland Area (Near WFBCBKG) & $\mathrm{A}-10$ \\
\hline WNSO43 & Live-Fire Range Wetland Drainage Area & A-10 \\
\hline \multicolumn{3}{|l|}{ GROUP 7} \\
\hline$\overline{\text { WNSO20 }}$ & Disposal Area Drainage (WNNDADR) & A-10 \\
\hline \multicolumn{3}{|l|}{ GROUP 8} \\
\hline WNSO27 & Drum Cell Drainage West & A-11 \\
\hline WNSO35 & Drum Cell Drainage East & A-11 \\
\hline WNSWR01 & Storm Water Precipitation pH Measurement Location Near the Site Rain Gauge & A-11 \\
\hline WNSWAMP & Northeast Swamp Drainage Point & A-11 \\
\hline WNSW74A & North Swamp Drainage Point & A-11 \\
\hline WNSP005 & South Facility Drainage & A-11 \\
\hline WNFRC67 & Franks Creek East & A-11 \\
\hline WNERB53 & Erdman Brook & $A-11$ \\
\hline WNNDADR & Disposal Area Drainage & $\mathrm{A}-11$ \\
\hline$\underline{\text { WNDNK Series }}$ & Site Potable Water & $\mathrm{A}-12$ \\
\hline WNDNKUR & Utility Room Potable Water Storage Tank & $\mathrm{A}-12$ \\
\hline WNDNKMP & Main Plant Drinking water & $\mathrm{A}-12$ \\
\hline WNDNKEL & Environmental Laboratory Drinking Water & $\mathrm{A}-12$ \\
\hline
\end{tabular}




\section{Index of Environmental Monitoring Program Sample Points (continued)}

On-Site Groundwater and Seeps (Figs. A-7 and A-8 [pp. A-29 and A-30]) Page

SSWMU \#1

SSWMU \#2

SSWMU \#3

SSWMU \#4

SSWMU \#5

SSWMU \#6

SSWMU \#7

SSWMU \#8

SSWMU \#9

SSWMU \#10

SSWMU \#11

RHWF

North Plateau Seeps

Miscellaneous

Well Points

WNWNB1S

WNSE Series
Low-Level Waste Treatment Facility Wells

Miscellaneous Small Units Wells

Liquid Waste Treatment System Wells

HLW Storage and Processing Tank Wells

Maintenance Shop Leach Field Wells

Low-Level Waste Storage Area Wells

CPC Waste Storage Area Wells

CDDL Wells

NDA Unit Wells and NDATR

IRTS Drum Cell Wells

SDA Unit Wells

Remote-Handled Waste Facility Wells

Northeastern Edge of North Plateau

Downgradient of Main Plant

Former North Plateau Background Well

Surface Water Elevation Points

A-12

A-12

A-12

A-12

A-12

A-12

A-12

A-12

A-12

A-13

A-13

A-13

A-13

A-13

A-13

A-13

Soil and Sediment (Figs. A-2 and A-5 [pp. A-24 and A-27])

SN Soil Series:

SNSW74A

SNSWAMP

SNSP006

SF Soil Series:

SFFXVRD

SFRT240

SFRSPRD

SFGRVAL

SF Sediment Series:

SFCCSED

SFSDSED

SFTCSED

SFBCSED
On-Site Soil/Sediment

A-13

Soil/Sediment at North Swamp Drainage Point

A-13

Soil/Sediment at Northeast Swamp Drainage Point

A-13

Soil/Sediment at Facility Main Drainage

A-13

Off-Site Soil Collected at Air Samplers

A-13

Surface Soil South-Southeast at Fox Valley

A-13

Surface Soil Northeast on Route 240

A-13

Surface Soil Northwest on Rock Springs Road

A-13

Surface Soil South at Great Valley, Background

A-13

Off-Site Sediment

A-14

Cattaraugus Creek at Felton Bridge, Sediment

A-14

Cattaraugus Creek at Springville Dam, Sediment

A-14

Buttermilk Creek at Thomas Corners, Sediment

A-14

Buttermilk Creek at Fox Valley Road, Background Sediment

Off-Site Ambient Air (Fig. A-12 [p. A-34])

AFGRVAL Great Valley Sampler, Background

A-14

Off-Site Surface Water (Fig. A-5 [p. A-27])

WFBCBKG

WFFELBR

WFBCTCB
Buttermilk Creek Near Fox Valley, Background

A-14

Cattaraugus Creek at Felton Bridge

Buttermilk Creek at Thomas Corners
A-14

A-15 


\section{Index of Environmental Monitoring Program Sample Points (concluded)}

Off-Site Biological (Figs. A-9 and A-12 [pp. A-31 and A-34]) Page

BFMWIDR Southeast Milk, Near-Site __ A-15

BFMCTLS Control Milk, South __ A-15

BFMBLSY Milk, West-Northwest ___ A-15

BFMSCHT Milk, South_A-15

BFDNEAR Venison, Near-Site ___ A-15

BFDCTRL Venison, Background __ A-15

BFVNEAR $^{a} \quad$ Produce, Near-Site ___ A-15

BFVCTRL $^{a} \quad$ Produce, Background___ A-15

BFFCATC Cattaraugus Creek Fish, Downstream ___ A-16

BFFCATD Cattaraugus Creek Fish, Downstream of Springville Dam _ A-16

BFFCTRL Cattaraugus Creek Fish, Background __ A-16

Direct Measurement Dosimetry (Figs. A-10 through A-12 [pp. A-32 through A-34])

DFTLD Series

Off-Site Direct Radiation

A-16

DNTLD Series

On-Site Direct Radiation

A-16

a Near-site and background produce samples (corn, apples, and beans) are identified specifically as follows: corn = BFVNEAC and BFVCTRC; apples = BFVNEAAF and BFVCTRA; beans = BFVNEAB and BFVCTRB. 


\begin{tabular}{|c|c|c|c|}
\hline Sample Location Code & $\begin{array}{l}\text { Sampling Type/ } \\
\text { Medium }\end{array}$ & $\begin{array}{l}\text { Collection Frequency/ } \\
\text { Total Annual Samples }\end{array}$ & Measurements/Analyses \\
\hline \multicolumn{4}{|c|}{ On-Site Air Emissions } \\
\hline \multirow{7}{*}{ 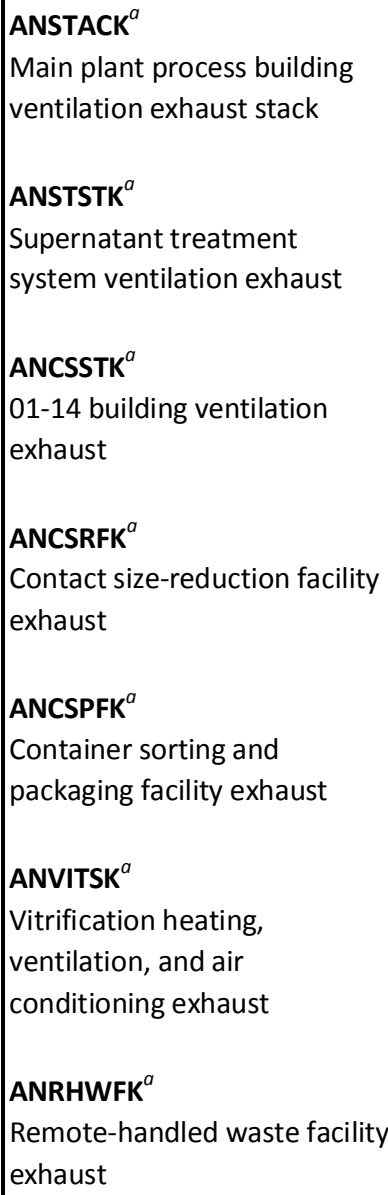 } & $\begin{array}{l}\text { Continuous off-line air } \\
\text { particulate monitors }\end{array}$ & $\begin{array}{l}\text { Continuous measurement of } \\
\text { fixed filter; replaced biweekly; } \\
\text { held as backup }\end{array}$ & Real-time alpha and beta monitoring \\
\hline & $\begin{array}{l}\text { Continuous off-line air } \\
\text { particulate filters }\end{array}$ & Biweekly; 26 each location & $\begin{array}{l}\text { Gross alpha/beta, gamma isotopic }{ }^{b} \\
\text { upon collection, flow }\end{array}$ \\
\hline & & & \\
\hline & $\begin{array}{l}\text { Composite of biweekly } \\
\text { particulate filters }\end{array}$ & Semiannually; 2 each location & $\begin{array}{l}\text { Sr-90, U-232, U-233/234, U-235/236, } \\
\text { U-238, total U, Pu-238, Pu-239/240, } \\
\text { Am-241, gamma isotopic, flow }\end{array}$ \\
\hline & $\begin{array}{l}\text { Continuous off-line } \\
\text { desiccant columns for } \\
\text { collection of water vapor }\end{array}$ & $\begin{array}{l}\text { Biweekly; } 26 \text { each at ANSTACK } \\
\text { and ANSTSTK only }\end{array}$ & $H-3$, flow \\
\hline & $\begin{array}{l}\text { Continuous off-line } \\
\text { charcoal cartridges }\end{array}$ & $\begin{array}{l}\text { Cartridges collected biweekly } \\
\text { and composited into } 2 \\
\text { semiannual samples at each } \\
\text { location }\end{array}$ & I-129 \\
\hline & & & \\
\hline \multirow{2}{*}{$\begin{array}{l}\text { OVEs/PVUs } \\
\text { Outdoor ventilated } \\
\text { enclosures/portable } \\
\text { ventilation units }\end{array}$} & $\begin{array}{l}\text { Continuous off-line air } \\
\text { particulate filter }\end{array}$ & Collected as required by project & $\begin{array}{l}\text { Gross alpha/beta, gamma isotopic } \\
\text { upon collection, flow }\end{array}$ \\
\hline & Composite of filters & Semiannually; 2 each location & $\begin{array}{l}\text { Sr-90, U-232, U-233/234, U-235/236, } \\
\text { U-238, total U, Pu-238, Pu-239/240, } \\
\text { Am-241, gamma isotopic, flow }\end{array}$ \\
\hline
\end{tabular}

a Required by 40 CFR 61, Subpart H. Results reported in the Annual NESHAP Report and evaluated in this ASER.

$b$ Gamma isotopic analysis done only if gross alpha/beta activity rises significantly. 


\begin{tabular}{|c|c|c|c|}
\hline Sample Location Code & $\begin{array}{l}\text { Sampling Type/ } \\
\text { Medium }\end{array}$ & $\begin{array}{l}\text { Collection Frequency/ } \\
\text { Total Annual Samples }\end{array}$ & Measurements/Analyses \\
\hline \multicolumn{4}{|c|}{ On-Site Liquid Effluents } \\
\hline \multirow[t]{12}{*}{$\begin{array}{l}\text { WNSPO01 }^{a} \\
\text { Lagoon } 3 \text { discharge weir }\end{array}$} & Grab liquid & $\begin{array}{l}\text { Daily during discharge. Lagoon } \\
3 \text { is discharged } 4 \text { to } 8 \text { times per } \\
\text { year, averaging } 6 \text { to } 7 \text { days per } \\
\text { discharge; } 24-56 \text { per year }\end{array}$ & $\begin{array}{l}\text { Daily flow, hold for flow-weighted } \\
\text { composite }\end{array}$ \\
\hline & Grab liquid & $\begin{array}{l}\text { Twice during discharge; 8-16 } \\
\text { per year }\end{array}$ & $\begin{array}{l}\text { Gross alpha/beta, } \mathrm{H}-3, \mathrm{Sr}-90 \text {, gamma } \\
\text { isotopic }\end{array}$ \\
\hline & $\begin{array}{l}\text { Flow-weighted composite } \\
\text { of daily samples for each } \\
\text { discharge }\end{array}$ & 4 to 8 per year & $\begin{array}{l}\text { Gross alpha/beta, H-3, C-14, Sr-90, Tc- } \\
\text { 99, I-129, gamma isotopic, U-232, U- } \\
\text { 233/234, U-235/236, U-238, total U, } \\
\text { Pu-238, Pu-239/240, Am-241 }\end{array}$ \\
\hline & 24-hour composite liquid & $\begin{array}{l}\text { Twice during discharge; 8-16 } \\
\text { per year }\end{array}$ & $\begin{array}{l}\mathrm{BOD}_{5}, \mathrm{TSS}, \mathrm{SO}_{4}, \mathrm{NO}_{3}-\mathrm{N}, \mathrm{NO}_{2}-\mathrm{N}, \mathrm{NH}_{3} \\
\text { total Fe and } \mathrm{Hg} \text { (method } 1631 \text { ) }\end{array}$ \\
\hline & Grab liquid & $\begin{array}{l}\text { Twice during discharge; 8-16 } \\
\text { per year }\end{array}$ & $\begin{array}{l}\text { Settleable solids, TDS, oil \& grease, } \\
\text { total recoverable Se }\end{array}$ \\
\hline & 24-hour composite liquid & $\begin{array}{l}\text { Once during discharge; } 4-8 \text { per } \\
\text { year }\end{array}$ & $\begin{array}{l}\text { Total Al, dissolved As, dissolved } \\
\text { sulfide }\end{array}$ \\
\hline & Grab liquid & $\begin{array}{l}\text { Once during discharge; } 4-8 \text { per } \\
\text { year }\end{array}$ & $\mathrm{pH}$, total recoverable $\mathrm{V}$, Co \\
\hline & 24-hour composite liquid & Quarterly; 4 per year & $\begin{array}{l}\text { Bromide and total } \mathrm{B} \text {, total } \\
\text { recoverable } \mathrm{Pb}\end{array}$ \\
\hline & 24-hour composite liquid & Semiannually; 2 per year & $\begin{array}{l}\text { Total } \mathrm{Ti}, \mathrm{Mn} \text {, dissolved } \mathrm{Cu} \text {, total } \\
\text { recoverable } \mathrm{Cu}, \mathrm{Cr}, \mathrm{Ni} \text {, and } \mathrm{Zn}\end{array}$ \\
\hline & 24-hour composite liquid & Annually; 1 per year & Total recoverable $\mathrm{Cd}$, total $\mathrm{Ba}$ and $\mathrm{Sb}$ \\
\hline & Grab liquid & Semiannually; 2 per year & $\begin{array}{l}\text { Heptachlor, cyanide amenable to } \\
\text { chlorination, surfactant (as LAS) }\end{array}$ \\
\hline & Grab liquid & Annually; 1 per year & $\begin{array}{l}\text { Chloroform, } \\
\text { dichlorodifluoromethane, } \\
\text { trichlorofluoromethane, 3,3- } \\
\text { dichlorobenzidine, tributyl phosphate, } \\
\text { hexachlorobenzene, alpha-BHC, } \\
x y l e n e, 2 \text {-butanone, total recoverable } \\
\mathrm{Cr}^{+6}\end{array}$ \\
\hline \multirow{2}{*}{$\begin{array}{l}\text { WNSP01B }^{a} \\
\text { Internal process monitoring } \\
\text { point }\end{array}$} & $\begin{array}{l}\text { Continuous; recorded } \\
\text { monthly }\end{array}$ & NA & Elapsed flow time \\
\hline & Composite liquid & $\begin{array}{l}\text { Twice per month when } \\
\text { operating; } 0-24 \text { per year }\end{array}$ & Total Hg \\
\hline $\begin{array}{l}\text { WNSP116 }^{a} \\
\text { Pseudo-monitoring point } \\
\text { outfall } 116\end{array}$ & Calculated & $\begin{array}{l}\text { Twice per lagoon discharge; } \\
\text { 8-16 per year }\end{array}$ & TDS \\
\hline
\end{tabular}

NA - Not applicable

a Required by SPDES Permit \#NY0000973. Results reported in the SPDES DMR and evaluated in this ASER. 


\begin{tabular}{|c|c|c|c|}
\hline Sample Location Code & $\begin{array}{l}\text { Sampling Type/ } \\
\text { Medium }\end{array}$ & $\begin{array}{l}\text { Collection Frequency/ } \\
\text { Total Annual Samples }\end{array}$ & Measurements/Analyses \\
\hline \multicolumn{4}{|c|}{ On-Site Liquid Effluents } \\
\hline \multirow{7}{*}{$\begin{array}{l}\text { WNSPOO7 }^{a} \\
\text { Sanitary waste discharge }\end{array}$} & 24-hour composite liquid & 1 per month; 12 per year & Gross alpha/beta, $\mathrm{H}-3$ \\
\hline & $\begin{array}{l}\text { Composite of monthly } \\
\text { samples }\end{array}$ & Annually; 1 per year & Sr-90, gamma isotopic \\
\hline & 24-hour composite liquid & 3 per month; 36 per year & TSS, $\mathrm{NH}_{3}, \mathrm{NO}_{2}-\mathrm{N}, \mathrm{BOD}_{5}$, total Fe, flow \\
\hline & Grab liquid & 3 per month; 36 per year & Oil \& grease \\
\hline & Grab liquid & Weekly; 52 per year & $\begin{array}{l}\mathrm{pH} \text {, settleable solids, total residual } \\
\text { chlorine }\end{array}$ \\
\hline & Grab liquid & Annually; 1 per year & Chloroform \\
\hline & Grab liquid & Monthly; 12 per year & Flow, flow time \\
\hline \multirow{3}{*}{$\begin{array}{l}\text { WNURRAW }^{a} \\
\text { Utility room raw water }\end{array}$} & Composite liquid & Weekly; 52 per year & Total Fe \\
\hline & Grab liquid & $\begin{array}{l}\text { Three per lagoon discharge; } \\
\text { before start, near start, and } \\
\text { near end; 12-24 per year }\end{array}$ & TDS \\
\hline & Grab liquid & Monthly; 12 per year & TOC, alkalinity \\
\hline \multirow[t]{4}{*}{$\begin{array}{l}\text { WNSP006 } \\
\text { Franks Creek at the security } \\
\text { fence }\end{array}$} & $\begin{array}{l}\text { Timed continuous } \\
\text { composite liquid }\end{array}$ & $\begin{array}{l}\text { Weekly during lagoon } \\
\text { discharge, otherwise biweekly; } \\
\text { 26-34 per year }\end{array}$ & Gross alpha/beta, $\mathrm{H}-3$ \\
\hline & $\begin{array}{l}\text { Composite of weekly and } \\
\text { biweekly samples }\end{array}$ & Monthly; 12 per year & Sr-90 and gamma isotopic \\
\hline & $\begin{array}{l}\text { Composite of weekly and } \\
\text { biweekly samples }\end{array}$ & Quarterly; 4 per year & $\begin{array}{l}\text { C-14, Tc-99, I-129, U-232, U-233/234, } \\
\text { U-235/236, U-238, total U, Pu-238, } \\
\text { Pu-239/240, Am-241 }\end{array}$ \\
\hline & Grab liquid & $\begin{array}{l}\text { Three per lagoon discharge: } \\
\text { before start; near start; and } \\
\text { after end, 12-24 per year }\end{array}$ & TDS \\
\hline \multirow{3}{*}{$\begin{array}{l}\text { WNSP008 }^{a} \\
\text { French drain } \\
\text { (Capped off in 2001; routinely } \\
\text { checked to verify no } \\
\text { discharge) }\end{array}$} & Grab liquid & $\begin{array}{l}\text { Monthly; } 12 \text { per year if } \\
\text { discharging }\end{array}$ & Gross alpha/beta, H-3 \\
\hline & Grab liquid & $\begin{array}{l}\text { Three per month if discharging; } \\
36 \text { per year }\end{array}$ & $\begin{array}{l}\text { Conductivity, } \mathrm{pH}, \mathrm{BOD}_{5} \text {, total } \mathrm{Fe} \text {, total } \\
\text { recoverable } \mathrm{Cd} \text { and } \mathrm{Pb} \text {, flow }\end{array}$ \\
\hline & Grab liquid & $\begin{array}{l}\text { Annually; } 1 \text { per year if } \\
\text { discharging }\end{array}$ & Total As, Cr, Ag, and Zn \\
\hline \multicolumn{4}{|c|}{ Storm Water Outfalls } \\
\hline \multirow[t]{2}{*}{$\begin{array}{l}\frac{\text { Group 1 }}{a}^{a} \\
\text { WNSO02 (S02) } \\
\text { WNSO04 (S04) }\end{array}$} & First flush grab liquid & Semiannually; 2 per year & $\begin{array}{l}\mathrm{pH} \text {, oil \& grease, } \mathrm{BOD}_{5}, \mathrm{TSS}, \mathrm{TDS} \text {, total } \\
\mathrm{P}, \mathrm{Al}, \mathrm{Fe} \text {, total recoverable } \mathrm{Cu}, \mathrm{Pb}, \mathrm{Zn} \text {, } \\
\mathrm{Cd}, \mathrm{Cr}, \mathrm{Se}, \mathrm{V}, \mathrm{Cr}^{+6}, \mathrm{TKN} \text {, ammonia (as } \\
\mathrm{NH}_{3} \text { ), } \mathrm{NO}_{3}-\mathrm{N}, \mathrm{NO}_{2}-\mathrm{N} \text {, total nitrogen (as } \\
\mathrm{N})\end{array}$ \\
\hline & $\begin{array}{l}\text { Flow-weighted composite } \\
\text { liquid }\end{array}$ & Semiannually; 2 per year & $\begin{array}{l}\text { Total flow, plus all of the above } \\
\text { constituents except for pH and oil \& } \\
\text { grease }\end{array}$ \\
\hline
\end{tabular}

a Required by SPDES Permit \#NY0000973. Results reported in the SPDES DMR and evaluated in this ASER. 


\begin{tabular}{|c|c|c|c|}
\hline Sample Location Code & $\begin{array}{l}\text { Sampling Type/ } \\
\text { Medium }\end{array}$ & $\begin{array}{l}\text { Collection Frequency/ } \\
\text { Total Annual Samples }\end{array}$ & Measurements/Analyses \\
\hline \multicolumn{4}{|c|}{ Storm Water Outfalls } \\
\hline \multirow[t]{2}{*}{$\begin{array}{l}\text { Group 2 }^{a} \\
\text { WNSO06 (S06) } \\
\text { WNSO33 (S33) }\end{array}$} & First flush grab liquid & Semiannually; 2 per year & $\begin{array}{l}\mathrm{pH} \text {, oil \& grease, } \mathrm{BOD}_{5}, \mathrm{TSS}, \mathrm{TDS} \text {, total } \\
\mathrm{P}, \mathrm{Al}, \mathrm{Fe} \text {, total recoverable } \mathrm{Cu}, \mathrm{Pb}, \mathrm{Zn} \text {, } \\
\text { surfactant (as LAS) }\end{array}$ \\
\hline & $\begin{array}{l}\text { Flow-weighted composite } \\
\text { liquid }\end{array}$ & Semiannually; 2 per year & $\begin{array}{l}\text { Total flow, plus all of the above } \\
\text { constituents except for } \mathrm{pH} \text { and oil \& } \\
\text { grease }\end{array}$ \\
\hline \multirow[t]{2}{*}{ 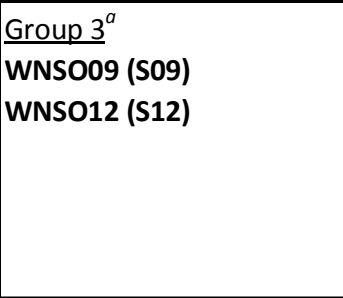 } & First flush grab liquid & Semiannually; 2 per year & $\begin{array}{l}\mathrm{pH} \text {, oil \& grease, } \mathrm{BOD}_{5}, \mathrm{TSS}, \mathrm{TDS} \text {, total } \\
\mathrm{P}, \mathrm{Al}, \mathrm{Fe} \text {, total recoverable } \mathrm{Cu}, \mathrm{Pb}, \mathrm{Zn} \text {, } \\
\mathrm{TKN} \text {, ammonia (as } \mathrm{NH}_{3} \text { ), } \mathrm{NO}_{3}-\mathrm{N}, \mathrm{NO}_{2^{-}} \\
\mathrm{N} \text {, alpha- } \mathrm{BHC} \text {, total nitrogen (as N) }\end{array}$ \\
\hline & $\begin{array}{l}\text { Flow-weighted composite } \\
\text { liquid }\end{array}$ & Semiannually; 2 per year & $\begin{array}{l}\text { Total flow, plus all of the above } \\
\text { constituents except for } \mathrm{pH} \text { and oil \& } \\
\text { grease }\end{array}$ \\
\hline \multirow[t]{2}{*}{$\begin{array}{l}\frac{\text { Group 4 }}{a}^{a} \\
\text { WNSO34 (S34) }\end{array}$} & First flush grab liquid & Semiannually; 2 per year & $\begin{array}{l}\mathrm{pH} \text {, oil \& grease, } \mathrm{BOD}_{5}, \mathrm{TSS}, \mathrm{TDS} \text {, total } \\
\mathrm{P}, \mathrm{Al}, \mathrm{Fe} \text {, total recoverable } \mathrm{Cu}, \mathrm{Pb}, \mathrm{Zn} \text {, } \\
\text { surfactant (as LAS) }\end{array}$ \\
\hline & $\begin{array}{l}\text { Flow-weighted composite } \\
\text { liquid }\end{array}$ & Semiannually; 2 per year & $\begin{array}{l}\text { Total flow, plus all of the above } \\
\text { constituents except for } \mathrm{pH} \text { and oil \& } \\
\text { grease }\end{array}$ \\
\hline \multirow[t]{2}{*}{$\begin{array}{l}\frac{\text { Group 5 }}{}^{a} \\
\text { WNSO14 (S14) } \\
\text { WNSO17 (S17) } \\
\text { WNSO28 (S28) }\end{array}$} & First flush grab liquid & Semiannually; 2 per year & $\begin{array}{l}\mathrm{pH} \text {, oil \& grease, } \mathrm{BOD}_{5}, \mathrm{TSS}, \mathrm{TDS} \text {, total } \\
\mathrm{P}, \mathrm{Al}, \mathrm{Fe} \text {, total recoverable } \mathrm{Cu}, \mathrm{Pb}, \mathrm{Zn} \text {, } \\
\mathrm{V}, \mathrm{TKN} \text {, ammonia (as } \mathrm{NH}_{3} \text { ), } \mathrm{NO}_{3}-\mathrm{N}, \\
\mathrm{NO}_{2}-\mathrm{N} \text {, surfactant (as } \mathrm{LAS} \text { ), sulfide, } \\
\text { settleable solids, total nitrogen (as } \mathrm{N} \text { ) }\end{array}$ \\
\hline & $\begin{array}{l}\text { Flow-weighted composite } \\
\text { liquid }\end{array}$ & Semiannually; 2 per year & $\begin{array}{l}\text { Total flow, plus all of the above } \\
\text { constituents except for } \mathrm{pH} \text { and oil \& } \\
\text { grease }\end{array}$ \\
\hline \multirow{2}{*}{\begin{tabular}{|l}
${\frac{\text { Group }^{a}}{\text { WNSO36 (S36) }}}$ \\
WNSO37 (S37) \\
WNSO38 (S38) \\
WNSO39 (S39) \\
WNSO40 (S40) \\
WNSO41 (S41) \\
WNSO42 (S42) \\
WNSO43 (S43)
\end{tabular}} & First flush grab liquid & Semiannually; 2 per year & $\begin{array}{l}\mathrm{pH} \text {, oil \& grease, } \mathrm{BOD}_{5}, \mathrm{TSS}, \mathrm{TDS} \text {, total } \\
\mathrm{P}, \mathrm{Al}, \mathrm{Fe} \text {, total recoverable } \mathrm{Cu}, \mathrm{Pb}, \mathrm{Zn} \text {, } \\
\mathrm{V}, \mathrm{TKN} \text {, ammonia (as } \mathrm{NH}_{3} \text { ), } \mathrm{NO}_{3}-\mathrm{N}, \\
\mathrm{NO}_{2}-\mathrm{N} \text {, surfactant (as } \mathrm{LAS} \text { ), sulfide, } \\
\text { settleable solids, total nitrogen (as } \mathrm{N} \text { ) }\end{array}$ \\
\hline & $\begin{array}{l}\text { Flow-weighted composite } \\
\text { liquid }\end{array}$ & Semiannually; 2 per year & $\begin{array}{l}\text { Total flow, plus all of the above } \\
\text { constituents except for } \mathrm{pH} \text { and oil \& } \\
\text { grease }\end{array}$ \\
\hline \multirow[t]{2}{*}{${\frac{\text { Group } 7^{a}}{\text { WNSO20 (S20) }}}^{\text {WNO }^{2}}$} & First flush grab liquid & Semiannually; 2 per year & $\begin{array}{l}\mathrm{pH} \text {, oil \& grease, } \mathrm{BOD}_{5}, \mathrm{TSS}, \mathrm{TDS} \text {, total } \\
\mathrm{P}, \mathrm{Al}, \mathrm{Fe} \text {, total recoverable } \mathrm{Cu}, \mathrm{Pb}, \mathrm{Zn} \text {, } \\
\mathrm{TKN} \text {, ammonia (as } \mathrm{NH}_{3} \text { ), } \mathrm{NO}_{3}-\mathrm{N}, \mathrm{NO}_{2^{-}} \\
\mathrm{N} \text {, surfactant (as LAS), sulfide, total } \\
\text { nitrogen (as } \mathrm{N} \text { ) }\end{array}$ \\
\hline & $\begin{array}{l}\text { Flow-weighted composite } \\
\text { liquid }\end{array}$ & Semiannually; 2 per year & $\begin{array}{l}\text { Total flow, plus all of the above } \\
\text { constituents except for } \mathrm{pH} \text { and oil \& } \\
\text { grease }\end{array}$ \\
\hline
\end{tabular}

a Required by SPDES Permit \#NY0000973. Results reported in the SPDES DMR and evaluated in this ASER. 


\begin{tabular}{|c|c|c|c|}
\hline Sample Location Code & $\begin{array}{l}\text { Sampling Type/ } \\
\text { Medium }\end{array}$ & $\begin{array}{l}\text { Collection Frequency/ } \\
\text { Total Annual Samples }\end{array}$ & Measurements/Analyses \\
\hline \multicolumn{4}{|c|}{ Storm Water Outfalls } \\
\hline \multirow{4}{*}{$\begin{array}{l}{\text { Group } 8^{a}}^{\text {WNSO27 (S27) }} \\
\text { WNSO35 (S35) }\end{array}$} & First flush grab liquid & Semiannually; 2 per year & $\mathrm{pH}$, oil \& grease, $\mathrm{BOD}_{5}, \mathrm{TSS}, \mathrm{TDS}$, total \\
\hline & & & $\mathrm{P}, \mathrm{Al}, \mathrm{Fe}$, total recoverable $\mathrm{Cu}, \mathrm{Pb}, \mathrm{Zn}$, \\
\hline & & & $\begin{array}{l}\left.\mathrm{TKN} \text {, ammonia (as } \mathrm{NH}_{3}\right), \mathrm{NO}_{3}-\mathrm{N}, \mathrm{NO}_{2}- \\
\mathrm{N} \text {, surfactant (as LAS), total nitrogen } \\
\text { (as } \mathrm{N} \text { ) }\end{array}$ \\
\hline & $\begin{array}{l}\text { Flow-weighted composite } \\
\text { liquid }\end{array}$ & Semiannually; 2 per year & $\begin{array}{l}\text { Total flow, plus all of the above } \\
\text { constituents except for } \mathrm{pH} \text { and oil \& } \\
\text { grease }\end{array}$ \\
\hline $\begin{array}{l}\text { WNSWRO1 }^{a} \\
\text { Site rain gauge }\end{array}$ & $\begin{array}{l}\text { Field measurement of } \\
\text { precipitation }\end{array}$ & 1 each storm water event & $\mathrm{pH}$ \\
\hline \multicolumn{4}{|c|}{ On-Site Surface Water } \\
\hline \multirow[t]{2}{*}{$\begin{array}{l}\text { WNSWAMP } \\
\text { Northeast swamp drainage }\end{array}$} & $\begin{array}{l}\text { Timed continuous } \\
\text { composite liquid }\end{array}$ & Biweekly; 26 per year & $\begin{array}{l}\text { Gross alpha/beta, } \mathrm{H}-3, \mathrm{pH} \text {, flow (at } \\
\text { WNSWAMP only) }\end{array}$ \\
\hline & $\begin{array}{l}\text { Composite of biweekly } \\
\text { samples }\end{array}$ & Monthly; 12 per year & Sr-90 and gamma isotopic \\
\hline $\begin{array}{l}\text { WNSW74A } \\
\text { North swamp drainage }\end{array}$ & $\begin{array}{l}\text { Composite of biweekly } \\
\text { samples }\end{array}$ & Semiannually; 2 per year & $\begin{array}{l}\text { C-14, I-129, U-232, U-233/234, U- } \\
\text { 235/236, U-238, total U, Pu-238, Pu- } \\
\text { 239/240, Am-241 }\end{array}$ \\
\hline \multirow{2}{*}{$\begin{array}{l}\text { WNSP005 } \\
\text { Facility yard drainage }\end{array}$} & Grab liquid & Quarterly; 4 per year & Gross alpha/beta, $\mathrm{H}-3, \mathrm{pH}$ \\
\hline & $\begin{array}{l}\text { Composite of quarterly } \\
\text { samples }\end{array}$ & Semiannually; 2 per year & Sr-90 and gamma isotopic \\
\hline \multirow[t]{2}{*}{$\begin{array}{l}\text { WNFRC67 } \\
\text { Franks Creek east of the SDA }\end{array}$} & Grab liquid & $\begin{array}{l}\text { Quarterly; } 4 \text { per year (collected } \\
\text { at same time as WNNDADR) }\end{array}$ & Gross alpha/beta, $\mathrm{H}-3, \mathrm{pH}$ \\
\hline & $\begin{array}{l}\text { Composite of quarterly } \\
\text { samples }\end{array}$ & Semiannually; 2 per year & Sr-90 and gamma isotopic \\
\hline \multirow{2}{*}{$\begin{array}{l}\text { WNERB53 } \\
\text { Erdman Brook north of } \\
\text { disposal areas }\end{array}$} & Grab liquid & $\begin{array}{l}\text { Quarterly; } 4 \text { per year (collected } \\
\text { at same time as WNNDADR) }\end{array}$ & Gross alpha/beta, $\mathrm{H}-3, \mathrm{pH}$ \\
\hline & $\begin{array}{l}\text { Composite of quarterly } \\
\text { samples }\end{array}$ & Semiannually; 2 per year & Sr-90 and gamma isotopic \\
\hline \multirow{3}{*}{$\begin{array}{l}\text { WNNDADR } \\
\text { Drainage between NDA and } \\
\text { SDA }\end{array}$} & $\begin{array}{l}\text { Timed continuous } \\
\text { composite liquid }\end{array}$ & Biweekly; 26 per year & Hold for composite \\
\hline & $\begin{array}{l}\text { Composite of biweekly } \\
\text { samples }\end{array}$ & Monthly; 12 per year & $\begin{array}{l}\text { Gross alpha/beta, } \mathrm{H}-3 \text {, gamma } \\
\text { isotopic }\end{array}$ \\
\hline & $\begin{array}{l}\text { Composite of biweekly } \\
\text { samples }\end{array}$ & Semiannually; 2 per year & Sr-90 and I-129 \\
\hline
\end{tabular}

a Required by SPDES Permit \#NY0000973. Results reported in the SPDES DMR and evaluated in this ASER. 


\begin{tabular}{|c|c|c|c|}
\hline Sample Location Code & $\begin{array}{l}\text { Sampling Type/ } \\
\text { Medium }\end{array}$ & $\begin{array}{l}\text { Collection Frequency/ } \\
\text { Total Annual Samples }\end{array}$ & Measurements/Analyses \\
\hline \multicolumn{4}{|c|}{ On-Site Potable (Drinking) Water } \\
\hline $\begin{array}{l}\text { WNDNKUR } \\
\text { Utility room (entry point [EP- } \\
\text { 1]) potable water storage tank }\end{array}$ & Grab liquid $^{a}$ & Annually; 1 per year & $\begin{array}{l}\text { As, } \mathrm{Ba}, \mathrm{Be}, \mathrm{Cd}, \mathrm{Cr}, \mathrm{Hg}, \mathrm{Ni}, \mathrm{Sb}, \mathrm{Se}, \mathrm{Tl} \text {, } \\
\text { cyanide, fluoride }\end{array}$ \\
\hline $\begin{array}{l}\text { WNDNKMP } \\
\text { Main plant drinking water }\end{array}$ & Grab liquid & Annually; 1 per year & Gross alpha/beta, $\mathrm{H}-3$ \\
\hline $\begin{array}{l}\text { WNDNKEL } \\
\text { Environmental Laboratory } \\
\text { drinking water }\end{array}$ & Grab liquid $^{a}$ & Annually; 1 per year & $\begin{array}{l}\text { Total haloacetic acids, total } \\
\text { trihalomethanes }\end{array}$ \\
\hline \multicolumn{4}{|c|}{ On-Site Groundwater } \\
\hline $\begin{array}{l}\text { Low-level waste treatment } \\
\text { facility: SSWMU \#1 (wells 103, } \\
\text { 104, 105, 106, 107, 108, 110, } \\
\text { 111, 116, 8604, 8605) } \\
\text { Miscellaneous small units: } \\
\text { SSWMU \#2 (wells 204, 205, } \\
\text { 206) }\end{array}$ & & 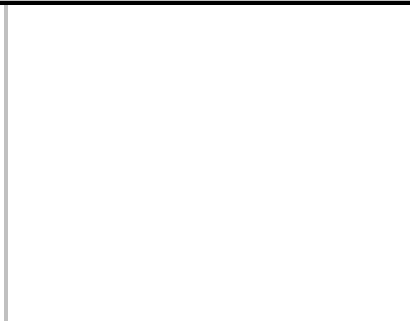 & . \\
\hline $\begin{array}{l}\text { Liquid waste treatment } \\
\text { system: SSWMU \#3 (wells } \\
301,302 \text { ) } \\
\text { High-level waste storage and } \\
\text { processing tank: SSWMU \#4 } \\
\text { (wells } 401,402,403,405,406 \text {, } \\
408,409 \text { ) }\end{array}$ & 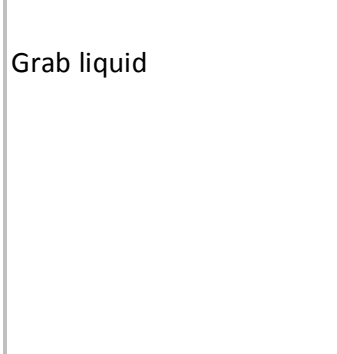 & $\begin{array}{l}\text { Quarterly during the fiscal year } \\
\left.\text { (generally }^{b}\right) ; 4 \text { per year }\end{array}$ & $\begin{array}{l}\text { Gross alpha/beta, H-3. VOAs, } \\
\text { SmVOAs or metals at select locations. } \\
\text { Refer to Chapter } 4 \text { Tables } 4-2 \text { and } 4-3 \text {. }\end{array}$ \\
\hline $\begin{array}{l}\text { Maintenance shop leach } \\
\text { field: SSWMU \#5 (wells 501, } \\
\text { 502) }\end{array}$ & 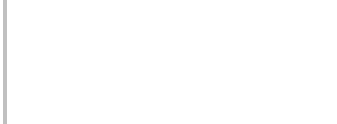 & 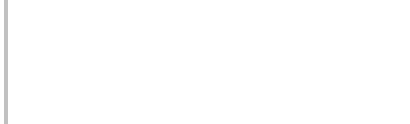 & \\
\hline $\begin{array}{l}\text { Low-level waste storage area: } \\
\text { SSWMU \#6 (wells 602A, 604, } \\
605,8607,8609 \text { ) }\end{array}$ & 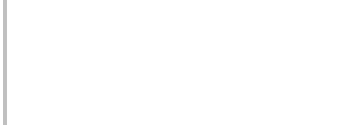 & & \\
\hline $\begin{array}{l}\text { Chemical process cell waste } \\
\text { storage area: SSWMU \#7 } \\
\text { (wells 704, 706, 707) } \\
\text { Construction and demolition } \\
\text { debris landfill: SSWMU \#8 } \\
\text { (wells } 801,802,803,804, \\
8603,8612 \text { ) }\end{array}$ & Direct field measurement & $\begin{array}{l}\text { Twice each sampling event; } 8 \\
\text { per year for wells sampled } \\
\text { quarterly }\end{array}$ & Conductivity, $\mathrm{pH}$ \\
\hline $\begin{array}{l}\text { NRC-licensed disposal area } \\
\text { (NDA): SSWMU \#9 (wells 901, } \\
\text { 902, 903, 906, 908, 908R, 909, } \\
\text { 910, 910R, 8610, 8611, trench } \\
\text { NDATR) }\end{array}$ & & & \\
\hline
\end{tabular}

a A sample for $\mathrm{NO}_{3}$ (as $\mathrm{N}$ ) is collected by the Cattaraugus County Health Department (CCHD). Pb and Cu are sampled at this site based upon CCHD guidance.

$b$ Sampling frequency and analyses vary from point to point. 


\begin{tabular}{|c|c|c|c|}
\hline Sample Location Code & $\begin{array}{l}\text { Sampling Type/ } \\
\text { Medium }\end{array}$ & $\begin{array}{l}\text { Collection Frequency/ } \\
\text { Total Annual Samples }\end{array}$ & Measurements/Analyses \\
\hline \multicolumn{4}{|c|}{ On-Site Groundwater } \\
\hline $\begin{array}{l}\text { IRTS drum cell: } \\
\text { SSWMU \#10 (wells 1005, } \\
\text { 1006, 1007, 1008B, 1008C) }\end{array}$ & Grab liquid & $\begin{array}{l}\text { Quarterly during the fiscal year } \\
\text { (generally }^{a} \text { ); } 4 \text { per year }\end{array}$ & $\begin{array}{l}\text { Gross alpha/beta, H-3. VOAs, } \\
\text { SmVOAs or metals at select locations, } \\
\text { refer to Chapter } 4 \text { Tables } 4-2 \text { and 4-3. }\end{array}$ \\
\hline $\begin{array}{l}\text { Remote-handled waste } \\
\text { facility (not in a SSWMU): } \\
\text { (wells 1301, 1302, 1303, } \\
21304 \text { ) }\end{array}$ & Direct field measurement & $\begin{array}{l}\text { Twice each sampling event; } 8 \\
\text { per year for wells sampled } \\
\text { quarterly }\end{array}$ & Conductivity, $\mathrm{pH}$ \\
\hline \multirow{2}{*}{$\begin{array}{l}\text { North plateau seeps (not in a } \\
\text { SSWMU): (points GSEEP, } \\
\text { SP04, SP06, SP11, SP12) }\end{array}$} & Grab liquid & $\begin{array}{l}\text { Semiannually (quarterly at } \\
\text { GSEEP); } 2 \text { (or 4) per year }\end{array}$ & $\begin{array}{l}\text { Gross alpha/beta, H-3 (also VOCs at } \\
\text { GSEEP and SP12) }\end{array}$ \\
\hline & $\begin{array}{l}\text { Direct field measurement } \\
\text { of sampled water }\end{array}$ & $\begin{array}{l}\text { Semiannually at SP12 (quarterly } \\
\text { at GSEEP); } 2 \text { (or 4) per year }\end{array}$ & $\mathrm{pH}$, conductivity \\
\hline \multirow{2}{*}{$\begin{array}{l}\text { Miscellaneous monitoring } \\
\text { locations (not in a SSWMU): } \\
\text { Well points WP-A, WP-C, WP- } \\
\text { H }\end{array}$} & Grab liquid & $\begin{array}{l}\text { Annually (quarterly at NB1S); } 1 \\
\text { (or 4) per year }\end{array}$ & Gross alpha/beta, H-3 \\
\hline & $\begin{array}{l}\text { Direct field measurement } \\
\text { of sampled water }\end{array}$ & $\begin{array}{l}\text { Annually (quarterly at NB1S); } 1 \\
\text { (or 4) per year }\end{array}$ & $\mathrm{pH}$, conductivity \\
\hline $\begin{array}{l}\text { Surface water elevation } \\
\text { points: (SE007, SE008, SE009, } \\
\text { SE011) }\end{array}$ & Direct field measurement & $\begin{array}{l}\text { Quarterly; } 4 \text { per year at each } \\
\text { location }\end{array}$ & Water level \\
\hline $\begin{array}{l}\text { State-licensed disposal area } \\
\text { (SDA) (SSWMU \#11) }\end{array}$ & \multicolumn{3}{|c|}{$\begin{array}{l}\text { Groundwater wells in SSWMU \#11 are sampled by NYSERDA under a separate program. For } \\
\text { information, see the NYSERDA website at www.nyserda.org. }\end{array}$} \\
\hline \multicolumn{4}{|c|}{ On-Site Soil/Sediment } \\
\hline $\begin{array}{l}\text { SN on-site soil series; } \\
\text { SNSW74A (near WNSW74A), } \\
\text { SNSWAMP (near } \\
\text { WNSWAMP), and SNSP006 } \\
\text { (near WNSP006) }\end{array}$ & $\begin{array}{l}\text { Surface plug composite } \\
\text { soil/sediment }\end{array}$ & $\begin{array}{l}1 \text { each location every five years } \\
\text { (last sampled in 2007) }\end{array}$ & $\begin{array}{l}\text { Gross alpha/beta, gamma isotopic, Sr- } \\
90, \text { U-232, U-233/234, U-235/236, U- } \\
238 \text {, total U, Pu-238, Pu-239/240, Am- } \\
241\end{array}$ \\
\hline \multicolumn{4}{|c|}{ Off-Site Soil } \\
\hline $\begin{array}{l}\text { SF off-site soil series } \\
\text { (collected at air sampling } \\
\text { location[s]) }\end{array}$ & $\begin{array}{l}\text { Surface plug composite } \\
\text { soil }\end{array}$ & $\begin{array}{l}1 \text { each location every five years } \\
\text { (last sampled in 2007) }\end{array}$ & $\begin{array}{l}\text { Gross alpha/beta, Sr-90, gamma } \\
\text { isotopic, Pu-238, Pu-239/240, Am- } \\
\text { 241. At nearest site and background } \\
\text { (SFGRVAL), also U-232, U-233/234, U- } \\
\text { 235/236, U-238, and total U }\end{array}$ \\
\hline
\end{tabular}

a Sampling frequency and analyses vary from point to point. 


\begin{tabular}{|c|c|c|c|}
\hline Sample Location Code & $\begin{array}{l}\text { Sampling Type/ } \\
\text { Medium }\end{array}$ & $\begin{array}{l}\text { Collection Frequency/ } \\
\text { Total Annual Samples }\end{array}$ & Measurements/Analyses \\
\hline \multicolumn{4}{|c|}{ Off-Site Sediment } \\
\hline $\begin{array}{l}\text { SFCCSED } \\
\text { Cattaraugus Creek at Felton } \\
\text { Bridge } \\
\text { SFSDSED } \\
\text { Cattaraugus Creek at } \\
\text { Springville Dam } \\
\text { SFTCSED } \\
\text { Buttermilk Creek at Thomas } \\
\text { Corners Road } \\
\text { SFBCSED } \\
\text { Buttermilk Creek at Fox Valley } \\
\text { Road (background) }\end{array}$ & Grab stream sediment & $\begin{array}{l}1 \text { each location every five years } \\
\text { (last sampled in 2007) }\end{array}$ & $\begin{array}{l}\text { Gross alpha/beta, gamma isotopic, Sr- } \\
90, \text { U-232, U-233/234, U-235/236, U- } \\
238 \text {, total U, Pu-238, Pu-239/240, Am- } \\
241\end{array}$ \\
\hline \multicolumn{4}{|c|}{ Off-Site Air } \\
\hline \multirow{4}{*}{$\begin{array}{l}\text { AFGRVAL } \\
29 \text { km south at Great Valley } \\
\text { (background) }\end{array}$} & $\begin{array}{l}\text { Continuous air particulate } \\
\text { filter }\end{array}$ & Biweekly; 26 per year & Gross alpha/beta, flow \\
\hline & $\begin{array}{l}\text { Composite of biweekly } \\
\text { filters }\end{array}$ & Semiannually; 2 per year & $\begin{array}{l}\text { Sr-90, gamma isotopic, U-232, U- } \\
\text { 233/234, U-235/236, U-238, total U, } \\
\text { Pu-238, Pu-239/240, Am-241, flow }\end{array}$ \\
\hline & $\begin{array}{l}\text { Continuous charcoal } \\
\text { cartridge }\end{array}$ & Monthly; 12 per year & Held for composite \\
\hline & $\begin{array}{l}\text { Composite of monthly } \\
\text { charcoal cartridges }\end{array}$ & Semiannually; 2 per year & I-129 \\
\hline \multicolumn{4}{|c|}{ Off-Site Surface Water } \\
\hline \multirow{3}{*}{$\begin{array}{l}\text { WFBCBKG } \\
\text { Buttermilk Creek near Fox } \\
\text { Valley (background) }\end{array}$} & $\begin{array}{l}\text { Timed continuous } \\
\text { composite liquid }\end{array}$ & Biweekly; 26 per year & Hold for composite \\
\hline & $\begin{array}{l}\text { Composite of biweekly } \\
\text { samples }\end{array}$ & Monthly; 12 per year & Gross alpha/beta, $\mathrm{H}-3$ \\
\hline & $\begin{array}{l}\text { Composite of biweekly } \\
\text { samples }\end{array}$ & Semiannually; 2 per year & $\begin{array}{l}\text { C-14, Sr-90, Tc-99, I-129, U-232, U- } \\
\text { 233/234, U-235/236, U-238, total U, } \\
\text { Pu-238, Pu-239/240, Am-241, gamma } \\
\text { isotopic }\end{array}$ \\
\hline \multirow{2}{*}{$\begin{array}{l}\text { WFFELBR } \\
\text { Cattaraugus Creek at Felton } \\
\text { Bridge (downstream of } \\
\text { confluence with Buttermilk } \\
\text { Creek); nearest point of public } \\
\text { access to waters receiving } \\
\text { WVDP effluents }\end{array}$} & $\begin{array}{l}\text { Timed continuous } \\
\text { composite liquid }\end{array}$ & $\begin{array}{l}\text { Weekly during lagoon } 3 \\
\text { discharge, otherwise biweekly; } \\
\text { 26-34 per year }\end{array}$ & Gross alpha/beta, $\mathrm{H}-3, \mathrm{pH}$, flow \\
\hline & $\begin{array}{l}\text { Flow-weighted composite } \\
\text { of weekly and biweekly } \\
\text { samples }\end{array}$ & Monthly; 12 per year & $\begin{array}{l}\text { Gross alpha/beta, } \mathrm{H}-3, \mathrm{Sr}-90 \text {, and } \\
\text { gamma isotopic }\end{array}$ \\
\hline
\end{tabular}




\begin{tabular}{|c|c|c|c|}
\hline Sample Location Code & $\begin{array}{l}\text { Sampling Type/ } \\
\text { Medium }\end{array}$ & $\begin{array}{l}\text { Collection Frequency/ } \\
\text { Total Annual Samples }\end{array}$ & Measurements/Analyses \\
\hline \multicolumn{4}{|c|}{ Off-Site Surface Water } \\
\hline \multirow{6}{*}{$\begin{array}{l}\text { WFBCTCB } \\
\text { Buttermilk Creek at Thomas } \\
\text { Corners Road, downstream of } \\
\text { WVDP and upstream of } \\
\text { confluence with Cattaraugus } \\
\text { Creek }\end{array}$} & $\begin{array}{l}\text { Timed continuous } \\
\text { composite liquid }\end{array}$ & Biweekly; 26 per year & Hold for composite \\
\hline & $\begin{array}{l}\text { Composite of biweekly } \\
\text { samples }\end{array}$ & Monthly; 12 per year & Gross alpha/beta, H-3 \\
\hline & $\begin{array}{l}\text { Composite of biweekly } \\
\text { samples }\end{array}$ & Semiannually; 2 per year & Sr-90, gamma isotopic \\
\hline & Grab liquid & Monthly; 12 per year & Hardness ( $\mathrm{Ca}$ and $\mathrm{Mg}$ ) \\
\hline & Grab liquid & Semiannually; 2 per year ${ }^{a}$ & $\begin{array}{l}\text { Temperature (field), pH (field), } \\
\text { dissolved oxygen (field), TOX, oil \& } \\
\text { grease }\end{array}$ \\
\hline & $\begin{array}{l}\text { 24-hour timed continuous } \\
\text { composite }\end{array}$ & Semiannually; 2 per year ${ }^{a}$ & $\begin{array}{l}\text { TSS, TDS, NPOC, } \mathrm{NH}_{3} \text { (as } \mathrm{N} \text { ), } \mathrm{NO}_{3} \text { (as } \\
\mathrm{N} \text { ), } \mathrm{NO}_{2} \text { (as N), bromide, fluoride, } \\
\text { sulfate, total sulfide, surfactant (as } \\
\mathrm{LAS} \text { ), alpha-BHC, B, Ba, Co, } \mathrm{Fe}, \mathrm{Na}, \\
\mathrm{Mn}, \mathrm{Sb}, \mathrm{Ti}, \mathrm{TI}, \mathrm{V} \text {, dissolved } \mathrm{Al}, \mathrm{As}, \mathrm{Cd} \text {, } \\
\mathrm{Cr}, \mathrm{Cu}, \mathrm{Hg} \text { (method 1631), } \mathrm{Ni}, \mathrm{Pb}, \mathrm{Se} \text {, } \\
\mathrm{Zn}\end{array}$ \\
\hline \multicolumn{4}{|c|}{ Off-Site Biological } \\
\hline $\begin{array}{l}\text { BFMWIDR } \\
\text { Dairy farm } 3.0 \mathrm{~km} \text { southeast } \\
\text { of WVDP }\end{array}$ & Grab milk sample & Annual; 1 per year & Sr-90, I-129, gamma isotopic \\
\hline $\begin{array}{l}\text { BFMCTLS } \\
\text { Control location } 22 \mathrm{~km} \text { south } \\
\text { (background) } \\
\text { BFMBLSY } \\
\text { Dairy farm } 5.5 \mathrm{~km} \text { west- } \\
\text { northwest } \\
\text { BFMSCHT } \\
\text { Dairy farm } 4.9 \mathrm{~km} \text { south }\end{array}$ & Grab milk sample & $\begin{array}{l}1 \text { each location every five years } \\
\text { (last sampled in 2007) }\end{array}$ & Sr-90, I-129, gamma isotopic \\
\hline $\begin{array}{l}\text { BFDNEAR } \\
\text { Deer in the vicinity of the } \\
\text { WVDP } \\
\text { BFDCTRL } \\
\text { Control deer } 16 \mathrm{~km} \text { or more } \\
\text { from the WVDP }\end{array}$ & $\begin{array}{l}\text { Individual collection of } \\
\text { venison samples, usually } \\
\text { from deer killed in } \\
\text { collisions with vehicles }\end{array}$ & $\begin{array}{l}\text { Six deer collected annually } \\
\text { during hunting season ( } 3 \text { near- } \\
\text { site, } 3 \text { background) }\end{array}$ & $\begin{array}{l}\text { Gamma isotopic and } \mathrm{Sr}-90 \text { in edible } \\
\text { portions of meat, \% moisture, } \mathrm{H}-3 \text { in } \\
\text { free moisture }\end{array}$ \\
\hline $\begin{array}{l}\text { BFVNEAR } \\
\text { Apples, beans, and corn from } \\
\text { locations near the WVDP } \\
\text { BFVCTRL } \\
\text { Control apples, beans, and } \\
\text { corn from locations far from } \\
\text { the WVDP }\end{array}$ & Grab biological & $\begin{array}{l}1 \text { every five years at time of } \\
\text { harvest (last sampled in 2007) }\end{array}$ & $\begin{array}{l}\text { Gamma isotopic and } \mathrm{Sr}-90 \text { in edible } \\
\text { portions, \% moisture, } \mathrm{H}-3 \text { in free } \\
\text { moisture }\end{array}$ \\
\hline
\end{tabular}

a Samples are collected when points WNSP001 and WNSP007 are discharging. 


\begin{tabular}{|c|c|c|c|}
\hline Sample Location Code & $\begin{array}{l}\text { Sampling Type/ } \\
\text { Medium }\end{array}$ & $\begin{array}{l}\text { Collection Frequency/ } \\
\text { Total Annual Samples }\end{array}$ & Measurements/Analyses \\
\hline \multicolumn{4}{|c|}{ Off-Site Biological } \\
\hline $\begin{array}{l}\text { BFFCATC } \\
\text { Fish from Cattaraugus Creek } \\
\text { downstream of its confluence } \\
\text { with Buttermilk Creek } \\
\text { BFFCATD } \\
\text { Fish from Cattaraugus Creek } \\
\text { downstream of the Springville } \\
\text { Dam } \\
\text { BFFCTRL } \\
\text { Control fish sample from } \\
\text { nearby stream not affected by } \\
\text { WVDP (7 km or more } \\
\text { upstream of site effluent } \\
\text { point); background }\end{array}$ & $\begin{array}{l}\text { Individual collection of } \\
\text { fish }\end{array}$ & $\begin{array}{l}\text { Once every } 5 \text { years; } 10 \text { fish } \\
\text { from each location (last } \\
\text { sampled in 2007) }\end{array}$ & $\begin{array}{l}\text { Gamma isotopic and } \mathrm{Sr}-90 \text { in edible } \\
\text { portions, \% moisture }\end{array}$ \\
\hline \multicolumn{4}{|c|}{ Off-Site Direct Radiation } \\
\hline $\begin{array}{l}\text { DFTLD Series: Off-site } \\
\text { environmental } \\
\text { thermoluminescent } \\
\text { dosimeters (TLDs): \#1 through } \\
\# 16 \text {, at each of } 16 \text { compass } \\
\text { sectors at nearest accessible } \\
\text { perimeter point } \\
\text { \#20: } 1,500 \text { m northwest } \\
\text { (downwind receptor) } \\
\text { \#23: } 29 \text { km south, Great } \\
\text { Valley (background) }\end{array}$ & Integrating TLD & $\begin{array}{l}\text { Semiannually; } 2 \text { per year at } \\
\text { each location }\end{array}$ & Gamma radiation exposure \\
\hline \multicolumn{4}{|c|}{ On-Site Direct Radiation } \\
\hline $\begin{array}{l}\text { DNTLD Series: On-site TLDs } \\
\text { \#33: Corner of the SDA } \\
\text { \#24, \#28: Security fence } \\
\text { around the WVDP } \\
\text { \#35, \#36, \#38, \#40: Near } \\
\text { operational areas on-site } \\
\text { \#43: SDA west perimeter } \\
\text { fence }\end{array}$ & Integrating TLD & $\begin{array}{l}\text { Semiannually; } 2 \text { per year at } \\
\text { each location }\end{array}$ & Gamma radiation exposure \\
\hline
\end{tabular}




\section{Summary of Monitoring Program Changes in 2008}

The monitoring program was completely evaluated and revised at the end of 2007. Modifications were made to reflect current site conditions and activities and to make the program more efficient. The revised program was put into place at the beginning of 2008.

Each sampling location was evaluated on several bases: (1) regulatory requirements or other drivers, (2) pathways and hazard conditions, (3) a statistical evaluation of up to 16 years of monitoring data, and (4) a determination of the need for each constituent. As a result, sampling at several locations was discontinued altogether, frequency of sampling at other locations was cut back, and the number of constituents monitored at some locations was reduced. A complete listing of changes at each monitoring location is presented below.

\section{Location Code}

ANLAGAM

WNSP01B

WNSP007

WNSP006

WNSWAMP

WNSW74A

WNSP005

WNCOOLW

WNFRC67

WNERB53

WNNDADR

\section{Description of Changes}

Continuous sampling of on-site ambient air at this location was discontinued. (Assume special ambient air sampling during activities with potential for radiological releases to air [e.g., demolition, soil excavation].)

Weekly monitoring of flow has been discontinued, monthly elapsed flow time retained. Required information is obtained without weekly measurement.

Frequency of gross alpha/beta and tritium sampling was decreased from twice a month to monthly. Compositing frequency for gamma isotopic and strontium-90 analysis was decreased from semiannual to annual.

Sampling for all nonradiological constituents was discontinued (except for TDS at WNSP006). Sufficient historical data are available to characterize.

Sampling frequency was decreased from monthly to quarterly. (The semiannual composite for gamma isotopic and strontium-90 was retained.) The location is well characterized by historical sampling, and the flow is ultimately captured at WNSP006.

Water sampling at the cooling tower has been dropped from monitoring program. (The point continues to be monitored for process control.)

Frequency of composites for strontium-90 and gamma isotopic analysis has been decreased from quarterly to semiannual. The location is well characterized by historical sampling and flow is ultimately captured at WNSP006.

Analysis of semiannual composites for gross alpha/beta and tritium has been discontinued. (These analyses are already performed on quarterly samples and need not be repeated.)

Biweekly grab sampling for $\mathrm{pH}$, tritium, NPOC, and TOX and quarterly grab sampling for gross alpha/beta and tritium have been discontinued. Biweekly sampling of timed continuous composites and monthly analysis of composites for gross alpha/beta, tritium, and gamma isotopic have been retained. This location is well characterized by historical sampling and flow is ultimately captured at WNSP006. 


\section{Summary of Monitoring Program Changes in 2008 (continued)}

Location Code

WNDCELD

WNNDATR

WNSTAW9

WNDNKMP

WNDNKEL

WNDNKUR

WFBCBKG

WFBIGBR

WFBCTCB

WFFELBR

WFWEL01

through

WFWEL10

AFFXVRD

AFRT240

AFRSPRD

AFSPRVL

AFWEVAL

\section{Description of Changes}

Sampling at the drum cell drainage point has been discontinued. (Drums of radioactive waste were removed from the drum cell and off-site shipment was completed in 2007.) The location is well characterized by historical sampling, and flow is ultimately captured at both WNFRC67 and WNSP006.

For program efficiency, this location will be sampled only under the groundwater monitoring program. Separate sampling under the environmental monitoring program has been discontinued.

Sampling was discontinued at the last remaining standing water location near the onsite lakes that provide site utility and drinking water. No contamination above background has been noted over its historical sampling period.

Sampling of on-site drinking water for radiological constituents and for all chemical constituents not required by Cattaraugus County has been discontinued. Sufficient historical data are available to characterize for non-regulatory constituents. (Sampling for radiological constituents will be continued in the MPPB at point WNDNKMP.)

Frequency of sampling at the Buttermilk Creek background location for gross alpha/ beta and tritium has been reduced from weekly to biweekly for consistency with the sampling schedule at other locations. Frequency of composites for radionuclides has been reduced from quarterly to semiannual. All sampling for nonradiological constituents has been discontinued. Sufficient historical data are available to characterize.

Sampling at Cattaraugus Creek background location has been discontinued. Sufficient historical data are available to characterize. (Sampling at Buttermilk Creek background has been retained.)

Semiannual composites for analysis of technetium-99 have been discontinued. Four years of data have shown no technetium-99 contamination downstream of site.

Sampling has been discontinued at near-site and background drinking water sources. Wells are not in aquifers affected by the site. Monitoring results from more than 15 years of sampling have shown no contamination from the WVDP.

Sample collection at near-site ambient air sampling points has been discontinued. Ambient air samples are not required to demonstrate NESHAP compliance. (NESHAP compliance at the WVDP is demonstrated on the basis of emission measurement and modeling.) It is planned that sampling of ambient air will be resumed once EPA approval is received to use an ambient air monitoring network to demonstrate NESHAP compliance. (It is assumed that special ambient air sampling will continue to be done on-site during activities with potential for radiological releases to air [e.g., demolition, soil excavation].)

Ambient air samplers in the nearby communities of Springville and West Valley were removed in early 2008. Historical data from more than 17 years of monitoring are indistinguishable from data at the background location, indicating no effect from the WVDP. 


\section{Summary of Monitoring Program Changes in 2008 (continued)}

Location Code

ANRGFOP

SFFXVRD

SFRT240

SFRSPRD

SFGRVAL

SFSPRVL

SFWEVAL

SFCCSED

SFSDSED

SFTCSED

SFBCSED

SNSW74A

SNSWAMP

SNSP006

SNSW74A

SNSWAMP

SNSP006

WNW0107

WNW0403

WNW0704

WNW0108

WNW0405

WNW0706

WNW0111

WNW8605

\section{Description of Changes}

Monthly sampling of precipitation for radiological constituents has been discontinued. Sufficient historical data are available to characterize.

The sampling frequency of off-site soils has been decreased from once every three years to once every five years, consistent with guidance on periodic confirmatory sampling in DOE/EH-0173T.

Sampling of off-site soils in the nearby communities of Springville and West Valley has been discontinued. The soils have been collected at the community air samplers, which have been deleted from the monitoring program. Historical data have shown no contamination.

Sampling frequency for radiological constituents in sediments has been reduced from annual to once every five years, consistent with guidance on periodic confirmatory sampling in DOE/EH-0173T.

Sampling for chemical constituents in on-site soils/sediments has been discontinued. Fifteen years of historical monitoring data are available for chemical characterization.

Discontinue annual analysis for volatile organic compounds (VOCs). None have been detected in several years of monitoring and no new sources have been identified.

Discontinue annual analysis of VOCs. None have been detected in several years of monitoring and no new sources have been identified. Reduce sampling frequency for radiological indicators from four to two times per year. No radiological contamination of the unweathered Lavery till (ULT) at well 108 has been observed to date, nor is expected.

Discontinue quarterly analysis for VOCs, semivolatile organic compounds (SVOCs), and radioisotopes. No VOCs or SVOCs have been detected in recent years and no new sources have been identified. Radiological indicator parameters will continue to be monitored downgradient of the waste tank farm (WTF).

Discontinue quarterly analysis for VOCs, SVOCs, and radioisotopes. Sampling and analyses was increased in this area to provide a pre-construction baseline for the remote-handled waste facility (RHWF). This baseline has now been established. No organics have been detected in this area. Potential radiological contamination (downgradient of active RHWF) will be monitored by radiological indicators.

Discontinue annual $\mathrm{Sr}-90$ analysis but continue to sample for gross beta. $\mathrm{Sr}-90$ is approximately equal to $50 \%$ of the gross beta result. 


\section{Summary of Monitoring Program Changes in 2008 (continued)}

Location Code

WNW0116

WNW0801

WNW0707

WNW0201

WNW0208

WNW0602A

WNW0604

WNW1007

WNW1008B

WNW1008C

WNW1301

WNW1302

WNW1303

WNW1304

\section{Description of Changes}

Discontinue annual $\mathrm{Sr}-90$ analysis but continue to sample for gross beta. $\mathrm{Sr}-90$ is approximately $50 \%$ of the gross beta result. Reduce analysis of indicator parameters from four to two times per year. Semiannual sampling will provide adequate coverage.

Reduce Sr-90 analysis from four times to once per year. The Sr-90/gross beta relationship in this area has been established. The well is sampled quarterly for radiological indicators, including gross beta.

Reduce analysis of indicators from four to two times per year. Semiannual sampling will provide adequate coverage.

Discontinue sampling. SWMUs in this area designated for No Further Action (NFA) in the RCRA Current Conditions report and subsequent NYSDEC correspondence. Wells are not monitored pursuant to the $3008(\mathrm{~h})$ Order. No regulatory approval is required.

Reduce sampling frequency for radiological indicators from four to two times per year. The lag storage areas are designated NFA and are scheduled for removal in the next four years. Retain sampling to define the western edge of the plume.

Reduce sampling for radiological indicators from four to two times per year. The lag storage areas are designated NFA. However, sampling at this location is used to monitor potential contamination downgradient of the WTF.

Discontinue semiannual sampling at this well on the south plateau near the drum cell. The drum cell has been emptied.

Reduce sampling for radiological indicators from two times per year to annually. Concentrations at these background locations are well characterized.

Discontinue quarterly sampling for VOCs, SVOCs, radioisotopes, and metals. Reduce sampling frequency for radiological indicators to once per year. No organic compounds or radionuclides have been detected in this upgradient well and none are anticipated as a result of size-reduction operations in the RHWF. Baseline concentrations for metals have been established insofar as possible (well 1301 is often dry).

Discontinue quarterly sampling for VOCs, SVOCs, and radioisotopes. Reduce sampling frequency for radiological indicators and metals to once per year. No organic compounds or radionuclides have been detected in this upgradient well and none are anticipated as a result of size-reduction operations in the RHWF. Baseline concentrations for metals have been established.

Discontinue quarterly sampling for VOCs, SVOCs, and radioisotopes. No organic compounds or radionuclides have been detected in this area and none are anticipated because this well monitors the ULT.

Discontinue quarterly sampling for VOCs and SVOCs. Reduce sampling for radioisotopes to once per year. No organic compounds have been detected in this area and none are anticipated. Continue monitoring dowgradient of the RHWF for radioisotopes. 


\section{Summary of Monitoring Program Changes in 2008 (continued)}

Location Code

WNW8603

WNW8609

WNWNB1S

SE001 through

SE006

SE010

BFFCATC (fish)

BFFCATD (fish)

BFFCTRL (fish)

BFMCTLS (milk)

BFMBLSY (milk)

BFMSCHT (milk)

BFVNEAAF (apples)

BFVCTRA (apples)

BFVNEAB (beans)

BFVCTRB (beans)

BFVNEAC (corn)

BFVCTRC (corn)

BFMWIDR (milk)

BFVNEAA (apples)

\section{Description of Changes}

Discontinue annual $\mathrm{Sr}-90$ analysis but continue to sample for gross beta. $\mathrm{Sr}-90$ is approximately $50 \%$ of the gross beta result. Reduce sampling for indicators from four to two times per year. Semiannual sampling will provide adequate coverage.

Reduce Sr-90 analysis from twice to once per year. The Sr-90/gross beta relationship in this area has been established.

Discontinue sampling. Well NB1S was originally drilled as a background location for the sand and gravel (S\&G) unit, but encountered only a very thin $S \& G$ interval. During the RFI new background locations were established. Subsequently, NB1S is no longer used for this purpose.

Discontinue water level measurements at select locations where the general pattern has been established.

Frequency of sampling of most off-site biological matrices (foodstuffs) has been decreased from annual to once every five years, consistent with guidance on periodic confirmatory sampling in DOE/EH-0173T.

This one milk sampling point (of four) has been retained for annual confirmation of low dose potential from the site. Sampling frequency has been reduced from monthly to annual. This dairy was sold in late 2008. A replacement sample point is being selected to provide similar representation.

Sampling of on-site apples has been discontinued. Sufficient historical data are available to characterize, and the apples are not available to the public for consumption. 


\section{Summary of Monitoring Program Changes in 2008 (concluded)}

Location Code

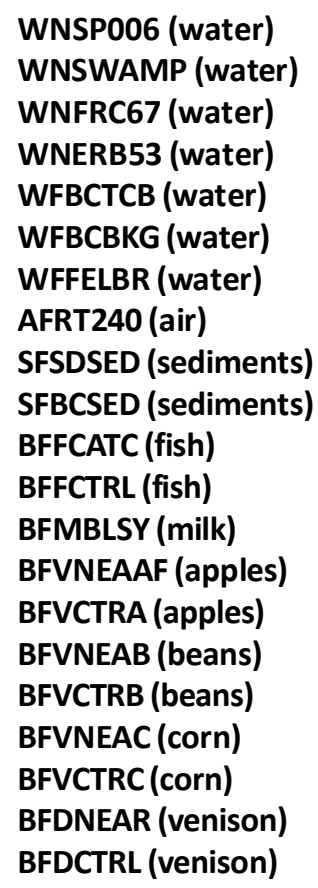

DNTLD24

DNTLD28

DNTLD33

DNTLD35

DNTLD36

DNTLD38

DNTLD40

DNTLD43

\section{Description of Changes}

Sample sharing with the New York State Department of Health (NYSDOH), performed as a courtesy, has been discontinued as a cost savings.

Frequency of sampling for perimeter thermoluminescent dosimeters (TLDs) has been reduced from quarterly to semiannually. Results at perimeter TLDs over more than two decades of monitoring have been statistically indistinguishable from results from background TLD measurements.

TLDs at the community air sampling locations in Springville and West Valley have been discontinued. (Off-site exposure is measured by TLDs around site perimeter.)

The frequency of background TLD measurements at Great Valley has been reduced from quarterly to semiannual to maintain the background on the same frequency as the other TLDs.

On-site TLDs at specific locations have been discontinued due to reduction and/or redistribution of radioactive sources on site.

The frequency of measurements at remaining on-site TLDs has been reduced from quarterly to semiannual to maintain all WVDP TLDs on the same frequency. On-site and off-site TLDs are submitted for analysis as a single batch, along with mailing control, field control, and laboratory storage control TLDs that serve as batch quality control samples. 
FIGURE A-1

West Valley Demonstration Project Base Map

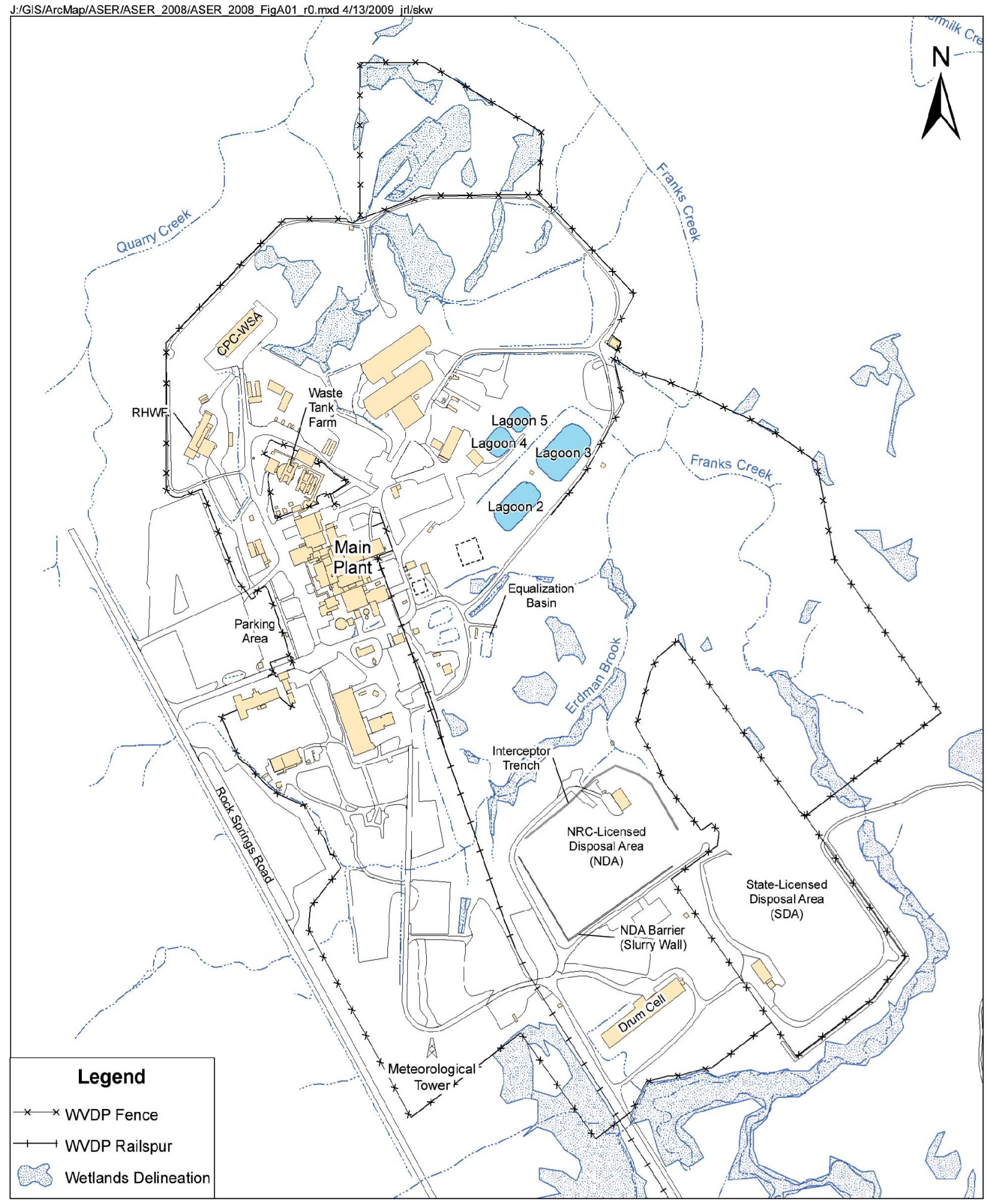


FIGURE A-2

\section{On-Site Surface Water, Drinking Water, and Soil/Sediment Sampling Locations}

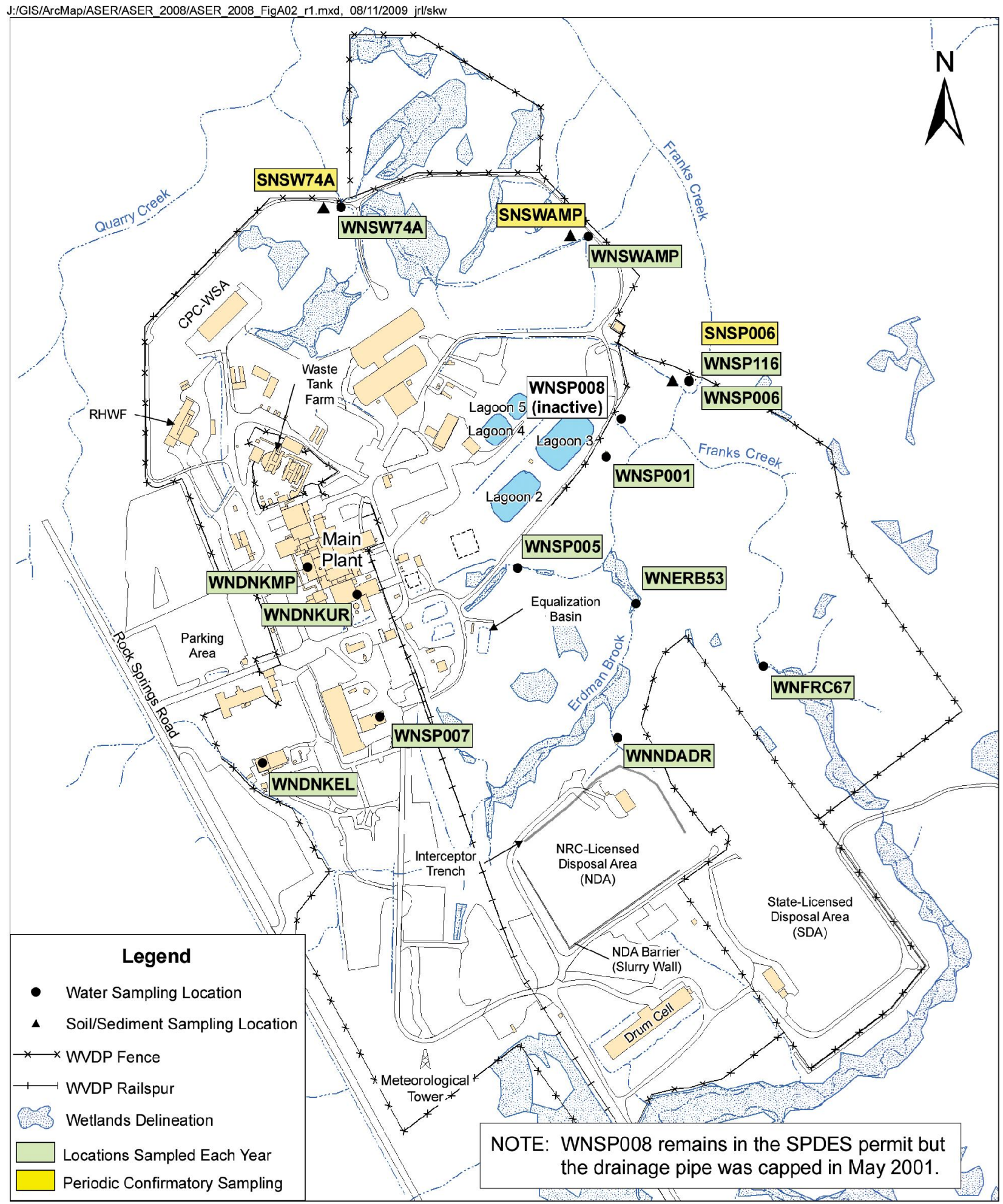

Program changes indicated in color are for CY 2008 (see pages A-17-A-22). 
FIGURE A-3

\section{On-Site Storm Water Outfalls}

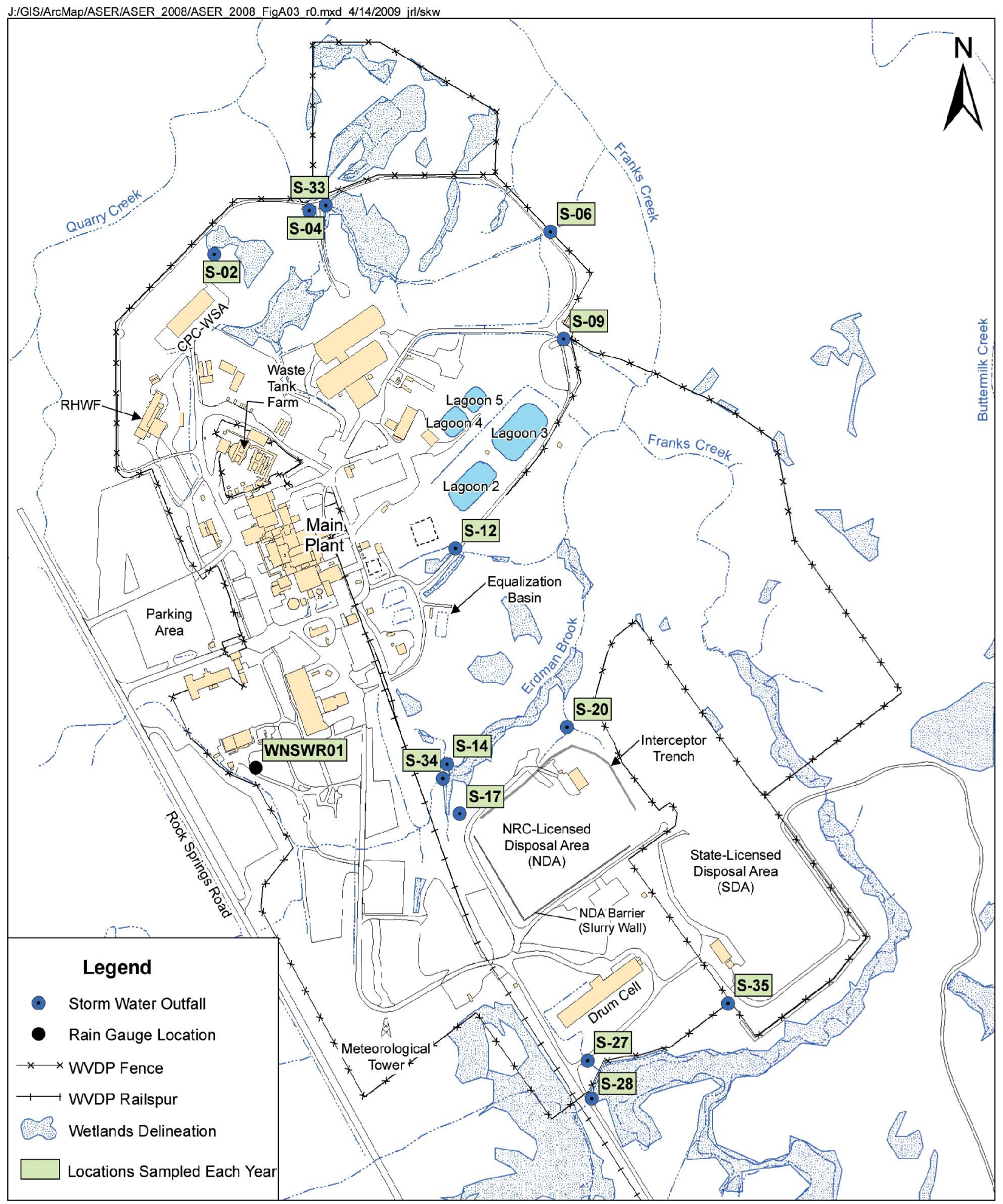

Program changes indicated in color are for CY 2008 (see pages A-17-A-22). 
FIGURE A-4

Rail Spur Storm Water Outfalls

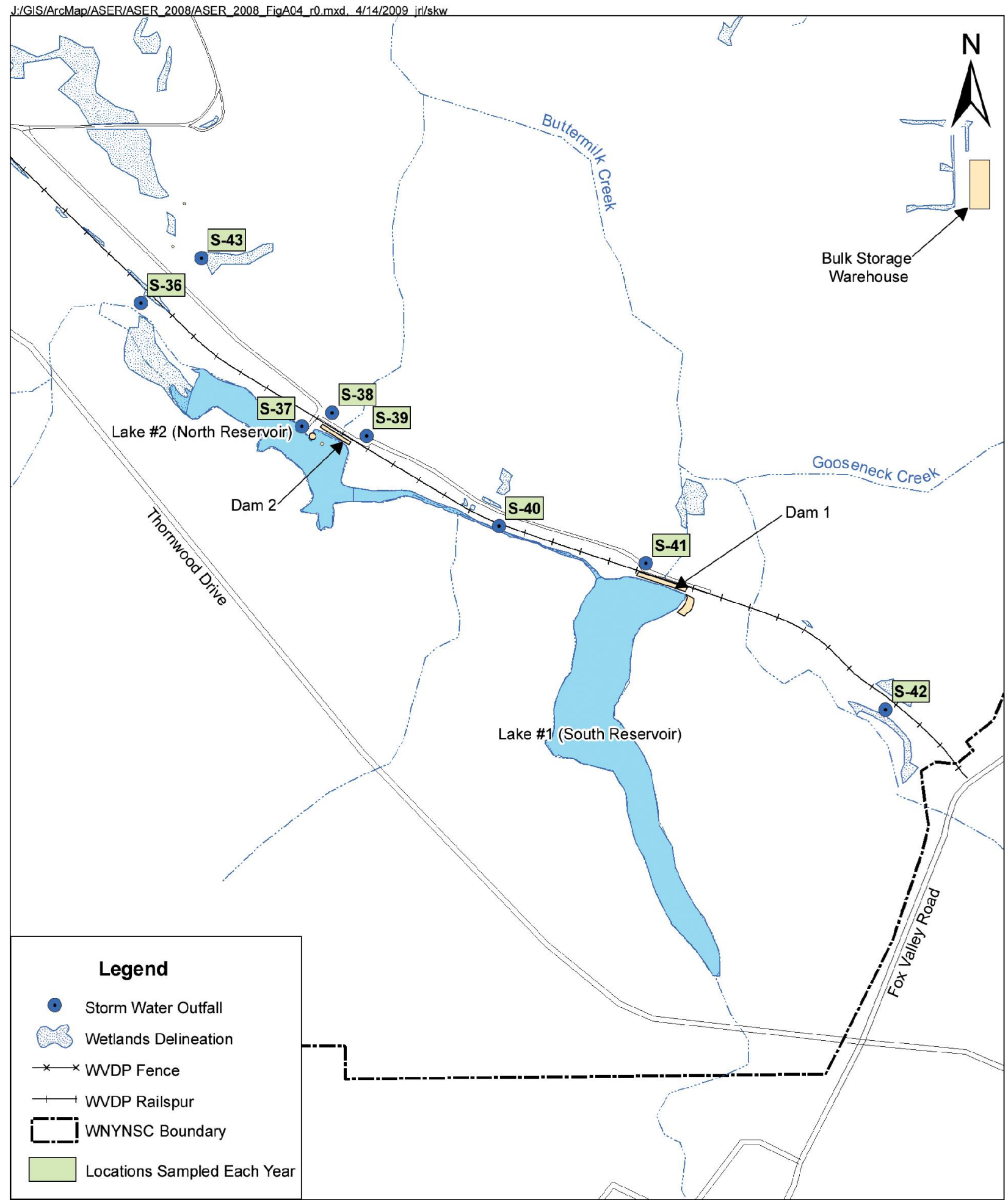

Program changes indicated in color are for CY 2008 (see pages A-17-A-22). 
FIGURE A-5

Off-Site Surface Water and Soil/Sediment Sampling Locations

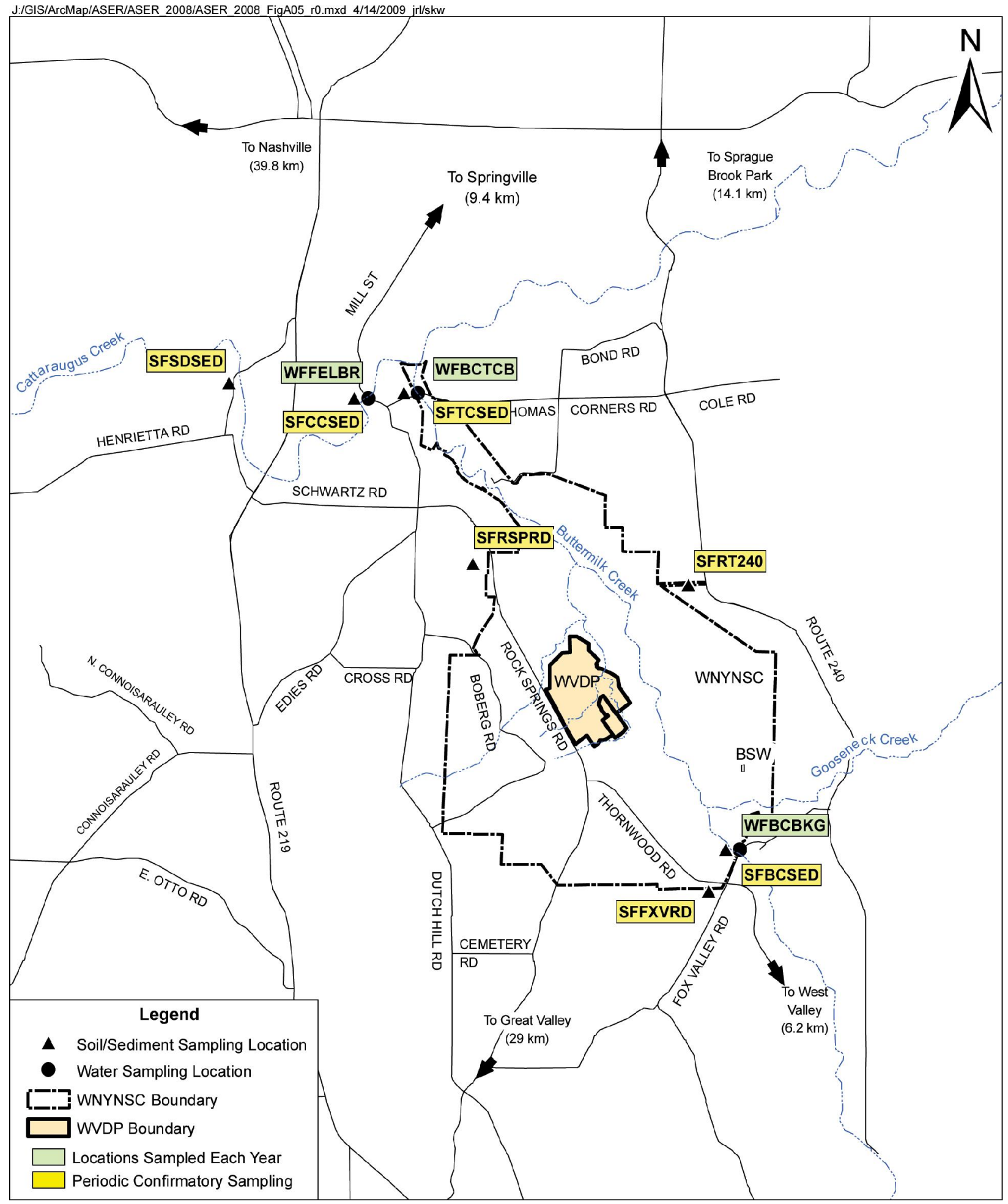

Program changes indicated in color are for CY 2008 (see pages A-17-A-22). 
FIGURE A-6

On-Site Air Monitoring and Sampling Locations

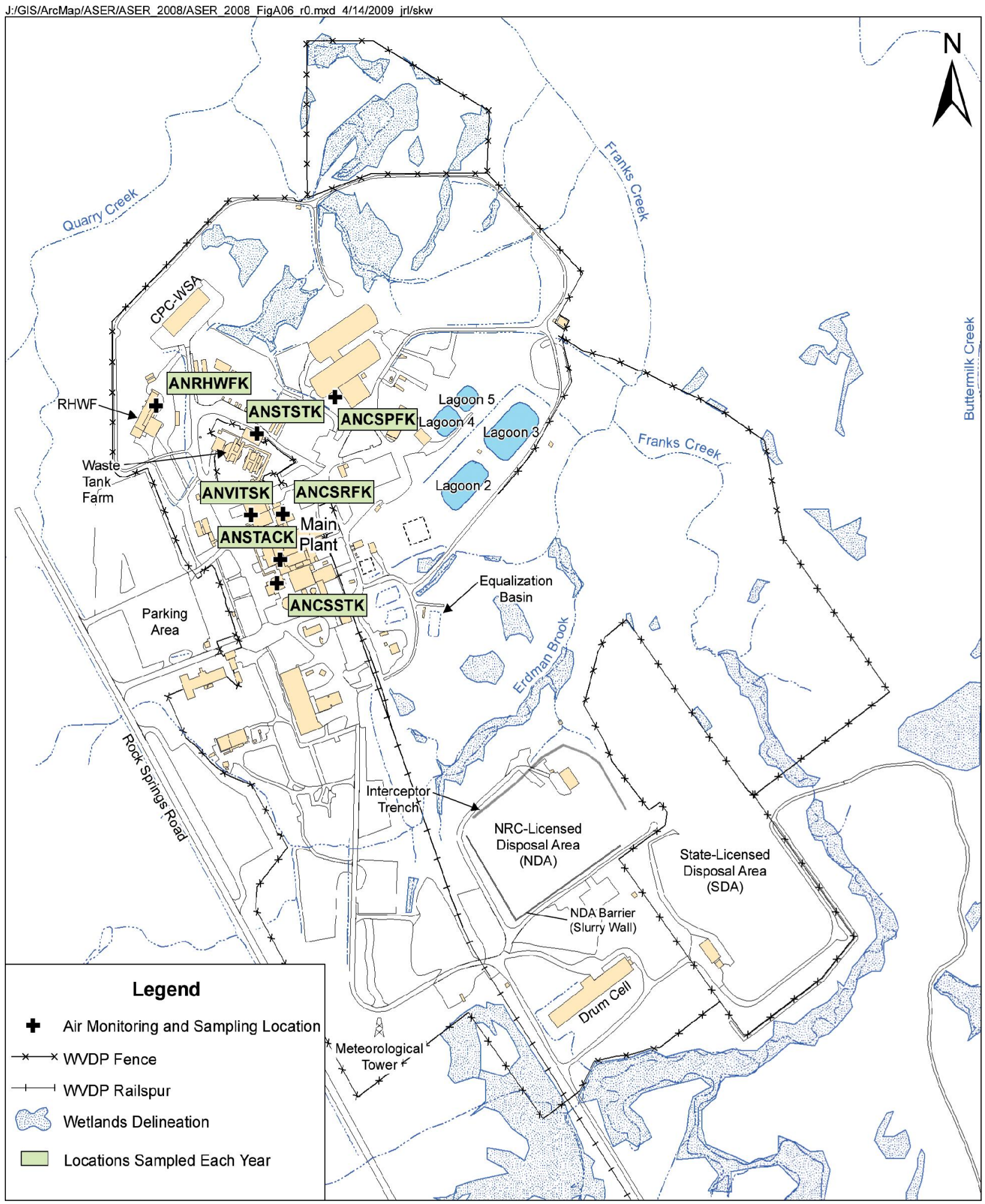

Program changes indicated in color are for CY 2008 (see pages A-17-A-22). 
FIGURE A-7

North Plateau Groundwater Monitoring Network (Includes Wells Used for Water-Level Measurements)

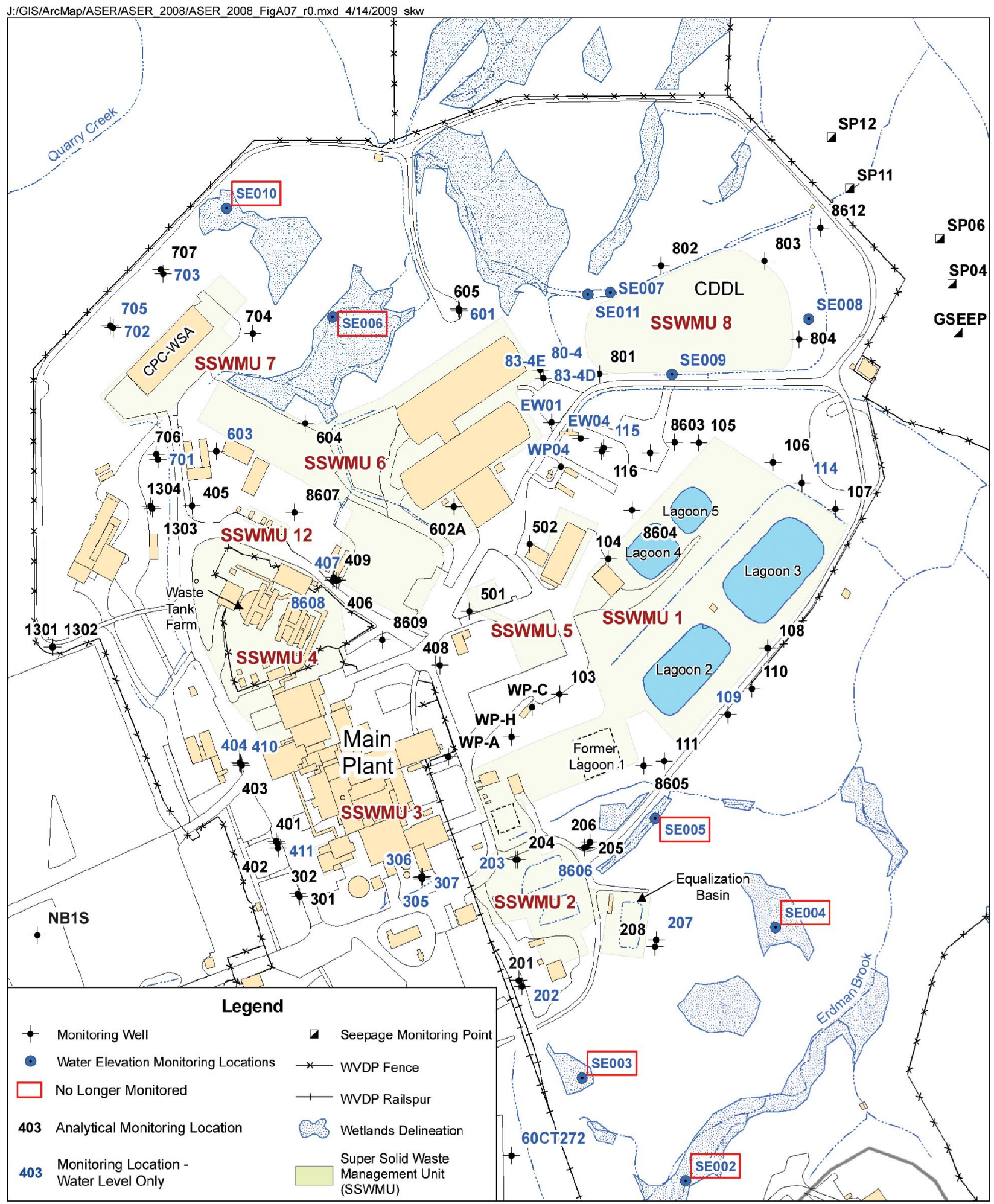

Program changes indicated in color are for CY 2008 (see pages A-17-A-22). 
FIGURE A-8

South Plateau Groundwater Monitoring Network (Includes Wells Used for Water-Level Measurements)

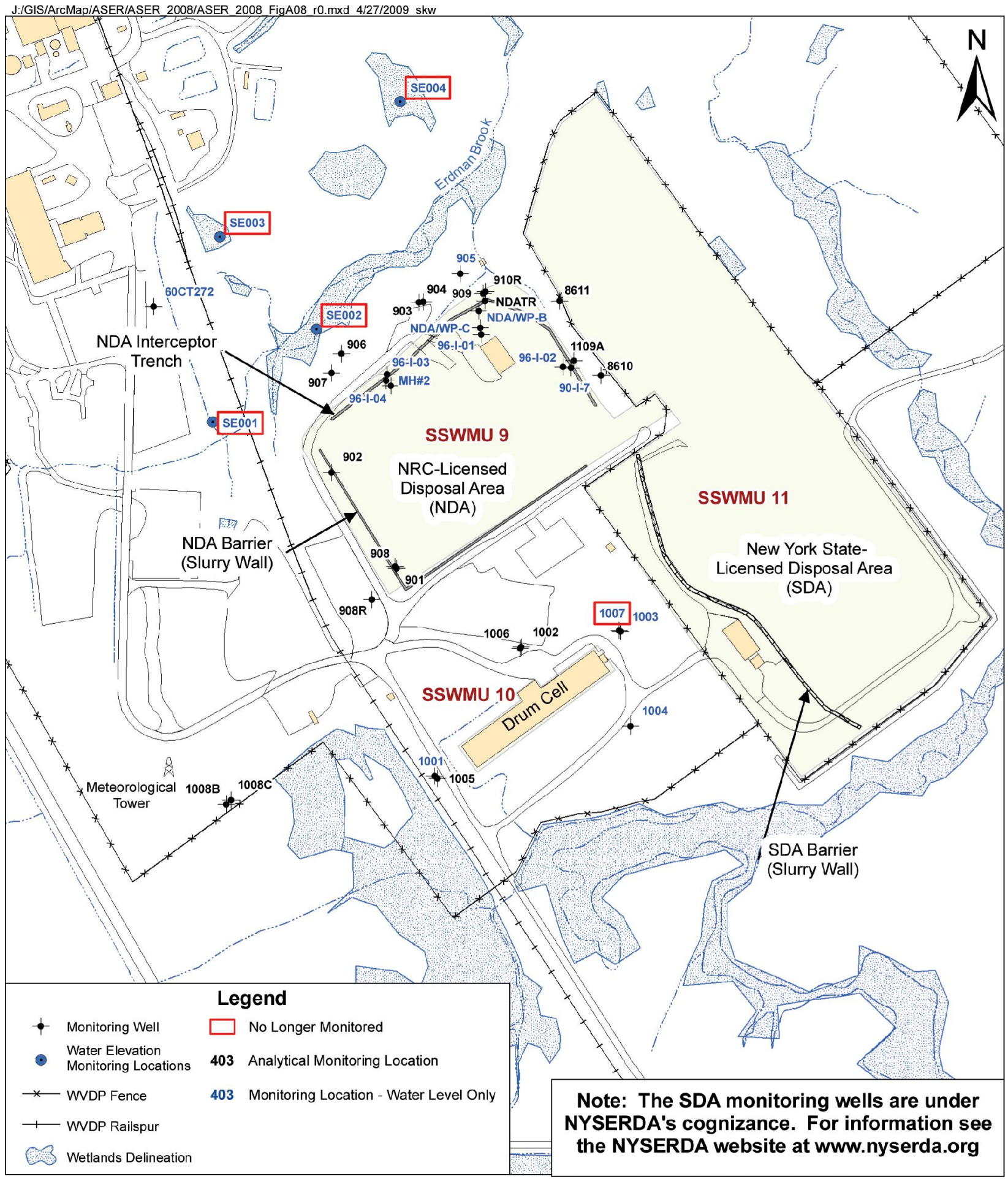

Program changes indicated in color are for CY 2008 (see pages A-17-A-22). 
FIGURE A-9

Biological Sampling Locations

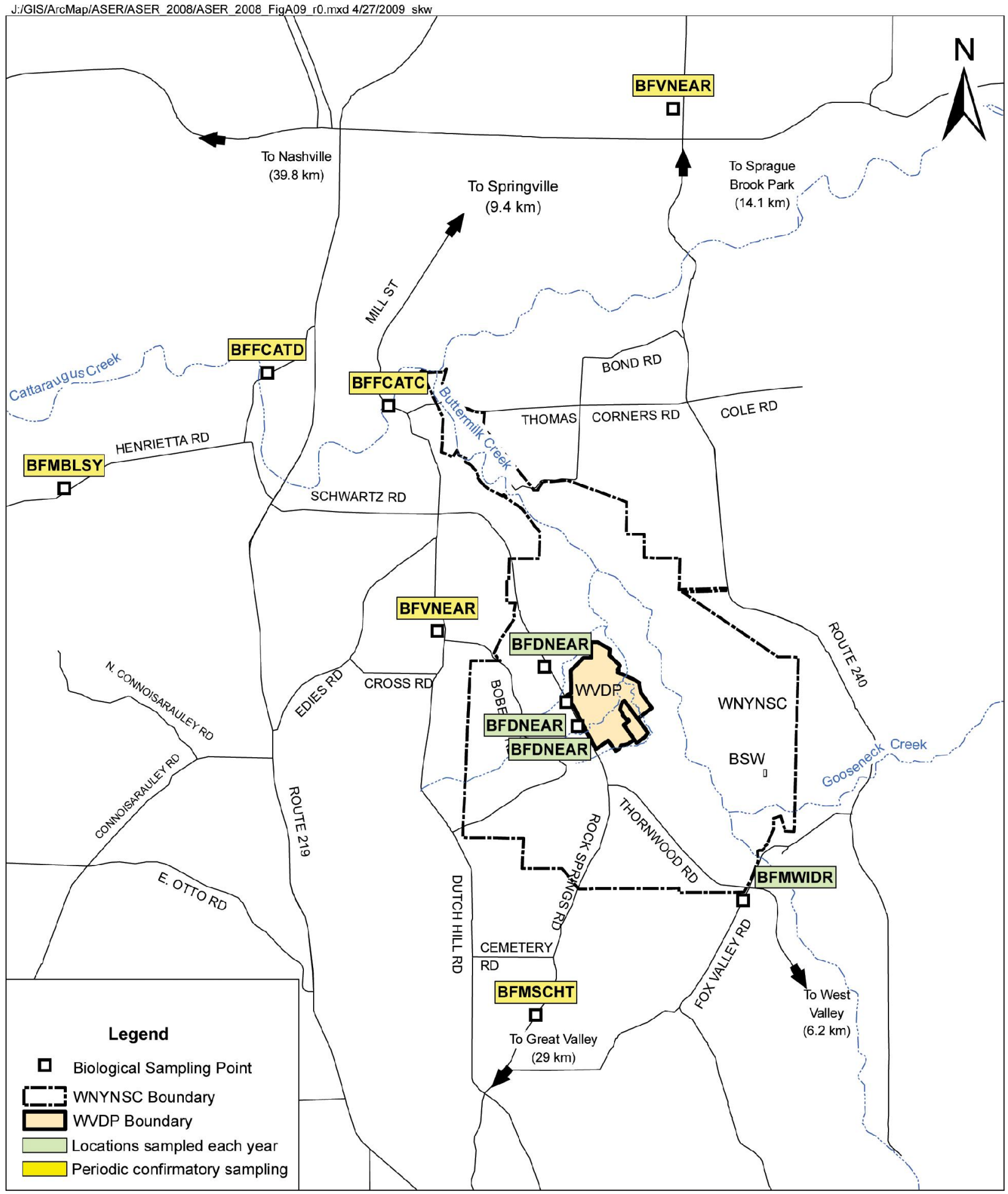

Program changes indicated in color are for CY 2008 (see pages A-17-A-22). 


\section{FIGURE A-10 \\ Location of On-Site Thermoluminescent Dosimeters (TLDs)}

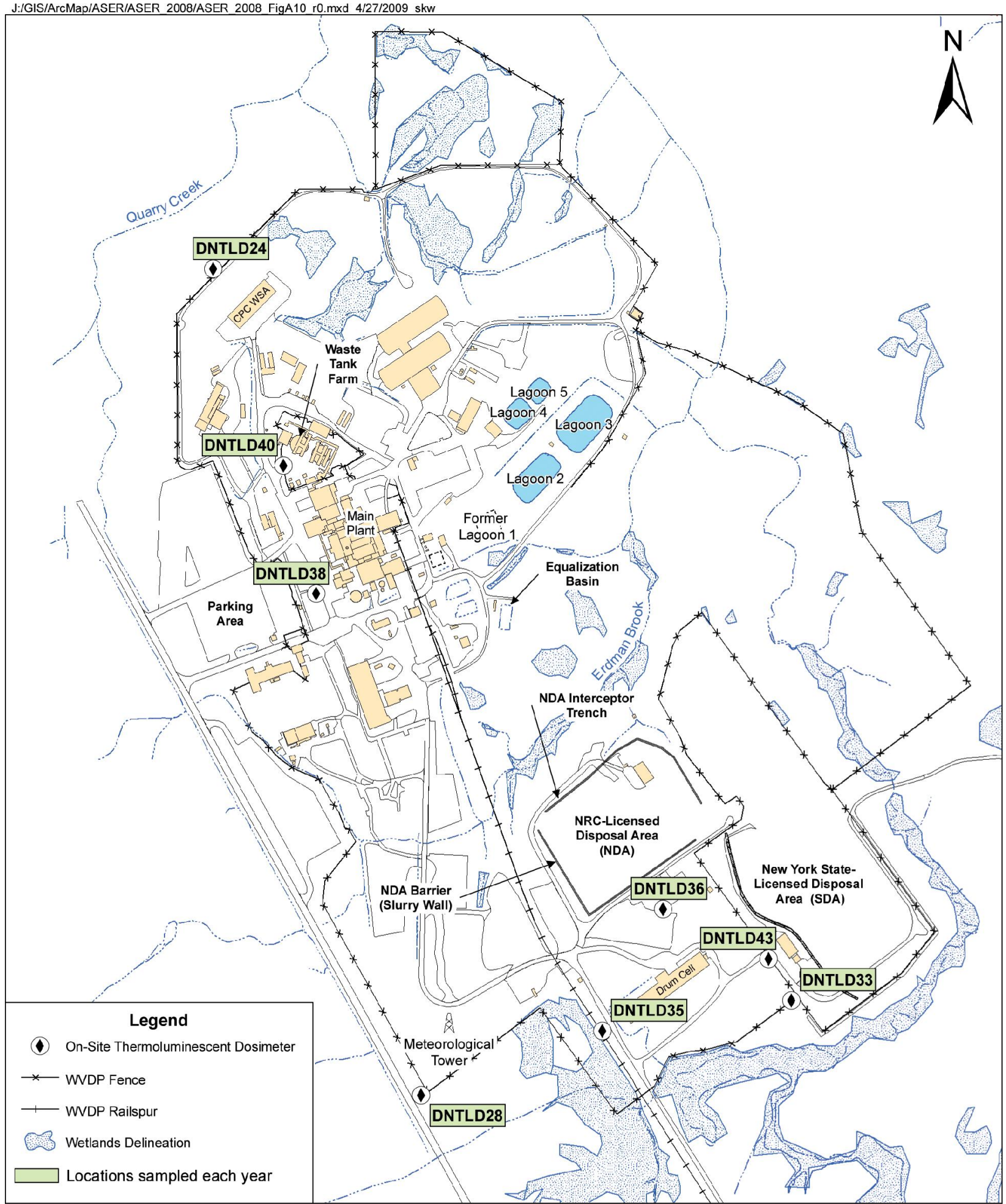

Program changes indicated in color are for CY 2008 (see pages A-17-A-22). 
FIGURE A-11

\section{Location of Off-Site Thermoluminescent Dosimeters (TLDs)}

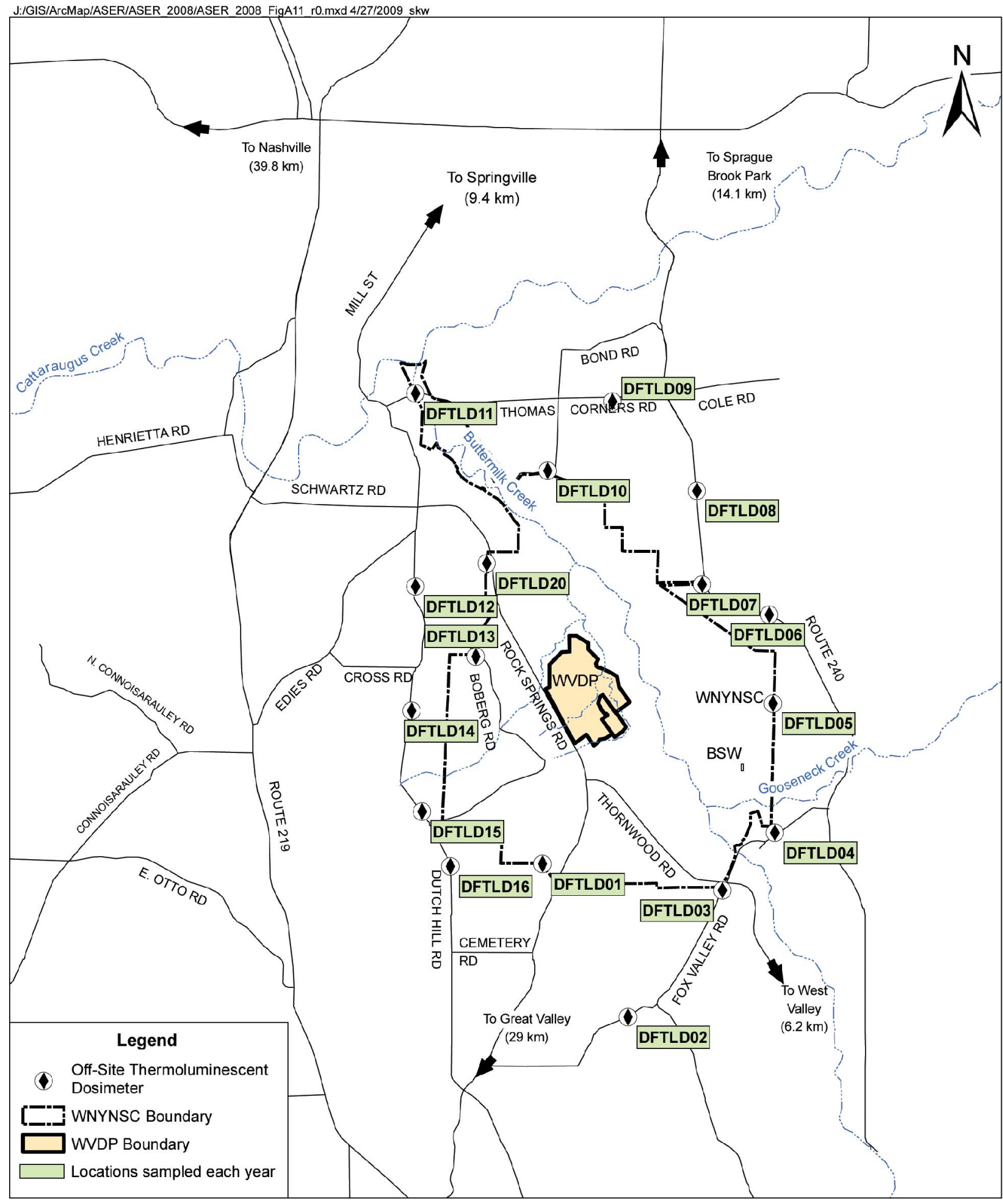

Program changes indicated in color are for CY 2008 (see pages A-17-A-22). 
FIGURE A-12

Environmental Sampling Locations More Than 5 Kilometers From the WVDP

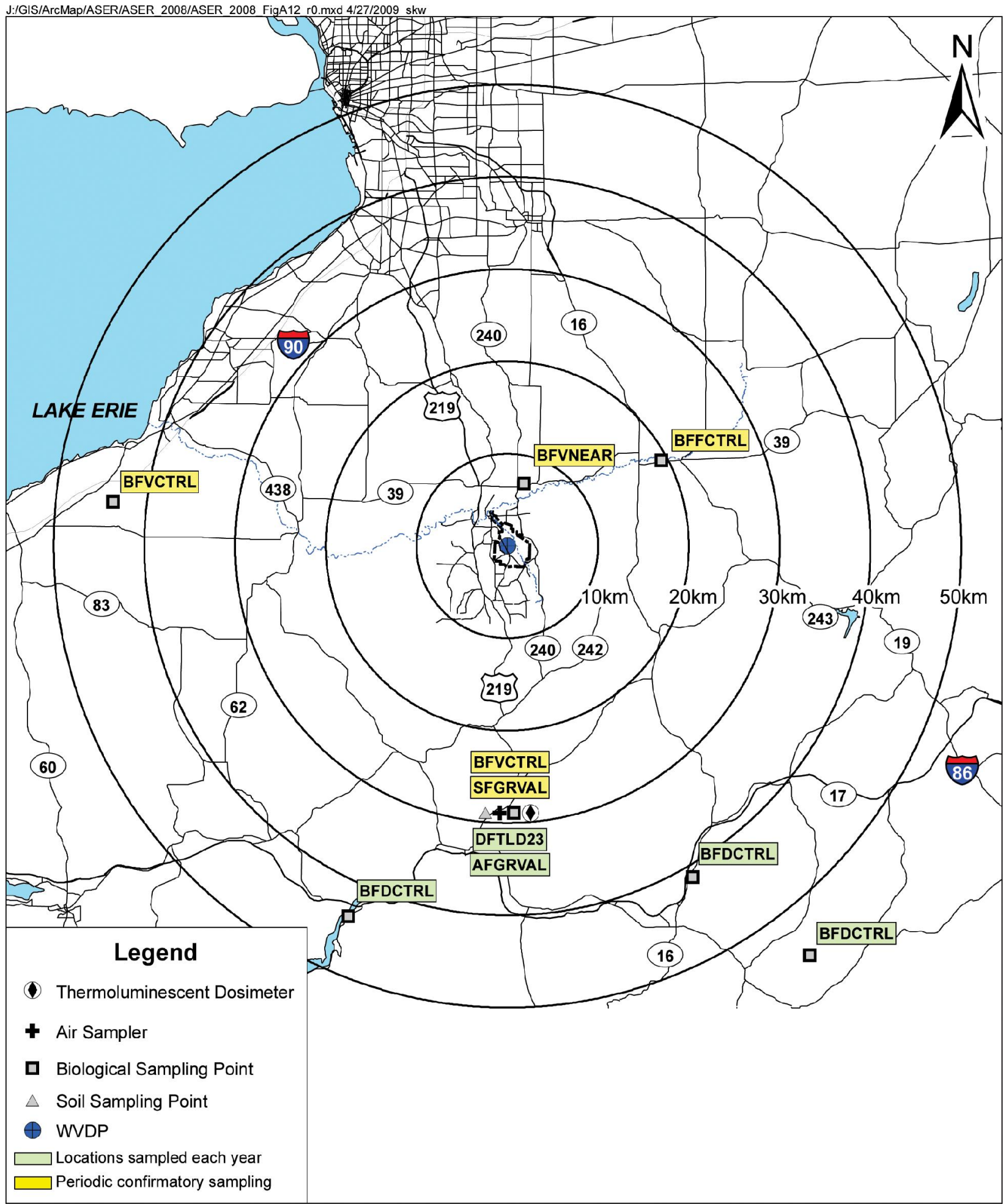

Program changes indicated in color are for CY 2008 (see pages A-17-A-22). 
FIGURE A-13

\section{U.S. Population by Sector Within 80 Kilometers of the WVDP (2002 Estimate)}

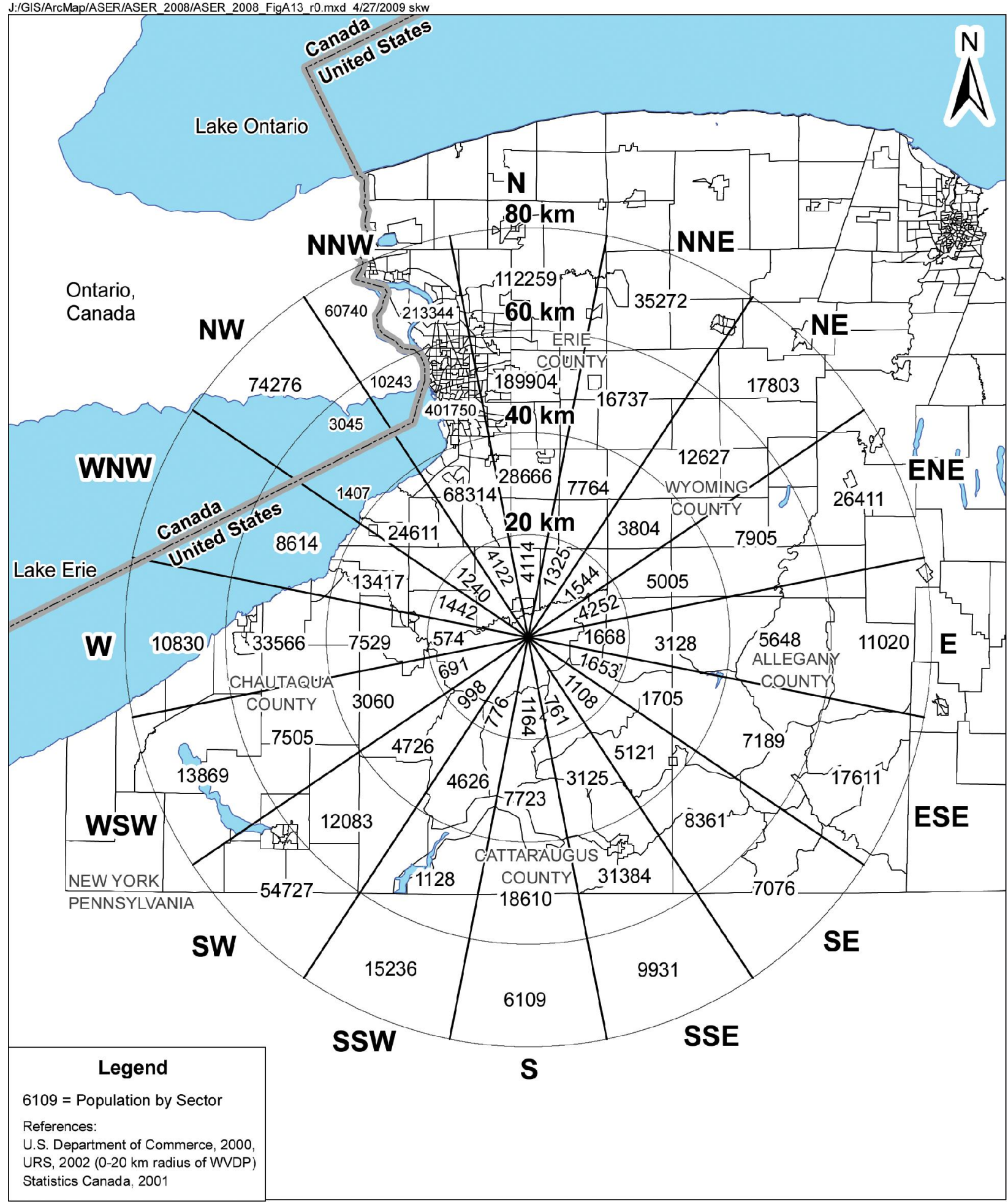


FIGURE A-14

2008 Geoprobe ${ }^{\circledR}$ Sampling Locations for the North Plateau Background Subsurface Soil Investigation

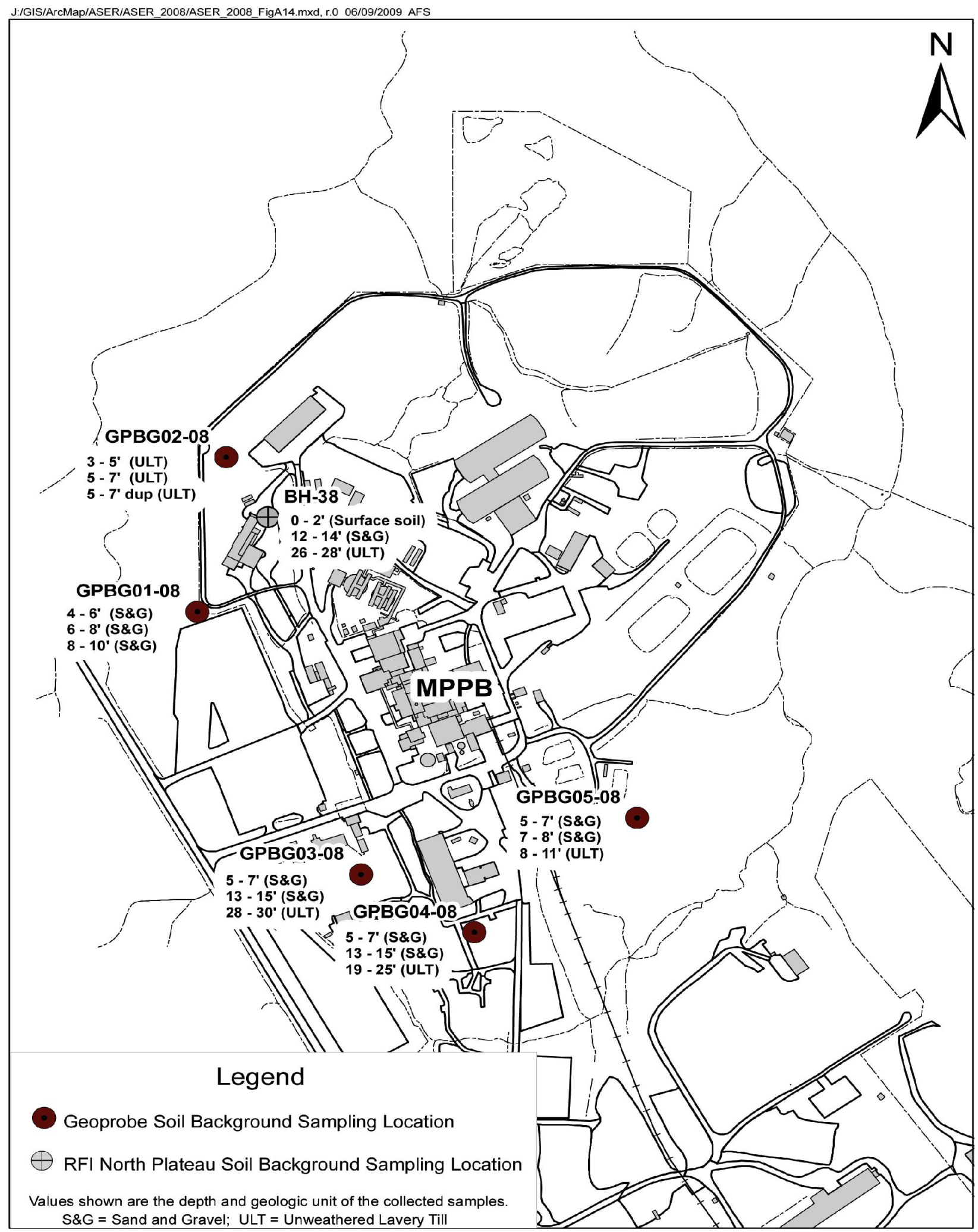


FIGURE A-15

2008 Geoprobe ${ }^{\circledR}$ Sampling Locations on the WVDP North Plateau

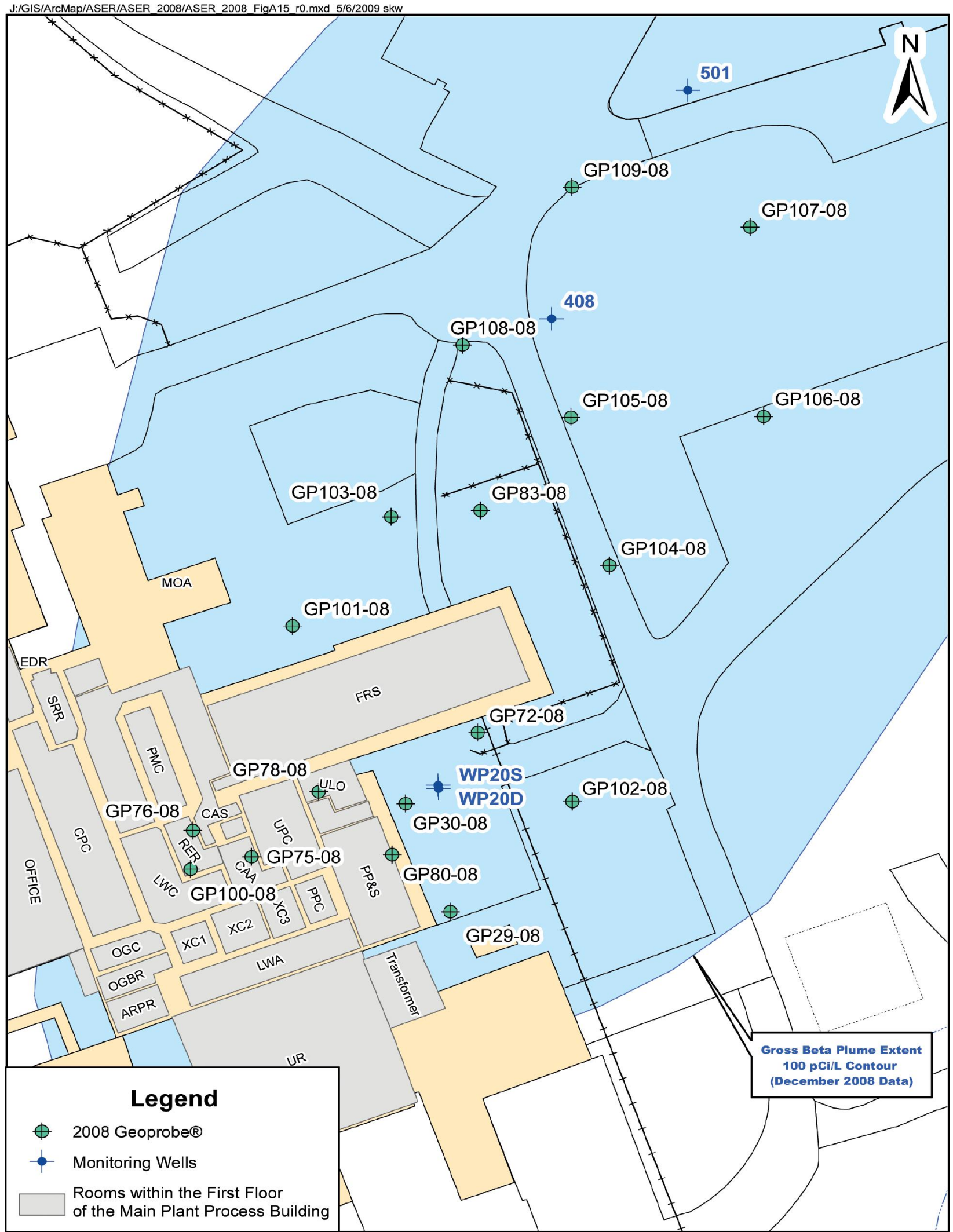


This page intentionally left blank 


\section{USEFUL INFORMAOIION}

This section provides background information that may be useful to the reader in understanding and interpreting the results presented in this Annual Site Environmental Report (ASER). First, it presents brief summaries of concepts pertaining to radiation and radioactivity, including:

- radioactive decay;

- types of ionizing radiation;

- measurement of radioactivity;

- measurement of dose;

- background radiation; and

- potential health effects of radiation.

It describes how data are presented in the ASER, and presents tables of unit prefixes, units of measure, and conversion factors. It discusses limits applicable to air emissions and water effluents, and describes (and presents a table of) the dose-based United States (U.S.) Department of Energy (DOE) derived concentration guides (DCGs). It includes a discussion of CAP88-PC, the computer code used to evaluate compliance with the air dose standard. It also presents discussions of 1 ) water quality classifications, standards, and limits for ambient water; 2) potable water standards; 3) soil and sediment guidelines; and 4) evaluation of monitoring data with respect to limits.

\section{Radiation and Radioactivity}

Radioactivity is a property of atoms with unstable nuclei. The unstable nuclei spontaneously decay by emitting radiation in the form of energy (such as gamma rays) or particles (such as alpha and beta particles) (see inset on following page). If the emitted energy or particle has enough energy to break a chemical bond or to knock an electron loose from another atom, a charged particle (an "ion") may be created. This radiation is known as "ionizing radiation."
As used in this ASER, the term "radiation" refers only to ionizing radiation and does not include nonionizing forms of radiation such as visible light, radio waves, microwaves, infrared light, or ultraviolet light.

\section{Radioactive Decay}

An atom is the smallest particle of an element. It cannot be broken down by chemical means. An atom consists of a central core (the nucleus), composed of positively charged particles (protons) and particles with no charge (neutrons), surrounded by negatively charged particles (electrons) that revolve in orbits in the region surrounding the nucleus. The protons and neutrons are much more massive than the electrons, therefore most of an atom's mass is in the nucleus.

An element is defined by the number of protons in its nucleus, its atomic number. For example, the atomic number of hydrogen is one (one proton), the atomic number of strontium is 38 (38 protons), and the atomic number of cesium is 55 ( 55 protons).

The mass number of an atom, its atomic weight, is equal to the total number of protons and neutrons in its nucleus. For example, although an atom of hydrogen will always have one proton in its nucleus, the number of neutrons may vary. Hydrogen atoms with zero, one, or two neutrons will have atomic weights of one, two, or three, respectively. These atoms are known as isotopes (or nuclides) of the element hydrogen. Elements may have many isotopes. For instance, the elements strontium and cesium have more than 30 isotopes each.

Isotopes may be stable or unstable. An atom from an unstable isotope will spontaneously change to another atom. The process by which this change occurs, that is, the spontaneous emission from the nucleus of alpha or beta particles, often accompanied by gamma radiation, is known as radioactive decay. Depending upon the type of radioactive decay,

Note: Much of the background information in this section was taken from The Handbook of Health Physics and Radiological Health (Shleien, 1998), from the Environmental Protection Agency website (www.epa.gov/radiation/ understand), and from The Health Physics Society website (http://hps.org/publicinformation). 


\section{Some Types of Ionizing Radiation}

Alpha Particles. An alpha particle is a positively charged particle consisting of two protons and two neutrons. Compared to beta particles, alpha particles are relatively large and heavy and do not travel very far when ejected by a decaying nucleus. Therefore, alpha radiation is easily stopped by a few centimeters of air or a thin layer of material, such as paper or skin. However, if radioactive material is ingested or inhaled, the alpha particles released inside the body can damage soft internal tissues because their energy can be absorbed by tissue cells in the immediate vicinity of the decay. An example of an alpha-emitting radionuclide is the uranium isotope with an atomic weight of 232 (uranium-232). Uranium-232 was in the high-level waste (HLW) mixture at the West Valley Demonstration Project (WVDP) as a result of a thorium-based nuclear fuel reprocessing campaign conducted by Nuclear Fuel Services, Inc. Uranium-232 has been detected in liquid waste streams.

Beta Particles. A beta particle is an electron emitted during the breakdown of a neutron in a radioactive nucleus. Compared to alpha particles, beta particles are smaller, have less of a charge, travel at a higher speed (close to the speed of light), and can be stopped by wood or a thin sheet of aluminum. If released inside the body, beta particles do much less damage than an equal number of alpha particles because beta particles deposit energy in tissue cells over a larger volume than alpha particles. Strontium-90, a fission product found in the liquids associated with the HLW, is an example of a beta-emitting radionuclide.

Gamma Rays. Gamma rays are high-energy "packets" of electromagnetic radiation, called photons, that are emitted from the nucleus. Gamma rays are similar to x-rays, but are generally more energetic. If an alpha or beta particle released by a decaying nucleus does not carry off all the energy generated by the nuclear disintegration, the excess energy may be emitted as gamma rays. If the released energy is high, a very penetrating gamma ray is produced that can be effectively reduced only by shielding consisting of several inches of a dense material, such as lead, or of water or concrete several feet thick. Although large amounts of gamma radiation are dangerous, gamma rays are also used in lifesaving medical procedures. An example of a gamma-emitting radionuclide is barium-137m, a short-lived daughter product of cesium-137. Both barium-137m and its precursor, cesium-137, are major constituents of the West Valley Demonstration Project (WVDP) HLW.

an atom may be transformed to another isotope of the same element or, if the number of protons in the nucleus has changed, to an isotope of another element.

Isotopes (nuclides) that undergo radioactive decay are called radioactive and are known as radioisotopes or radionuclides. Radionuclides are customarily referred to by their atomic weights. For instance, the radionuclides of hydrogen, strontium, and cesium measured at the WVDP are hydrogen-3 (also known as tritium), strontium-90, and cesium-137. For some radionuclides, such as cesium-137, a short-lived intermediate is formed that decays by gamma emission. This intermediate radionuclide may be designated by the letter " $m$ " (for metastable) following the atomic weight. For cesium-137, the intermediate radionuclide is barium-137m, with a half-life of less than three minutes.
The process of radioactive decay will continue until only a stable, nonradioactive isotope remains. Depending on the radionuclide, this process can take anywhere from less than a second to billions of years. The time required for half of the radioactivity to decay is called the radionuclide's half-life. Each radionuclide has a unique half-life. The half-life of hydrogen-3 is slightly more than 12 years, both strontium-90 and cesium-137 have half-lives of approximately 30 years, and plutonium-239 has a half-life of more than 24,000 years.

Knowledge of radionuclide half-lives is often used to estimate past and future inventories of radioactive material. For example, a 1.0 millicurie source of cesium-137 in 2006 would have measured 2.0 millicuries in 1976 and will be 0.5 millicuries in 2036. For a list of half-lives of radionuclides applicable to the WVDP, see Table UI-4. 


\section{Measurement of Radioactivity}

As they decay, radionuclides emit one or more types of radiation at characteristic energies that can be measured and used to identify the radionuclide. Detection instruments measure the quantity of radiation emitted over a specified time. From this measurement, the number of decay events (nuclear transformations) over a fixed time can be calculated.

Radioactivity is measured in units of curies (Ci) or becquerels (Bq). One $\mathrm{Ci}$ (based on the rate of decay of one gram of radium-226) is defined as the "quantity of any radionuclide that undergoes an average transformation rate of 37 billion transformations per second." In the International System of Units (SI), one Bq is equal to one transformation per second. In this ASER, radioactivity is customarily expressed in units of $\mathrm{Ci}$ followed by the equivalent $\mathrm{SI}$ unit in parentheses, as follows: $1 \mathrm{Ci}(3.7 \mathrm{E}+10 \mathrm{~Bq})$.

In this report, measurements of radioactivity in a defined volume of an environmental media, such as air or water, are presented in units of concentration. Since levels of radioactivity in the environment are typically very low, concentrations may be expressed in microcuries per milliliter, with SI units (becquerels per liter) in parentheses, as follows: $1.00 \mathrm{E}-06 \mu \mathrm{Ci} /$ $\mathrm{mL}(3.7 \mathrm{E}+01 \mathrm{~Bq} / \mathrm{L})$. (One microcurie is equal to one millionth of a curie.)

\section{Measurement of Dose}

The amount of energy absorbed by a material that receives radiation is measured in rads. A rad is 100 ergs of radiation energy absorbed per gram of material. (An erg is the approximate amount of energy necessary to lift a mosquito one-sixteenth of an inch.) "Dose" is a means of expressing the amount of energy absorbed, taking into account the effects of different kinds of radiation.

Alpha, beta, and gamma radiation affect the body to different degrees. Each type of radiation is given a quality factor that indicates the extent of human cell damage it can cause compared with equal amounts of other ionizing radiation energy. Alpha particles cause 20 times as much damage to internal tissues as $\mathrm{x}$-rays, so alpha radiation has a quality factor of 20 , compared to gamma rays, x-rays, or beta particles, each of which have a quality factor of one.

The unit of dose measurement to humans is the rem. The number of rem is equal to the number of rads multiplied by the quality factor for each type of radiation. In the SI system, dose is expressed in sieverts. One sievert (Sv) equals $100 \mathrm{rem}$. One rem equals 1,000 millirem (mrem), the unit used to express standards for dose to man from air and water sources, as applicable to this ASER. This ASER expresses dose in standard units, followed by equivalent $S I$ units in parentheses, as follows: $1 \mathrm{mrem}(0.01 \mathrm{mSv})$.

\section{Background Radiation}

Background radiation is always present, and everyone is constantly exposed to low levels of such radiation from both naturally occurring and man-made sources. In the United States the average total annual exposure to low-level background radiation is estimated to be about 360 mrem or 3.6 millisieverts (mSv). Most of this radiation, approximately 295 mrem (2.95 $\mathrm{mSv}$ ), comes from natural sources. The rest (about 65 mrem [0.65 mSv]) comes from medical procedures, consumer products, and other man-made sources (National Council on Radiation Protection and Measurements Report 93, 1987). (See Figure 3-1 in Chapter 3.)

Background radiation includes cosmic rays; the decay of natural elements, such as potassium, uranium, thorium, and radon; and radiation from sources such as chemical fertilizers, smoke detectors, and cigarettes. Actual doses vary depending on such factors as geographic location, building ventilation, and personal health and habits.

\section{Potential Health Effects of Radiation}

The three primary pathways by which people may be exposed to radiation are (1) direct exposure, (2) inhalation, and (3) ingestion. Exposure from radiation may be from a source outside the body (external exposure) or from radioactive particles that have been taken in by breathing or eating and have become lodged inside the body (internal exposure). Radionuclides that are taken in are not distributed in the same way throughout the body. Radionuclides of strontium, plutonium, and americium concentrate in the skeleton, while radioisotopes of iodine concentrate in the thyroid. Radionuclides such as hydrogen-3 (tritium), carbon-14, or cesium-137, however, will be distributed uniformly throughout the body.

Living tissue in the human body can be damaged by ionizing radiation. The severity of the damage depends upon several factors, among them the amount of exposure (low or high), the duration of the exposure (longterm [chronic] or short-term [acute]), the type of radiation 
(alpha, beta, and gamma radiations of various energies), and the sensitivity of the human (or organ) receiving the radiation. The human body has mechanisms that repair damage from exposure to radiation; however, repair processes are not always successful.

Biological effects of exposure to radiation may be either somatic or genetic. Somatic effects are limited to the exposed individual. For example, a sufficiently high exposure could cause clouding of the lens of the eye or a decrease in the number of white blood cells. Genetic effects may show up in future generations. Radiation could damage chromosomes, causing them to break or join incorrectly with other chromosomes. Radiation-produced genetic defects and mutations in the offspring of an exposed parent, while not positively identified in humans, have been observed in some animal studies.

Assessing the biological damage from low-level radiation is difficult because other factors can cause the same symptoms as radiation exposure. Moreover, the body is able to repair damage caused by low-level radiation. Epidemiological studies have not demonstrated adverse health effects in individuals exposed to small doses (less than 10 rem) over a period of years. (For comparison, note that average background radiation in the United States is about $0.36 \mathrm{rem} /$ year, and estimated annual dose from activities at the WVDP in 2008 was calculated to be about $0.000065 \mathrm{rem} /$ year [0.065 mrem/year].)

The effect most often associated with exposure to relatively high levels of radiation appears to be an increased risk of cancer. However, scientists have not been able to demonstrate with certainty that exposure to low-level radiation causes an increase in injurious biological effects, nor have they been able to determine if there is a level of radiation exposure below which there are no adverse biological effects.

\section{Data Reporting}

In the text of this ASER, radiological units (e.g., rem, rad, curie) are presented first, followed by the International System of Units (SI) equivalent in parentheses. Nonradiological measurements are presented in English units, followed by the metric unit equivalent in parentheses. See Tables UI-1, UI-2, and UI-3 for a summary of unit prefixes, units of measurement, and basic conversion factors used in this ASER.

Where results are very large or very small, scientific notation is used. Numbers greater than 10 are expressed with a positive exponent. To convert the number to its decimal form, the decimal point must be moved to the right by the number of places equal to the exponent. For example, 1.0E+06 would be expressed as 1,000,000 (one million). Numbers smaller than 1 are expressed with a negative exponent. For example, 1.0E-06 would be expressed as 0.000001 (one millionth).

TABLE UI-1 Unit Prefixes Used in This ASER

\begin{tabular}{crcc}
\multicolumn{2}{c}{ Multiplication factor } & & \\
Scientific notation & Decimal form & Prefix & Symbol \\
\hline $1.0 \mathrm{E}+06$ & 1000000 & mega & $\mathrm{M}$ \\
$1.0 \mathrm{E}+03$ & 1000 & kilo & $\mathrm{k}$ \\
$1.0 \mathrm{E}-02$ & 0.01 & centi & $\mathrm{C}$ \\
$1.0 \mathrm{E}-03$ & 0.001 & milli & $\mathrm{m}$ \\
$1.0 \mathrm{E}-06$ & 0.000001 & micro & $\mu$ \\
$1.0 \mathrm{E}-09$ & 0.000000001 & nano & $\mathrm{n}$ \\
$1.0 \mathrm{E}-12$ & 0.000000000001 & pico & $\mathrm{p}$
\end{tabular}

Radiological data are reported as a result plus or minus $( \pm)$ an associated uncertainty, customarily the $95 \%$ confidence interval. The uncertainty is in part due to the random nature of radioactive decay. Generally, the relative uncertainty in a measurement increases as the amount of radioactivity being sampled decreases. For this reason, low-level environmental analyses for radioactivity are especially prone to significant uncertainty in comparison with the result. Radiological data are presented in the following manner:

$$
\text { Example: } \begin{aligned}
& 1.04 \pm 0.54 \mathrm{E}-09 \\
& \text { Where: } \quad \begin{array}{l}
1.04=\text { the result } \\
\pm 0.54=\quad \begin{array}{l}
\text { plus or minus the } \\
\text { associated uncertainty } \\
\text { times } 10 \text { raised to the } \\
\text { power }-09
\end{array}
\end{array}
\end{aligned}
$$

Radiological results are calculated using both sample counts and background counts. If the background count is greater than the sample count, a negative result term will be reported. The constituent is considered to be detected if the result is larger than the associated uncertainty (i.e., a "positive" detection). Nonradiological data are not reported with an associated uncertainty.

In general, the detection limit is the minimum amount of a constituent that can be detected, or distinguished from background, by an instrument or a measurement 
TABLE UI-2

Units of Measure Used in This ASER

\begin{tabular}{|c|c|c|c|c|c|}
\hline Type & Measurement & Symbol & |Type & Measurement & Symbol \\
\hline \multirow[t]{6}{*}{ Length } & meter & $\mathrm{m}$ & Dose & rad (absorbed dose) & $\mathrm{rad}$ \\
\hline & centimeter & $\mathrm{cm}$ & & rem (dose equivalent) & rem \\
\hline & kilometer & $\mathrm{km}$ & & millirem & mrem \\
\hline & inch & in & & sievert & Sv \\
\hline & foot & $\mathrm{ft}$ & & millisievert & $\mathrm{mSv}$ \\
\hline & mile & $\mathrm{mi}$ & & gray & Gy \\
\hline \multirow[t]{5}{*}{ Volume } & gallon & gal & Exposure & roentgen & $\mathrm{R}$ \\
\hline & liter & $\mathrm{L}$ & & milliroentgen & $\mathrm{mR}$ \\
\hline & milliliter & $\mathrm{mL}$ & & microroentgen & $\mu \mathrm{R}$ \\
\hline & cubic meter & $\mathrm{m}^{3}$ & Concentration & parts per million & ppm \\
\hline & cubic feet & $\mathrm{ft}^{3}$ & & parts per billion & $\mathrm{ppb}$ \\
\hline \multirow[t]{4}{*}{ Area } & acre & $\mathrm{ac}$ & & parts per trillion & ppt \\
\hline & hectare & ha & & milligrams per L (ppm) & $\mathrm{mg} / \mathrm{L}$ \\
\hline & square meter & $m^{2}$ & & micrograms per $L$ (ppb) & $\mu \mathrm{g} / \mathrm{L}$ \\
\hline & square foot & $\mathrm{ft}^{2}$ & & nanograms per L (ppt) & $\mathrm{ng} / \mathrm{L}$ \\
\hline \multirow[t]{2}{*}{ Temperature } & degrees Fahrenheit & ${ }^{\circ} \mathrm{F}$ & & milligrams per kg (ppm) & $\mathrm{mg} / \mathrm{kg}$ \\
\hline & degrees Celsius & ${ }^{\circ} \mathrm{C}$ & & micrograms per g (ppm) & $\mu \mathrm{g} / \mathrm{g}$ \\
\hline \multirow[t]{8}{*}{ Mass } & gram & $\mathrm{g}$ & & micrograms per $\mathrm{mL}$ (ppm) & $\mu \mathrm{g} / \mathrm{mL}$ \\
\hline & kilogram & $\mathrm{kg}$ & & milliliters per $\mathrm{mL}$ & $\mathrm{mL} / \mathrm{L}$ \\
\hline & milligram & $\mathrm{mg}$ & & microcuries per $\mathrm{mL}$ & $\mu \mathrm{Ci} / \mathrm{mL}$ \\
\hline & microgram & $\mu g$ & & picocuries per $\mathrm{L}$ & $\mathrm{pCi} / \mathrm{L}$ \\
\hline & nanogram & ng & & microcuries per $\mathrm{g}$ & $\mu \mathrm{Ci} / \mathrm{g}$ \\
\hline & pound & $\mathrm{lb}$ & & Becquerels per $\mathrm{L}$ & $\mathrm{Bq} / \mathrm{L}$ \\
\hline & tonne (metric ton) & $\mathrm{t}$ & & nephelometric turbidity units & NTU \\
\hline & ton, short & $\mathrm{T}$ & & standard units $(\mathrm{pH})$ & SU \\
\hline \multirow[t]{6}{*}{ Radoactivity } & curie & $\mathrm{Ci}$ & Flow rate & gallons per day & gpd \\
\hline & millicurie & $\mathrm{mCi}$ & & million gallons per day & mgd \\
\hline & microcurie & $\mu \mathrm{Ci}$ & & cubic feet per minute & $\mathrm{cfm}$ \\
\hline & nanocurie & $\mathrm{nCi}$ & & liters per minute & Ipm \\
\hline & picocurie & $\mathrm{pCi}$ & & meters per second & $\mathrm{m} / \mathrm{sec}$ \\
\hline & becquerel & $\mathrm{Bq}$ & & & \\
\hline
\end{tabular}

TABLE UI-3

Conversion Factors Used in This ASER

\begin{tabular}{llc} 
To convert from & to & Multiply by \\
\hline miles & kilometers & 1.609344 \\
feet & meters & 0.3048 \\
inches & centimeters & 2.54 \\
acres & hectares & 0.4046873 \\
pounds & kilograms & 0.45359237 \\
gallons & liters & 3.785412 \\
curies & becquerels & $3.7 \mathrm{E}+10$ \\
rad & gray & 0.01 \\
rem & sievert & 0.01
\end{tabular}

Note: To convert from the units in column two to the units in column one, divide by the conversion factor. 
technique. If a result is preceded by the symbol "<" (i.e., $<5 \mathrm{ppm}$ ), the constituent was not measurable below the detection limit (in this example, 5 ppm).

The number of significant digits reported depends on the precision of the measurement technique. Integer counts are reported without rounding. Calculated values are customarily reported to three significant figures. Dose estimates are usually reported to two significant figures. All calculations are completed before values are rounded.

\section{Limits Applicable to Environmental Media}

Dose Standards. The two dose standards against which releases at the WVDP are assessed are those established by the U.S. Environmental Protection Agency (EPA) for air emissions and that established by the DOE regarding all exposure modes from DOE activities.

Radiological air emissions other than radon from DOE facilities are regulated by the EPA under the Na- tional Emission Standards for Hazardous Air Pollutants (NESHAP) regulation (40 Code of Federal Regulation [CFR] 61, Subpart H), which establishes a standard of $10 \mathrm{mrem} /$ year effective dose equivalent to any member of the public. See "CAP88-PC Computer Code" in inset.

DOE Order 5400.5 sets the DOE primary standard of $100 \mathrm{mrem} /$ year effective dose equivalent to members of the public considering all exposure modes from DOE activities. (Currently there are no EPA standards establishing limits on the radiation dose to members of the public from liquid effluents.)

Note that the EPA establishes a drinking water limit of 4-mrem/year (0.04-mSv/year) (40 CFR Parts 141 and 143, Drinking Water Guidelines). Corollary limits for community water supplies are set by the New York State Department of Health (NYSDOH) in the New York State Sanitary Code (Title 10 of the Official Compilation of Codes, Rules, and Regulations of the State of New York [NYCRR] 5-152). These limits are not applicable at the WVDP because no drinking water

\section{CAP88-PC Computer Code}

The WVDP ASER summarizes the airborne radioactivity released (see Appendix $C^{\mathrm{GP}}$ ) and the effect from those releases (Chapter 3). The computer code Clean Air Act Assessment Package-1988 for personal computers (CAP88-PC), Version 2.0, approved in October 1999, is used to perform radiation dose and risk calculations from WVDP airborne releases.

Version 3.0 of CAP88-PC (Trinity Engineering Associates, Inc., March 2006, with updates in November 2006, and March, October, and December of 2007) was approved by the EPA for use in February 2006 to demonstrate compliance with the 10-mrem/year NESHAP standard. Version 3.0 incorporates updated scientific methods to calculate radiation dose and risk. Version 3.0 also considers age and gender factors not considered in Version 2.0. Both versions use weighting factors that consider the sensitivity of various human organs to radiation. The models also calculate how long radioactive material will remain in a particular organ or system. Together, these factors are used to calculate dose and risk. Version 2.0 uses seven different organs and Version 3.0 uses 23. The risk of getting cancer from radiation exposure is calculated for 15 sites in Version 3.0 versus 10 in Version 2.0.

Upon initial and follow-up evaluation of code releases through December 2007, issues were encountered in running this new software code. At this juncture, the EPA accepts the use of any of the three approved versions of CAP88 for compliance purposes. After final evaluation (post-revision) at the WVDP, this updated (Version 3.0) code, or an appropriate approved alternative, will be used in the future at the WVDP, as recommended in the Federal Register notice.

The net effect is that dose and risk estimates summarized in the ASER from using CAP88-PC Version 2.0 and Version 3.0 are slightly different, even if the radioactivity released from WVDP and meteorology both remain constant. However, test calculations with both versions have resulted in estimated doses far below the compliance limit. 
sources within the Cattaraugus Creek drainage basin are affected by the WVDP.

Derived Concentration Guides (DCGs). A DCG is defined as the concentration of a radionuclide in air or water that, under conditions of continuous exposure by one exposure mode (i.e., ingestion of water, immersion in air, or inhalation) for one year, would result in an effective dose equivalent of 100 mrem (1 $\mathrm{mSv}$ ) to a "reference man" (DOE Order 5400.5). DCGs are applicable only at locations where members of the public could be exposed to air or water containing contaminants. DCGs for radionuclides measured at the WVDP are listed in Table UI-4. At the WVDP, DCGs are used as a screening tool for evaluating liquid effluents and airborne emissions. (DCGs are not used to estimate dose.)

State Pollutant Discharge Elimination System (SPDES) Permit Requirements. The site's SPDES permit defines points where sampling must be conducted, sampling frequency, the type of samples to be collected, constituents for which samples must be analyzed, and the limits applicable to these constituents. Results are reported monthly to the New York State Department of Environmental Conservation in a Discharge Monitoring Report. Requirements of the current permit are summarized in Appendix B-1 ${ }^{\text {ㅁ }}$.

Water Quality Classifications, Standards, and Limits for Ambient Water. The objective of the Clean Water Act of 1972 (CWA) is to restore and maintain the integrity of the nation's waters and ensure that, wherever attainable, waters be made useful for fishing and swimming. To achieve this goal, New York State is delegated with authority under Sections 118, 303, and 510 of the CWA to (1) classify and designate the best uses for receiving waters, such as streams and rivers, within its jurisdiction, and (2) establish and assign water quality standards - goals for achieving the designated best uses for these classified waters.

In addition to achieving CWA goals for fishing and swimming, New York has further classified its jurisdictional waters and established ambient water standards, guidelines, and maximum contaminant levels (MCLs) to achieve objectives under the Safe Drinking Water Act for drinking water. These standards serve as the basis for periodic evaluation of the integrity of the receiving waters and identification of needed controls.

The definitions for best usage classification of New York's jurisdictional waters and the water quality standard goals for these classifications are provided in 6 NYCRR Parts 701-704. Mapping of the Cattaraugus Creek drainage basin and assignment of best usage designations and classification to each receiving water segment within this drainage basin are described in 6 NYCRR Part 838.

According to these regulations, Franks Creek, Quarry Creek, and segments of Buttermilk Creek under the influence of water effluents from the WVDP are identified as Class " $C$ " receiving waters with a minimum designated best usage for fishing with conditions suitable for fish propagation and survival.

Cattaraugus Creek, in the immediate downstream vicinity of the Western New York Nuclear Service Center (WNYNSC), is identified as a Class "B" receiving water with best designated usages for swimming and fishing. All fresh (nonsaline) groundwaters within New York are assigned a "GA" classification with a designated best usage as a potable water supply source.

Refer to Appendix $B^{\text {GD }}$ for a summary of the water quality standards, guidelines, and MCLs assigned to these water classifications for those constituents that are included in the WVDP environmental monitoring program for ambient water.

Potable Water Standards. Standards for drinking water are established by the EPA and by NYSDOH. These standards are expressed as MCLs or maximum contaminant level goals. See Appendix $B^{\mathrm{GD}}$ for a summary of these levels.

Soil and Sediment Concentration Guidelines. The Nuclear Regulatory Commission (NRC) and the EPA, in a 2002 memorandum of understanding pertaining to decommissioning and decontamination of contaminated sites, agreed upon concentrations of residual radioactivity in soil that would trigger consultation between the two agencies. Consultation "trigger" levels for radioactive contamination in both residential and industrial soil are listed in Appendix $\mathrm{F}^{\mathrm{GD}}$ for nuclides applicable to the WVDP.

In 2006, the NRC, in a decommissioning guidance document (NUREG-1757, Vol. 2, 2006), provided concentration screening values for common radionuclides in soil that could result in a dose of 25 mrem/year. For summary tables of screening levels for radionuclides of interest at the WVDP, see Appendix $F^{\text {cod }}$.

In 1999, NYSDEC issued updated guidance for screening contaminated aquatic sediments for metals. This guidance includes sediment quality criteria correlated 
to the severity of environmental impact. These criteria, which are derived from National Oceanic and Atmospheric Administration (Long and Morgan, 1990) and 1992 Ministry of Ontario "Guidelines for the Protection and Management of Aquatic Sediment Quality in Ontario" (Persaud et al., 1992), are presented in Appendix $\mathrm{F}^{\mathrm{GD}}$.

Contaminants in soil are potential sources for contamination of groundwater, ambient air, and plants and animals. Appendix $\mathrm{F}^{\mathrm{GD}}$ includes a summary of screening criteria from NYSDEC and 6 NYCRR. Criteria include background concentration ranges for eastern United States soil.
No criteria specific to subsurface soil are presently available. However, dose-based derived concentration guideline levels specific to subsurface soil at the WVDP were proposed as part of the "Phase I Decommissioning Plan for the West Valley Demonstration Project" (March 2009).

\section{Evaluation of Monitoring Data with Respect to Limits}

Monitoring data for this report were evaluated against the limits presented in Table UI-4, and Appendix $\mathrm{B}^{\mathrm{KD}}$. Those locations with results exceeding the limits are listed in Chapter 2, Table 2-4.

\begin{tabular}{|c|c|c|c|}
\hline \multicolumn{4}{|c|}{$\begin{array}{c}\text { TABLE UI-4 } \\
\text { U.S. Department of Energy Derived Concentration Guides (DCGs) }{ }^{a} \text { for Inhaled Air or } \\
\text { Ingested Water }(\mu \mathrm{Ci} / \mathrm{mL})\end{array}$} \\
\hline Radionuclide & Half-life (years) ${ }^{b}$ & DCG in Air & DCG in Water \\
\hline Gross Alpha (as Am-241) ${ }^{c}$ & NA & $2 \mathrm{E}-14$ & $3 \mathrm{E}-08$ \\
\hline Gross Beta (as Sr-90) ${ }^{c}$ & NA & $9 \mathrm{E}-12$ & $1 \mathrm{E}-06$ \\
\hline Tritium (H-3) & $1.23 \mathrm{E}+01$ & $1 \mathrm{E}-07$ & $2 \mathrm{E}-03$ \\
\hline Carbon-14 (C-14) & $5.70 \mathrm{E}+03$ & $6 \mathrm{E}-09$ & 7E-05 \\
\hline Potassium-40 (K-40) & $1.25 \mathrm{E}+09$ & $9 \mathrm{E}-10$ & $7 E-06$ \\
\hline Cobalt-60 (Co-60) & $5.27 \mathrm{E}+00$ & $8 \mathrm{E}-11$ & $5 \mathrm{E}-06$ \\
\hline Strontium-90 (Sr-90) & $2.89 \mathrm{E}+01$ & $9 \mathrm{E}-12$ & $1 \mathrm{E}-06$ \\
\hline Technetium-99 (Tc-99) & $2.11 \mathrm{E}+05$ & $2 \mathrm{E}-09$ & $1 \mathrm{E}-04$ \\
\hline lodine-129 (I-129) & $1.57 \mathrm{E}+07$ & $7 E-11$ & $5 \mathrm{E}-07$ \\
\hline Cesium-137 (Cs-137) & $3.00 \mathrm{E}+01$ & $4 \mathrm{E}-10$ & $3 \mathrm{E}-06$ \\
\hline Europium-154 (Eu-154) & $8.59 \mathrm{E}+00$ & $5 \mathrm{E}-11$ & $2 \mathrm{E}-05$ \\
\hline Uranium-232 (U-232) & $6.89 E+01$ & $2 \mathrm{E}-14$ & $1 \mathrm{E}-07$ \\
\hline Uranium-233 (U-233) & $1.59 \mathrm{E}+05$ & $9 \mathrm{E}-14$ & $5 \mathrm{E}-07$ \\
\hline Uranium-234 (U-234) & $2.46 \mathrm{E}+05$ & $9 \mathrm{E}-14$ & $5 \mathrm{E}-07$ \\
\hline Uranium-235 (U-235) & $7.04 \mathrm{E}+08$ & $1 \mathrm{E}-13$ & $6 \mathrm{E}-07$ \\
\hline Uranium-236 (U-236) & $2.34 \mathrm{E}+07$ & $1 \mathrm{E}-13$ & $5 E-07$ \\
\hline Uranium-238 (U-238) & $4.47 E+09$ & $1 \mathrm{E}-13$ & $6 \mathrm{E}-07$ \\
\hline Plutonium-238 (Pu-238) & $8.77 E+01$ & $3 E-14$ & $4 \mathrm{E}-08$ \\
\hline Plutonium-239 (Pu-239) & $2.41 \mathrm{E}+04$ & $2 \mathrm{E}-14$ & $3 \mathrm{E}-08$ \\
\hline Plutonium-240 (Pu-240) & $6.56 \mathrm{E}+03$ & $2 \mathrm{E}-14$ & $3 \mathrm{E}-08$ \\
\hline Americium-241 (Am-241) & $4.32 \mathrm{E}+02$ & $2 \mathrm{E}-14$ & $3 \mathrm{E}-08$ \\
\hline \multicolumn{4}{|c|}{$\begin{array}{l}\text { DCGs are established in DOE Order } 5400.5 \text { and are defined as the concentration of a radionuclide that, under } \\
\text { conditions of continuous exposure for one year by one exposure mode, would result in an effective dose } \\
\text { equivalent of } 100 \text { mrem ( } 1 \mathrm{mSv} \text { ). } \\
\text { b Nuclear Wallet Cards. April 2005. National Nuclear Data Center. Brookhaven National Laboratory. Upton, New York. } \\
\text { c Because there are no DCGs for gross alpha and gross beta concentrations, the DCGs for the most restrictive } \\
\text { alpha and beta emitters at the WVDP (americium-241 and strontium-90, respectively) are used as a conserva- } \\
\text { tive basis for comparison at locations for which there are no radionuclide-specific data, in which case a more } \\
\text { appropriate DCG may be applied. }\end{array}$} \\
\hline
\end{tabular}




\section{GLOSSARY}

A

accuracy - The degree of agreement between a measurement and its true value. The accuracy of a data set is assessed by evaluating results from standards or sample spikes containing known quantities of an analyte.

action plan - An action plan addresses assessment findings and root causes that have been identified in an audit or an assessment report. It is intended to define specific actions that the responsible group will undertake to remedy deficiencies. The plan includes a timetable and resource requirements for implementation of the planned activities.

aquifer - A water-bearing unit of permeable rock or soil that will yield water in usable quantities via wells. Confined aquifers are bounded above and below by less permeable layers. Groundwater in a confined aquifer may be under a pressure greater than the atmospheric pressure. Unconfined aquifers are bounded below by less permeable material, but are not bounded above. The pressure on the groundwater at the surface of an unconfined aquifer is equal to that of the atmosphere.

as low as reasonably achievable (ALARA) - An approach to radiation protection that advocates controlling or managing exposures (both individual and collective) to the work force and the general public and releases of radioactive material to the environment as low as social, technical, economic, practical, and public policy considerations permit. As used in United States Department of Energy (DOE) Order 5400.5, ALARA is not a dose limit but, rather, a process that has as its objective the attainment of dose levels as far below the applicable limits of the Order as practicable.

\section{B}

background radiation - Natural and man-made radiation such as: cosmic radiation, radiation from naturally radioactive elements, and radiation from commercial sources and medical procedures. becquerel (Bq) - A unit of radioactivity equal to one nuclear transformation per second.

C

categorical exclusion (CX) - A proposed action that the DOE has determined does not individually or cumulatively have a significant effect on the human environment. See 10 Code of Federal Regulations (CFR) 1021.410.

Class A, B, and C low-level waste - Waste classifications from the Nuclear Regulatory Commission's 10 CFR Part 61 rule. Maximum concentration limits are set for specific isotopes. Class A waste disposal is minimally restricted with respect to the form of the waste. Class B waste must meet more rigorous requirements to ensure physical stability after disposal. Higher radionuclide concentration limits are set for Class $C$ waste (the most radioactive), which also must meet physical stability requirements. Moreover, special measures must be taken at the disposal facility to protect against inadvertent intrusion.

compliance findings - Conditions that may not satisfy applicable environmental or safety and health regulations, DOE Orders and memoranda, enforcement actions, agreements with regulatory agencies, or permit conditions.

confidence interval - The range of values within which some parameter may be expected to lie with a stated degree of confidence. For example, a value of 10 with an uncertainty of 5 calculated at the $95 \%$ confidence level $(10 \pm 5)$ indicates there is a $95 \%$ probability that the true value of that parameter lies between 5 and 15 .

consistency - The condition of showing steady conformity to practices. In the environmental monitoring program, approved procedures are in place so that data collection activities are carried out in a uniform manner to minimize variability.

Core Team - The "core team approach" is a formalized, consensus-based process in which those individuals with decision-making authority, including the 
U.S. Department of Energy (DOE), the U.S. Environmental Protection Agency (EPA), and State remedial project managers, work together to reach agreement on key remediation decisions (DOE/EH-413-9911, October 1999). In August 2006, the DOE-West Valley Demonstration Project (DOE-WVDP) requested that the New York State Department of Health (NYSDOH), the U.S. Nuclear Regulatory Commission (NRC), the EPA (region 2), the New York State Department of Environmental Conservation (NYSDEC), and the New York State Energy Research and Development Authority (NYSERDA) participate in a collaborative process (i.e., Core Team) to resolve technical issues associated with the "Draft Environmental Impact Statement for Decommissioning and/or Long-Term Stewardship at the West Valley Demonstration Project and Western New York Nuclear Service Center" (DEIS). The WVDP Core Team has been participating in this process since then.

cosmic radiation - High-energy subatomic particles from outer space that bombard the earth's atmosphere. Cosmic radiation is part of natural background radiation.

curie (Ci) - A unit of radioactivity equal to 37 billion $\left(3.7 \times 10^{10}\right)$ nuclear transformations per second.

\section{D}

data set - A group of data (e.g., factual information such as measurements or statistics) used as a basis for reasoning, discussion, or calculation.

decay (radioactive) - Disintegration of the nucleus of an unstable nuclide by spontaneous emission of charged particles and/or photons or by spontaneous fission.

derived concentration guide (DCG) - The concentration of a radionuclide in air and water that, under conditions of continuous human exposure for one year by one exposure mode (i.e., ingestion of water, inhalation, or immersion in a gaseous cloud), would result in an effective dose equivalent of 100 mrem (1 $\mathrm{mSv}$ ). See Table UI-4 in the "Useful Information" section of this report.

detection limit or level (DL) - This term may also be expressed as "method detection limit" (MDL). The smallest amount of a substance that can be distinguished in a sample by a given measurement procedure at a given confidence level. (See lower limit of detection.) dispersion (airborne) - The process whereby particulates or gases are spread and diluted in air as they move away from a source.

dispersion (groundwater) - The process whereby solutes are spread or mixed as they are transported by groundwater as it moves through the subsurface.

dosimeter - A portable device for measuring the total accumulated exposure to ionizing radiation.

downgradient - The direction of water flow from a reference point to a selected point of interest at a lower elevation than the reference point. (See gradient.)

E

effective dose - (See effective dose equivalent under radiation dose.)

effluent - Any treated or untreated air emission or liquid discharge to the environment.

effluent monitoring - Sampling or measuring specific liquid or gaseous effluent streams for the presence of pollutants to determine compliance with applicable standards, permit requirements, and administrative controls.

environmental assessment (EA) - An evaluation that provides sufficient evidence and analysis for determining whether an environmental impact statement is required or a finding of no significant impact should be issued. See 10 CFR 1021.

environmental impact statement (EIS) - A detailed statement that includes the environmental impact of the proposed action, any adverse environmental effects that cannot be avoided should the proposal be implemented, and alternatives to the proposed action. Detailed information may be found in Section 10 CFR 1021.

environmental management system (EMS) - The systematic application of business management practices to environmental issues, including defining the organizational structure, planning for activities, identifying responsibilities, and defining practices, procedures, processes, and resources.

environmental monitoring - The collection and analysis of samples or the direct measurement of environmental media. Environmental monitoring consists of 
two major activities: effluent monitoring and environmental surveillance.

environmental surveillance - The collection and analysis of samples or the direct measurement of air, water, soil, foodstuff, and biota in the environs of a facility of interest to determine compliance with applicable standards and to detect trends and environmental pollutant transport.

exposure - The subjection of a target (usually living tissue) to radiation.

\section{$\mathbf{F}$}

fallout - The settling to earth of radioactive materials mixed into the earth's atmosphere.

finding - A DOE compliance term. A finding is a statement of fact concerning a condition in the Environmental, Safety, and Health program that was investigated during an appraisal. Findings include best management practice findings, compliance findings, and noteworthy practices. A finding may be a simple statement of proficiency or a description of deficiency (i.e., a variance from procedures or criteria). (See also self-assessment.)

fission - The act or process of splitting into parts. A nuclear reaction in which an atomic nucleus splits into fragments (i.e., fission products, usually fragments of comparable mass) with the evolution of approximately 100 million to several hundred million electron volts of energy.

\section{G}

gamma isotopic (also gamma scan) - An analytical method by which the quantity of several gamma rayemitting radioactive isotopes may be determined simultaneously. Typical nuclear fuel cycle isotopes determined by this method include, but are not limited to, cobalt-60, zirconium-95, ruthenium-106, silver-110m, antimony-125, cesium-134, cesium-137, and europium-154. Naturally occurring isotopes for which samples may be analyzed are beryllium-7, potassium-40, radium-224, and radium-226.

gradient - Change in value of one variable with respect to another variable, such as a vertical change over a horizontal distance.

groundwater - Subsurface water in the pore spaces and fractures of soil and bedrock units.
H

half-life - The time in which half the atoms of a radionuclide disintegrate into another nuclear form. The half-life may vary from a fraction of a second to billions of years.

hazardous waste - $A$ waste or combination of wastes that because of quantity, concentration, or physical, chemical, or infectious characteristics may: a) cause or significantly contribute to an increase in mortality or an increase in serious irreversible or incapacitating reversible illness; or (b) pose a substantial present or potential hazard to human health or the environment when improperly treated, stored, transported, disposed of, or otherwise managed.

high-level waste (HLW) - The highly radioactive waste material that results from the reprocessing of spent nuclear fuel, including liquid waste produced directly in reprocessing and solid waste derived from the liquid, that contains a combination of transuranic waste and fission products in concentrations sufficient to require permanent isolation. (See also transuranic waste.)

hydraulic conductivity - The ratio of flow velocity to driving force for viscous flow under saturated conditions of a specified liquid in a porous medium; the ratio describing the rate at which water can move through a permeable medium.

\section{I}

integrated safety management system (ISMS) - The ISMS describes the programs, policies, and procedures used by West Valley Environmental Services LLC (WVES) and the DOE to ensure that WVES establishes a safe workplace for the employees, the public, and the environment. The guiding principles of ISMS are line management responsibility for safety; clear roles and responsibilities; competence commensurate with responsibilities; balanced priorities; identification of safety standards and requirements; hazard controls; and operations authorization.

interim status - The status of any currently existing facility that becomes subject to the requirement to have a Resource Conservation and Recovery Act (RCRA) permit because of a new statutory or regulatory amendment to RCRA.

ion - An atom or group of atoms with an electric charge. 
ion exchange - The reversible exchange of ions contained in solution with other ions that are part of the ion-exchange material.

isotope - Different forms of the same chemical element that are distinguished by having the same number of protons but a different number of neutrons in the nucleus. An element can have many isotopes. For example, the three isotopes of hydrogen are protium, deuterium, and tritium, with one, two, and three neutrons in the nucleus, respectively.

$\mathbf{L}$

land disposal restrictions (LDR) - Regulations promulgated by the United States Environmental Protection Agency (EPA) (and by the New York State Department of Environmental Conservation [NYSDEC] in New York State) governing the land disposal of hazardous wastes. The wastes must be treated using the best demonstrated available technology or must meet certain treatment standards before being disposed.

lower limit of detection (LLD) - The lowest limit of a given parameter that an instrument is capable of detecting. A measurement of analytical sensitivity.

low-level waste (LLW) - Radioactive waste not classified as high-level waste, transuranic waste, spent fuel, or uranium mill tailings. (See Class $A, B$, and $C$ low-level waste.)

\section{M}

maximally exposed individual (MEI) - On-site (occupational) or off-site (nonoccupational) person that receives the highest dose from a release scenario.

maximally exposed off-site individual (MEOSI) - Member of the general public receiving the highest dose from the effluent release.

mean - The average value of a series of measurements.

metric ton - (See ton, metric.)

millirem (mrem) - A unit of radiation dose equivalent that is equal to one one-thousandth of a rem. An individual member of the public can receive up to 100 mrem per year according to DOE standards. This limit does not include radiation received for medical treatment (approximately $65 \mathrm{mrem}$ ) or the roughly 295 mrem, on average, that people receive annually from background radiation. minimum detectable concentration (MDC) or method detection limit (MDL) - Depending on the sample medium, the smallest amount or concentration of a radioactive or nonradioactive analyte that can be reliably detected using a specific analytical method. Calculations of the minimum detectable concentrations are based on the lower limit of detection.

mixed waste (MW) - A waste that is both radioactive and RCRA hazardous.

$\mathbf{N}$

n-Dodecane/tributyl phosphate - An organic solution composed of $30 \%$ tributyl phosphate (TBP) dissolved in $n$-dodecane used to first separate the uranium and plutonium from the fission products in dissolved nuclear fuel and then to separate the uranium from the plutonium.

neutron - An electrically neutral subatomic particle in the baryon family with a mass 1,839 times that of an electron, stable when bound in an atomic nucleus, and having a mean lifetime of approximately 16.6 minutes as a free particle.

notice of violation (NOV) - Generally, an official notification from a regulatory agency of noncompliance with permit requirements. (An example would be a letter of notice from a regional water engineer in response to an instance of significant noncompliance with a State Pollutant Discharge Elimination System [SPDES] permit.)

nucleus - The positively-charged central region of an atom, made up of protons and neutrons and containing almost all of the mass of the atom.

-

outfall - The discharge end of a drain or pipe that carries wastewater or other liquid effluents into a ditch, pond, or river.

$\mathbf{P}$

parameter - Any of a set of physical properties whose values determine the characteristics or behavior of something (e.g., temperature, pressure, density of air). In relation to environmental monitoring, a monitoring parameter is a constituent of interest. Statistically, the term "parameter" is a calculated quantity, such as a mean or variance, that describes a statistical population. 
particulates - Solid particles and liquid droplets small enough to become airborne.

person-rem - The sum of the individual radiation dose equivalents received by members of a certain group or population. It may be calculated by multiplying the average dose per person by the number of persons exposed. For example, a thousand people each exposed to one millirem would have a collective dose of one person-rem.

plume - The distribution of a pollutant in air or water after being released from a source.

practical quantitation limits (PQLs) - The PQL is the minimum concentration of an analyte that can be measured within specified limits of precision during routine laboratory operations (New York State Department of Environmental Conservation, 1991).

precision - The degree of reproducibility of a measurement under a given set of conditions. Precision in a data set is assessed by evaluating results from duplicate field or analytical samples.

proton - A stable, positively-charged subatomic particle in the baryon family with a mass 1,836 times that of an electron.

pseudo-monitoring point - $A$ theoretical monitoring location rather than an actual physical location; a calculation based on analytical test results of samples obtained from other associated, tributary, monitored locations. (Point 116 at the WVDP is classified as a "pseudo" monitoring point because samples are not physically collected at that location. Rather, using analytical results from samples collected from "real" upstream outfall locations, compliance with the total dissolved solids limit in the WVDP's SPDES permit is calculated for this theoretical point.)

\section{Q}

quality factor (QF) - The extent of tissue damage caused by different types of radiation of the same energy. The greater the damage, the higher the quality factor. More specifically, the factor by which absorbed doses are multiplied to obtain a quantity that indicates the degree of biological damage produced by ionizing radiation. See radiation dose.) The factor is dependent upon radiation type (alpha, beta, gamma, or x-ray) and exposure (internal or external).
$\mathbf{R}$

rad - Radiation absorbed dose. One hundred ergs of energy absorbed per gram of solid material.

radiation - The process of emitting energy in the form of rays or particles that are thrown off by disintegrating atoms. The rays or particles emitted may consist of alpha, beta, or gamma radiation.

alpha radiation - The least penetrating type of radiation. Alpha radiation (similar to a helium nucleus) can be stopped by a sheet of paper or the outer dead layer of skin.

beta radiation - Electrons emitted from a nucleus during fission and nuclear decay. Beta radiation can be stopped by an inch of wood or a thin sheet of aluminum.

gamma radiation - A form of electromagnetic, high-energy radiation emitted from a nucleus. Gamma rays are essentially the same as $x$-rays and require heavy shielding such as lead, concrete, or steel to be effectively attenuated.

internal radiation - Radiation originating from a source within the body as a result of the inhalation, ingestion, or implantation of natural or man-made radionuclides in body tissues.

\section{radiation dose:}

absorbed dose - The amount of energy absorbed per unit mass in any kind of matter from any kind of ionizing radiation. Absorbed dose is measured in rads or grays.

collective dose equivalent - The sum of the dose equivalents for all the individuals comprising a defined population. The per capita dose equivalent is the quotient of the collective dose equivalent divided by the population. The unit of collective dose equivalent is person-rem or person-sievert.

collective effective dose equivalent - The sum of the effective dose equivalents for the individuals comprising a defined population. Units of measurement are person-rem or person-sievert. The per capita effective dose equivalent is obtained by dividing the collective dose equivalent by the population. Units of measurement are rem or sievert. 
committed dose equivalent - A measure of internal radiation. The predicted total dose equivalent to a tissue or organ over a fifty-year period after a known intake of a radionuclide into the body. It does not include contributions from sources of external penetrating radiation. Committed dose equivalent is measured in rem or sievert.

committed effective dose equivalent - The sum of the committed dose equivalents to various tissues in the body, each multiplied by the appropriate weighting factor. Committed effective dose equivalent is measured in rem or sievert.

total effective dose equivalent - The summation of the products of the dose equivalent received by specified tissues of the body and the appropriate weighting factors. It includes the dose from radiation sources internal and/or external to the body. The effective dose equivalent is expressed in units of rem or seivert.

radioactivity - A property possessed by some elements (such as uranium) whereby alpha, beta, or gamma rays are spontaneously emitted.

radioisotope - A radioactive isotope of a specified element. Carbon-14 is a radioisotope of carbon. Tritium is a radioisotope of hydrogen. (See isotope.)

radionuclide - A radioactive nuclide. Radionuclides are variations (isotopes) of elements. They have the same number of protons and electrons but different numbers of neutrons, resulting in different atomic masses. There are hundreds of known nuclides, both man-made and naturally occurring.

reference man - A hypothetical aggregation of human physical and physiological characteristics arrived at by international consensus. These characteristics may be used by researchers and public health workers to standardize results of experiments and to relate biological insult to a common base.

rem - An acronym for Roentgen Equivalent Man. A unit of radiation exposure that indicates the potential effect of radiation on human cells.

remote-handled waste - At the WVDP, waste that has an external surface dose rate that exceeds 100 millirem per hour or a high level of alpha and/or beta surface contamination and, therefore, must be handled in such a manner that it does not come into physical contact with workers. roentgen - $A$ unit of exposure to ionizing radiation. It is that quantity of gamma or x-rays required to produce ions carrying one electrostatic unit of electrical charge in one cubic centimeter of dry air under standard conditions. The unit is named after Wilhelm Roentgen, German scientist who discovered x-rays in 1895.

\section{S}

self-assessment - Appraisals of work at the WVDP by individuals, groups, or organizations responsible for overseeing and/or performing the work. Self-assessments are intended to provide an internal review of performance to determine that specific functional areas are in programmatic and site-specific compliance with applicable DOE directives, WVDP procedures, and regulations.

finding - A direct and significant violation of applicable DOE, regulatory, or other procedural or programmatic requirements. A finding requires documented corrective action.

observation - A condition that, while not a direct and significant violation of applicable DOE, regulatory, or other procedural or programmatic requirements, could result in a finding if not corrected. An observation requires documented corrective action.

good practice - A statement of proficiency or confirmed excellence worthy of documenting.

sievert - A unit of dose equivalent from the International System of Units (Systeme Internationale). Equal to one joule per kilogram.

solid waste management unit (swmu) - Any discernible unit at which solid wastes have been placed at any time, irrespective of whether the unit was intended for the management of solid or hazardous waste. Such units include any area at a facility at which solid wastes have been routinely and systematically released or created. (See also super solid waste management unit.)

spent fuel - Nuclear fuel that has been used in a nuclear reactor; this fuel contains uranium, activation products, fission products, and plutonium.

spill - A spill or release is defined as "any spilling, leaking, pumping, pouring, emitting, emptying, discharging, injecting, escaping, leaching, dumping, or otherwise disposing of substances from the ordinary 
containers employed in the normal course of storage, transfer, processing, or use", outside of the intended procedural action.

stakeholder - A person or group that has an investment, share, or interest in something. At the WVDP stakeholders include Project management, scientists, other employees, politicians, regulatory agencies, local and national interest groups, and members of the general public.

standard deviation - An indication of the dispersion of a set of results around their average.

super solid waste management unit (SSWMU) - Individual solid waste management units that have been grouped and ranked into larger units - super solid waste management units - because some individual units are contiguous or so close together as to make monitoring of separate units impractical. This terminology is unique to the WVDP, and is not an official regulatory term. (See also solid waste management unit.)

surface water - Water that is exposed to the atmospheric conditions of temperature, pressure, and chemical composition at the surface of the earth.

surveillance - The act of monitoring or observing a process or activity to verify conformance with specified requirements.

$\mathbf{T}$

thermoluminescent dosimeter (TLD) - A device that luminesces upon heating after being exposed to radiation. The amount of light emitted is proportional to the amount of radiation to which the luminescent material has been exposed.

ton, metric (also tonne) - A unit of mass equal to 1,000 kilograms. (See also Table UI-2, "Units of Measure Used in This ASER.")

ton (short ton) - A unit of weight equal to 2,000 pounds or 907.1847 kilograms. (See also Table UI-2, "Units of Measure Used in This ASER.)

transuranic (TRU) waste - Waste containing transuranic elements, that is, those elements with an atomic number greater than 92, including neptunium, plutonium, americium, and curium.
U

universal wastes - Wastes subject to special management provisions that are intended to ease the management burden and facilitate recycling of such materials. Four types of waste are currently covered under the universal waste regulations: hazardous waste batteries, hazardous waste pesticides that are either recalled or collected in waste pesticide collection programs, hazardous waste thermostats, and hazardous waste lamps.

upgradient - Referring to the flow of water or air, "upgradient" is analogous to upstream. Upgradient is a point that is "before" an area of study and that is used as a baseline for comparison with downstream or downgradient data. (See gradient and downgradient.)

V

vitrification - A waste treatment process that encapsulates or immobilizes radioactive wastes in a glassy matrix to prevent them from reacting in disposal sites. Vitrification involves adding chemicals, glass formers, and waste to a heated vessel and melting the mixture into a glass that is then poured into a canister.

$\mathbf{W}$

watershed - The area contained within a drainage divide above a specified point on a stream or river.

water table - The upper surface in a body of groundwater; the surface in an unconfined aquifer or confining bed at which the pore water pressure is equal to atmospheric pressure.

\section{$\mathbf{x}$}

x-ray - Penetrating electromagnetic radiations having wave lengths shorter than those of visible light. They are usually produced by bombarding a metallic target with fast electrons in a high vacuum. In nuclear reactions it is customary to refer to photons originating in the nucleus as gamma rays and those originating in the extranuclear part of the atom as $x$-rays. These rays are sometimes called Roentgen rays after their discoverer, W.C. Roentgen. 
This page intentionally left blank 

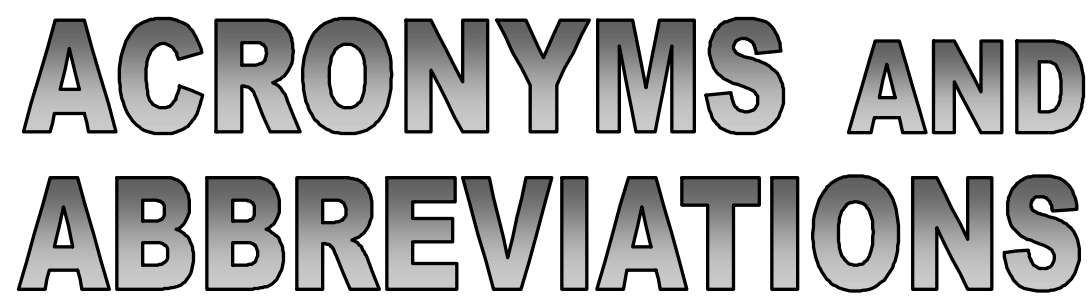

A

ACM - Asbestos-Containing Material

AEA - Atomic Energy Act

ALARA - As Low As Reasonably Achievable

alpha-BHC - alpha-Hexachlorocyclohexane

ANSI - American National Standards Institute

ASER - Annual Site Environmental Report

ASME - American Society of Mechanical Engineers

ASQ - American Society for Quality

AWQS - Ambient Water Quality Standard

B

BAT - Best Available Technology

BCG - Biota Concentration Guide

BEIR - Biological Effects of Ionizing Radiation

BOD $_{5}$ - Biochemical Oxygen Demand (5-day)

Bq - Becquerel

BR - Shale Bedrock

BSW - Bulk Storage Warehouse

$$
\text { C }
$$

CAA - Clean Air Act

CBS - Chemical Bulk Storage

CCHD - Cattaraugus County Health Department

CCZ - Criticality Control Zone

CD - Compact Disk

CDDL - Construction and Demolition Debris Landfill

CEDE - Committed Effective Dose Equivalent

CEMP - Code of Environmental Management Principles (for Federal Agencies)

CERCLA - Comprehensive Environmental Response,

Compensation, and Liability Act

CFR - Code of Federal Regulations

Ci - Curie

CMS - Corrective Measures Study

CPC - Chemical Process Cell

CPC-WSA - Chemical Process Cell Waste Storage Area

CSPF - Container Sorting and Packaging Facility

CSRF - Contact Size-Reduction Facility

CSS - Cement Solidification System

CTF - (West Valley) Citizen Task Force
CUP - Cask Unloading Pool

CWA - Clean Water Act

CX - Categorical Exclusion

CY - Calendar Year

D

D\&D - Decontamination and Decommissioning

DCDFMeth - Dichlorodifluoromethane

DEIS - Draft Environmental Impact Statement

DCG - Derived Concentration Guide

DL - Detection Limit or Detection Level

DMR - Discharge Monitoring Report

DOE - (U.S.) Department of Energy

DOE-EM - Department of Energy, Office of Environmental Management

DOE-HQ - Department of Energy, Headquarters Office DOE-WVDP - Department of Energy, West Valley Demonstration Project (title as of June 2006)

DOT - (U.S.) Department of Transportation

DWW - Dewatering Well

E

E.O. - Executive Order

EA - Environmental Assessment

ECL - (New York State) Environmental Conservation Law

EDE - Effective Dose Equivalent

EHS - Extremely Hazardous Substance

EIS - Environmental Impact Statement

ELAB - (WVDP) Environmental Laboratory

ELAP - (New York State Department of Health) Envi-

ronmental Laboratory Approval Program

EMS - Environmental Management System

EOC - Emergency Operations Center

EPA - (U.S.) Environmental Protection Agency

EPCRA - Emergency Planning and Community Rightto-Know Act

ERO - Emergency Response Organization

ES\&H - Environmental, Safety, and Health

ESR - (WVDP) Effluent Summary Report

Note: For abbreviations of units of measure, see Table UI-2 ("Units of Measure Used in This ASER") in the "Useful Information" section. 


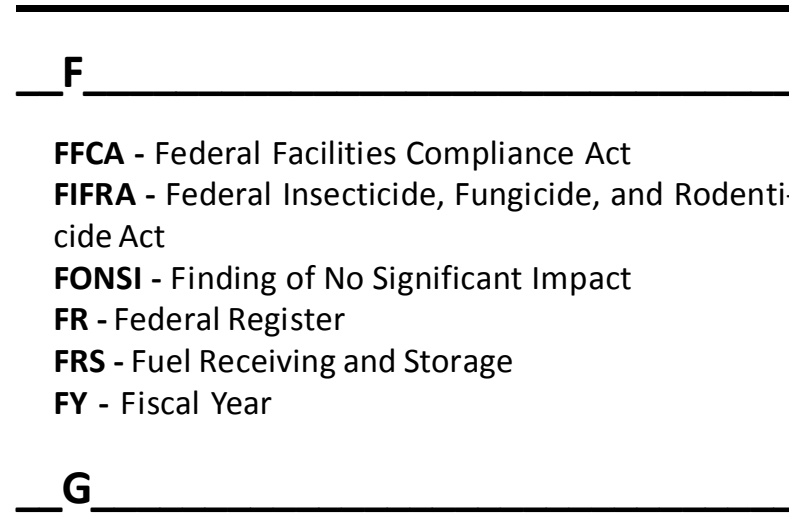

GEL - General Engineering Laboratory GMP - Groundwater Monitoring Plan GSL - (Site-Specific) Ground water (Metals) Screening Levels

GTAR - Groundwater Trend Analysis Report

H

HEPA - High-Efficiency Particulate Air (filter)

HLW - High-Level (radioactive) Waste

HP/BBS - Human Performance/Behavior-Based Safety

HPIC - High-Pressure Ion Chamber

HTO - Hydrogen Tritium Oxide

HVAC - Heating, Ventilation, and Air Conditioning

1

IAEA - International Atomic Energy Agency

IAP - Integrated Assessment Program

ICRP - International Commission on Radiological Protection

IM - Interim Measure

INEEL - Idaho National Engineering and Environmental Laboratory (historical)

INL - Idaho National Laboratory

IRTS - Integrated Radwaste Treatment System

ISCORS - Interagency Steering Committee on Radiation Standards

ISMS - Integrated Safety Management System

ISO - International Organization for Standardization

IWSF - Interim Waste Storage Facility

$\mathbf{K}$

KRS - Kent Recessional Sequence

KT - Kent Till
$\mathbf{L}$

LAS - Linear Alkylate Sulfonate

LDR - Land Disposal Restriction

LFR - Live-Fire Range

LIMS - Laboratory Information Management System

LLD - Lower Limit of Detection

LLW - LoW-Level (radioactive) Waste

LLW2 - Low-Level (liquid) Waste Treatment Facility

LPS - Liquid Pretreatment System

LSA - Lag (Low-Level Radioactive Waste) Storage Area

LSA \#1 - Lag Storage Addition \#1

LSA \#2 - Lag Storage Hardstand \#2

LSB - Lag Storage Building

LTR - License Termination Rule

LTS - Lavery Till Sand

LWTS - Liquid Waste Treatment System

M

MAPEP - Mixed Analyte Performance Evaluation Program

MCL - Maximum Contaminant Level

MCLG - Maximum Contaminant Level Goal

MDC - Minimum Detectable Concentration

MDL - Method Detection Limit (also Minimum Detection Level)

MEI - Maximally Exposed Individual

MEOSI - Maximally Exposed Off-Site Individual

MGD - Million Gallons per Day

MOU - Memorandum of Understanding

MPPB - Main Plant Process Building

MSDS - Material Safety Data Sheet

MW - (Radioactive and Hazardous) Mixed Waste

$\mathbf{N}$

NCRP - National Council on Radiation Protection and Measurements

NDA - Nuclear Regulatory Commission (NRC)-Licensed Disposal Area

NELAC - National Environmental Laboratory Accreditation Conference

NEPA - National Environmental Policy Act

NESHAP - National Emission Standards for Hazardous Air Pollutants

NFS - Nuclear Fuel Services, Inc.

NGVD - National Geodetic Vertical Datum

$\mathrm{NH}_{\mathbf{3}}$ - Ammonia

NIST - National Institute of Standards and Technology

Note: For abbreviations of units of measure, see Table UI-2 ("Units of Measure Used in This ASER") in the "Useful Information" section. 
NOAA - National Oceanic and Atmospheric Administration

NOI - Notice of Intent

NOV - Notice of Violation

$\mathrm{NO}_{\mathbf{x}}$ - Nitrogen Oxides

NPDES - National Pollutant Discharge Elimination System

NPGRS - North Plateau Groundwater Recovery System

NPOC - Nonpurgeable Organic Carbon

NRC - (U.S.) Nuclear Regulatory Commission

NTS - Nevada Test Site

NYCRR - New York Official Compilation of Codes, Rules, and Regulations

NYS - New York State

NYSDEC - New York State Department of Environmen-

tal Conservation

NYSDOH - New York State Department of Health

NYSDOH ELAP - (NYSDOH) Environmental Laboratory Approval Program

NYSDOL - New York State Department of Labor

NYSERDA - New York State Energy Research and Development Authority

NYSGS - New York State Geological Survey

$$
\text { - }
$$

OAD - Office of Atomic Development

OSHA - Occupational Safety and Health Administration

OVE - Outdoor Ventilated Enclosure

$\mathbf{P}$

P-track - (EPA) Performance Track Program

PCB - Polychlorinated Biphenyl

PE - Professional Engineer

PNL - Pacific Northwest Laboratory

PQL - Practical Quantitation Limit

PTW - Permeable Treatment Wall

PUREX - Plutonium Uranium Reduction Extraction

PVC - Polyvinyl Chloride

PVS - Permanent Ventilation System

PVU - Portable Ventilation Unit

$\mathbf{Q}$

QA - Quality Assurance

QAP - Quality Assessment Program (also Quality Assurance Program)

QC - Quality Control

QF - Quality Factor
$\mathbf{R}$

RCRA - Resource Conservation and Recovery Act

REM - Roentgen Equivalent Man

RFI - RCRA Facility Investigation

RHWF - Remote-Handled Waste Facility

RIDS - Records Inventory and Disposition Schedule

RMW - Regulated Medical Waste

ROD - Record of Decision

S

S\&G - Sand and Gravel Unit

SAR - Safety Analysis Report

SARA - Superfund Amendments and Reauthorization

Act

SD - Standard Deviation

SDA - (New York) State-Licensed Disposal Area

SDWA - Safe Drinking Water Act

SEQR - (New York) State Environmental Quality Review Act

SI - Systeme Internationale (International System of Units)

SMS - Safety Management System

SO $_{\mathbf{x}}$ - Sulfur Oxides

SPCC - Spill Prevention, Control, and Countermeasures (Plan)

SPDES - (New York) State Pollutant Discharge Elimination System

SRM - Standard Reference Material

SSWMU - Super Solid Waste Management Unit

STL - Severn Trent Laboratory

STP - Site Treatment Plan

STS - Supernatant Treatment System

SU - Standard Unit

SWPPP - Storm Water Pollution Prevention Plan

SVOC - Semivolatile Organic Compound

SWMU - Solid Waste Management Unit

SWS - (S\&G) Slackwater Sequence

T

TAGM - Technical and Administrative Guidance Memorandum

TBP - Tributyl Phosphate

TBU - (S\&G) Thick-Bedded Unit

TCE - Trichloroethylene

TDS - Total Dissolved Solids

TEDE - Total Effective Dose Equivalent

THOREX - Thorium Reduction Extraction

TKN - Total Kjeldahl Nitrogen

Note: For abbreviations of units of measure, see Table UI-2 ("Units of Measure Used in This ASER") in the "Useful Information" section. 
TLD - Thermoluminescent Dosimeter

TOC - Total Organic Carbon

TOGS - Technical and Operational Guidance Series

TOX - Total Organic Halides

TRI - Toxic Release Inventory

TRIEX - Triennial Emergency Exercise

TRU - Transuranic

TSC - Technical Support Center

TSCA - Toxic Substances Control Act

TSDF - Treatment, Storage, and Disposal Facility

TSS - Total Suspended Solids

\section{U}

U.S. - United States

UDF - Unit Dose Factor

ULT - Unweathered Lavery Till

USACE - U.S. Army Corps of Engineers

URS - URS - Washington Division

USC - United States Code

USGS - United States Geological Survey

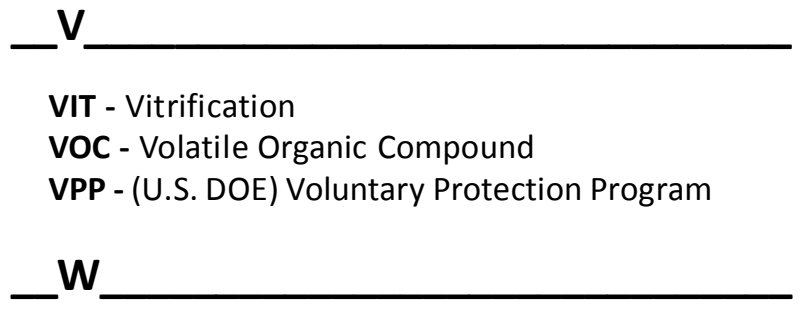

WLT - Weathered Lavery Till

WMIN/P2 - Waste Minimization/Pollution Prevention WNYNSC - Western New York Nuclear Service Center WRES - Washington Regulatory and Environmental Services

WTF - Waste Tank Farm

WVDP - West Valley Demonstration Project

WVES - West Valley Environmental Services LLC

WVNS - West Valley Nuclear Services (historical)

WVNSCO - West Valley Nuclear Services Company (historical)

WWTF - Wastewater Treatment Facility

Note: For abbreviations of units of measure, see Table UI-2 ("Units of Measure Used in This ASER") in the "Useful Information" section. 


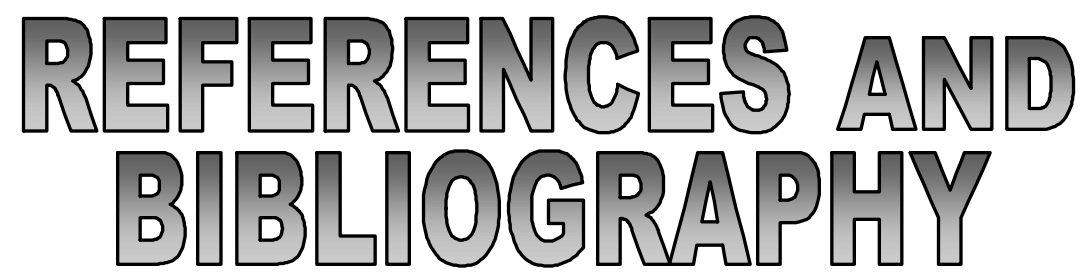

(For a bibliographical listing that includes basis documents not specifically cited in the text, see the WVDP Annual Site Environmental Report for 2003. [Available on the DOE-WVDP website at www.wv.doe.gov])

American National Standards Institute, Inc. August 20, 1975. American National Standard: Performance Testing, and Procedural Specifications for Thermoluminescent Dosimetry (Environmental Applications). ANSI N5451975.

American Society of Mechanical Engineers. 1989. Quality Assurance Program Requirements for Nuclear Facilities. ASME-NQA-1. New York: The American Society of Mechanical Engineers.

Brookhaven National Laboratory. April 2005. Nuclear Wallet Cards. National Nuclear Data Center. Upton, New York.

Citizen Task Force. July 29, 1998. West Valley Citizen Task Force Final Report.

Executive Order 11988. May 24, 1977. Floodplain Management. 42 FR 26951.

Executive Order 11990. May 25, 1977. Protection of Wetlands. 42 FR 26961.

Executive Order 13101. September 16, 1998. Greening the Government Through Waste Prevention, Recycling, and Federal Acquisition. 63 FR 49643. (Revoked by Executive Order 13423, January 24, 2007.)

Executive Order 13148. April 26, 2000. Greening the Government Through Leadership in Environmental Management. 65 FR 24595. (Revoked by Executive Order 13423, January 24, 2007.)

Executive Order 13423. January 24, 2007. Strengthening Federal Environmental, Energy, and Transportation Management. 72 FR 3919.

International Atomic Energy Agency (IAEA). 1992. Effects of lonizing Radiation on Plants and Animals at Levels Implied by Current Radiation Protection Standards. Technical Report Series No. 332, IAEA, Vienna, Austria.

International Commission on Radiological Protection. 1977. Recommendations of the International Commission on Radiological Protection. ICRP Publication 26. Oxford: Pergamon Press.

1979. Recommendations of the International Commission on Radiological Protection - Limits for Intakes of Radionuclides by Workers. ICRP Publication 30. Oxford: Pergamon Press.

1991. Recommendations of the International Commission on Radiological Protection. ICRP Publication 60, Pergamon Press, New York.

International Organization for Standardization. 1996. Environmental Management Systems. ISO 14001:2004. 
Long, E.R., and L.G. Morgan. 1990. The Potential for Biological Effects of Sediment-Sorbed Contaminants Tested in the National States and Trends Program. National Oceanic Atmospheric Administration (NOAA) Technical Memorandum No. 5, OMA52, NOAA National Ocean Service, Seattle, Washington.

Mitrey, R.J. October 28, 1986. Correspondence from New York State Department of Environmental Conservation to J.P. Hamric, Department of Energy, Idaho Operations Office, West Valley Project Office, regarding the construction landfill.

National Council on Radiation Protection and Measurements. 1987. lonizing Radiation Exposure of the Population of the United States. NCRP-93. Bethesda, Maryland.

National Environmental Laboratory Accreditation Conference (NELAC) Standard. June 2003, effective July 2005.

National Research Council. 1990. Health Effects of Exposure to Low Levels of Ionizing Radiation. Biological Effects of Ionizing Radiation (BEIR) V. Washington: National Academy Press.

New York State. nd. Environmental Conservation Law (ECL). Article 27, Collection, treatment, and Disposal of Refuse and Other Solid Waste. Title 9. Industrial Hazardous Waste Management.

.nd. ECL. Article 15. Water Resources. Title 5. Protection of Water.

.nd. ECL. Article 17. Water Pollution Control. Title 8. State Pollutant Discharge Elimination System.

.nd. ECL. Article 40. Hazardous Substances Bulk Storage Act.

.nd. Navigation Law. Article 12. Oil Spill Prevention, Control, and Compensation.

.nd. Public Health Law. Article 5. Laboratories. Section 502. Laboratories; Examinations;

Certificates of Approval.

New York State Department of Environmental Conservation. nd. Title 6, New York Codes, Rules, and Regulations (6 NYCRR). Environmental Conservation Rules and Regulations.

.nd. Hazardous Waste Management Facilities. 6 NYCRR Subpart 373.

.nd. Management of Specific Hazardous Waste. 6 NYCRR Subpart 374.

nd. Solid Waste Management Facilities. 6 NYCRR Part 360.

.nd. Title 6 NYCRR, Subchapter D, Water Regulation, Parts 595 (Releases of Hazardous Sub-

stances Reporting, Response and Corrective Action); 596 (Hazardous Substance Bulk Storage Regulations), 597 (List of Hazardous Substances), 598 (Handling and Storage of Hazardous Substances); and 599

(Standards for New or Modified Hazardous Substance Storage Facilities).

. December 27, 1985 (amended February 12, 1992). Title 6 NYCRR Parts 612 (Registration of

Petroleum Storage Facilities), 613 (Handling and Storage of Petroleum), and 614 (Standards for New and Substantially Modified Petroleum Storage Facilities).

. December 31, 1988 (last revised May 12, 2006). Used Oil. 6 NYCRR Subpart 360-14.

. January 24, 1994. Determination of Soil Cleanup Objectives and Cleanup Levels. Technical and Administrative Guidance Memorandum (TAGM) \#4046. 
. 1995. Appendix 33 - Groundwater Monitoring List. Title 6 NYCRR Subpart 373-2.

. January 1, 1996. State Environmental Quality Review. Title 6 NYCRR, Part 617.

. September 3, 1996. Federal Facility Compliance Act: Order on Consent.

. June 1998. Ambient Water Quality Standards and Guidance Values and Groundwater Effluent Limitations. Technical and Operational Guidance Series (TOGS) 1.1.1.

. January 25, 1999. Technical Guidance for Screening Contaminated Sediments.

. March 19, 1999. Stipulation of Agreement Pursuant to Section 17-0303 of the Environmental Conservation Law and Section 176 of the Navigation Law.

. January 2003. Draft Technical and Operational Guidance Series (TOGS) \#5.1.9. In-Water and Riparian Management of Sediment and Dredge Material.

. March 10, 2003 (amended May 12, 2006). 6 NYCRR Part 364, Waste Transportation, Subpart 364.9. Standards for the Tracking and Management of Medical Waste.

. February 1, 2004 and modification dates January 1, 2005 and September 1, 2006. State Pollutant Discharge Elimination System (SPDES) Discharge Permit NY0000973.

. October 21, 2004. Air Facility Registration Certificate in accordance with 6 NYCRR Part 201-4.

. September 5, 2006. Hazardous Waste Manifest System and Related Standards for Generators, Transporters, and Facilities. 6 NYCRR Subpart 372.

September 5, 2006. Identification and Listing of Hazardous Wastes. 6 NYCRR Subpart 371.

. September 5, 2006. Interim Status Standards for Owners and Operators of Hazardous Waste Facilities. 6 NYCRR Subpart 373-3.

. September 6, 2006. Final Status Standards for Owners and Operators of Hazardous Waste Treatment, Storage, and Disposal Facilities. 6 NYCRR Subpart 373-2.

. September 6, 2006. Hazardous Waste Management System - General. 6 NYCRR Subpart 370.

. December 5, 2006. Land Disposal Restrictions. 6 NYCRR Subpart 376.

New York State Department of Health. nd. Environmental Laboratory Approval Program (ELAP) Certification Manual.

. nd. Title 10, New York Code, Rules, and Regulations (10 NYCRR). Sources of Water Supply. Part 5 (Drinking Water Supplies) and Part 170 (Sources of Water Supply).

Pacific Northwest Laboratory (PNL). November 1988. Napier, B.A., Strenge, D.L., Pelequin, R.A., and Ramsdell, J.V. GENII - The Hanford Environmental Radiation Dosimetry Software System. Version 1.485, PNL-6584.

Parks B.L. March 1992. User's Guide for CAP88-PC. Version 1.0. Las Vegas, NV: U.S. Environmental Protection Agency Office of Radiation Programs. 402-B-92-001.

. June 1997. CAP88-PC Version 2.0 User's Guide. Germantown, Maryland. U.S. Department of Energy. 
Persaud, D., Jaagumagi, R., and A. Hayton. 1992. Guidelines for the Protection and Management of Aquatic Sediment Quality in Ontario. Ontario Ministry of the Environment, Queen's Printer for Ontario.

Rickard, L.V. 1975. Correlation of the Silurian and Devonian Rocks in New York State. New York State Museum and Science Service Map and Chart Series No. 24.

Simpson, D.B., and B.L. McGill. 1980. LADTAP II: A Computer Program for Calculating Radiation Exposure to Man from Routine Release of Nuclear Reactor Liquid Effluents. Technical Data Management Center. ORNL/ NUREG/TDMC-1.

Standish, P.N. 1985. Closure of the Construction Landfill Site. Letter (WD:85:0434) to W.H. Hannum, Department of Energy, West Valley Project Office.

Statistics Canada. 2001. Population and Dwelling Counts for Canada, Provinces and Territories, and Census Subdivisions (Municipalities), 2001 and 1996 censuses -- 100\% data, and topic-based tabulaions. <http:// www.statcan.ca/english/census01/products/standard>

Trinity Engineering Associates, Inc. March 2006. CAP88-PC Version 3.0 User Guide.

U.S. Congress. 1918. Migratory Bird Treaty Act. 16 United States Code (USC) §703 et seq. 1954. Atomic Energy Act of 1954. 42 USC §2011 et seq. 1966. National Historic Preservation Act of 1966. 16 USC $\S 470$ et seq. 1969. National Environmental Policy Act of 1969. 42 USC §4321 et seq. 1970. Clean Air Act of 1970. 42 USC $§ 7401$ et seq. . 1973. Endangered Species Act of 1973. 16 USC $\$ 1531$ et seq. . 1974. Safe Drinking Water Act. 42 USC $\S 300 f$ et seq. . 1976. Resource Conservation and Recovery Act of 1976. Public Law 94-580, 90 Stat. 2795, 42 USC $\$ 6901$ et seq.

.1976. Toxic Substances Control Act. 15 USC §2601 et seq.

. 1977. Federal Water Pollution Control Act of 1977. 33 USC $\S 1251$ et seq. (Also known as the Clean Water Act)

. October 1, 1980. An Act to Authorize the Department of Energy to Carry Out a High-Level Liquid Nuclear Waste Management Demonstration Project at the Western New York Service Center in West Valley, New York. Public Law 96-368 [S. 2443]. Congressional Record, Vol. 126. (Also known as the WVDP Act)

.1980. Comprehensive Environmental Response, Compensation, and Liability Act of 1980. Public Law 96-510, 42 USC §9601 et seq. .1986. Emergency Planning and Community Right-to-Know Act of 1986. 42 USC $\$ 11001$ et seq. . October 17, 1986. Superfund Amendments and Reauthorization Act (SARA) of 1986. Public Law 99-499, 100 Stat. 1613, Title 10. 
1992. Federal Facilities Compliance Act of 1992. Amendment to Section 6001 of the Solid Waste Disposal Act (42 USC 6961).

1996. Federal Insecticide, Fungicide, and Rodenticide Act. 7 USC §136 et seq.

U.S. Department of Commerce. U.S. Census Bureau. Census 2000.

U.S. Department of Energy. nd. National Environmental Policy Act Implementing Procedures. 10 CFR Part 1021. Subpart D, Typical Classes of Actions. Appendix B, Categorical Exclusions Applicable to Specific Agency Actions. B6-1, Small-scale, short-term cleanup actions under RCRA, Atomic Energy Act, or other authorities.

.nd. Quality Assurance Criteria. 10 CFR 830.122.

. 1981. West Valley Demonstration Project Memorandum of Understanding Between the U.S. Department of Energy and the U.S. Nuclear Regulatory Commission.

. July 1981. A Guide for Environmental Radiological Surveillance at U.S. Department of Energy Installations. DOE/EP-0023. Washington, D.C.

. July 1983. A Guide for Effluent Radiological Measurements at DOE Installations. DOE/EP-0096. Washington, D.C.

. February 8, 1990. Radiation Protection of the Public and the Environment. DOE Order 5400.5, including Change 2 (January 7, 1993). Washington, D.C.

. January 1991. Environmental Regulatory Guide for Radiological Effluent Monitoring and Environmental Surveillance. DOE/EH-0173T. Washington, D.C.

. January 1996. Draft Environmental Impact Statement for Completion of the West Valley Demonstration Project and Closure or Long-Term Management of Facilities at the Western New York Nuclear Services Center. DOE/EIS-0226-D.

. May 1997. Final Waste Management Programmatic Environmental Impact Statement for Managing Treatment, Storage, and Disposal of Radioactive and Hazardous Waste. DOE/EIS-0200-F.

. March 27, 1998. Worker Protection Management for DOE Federal and Contractor Employees. DOE Order 440.1A. Washington, D.C.

. July 9, 1999. Radioactive Waste Management. DOE Order 435.1, including Change 1 (August 28, 2001). Washington, D.C.

. August 26, 1999. Record of Decision for the Department of Energy's Waste Management Program: Storage of High-Level Radioactive Waste. 64 FR 46661.

. October 1999. Expediting Cleanup Through a Core Team Approach. DOE/EH-413-9911.

. February 25, 2000. Record of Decision for the Department of Energy's Waste Management Program: Treatment and Disposal of Low-Level Waste and Mixed Low-Level Waste; Amendment of the Record of Decision for the Nevada Test Site. 65 FR 10061.

. October 26, 2000. National Environmental Policy Act Compliance Program. DOE Order 451.1B, including Change 1 (September 28, 2001). Washington, D.C. 
. March 1, 2001. Integrated Safety Management System Guide (Volume 1) for Use With Safety Management System Policies (DOE P 450.4, DOE P 450.5, and DOE P 450.6); the Functions, Responsibilities, and Authorities Manual; and the DOE Acquisition Regulation, (DOE G 450.4-1B) (Volumes 1 and 2).

. March 26, 2001. Revised Strategy for the Environmental Impact Statement for Completion of the West Valley Demonstration Project and Closure or Long-Term Management of Facilities at the Western New York Nuclear Service Center and Solicitation of Scoping Comments. 66 FR 16447.

. May 2, 2001. Department of Energy Management of Cultural Resources. DOE Policy 141.1.

. November 6, 2001. Advance Notice of Intent to Prepare an Environmental Impact Statement to Evaluate Decommissioning and/or Long-Term Stewardship at the West Valley Demonstration Project and Western New York Nuclear Service Center. 66 FR 56090.

. July 2002. DOE Standard: A Graded Approach for Evaluating Radiation Doses to Aquatic and Terrestrial Biota. DOE-STD-1153-2002. Washington, D.C.

. January 2003. Estimating Radiation Risk from Total Effective Dose Equivalent (TEDE). Interagency Steering Committee on Radiation Standards (ISCORS) Technical Report No. 1. DOE/EH-412/0015/0502, Rev. 1.

. March 13, 2003. Notice of Intent to Prepare an Environmental Impact Statement for Decommissioning and/or Long-Term Stewardship at the West Valley Demonstration Project and Western New York Nuclear Services Center. 68 FR 12044.

. May 16, 2003. Notice of Availability of the West Valley Demonstration Project Draft Waste Management Environmental Impact Statement. 68 FR 26587.

. August 19, 2003. Environment, Safety, and Health Reporting. DOE Order 231.1A, including Change 1 (June 3, 2004). Washington, D.C.

. December 2003. West Valley Demonstration Project Waste Management Environmental Impact Statement. DOE/EIS-0337F.

. January 2004. Users Guide: RESRAD-BIOTA: A Tool for Implementing a Graded Approach to Biota Dose Evaluation. Version 1. DOE/EH-0676. (ISCORS Technical Report 2004-2).

. March 19, 2004. Environment, Safety, and Health Reporting Manual. DOE M 231.1-1A, including Change 2 (June 12, 2007).

. June 16, 2005. Record of Decision for WVDP Waste Management Activities. 70 FR 35073.

.June 17, 2005. Quality Assurance. DOE Order 414.1C.

. February 2006. Worker Safety and Health Program. 10 CFR 851.

. September 14, 2006. Environmental Assessment for the Decontamination, Demolition, and Removal of Certain Facilities at the West Valley Demonstration Project. DOE/EA-1552. West Valley, New York.

. June 4, 2008. Environmental Protection Program. DOE Order 450.1A. (Canceled DOE Order

450.1.)

. June 4, 2008. Radioactive Material Transportation Practices Manual. DOE M 460.2-1. 
. December 2008. Revised Draft Environmental Impact Statement for Decommissioning and/or Long-Term Stewardship at the West Valley Demonstration Project and Western New York Nuclear Service Center. DOE/EIS-0226-D (Revised).

. December 5, 2008. Notice of Availability of the Revised Draft Environmental Impact Statement for Decommissioning and/or Long-Term Stewardship at the West Valley Demonstration Project and Western New York Nuclear Service Center. 73 FR 74160.

. December 5, 2008. Proposed Phase 1 Decommissioning Plan for the West Valley Demonstration Project, West Valley, New York. 73 FR 74162.

. December 2008 and March 2009. Phase 1 Decommissioning Plan for the West Valley Demonstration Project. Revs. 0 and 1. Prepared by: Washington Safety Management Solutions - URS Washington Division and Science Applications International Corporation.

U.S. Department of Energy and New York State Energy Research and Development Authority. 1981. Cooperative Agreement between United States Department of Energy and New York State Energy Research and Development Authority on the Western New York Nuclear Service Center at West Valley, New York, effective October 1, 1980, as amended September 18, 1981.

U.S. Department of Transportation. nd. 49 CFR Chapter 1, Pipeline and Hazardous Materials Safety Administration, Department of Transportation. Part 172. Hazardous Materials Table, Special Provisions, Hazardous Materials Communications, Emergency Response Information, and Training Requirements.

U.S. Environmental Protection Agency. nd. 40 Code of Federal Regulations, Protection of the Environment, Chapter 1, Environmental Protection Agency.

. March 1983. Mercury, Method 245.1 (Manual Cold Vapor Technique). Methods for Chemical Analysis of Water and Wastes. Environmental Monitoring and Support Laboratory. Cincinnati, Ohio.

.1984a. Drinking Water Guidelines. 40 CFR 141, National Secondary Drinking Water Regulations, Subpart B, Maximum Contaminant Levels.

.1984b. Drinking Water Guidelines. 40 CFR 143, National Secondary Drinking Water Regulations, Section 143.3, Secondary Maximum Contaminant Levels.

. December 15, 1989. National Emission Standards for Hazardous Air Pollutants: Standards for Radionuclides. 40 CFR 61, including update of September 9, 2002. Subpart H. National Emission Standards for Emissions of Radion uclides Other Than Radon From Department of Energy Facilities. Washington, D.C.: U.S. Government Printing Office.

1992. Region II Administrative Order on Consent. Docket No. II RCRA 3008(h) -92-0202. In the Matter of: Western New York Nuclear Service Center.

1995. Comprehensive Procurement Guidelines for Products Containing Recovered Material. 40 CFR 247.

. October 16, 1996. Code of Environmental Management Principles. 61 FR 54062.

. August 2002. Method 1631, Revision E: Mercury in Water by Oxidation, Purge and Trap, and Cold Vapor Atomic Fluorescence Spectrometry. EPA-821-R-02-019. 
. October 9, 2002. Memorandum of Understanding Between the Environmental Protection Agency and the Nuclear Regulatory Commission. Consultation and Finality on Decommissioning and Decontamination of Contaminated Sites.

U.S. Nuclear Regulatory Commission. October 1977. Regulatory Guide 1.109: Calculation of Annual Doses to Man from Routine Releases of Reactor Effluents for the Purpose of Evaluating Compliance with 10 CFR Part 50, Appendix I.

. July 1997. Radiological Criteria for License Termination. 10 CFR Part 20, Appendix E.

. February 1, 2002. Decommissioning Criteria for the West Valley Demonstration Project (M-32) at the West Valley Site; Final Policy Statement. 67 FR 5003.

September 2006. Consolidated Decommissioning Guidance: Characterization, Survey, and Determination of Radiological Criteria. NUREG-1757, Vol. 2.

U.S. General Accounting Office. May 2001. Nuclear Waste Agreement Among Agencies Responsible for the West Valley Site is Critically Needed. Report to Congressional Requestors. GAO-01-314.

URS Group, Inc. April 8, 2002. Land Use Survey. Rev. 0. AR \#2002-171.

West Valley Environmental Services LLC. March 13, 2007 and November 12, 2008. Low-Level Waste Management Program Plan. Revs. 25 and 26. WVDP-019.

. September 7, 2007; October 14, 2008; and November 11, 2008. WVDP Safety Management System (SMS) Description. Revs. 14, 15, and 16. WVDP-310, including Addendum 1, WVDP Worker Safety and Health Plan, Rev. 2, September 11, 2007.

. November 19, 2007. Waste Minimization/Pollution Prevention Awareness Plan. Rev. 9. WVDP-087.

. December 13, 2007. WVDP Environmental Management System. Rev. 18. WV-980.

. January 7, 2008. Environmental Monitoring Program Plan. Rev. 15. WVDP-098.

. January 16, 2008; February 26, 2008; and December 29, 2008. Groundwater Monitoring Plan. Revs. 11, 12, and 13. WVDP-239.

. June 25, 2008. CY 2007 Annual Status Report for the Hazardous Waste Reduction Program.

. October 15, 2008. Characterization Plan for the Mitigation of the Leading Edge of the WVDP North Plateau Strontium-90 Plume. Rev. 1. WVDP-489.

. February 5, 2009. Site Treatment Plan: Fiscal Year 2008 Update. Rev. 15. WVDP-299.

. February 12, 2009. New York State Department of Environmental Conservation Hazardous Waste Report for 2008.

. April 28, 2009. West Valley Demonstration Project North Plateau Plume Area Characterization Report. Rev. 0. WVDP-494.

West Valley Environmental Services LLC and URS - Washington Division. December 2008. West Valley Demonstration Project Annual Site Environmental Report, Calendar Year 2007. 
West Valley Nuclear Services Co., Inc. May 1, 1995. Subsurface Probing Investigation on the North Plateau at the West Valley Demonstration Project. Rev. 0. WVDP-220.

. March 1996. Environmental Information Document, Volume III: Hydrology, Part 4. WVDP-EIS-009.

. June 11, 1999. 1998 Geoprobe Investigation in the Core Area of the North Plateau Groundwater Plume. Rev. 0. WVDP-346.

. October 26, 1999. Asbestos Management Plan. Rev. 5. WVDP-072.

. April 15, 2003. Manual for Radiological Assessment of Environmental Releases at the WVDP. Rev.

4. WVDP-065.

. March 24, 2004. TRU Waste Management Program Plan. Rev. 0. WVDP-417.

. December 21, 2004 and December 13, 2008. Clean Water Act/State Pollutant Discharge Elimination System Best Management Practices and Storm Water Pollution Prevention Plan for the West Valley Demonstration Project. Revs. 1 and 2. WVDP-206.

. March 30, 2005. Monitoring Plan for Storm Water Discharges at the West Valley Demonstration Project. Rev. 2. WVDP-233.

. November 3, 2005 and December 23, 2008. WVDP Groundwater Protection Management Program Plan. Revs. 7 and 8. WVDP-091.

. November 17, 2005. PCB and PCB-Contaminated Material Management Plan. Rev. 8. WVDP-080.

. January 2006. Draft Corrective Measures Study Work Plan for the West Valley Demonstration

Project.

. May 24, 2006. West Valley Demonstration Project (WVDP) Waste Acceptance Manual. Rev. 15. WVDP-200.

. August 16, 2007. Sampling and Analysis Plan for Background Subsurface Soil on the North Plateau. Rev. 0. WVDP-466.

. August 16, 2007. Sampling and Analysis Plan for the North Plateau Plume Area. Rev. 0. WVDP-465.

West Valley Nuclear Services Co., Inc. and Dames \& Moore. June 1997. West Valley Demonstration Project Site Environmental Report, Calendar Year 1996.

. July 1997. Resource Conservation and Recovery Act Facility Investigation Report, Vol.1: Introduction and General Site Overview. WVDP-RFI-017.

. June 1998. Final Report: Evaluation of the Pilot Program to Investigate Chromium and Nickel Concentrations in Groundwater in the Sand and Gravel Unit.

West Valley Nuclear Services Co. and URS Group, Inc. January 2001. Results of Corrosion Evaluation in Selected Stainless Steel Monitoring Wells on the North Plateau and Recommendations for Long-Term Management.

. August 2004. West Valley Demonstration Project Annual Site Environmental Report, Calendar Year 2003. 
This page intentionally left blank 


\section{DISTRIBUTLON}

$\underline{\text { Recipient } \quad \text { Federal Organization }}$

DOE Office of Scientific and Technical Information

C. Anderson DOE-HQ

D. Crouther DOE-HQ

W. Eckroade DOE-HQ

D. Geiser DOE-HQ

R. Hardwick DOE-HQ

A. Lawrence DOE-HQ

F. Marcinowski DOE-HQ

R. Natoli DOE-HQ

G. Podonsky DOE-HQ

M. Rawlings DOE-HQ

J. Rhoderick DOE-HQ

W. Roege DOE-HQ

L. Camper NRC-HQ

C. Glenn NRC-HQ

R. Prince

G. Suber

M. Roberts

$\mathrm{NRC}-\mathrm{HQ}$

$\mathrm{NRC}-\mathrm{HQ}$

NRC - Region 1

R. Chaput

J. Eng

A. Everett

P. Giardina

A. Park

J. Reidy

W. Kappel

C. Lee

B. Higgins

L. Slaughter

E. Massa

K. Gillibrand

C. Schumer
U.S. EPA - Region II

U.S. EPA - Region II

U.S. EPA - Region II

U.S. EPA - Region II

U.S. EPA - Region II

U.S. EPA - Region II

USGS

U.S. Congress, 26th Dist.

U.S. Congress, 27th Dist.

U.S. Congress, 28th Dist.

U.S. Congress, 29th Dist.

U.S. Senate, New York

U.S. Senate, New York

\section{$\underline{\text { Recipient }}$}

L. White

E. Dassatti

S. Hammond

J. Nasca

R. Phaneuf

T. Rice

A. Salame-Alfie

M. Wang

L. Winterberger

R. Biss

P. Concannon

S. Doleski

M. Jackson

F. Price

J. Sciascia

J. Strickland

L. Sturman

G. Baker

B. Ignatz

R. Snyder

R. Callender

J. Spath

D. Munroe

J. Kelly

T. Attridge

P. Bembia

A. Mellon

M. Willett

D. Gabryszak

M. Schroeder

J. Quinn

D. Burling

J. Giglio

C. Young

W. Stachowski

D. Volker

\section{State Organization}

NYS Attorney Generals Office

NYSDEC - Albany

NYSDEC - Albany

NYSDEC - Albany

NYSDEC - Albany

NYSDEC - Albany

NYSDEC - Albany

NYSDEC - Albany

NYSDEC - Albany

NYSDEC - Region 9

NYSDEC - Region 9

NYSDEC - Region 9

NYSDEC - Region 9

NYSDEC - Region 9

NYSDEC - Region 9

NYSDEC - Region 9

NYSDOH - Albany

NYSDOH - Buffalo

NYSDOH - Buffalo

NYSDOH - Troy

NYSERDA - Albany (President)

NYSERDA - Albany

NYSERDA - Deputy Counsel

NYSERDA - Director WVDP

NYSERDA

NYSERDA

NYSERDA

NYSERDA

New York Assembly, 143rd Dist. New York Assembly, 145th Dist. New York Assembly, 146th Dist. New York Assembly, 147th Dist. New York Assembly, 149th Dist. New York Senate, 57th Dist. New York Senate, 58th Dist. New York Senate, 59th Dist. 


\section{Recipient}

B. Hastings

E. Wohlers

C. Abers

J. Burrell

E. Ellis

C. Hebdon

K. McClune

P. Murphy

J. Searles

D. Vickman

J. Williams

A. Billittier IV

P. Kranz

H. Sinnott

E. Giardini

Laborers Local \#621, Olean

M. Resnikoff

D. Rychnowski

Radioactive Waste Management Associates

Southern Tier West Development Foundation

Citizen Task Force Membership and Alternates

West Valley Volunteer Hose Co., Inc.

Publication

Buffalo News ${ }^{a}$, Buffalo, New York

Salamanca Republican Press ${ }^{a}$, Salamanca, New York

Springville Journal ${ }^{a}$, Springville, New York

Olean Times Herald ${ }^{a}$, Olean, New York

${ }^{a}$ Notice of public availability

\section{Recipient $\quad$ Local Organization}

H. Bowen Superintendent, West Valley Central School

S. Kowalski West Valley Central School Board of Education

D. McCauley West Valley Central School Board

of Education

B. Snyder President, Seneca Nation of Indians

A. Memmo Seneca Nation of Indians

Energy Planner

S. Patterson Seneca Nation of Indians

Environmental Protection

Department

W. Krebs Mayor, Village of Springville

T. Skelton Village of Springville

C. Gerwitz Supervisor, Town of Ashford

P. Dashnaw Town Clerk, Town of Ashford

G. Eppolito Supervisor, Town of Concord

T. Engels Council, Town of Ashford

J. Pfeffer Council, Town of Ashford

B. Snyder Council, Town of Concord

M. Hutchinson Superintendent, Gowanda

Public Works

C. Couture West Valley Chamber of Commerce

L. Lambert League of Women Voters

J. Einach Coalition on West Valley Nuclear Wastes

\section{Library}

Town of Concord Hulbert Library, Springville, New York

Seneca Nation of Indians Library, Cattaraugus Reservation, Irving, New York

Seneca Nation of Indians Library, Allegheny Reservation, Salamanca, New York

West Valley Central School Library, West Valley, New York. 


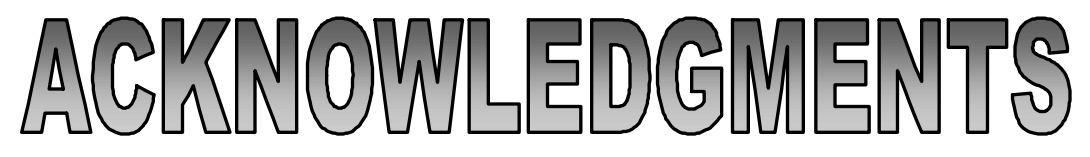

This report was compiled and edited by N.A. McNeil (team leader) and P.J. Hadden-Carter of the URS West Valley Demonstration Project staff. J.M. Wilcox, also of the URS WVDP staff, provided editing support and desktop publishing services. Other technical preparers and reviewers are listed below.

$\begin{array}{ll}\text { Alberico, K.S. } & \text { Maloney, M.N. } \\ \text { Alkema, K.L. } & \text { McKune, B.N. } \\ \text { Allen, S.J. } & \text { Michalczak, L.M. } \\ \text { Biedermann, C.A. } & \text { Olson, E.W. } \\ \text { Biela, D. } & \text { Paskuly, S.J. } \\ \text { Casey, P.J. } & \text { Payne, H.L. } \\ \text { Cohen, F.J. } & \text { Pendl, M.P. } \\ \text { Dundas, J.M. } & \text { Picazo, E.D. } \\ \text { Erlandson, V.M. } & \text { Rizzo, J.M. } \\ \text { Fox, J.R. } & \text { Ruszczyk, D.M. } \\ \text { Gerber, J.R. } & \text { Scalise, D.M. } \\ \text { Hackett, M.A. } & \text { Scharf, R.L. } \\ \text { Hoch, J.J. } & \text { Selent, K.A. } \\ \text { Kean, W.N. } & \text { Steiner, A.F. } \\ \text { Klenk, D.P. } & \text { Warren, S.D. } \\ \text { Krentz, M. } & \text { Wedvik, S.K. } \\ \text { Loney, J. } & \text { Willett, M.J. } \\ \text { Loop, M.B. } & \\ \text { Love, R.D. } & \\ \text { Lund, L.M. } & \\ \text { Luellen, J.R. } & \end{array}$


This page intentionally left blank 


\section{APPENDIX B-1}

\section{Summary of Water Limits, Guidelines, and Standards}

TABLE B-1A

West Valley Demonstration Project State Pollutant Discharge Elimination System
(SPDES) Sampling Program

Outfall

Parameter

Daily Maximum Limit ${ }^{a}$

Sample Frequency

001 (Process and Storm Wastewater)

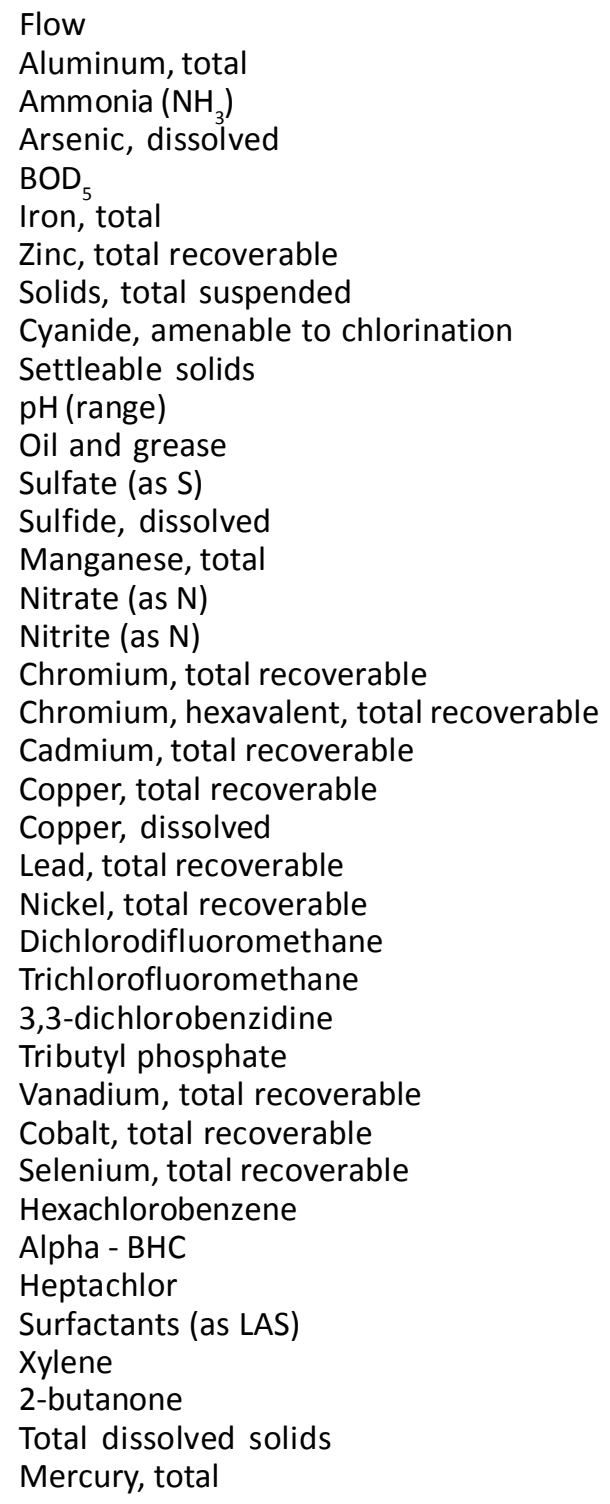

2/discharge

1 /discharge

2/discharge

1 discharge

2/discharge

2/discharge

2/year

2/discharge

2/year

2/discharge

1 /discharge

2/discharge

2/discharge

1 /discharge

2/year

2/discharge

2/discharge

2/year

1/year

1/year

2/year

2/year

4/year

2/year

1/year

1/year

1/year

$1 /$ year

1/discharge

1 /discharge

2/discharge

1/year

1/year

2/year

2/year

1/year

1/year

2/discharge

2/discharge

a Daily average limitations are also identified in the permit but require only monitoring for all parameters except total aluminum (daily average limit - $7.0 \mathrm{mg} / \mathrm{L}$ ); total suspended solids (daily average limit - $30 \mathrm{mg} / \mathrm{L}$ ); BOD $_{5}$ for the sum of outfalls 001,007 , and 008 (daily average limit - $5.0 \mathrm{mg} / \mathrm{L}$ ); and ammonia for the sum of outfalls 001 and 007 (daily average limit $-1.49 \mathrm{mg} / \mathrm{L}$ ). 


\section{TABLE B-1A (continued) \\ West Valley Demonstration Project State Pollutant Discharge Elimination System (SPDES) Sampling Program}

\begin{tabular}{|c|c|c|c|}
\hline Outfall & Parameter & Daily Maximum Limit ${ }^{a}$ & Sample Frequency \\
\hline $\begin{array}{l}\text { 01B (Internal Process } \\
\text { Monitoring Point) }\end{array}$ & $\begin{array}{l}\text { Flow } \\
\text { Mercury, total }\end{array}$ & $\begin{array}{l}\text { Monitor } \\
10.0 \mu \mathrm{g} / \mathrm{L}\end{array}$ & $\begin{array}{l}\text { weekly } \\
2 / \text { month }\end{array}$ \\
\hline $\begin{array}{l}007 \text { (Sanitary and } \\
\text { Utility Wastewater) }\end{array}$ & $\begin{array}{l}\text { Flow } \\
\text { Ammonia }\left(\text { as } \mathrm{NH}_{3}\right) \\
\text { BOD5 } \\
\text { Iron, total } \\
\text { Solids, total suspended } \\
\text { Solids, settleable } \\
\text { pH (range) } \\
\text { Nitrite (as N) } \\
\text { Oil and grease } \\
\text { Chlorine, total residual }\end{array}$ & $\begin{array}{c}\text { Monitor } \\
\text { Monitor } \\
10.0 \mathrm{mg} / \mathrm{L} \\
\text { Monitor } \\
45 \mathrm{mg} / \mathrm{L} \\
0.3 \mathrm{~mL} / \mathrm{L} \\
6.5-8.5 \mathrm{SU} \\
0.1 \mathrm{mg} / \mathrm{L} \\
15.0 \mathrm{mg} / \mathrm{L} \\
0.1 \mathrm{mg} / \mathrm{L}\end{array}$ & $\begin{array}{l}\text { 3/month } \\
\text { 3/month } \\
\text { 3/month } \\
\text { 3/month } \\
\text { 3/month } \\
\text { weekly } \\
\text { weekly } \\
\text { 3/month } \\
\text { 3/month } \\
\text { weekly }\end{array}$ \\
\hline $\begin{array}{l}\text { Sum of Outfalls 001, } \\
007, \text { and } 008\end{array}$ & $\begin{array}{l}\text { Iron, total } \\
\mathrm{BOD}_{5}\end{array}$ & $\begin{array}{l}0.30 \mathrm{mg} / \mathrm{L} \\
\text { Monitor }\end{array}$ & $\begin{array}{l}\text { 3/month } \\
\text { 3/month }\end{array}$ \\
\hline $\begin{array}{l}\text { Sum of Outfalls } 001 \\
\text { and } 007\end{array}$ & Ammonia (as $\mathrm{NH}_{3}$ ) & $2.1 \mathrm{mg} / \mathrm{L}$ & 3/month \\
\hline $\begin{array}{l}\text { Pseudo-monitoring } \\
\text { point (116) }\end{array}$ & Solids, total dissolved & $500 \mathrm{mg} / \mathrm{L}$ & 2/discharge \\
\hline
\end{tabular}

\begin{tabular}{|c|c|c|c|}
\hline Outfall & Parameter & Action Level & Sample Frequenc \\
\hline $\begin{array}{l}001 \text { (Process and Storm } \\
\text { Wastewater) }\end{array}$ & $\begin{array}{l}\text { Barium } \\
\text { Antimony } \\
\text { Chloroform } \\
\text { Titanium } \\
\text { Bromide } \\
\text { Boron }\end{array}$ & $\begin{array}{c}0.5 \mathrm{mg} / \mathrm{L} \\
1.0 \mathrm{mg} / \mathrm{L} \\
0.3 \mathrm{mg} / \mathrm{L} \\
0.65 \mathrm{mg} / \mathrm{L} \\
5.0 \mathrm{mg} / \mathrm{L} \\
2.0 \mathrm{mg} / \mathrm{L}\end{array}$ & $\begin{array}{c}\text { annual } \\
\text { annual } \\
\text { annual } \\
\text { semiannual } \\
\text { quarterly } \\
\text { quarterly }\end{array}$ \\
\hline $\begin{array}{l}007 \text { (Sanitary and } \\
\text { Utility Wastewater) }\end{array}$ & Chloroform & $0.20 \mathrm{mg} / \mathrm{L}$ & annual \\
\hline
\end{tabular}

Note: Limits for point 008 (French Drain) are not listed because the point has been closed off since 2001.

a Daily average limitations are also identified in the permit but require only monitoring for all parameters except total aluminum (daily average limit - $7.0 \mathrm{mg} / \mathrm{L}$ ); total suspended solids (daily average limit - $30 \mathrm{mg} / \mathrm{L}$ ); $B O D_{5}$ for the sum of outfalls 001, 007, and 008 (daily average limit - $5.0 \mathrm{mg} / \mathrm{L}$ ); and ammonia for the sum of outfalls 001 and 007 (daily average limit - $1.49 \mathrm{mg} / \mathrm{L}$ ). 


\section{TABLE B-1A (concluded) \\ West Valley Demonstration Project State Pollutant Discharge Elimination System (SPDES) Sampling Program}

\begin{tabular}{|c|c|c|c|c|}
\hline $\begin{array}{l}\text { Storm Water } \\
\text { Group Number }\end{array}$ & $\begin{array}{l}\text { Storm } \\
\text { Water } \\
\text { Outfall }\end{array}$ & Parameter $^{a}$ & Rationale $^{a}$ & $\begin{array}{c}\text { Rotational } \\
\text { Sampling } \\
\text { Frequency }\end{array}$ \\
\hline 1 & $\begin{array}{l}\mathrm{SO} 2 \\
\mathrm{SO} 4\end{array}$ & \multirow{8}{*}{$\begin{array}{l}\text { Alpha-hexachlorocyclohexane (alpha BHC) } \\
\text { Aluminium, total } \\
{\text { Ammonia (as } \mathrm{NH}_{3} \text { ) }} \text { BOD }_{5} \\
\text { Cadmium, total recoverable (TR) }_{\text {Chromium, TR }} \\
\text { Copper, TR } \\
\text { Cr }^{+6}, \text { TR } \\
\text { Iron, total } \\
\text { Lead, TR } \\
\text { Nitrate-N } \\
\text { Nitrite-N } \\
\text { Phosphorous, total } \\
\text { Selenium, TR } \\
\text { Settleable solids } \\
\text { Solids, total dissolved } \\
\text { Solids, total settleable } \\
\text { Sulfide } \\
\text { Surfactant as linear alkylate sulfonate (LAS) } \\
\text { Total Kjeldhal nitrogen (TKN) } \\
\text { Total nitrogen } \\
\text { Vanadium, TR } \\
\text { Zinc, TR } \\
\text { Oil \& grease - daily max limit = 15 mg/L } \\
\text { during rain event } \\
\text { pH - Measured once per event and shall not } \\
\text { be less than the measured pH of rainfall } \\
\text { collected from the site rain gauge during } \\
\text { storm water discharge sampling or } 6.0 \mathrm{SU}, \\
\text { whichever is less, and the pH shall not exceed } \\
9.0 \text { SU. } \\
\end{array}$} & \multirow{8}{*}{$\begin{array}{l}\text { Specific combinations of } \\
\text { the storm water } \\
\text { monitoring parameters } \\
\text { for semiannual sampling } \\
\text { at each storm water } \\
\text { group are specified in the } \\
\text { SPDES permit and were } \\
\text { selected in accordance } \\
\text { with construction } \\
\text { activities that have } \\
\text { occurred, or currently } \\
\text { occur, within each } \\
\text { drainage basin at the } \\
\text { WVDP. }\end{array}$} & \multirow{8}{*}{$\begin{array}{l}\text { Semiannual } \\
\text { monitoring } \\
\text { for each } \\
\text { storm water } \\
\text { group, } \\
\text { selecting one } \\
\text { outfall from } \\
\text { each group }\end{array}$} \\
\hline 2 & $\begin{array}{l}\text { S06 } \\
\text { S33 }\end{array}$ & & & \\
\hline 3 & $\begin{array}{l}\text { S09 } \\
\text { S12 } \\
\end{array}$ & & & \\
\hline 4 & S34 & & & \\
\hline 5 & $\begin{array}{l}\text { S14 } \\
\text { S17 } \\
\text { S28 } \\
\end{array}$ & & & \\
\hline 6 & $\begin{array}{l}\mathrm{S} 36 \\
\mathrm{~S} 37 \\
\mathrm{~S} 38 \\
\mathrm{~S} 39 \\
\mathrm{~S} 40 \\
\mathrm{~S} 41 \\
\mathrm{~S} 42 \\
\mathrm{~S} 43^{b} \\
\end{array}$ & & & \\
\hline 7 & $\mathrm{~S} 20$ & & & \\
\hline 8 & $\begin{array}{l}\text { S27 } \\
\text { S35 }\end{array}$ & & & \\
\hline \multirow{8}{*}{$\begin{array}{c}\text { Each Storm } \\
\text { Sampling Event }\end{array}$} & \multirow{8}{*}{ All } & Field Data & \multirow{8}{*}{\multicolumn{2}{|c|}{$\begin{array}{l}\text { Reported for each outfall during each } \\
\text { sampling event. }\end{array}$}} \\
\hline & & Date of storm event & & \\
\hline & & Duration of storm event & & \\
\hline & & Total Flow of storm event & & \\
\hline & & $\begin{array}{l}\text { Maximum gallons per minute flow during } \\
\text { event }\end{array}$ & & \\
\hline & & Total rainfall during event & & \\
\hline & & Hours since previous storm event & & \\
\hline & & Flow measurement device & & \\
\hline
\end{tabular}

a See the sampling schedule in Appendix A for a list of analyses specific to each storm water collection point.

$b$ A request to add point S43, the live-fire range wetland drainage area, to the SPDES permit has been submitted to NYSDEC. 
TABLE B-1B

New York State Water Quality Standards and Guidelines ${ }^{a}$

\begin{tabular}{|c|c|c|c|c|c|c|}
\hline \multicolumn{7}{|c|}{ New York Water Quality Standards and Guidelines ${ }^{a}$} \\
\hline Parameter & Units & Class A & Class B & Class C & Class D & Class GA \\
\hline Gross Alpha $^{b}$ & $\mathrm{pCi} / \mathrm{L}(\mu \mathrm{Ci} / \mathrm{mL})$ & 15 (1.5E-08) & -- & -- & -- & 15 (1.5E-08) \\
\hline Gross Beta $^{c}$ & $\mathrm{pCi} / \mathrm{L}(\mu \mathrm{Ci} / \mathrm{mL})$ & $1,000(1 \mathrm{E}-06)$ & -- & -- & -- & $1,000(1 \mathrm{E}-06)$ \\
\hline Tritium (H-3) & $\mathrm{pCi} / \mathrm{L}(\mu \mathrm{Ci} / \mathrm{mL})$ & $20,000(2 \mathrm{E}-05)$ & -- & -- & -- & -- \\
\hline Strontium-90 & $\mathrm{pCi} / \mathrm{L}(\mu \mathrm{Ci} / \mathrm{mL})$ & $8(8 \mathrm{E}-09)$ & -- & -- & -- & -- \\
\hline Alpha BHC & $\mathrm{mg} / \mathrm{L}$ & 0.000002 & 0.000002 & 0.000002 & 0.000002 & 0.00001 \\
\hline Aluminum, Dissolved & $\mathrm{mg} / \mathrm{L}$ & 0.10 & 0.10 & 0.10 & -- & -- \\
\hline Aluminum, Total & $\mathrm{mg} / \mathrm{L}$ & -- & -- & -- & -- & -- \\
\hline Ammonia, Total as $\mathbf{N}$ & $\mathrm{mg} / \mathrm{L}$ & $0.09-2.1$ & $0.09-2.1$ & $0.09-2.1$ & $0.67-29$ & 2.0 \\
\hline Antimony, Total & $\mathrm{mg} / \mathrm{L}$ & 0.003 & -- & -- & -- & 0.003 \\
\hline Arsenic, Dissolved & $\mathrm{mg} / \mathrm{L}$ & 0.050 & 0.150 & 0.150 & 0.340 & -- \\
\hline Arsenic, Total & $\mathrm{mg} / \mathrm{L}$ & 0.050 & -- & -- & -- & 0.025 \\
\hline Barium, Total & $\mathrm{mg} / \mathrm{L}$ & 1.00 & -- & -- & -- & 1.00 \\
\hline Beryllium, Total & $\mathrm{mg} / \mathrm{L}$ & 0.003 & $d$ & $d$ & -- & 0.003 \\
\hline Boron, Total & $\mathrm{mg} / \mathrm{L}$ & 10.0 & 10.0 & 10.0 & -- & 1.00 \\
\hline Bromide & $\mathrm{mg} / \mathrm{L}$ & 2.00 & -- & -- & -- & 2.00 \\
\hline Cadmium, Dissolved $^{e}$ & $\mathrm{mg} / \mathrm{L}$ & -- & -- & -- & -- & -- \\
\hline Cadmium, Total & $\mathrm{mg} / \mathrm{L}$ & 0.005 & -- & - & -- & 0.005 \\
\hline Calcium, Total & $\mathrm{mg} / \mathrm{L}$ & -- & -- & -- & -- & -- \\
\hline Chloride & $\mathrm{mg} / \mathrm{L}$ & 250 & -- & -- & -- & 250 \\
\hline Chromium, Dissolved $^{e}$ & $\mathrm{mg} / \mathrm{L}$ & -- & -- & -- & -- & -- \\
\hline Chromium, Total & $\mathrm{mg} / \mathrm{L}$ & 0.05 & -- & -- & -- & 0.05 \\
\hline Cobalt, Totalf & $\mathrm{mg} / \mathrm{L}$ & 0.005 & 0.005 & 0.005 & 0.110 & -- \\
\hline Conductivity & $\mu \mathrm{mhos} / \mathrm{cm} @ 25^{\circ} \mathrm{C}$ & -- & -- & -- & -- & -- \\
\hline Copper, Dissolved ${ }^{e}$ & $\mathrm{mg} / \mathrm{L}$ & -- & -- & -- & -- & -- \\
\hline Copper, Total & $\mathrm{mg} / \mathrm{L}$ & 0.20 & -- & -- & -- & 0.20 \\
\hline Cyanide & $\mathrm{mg} / \mathrm{L}$ & 0.0052 & 0.0052 & 0.0052 & 0.22 & 0.200 \\
\hline Dissolved Oxygen (minimum) & $\mathrm{mg} / \mathrm{L}$ & 4.0 & 4.0 & 4.0 & 3.0 & -- \\
\hline Fluoride $^{e}$ & $\mathrm{mg} / \mathrm{L}$ & -- & -- & -- & -- & 1.5 \\
\hline Hardness & $\mathrm{mg} / \mathrm{L}$ & -- & -- & -- & -- & -- \\
\hline Iron and Manganese (sum) & $\mathrm{mg} / \mathrm{L}$ & -- & -- & -- & -- & 0.500 \\
\hline Iron, Total & $\mathrm{mg} / \mathrm{L}$ & 0.30 & 0.30 & 0.30 & 0.30 & 0.30 \\
\hline
\end{tabular}

-- No applicable guideline or reference standard available

Note: All water quality and metals standards are presented in $\mathrm{mg} / \mathrm{L}(\mathrm{ppm})$ to provide consistency in comparisons.

a Source: 6 NYCRR Parts 701-704; The most stringent applicable pathway (e.g., wildlife, aquatic, human health) values are reported.

${ }^{b}$ Gross alpha standard includes radium-226, but excludes radon and uranium; however WVDP results include these isotopes.

c Gross beta standard excludes strontium-90 and alpha emitters, however WVDP results include these isotopes.

$d$ Beryllium standard for classes " $\mathrm{B}$ " and " $\mathrm{C}$ " are based on stream hardness values.

e Standards for these constituents vary according to stream location hardness values.

$f$ Standards for cobalt, thallium, and vanadium are applicable to the acid-soluble fraction.

$g$ Applies to the sum of those organic substances which have individual human health water source standards listed at $0.100 \mathrm{mg} / \mathrm{L}$ or less in 6 NYCRR Part 703.5

${ }^{h} \mathrm{pH}$ shall not be lower than 6.5 or the $\mathrm{pH}$ of natural groundwater, whichever is lower, nor shall $\mathrm{pH}$ be greater than 8.5 or the $\mathrm{pH}$ of the natural groundwater, whichever is greater. 
TABLE B-1B (concluded)

New York State Water Quality Standards and Guidelines ${ }^{a}$

\begin{tabular}{|c|c|c|c|c|c|c|}
\hline \multicolumn{7}{|c|}{ New York Water Quality Standards and Guidelines ${ }^{a}$} \\
\hline Parameter & Units & Class A & Class B & Class C & Class D & Class GA \\
\hline Lead, Dissolved $^{e}$ & $\mathrm{mg} / \mathrm{L}$ & -- & -- & -- & -- & -- \\
\hline Lead, Total & $\mathrm{mg} / \mathrm{L}$ & 0.050 & -- & -- & -- & 0.025 \\
\hline Magnesium, Total & $\mathrm{mg} / \mathrm{L}$ & 35.0 & -- & -- & -- & 35.0 \\
\hline Manganese, Total & $\mathrm{mg} / \mathrm{L}$ & 0.30 & -- & -- & -- & 0.30 \\
\hline Mercury, Dissolved & $\mathrm{mg} / \mathrm{L}$ & 0.0000007 & 0.0000007 & 0.0000007 & 0.0000007 & -- \\
\hline Mercury, Total & $\mathrm{mg} / \mathrm{L}$ & 0.0007 & -- & -- & -- & 0.0007 \\
\hline Nickel, Dissolved $^{e}$ & $\mathrm{mg} / \mathrm{L}$ & -- & -- & -- & -- & -- \\
\hline Nickel, Total & $\mathrm{mg} / \mathrm{L}$ & 0.10 & -- & -- & -- & 0.10 \\
\hline Nitrate-N & $\mathrm{mg} / \mathrm{L}$ & 10.0 & -- & -- & -- & 10.0 \\
\hline Nitrate + Nitrite & $\mathrm{mg} / \mathrm{L}$ & 10.0 & 10.0 & 10.0 & 10.0 & 10.0 \\
\hline Nitrite-N & $\mathrm{mg} / \mathrm{L}$ & 0.10 & 0.10 & 0.10 & -- & 1.00 \\
\hline NPOC $^{g}$ & $\mathrm{mg} / \mathrm{L}$ & 0.10 & -- & -- & -- & -- \\
\hline Oil \& Grease & $\mathrm{mg} / \mathrm{L}$ & -- & -- & -- & -- & -- \\
\hline pH & SU & $6.5-8.5^{h}$ & $6.5-8.5^{h}$ & $6.5-8.5^{h}$ & $6.0-9.5$ & $6.5-8.5^{h}$ \\
\hline Potassium, Total & $\mathrm{mg} / \mathrm{L}$ & -- & -- & -- & -- & -- \\
\hline Selenium, Dissolved & $\mathrm{mg} / \mathrm{L}$ & 0.0046 & 0.0046 & 0.0046 & -- & -- \\
\hline Selenium, Total & $\mathrm{mg} / \mathrm{L}$ & 0.01 & -- & -- & -- & 0.01 \\
\hline Silver, Total & $\mathrm{mg} / \mathrm{L}$ & 0.05 & -- & -- & -- & 0.05 \\
\hline Sodium, Total & $\mathrm{mg} / \mathrm{L}$ & -- & -- & -- & -- & 20.0 \\
\hline Solids, Settleable & $\mathrm{mg} / \mathrm{L}$ & -- & -- & -- & -- & -- \\
\hline Solids, Total Dissolved & $\mathrm{mg} / \mathrm{L}$ & 500 & 500 & 500 & -- & 500 \\
\hline Solids, Total Suspended & $\mathrm{mg} / \mathrm{L}$ & - & -- & -- & -- & -- \\
\hline Sulfate & $\mathrm{mg} / \mathrm{L}$ & 250 & -- & -- & -- & 250 \\
\hline Sulfide (undissociated form) & $\mathrm{mg} / \mathrm{L}$ & 0.002 & 0.002 & 0.002 & -- & 0.050 (as HS) \\
\hline Surfactants (as LAS) & $\mathrm{mg} / \mathrm{L}$ & 0.04 & 0.04 & 0.04 & -- & -- \\
\hline Thallium, Totalf & $\mathrm{mg} / \mathrm{L}$ & 0.0005 & 0.008 & 0.008 & 0.020 & 0.0005 \\
\hline Titanium, Total & $\mathrm{mg} / \mathrm{L}$ & -- & -- & -- & -- & -- \\
\hline TOX (total organic halides) ${ }^{g}$ & $\mathrm{mg} / \mathrm{L}$ & 0.10 & -- & -- & -- & -- \\
\hline Vanadium, Total ${ }^{f}$ & $\mathrm{mg} / \mathrm{L}$ & 0.014 & 0.014 & 0.014 & 0.190 & -- \\
\hline Zinc, Dissolved $^{e}$ & $\mathrm{mg} / \mathrm{L}$ & -- & -- & -- & -- & -- \\
\hline Zinc, Total & $\mathrm{mg} / \mathrm{L}$ & 2.00 & -- & -- & -- & 2.00 \\
\hline
\end{tabular}

-- No applicable guideline or reference standard available

Note: All water quality and metals standards are presented in $\mathrm{mg} / \mathrm{L}(\mathrm{ppm})$ to provide consistency in comparisons.

a Source: 6 NYCRR Parts 701-704; The most stringent applicable pathway (e.g., wildlife, aquatic, human health) values are reported.

$b$ Gross alpha standard includes radium-226, but excludes radon and uranium; however WVDP results include these isotopes.

c Gross beta standard excludes strontium-90 and alpha emitters, however WVDP results include these isotopes.

$d$ Beryllium standards for classes " $B$ " and " $C$ " are based on stream hardness values.

$e$ Standards for these constituents vary according to stream location hardness values.

f Standards for cobalt, thallium, and vanadium are applicable to the acid-soluble fraction.

$g$ Applies to the sum of those organic substances which have individual human health water source standards listed at $0.100 \mathrm{mg} / \mathrm{L}$ or less in 6 NYCRR Part 703.5

${ }^{h} \mathrm{pH}$ shall not be lower than 6.5 or the $\mathrm{pH}$ of natural groundwater, whichever is lower, nor shall $\mathrm{pH}$ be greater than 8.5 or the $\mathrm{pH}$ of the natural groundwater, whichever is greater. 
TABLE B-1C

New York State Department of Health/U.S. Environmental Protection Agency Potable Water MCLs, MCLGs, and Raw Water Standards

\begin{tabular}{|c|c|c|c|c|}
\hline Parameter & Units & $\begin{array}{l}\text { NYSDOH or } \\
\text { EPA MCL } \\
\end{array}$ & EPA MCLG ${ }^{b}$ & $\begin{array}{c}\text { NYSDOH Raw } \\
\text { Water Standards }^{c}\end{array}$ \\
\hline Gross Alpha & $\mathrm{pCi} / \mathrm{L}(\mu \mathrm{Ci} / \mathrm{mL})$ & $15(1.5 \mathrm{E}-08)^{d}$ & 0 & -- \\
\hline Gross Beta & $\mathrm{pCi} / \mathrm{L}(\mu \mathrm{Ci} / \mathrm{mL})$ & $50(5 \mathrm{E}-08)^{e}$ & 0 & 1,000 (1E-06) \\
\hline Tritium (H-3) & $\mathrm{pCi} / \mathrm{L}(\mu \mathrm{Ci} / \mathrm{mL})$ & 20,000 (2E-05) & -- & -- \\
\hline Strontium-90 & $\mathrm{pCi} / \mathrm{L}(\mu \mathrm{Ci} / \mathrm{mL})$ & $8(8 \mathrm{E}-09)$ & -- & $10(1 \mathrm{E}-08)$ \\
\hline Antimony, Total & $\mathrm{mg} / \mathrm{L}$ & 0.006 & 0.006 & -- \\
\hline Arsenic, Total & $\mathrm{mg} / \mathrm{L}$ & 0.05 & -- & 0.05 \\
\hline Barium, Total & $\mathrm{mg} / \mathrm{L}$ & 2.00 & 2.00 & 1.0 \\
\hline Beryllium, Total & $\mathrm{mg} / \mathrm{L}$ & 0.004 & 0.004 & -- \\
\hline Cadmium, Total & $\mathrm{mg} / \mathrm{L}$ & 0.005 & 0.005 & 0.01 \\
\hline Chromium, Total & $\mathrm{mg} / \mathrm{L}$ & 0.10 & 0.10 & -- \\
\hline Conductivity & $\mu \mathrm{mhos} / \mathrm{cm} @ 25^{\circ} \mathrm{C}$ & -- & -- & -- \\
\hline Copper, Total & $\mathrm{mg} / \mathrm{L}$ & 1.3 & 1.3 & $<0.2$ \\
\hline Cyanide & $\mathrm{mg} / \mathrm{L}$ & 0.2 & 0.2 & $<0.1$ \\
\hline E. Coli & NA & one positive sample & 0 & -- \\
\hline Fluoride & $\mathrm{mg} / \mathrm{L}$ & 2.2 & -- & $<1.5$ \\
\hline Free Residual Chlorine & $\mathrm{mg} / \mathrm{L}$ & $0.02(\min ) 4.0(\max )$ & -- & -- \\
\hline Haloacetic Acids-Five (5) & $\mathrm{mg} / \mathrm{L}$ & 0.060 & -- & -- \\
\hline Iron, Total & $\mathrm{mg} / \mathrm{L}$ & 0.3 & -- & -- \\
\hline Lead, Total & $\mathrm{mg} / \mathrm{L}$ & 0.015 & 0 & 0.05 \\
\hline Mercury, Total & $\mathrm{mg} / \mathrm{L}$ & 0.002 & 0.002 & 0.005 \\
\hline Nickel, Total & $\mathrm{mg} / \mathrm{L}$ & -- & -- & -- \\
\hline Nitrate-N & $\mathrm{mg} / \mathrm{L}$ & 10 & 10 & -- \\
\hline pH & SU & -- & -- & $6.5-8.5$ \\
\hline POC (Principle Organic Contaminant) & $\mathrm{mg} / \mathrm{L}$ & -- & 0.0005 & -- \\
\hline Selenium, Total & $\mathrm{mg} / \mathrm{L}$ & 0.05 & 0.05 & 0.01 \\
\hline Solids, Total Dissolved & $\mathrm{mg} / \mathrm{L}$ & -- & -- & 500 \\
\hline Thallium, Total & $\mathrm{mg} / \mathrm{L}$ & 0.002 & 0.0005 & -- \\
\hline Total Coliform & NA & $\begin{array}{c}2 \text { or more } \\
\text { positive samples }\end{array}$ & 0 & -- \\
\hline Total Trihalomethanes & $\mathrm{mg} / \mathrm{L}$ & 0.080 & -- & -- \\
\hline Turbidity & NTU & 1 (max) & -- & -- \\
\hline
\end{tabular}

-- No applicable guideline or reference standard available

Note: All water quality and metals standards are presented in $\mathrm{mg} / \mathrm{L}(\mathrm{ppm})$ to provide consistency in comparisons.

NA - Not applicable

a MCL - Listed is NYSDOH or EPA Maximum Contaminant Level. Sources: 40 CFR 141 and/or 5 NYCRR 5-1.52, whichever is more stringent.

b MCLG - Maximum Contaminant Level Goal (non-enforceable) as listed in 40 CFR Part 141

c Source: 10 NYCRR Part 170.4

$d$ Alpha guideline includes radium-226, but excludes uranium; however, WVDP results include these isotopes.

$e$ Average annual concentration assumed to produce a total body organ dose of $4 \mathrm{mrem} /$ year 
TABLE B-1D

\section{U.S. Department of Energy Derived Concentration Guides (DCGs) ${ }^{a}$ in Ingested Water}

\begin{tabular}{|c|c|c|}
\hline Radionuclide & Units & Concentration in Ingested Water \\
\hline Gross Alpha (as Am-241) ${ }^{b}$ & $\mu \mathrm{Ci} / \mathrm{mL}$ & $3 \mathrm{E}-08$ \\
\hline Gross Beta (as Sr-90) $^{b}$ & $\mu \mathrm{Ci} / \mathrm{mL}$ & $1 \mathrm{E}-06$ \\
\hline Tritium (H-3) & $\mu \mathrm{Ci} / \mathrm{mL}$ & $2 \mathrm{E}-03$ \\
\hline Carbon-14 (C-14) & $\mu \mathrm{Ci} / \mathrm{mL}$ & $7 \mathrm{E}-05$ \\
\hline Potassium-40 (K-40) & $\mu \mathrm{Ci} / \mathrm{mL}$ & $7 \mathrm{E}-06$ \\
\hline Cobalt-60 (Co-60) & $\mu \mathrm{Ci} / \mathrm{mL}$ & $5 \mathrm{E}-06$ \\
\hline Strontium-90 (Sr-90) & $\mu \mathrm{Ci} / \mathrm{mL}$ & $1 \mathrm{E}-06$ \\
\hline Technetium-99 (Tc-99) & $\mu \mathrm{Ci} / \mathrm{mL}$ & $1 \mathrm{E}-04$ \\
\hline lodine-129 (I-129) & $\mu \mathrm{Ci} / \mathrm{mL}$ & $5 \mathrm{E}-07$ \\
\hline Cesium-137 (Cs-137) & $\mu \mathrm{Ci} / \mathrm{mL}$ & $3 \mathrm{E}-06$ \\
\hline Europium-154 (Eu-154) & $\mu \mathrm{Ci} / \mathrm{mL}$ & $2 \mathrm{E}-05$ \\
\hline Uranium-232 (U-232) & $\mu \mathrm{Ci} / \mathrm{mL}$ & $1 \mathrm{E}-07$ \\
\hline Uranium-233 (U-233) & $\mu \mathrm{Ci} / \mathrm{mL}$ & $5 \mathrm{E}-07$ \\
\hline Uranium-234 (U-234) & $\mu \mathrm{Ci} / \mathrm{mL}$ & $5 \mathrm{E}-07$ \\
\hline Uranium-235 (U-235) & $\mu \mathrm{Ci} / \mathrm{mL}$ & $6 \mathrm{E}-07$ \\
\hline Uranium-236 (U-236) & $\mu \mathrm{Ci} / \mathrm{mL}$ & $5 \mathrm{E}-07$ \\
\hline Uranium-238 (U-238) & $\mu \mathrm{Ci} / \mathrm{mL}$ & $6 \mathrm{E}-07$ \\
\hline Plutonium-238 (Pu-238) & $\mu \mathrm{Ci} / \mathrm{mL}$ & $4 \mathrm{E}-08$ \\
\hline Plutonium-239 (Pu-239) & $\mu \mathrm{Ci} / \mathrm{mL}$ & $3 \mathrm{E}-08$ \\
\hline Plutonium-240 (Pu-240) & $\mu \mathrm{Ci} / \mathrm{mL}$ & $3 \mathrm{E}-08$ \\
\hline Americium-241 (Am-241) & $\mu \mathrm{Ci} / \mathrm{mL}$ & $3 \mathrm{E}-08$ \\
\hline
\end{tabular}

a DCG: Derived Concentration Guide. DCGs are established in DOE Order 5400.5 and are defined as the concentration of a radionuclide that, under conditions of continuous exposure for one year by one exposure mode, would result in an effective dose equivalent of 100 mrem (1mSv).

$b$ Because there are no DCGs for gross alpha and gross beta concentrations, the DCGs for the most restrictive alpha and beta emitters at the WVDP, americium-241 and strontium-90 (3E-08 and 1E-06 $\mu \mathrm{Ci} / \mathrm{mL}$, respectively) are used as a conservative basis for comparison at locations for which there are no radionuclide-specific data, in which case a more appropriate DCG may be applied. 
This page intentionally left blank 


\section{APPENDIX B-2}

\section{Process Effluent Data}

TABLE B-2A

Comparison of 2008 Lagoon 3 (WNSP001) Liquid Effluent Radioactivity Concentrations With U.S. Department of Energy Guidelines

\begin{tabular}{|c|c|c|c|c|c|}
\hline Isotope $e^{a}$ & $\begin{array}{l}\text { Discharge } \\
\text { Activity }^{b} \\
\text { (Ci) }\end{array}$ & $\begin{array}{c}\text { Radioactivity }^{c} \\
\text { (Becquerels) }\end{array}$ & $\begin{array}{c}\text { Average } \\
\text { Concentration } \\
(\mu \mathrm{Ci} / \mathrm{mL})\end{array}$ & $\begin{array}{c}D C G^{d} \\
(\mu \mathrm{Ci} / \mathrm{mL})\end{array}$ & $\begin{array}{c}\text { Ratio of } \\
\text { Concentration } \\
\text { to DCG }\end{array}$ \\
\hline Gross Alpha & $9.20 \pm 1.04 \mathrm{E}-04$ & $3.40 \pm 0.38 \mathrm{E}+07$ & $1.91 \pm 0.22 \mathrm{E}-08$ & $N A^{e}$ & NA \\
\hline Gross Beta & $1.71 \pm 0.03 \mathrm{E}-02$ & $6.34 \pm 0.10 E+08$ & $3.56 \pm 0.06 \mathrm{E}-07$ & $\mathrm{NA}^{e}$ & NA \\
\hline $\mathrm{H}-3$ & 4.73 $\pm 0.09 E-02$ & $1.75 \pm 0.03 E+09$ & $9.83 \pm 0.19 E-07$ & $2 \mathrm{E}-03$ & 0.0005 \\
\hline C-14 & $2.23 \pm 5.73 \mathrm{E}-04$ & $0.82 \pm 2.12 E+07$ & $0.46 \pm 1.19 \mathrm{E}-08$ & $7 \mathrm{E}-05$ & $<0.0002$ \\
\hline K-40 & $0.58 \pm 1.04 \mathrm{E}-03$ & $2.16 \pm 3.84 \mathrm{E}+07$ & $1.21 \pm 2.16 \mathrm{E}-08$ & $N A^{f}$ & NA \\
\hline Co-60 & $-0.03 \pm 3.55 E-05$ & $-0.01 \pm 1.31 E+06$ & $-0.06 \pm 7.37 \mathrm{E}-10$ & $5 \mathrm{E}-06$ & $<0.0002$ \\
\hline Sr-90 & $6.89 \pm 0.09 E-03$ & $2.55 \pm 0.03 E+08$ & $1.43 \pm 0.02 E-07$ & $1 \mathrm{E}-06$ & 0.143 \\
\hline Tc-99 & $7.66 \pm 0.49 E-04$ & $2.84 \pm 0.18 E+07$ & $1.59 \pm 0.10 \mathrm{E}-08$ & $1 \mathrm{E}-04$ & 0.0002 \\
\hline I-129 & $2.02 \pm 1.85 \mathrm{E}-05$ & $7.48 \pm 6.85 E+05$ & $4.21 \pm 3.85 \mathrm{E}-10$ & $5 \mathrm{E}-07$ & 0.0008 \\
\hline Cs-137 & $3.87 \pm 0.11 \mathrm{E}-03$ & $1.43 \pm 0.04 \mathrm{E}+08$ & $8.06 \pm 0.23 E-08$ & $3 \mathrm{E}-06$ & 0.0269 \\
\hline $\mathbf{U}-232^{g}$ & $3.85 \pm 0.13 \mathrm{E}-04$ & $1.42 \pm 0.05 E+07$ & $8.00 \pm 0.28 \mathrm{E}-09$ & $1 \mathrm{E}-07$ & 0.0800 \\
\hline $\mathrm{U}-233 / 234^{g}$ & $2.33 \pm 0.10 \mathrm{E}-04$ & $8.62 \pm 0.38 \mathrm{E}+06$ & $4.84 \pm 0.21 E-09$ & $5 \mathrm{E}-07$ & 0.0097 \\
\hline U-235/236 ${ }^{g}$ & $1.20 \pm 0.25 \mathrm{E}-05$ & $4.43 \pm 0.91 E+05$ & $2.49 \pm 0.51 \mathrm{E}-10$ & $5 \mathrm{E}-07^{h}$ & 0.0005 \\
\hline $\mathrm{U}-238^{g}$ & $1.97 \pm 0.10 \mathrm{E}-04$ & $7.30 \pm 0.36 \mathrm{E}+06$ & $4.10 \pm 0.20 \mathrm{E}-09$ & $6 \mathrm{E}-07$ & 0.0068 \\
\hline Pu-238 & $2.63 \pm 0.83 E-06$ & $9.71 \pm 3.09 E+04$ & $5.46 \pm 1.73 \mathrm{E}-11$ & $4 \mathrm{E}-08$ & 0.0014 \\
\hline Pu-239/240 & $2.23 \pm 0.71 \mathrm{E}-06$ & $8.26 \pm 2.63 E+04$ & $4.64 \pm 1.48 \mathrm{E}-11$ & $3 \mathrm{E}-08$ & 0.0015 \\
\hline Am-241 & $5.38 \pm 1.49 E-06$ & $1.99 \pm 0.55 E+05$ & $1.12 \pm 0.31 E-10$ & $3 \mathrm{E}-08$ & 0.0037 \\
\hline \multicolumn{5}{|l|}{ Sum of Ratios } & 0.28 \\
\hline
\end{tabular}

NA - Not applicable

a Half-lives are listed in Table UI-4.

$b$ Total volume released: $4.81 \mathrm{E}+10 \mathrm{~mL}(1.27 \mathrm{E}+07$ gal)

c 1 curie $(\mathrm{Ci})=3.7 \mathrm{E}+10$ becquerels $(\mathrm{Bq}) ; 1 \mathrm{~Bq}=2.7 \mathrm{E}-11 \mathrm{Ci}$

$d$ DOE-derived concentration guides (DCGs) are listed for reference only. DCGs are applicable at the point at which water is available for ingestion by the public (i.e., at the site boundary), but not to release point concentrations, as might be inferred from their inclusion in this table.

$e$ DOE DCGs do not exist for indicator parameters gross alpha and gross beta.

$f$ The DCG is not applied to potassium-40 (K-40) activity because of its natural origin.

$g$ Total $U(\mathrm{~g})=5.39 \pm 0.13 \mathrm{E}+02$; Average $U(\mu \mathrm{g} / \mathrm{mL})=1.12 \pm 0.03 \mathrm{E}-02$

$h$ DCG for U-236 is used for this comparison. 
TABLE B-2B

2008 SPDES Results for Outfall 001 (WNSP001): Water Quality

\begin{tabular}{|c|c|c|c|c|c|c|c|c|}
\hline \multirow{2}{*}{\begin{tabular}{|l} 
Permit Limit \\
Month \\
\end{tabular}} & \multicolumn{2}{|c|}{$\begin{array}{c}\text { Ammonia } \\
\text { (mg/L) } \\
\text { Monitor }\end{array}$} & \multicolumn{2}{|c|}{$\begin{array}{c}\text { BOD5 day } \\
(\mathrm{mg} / \mathrm{L}) \\
10.0 \mathrm{mg} / \mathrm{L} \text { daily } \\
\text { maximum }\end{array}$} & \multicolumn{2}{|c|}{$\begin{array}{c}\text { Discharge Rate } \\
\text { (MGD) } \\
\text { Monitor }\end{array}$} & \multicolumn{2}{|c|}{$\begin{array}{c}\text { Nitrate (as N) } \\
(\mathrm{mg} / \mathrm{L}) \\
\text { Monitor }\end{array}$} \\
\hline & Avg & Max & Avg & Max & Avg & Max & Avg & Max \\
\hline January & 0.049 & 0.054 & $<2.0$ & $<2.0$ & 0.345 & 0.357 & 1.6 & 1.6 \\
\hline February $^{a}$ & -- & -- & -- & -- & -- & -- & -- & -- \\
\hline March & 0.038 & 0.049 & $<2.0$ & $<2.0$ & 0.286 & 0.361 & 1.3 & 1.3 \\
\hline April & $<0.011$ & $<0.011$ & $<2.0$ & $<2.0$ & 0.262 & 0.282 & 1.3 & 1.4 \\
\hline May $^{a}$ & - & -- & -- & -- & - & - & -- & -- \\
\hline June & 0.031 & 0.042 & $<2.0$ & $<2.0$ & 0.227 & 0.248 & 0.16 & 0.18 \\
\hline July $^{a}$ & -- & -- & -- & -- & -- & -- & -- & -- \\
\hline August & $<0.019$ & 0.026 & 4.1 & 4.5 & 0.192 & 0.215 & $<0.011$ & $<0.011$ \\
\hline September & $<0.011$ & $<0.011$ & 4.2 & 4.3 & 0.151 & 0.175 & 0.16 & 0.17 \\
\hline October $^{a}$ & - & -- & -- & -- & - & - & - & -- \\
\hline November & 0.15 & 0.17 & $<2.8$ & 3.6 & 0.200 & 0.218 & 0.33 & 0.33 \\
\hline December $^{a}$ & -- & -- & -- & -- & -- & -- & -- & -- \\
\hline
\end{tabular}

\begin{tabular}{|c|c|c|c|c|c|c|c|c|}
\hline \multirow{2}{*}{\begin{tabular}{|l} 
Permit Limit \\
Month \\
\end{tabular}} & \multicolumn{2}{|c|}{$\begin{array}{l}\text { Nitrite (as N) } \\
(\mathrm{mg} / \mathrm{L}) \\
0.1 \mathrm{mg} / \mathrm{L} \text { daily } \\
\text { maximum }\end{array}$} & \multicolumn{2}{|c|}{$\begin{array}{c}\text { Oil \& Grease } \\
(\mathrm{mg} / \mathrm{L}) \\
15.0 \mathrm{mg} / \mathrm{L} \text { daily } \\
\text { maximum }\end{array}$} & \multicolumn{2}{|c|}{$\begin{array}{c}p H \\
\text { (standard units) } \\
6.5 \text { to } 8.5\end{array}$} & \multicolumn{2}{|c|}{$\begin{array}{c}\text { Solids, } \\
\text { Settleable } \\
(\mathrm{ml} / \mathrm{L}) \\
0.3 \mathrm{ml} / \mathrm{L} \text { daily } \\
\text { maximum }\end{array}$} \\
\hline & Avg & Max & Avg & Max & Min & Max & Avg & Max \\
\hline January & $<0.02$ & $<0.02$ & $<3.4$ & 4.6 & 7.5 & 7.5 & $<0.1$ & $<0.1$ \\
\hline February $^{a}$ & -- & -- & -- & -- & -- & -- & -- & -- \\
\hline March & $<0.02$ & $<0.02$ & $<2.2$ & $<2.2$ & 7.6 & 7.6 & $<0.1$ & $<0.1$ \\
\hline April & $<0.02$ & $<0.02$ & $<3.7$ & 5.1 & 7.7 & 7.7 & $<0.1$ & $<0.1$ \\
\hline$M_{a y}{ }^{a}$ & -- & -- & -- & -- & -- & -- & -- & -- \\
\hline June & $<0.02$ & $<0.02$ & $<2.2$ & $<2.2$ & 7.1 & 7.1 & $<0.1$ & $<0.1$ \\
\hline July ${ }^{a}$ & -- & -- & -- & -- & -- & -- & -- & -- \\
\hline August & $<0.02$ & $<0.02$ & $<2.2$ & $<2.2$ & 7.4 & 7.4 & $<0.1$ & $<0.1$ \\
\hline September & $<0.02$ & $<0.02$ & $<2.2$ & $<2.2$ & 7.2 & 7.2 & $<0.1$ & $<0.1$ \\
\hline October $^{a}$ & -- & -- & -- & -- & -- & -- & -- & -- \\
\hline November & $<0.02$ & $<0.02$ & $<2.2$ & $<2.2$ & 7.3 & 7.3 & $<0.1$ & $<0.1$ \\
\hline December $^{a}$ & -- & -- & -- & -- & -- & -- & -- & -- \\
\hline
\end{tabular}

Note: No results exceeded the permit limits.

a No discharge this month 
TABLE B-2B (concluded)

2008 SPDES Results for Outfall 001 (WNSP001): Water Quality

\begin{tabular}{|c|c|c|c|c|c|c|c|c|}
\hline \multirow{2}{*}{$\begin{array}{l}\text { Permit Limit } \\
\text { Month } \\
\end{array}$} & \multicolumn{2}{|c|}{$\begin{array}{c}\text { Solids, } \\
\text { Total Dissolved } \\
\text { (mg/L) } \\
\text { Monitor }\end{array}$} & \multicolumn{2}{|c|}{$\begin{array}{c}\text { Solids, } \\
\text { Total Suspended } \\
\text { (mg/L) } \\
45 \mathrm{mg} / \mathrm{L} \text { daily } \\
\text { maximum; } \\
30 \mathrm{mg} / \mathrm{L} \text { daily average } \\
\end{array}$} & \multicolumn{2}{|c|}{$\begin{array}{c}\text { Sulfate (as S) } \\
\text { (mg/L) }\end{array}$} & \multicolumn{2}{|c|}{$\begin{array}{l}\text { Sulfide (as S) } \\
\text { Dissolved } \\
\text { (mg/L) } \\
0.4 \mathrm{mg} / \mathrm{L} \text { daily } \\
\text { maximum }\end{array}$} \\
\hline & Avg & Max & Avg & Max & Avg & Max & Avg & Max \\
\hline January & 787 & 789 & $<4.0$ & $<4.0$ & 42 & 42 & $<0.02$ & $<0.02$ \\
\hline February $^{a}$ & -- & -- & -- & -- & -- & -- & -- & -- \\
\hline March & 826 & 830 & $<4.0$ & $<4.0$ & 35 & 39 & $<0.02$ & $<0.02$ \\
\hline April & 865 & 866 & $<4.8$ & 5.6 & 38 & 39 & $<0.02$ & $<0.02$ \\
\hline May $^{a}$ & -- & -- & -- & -- & -- & -- & -- & -- \\
\hline June & 975 & 977 & $<4.0$ & $<4.0$ & 63 & 64 & $<0.02$ & $<0.02$ \\
\hline July ${ }^{a}$ & -- & -- & -- & -- & -- & -- & -- & -- \\
\hline August & 939 & 940 & $<4.2$ & 4.4 & 76 & 86 & $<0.02$ & $<0.02$ \\
\hline September & 1026 & 1035 & 7.0 & 8.8 & 66 & 67 & $<0.02$ & $<0.02$ \\
\hline October $^{a}$ & -- & -- & -- & -- & -- & -- & -- & -- \\
\hline November & 942 & 950 & $<4.0$ & $<4.0$ & 71 & 71 & $<0.02$ & $<0.02$ \\
\hline December $^{a}$ & -- & -- & -- & -- & -- & -- & -- & -- \\
\hline
\end{tabular}

Note: No results exceeded the permit limits.

a No discharge this month 
TABLE B-2C

2008 SPDES Results for Outfall 001 (WNSP001): Metals

\begin{tabular}{|c|c|c|c|c|c|c|c|c|}
\hline \multirow{2}{*}{\begin{tabular}{|l} 
Permit Limit \\
Month \\
\end{tabular}} & \multicolumn{2}{|c|}{$\begin{array}{c}\text { Aluminum } \\
\text { Total } \\
\text { ( } \mathrm{mg} / \mathrm{L}) \\
14.0 \mathrm{mg} / \mathrm{L} \text { daily maximum; } \\
7.0 \mathrm{mg} / \mathrm{L} \text { daily average }\end{array}$} & \multicolumn{2}{|c|}{$\begin{array}{c}\text { Arsenic } \\
\text { Dissolved } \\
\text { ( } \mathrm{mg} / \mathrm{L}) \\
0.15 \mathrm{mg} / \mathrm{L} \text { daily } \\
\text { maximum }\end{array}$} & \multicolumn{2}{|c|}{$\begin{array}{c}\text { Cobalt } \\
\text { Total Recoverable } \\
\text { (mg/L) } \\
0.005 \mathrm{mg} / \mathrm{L} \text { daily } \\
\text { maximum }\end{array}$} & \multicolumn{2}{|c|}{$\begin{array}{c}\text { Iron } \\
\text { Total } \\
\text { (mg/L) } \\
\text { Monitor }\end{array}$} \\
\hline & Avg & $\operatorname{Max}$ & Avg & $\operatorname{Max}$ & Avg & Max & Avg & $\operatorname{Max}$ \\
\hline January & 0.470 & 0.470 & 0.0011 & 0.0011 & $<0.0009$ & $<0.0009$ & 0.324 & 0.365 \\
\hline February $^{a}$ & -- & -- & -- & -- & -- & -- & -- & -- \\
\hline March & 1.17 & 1.17 & 0.0016 & 0.0016 & 0.0006 & 0.0006 & 0.816 & 0.878 \\
\hline April & 0.860 & 0.860 & 0.0018 & 0.0018 & $<0.0007$ & $<0.0007$ & 0.730 & 0.772 \\
\hline $\operatorname{May}^{a}$ & -- & - & -- & -- & -- & -- & -- & -- \\
\hline June & 0.247 & 0.247 & 0.0022 & 0.0022 & $<0.0007$ & $<0.0007$ & 0.252 & 0.273 \\
\hline July $^{a}$ & -- & -- & -- & -- & -- & -- & -- & -- \\
\hline August & 0.603 & 0.603 & 0.0031 & 0.0031 & $<0.001$ & $<0.001$ & 0.655 & 0.775 \\
\hline September & 0.218 & 0.218 & 0.0030 & 0.0030 & $<0.001$ & $<0.001$ & 0.504 & 0.632 \\
\hline October $^{a}$ & - & - & - & -- & - & - & -- & - \\
\hline November & 1.34 & 1.34 & 0.0022 & 0.0022 & $<0.001$ & $<0.001$ & 0.999 & 1.02 \\
\hline December $^{a}$ & -- & -- & -- & -- & -- & -- & -- & - \\
\hline
\end{tabular}

\begin{tabular}{|c|c|c|c|c|c|c|}
\hline \multirow{2}{*}{\begin{tabular}{|l} 
Permit Limit \\
Month \\
\end{tabular}} & \multicolumn{2}{|c|}{$\begin{array}{c}\text { Mercury, Total } \\
\text { (per EPA Method } \\
1631)(\mathrm{ng} / \mathrm{L}) \\
200 \mathrm{ng} / \mathrm{L} \text { daily } \\
\text { maximum } \\
\end{array}$} & \multicolumn{2}{|c|}{$\begin{array}{c}\text { Selenium } \\
\text { Total Recoverable } \\
(\mathrm{mg} / \mathrm{L}) \\
0.004 \mathrm{mg} / \mathrm{L} \text { daily } \\
\text { maximum } \\
\end{array}$} & \multicolumn{2}{|c|}{$\begin{array}{c}\text { Vanadium } \\
\text { Total Recoverable } \\
\text { ( } \mathrm{mg} / \mathrm{L}) \\
0.014 \mathrm{mg} / \mathrm{L} \text { daily } \\
\text { maximum }\end{array}$} \\
\hline & Avg & Max & Avg & Max & Avg & Max \\
\hline January & 6.64 & 7.06 & $<0.0004$ & $<0.0004$ & 0.0019 & 0.0019 \\
\hline February $^{a}$ & -- & -- & -- & -- & -- & -- \\
\hline March & 5.25 & 5.76 & $<0.0005$ & 0.0006 & 0.0015 & 0.0015 \\
\hline April & 3.96 & 4.21 & $<0.0004$ & $<0.0004$ & 0.0024 & 0.0024 \\
\hline May $^{a}$ & -- & -- & -- & -- & -- & - \\
\hline June & 4.09 & 4.20 & $<0.0004$ & $<0.0004$ & $<0.00098$ & $<0.00098$ \\
\hline July ${ }^{a}$ & -- & - & -- & -- & -- & -- \\
\hline August & 5.21 & 5.24 & $<0.0004$ & $<0.0004$ & 0.0012 & 0.0012 \\
\hline September & 5.24 & 5.38 & 0.001 & 0.001 & $<0.00098$ & $<0.00098$ \\
\hline October $^{a}$ & -- & -- & -- & -- & -- & -- \\
\hline November & 6.96 & 7.91 & $<0.0004$ & $<0.0004$ & 0.0035 & 0.0035 \\
\hline December $^{a}$ & -- & -- & -- & -- & -- & -- \\
\hline
\end{tabular}

Note: No results exceeded the permit limits.

a No discharge this month 
TABLE B-2D

2008 SPDES Results for Outfall 007 (WNSP007): Water Quality and Iron

\begin{tabular}{|c|c|c|c|c|c|c|c|c|c|c|}
\hline \multirow{2}{*}{\begin{tabular}{|l} 
\\
Permit Limit \\
Month \\
\end{tabular}} & \multicolumn{2}{|c|}{$\begin{array}{c}\text { Ammonia } \\
\text { (as NH3) } \\
\text { (mg/L) } \\
\text { Monitor }\end{array}$} & \multicolumn{2}{|c|}{$\begin{array}{c}\text { BOD5 } \\
(\mathrm{mg} / \mathrm{L}) \\
10.0 \mathrm{mg} / \mathrm{L} \text { daily } \\
\text { maximum }\end{array}$} & \multicolumn{2}{|c|}{$\begin{array}{c}\text { Chlorine } \\
\text { Total Residual } \\
\text { (mg/L) } \\
0.1 \mathrm{mg} / \mathrm{L} \text { daily } \\
\text { maximum }\end{array}$} & \multicolumn{2}{|c|}{$\begin{array}{c}\text { Discharge Rate } \\
\text { (MGD) } \\
\text { Monitor }\end{array}$} & \multicolumn{2}{|c|}{$\begin{array}{c}\text { Iron } \\
\text { Total } \\
\text { (mg/L) } \\
\text { Monitor }\end{array}$} \\
\hline & Avg & Max & Avg & Max & Avg & Max & Avg & $\operatorname{Max}$ & Avg & Max \\
\hline January & $<0.015$ & 0.024 & $<2.5$ & 3.6 & 0.02 & 0.04 & 0.011 & 0.019 & 0.169 & 0.208 \\
\hline February & $<0.013$ & 0.016 & $<2.0$ & $<2.0$ & $<0.05$ & 0.09 & 0.010 & 0.015 & 0.124 & 0.140 \\
\hline March & $<0.015$ & 0.024 & $<2.0$ & $<2.0$ & $<0.03$ & 0.05 & 0.013 & 0.016 & 0.141 & 0.174 \\
\hline April & $<0.018$ & 0.028 & $<2.0$ & $<2.0$ & $<0.01$ & 0.02 & 0.011 & 0.016 & 0.164 & 0.183 \\
\hline May & $<0.011$ & $<0.011$ & $<2.0$ & $<2.0$ & $<0.02$ & 0.05 & 0.008 & 0.022 & 0.125 & 0.259 \\
\hline June & $<0.011$ & $<0.011$ & $<2.0$ & $<2.0$ & $<0.04$ & 0.06 & 0.011 & 0.018 & 0.111 & 0.204 \\
\hline July & $<0.028$ & 0.057 & $<2.0$ & $<2.0$ & $<0.03$ & 0.04 & 0.011 & 0.019 & 0.067 & 0.127 \\
\hline August & $<0.015$ & 0.022 & $<2.8$ & 3.5 & 0.03 & 0.07 & 0.016 & 0.016 & 0.126 & 0.310 \\
\hline September & $<0.014$ & 0.019 & $<3.1$ & 4.0 & 0.03 & 0.08 & 0.007 & 0.009 & $<0.0343$ & 0.0512 \\
\hline October & $<0.011$ & $<0.011$ & $<2.2$ & 2.6 & 0.04 & 0.07 & 0.014 & 0.026 & 0.0619 & 0.0879 \\
\hline November & $<0.011$ & $<0.011$ & $<2.1$ & 2.2 & 0.03 & 0.08 & 0.018 & 0.035 & 0.137 & 0.177 \\
\hline December & $<0.011$ & $<0.011$ & $<2.0$ & $<2.0$ & 0.02 & 0.03 & 0.021 & 0.032 & 0.146 & 0.186 \\
\hline
\end{tabular}

\begin{tabular}{|c|c|c|c|c|c|c|c|c|c|c|}
\hline \multirow{2}{*}{$\begin{array}{l}\text { Permit Limit } \\
\text { Month }\end{array}$} & \multicolumn{2}{|c|}{$\begin{array}{c}\text { Nitrite } \\
\text { (as } \mathrm{N}) \\
(\mathrm{mg} / \mathrm{L}) \\
0.1 \mathrm{mg} / \mathrm{L} \text { daily } \\
\text { maximum }\end{array}$} & \multicolumn{2}{|c|}{$\begin{array}{c}\text { Oil \& Grease } \\
(\mathrm{mg} / \mathrm{L}) \\
15.0 \mathrm{mg} / \mathrm{L} \text { daily } \\
\text { maximum }\end{array}$} & \multicolumn{2}{|c|}{$\begin{array}{c}p H \\
\text { (standard units) } \\
6.5 \text { to } 8.5\end{array}$} & \multicolumn{2}{|c|}{$\begin{array}{c}\text { Solids } \\
\text { Settleable } \\
(\mathrm{mL} / \mathrm{L}) \\
0.3 \mathrm{~mL} / \mathrm{L} \text { daily } \\
\text { maximum }\end{array}$} & \multicolumn{2}{|c|}{$\begin{array}{c}\text { Solids } \\
\text { Total Suspended } \\
\text { (mg/L) } \\
45 \mathrm{mg} / \mathrm{L} \text { daily maximum; } \\
30 \mathrm{mg} / \mathrm{L} \text { daily average }\end{array}$} \\
\hline & Avg & Max & Avg & Max & Min & Max & Avg & Max & Avg & Max \\
\hline \begin{tabular}{|l|} 
January \\
\end{tabular} & $<0.02$ & $<0.02$ & $<2.2$ & $<2.2$ & 7.1 & 7.9 & $<0.1$ & $<0.1$ & $<4.0$ & $<4.0$ \\
\hline February & $<0.02$ & $<0.02$ & $<2.2$ & $<2.2$ & 7.5 & 7.8 & $<0.1$ & $<0.1$ & $<4.0$ & $<4.0$ \\
\hline March & $<0.02$ & $<0.02$ & $<2.2$ & $<2.2$ & 7.3 & 7.9 & $<0.1$ & 0.1 & $<4.0$ & $<4.0$ \\
\hline April & $<0.02$ & $<0.02$ & $<2.2$ & $<2.2$ & 7.3 & 7.4 & $<0.1$ & $<0.1$ & $<4.0$ & $<4.0$ \\
\hline May & $<0.02$ & $<0.02$ & $<2.4$ & 2.8 & 7.2 & 7.9 & $<0.1$ & $<0.1$ & $<4.0$ & $<4.0$ \\
\hline June & $<0.02$ & $<0.02$ & $<2.8$ & 4.0 & 7.4 & 7.8 & $<0.1$ & $<0.1$ & $<4.0$ & $<4.0$ \\
\hline July & $<0.02$ & $<0.02$ & $<2.2$ & $<2.2$ & 7.4 & 7.8 & $<0.1$ & $<0.1$ & $<4.0$ & $<4.0$ \\
\hline August & $<0.02$ & $<0.02$ & $<2.2$ & $<2.2$ & 7.3 & 7.5 & $<0.1$ & $<0.1$ & $<4.0$ & $<4.0$ \\
\hline September & $<0.02$ & $<0.02$ & $<2.2$ & $<2.2$ & 7.7 & 7.9 & $<0.1$ & $<0.1$ & $<7.2$ & 14.0 \\
\hline October & $<0.02$ & $<0.02$ & $<2.3$ & 2.5 & 7.5 & 7.7 & $<0.1$ & $<0.1$ & $<4.0$ & $<4.0$ \\
\hline November & $<0.02$ & $<0.02$ & $<2.2$ & $<2.2$ & 7.4 & 8.0 & $<0.1$ & $<0.1$ & $<4.0$ & $<4.0$ \\
\hline December & $<0.02$ & $<0.02$ & $<2.2$ & $<2.2$ & 7.3 & 8.0 & $<0.1$ & $<0.1$ & $<4.0$ & $<4.0$ \\
\hline
\end{tabular}

Note: No results exceeded the permit limits. 
TABLE B-2E

2008 SPDES Results for Sums of Outfalls 001, 007, 008, and 116: Water Quality

2008 Results for Sums of Outfalls 001, 007, and 008

\begin{tabular}{|c|c|c|c|c|c|c|}
\hline \multirow{3}{*}{\begin{tabular}{|l} 
Permit Limit \\
Month \\
\end{tabular}} & \multicolumn{2}{|c|}{$\begin{array}{c}\text { Ammonia }^{a} \\
\text { Flow-Weighted }\end{array}$} & \multirow{2}{*}{\multicolumn{2}{|c|}{$\begin{array}{c}\mathrm{BOD}_{5} \\
\text { Flow-Weighted } \\
5.0 \mathrm{mg} / \mathrm{L} \\
\text { daily average }\end{array}$}} & \multirow{2}{*}{\multicolumn{2}{|c|}{$\begin{array}{c}\text { Iron Total } \\
\text { Net Effluent Limitation } \\
0.30 \mathrm{mg} / \mathrm{L} \\
\text { daily maximum }\end{array}$}} \\
\hline & $\begin{array}{c}1.49 \mathrm{mg} / \mathrm{L} \\
\text { daily average }\end{array}$ & $\begin{array}{c}2.1 \mathrm{mg} / \mathrm{L} \\
\text { daily maximum }\end{array}$ & & & & \\
\hline & Avg & $\operatorname{Max}$ & Avg & $\operatorname{Max}$ & Avg & $\operatorname{Max}$ \\
\hline January & $<0.040$ & $<0.053$ & $<2.0$ & $<2.0$ & 0.05 & 0.05 \\
\hline February & $<0.013$ & 0.016 & $<2.0$ & $<2.0$ & 0.00 & 0.00 \\
\hline March & $<0.032$ & $<0.048$ & $<2.0$ & $<2.0$ & 0.26 & 0.26 \\
\hline April & $<0.013$ & 0.016 & $<2.0$ & $<2.0$ & 0.17 & 0.17 \\
\hline May & $<0.011$ & $<0.011$ & $<2.0$ & $<2.0$ & 0.00 & 0.00 \\
\hline June & $<0.024$ & $<0.040$ & $<2.0$ & $<2.0$ & 0.00 & 0.00 \\
\hline July & $<0.028$ & 0.057 & $<2.0$ & $<2.0$ & 0.00 & 0.00 \\
\hline August & $<0.019$ & $<0.025$ & $<3.8$ & $<4.4$ & 0.16 & 0.16 \\
\hline September & $<0.011$ & $<0.011$ & $<3.5$ & 4.3 & $<0.19$ & $<0.19$ \\
\hline October & $<0.011$ & $<0.011$ & $<2.2$ & 2.6 & 0.00 & 0.00 \\
\hline November & $<0.094$ & $<0.159$ & $<2.6$ & $<3.5$ & 0.00 & 0.00 \\
\hline December & $<0.011$ & $<0.011$ & $<2.0$ & $<2.0$ & 0.00 & 0.00 \\
\hline
\end{tabular}

\section{Results for Outfall 116}

\begin{tabular}{|c|c|c|}
\hline \multirow{2}{*}{\begin{tabular}{|l} 
Permit Limit \\
Month \\
\end{tabular}} & \multicolumn{2}{|c|}{$\begin{array}{c}\text { Total Dissolved Solids } \\
\text { (mg/L) } \\
500 \mathrm{mg} / \mathrm{L} \text { daily } \\
\text { maximum }\end{array}$} \\
\hline & Avg & Max \\
\hline January & 319 & 366 \\
\hline February $^{b}$ & -- & -- \\
\hline March & 332 & 390 \\
\hline April & 342 & 351 \\
\hline$M a y^{b}$ & -- & -- \\
\hline June & 388 & 421 \\
\hline July ${ }^{b}$ & -- & -- \\
\hline August & 335 & 402 \\
\hline September & 361 & 374 \\
\hline October $^{b}$ & -- & -- \\
\hline November & 350 & 384 \\
\hline December $^{b}$ & -- & -- \\
\hline
\end{tabular}

Note: No results exceeded the permit limits.

a Sum of Outfalls 001 and 007 only

$b$ No discharge this month 
TABLE B-2F

2008 Annual, Semiannual, and Quarterly SPDES Results for Outfall 001: Metals, Organics, and Water Quality

\begin{tabular}{|c|c|c|c|c|}
\hline Permit Limit Parameters & Permit Limit & $\begin{array}{l}\text { Monitoring } \\
\text { Frequency }\end{array}$ & $\begin{array}{l}\text { Collection } \\
\text { Date }\end{array}$ & $\begin{array}{c}\text { Maximum } \\
\text { Measured } \\
\text { (mg/L) }\end{array}$ \\
\hline 2-Butanone & $\begin{array}{c}0.5 \mathrm{mg} / \mathrm{L} \text { daily } \\
\text { maximum }\end{array}$ & Annual & January 2009 & $<0.006$ \\
\hline 3,3-Dichlorobenzidine & $\begin{array}{c}0.01 \mathrm{mg} / \mathrm{L} \text { daily } \\
\text { maximum }\end{array}$ & Annual & January 2009 & $<0.00008$ \\
\hline Alpha-BHC & $\begin{array}{c}0.00001 \mathrm{mg} / \mathrm{L} \text { daily } \\
\text { maximum }\end{array}$ & Annual & January 2009 & $<0.000007$ \\
\hline Cadmium, Total Recoverable & $\begin{array}{c}0.002 \mathrm{mg} / \mathrm{L} \text { daily } \\
\text { maximum }\end{array}$ & Annual & January 2009 & 0.0004 \\
\hline Chromium VI, Total Recoverable & $\begin{array}{c}0.011 \mathrm{mg} / \mathrm{L} \text { daily } \\
\text { maximum }\end{array}$ & Annual & January 2009 & $<0.008$ \\
\hline Chromium, Total Recoverable & $\begin{array}{c}0.3 \mathrm{mg} / \mathrm{L} \text { daily } \\
\text { maximum }\end{array}$ & Semiannual & $\begin{array}{c}\text { July } 2008 \\
\text { January } 2009 \\
\end{array}$ & $\begin{array}{l}<0.0008 \\
<0.0009 \\
\end{array}$ \\
\hline Copper, Dissolved & Monitor & Semiannual & $\begin{array}{c}\text { July } 2008 \\
\text { January } 2009\end{array}$ & $\begin{array}{l}0.0061 \\
0.0058 \\
\end{array}$ \\
\hline Copper, Total Recoverable & $\begin{array}{c}0.030 \mathrm{mg} / \mathrm{L} \text { daily } \\
\text { maximum }\end{array}$ & Semiannual & $\begin{array}{c}\text { July } 2008 \\
\text { January } 2009 \\
\end{array}$ & $\begin{array}{l}0.0048 \\
0.0050 \\
\end{array}$ \\
\hline Cyanide, Amenable to chlorination & $\begin{array}{c}0.022 \mathrm{mg} / \mathrm{L} \text { daily } \\
\text { maximum }\end{array}$ & Semiannual & $\begin{array}{c}\text { July } 2008 \\
\text { January } 2009 \\
\end{array}$ & $\begin{array}{l}<0.0030 \\
<0.0030 \\
\end{array}$ \\
\hline Dichlorodifluoromethane & $\begin{array}{c}0.01 \mathrm{mg} / \mathrm{L} \text { daily } \\
\text { maximum }\end{array}$ & Annual & January 2009 & $<0.001$ \\
\hline Heptachlor & $\begin{array}{c}0.00001 \mathrm{mg} / \mathrm{L} \text { daily } \\
\text { maximum }\end{array}$ & Semiannual & $\begin{array}{c}\text { July } 2008 \\
\text { January } 2009 \\
\end{array}$ & $\begin{array}{l}<0.000009 \\
<0.000009 \\
\end{array}$ \\
\hline Hexachlorobenzene & $\begin{array}{c}0.02 \mathrm{mg} / \mathrm{L} \text { daily } \\
\text { maximum }\end{array}$ & Annual & January 2009 & $<0.00006$ \\
\hline Lead, Total Recoverable & $\begin{array}{l}0.006 \mathrm{mg} / \mathrm{L} \text { daily } \\
\text { maximum }\end{array}$ & Quarterly & $\begin{array}{c}\text { April } 2008 \\
\text { July } 2008 \\
\text { October } 2008 \\
\text { January } 2009 \\
\end{array}$ & $\begin{array}{l}0.0009 \\
0.0005 \\
0.0005 \\
0.0009 \\
\end{array}$ \\
\hline Manganese, Total & $\begin{array}{c}2.0 \mathrm{mg} / \mathrm{L} \text { daily } \\
\text { maximum }\end{array}$ & Semiannual & $\begin{array}{c}\text { July } 2008 \\
\text { January } 2009 \\
\end{array}$ & $\begin{array}{l}0.066 \\
0.066 \\
\end{array}$ \\
\hline Nickel, Total Recoverable & $\begin{array}{c}0.14 \mathrm{mg} / \mathrm{L} \text { daily } \\
\text { maximum }\end{array}$ & Semiannual & $\begin{array}{c}\text { July } 2008 \\
\text { January } 2009 \\
\end{array}$ & $\begin{array}{l}0.0010 \\
0.0018 \\
\end{array}$ \\
\hline Surfactant as LAS & $\begin{array}{c}0.4 \mathrm{mg} / \mathrm{L} \text { daily } \\
\text { minimum }\end{array}$ & Semiannual & $\begin{array}{c}\text { July } 2008 \\
\text { January } 2009 \\
\end{array}$ & $\begin{array}{l}0.01 \\
0.04 \\
\end{array}$ \\
\hline Tributyl phosphate & $\begin{array}{c}32 \mathrm{mg} / \mathrm{L} \text { daily } \\
\text { maximum }\end{array}$ & Annual & January 2009 & $<0.00083$ \\
\hline Trichlorofluoromethane & $\begin{array}{c}0.01 \mathrm{mg} / \mathrm{L} \text { daily } \\
\text { maximum }\end{array}$ & Annual & January 2009 & $<0.001$ \\
\hline Xylene & $\begin{array}{c}0.05 \mathrm{mg} / \mathrm{L} \text { daily } \\
\text { maximum }\end{array}$ & Annual & January 2009 & $<0.002$ \\
\hline Zinc, Total Recoverable & $\begin{array}{c}0.48 \mathrm{mg} / \mathrm{L} \text { daily } \\
\text { maximum }\end{array}$ & Semiannual & $\begin{array}{c}\text { July } 2008 \\
\text { January } 2009 \\
\end{array}$ & $\begin{array}{l}0.013 \\
0.011 \\
\end{array}$ \\
\hline
\end{tabular}


TABLE B-2G

2008 SPDES Action Level Requirement Monitoring Results for Outfalls 001, 007, and 008: Metals, Organics, and Water Quality

\begin{tabular}{|c|c|c|c|c|c|}
\hline Outfall & $\begin{array}{l}\text { Action Level } \\
\text { Parameters }\end{array}$ & Action Level & $\begin{array}{l}\text { Monitoring } \\
\text { Frequency }\end{array}$ & $\begin{array}{c}\text { Collection } \\
\text { Date }\end{array}$ & $\begin{array}{c}\text { Maximum } \\
\text { Measured }(\mathrm{mg} / \mathrm{L})\end{array}$ \\
\hline \multirow{9}{*}{001} & Antimony, Total & $\begin{array}{c}1.0 \mathrm{mg} / \mathrm{L} \text { daily } \\
\text { maximum }\end{array}$ & Annual & January 2009 & $<0.0055$ \\
\hline & Barium, Total & $\begin{array}{c}0.5 \mathrm{mg} / \mathrm{L} \text { daily } \\
\text { maximum }\end{array}$ & Annual & January 2009 & 0.03 \\
\hline & Boron, Total & $\begin{array}{l}2.0 \mathrm{mg} / \mathrm{L} \text { daily } \\
\text { maximum }\end{array}$ & Quarterly & $\begin{array}{c}\text { April } 2008 \\
\text { July } 2008 \\
\text { October } 2008 \\
\text { January } 2009\end{array}$ & $\begin{array}{l}0.033 \\
0.041 \\
0.048 \\
0.056\end{array}$ \\
\hline & \multirow{4}{*}{ Bromide, Total } & \multirow{4}{*}{$\begin{array}{l}5.0 \mathrm{mg} / \mathrm{L} \text { daily } \\
\text { maximum }\end{array}$} & \multirow{4}{*}{ Quarterly } & April 2008 & 1.2 \\
\hline & & & & July 2008 & 1.4 \\
\hline & & & & October 2008 & 1.2 \\
\hline & & & & January 2009 & 0.84 \\
\hline & Chloroform & $\begin{array}{c}0.3 \mathrm{mg} / \mathrm{L} \text { daily } \\
\text { maximum }\end{array}$ & Annual & January 2009 & $<0.001$ \\
\hline & Titanium & $\begin{array}{c}0.65 \mathrm{mg} / \mathrm{L} \text { daily } \\
\text { maximum }\end{array}$ & Semiannual & $\begin{array}{c}\text { July } 2008 \\
\text { January } 2009 \\
\end{array}$ & $\begin{array}{l}0.025 \\
0.010 \\
\end{array}$ \\
\hline 007 & Chloroform & $\begin{array}{c}0.20 \mathrm{mg} / \mathrm{L} \text { daily } \\
\text { maximum }\end{array}$ & Annual & January 2009 & $<0.0011$ \\
\hline \multirow{4}{*}{008} & Arsenic, Total & $\begin{array}{c}0.17 \mathrm{mg} / \mathrm{L} \text { daily } \\
\text { maximum }\end{array}$ & Annual & $a$ & -- \\
\hline & Chromium, Total & $\begin{array}{c}0.13 \mathrm{mg} / \mathrm{L} \text { daily } \\
\text { maximum }\end{array}$ & Annual & $a$ & -- \\
\hline & Silver, Total & $\begin{array}{c}0.008 \mathrm{mg} / \mathrm{L} \text { daily } \\
\text { maximum }\end{array}$ & Annual & $a$ & -- \\
\hline & Zinc, Total & $\begin{array}{l}0.1 \mathrm{mg} / \mathrm{L} \text { daily } \\
\text { maximum }\end{array}$ & Annual & $a$ & -- \\
\hline
\end{tabular}

a No discharge at this outfall, drainage pipe was capped in May 2001. 
TABLE B-2H

2008 SPDES Results for Outfall 01B (WNSP01B): Water Quality

Internal process monitoring point did not operate during 2008

TABLE B-2I

2008 SPDES Results for Outfall 008 (WNSP008): Water Quality

No discharge; Drainage pipe was capped in May 2001

TABLE B-2J

2008 Results for Sewage Treatment Outfall (WNSP007)

\begin{tabular}{|c|c|c|c|c|c|c|}
\hline Isotope $^{a}$ & $N$ & $\begin{array}{l}\text { Discharge } \\
\text { Activity }^{b} \\
\text { (Ci) }\end{array}$ & $\begin{array}{c}\text { Radioactivity }^{c} \\
\text { Becquerels }\end{array}$ & $\begin{array}{c}\text { Average } \\
\text { Concentration } \\
(\mu \mathrm{Ci} / \mathrm{mL})\end{array}$ & $\begin{array}{c}D C G \\
(\mu C i / m L)\end{array}$ & $\begin{array}{c}\text { Ratio of } \\
\text { Concentration } \\
\text { to DCG }\end{array}$ \\
\hline Gross Alpha & 12 & $0.38 \pm 2.53 \mathrm{E}-05$ & $1.42 \pm 9.36 \mathrm{E}+05$ & $0.22 \pm 1.45 \mathrm{E}-09$ & $\mathrm{NA}^{d}$ & NA \\
\hline Gross Beta & 12 & $1.62 \pm 0.25 \mathrm{E}-05$ & $5.98 \pm 0.91 \mathrm{E}+06$ & $9.29 \pm 1.41 \mathrm{E}-09$ & $\mathrm{NA}^{d}$ & NA \\
\hline Tritium & 12 & $0.56 \pm 2.18 \mathrm{E}-04$ & $2.07 \pm 8.05 E+06$ & $0.32 \pm 1.25 \mathrm{E}-08$ & $2 \mathrm{E}-03$ & $<0.0001$ \\
\hline Sr-90 & 1 & $8.51 \pm 9.52 \mathrm{E}-06$ & $3.15 \pm 3.52 E+05$ & $4.89 \pm 5.47 \mathrm{E}-10$ & $1 \mathrm{E}-06$ & $<0.0006$ \\
\hline Cs-137 & 1 & $3.17 \pm 3.51 \mathrm{E}-05$ & $1.17 \pm 1.30 \mathrm{E}+06$ & $1.82 \pm 2.01 \mathrm{E}-09$ & $3 \mathrm{E}-06$ & $<0.0007$ \\
\hline \multicolumn{6}{|l|}{ Sum of Ratios } & $<0.0012$ \\
\hline
\end{tabular}

$\mathrm{N}$ - Number of samples

NA - Not applicable

a Half-lives are listed in Table UI-4.

$b$ Total volume released; $1.74 \mathrm{E}+10 \mathrm{~mL}(4.60 \mathrm{E}+06$ gal)

c 1 curie $(\mathrm{Ci})=3.7 \mathrm{E}+10$ becquerels $(\mathrm{Bq}) ; 1 \mathrm{~Bq}=2.7 \mathrm{E}-11 \mathrm{Ci}$

d DOE derived concentration guides (DCGs) do not exist for indicator parameters gross alpha and beta. 
This page intentionally left blank 


\section{APPENDIX B-3}

\section{SPDES-Permitted Storm Water Outfall Discharge Data}

TABLE B-3A

\section{Storm Water Discharge Monitoring Data for Outfall Group 1}

\section{Storm Water Outfall S04}

\begin{tabular}{|c|c|c|c|c|}
\hline \multirow[t]{2}{*}{ Analyte } & \multirow[t]{2}{*}{ Units } & \multirow[t]{2}{*}{$\mathbf{N}$} & \multirow{2}{*}{$\begin{array}{c}\text { First Flush Grab } \\
4 / 4 / 08\end{array}$} & \multirow{2}{*}{$\begin{array}{c}\text { Flow-weighted } \\
\text { Composite }\end{array}$} \\
\hline & & & & \\
\hline Aluminum, Total & $\mathrm{mg} / \mathrm{L}$ & 2 & 3.6 & 6.6 \\
\hline Ammonia (as $\mathrm{NH}_{3}$ ) & $\mathrm{mg} / \mathrm{L}$ & 2 & 0.013 & 0.046 \\
\hline $\mathrm{BOD}_{5}$ & $\mathrm{mg} / \mathrm{L}$ & 2 & $<2.0$ & $<2.0$ \\
\hline Cadmium, Total Recoverable & $\mathrm{mg} / \mathrm{L}$ & 2 & $<0.0005$ & $<0.0005$ \\
\hline Chromium, Total Recoverable & $\mathrm{mg} / \mathrm{L}$ & 2 & 0.0029 & 0.006 \\
\hline Chromium, Hexavalent, Total Recoverable & $\mathrm{mg} / \mathrm{L}$ & 2 & $<0.008$ & $<0.008$ \\
\hline Copper, Total Recoverable & $\mathrm{mg} / \mathrm{L}$ & 2 & 0.0049 & 0.0088 \\
\hline Iron, Total & $\mathrm{mg} / \mathrm{L}$ & 2 & 2.6 & 4.2 \\
\hline Lead, Total Recoverable & $\mathrm{mg} / \mathrm{L}$ & 2 & 0.0016 & 0.0026 \\
\hline Nitrogen, Nitrate (as N) & $\mathrm{mg} / \mathrm{L}$ & 2 & 0.20 & 0.32 \\
\hline Nitrogen, Nitrite (as N) & $\mathrm{mg} / \mathrm{L}$ & 2 & 0.026 & $<0.020$ \\
\hline Nitrogen, Total (as N) & $\mathrm{mg} / \mathrm{L}$ & 2 & 0.41 & $<0.48$ \\
\hline Nitrogen, Total Kjeldahl & $\mathrm{mg} / \mathrm{L}$ & 2 & 0.18 & 0.14 \\
\hline Oil \& Grease ${ }^{a}$ & $\mathrm{mg} / \mathrm{L}$ & 1 & $<2.2$ & NR \\
\hline $\mathrm{pH}^{b}$ & SU & 1 & 7.4 & $\mathrm{NR}$ \\
\hline Phosphorous, Total & $\mathrm{mg} / \mathrm{L}$ & 2 & $<0.005$ & 0.05 \\
\hline Selenium, Total Recoverable & $\mathrm{mg} / \mathrm{L}$ & 2 & $<0.0022$ & $<0.0022$ \\
\hline Solids, Total Dissolved & $\mathrm{mg} / \mathrm{L}$ & 2 & 720 & 812 \\
\hline Solids, Total Suspended & $\mathrm{mg} / \mathrm{L}$ & 2 & 24 & 50 \\
\hline Vanadium, Total Recoverable & $\mathrm{mg} / \mathrm{L}$ & 2 & 0.0047 & 0.0096 \\
\hline Zinc, Total Recoverable & $\mathrm{mg} / \mathrm{L}$ & 2 & 0.033 & 0.047 \\
\hline \multicolumn{5}{|c|}{ Rain Event Summary } \\
\hline $\mathrm{pH}$ of Rainfall During Sampling Event & SU & 1 & \multicolumn{2}{|c|}{7.06} \\
\hline Rainfall During Sampling Event & inches & -- & \multicolumn{2}{|c|}{0.13} \\
\hline Total Flow During Sampling Event & gallons & -- & \multicolumn{2}{|c|}{64,000} \\
\hline Maximum Flow Rate During Sampling Event & gpm & -- & \multicolumn{2}{|c|}{670} \\
\hline
\end{tabular}

$\mathrm{N}$ - Number of samples

NR - Not required by permit

$a$ The SPDES permit specifies that oil and grease concentrations shall not exceed $15 \mathrm{mg} / \mathrm{L}$.

$b$ The SPDES permit specifies that $\mathrm{pH}$ shall not be less than the measured $\mathrm{pH}$ of rainfall collected from the site rain gauge at WNSWR01 during storm water discharge sampling or $6.0 \mathrm{SU}$, whichever is less, and the $\mathrm{pH}$ shall not exceed 9.0. 
TABLE B-3A (concluded)

2008 Storm Water Discharge Monitoring Data for Outfall Group 1

Storm Water Outfall S04

\begin{tabular}{|c|c|c|c|c|}
\hline \multirow[t]{2}{*}{ Analyte } & \multirow[t]{2}{*}{ Units } & \multirow[t]{2}{*}{$\boldsymbol{N}$} & \multirow{2}{*}{$\begin{array}{c}\text { First Flush Grab } \\
7 / 9 / 08\end{array}$} & \multirow{2}{*}{$\begin{array}{c}\text { Flow-weighted } \\
\text { Composite }\end{array}$} \\
\hline & & & & \\
\hline Aluminum, Total & $\mathrm{mg} / \mathrm{L}$ & 2 & 1.5 & 1.4 \\
\hline Ammonia (as $\mathrm{NH}_{3}$ ) & $\mathrm{mg} / \mathrm{L}$ & 2 & $<0.011$ & 0.046 \\
\hline $\mathrm{BOD}_{5}$ & $\mathrm{mg} / \mathrm{L}$ & 2 & $<2.0$ & $<2.0$ \\
\hline Cadmium, Total Recoverable & $\mathrm{mg} / \mathrm{L}$ & 2 & $<0.0001$ & $<0.0001$ \\
\hline Chromium, Total Recoverable & $\mathrm{mg} / \mathrm{L}$ & 2 & 0.0024 & 0.0018 \\
\hline Chromium, Hexavalent, Total Recoverable & $\mathrm{mg} / \mathrm{L}$ & 2 & $<0.008$ & $<0.008$ \\
\hline Copper, Total Recoverable & $\mathrm{mg} / \mathrm{L}$ & 2 & 0.0054 & 0.0033 \\
\hline Iron, Total & $\mathrm{mg} / \mathrm{L}$ & 2 & 1.9 & 1.3 \\
\hline Lead, Total Recoverable & $\mathrm{mg} / \mathrm{L}$ & 2 & 0.0016 & 0.0013 \\
\hline Nitrogen, Nitrate (as N) & $\mathrm{mg} / \mathrm{L}$ & 2 & 0.23 & 0.15 \\
\hline Nitrogen, Nitrite (as N) & $\mathrm{mg} / \mathrm{L}$ & 2 & $<0.020$ & $<0.020$ \\
\hline Nitrogen, Total (as N) & $\mathrm{mg} / \mathrm{L}$ & 2 & $<0.77$ & $<2.3$ \\
\hline Nitrogen, Total Kjeldahl & $\mathrm{mg} / \mathrm{L}$ & 2 & 0.52 & 2.1 \\
\hline Oil \& Grease ${ }^{a}$ & $\mathrm{mg} / \mathrm{L}$ & 1 & $<2.2$ & NR \\
\hline $\mathrm{pH}^{b}$ & SU & 1 & 7.9 & NR \\
\hline Phosphorous, Total & $\mathrm{mg} / \mathrm{L}$ & 2 & $<0.005$ & $<0.005$ \\
\hline Selenium, Total Recoverable & $\mathrm{mg} / \mathrm{L}$ & 2 & 0.00049 & $<0.00044$ \\
\hline Solids, Total Dissolved & $\mathrm{mg} / \mathrm{L}$ & 2 & 857 & 242 \\
\hline Solids, Total Suspended & $\mathrm{mg} / \mathrm{L}$ & 2 & 42 & 19 \\
\hline Vanadium, Total Recoverable & $\mathrm{mg} / \mathrm{L}$ & 2 & 0.0028 & 0.0018 \\
\hline Zinc, Total Recoverable & $\mathrm{mg} / \mathrm{L}$ & 2 & 0.032 & 0.021 \\
\hline \multicolumn{5}{|c|}{ Rain Event Summary } \\
\hline $\mathrm{pH}$ of Rainfall During Sampling Event & SU & 1 & \multicolumn{2}{|c|}{5.05} \\
\hline Rainfall During Sampling Event & inches & -- & \multicolumn{2}{|c|}{0.27} \\
\hline Total Flow During Sampling Event & gallons & -- & \multicolumn{2}{|c|}{296,000} \\
\hline Maximum Flow Rate During Sampling Event & gpm & -- & \multicolumn{2}{|c|}{4,500} \\
\hline
\end{tabular}

$\mathrm{N}$ - Number of samples

NR - Not required by permit

$a$ The SPDES permit specifies that oil and grease concentrations shall not exceed $15 \mathrm{mg} / \mathrm{L}$.

$b$ The SPDES permit specifies that $\mathrm{pH}$ shall not be less than the measured $\mathrm{pH}$ of rainfall collected from the site rain gauge at WNSWR01 during storm water discharge sampling or $6.0 \mathrm{SU}$, whichever is less, and the $\mathrm{pH}$ shall not exceed 9.0 . 
TABLE B-3B

\section{Storm Water Discharge Monitoring Data for Outfall Group 2}

\section{Storm Water Outfall S06}

\begin{tabular}{|c|c|c|c|c|}
\hline \multirow[t]{2}{*}{ Analyte } & \multirow[t]{2}{*}{ Units } & \multirow[t]{2}{*}{$N$} & \multirow{2}{*}{$\begin{array}{c}\text { First Flush Grab } \\
6 / 17 / 08\end{array}$} & \multirow{2}{*}{$\begin{array}{c}\text { Flow-weighted } \\
\text { Composite }\end{array}$} \\
\hline & & & & \\
\hline Aluminum, Total & $\mathrm{mg} / \mathrm{L}$ & 2 & $<0.068$ & $<0.068$ \\
\hline $\mathrm{BOD}_{5}$ & $\mathrm{mg} / \mathrm{L}$ & 2 & $<1.0$ & $<1.0$ \\
\hline Copper, Total Recoverable & $\mathrm{mg} / \mathrm{L}$ & 2 & 0.00055 & 0.00042 \\
\hline Iron, Total & $\mathrm{mg} / \mathrm{L}$ & 2 & 0.056 & 0.087 \\
\hline Lead, Total Recoverable & $\mathrm{mg} / \mathrm{L}$ & 2 & $<0.0005$ & $<0.0005$ \\
\hline Oil \& Grease ${ }^{a}$ & $\mathrm{mg} / \mathrm{L}$ & 1 & 1.4 & NR \\
\hline $\mathrm{pH}^{b}$ & SU & 1 & 7.50 & NR \\
\hline Phosphorous, Total & $\mathrm{mg} / \mathrm{L}$ & 2 & 0.060 & 0.049 \\
\hline Solids, Total Dissolved & $\mathrm{mg} / \mathrm{L}$ & 2 & 785 & 764 \\
\hline Solids, Total Suspended & $\mathrm{mg} / \mathrm{L}$ & 2 & 1.2 & $<1.1$ \\
\hline Surfactant (as LAS) & $\mathrm{mg} / \mathrm{L}$ & 2 & 0.035 & 0.058 \\
\hline Zinc, Total Recoverable & $\mathrm{mg} / \mathrm{L}$ & 2 & 0.0068 & 0.0055 \\
\hline \multicolumn{5}{|c|}{ Rain Event Summary } \\
\hline pH of Rainfall During Sampling Event & SU & 1 & \multicolumn{2}{|c|}{5.91} \\
\hline Rainfall During Sampling Event & inches & -- & \multicolumn{2}{|c|}{0.08} \\
\hline Total Flow During Sampling Event & gallons & -- & \multicolumn{2}{|c|}{1,900} \\
\hline Maximum Flow Rate During Sampling Event & gpm & -- & \multicolumn{2}{|c|}{11.5} \\
\hline
\end{tabular}

\section{$\mathrm{N}$ - Number of samples}

NR - Not required by permit

a The SPDES permit specifies that oil and grease concentrations shall not exceed $15 \mathrm{mg} / \mathrm{L}$.

b The SPDES permit specifies that the outfall pH shall not be less than the measured pH of rainfall collected from the site rain gauge at WNSWRO1 during storm water discharge sampling or $6.0 \mathrm{SU}$, whichever is less, and the $\mathrm{pH}$ shall not exceed 9.0 SU. 
TABLE B-3B (concluded)

2008 Storm Water Discharge Monitoring Data for Outfall Group 2

\section{Storm Water Outfall S33}

\begin{tabular}{|c|c|c|c|c|}
\hline \multirow[t]{2}{*}{ Analyte } & \multirow[t]{2}{*}{ Units } & \multirow[t]{2}{*}{$N$} & \multirow{2}{*}{$\begin{array}{c}\text { First Flush Grab } \\
7 / 9 / 08\end{array}$} & \multirow{2}{*}{$\begin{array}{c}\text { Flow-weighted } \\
\text { Composite }\end{array}$} \\
\hline & & & & \\
\hline Aluminum, Total & $\mathrm{mg} / \mathrm{L}$ & 2 & 1.9 & 0.45 \\
\hline $\mathrm{BOD}_{5}$ & $\mathrm{mg} / \mathrm{L}$ & 2 & 5.0 & $<2.0$ \\
\hline Copper, Total Recoverable & $\mathrm{mg} / \mathrm{L}$ & 2 & 0.0032 & 0.0014 \\
\hline Iron, Total & $\mathrm{mg} / \mathrm{L}$ & 2 & 8.8 & 2.1 \\
\hline Lead, Total Recoverable & $\mathrm{mg} / \mathrm{L}$ & 2 & 0.0033 & 0.0007 \\
\hline Oil \& Grease ${ }^{a}$ & $\mathrm{mg} / \mathrm{L}$ & 1 & $<2.2$ & NR \\
\hline $\mathrm{pH}^{b}$ & SU & 1 & 7.40 & NR \\
\hline Phosphorous, Total & $\mathrm{mg} / \mathrm{L}$ & 2 & 0.14 & 0.04 \\
\hline Solids, Total Dissolved & $\mathrm{mg} / \mathrm{L}$ & 2 & 484 & 417 \\
\hline Solids, Total Suspended & $\mathrm{mg} / \mathrm{L}$ & 2 & 8.8 & 36 \\
\hline Surfactant (as LAS) & $\mathrm{mg} / \mathrm{L}$ & 2 & 0.018 & $<0.013$ \\
\hline Zinc, Total Recoverable & $\mathrm{mg} / \mathrm{L}$ & 2 & 0.032 & 0.010 \\
\hline \multicolumn{5}{|c|}{ Rain Event Summary } \\
\hline pH of Rainfall During Sampling Event & SU & 1 & \multicolumn{2}{|c|}{5.05} \\
\hline Rainfall During Sampling Event & inches & -- & \multicolumn{2}{|c|}{0.27} \\
\hline Total Flow During Sampling Event & gallons & -- & \multicolumn{2}{|c|}{69,000} \\
\hline Maximum Flow Rate During Sampling Event & gpm & -- & \multicolumn{2}{|c|}{400} \\
\hline
\end{tabular}

$\mathrm{N}$ - Number of samples

NR - Not required by permit

$a$ The SPDES permit specifies that oil and grease concentrations shall not exceed $15 \mathrm{mg} / \mathrm{L}$.

b The SPDES permit specifies that the outfall $\mathrm{pH}$ shall not be less than the measured $\mathrm{pH}$ of rainfall collected from the site rain gauge at WNSWR01 during storm water discharge sampling or $6.0 \mathrm{SU}$, whichever is less, and the $\mathrm{pH}$ shall not exceed $9.0 \mathrm{SU}$. 
TABLE B-3C

\section{Storm Water Discharge Monitoring Data for Outfall Group 3}

\section{Storm Water Outfall S09}

\begin{tabular}{|c|c|c|c|c|}
\hline \multirow[t]{2}{*}{ Analyte } & \multirow[t]{2}{*}{ Units } & \multirow[t]{2}{*}{$N$} & \multirow{2}{*}{$\begin{array}{c}\text { First Flush Grab } \\
4 / 28 / 08 \\
\end{array}$} & \multirow{2}{*}{$\begin{array}{c}\text { Flow-weighted } \\
\text { Composite }\end{array}$} \\
\hline & & & & \\
\hline Alpha-BHC & $\mathrm{mg} / \mathrm{L}$ & 2 & $<0.000007$ & $<0.000007$ \\
\hline Aluminum, Total & $\mathrm{mg} / \mathrm{L}$ & 2 & 3.3 & 3.3 \\
\hline Ammonia (as $\mathrm{NH}_{3}$ ) & $\mathrm{mg} / \mathrm{L}$ & 2 & 0.098 & 0.088 \\
\hline $\mathrm{BOD}_{5}$ & $\mathrm{mg} / \mathrm{L}$ & 2 & 2.2 & $<2.0$ \\
\hline Copper, Total Recoverable & $\mathrm{mg} / \mathrm{L}$ & 2 & 0.0053 & 0.0053 \\
\hline Iron, Total & $\mathrm{mg} / \mathrm{L}$ & 2 & 3.2 & 3.5 \\
\hline Lead, Total Recoverable & $\mathrm{mg} / \mathrm{L}$ & 2 & 0.012 & 0.012 \\
\hline Nitrogen, Nitrate (as N) & $\mathrm{mg} / \mathrm{L}$ & 2 & 0.88 & 0.82 \\
\hline Nitrogen, Nitrite (as N) & $\mathrm{mg} / \mathrm{L}$ & 2 & $<0.020$ & $<0.020$ \\
\hline Nitrogen, Total (as N) & $\mathrm{mg} / \mathrm{L}$ & 2 & $<1.6$ & $<3.3$ \\
\hline Nitrogen, Total Kjeldahl & $\mathrm{mg} / \mathrm{L}$ & 2 & 0.66 & 2.5 \\
\hline Oil \& Grease ${ }^{a}$ & $\mathrm{mg} / \mathrm{L}$ & 1 & $<2.2$ & NR \\
\hline $\mathrm{pH}^{b}$ & SU & 1 & 8.20 & NR \\
\hline Phosphorous, Total & $\mathrm{mg} / \mathrm{L}$ & 2 & 0.069 & 0.080 \\
\hline Solids, Total Dissolved & $\mathrm{mg} / \mathrm{L}$ & 2 & 177 & 191 \\
\hline Solids, Total Suspended & $\mathrm{mg} / \mathrm{L}$ & 2 & 64 & 60 \\
\hline Zinc, Total Recoverable & $\mathrm{mg} / \mathrm{L}$ & 2 & 0.036 & 0.038 \\
\hline \multicolumn{5}{|c|}{ Rain Event Summary } \\
\hline pH of Rainfall During Sampling Event & SU & 1 & \multicolumn{2}{|c|}{6.87} \\
\hline Rainfall During Sampling Event & inches & -- & \multicolumn{2}{|c|}{0.42} \\
\hline Total Flow During Sampling Event & gallons & -- & \multicolumn{2}{|c|}{2,900} \\
\hline Maximum Flow Rate During Sampling Event & gpm & -- & \multicolumn{2}{|c|}{39} \\
\hline
\end{tabular}

$\mathrm{N}$ - Number of samples

NR - Not required by permit

$a$ The SPDES permit specifies that oil and grease concentrations shall not exceed $15 \mathrm{mg} / \mathrm{L}$.

$b$ The SPDES permit specifies that the outfall pH shall not be less than the measured pH of rainfall collected from the site rain gauge at WNSWR01 during storm water discharge sampling or $6.0 \mathrm{SU}$, whichever is less, and the $\mathrm{pH}$ shall not exceed $9.0 \mathrm{SU}$. 
TABLE B-3C (concluded)

2008 Storm Water Discharge Monitoring Data for Outfall Group 3

\section{Storm Water Outfall S12}

\begin{tabular}{|c|c|c|c|c|}
\hline \multirow[t]{2}{*}{ Analyte } & \multirow[t]{2}{*}{ Units } & \multirow[t]{2}{*}{$N$} & \multirow{2}{*}{$\begin{array}{c}\text { First Flush Grab } \\
12 / 15 / 08\end{array}$} & \multirow{2}{*}{$\begin{array}{c}\text { Flow-weighted } \\
\text { Composite }\end{array}$} \\
\hline & & & & \\
\hline Alpha-BHC & $\mathrm{mg} / \mathrm{L}$ & 2 & $<0.0000062$ & $<0.0000063$ \\
\hline Aluminum, Total & $\mathrm{mg} / \mathrm{L}$ & 2 & 0.348 & 0.778 \\
\hline Ammonia (as $\mathrm{NH}_{3}$ ) & $\mathrm{mg} / \mathrm{L}$ & 2 & 0.22 & 0.16 \\
\hline $\mathrm{BOD}_{5}$ & $\mathrm{mg} / \mathrm{L}$ & 2 & $<2.0$ & $<2.0$ \\
\hline Copper, Total Recoverable & $\mathrm{mg} / \mathrm{L}$ & 2 & 0.0034 & 0.0061 \\
\hline Iron, Total & $\mathrm{mg} / \mathrm{L}$ & 2 & 0.561 & 1.08 \\
\hline Lead, Total Recoverable & $\mathrm{mg} / \mathrm{L}$ & 2 & 0.0005 & 0.0016 \\
\hline Nitrogen, Nitrate (as N) & $\mathrm{mg} / \mathrm{L}$ & 2 & 0.073 & 0.081 \\
\hline Nitrogen, Nitrite (as N) & $\mathrm{mg} / \mathrm{L}$ & 2 & $<0.020$ & $<0.020$ \\
\hline Nitrogen, Total (as N) & $\mathrm{mg} / \mathrm{L}$ & 2 & $<0.24$ & $<0.51$ \\
\hline Nitrogen, Total Kjeldahl & $\mathrm{mg} / \mathrm{L}$ & 2 & $<0.15$ & 0.41 \\
\hline Oil \& Grease ${ }^{a}$ & $\mathrm{mg} / \mathrm{L}$ & 1 & $<2.2$ & NR \\
\hline $\mathrm{pH}^{b}$ & SU & 1 & 7.70 & NR \\
\hline Phosphorous, Total & $\mathrm{mg} / \mathrm{L}$ & 2 & 0.018 & 0.046 \\
\hline Solids, Total Dissolved & $\mathrm{mg} / \mathrm{L}$ & 2 & 657 & 609 \\
\hline Solids, Total Suspended & $\mathrm{mg} / \mathrm{L}$ & 2 & 11 & 31 \\
\hline Zinc, Total Recoverable & $\mathrm{mg} / \mathrm{L}$ & 2 & 0.012 & 0.027 \\
\hline \multicolumn{5}{|c|}{ Rain Event Summary } \\
\hline pH of Rainfall During Sampling Event & SU & 1 & \multicolumn{2}{|c|}{6.61} \\
\hline Rainfall During Sampling Event & inches & -- & \multicolumn{2}{|c|}{0.35} \\
\hline Total Flow During Sampling Event & gallons & -- & \multicolumn{2}{|c|}{48,000} \\
\hline Maximum Flow Rate During Sampling Event & gpm & -- & \multicolumn{2}{|c|}{380} \\
\hline
\end{tabular}

$\mathrm{N}$ - Number of samples

NR - Not required by permit

$a$ The SPDES permit specifies that oil and grease concentrations shall not exceed $15 \mathrm{mg} / \mathrm{L}$.

b The SPDES permit specifies that the outfall $\mathrm{pH}$ shall not be less than the measured $\mathrm{pH}$ of rainfall collected from the site rain gauge at WNSWR01 during storm water discharge sampling or $6.0 \mathrm{SU}$, whichever is less, and the $\mathrm{pH}$ shall not exceed $9.0 \mathrm{SU}$. 
TABLE B-3D

\section{Storm Water Discharge Monitoring Data for Outfall Group 4}

\section{Storm Water Outfall S34}

\begin{tabular}{|c|c|c|c|c|}
\hline \multirow[t]{2}{*}{ Analyte } & \multirow[t]{2}{*}{ Units } & \multirow[t]{2}{*}{$N$} & \multirow{2}{*}{$\begin{array}{c}\text { First Flush Grab } \\
6 / 17 / 08\end{array}$} & \multirow{2}{*}{$\begin{array}{c}\text { Flow-weighted } \\
\text { Composite }\end{array}$} \\
\hline & & & & \\
\hline Aluminum, Total & $\mathrm{mg} / \mathrm{L}$ & 2 & 0.85 & 1.1 \\
\hline $\mathrm{BOD}_{5}$ & $\mathrm{mg} / \mathrm{L}$ & 2 & $<2.0$ & $<2.0$ \\
\hline Copper, Total Recoverable & $\mathrm{mg} / \mathrm{L}$ & 2 & 0.0033 & 0.0031 \\
\hline Iron, Total & $\mathrm{mg} / \mathrm{L}$ & 2 & 1.7 & 1.6 \\
\hline Lead, Total Recoverable & $\mathrm{mg} / \mathrm{L}$ & 2 & 0.0014 & 0.00088 \\
\hline Oil \& Grease $^{a}$ & $\mathrm{mg} / \mathrm{L}$ & 1 & $<2.2$ & NR \\
\hline $\mathrm{pH}^{b}$ & SU & 1 & 7.60 & NR \\
\hline Phosphorous, Total & $\mathrm{mg} / \mathrm{L}$ & 2 & $<0.005$ & $<0.005$ \\
\hline Solids, Total Dissolved & $\mathrm{mg} / \mathrm{L}$ & 2 & 330 & 330 \\
\hline Solids, Total Suspended & $\mathrm{mg} / \mathrm{L}$ & 2 & 52 & 24 \\
\hline Surfactant (as LAS) & $\mathrm{mg} / \mathrm{L}$ & 2 & $<0.013$ & 0.052 \\
\hline Zinc, Total Recoverable & $\mathrm{mg} / \mathrm{L}$ & 2 & 0.030 & 0.022 \\
\hline \multicolumn{5}{|c|}{ Rain Event Summary } \\
\hline pH of Rainfall During Sampling Event & SU & 1 & \multicolumn{2}{|c|}{5.91} \\
\hline Rainfall During Sampling Event & inches & -- & \multicolumn{2}{|c|}{0.08} \\
\hline Total Flow During Sampling Event & gallons & -- & \multicolumn{2}{|c|}{32,000} \\
\hline Maximum Flow Rate During Sampling Event & gpm & -- & \multicolumn{2}{|c|}{530} \\
\hline
\end{tabular}

Note: The first flush grab samples were sampled and analyzed in duplicate.

$\mathrm{N}$ - Number of samples

NR - Not required by permit

${ }^{a}$ The SPDES permit specifies that oil and grease concentrations shall not exceed $15 \mathrm{mg} / \mathrm{L}$.

b The SPDES permit specifies that the outfall $\mathrm{pH}$ shall not be less than the measured $\mathrm{pH}$ of rainfall collected from the site rain gauge at WNSWR01 during storm water discharge sampling or $6.0 \mathrm{SU}$, whichever is less, and the $\mathrm{pH}$ shall not exceed $9.0 \mathrm{SU}$. 
TABLE B-3D (concluded)

2008 Storm Water Discharge Monitoring Data for Outfall Group 4

Storm Water Outfall S34

\begin{tabular}{|c|c|c|c|c|}
\hline \multirow[t]{2}{*}{ Analyte } & \multirow[t]{2}{*}{ Units } & \multirow[t]{2}{*}{$N$} & \multirow{2}{*}{$\begin{array}{c}\text { First Flush Grab } \\
7 / 9 / 08\end{array}$} & \multirow{2}{*}{$\begin{array}{c}\text { Flow-weighted } \\
\text { Composite }\end{array}$} \\
\hline & & & & \\
\hline Aluminum, Total & $\mathrm{mg} / \mathrm{L}$ & 2 & 0.74 & 2.3 \\
\hline $\mathrm{BOD}_{5}$ & $\mathrm{mg} / \mathrm{L}$ & 2 & $<2.0$ & 3.8 \\
\hline Copper, Total Recoverable & $\mathrm{mg} / \mathrm{L}$ & 2 & 0.0027 & 0.0069 \\
\hline Iron, Total & $\mathrm{mg} / \mathrm{L}$ & 2 & 1.2 & 4.2 \\
\hline Lead, Total Recoverable & $\mathrm{mg} / \mathrm{L}$ & 2 & 0.0010 & 0.0049 \\
\hline Oil \& Grease $^{a}$ & $\mathrm{mg} / \mathrm{L}$ & 1 & $<2.2$ & NR \\
\hline $\mathrm{pH}^{b}$ & SU & 1 & 7.90 & NR \\
\hline Phosphorous, Total & $\mathrm{mg} / \mathrm{L}$ & 2 & $<0.005$ & 0.15 \\
\hline Solids, Total Dissolved & $\mathrm{mg} / \mathrm{L}$ & 2 & 504 & 268 \\
\hline Solids, Total Suspended & $\mathrm{mg} / \mathrm{L}$ & 2 & 33 & 92 \\
\hline Surfactant (as LAS) & $\mathrm{mg} / \mathrm{L}$ & 2 & $<0.013$ & 0.062 \\
\hline Zinc, Total Recoverable & $\mathrm{mg} / \mathrm{L}$ & 2 & 0.019 & 0.065 \\
\hline \multicolumn{5}{|c|}{ Rain Event Summary } \\
\hline pH of Rainfall During Sampling Event & SU & 1 & \multicolumn{2}{|c|}{5.05} \\
\hline Rainfall During Sampling Event & inches & -- & \multicolumn{2}{|c|}{0.27} \\
\hline Total Flow During Sampling Event & gallons & -- & \multicolumn{2}{|c|}{121,000} \\
\hline Maximum Flow Rate During Sampling Event & gpm & -- & \multicolumn{2}{|c|}{2,800} \\
\hline
\end{tabular}

$\mathrm{N}$ - Number of samples

NR - Not required by permit

a The SPDES permit specifies that oil and grease concentrations shall not exceed $15 \mathrm{mg} / \mathrm{L}$.

b The SPDES permit specifies that the outfall $\mathrm{pH}$ shall not be less than the measured $\mathrm{pH}$ of rainfall collected from the site rain gauge at WNSWR01 during storm water discharge sampling or $6.0 \mathrm{SU}$, whichever is less, and the $\mathrm{pH}$ shall not exceed $9.0 \mathrm{SU}$. 
TABLE B-3E

\section{Storm Water Discharge Monitoring Data for Outfall Group 5}

\section{Storm Water Outfall S28}

\begin{tabular}{|c|c|c|c|c|}
\hline \multirow[t]{2}{*}{ Analyte } & \multirow[t]{2}{*}{ Units } & \multirow[t]{2}{*}{$\mathbf{N}$} & \multirow{2}{*}{$\begin{array}{c}\text { First Flush Grab } \\
6 / 18 / 08\end{array}$} & \multirow{2}{*}{$\begin{array}{c}\begin{array}{c}\text { Flow-weighted } \\
\text { Composite }\end{array} \\
6 / 18 / 08 \\
\end{array}$} \\
\hline & & & & \\
\hline Aluminum, Total & $\mathrm{mg} / \mathrm{L}$ & 2 & 0.41 & 4.6 \\
\hline Ammonia (as $\mathrm{NH}_{3}$ ) & $\mathrm{mg} / \mathrm{L}$ & 2 & 0.021 & $<0.011$ \\
\hline $\mathrm{BOD}_{5}$ & $\mathrm{mg} / \mathrm{L}$ & 2 & $<2.0$ & $<2.0$ \\
\hline Copper. Total Recoverable & $\mathrm{mg} / \mathrm{L}$ & 2 & 0.0033 & 0.0075 \\
\hline Iron, Total & $\mathrm{mg} / \mathrm{L}$ & 2 & 0.41 & 4.7 \\
\hline Lead, Total Recoverable & $\mathrm{mg} / \mathrm{L}$ & 2 & 0.00049 & 0.0048 \\
\hline Nitrogen, Nitrate (as N) & $\mathrm{mg} / \mathrm{L}$ & 2 & $<0.011$ & $<0.011$ \\
\hline Nitrogen, Nitrite (as N) & $\mathrm{mg} / \mathrm{L}$ & 2 & $<0.020$ & $<0.020$ \\
\hline Nitrogen, Total (as N) & $\mathrm{mg} / \mathrm{L}$ & 2 & $<0.43$ & $<0.48$ \\
\hline Nitrogen, Total Kjeldahl & $\mathrm{mg} / \mathrm{L}$ & 2 & 0.40 & 0.45 \\
\hline Oil \& Grease G $^{a}$ & $\mathrm{mg} / \mathrm{L}$ & 1 & 8.4 & NR \\
\hline $\mathrm{pH}^{b}$ & SU & 1 & 7.80 & NR \\
\hline Phosphorous, Total & $\mathrm{mg} / \mathrm{L}$ & 2 & $<0.005$ & 0.064 \\
\hline Solids, Settleable & $\mathrm{ml} / \mathrm{L}$ & 2 & $<0.1$ & $<0.1$ \\
\hline Solids, Total Dissolved & $\mathrm{mg} / \mathrm{L}$ & 2 & 458 & 520 \\
\hline Solids, Total Suspended & $\mathrm{mg} / \mathrm{L}$ & 2 & $<4.0$ & 79 \\
\hline Sulfide & $\mathrm{mg} / \mathrm{L}$ & 2 & 0.04 & $<0.022$ \\
\hline Surfactant (as LAS) & $\mathrm{mg} / \mathrm{L}$ & 2 & 0.023 & $<0.013$ \\
\hline Vanadium, Total Recoverable & $\mathrm{mg} / \mathrm{L}$ & 2 & $<0.00098$ & 0.0084 \\
\hline Zinc, Total Recoverable & $\mathrm{mg} / \mathrm{L}$ & 2 & 0.007 & 0.025 \\
\hline \multicolumn{5}{|c|}{ Rain Event Summary } \\
\hline pH of Rainfall During Sampling Event & SU & 1 & \multicolumn{2}{|c|}{7.06} \\
\hline Rainfall During Sampling Event & inches & -- & \multicolumn{2}{|c|}{0.50} \\
\hline Total Flow During Sampling Event & gallons & -- & \multicolumn{2}{|c|}{1,600} \\
\hline Maximum Flow Rate During Sampling Event & gpm & -- & \multicolumn{2}{|c|}{18} \\
\hline
\end{tabular}

\section{$\mathrm{N}$ - Number of samples}

NR - Not required by permit

$a$ The SPDES permit specifies that oil and grease concentrations shall not exceed $15 \mathrm{mg} / \mathrm{L}$.

b The SPDES permit specifies that the outfall pH shall not be less than the measured $\mathrm{pH}$ of rainfall collected from the site rain gauge at WNSWRO1 during storm water discharge sampling or $6.0 \mathrm{SU}$, whichever is less, and the $\mathrm{pH}$ shall not exceed 9.0 SU. 
TABLE B-3E (concluded)

\section{Storm Water Discharge Monitoring Data for Outfall Group 5}

\section{Storm Water Outfall S14}

\begin{tabular}{|c|c|c|c|c|}
\hline \multirow[t]{2}{*}{ Analyte } & \multirow[t]{2}{*}{ Units } & \multirow[t]{2}{*}{$\mathbf{N}$} & \multirow{2}{*}{$\begin{array}{c}\text { First Flush Grab } \\
7 / 9 / 08\end{array}$} & \multirow{2}{*}{$\begin{array}{c}\text { Flow-weighteo } \\
\text { Composite } \\
7 / 9 / 08\end{array}$} \\
\hline & & & & \\
\hline Aluminum, Total & $\mathrm{mg} / \mathrm{L}$ & 2 & 15 & 2.1 \\
\hline Ammonia (as $\mathrm{NH}_{3}$ ) & $\mathrm{mg} / \mathrm{L}$ & 2 & 0.021 & $<0.011$ \\
\hline $\mathrm{BOD}_{5}$ & $\mathrm{mg} / \mathrm{L}$ & 2 & 25 & 14 \\
\hline Copper. Total Recoverable & $\mathrm{mg} / \mathrm{L}$ & 2 & 0.0093 & 0.0069 \\
\hline Iron, Total & $\mathrm{mg} / \mathrm{L}$ & 2 & 11 & 2.5 \\
\hline Lead, Total Recoverable & $\mathrm{mg} / \mathrm{L}$ & 2 & 0.0076 & 0.0041 \\
\hline Nitrogen, Nitrate (as N) & $\mathrm{mg} / \mathrm{L}$ & 2 & 4.7 & 2.3 \\
\hline Nitrogen, Nitrite (as N) & $\mathrm{mg} / \mathrm{L}$ & 2 & 0.15 & $<0.020$ \\
\hline Nitrogen, Total (as N) & $\mathrm{mg} / \mathrm{L}$ & 2 & 9.5 & $<4.4$ \\
\hline Nitrogen, Total Kjeldahl & $\mathrm{mg} / \mathrm{L}$ & 2 & 4.6 & 2.1 \\
\hline Oil \& Grease ${ }^{a}$ & $\mathrm{mg} / \mathrm{L}$ & 1 & 2.6 & NR \\
\hline $\mathrm{pH}^{b}$ & SU & 1 & 7.40 & NR \\
\hline Phosphorous, Total & $\mathrm{mg} / \mathrm{L}$ & 2 & 0.4 & 0.3 \\
\hline Solids, Settleable & $\mathrm{ml} / \mathrm{L}$ & 2 & 0.7 & 0.5 \\
\hline Solids, Total Dissolved & $\mathrm{mg} / \mathrm{L}$ & 2 & 492 & 505 \\
\hline Solids, Total Suspended & $\mathrm{mg} / \mathrm{L}$ & 2 & 389 & 112 \\
\hline Sulfide & $\mathrm{mg} / \mathrm{L}$ & 2 & $<0.022$ & $<0.022$ \\
\hline Surfactant (as LAS) & $\mathrm{mg} / \mathrm{L}$ & 2 & $<0.013$ & $<0.013$ \\
\hline Vanadium, Total Recoverable & $\mathrm{mg} / \mathrm{L}$ & 2 & 0.017 & 0.0082 \\
\hline Zinc, Total Recoverable & $\mathrm{mg} / \mathrm{L}$ & 2 & 0.029 & 0.020 \\
\hline \multicolumn{5}{|c|}{ Rain Event Summary } \\
\hline $\mathrm{pH}$ of Rainfall During Sampling Event & SU & 1 & \multicolumn{2}{|c|}{5.05} \\
\hline Rainfall During Sampling Event & inches & -- & \multicolumn{2}{|c|}{0.27} \\
\hline Total Flow During Sampling Event & gallons & -- & \multicolumn{2}{|c|}{35} \\
\hline Maximum Flow Rate During Sampling Event & gpm & -- & \multicolumn{2}{|c|}{0.7} \\
\hline
\end{tabular}

\section{$\mathrm{N}$ - Number of samples}

NR - Not required by permit

$a$ The SPDES permit specifies that oil and grease concentrations shall not exceed $15 \mathrm{mg} / \mathrm{L}$.

b The SPDES permit specifies that the outfall $\mathrm{pH}$ shall not be less than the measured $\mathrm{pH}$ of rainfall collected from the site rain gauge at WNSWR01 during storm water discharge sampling or $6.0 \mathrm{SU}$, whichever is less, and the $\mathrm{pH}$ shall not exceed $9.0 \mathrm{SU}$. 
TABLE B-3F

\section{Storm Water Discharge Monitoring Data for Outfall Group 6}

\section{Storm Water Outfall S36}

\begin{tabular}{|c|c|c|c|c|}
\hline \multirow[t]{2}{*}{ Analyte } & \multirow[t]{2}{*}{ Units } & \multirow[t]{2}{*}{$N$} & \multirow{2}{*}{$\begin{array}{c}\text { First Flush Grab } \\
6 / 18 / 08\end{array}$} & \multirow{2}{*}{$\begin{array}{c}\text { Flow-weighted } \\
\text { Composite }\end{array}$} \\
\hline & & & & \\
\hline Aluminum, Total & $\mathrm{mg} / \mathrm{L}$ & 2 & 0.60 & 0.93 \\
\hline Ammonia (as $\mathrm{NH}_{3}$ ) & $\mathrm{mg} / \mathrm{L}$ & 2 & 0.012 & $<0.011$ \\
\hline $\mathrm{BOD}_{5}$ & $\mathrm{mg} / \mathrm{L}$ & 2 & $<2.0$ & $<2.0$ \\
\hline Copper, Total Recoverable & $\mathrm{mg} / \mathrm{L}$ & 2 & 0.0013 & 0.0014 \\
\hline Iron, Total & $\mathrm{mg} / \mathrm{L}$ & 2 & 0.73 & 1.1 \\
\hline Lead, Total Recoverable & $\mathrm{mg} / \mathrm{L}$ & 2 & 0.00039 & 0.00044 \\
\hline Nitrogen, Nitrate (as N) & $\mathrm{mg} / \mathrm{L}$ & 2 & 0.075 & 0.046 \\
\hline Nitrogen, Nitrite (as N) & $\mathrm{mg} / \mathrm{L}$ & 2 & $<0.020$ & $<0.020$ \\
\hline Nitrogen, Total (as N) & $\mathrm{mg} / \mathrm{L}$ & 2 & $<0.30$ & $<0.27$ \\
\hline Nitrogen, Total Kjeldahl & $\mathrm{mg} / \mathrm{L}$ & 2 & $<0.20$ & $<0.20$ \\
\hline Oil \& Grease ${ }^{a}$ & $\mathrm{mg} / \mathrm{L}$ & 1 & $<2.2$ & $\mathrm{NR}$ \\
\hline $\mathrm{pH}^{b}$ & SU & 1 & 7.90 & NR \\
\hline Phosphorous, Total & $\mathrm{mg} / \mathrm{L}$ & 2 & $<0.005$ & $<0.005$ \\
\hline Solids, Settleable & $\mathrm{ml} / \mathrm{L}$ & 2 & $<0.1$ & $<0.1$ \\
\hline Solids, Total Dissolved & $\mathrm{mg} / \mathrm{L}$ & 2 & 268 & 276 \\
\hline Solids, Total Suspended & $\mathrm{mg} / \mathrm{L}$ & 2 & 19 & 12 \\
\hline Sulfide & $\mathrm{mg} / \mathrm{L}$ & 2 & $<0.022$ & $<0.022$ \\
\hline Surfactant (as LAS) & $\mathrm{mg} / \mathrm{L}$ & 2 & $<0.013$ & $<0.013$ \\
\hline Vanadium, Total Recoverable & $\mathrm{mg} / \mathrm{L}$ & 2 & 0.0011 & $<0.00098$ \\
\hline Zinc, Total Recoverable & $\mathrm{mg} / \mathrm{L}$ & 2 & 0.013 & 0.013 \\
\hline \multicolumn{5}{|c|}{ Rain Event Summary } \\
\hline $\mathrm{pH}$ of Rainfall During Sampling Event & SU & 1 & \multicolumn{2}{|c|}{7.06} \\
\hline Rainfall During Sampling Event & inches & -- & \multicolumn{2}{|c|}{0.50} \\
\hline Total Flow During Sampling Event & gallons & -- & \multicolumn{2}{|c|}{2,000} \\
\hline Maximum Flow Rate During Sampling Event & gpm & -- & \multicolumn{2}{|c|}{12} \\
\hline
\end{tabular}

\section{$\mathrm{N}$ - Number of samples}

NR - Not required by permit

$a$ The SPDES permit specifies that oil and grease concentrations shall not exceed $15 \mathrm{mg} / \mathrm{L}$.

b The SPDES permit specifies that the outfall pH shall not be less than the measured $\mathrm{pH}$ of rainfall collected from the site rain gauge at WNSWR01 during storm water discharge sampling or $6.0 \mathrm{SU}$, whichever is less, and the $\mathrm{pH}$ shall not exceed $9.0 \mathrm{SU}$. 
TABLE B-3F (concluded)

\section{Storm Water Discharge Monitoring Data for Outfall Group 6}

\section{Storm Water Outfall S37}

\begin{tabular}{|c|c|c|c|c|}
\hline \multirow[t]{2}{*}{ Analyte } & \multirow[t]{2}{*}{ Units } & \multirow[t]{2}{*}{$N$} & \multirow{2}{*}{$\begin{array}{c}\text { First Flush Grab } \\
12 / 15 / 08\end{array}$} & \multirow{2}{*}{$\begin{array}{c}\text { Flow-weighted } \\
\text { Composite }\end{array}$} \\
\hline & & & & \\
\hline Aluminum, Total & $\mathrm{mg} / \mathrm{L}$ & 2 & 0.78 & 0.52 \\
\hline Ammonia (as $\mathrm{NH}_{3}$ ) & $\mathrm{mg} / \mathrm{L}$ & 2 & 0.15 & $<0.011$ \\
\hline $\mathrm{BOD}_{5}$ & $\mathrm{mg} / \mathrm{L}$ & 2 & $<2.0$ & $<2.0$ \\
\hline Copper, Total Recoverable & $\mathrm{mg} / \mathrm{L}$ & 2 & 0.0015 & 0.00095 \\
\hline Iron, Total & $\mathrm{mg} / \mathrm{L}$ & 2 & 0.43 & 0.25 \\
\hline Lead, Total Recoverable & $\mathrm{mg} / \mathrm{L}$ & 2 & 0.00042 & 0.00021 \\
\hline Nitrogen, Nitrate (as N) & $\mathrm{mg} / \mathrm{L}$ & 2 & 0.035 & 0.081 \\
\hline Nitrogen, Nitrite (as N) & $\mathrm{mg} / \mathrm{L}$ & 2 & $<0.020$ & $<0.020$ \\
\hline Nitrogen, Total (as N) & $\mathrm{mg} / \mathrm{L}$ & 2 & $<0.21$ & $<0.25$ \\
\hline Nitrogen, Total Kjeldahl & $\mathrm{mg} / \mathrm{L}$ & 2 & $<0.15$ & $<0.15$ \\
\hline Oil \& Grease ${ }^{a}$ & $\mathrm{mg} / \mathrm{L}$ & 1 & $<2.2$ & NR \\
\hline $\mathrm{pH}^{b}$ & SU & 1 & 8.30 & NR \\
\hline Phosphorous, Total & $\mathrm{mg} / \mathrm{L}$ & 2 & $<0.005$ & $<0.005$ \\
\hline Solids, Settleable & $\mathrm{ml} / \mathrm{L}$ & 2 & $<0.1$ & $<0.1$ \\
\hline Solids, Total Dissolved & $\mathrm{mg} / \mathrm{L}$ & 2 & 145 & 116 \\
\hline Solids, Total Suspended & $\mathrm{mg} / \mathrm{L}$ & 2 & 11 & $<4.0$ \\
\hline Sulfide & $\mathrm{mg} / \mathrm{L}$ & 2 & $<0.022$ & $<0.022$ \\
\hline Surfactant (as LAS) & $\mathrm{mg} / \mathrm{L}$ & 2 & $<0.013$ & 0.041 \\
\hline Vanadium, Total Recoverable & $\mathrm{mg} / \mathrm{L}$ & 2 & 0.0023 & $<0.00098$ \\
\hline Zinc, Total Recoverable & $\mathrm{mg} / \mathrm{L}$ & 2 & 0.0067 & 0.0053 \\
\hline \multicolumn{5}{|c|}{ Rain Event Summary } \\
\hline $\mathrm{pH}$ of Rainfall During Sampling Event & SU & 1 & \multicolumn{2}{|c|}{6.61} \\
\hline Rainfall During Sampling Event & inches & -- & \multicolumn{2}{|c|}{0.35} \\
\hline Total Flow During Sampling Event & gallons & -- & \multicolumn{2}{|c|}{6,700} \\
\hline Maximum Flow Rate During Sampling Event & gpm & -- & \multicolumn{2}{|c|}{46} \\
\hline
\end{tabular}

\section{$\mathrm{N}$ - Number of samples}

NR - Not required by permit

$a$ The SPDES permit specifies that oil and grease concentrations shall not exceed $15 \mathrm{mg} / \mathrm{L}$.

b The SPDES permit specifies that the outfall $\mathrm{pH}$ shall not be less than the measured $\mathrm{pH}$ of rainfall collected from the site rain gauge at WNSWRO1 during storm water discharge sampling or $6.0 \mathrm{SU}$, whichever is less, and the $\mathrm{pH}$ shall not exceed $9.0 \mathrm{SU}$. 
TABLE B-3G

\section{Storm Water Discharge Monitoring Data for Outfall Group 7}

\section{Storm Water Outfall S20}

\begin{tabular}{|c|c|c|c|c|}
\hline \multirow[t]{2}{*}{ Analyte } & \multirow[t]{2}{*}{ Units } & \multirow[t]{2}{*}{$N$} & \multirow{2}{*}{$\begin{array}{c}\text { First Flush Grab } \\
6 / 17 / 08\end{array}$} & \multirow{2}{*}{$\begin{array}{c}\text { Flow-weighted } \\
\text { Composite }\end{array}$} \\
\hline & & & & \\
\hline Aluminum, Total & $\mathrm{mg} / \mathrm{L}$ & 2 & 0.17 & 1.1 \\
\hline Ammonia (as $\mathrm{NH}_{3}$ ) & $\mathrm{mg} / \mathrm{L}$ & 2 & 0.026 & 0.040 \\
\hline $\mathrm{BOD}_{5}$ & $\mathrm{mg} / \mathrm{L}$ & 2 & 3.6 & $<2.0$ \\
\hline Copper, Total Recoverable & $\mathrm{mg} / \mathrm{L}$ & 2 & 0.0015 & 0.0016 \\
\hline Iron, Total & $\mathrm{mg} / \mathrm{L}$ & 2 & 0.41 & 1.2 \\
\hline Lead, Total Recoverable & $\mathrm{mg} / \mathrm{L}$ & 2 & 0.00053 & 0.00072 \\
\hline Nitrogen, Nitrate (as N) & $\mathrm{mg} / \mathrm{L}$ & 2 & 0.31 & 0.22 \\
\hline Nitrogen, Nitrite (as N) & $\mathrm{mg} / \mathrm{L}$ & 2 & $<0.020$ & $<0.020$ \\
\hline Nitrogen, Total (as N) & $\mathrm{mg} / \mathrm{L}$ & 2 & $<0.95$ & $<0.39$ \\
\hline Nitrogen, Total Kjeldahl & $\mathrm{mg} / \mathrm{L}$ & 2 & 0.62 & 0.15 \\
\hline Oil \& Grease ${ }^{a}$ & $\mathrm{mg} / \mathrm{L}$ & 1 & 6.4 & NR \\
\hline $\mathrm{pH}^{b}$ & SU & 1 & 7.60 & NR \\
\hline Phosphorous, Total & $\mathrm{mg} / \mathrm{L}$ & 2 & $<0.005$ & $<0.005$ \\
\hline Solids, Total Dissolved & $\mathrm{mg} / \mathrm{L}$ & 2 & 164 & 73 \\
\hline Solids, Total Suspended & $\mathrm{mg} / \mathrm{L}$ & 2 & 16 & 26 \\
\hline Sulfide & $\mathrm{mg} / \mathrm{L}$ & 2 & $<0.022$ & $<0.022$ \\
\hline Surfactant (as LAS) & $\mathrm{mg} / \mathrm{L}$ & 2 & 0.015 & 0.013 \\
\hline Zinc, Total Recoverable & $\mathrm{mg} / \mathrm{L}$ & 2 & 0.013 & 0.0095 \\
\hline \multicolumn{5}{|c|}{ Rain Event Summary } \\
\hline pH of Rainfall During Sampling Event & SU & 1 & \multicolumn{2}{|c|}{5.91} \\
\hline Total Rainfall During Sampling Event & inches & -- & \multicolumn{2}{|c|}{0.08} \\
\hline Total Flow During SamplingEvent & gallons & -- & \multicolumn{2}{|c|}{33,000} \\
\hline Maximum Flow Rate During Sampling Event & gpm & -- & \multicolumn{2}{|c|}{320} \\
\hline
\end{tabular}

$\mathrm{N}$ - Number of samples

NR - Not required by permit

a The SPDES permit specifies that oil and grease concentrations shall not exceed $15 \mathrm{mg} / \mathrm{L}$.

b The SPDES permit specifies that the outfall $\mathrm{pH}$ shall not be less than the measured $\mathrm{pH}$ of rainfall collected from the site rain gauge at WNSWR01 during storm water discharge sampling or $6.0 \mathrm{SU}$, whichever is less, and the $\mathrm{pH}$ shall not exceed $9.0 \mathrm{SU}$. 
TABLE B-3G (concluded)

2008 Storm Water Discharge Monitoring Data for Outfall Group 7

Storm Water Outfall S20

\begin{tabular}{|c|c|c|c|c|}
\hline \multirow[t]{2}{*}{ Analyte } & \multirow[t]{2}{*}{ Units } & \multirow[t]{2}{*}{$N$} & \multirow{2}{*}{$\begin{array}{c}\text { First Flush Grab } \\
7 / 9 / 08\end{array}$} & \multirow{2}{*}{$\begin{array}{c}\text { Flow-weighted } \\
\text { Composite }\end{array}$} \\
\hline & & & & \\
\hline Aluminum, Total & $\mathrm{mg} / \mathrm{L}$ & 2 & 0.38 & 0.29 \\
\hline Ammonia (as $\mathrm{NH}_{3}$ ) & $\mathrm{mg} / \mathrm{L}$ & 2 & 0.09 & 0.014 \\
\hline $\mathrm{BOD}_{5}$ & $\mathrm{mg} / \mathrm{L}$ & 2 & $<2.0$ & 2.3 \\
\hline Copper, Total Recoverable & $\mathrm{mg} / \mathrm{L}$ & 2 & 0.0013 & 0.00092 \\
\hline Iron, Total & $\mathrm{mg} / \mathrm{L}$ & 2 & 0.43 & 0.34 \\
\hline Lead, Total Recoverable & $\mathrm{mg} / \mathrm{L}$ & 2 & 0.00042 & 0.00032 \\
\hline Nitrogen, Nitrate (as N) & $\mathrm{mg} / \mathrm{L}$ & 2 & 0.42 & 0.15 \\
\hline Nitrogen, Nitrite (as N) & $\mathrm{mg} / \mathrm{L}$ & 2 & 0.046 & $<0.020$ \\
\hline Nitrogen, Total (as N) & $\mathrm{mg} / \mathrm{L}$ & 2 & 2.2 & $<0.45$ \\
\hline Nitrogen, Total Kjeldahl & $\mathrm{mg} / \mathrm{L}$ & 2 & 1.7 & 0.28 \\
\hline Oil \& Grease ${ }^{a}$ & $\mathrm{mg} / \mathrm{L}$ & 1 & 2.6 & NR \\
\hline $\mathrm{pH}^{b}$ & SU & 1 & 7.70 & NR \\
\hline Phosphorous, Total & $\mathrm{mg} / \mathrm{L}$ & 2 & $<0.005$ & $<0.005$ \\
\hline Solids, Total Dissolved & $\mathrm{mg} / \mathrm{L}$ & 2 & 72 & 70 \\
\hline Solids, Total Suspended & $\mathrm{mg} / \mathrm{L}$ & 2 & 126 & $<4.0$ \\
\hline Sulfide & $\mathrm{mg} / \mathrm{L}$ & 2 & $<0.022$ & $<0.022$ \\
\hline Surfactant (as LAS) & $\mathrm{mg} / \mathrm{L}$ & 2 & $<0.013$ & $<0.013$ \\
\hline Zinc, Total Recoverable & $\mathrm{mg} / \mathrm{L}$ & 2 & 0.0076 & 0.0094 \\
\hline \multicolumn{5}{|c|}{ Rain Event Summary } \\
\hline pH of Rainfall During Sampling Event & SU & 1 & \multicolumn{2}{|c|}{5.05} \\
\hline Total Rainfall During Sampling Event & inches & -- & \multicolumn{2}{|c|}{0.27} \\
\hline Total Flow During SamplingEvent & gallons & -- & \multicolumn{2}{|c|}{56,000} \\
\hline Maximum Flow Rate During Sampling Event & gpm & -- & \multicolumn{2}{|c|}{380} \\
\hline
\end{tabular}

$\mathrm{N}$ - Number of samples

NR - Not required by permit

$a$ The SPDES permit specifies that oil and grease concentrations shall not exceed $15 \mathrm{mg} / \mathrm{L}$.

b The SPDES permit specifies that the outfall $\mathrm{pH}$ shall not be less than the measured $\mathrm{pH}$ of rainfall collected from the site rain gauge at WNSWR01 during storm water discharge sampling or $6.0 \mathrm{SU}$, whichever is less, and the $\mathrm{pH}$ shall not exceed $9.0 \mathrm{SU}$. 
TABLE B-3H

\section{Storm Water Discharge Monitoring Data for Outfall Group 8}

\section{Storm Water Outfall S27}

\begin{tabular}{|c|c|c|c|c|}
\hline \multirow[t]{2}{*}{ Analyte } & \multirow[t]{2}{*}{ Units } & \multirow[t]{2}{*}{$N$} & \multirow{2}{*}{$\begin{array}{c}\text { First Flush Grab } \\
6 / 17 / 08\end{array}$} & \multirow{2}{*}{$\begin{array}{c}\text { Flow-weighted } \\
\text { Composite }\end{array}$} \\
\hline & & & & \\
\hline Aluminum, Total & $\mathrm{mg} / \mathrm{L}$ & 3 & $0.39 / 0.19$ & 0.61 \\
\hline Ammonia (as $\mathrm{NH}_{3}$ ) & $\mathrm{mg} / \mathrm{L}$ & 3 & $0.011 /<0.011$ & $<0.011$ \\
\hline $\mathrm{BOD}_{5}$ & $\mathrm{mg} / \mathrm{L}$ & 3 & $<2.0 /<2.0$ & $<2.0$ \\
\hline Copper, Total Recoverable & $\mathrm{mg} / \mathrm{L}$ & 3 & $0.0020 / 0.0021$ & 0.0023 \\
\hline Iron, Total & $\mathrm{mg} / \mathrm{L}$ & 3 & $0.40 / 0.21$ & 0.80 \\
\hline Lead, Total Recoverable & $\mathrm{mg} / \mathrm{L}$ & 3 & $0.00066 / 0.00069$ & 0.00071 \\
\hline Nitrogen, Nitrate (as N) & $\mathrm{mg} / \mathrm{L}$ & 3 & $<0.011 /<0.011$ & $<0.011$ \\
\hline Nitrogen, Nitrite (as N) & $\mathrm{mg} / \mathrm{L}$ & 3 & $<0.020 /<0.020$ & $<0.020$ \\
\hline Nitrogen, Total (as N) & $\mathrm{mg} / \mathrm{L}$ & 3 & $<0.59 /<0.51$ & $<0.63$ \\
\hline Nitrogen, Total Kjeldahl & $\mathrm{mg} / \mathrm{L}$ & 3 & $0.56 / 0.48$ & 0.60 \\
\hline Oil \& Grease ${ }^{a}$ & $\mathrm{mg} / \mathrm{L}$ & 2 & $2.4 / 3.0$ & NR \\
\hline $\mathrm{pH}^{b}$ & SU & 2 & $7.70 / 7.70$ & NR \\
\hline Phosphorous, Total & $\mathrm{mg} / \mathrm{L}$ & 3 & $0.030 / 0.017$ & 0.005 \\
\hline Solids, Total Dissolved & $\mathrm{mg} / \mathrm{L}$ & 3 & $266 / 264$ & 253 \\
\hline Solids, Total Suspended & $\mathrm{mg} / \mathrm{L}$ & 3 & $6.0 / 10$ & 12 \\
\hline Surfactant (as LAS) & $\mathrm{mg} / \mathrm{L}$ & 3 & $<0.013 /<0.013$ & $<0.013$ \\
\hline Zinc, Total Recoverable & $\mathrm{mg} / \mathrm{L}$ & 3 & $0.0052 / 0.0062$ & 0.0072 \\
\hline \multicolumn{5}{|c|}{ Rain Event Summary } \\
\hline $\mathrm{pH}$ of Rainfall During Sampling Event & SU & 1 & \multicolumn{2}{|c|}{5.91} \\
\hline Rainfall During Sampling Event & inches & -- & \multicolumn{2}{|c|}{0.08} \\
\hline Total Flow During Sampling Event & gallons & -- & \multicolumn{2}{|c|}{450} \\
\hline Maximum Flow Rate During Sampling Event & gpm & -- & \multicolumn{2}{|c|}{5.4} \\
\hline
\end{tabular}

Note: The first flush grab samples were sampled and analyzed in duplicate.

$\mathrm{N}$ - Number of samples

NR - Not required by permit

$a$ The SPDES permit specifies that oil and grease concentrations shall not exceed $15 \mathrm{mg} / \mathrm{L}$.

b The SPDES permit specifies that the outfall pH shall not be less than the measured $\mathrm{pH}$ of rainfall collected from the site rain gauge at WNSWR01 during storm water discharge sampling or $6.0 \mathrm{SU}$, whichever is less, and the $\mathrm{pH}$ shall not exceed $9.0 \mathrm{SU}$. 
TABLE B-3H (concluded)

2008 Storm Water Discharge Monitoring Data for Outfall Group 8

\section{Storm Water Outfall S35}

\begin{tabular}{|c|c|c|c|c|}
\hline \multirow[t]{2}{*}{ Analyte } & \multirow[t]{2}{*}{ Units } & \multirow[t]{2}{*}{$N$} & \multirow{2}{*}{$\begin{array}{c}\text { First Flush Grab } \\
7 / 9 / 08\end{array}$} & \multirow{2}{*}{$\begin{array}{c}\begin{array}{c}\text { Flow-weighted } \\
\text { Composite }\end{array} \\
7 / 9 / 08\end{array}$} \\
\hline & & & & \\
\hline Aluminum, Total & $\mathrm{mg} / \mathrm{L}$ & 3 & $3.9 / 4.5$ & 0.52 \\
\hline Ammonia (as $\mathrm{NH}_{3}$ ) & $\mathrm{mg} / \mathrm{L}$ & 3 & $<0.011 /<0.011$ & 0.026 \\
\hline $\mathrm{BOD}_{5}$ & $\mathrm{mg} / \mathrm{L}$ & 3 & $8.0 / 7.2$ & 2.8 \\
\hline Copper, Total Recoverable & $\mathrm{mg} / \mathrm{L}$ & 3 & $0.0048 / 0.0052$ & 0.0024 \\
\hline Iron, Total & $\mathrm{mg} / \mathrm{L}$ & 3 & $3.4 / 4.0$ & 0.65 \\
\hline Lead, Total Recoverable & $\mathrm{mg} / \mathrm{L}$ & 3 & $0.013 / 0.015$ & 0.0016 \\
\hline Nitrogen, Nitrate (as N) & $\mathrm{mg} / \mathrm{L}$ & 3 & $0.16 / 0.14$ & 0.041 \\
\hline Nitrogen, Nitrite (as N) & $\mathrm{mg} / \mathrm{L}$ & 3 & $<0.020 /<0.020$ & $<0.020$ \\
\hline Nitrogen, Total (as N) & $\mathrm{mg} / \mathrm{L}$ & 3 & $<3.1 /<2.6$ & $<0.98$ \\
\hline Nitrogen, Total Kjeldahl & $\mathrm{mg} / \mathrm{L}$ & 3 & $2.9 / 2.4$ & 0.92 \\
\hline Oil \& Grease ${ }^{a}$ & $\mathrm{mg} / \mathrm{L}$ & 2 & $<2.2 /<2.2$ & NR \\
\hline $\mathrm{pH}^{b}$ & SU & 2 & 7.60 & NR \\
\hline Phosphorous, Total & $\mathrm{mg} / \mathrm{L}$ & 3 & $0.048 / 0.088$ & 0.056 \\
\hline Solids, Total Dissolved & $\mathrm{mg} / \mathrm{L}$ & 3 & $480 / 446$ & 489 \\
\hline Solids, Total Suspended & $\mathrm{mg} / \mathrm{L}$ & 3 & $87 / 72$ & 15.0 \\
\hline Surfactant (as LAS) & $\mathrm{mg} / \mathrm{L}$ & 3 & $<0.013 / 0.017$ & $<0.013$ \\
\hline Zinc, Total Recoverable & $\mathrm{mg} / \mathrm{L}$ & 3 & $0.058 / 0.067$ & 0.057 \\
\hline \multicolumn{5}{|c|}{ Rain Event Summary } \\
\hline pH of Rainfall During Sampling Event & SU & 1 & \multicolumn{2}{|c|}{5.05} \\
\hline Rainfall During Sampling Event & inches & -- & \multicolumn{2}{|c|}{0.27} \\
\hline Total Flow During Sampling Event & gallons & -- & \multicolumn{2}{|c|}{1,300} \\
\hline Maximum Flow Rate During Sampling Event & gpm & -- & \multicolumn{2}{|c|}{15} \\
\hline
\end{tabular}

Note: The first flush grab samples were sampled and analyzed in duplicate.

$\mathrm{N}$ - Number of samples

NR - Not required by permit

$a$ The SPDES permit specifies that oil and grease concentrations shall not exceed $15 \mathrm{mg} / \mathrm{L}$.

b The SPDES permit specifies that the outfall $\mathrm{pH}$ shall not be less than the measured $\mathrm{pH}$ of rainfall collected from the site rain gauge at WNSWR01 during storm water discharge sampling or $6.0 \mathrm{SU}$, whichever is less, and the $\mathrm{pH}$ shall not exceed $9.0 \mathrm{SU}$. 


\section{APPENDIX B-4}

\section{Site Surface Drainage, Subsurface Drainage, and Contained Water Data}

TABLE B-4A

2008 Radioactivity and pH in Surface Water at Facility Yard Drainage (WNSP005)

\begin{tabular}{|c|c|c|c|c|c|c|}
\hline \multirow{2}{*}{ Analyte } & \multirow{2}{*}{ Units } & \multirow{2}{*}{$N$} & \multicolumn{3}{|c|}{ WNSP005 Concentrations } & \multirow{2}{*}{$\begin{array}{c}\text { Guideline }^{a} \text { or } \\
\text { Standard }^{b}\end{array}$} \\
\hline & & & Minimum & Average & Maximum & \\
\hline Gross Alpha & $\mu \mathrm{Ci} / \mathrm{mL}$ & 4 & $2.72 \mathrm{E}-09$ & $-0.95 \pm 5.02 E-09$ & $2.72 \mathrm{E}-09$ & $3 \mathrm{E}-08^{c}$ \\
\hline Gross Beta & $\mu \mathrm{Ci} / \mathrm{mL}$ & 4 & $1.08 \mathrm{E}-07$ & $2.04 \pm 0.15 \mathrm{E}-07$ & $2.77 \mathrm{E}-07$ & $1 \mathrm{E}-06^{d}$ \\
\hline Tritium & $\mu \mathrm{Ci} / \mathrm{mL}$ & 4 & $<3.49 \mathrm{E}-08$ & $4.27 \pm 4.46 \mathrm{E}-08$ & $6.99 \mathrm{E}-08$ & $2 \mathrm{E}-03$ \\
\hline Sr-90 & $\mu \mathrm{Ci} / \mathrm{mL}$ & 2 & $8.63 \mathrm{E}-08$ & $1.05 \pm 0.04 \mathrm{E}-07$ & $1.24 \mathrm{E}-07$ & $1 \mathrm{E}-06$ \\
\hline Cs-137 & $\mu \mathrm{Ci} / \mathrm{mL}$ & 2 & $<1.33 \mathrm{E}-09$ & $0.58 \pm 1.69 \mathrm{E}-09$ & $<1.98 \mathrm{E}-09$ & $3 E-06$ \\
\hline $\mathrm{pH}$ & SU & 5 & 7.36 & 7.63 & 7.91 & $6.0-9.5$ \\
\hline
\end{tabular}

$\mathrm{N}$ - Number of samples

a DOE ingestion-based DCGs for 100 mrem/yr dose limit are provided as a guideline for radiological results.

$b$ New York State Water Quality Standards for Class " $D$ " as a comparative reference for nonradiological results

c Alpha as Am-241

d Beta as Sr-90

TABLE B-4B

2008 Radioactivity in Surface Water at French Drain (WNSP008)

No Discharge From the French Drain Since May 2001 
TABLE B-4C

2008 Radioactivity in Surface Water at the North Swamp (WNSW74A)

\begin{tabular}{|c|c|c|c|c|c|c|}
\hline Isotope ${ }^{a}$ & $\mathbf{N}$ & $\begin{array}{c}\text { Discharge } \\
\text { Activity }^{b} \\
\text { (Ci) } \\
\end{array}$ & $\begin{array}{c}\text { Radioactivity }^{c} \\
\text { (Becquerels) }\end{array}$ & $\begin{array}{c}\text { Average } \\
\text { Concentration } \\
(\mu \mathrm{Ci} / \mathrm{mL})\end{array}$ & $\begin{array}{c}D C G \\
(\mu C i / m L) \\
\end{array}$ & $\begin{array}{c}\text { Ratio of } \\
\text { Concentration } \\
\text { to DCG } \\
\end{array}$ \\
\hline Gross Alpha & 26 & $-3.15 \pm 6.87 E-05$ & $-1.16 \pm 2.54 \mathrm{E}+06$ & $-0.69 \pm 1.49 E-09$ & $\mathrm{NA}^{d}$ & NA \\
\hline Gross Beta & 26 & $6.11 \pm 0.66 \mathrm{E}-04$ & $2.26 \pm 0.25 \mathrm{E}+07$ & $1.33 \pm 0.14 \mathrm{E}-08$ & $N A^{d}$ & $\mathrm{NA}$ \\
\hline Tritium & 26 & $-1.87 \pm 6.02 \mathrm{E}-04$ & $-0.69 \pm 2.23 E+07$ & $-0.41 \pm 1.31 \mathrm{E}-08$ & $2 \mathrm{E}-03$ & $<0.0001$ \\
\hline C-14 & 2 & $-4.76 \pm 9.93 E-04$ & $-1.76 \pm 3.68 \mathrm{E}+07$ & $-1.04 \pm 2.16 \mathrm{E}-08$ & 7E-05 & $<0.0003$ \\
\hline Sr-90 & 12 & $2.68 \pm 0.16 \mathrm{E}-04$ & $9.93 \pm 0.58 \mathrm{E}+06$ & $5.84 \pm 0.34 \mathrm{E}-09$ & $1 \mathrm{E}-06$ & 0.0058 \\
\hline I-129 & 2 & $0.27 \pm 1.86 \mathrm{E}-05$ & $0.99 \pm 6.87 E+05$ & $0.58 \pm 4.04 \mathrm{E}-10$ & $5 \mathrm{E}-07$ & $<0.0008$ \\
\hline Cs-137 & 12 & $1.83 \pm 2.58 \mathrm{E}-05$ & $6.78 \pm 9.55 E+05$ & $3.99 \pm 5.62 \mathrm{E}-10$ & $3 \mathrm{E}-06$ & $<0.0002$ \\
\hline $\mathrm{U}-232^{e}$ & 2 & $0.16 \pm 3.10 \mathrm{E}-06$ & $0.06 \pm 1.15 E+05$ & $0.36 \pm 6.74 \mathrm{E}-11$ & $1 \mathrm{E}-07$ & $<0.0007$ \\
\hline U-233/234 ${ }^{e}$ & 2 & $8.87 \pm 3.77 \mathrm{E}-06$ & $3.28 \pm 1.39 E+05$ & $1.93 \pm 0.82 \mathrm{E}-10$ & $5 \mathrm{E}-07$ & 0.0004 \\
\hline $\mathrm{U}-235 / 236^{e}$ & 2 & $3.18 \pm 2.04 \mathrm{E}-06$ & $1.18 \pm 0.76 \mathrm{E}+05$ & $6.92 \pm 4.45 \mathrm{E}-11$ & $5 \mathrm{E}-07^{f}$ & 0.0001 \\
\hline $\mathrm{U}-238^{e}$ & 2 & $4.38 \pm 2.39 \mathrm{E}-06$ & $1.62 \pm 0.89 E+05$ & $9.54 \pm 5.21 \mathrm{E}-11$ & $6 \mathrm{E}-07$ & 0.0002 \\
\hline Pu-238 & 2 & $-1.49 \pm 7.75 E-07$ & $-0.55 \pm 2.87 E+04$ & $-0.33 \pm 1.69 \mathrm{E}-11$ & $4 \mathrm{E}-08$ & $<0.0004$ \\
\hline Pu-239/240 & 2 & $2.04 \pm 8.70 \mathrm{E}-07$ & $0.75 \pm 3.22 E+04$ & $0.44 \pm 1.89 \mathrm{E}-11$ & $3 \mathrm{E}-08$ & $<0.0006$ \\
\hline Am-241 & 2 & $-0.32 \pm 1.23 E-06$ & $-1.16 \pm 4.55 E+04$ & $-0.69 \pm 2.68 \mathrm{E}-11$ & $3 \mathrm{E}-08$ & $<0.0009$ \\
\hline \multicolumn{6}{|l|}{ Sum of Ratios } & $<0.0104$ \\
\hline
\end{tabular}

Note: The average $\mathrm{pH}$ at this location was $7.46 \mathrm{SU}$.

$\mathrm{N}$ - Number of samples

NA - Not applicable

a Half-lives are listed in Table UI-1.

$b$ Total estimated volume released: $4.59 \mathrm{E}+10 \mathrm{~mL}(1.21 \mathrm{E}+07$ gal)

c 1 curie $(\mathrm{Ci})=3.7 \mathrm{E}+10$ becquerels $(\mathrm{Bq}) ; 1 \mathrm{~Bq}=2.7 \mathrm{E}-11 \mathrm{Ci}$

$d$ DOE-derived concentration guides (DCGs) do not exist for indicator parameters gross alpha and gross beta.

$e$ Total Uranium $(\mathrm{g})=1.60 \pm 0.05 \mathrm{E}+01$; Average Total Uranium $(\mu \mathrm{g} / \mathrm{mL})=3.48 \pm 0.12 \mathrm{E}-04$

$f$ DCG for $\mathrm{U}-236$ is used for this comparison. 
TABLE B-4D

2008 Radioactivity in Surface Water at the Northeast Swamp (WNSWAMP)

\begin{tabular}{|c|c|c|c|c|c|}
\hline Isotope $^{a}$ & $\begin{array}{l}\text { Discharge } \\
\text { Activity }^{b} \\
\text { (Ci) } \\
\end{array}$ & $\begin{array}{c}\text { Radioactivity }^{c} \\
\text { (Becquerels) }\end{array}$ & $\begin{array}{c}\text { Average } \\
\text { Concentration } \\
(\mu \mathrm{Ci} / \mathrm{mL})\end{array}$ & $\begin{array}{c}D_{C G}{ }^{d} \\
(\mu C i / m L) \\
\end{array}$ & \begin{tabular}{|c|} 
Ratio of \\
Concentration to \\
DCG \\
\end{tabular} \\
\hline Gross Alpha & $0.27 \pm 1.34 \mathrm{E}-04$ & $0.98 \pm 4.95 \mathrm{E}+06$ & $0.23 \pm 1.15 \mathrm{E}-09$ & $N A^{e}$ & NA \\
\hline Gross Beta & $5.24 \pm 0.05 \mathrm{E}-01$ & $1.94 \pm 0.02 E+10$ & 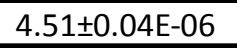 & $N A^{e}$ & NA \\
\hline $\mathrm{H}-3$ & $4.22 \pm 1.85 \mathrm{E}-03$ & $1.56 \pm 0.69 \mathrm{E}+08$ & $3.63 \pm 1.59 \mathrm{E}-08$ & $2 \mathrm{E}-03$ & $<0.0001$ \\
\hline C-14 & $-2.15 \pm 2.97 \mathrm{E}-03$ & $-0.80 \pm 1.10 \mathrm{E}+08$ & $-1.85 \pm 2.55 \mathrm{E}-08$ & 7E-05 & $<0.0004$ \\
\hline Sr-90 & $2.86 \pm 0.02 \mathrm{E}-01$ & $1.06 \pm 0.01 \mathrm{E}+10$ & $2.46 \pm 0.01 \mathrm{E}-06$ & $1 \mathrm{E}-06$ & 2.46 \\
\hline I-129 & $-1.00 \pm 6.30 \mathrm{E}-05$ & $-0.37 \pm 2.33 \mathrm{E}+06$ & $-0.86 \pm 5.42 \mathrm{E}-10$ & $5 \mathrm{E}-07$ & $<0.0011$ \\
\hline Cs-137 & $1.22 \pm 0.88 \mathrm{E}-04$ & $4.52 \pm 3.26 \mathrm{E}+06$ & $1.05 \pm 0.76 \mathrm{E}-09$ & $3 \mathrm{E}-06$ & 0.0004 \\
\hline $\mathbf{U}-232^{f}$ & $2.04 \pm 5.75 \mathrm{E}-06$ & $0.76 \pm 2.13 \mathrm{E}+05$ & $1.76 \pm 4.95 \mathrm{E}-11$ & $1 \mathrm{E}-07$ & $<0.0005$ \\
\hline $\mathrm{U}-233 / 234^{f}$ & $2.36 \pm 0.87 \mathrm{E}-05$ & $8.74 \pm 3.23 E+05$ & $2.03 \pm 0.75 \mathrm{E}-10$ & $5 \mathrm{E}-07$ & 0.0004 \\
\hline $\mathrm{U}-235 / 236^{f}$ & $3.04 \pm 4.96 \mathrm{E}-06$ & $1.13 \pm 1.83 \mathrm{E}+05$ & $2.62 \pm 4.26 \mathrm{E}-11$ & $5 \mathrm{E}-07^{g}$ & $<0.0001$ \\
\hline U-238 & $1.87 \pm 0.75 \mathrm{E}-05$ & $6.91 \pm 2.78 \mathrm{E}+05$ & $1.61 \pm 0.65 \mathrm{E}-10$ & $6 \mathrm{E}-07$ & 0.0003 \\
\hline Pu-238 & $0.17 \pm 4.91 \mathrm{E}-06$ & $0.06 \pm 1.82 \mathrm{E}+05$ & $0.14 \pm 4.22 \mathrm{E}-11$ & $4 \mathrm{E}-08$ & $<0.0011$ \\
\hline Pu-239/240 & $3.02 \pm 4.89 \mathrm{E}-06$ & $1.12 \pm 1.81 \mathrm{E}+05$ & $2.60 \pm 4.20 \mathrm{E}-11$ & $3 \mathrm{E}-08$ & $<0.0014$ \\
\hline Am-241 & $1.20 \pm 1.70 \mathrm{E}-06$ & $4.44 \pm 6.28 \mathrm{E}+04$ & $1.03 \pm 1.46 \mathrm{E}-11$ & $3 \mathrm{E}-08$ & $<0.0005$ \\
\hline \multicolumn{5}{|l|}{ Sum of Ratios } & 2.47 \\
\hline
\end{tabular}

Note: The average $\mathrm{pH}$ at this location was 7.64 SU.

NA - Not applicable

a Half-lives are listed in Table UI-4.

$b$ Total volume released: $1.16 \mathrm{E}+11 \mathrm{~mL}(3.07 \mathrm{E}+07$ gal)

c 1 curie $(\mathrm{Ci})=3.7 \mathrm{E}+10$ becquerels $(\mathrm{Bq}) ; 1 \mathrm{~Bq}=2.7 \mathrm{E}-11 \mathrm{Ci}$

d DCGs are listed for reference only. DCGs are applicable at the point at which water is available for ingestion by the public (i.e., at the site boundary), but not to release point concentrations, as might be inferred from their inclusion in this table.

e DOE DCGs do not exist for indicator parameters gross alpha and gross beta.

$f$ Total Uranium $(\mathrm{g})=3.13 \pm 0.17 \mathrm{E}+01$; Average Total Uranium $(\mu \mathrm{g} / \mathrm{mL})=2.86 \pm 0.15 \mathrm{E}-04$

$g$ DCG for U-236 is used for this comparison.

TABLE B-4E

2008 Radioactivity in Surface Water at Storage and Disposal Area Drainage (WNNDADR)

\begin{tabular}{|c|c|c|c|c|c|}
\hline \multirow{2}{*}{ Analyte } & \multirow{2}{*}{ Units } & \multirow{2}{*}{$N$} & \multicolumn{3}{|c|}{ WNNDADR Concentrations } \\
\hline & & & Minimum & Average & Maximum \\
\hline Gross Alpha & $\mu \mathrm{Ci} / \mathrm{mL}$ & 12 & $<1.24 \mathrm{E}-09$ & $0.89 \pm 2.25 \mathrm{E}-09$ & 6.37E-09 \\
\hline Gross Beta & $\mu \mathrm{Ci} / \mathrm{mL}$ & 12 & $4.80 \mathrm{E}-08$ & $1.91 \pm 0.09 E-07$ & $2.98 \mathrm{E}-07$ \\
\hline Tritium & $\mu \mathrm{Ci} / \mathrm{mL}$ & 12 & $3.22 \mathrm{E}-07$ & $5.87 \pm 0.53 E-07$ & 8.94E-07 \\
\hline Sr-90 & $\mu \mathrm{Ci} / \mathrm{mL}$ & 2 & $9.71 \mathrm{E}-08$ & $1.00 \pm 0.05 E-07$ & $1.03 \mathrm{E}-07$ \\
\hline |-129 & $\mu \mathrm{Ci} / \mathrm{mL}$ & 2 & $<3.38 \mathrm{E}-10$ & $0.70 \pm 7.31 \mathrm{E}-10$ & $<9.77 \mathrm{E}-10$ \\
\hline Cs-137 & $\mu \mathrm{Ci} / \mathrm{mL}$ & 12 & $<1.32 \mathrm{E}-09$ & $0.52 \pm 1.91 E-09$ & $3.63 E-09$ \\
\hline
\end{tabular}

$\mathrm{N}$ - Number of samples 
This page intentionally left blank 


\section{APPENDIX B-5}

\section{Ambient Surface Water Data}

TABLE B-5A

2008 Radioactivity and pH in Surface Water Downstream of the WVDP in Cattaraugus Creek at Felton Bridge (WFFELBR)

\begin{tabular}{|c|c|c|c|c|c|}
\hline \multirow[t]{2}{*}{ Analyte } & \multirow[t]{2}{*}{ Units } & \multirow[t]{2}{*}{$N$} & \multicolumn{2}{|c|}{$\begin{array}{c}\text { WFFELBR } \\
\text { Concentrations }\end{array}$} & \multirow{2}{*}{$\begin{array}{c}\text { Reference Values } \\
\text { Guideline }^{a} \\
\text { or Standard }^{b}\end{array}$} \\
\hline & & & Average & Maximum & \\
\hline Gross Alpha & $\mu \mathrm{Ci} / \mathrm{mL}$ & 12 & $0.34 \pm 1.44 \mathrm{E}-09^{c}$ & $2.84 \mathrm{E}-09^{c}$ & $3 \mathrm{E}-08^{d}$ \\
\hline Gross Beta & $\mu \mathrm{Ci} / \mathrm{mL}$ & 12 & $3.33 \pm 1.73 \mathrm{E}-09^{c}$ & $5.54 \mathrm{E}-09^{c}$ & $1 \mathrm{E}-06^{e}$ \\
\hline Tritium & $\mu \mathrm{Ci} / \mathrm{mL}$ & 12 & $0.47 \pm 4.71 \mathrm{E}-08^{c}$ & $6.30 \mathrm{E}-08^{c}$ & $2 \mathrm{E}-03$ \\
\hline Sr-90 & $\mu \mathrm{Ci} / \mathrm{mL}$ & 12 & $5.61 \pm 7.42 \mathrm{E}-10$ & $1.38 \mathrm{E}-09$ & $1 \mathrm{E}-06$ \\
\hline Cs-137 & $\mu \mathrm{Ci} / \mathrm{mL}$ & 12 & $0.57 \pm 1.76 \mathrm{E}-09$ & $2.16 \mathrm{E}-09$ & $3 E-06$ \\
\hline pH & SU & 35 & 8.04 & 8.23 & $6.5-8.5$ \\
\hline
\end{tabular}

$\mathrm{N}$ - Number of samples

a DOE ingestion-based DCGs for 100 mrem/yr dose limit are provided as a guideline for radiological results in the absence of water quality standards.

$b$ New York State Water Quality Standards, Class "B" as a comparative reference for nonradiological results

c Values represent composite concentrations weighted to monthly stream flow.

d Alpha as Am-241

e Beta as Sr-90

TABLE B-5B

2008 Water Quality of Surface Water Downstream of the WVDP in Buttermilk Creek at Thomas Corners Bridge (WFBCTCB)

RADIOACTIVE CONSTITUENTS

\begin{tabular}{|c|c|c|c|c|c|c|c|}
\hline \multirow{3}{*}{ Analyte } & \multirow{3}{*}{ Units } & \multirow{3}{*}{$N$} & \multirow{2}{*}{\multicolumn{2}{|c|}{$\begin{array}{c}\text { WFBCTCB } \\
\text { Concentrations }\end{array}$}} & \multirow{3}{*}{$N$} & \multicolumn{2}{|c|}{ Reference Values } \\
\hline & & & & & & \multirow{2}{*}{$\begin{array}{c}\text { WFBCBKG }^{a} \\
\text { Background Range }\end{array}$} & \multirow{2}{*}{ Guideline } \\
\hline & & & Average & Maximum & & & \\
\hline Gross Alpha & $\mu \mathrm{Ci} / \mathrm{mL}$ & 12 & $0.42 \pm 1.45 \mathrm{E}-09$ & $2.51 \mathrm{E}-09$ & 12 & $6.18 \mathrm{E}-10-9.18 \mathrm{E}-10$ & $3 \mathrm{E}-08^{c}$ \\
\hline Gross Beta & $\mu \mathrm{Ci} / \mathrm{mL}$ & 12 & $7.59 \pm 1.98 \mathrm{E}-09$ & $1.08 \mathrm{E}-08$ & 12 & 1.38E-09-3.27E-09 & $1 \mathrm{E}-06^{d}$ \\
\hline Tritium & $\mu \mathrm{Ci} / \mathrm{mL}$ & 12 & $1.37 \pm 4.49 \mathrm{E}-08$ & $8.24 \mathrm{E}-08$ & 12 & $<3.26 \mathrm{E}-08-7.90 \mathrm{E}-08$ & $2 \mathrm{E}-03$ \\
\hline Sr-90 & $\mu \mathrm{Ci} / \mathrm{mL}$ & 2 & $3.14 \pm 0.95 \mathrm{E}-09$ & 3.69E-09 & 2 & $<4.73 \mathrm{E}-10-<7.12 \mathrm{E}-10$ & $1 \mathrm{E}-06$ \\
\hline Cs-137 & $\mu \mathrm{Ci} / \mathrm{mL}$ & 2 & $0.95 \pm 1.91 \mathrm{E}-09$ & $2.12 \mathrm{E}-09$ & 2 & $<1.84 \mathrm{E}-09-<2.05 \mathrm{E}-09$ & $3 \mathrm{E}-06$ \\
\hline
\end{tabular}

$\mathrm{N}$ - Number of samples

a Background location

$b$ DOE ingestion-based DCGs for $100 \mathrm{mrem} / \mathrm{yr}$ dose limit are provided as a guideline for radiological results in the absence of water quality standards.

c Alpha as Am-241

d Beta as Sr-90 
TABLE B-5B (continued)

\section{Water Quality of Surface Water Downstream of the WVDP in Buttermilk Creek at Thomas Corners Bridge (WFBCTCB)}

CHEMICAL CONSTITUENTS

\begin{tabular}{|c|c|c|c|c|c|}
\hline \multirow[t]{2}{*}{ Analyte } & \multirow[t]{2}{*}{ Units } & \multirow[t]{2}{*}{$N$} & \multicolumn{2}{|c|}{$\begin{array}{c}\text { WFBCTCB } \\
\text { Concentration }\end{array}$} & \multirow[t]{2}{*}{ Standard $^{a}$} \\
\hline & & & Average & Maximum & \\
\hline Alpha-BHC & $\mu \mathrm{g} / \mathrm{L}$ & 2 & $<0.009$ & $<0.009$ & 0.002 \\
\hline Aluminum, Dissolved & $\mathrm{mg} / \mathrm{L}$ & 2 & $<0.117$ & 0.134 & 0.10 \\
\hline Ammonia-N & $\mathrm{mg} / \mathrm{L}$ & 2 & $<0.02$ & $<0.02$ & $0.09-2.1$ \\
\hline Antimony, Total & $\mathrm{mg} / \mathrm{L}$ & 2 & $<0.003$ & $<0.003$ & -- \\
\hline Arsenic, Dissolved & $\mathrm{mg} / \mathrm{L}$ & 2 & $<0.005$ & $<0.005$ & 0.150 \\
\hline \begin{tabular}{|l|} 
Barium, Total \\
\end{tabular} & $\mathrm{mg} / \mathrm{L}$ & 2 & 0.07 & 0.08 & -- \\
\hline Boron, Total & $\mathrm{mg} / \mathrm{L}$ & 2 & 0.03 & 0.03 & 10.0 \\
\hline Bromide & $\mathrm{mg} / \mathrm{L}$ & 2 & $<0.50$ & $<0.50$ & -- \\
\hline Cadmium, Dissolved & $\mathrm{mg} / \mathrm{L}$ & 2 & $<0.001$ & $<0.001$ & $0.003^{b}$ \\
\hline Calcium, Total & $\mathrm{mg} / \mathrm{L}$ & 12 & 36.1 & 48.9 & -- \\
\hline Chloride & $\mathrm{mg} / \mathrm{L}$ & 2 & 32 & 35 & -- \\
\hline Chromium, Dissolved & $\mathrm{mg} / \mathrm{L}$ & 2 & $<0.01$ & $<0.01$ & $0.106^{b}$ \\
\hline Cobalt, Total & $\mathrm{mg} / \mathrm{L}$ & 2 & $<0.005$ & $<0.005$ & $0.005^{c}$ \\
\hline Copper, Dissolved & $\mathrm{mg} / \mathrm{L}$ & 2 & $<0.005$ & $<0.005$ & $0.013^{b}$ \\
\hline Dissolved, Oxygen & $\mathrm{mg} / \mathrm{L}$ & 2 & 8.2 & 8.6 & 4.0 (min) \\
\hline Fluoride & $\mathrm{mg} / \mathrm{L}$ & 2 & $<0.10$ & $<0.10$ & $3.14^{b}$ \\
\hline Hardness & $\mathrm{mg} / \mathrm{L}$ & 12 & 114 & 154 & -- \\
\hline \begin{tabular}{|l|} 
Iron, Total \\
\end{tabular} & $\mathrm{mg} / \mathrm{L}$ & 2 & 0.31 & 0.39 & 0.30 \\
\hline Lead, Dissolved & $\mathrm{mg} / \mathrm{L}$ & 2 & $<0.0005$ & $<0.0005$ & $0.006^{b}$ \\
\hline Magnesium, Total & $\mathrm{mg} / \mathrm{L}$ & 12 & 5.88 & 7.81 & -- \\
\hline Manganese, Total & $\mathrm{mg} / \mathrm{L}$ & 2 & 0.09 & 0.12 & -- \\
\hline \begin{tabular}{|l|} 
Mercury, Dissolved, \\
Method 1631 \\
\end{tabular} & $\mu \mathrm{g} / \mathrm{L}$ & 2 & 0.000577 & 0.000617 & - \\
\hline Nickel, Dissolved & $\mathrm{mg} / \mathrm{L}$ & 2 & $<0.04$ & $<0.04$ & $0.075^{b}$ \\
\hline Nitrate-N & $\mathrm{mg} / \mathrm{L}$ & 2 & 0.25 & 0.36 & -- \\
\hline \begin{tabular}{|l|} 
Nitrite-N \\
\end{tabular} & $\mathrm{mg} / \mathrm{L}$ & 2 & $<0.05$ & $<0.05$ & 0.10 \\
\hline NPOC & $\mathrm{mg} / \mathrm{L}$ & 2 & 2.3 & 2.4 & -- \\
\hline
\end{tabular}

$\mathrm{N}$ - Number of samples

-- No reference standard available for this analyte

a New York State Water Quality Standards, Class "C" as a comparative reference for nonradiological results

${ }^{b}$ Calculated from maximum measurement of hardness of surface water stream at WFBCTCB

c Standards for cobalt, thallium, and vanadium are applicable to the acid-soluble fraction. 
TABLE B-5B (concluded)

2008 Water Quality of Surface Water Downstream of the WVDP in Buttermilk Creek at Thomas Corners Bridge (WFBCTCB)

\section{CHEMICAL CONSTITUENTS (concluded)}

\begin{tabular}{|c|c|c|c|c|c|}
\hline \multirow[t]{2}{*}{ Analyte } & \multirow[t]{2}{*}{ Units } & \multirow[t]{2}{*}{$N$} & \multicolumn{2}{|c|}{$\begin{array}{c}\text { WFBCTCB } \\
\text { Concentration }\end{array}$} & \multirow[t]{2}{*}{ Standard $^{b}$} \\
\hline & & & Average & Maximum & \\
\hline Oil \& Grease & $\mathrm{mg} / \mathrm{L}$ & 2 & $<5$ & $<5$ & -- \\
\hline pH & SU & 2 & 7.79 & 8.19 & $6.5-8.5$ \\
\hline Selenium, Dissolved & $\mathrm{mg} / \mathrm{L}$ & 2 & $<0.001$ & $<0.001$ & 0.0046 \\
\hline Sodium, Total & $\mathrm{mg} / \mathrm{L}$ & 2 & 24.2 & 24.6 & -- \\
\hline Solids, Total Dissolved & $\mathrm{mg} / \mathrm{L}$ & 2 & 218 & 224 & 500 \\
\hline Solids, Total Suspended & $\mathrm{mg} / \mathrm{L}$ & 2 & $<4$ & $<4$ & -- \\
\hline Sulfate & $\mathrm{mg} / \mathrm{L}$ & 2 & 27 & 28 & -- \\
\hline Sulfide (as S) & $\mathrm{mg} / \mathrm{L}$ & 2 & $<0.04$ & $<0.04$ & 0.002 \\
\hline Surfactant & $\mathrm{mg} / \mathrm{L}$ & 2 & $<0.06$ & $<0.10$ & 0.04 \\
\hline Thallium, Total & $\mathrm{mg} / \mathrm{L}$ & 2 & $<0.008$ & $<0.008$ & $0.008^{c}$ \\
\hline Titanium, Total & $\mathrm{mg} / \mathrm{L}$ & 2 & $<0.0500$ & $<0.0500$ & -- \\
\hline TOX & $\mathrm{mg} / \mathrm{L}$ & 2 & $<0.01$ & $<0.01$ & -- \\
\hline Vanadium, Total & $\mathrm{mg} / \mathrm{L}$ & 2 & $<0.0100$ & $<0.0100$ & $0.014^{c}$ \\
\hline Zinc, Dissolved & $\mathrm{mg} / \mathrm{L}$ & 2 & $<0.02$ & $<0.02$ & $0.120^{b}$ \\
\hline
\end{tabular}

$\mathrm{N}$ - Number of samples

-- No reference standard available for this analyte

a New York State Water Quality Standards, Class "C" as a comparative reference for nonradiological results

$b$ Calculated from maximum measurement of hardness of surface water stream at WFBCTCB

c Standards for cobalt, thallium, and vanadium are applicable to the acid-soluble fraction. 
TABLE B-5C

2008 Radioactivity in Surface Water Downstream of the WVDP at Franks Creek (WNSP006)

\begin{tabular}{|c|c|c|c|c|c|c|c|}
\hline \multirow{3}{*}{ Analyte } & \multirow{3}{*}{ Units } & \multirow{3}{*}{$\mathbf{N}$} & \multirow{2}{*}{\multicolumn{2}{|c|}{$\begin{array}{c}\text { WNSP006 } \\
\text { Concentrations }\end{array}$}} & \multirow{3}{*}{$N$} & \multicolumn{2}{|c|}{ Reference Values } \\
\hline & & & & & & \multirow{2}{*}{$\begin{array}{c}\text { WFBCBKG }^{a} \\
\text { Background Range }\end{array}$} & \multirow{2}{*}{ Guideline $^{b}$} \\
\hline & & & Average & Maximum & & & \\
\hline Gross Alpha & $\mu \mathrm{Ci} / \mathrm{mL}$ & 34 & $0.88 \pm 1.96 \mathrm{E}-09$ & 5.87E-09 & 12 & $6.18 \mathrm{E}-10-9.18 \mathrm{E}-10$ & $3 \mathrm{E}-08^{c}$ \\
\hline Gross Beta & $\mu \mathrm{Ci} / \mathrm{mL}$ & 34 & $4.56 \pm 0.44 \mathrm{E}-08$ & $1.27 \mathrm{E}-07$ & 12 & $1.38 \mathrm{E}-09-3.27 \mathrm{E}-09$ & $1 \mathrm{E}-06^{d}$ \\
\hline Tritium & $\mu \mathrm{Ci} / \mathrm{mL}$ & 34 & $6.39 \pm 4.69 \mathrm{E}-08$ & $3.54 \mathrm{E}-07$ & 12 & $<3.26 \mathrm{E}-08-7.90 \mathrm{E}-08$ & $2 \mathrm{E}-03$ \\
\hline C-14 & $\mu \mathrm{Ci} / \mathrm{mL}$ & 4 & $0.07 \pm 2.99 E-08$ & $<3.35 \mathrm{E}-08$ & 2 & $<3.01 \mathrm{E}-08-<3.06 \mathrm{E}-08$ & 7E-05 \\
\hline Sr-90 & $\mu \mathrm{Ci} / \mathrm{mL}$ & 12 & $2.02 \pm 0.20 \mathrm{E}-08$ & $3.25 \mathrm{E}-08$ & 2 & $<4.73 \mathrm{E}-10-<7.12 \mathrm{E}-10$ & $1 \mathrm{E}-06$ \\
\hline Tc-99 & $\mu \mathrm{Ci} / \mathrm{mL}$ & 4 & $0.72 \pm 2.19 \mathrm{E}-09$ & $2.36 \mathrm{E}-09$ & 2 & $<2.38 \mathrm{E}-09-<2.72 \mathrm{E}-09$ & $1 \mathrm{E}-04$ \\
\hline I-129 & $\mu \mathrm{Ci} / \mathrm{mL}$ & 4 & $-0.77 \pm 4.50 \mathrm{E}-10$ & $<6.23 \mathrm{E}-10$ & 2 & $<2.97 \mathrm{E}-10-<7.92 \mathrm{E}-10$ & $5 \mathrm{E}-07$ \\
\hline Cs-137 & $\mu \mathrm{Ci} / \mathrm{mL}$ & 12 & $4.99 \pm 3.12 E-09$ & $1.20 \mathrm{E}-08$ & 2 & $<1.84 \mathrm{E}-09-<2.05 \mathrm{E}-09$ & $3 \mathrm{E}-06$ \\
\hline U-232 & $\mu \mathrm{Ci} / \mathrm{mL}$ & 4 & $2.63 \pm 0.98 \mathrm{E}-10$ & $4.41 \mathrm{E}-10$ & 2 & $<3.75 \mathrm{E}-11-<6.31 \mathrm{E}-11$ & $1 \mathrm{E}-07$ \\
\hline U-233/234 & $\mu \mathrm{Ci} / \mathrm{mL}$ & 4 & $3.20 \pm 1.11 \mathrm{E}-10$ & $5.54 \mathrm{E}-10$ & 2 & $<3.97 \mathrm{E}-11-1.60 \mathrm{E}-10$ & $5 \mathrm{E}-07$ \\
\hline U-235/236 & $\mu \mathrm{Ci} / \mathrm{mL}$ & 4 & $6.31 \pm 5.01 \mathrm{E}-11$ & $1.42 \mathrm{E}-10$ & 2 & $<3.68 \mathrm{E}-11-3.84 \mathrm{E}-11$ & $5 \mathrm{E}-07^{e}$ \\
\hline U-238 & $\mu \mathrm{Ci} / \mathrm{mL}$ & 4 & $2.45 \pm 0.99 \mathrm{E}-10$ & $3.09 \mathrm{E}-10$ & 2 & $<3.54 \mathrm{E}-11-7.87 \mathrm{E}-11$ & $6 \mathrm{E}-07$ \\
\hline Total U & $\mu \mathrm{g} / \mathrm{mL}$ & 4 & $9.60 \pm 0.30 \mathrm{E}-04$ & $1.59 \mathrm{E}-03$ & 2 & 1.63E-04-3.35E-04 & -- \\
\hline Pu-238 & $\mu \mathrm{Ci} / \mathrm{mL}$ & 4 & $1.38 \pm 3.75 \mathrm{E}-11$ & $<5.22 \mathrm{E}-11$ & 2 & $<2.07 \mathrm{E}-11-<3.42 \mathrm{E}-11$ & $4 \mathrm{E}-08$ \\
\hline Pu-239/240 & $\mu \mathrm{Ci} / \mathrm{mL}$ & 4 & $0.21 \pm 2.48 \mathrm{E}-11$ & $<3.18 \mathrm{E}-11$ & 2 & $<1.74 \mathrm{E}-11-<2.45 \mathrm{E}-11$ & $3 \mathrm{E}-08$ \\
\hline Am-241 & $\mu \mathrm{Ci} / \mathrm{mL}$ & 4 & $0.35 \pm 3.43 E-11$ & $<4.25 \mathrm{E}-11$ & 2 & $<2.62 \mathrm{E}-11-<5.00 \mathrm{E}-11$ & $3 \mathrm{E}-08$ \\
\hline
\end{tabular}

$\mathrm{N}$ - Number of samples

-- No guideline or standard available for these analytes

a Background location

$b$ DOE ingestion-based DCGs for 100 mrem/yr dose limit are provided as a guideline for radiological results.

c Alpha as Am-241

d Beta as Sr-90

e DCG for U-236 is used for this comparison.

TABLE B-5D

2008 Radioactivity and pH in Surface Water at Erdman Brook (WNERB53)

\begin{tabular}{|c|c|c|c|c|c|c|}
\hline \multirow{2}{*}{ Analyte } & \multirow{2}{*}{ Units } & \multirow{2}{*}{$N$} & \multicolumn{3}{|c|}{ WNERB53 Concentrations } & \multirow{2}{*}{$\begin{array}{c}\text { Reference } \\
\text { Guideline }^{a} \text { or } \\
\text { Standard }^{b}\end{array}$} \\
\hline & & & Minimum & Average & Maximum & \\
\hline Gross Alpha & $\mu \mathrm{Ci} / \mathrm{mL}$ & 4 & $<1.07 \mathrm{E}-09$ & $0.14 \pm 3.97 E-09$ & $2.28 \mathrm{E}-09$ & $3 \mathrm{E}-08^{c}$ \\
\hline Gross Beta & $\mu \mathrm{Ci} / \mathrm{mL}$ & 4 & 8.79E-09 & $1.73 \pm 0.38 \mathrm{E}-08$ & $2.36 \mathrm{E}-08$ & $1 \mathrm{E}-06^{d}$ \\
\hline Tritium & $\mu \mathrm{Ci} / \mathrm{mL}$ & 4 & $<4.64 \mathrm{E}-08$ & $4.18 \pm 4.71 \mathrm{E}-08$ & $1.14 \mathrm{E}-07$ & $2 \mathrm{E}-03$ \\
\hline Sr-90 & $\mu \mathrm{Ci} / \mathrm{mL}$ & 2 & $6.73 \mathrm{E}-09$ & $9.36 \pm 1.66 \mathrm{E}-09$ & $1.20 \mathrm{E}-08$ & $1 \mathrm{E}-06$ \\
\hline Cs-137 & $\mu \mathrm{Ci} / \mathrm{mL}$ & 2 & $<1.85 \mathrm{E}-09$ & $0.87 \pm 1.88 \mathrm{E}-09$ & $<1.90 \mathrm{E}-09$ & $3 \mathrm{E}-06$ \\
\hline $\mathrm{pH}$ & SU & 5 & 7.8 & 7.94 & 8.03 & $6.0-9.5$ \\
\hline
\end{tabular}

$\mathrm{N}$ - Number of samples

a DOE ingestion-based DCGs for $100 \mathrm{mrem} / \mathrm{yr}$ dose limit are provided as a guideline for radiological results.

$b$ New York State Water Quality Standards, Class “D” for surface waters as a standard for nonradiological results

c Alpha as Am-241

d Beta as Sr-90 
TABLE B-5E

2008 Radioactivity and pH in Surface Water at Franks Creek East of the SDA (WNFRC67)

\begin{tabular}{|c|c|c|c|c|c|c|}
\hline \multirow{2}{*}{ Analyte } & \multirow{2}{*}{ Units } & \multirow{2}{*}{$N$} & \multicolumn{3}{|c|}{ WNFRC67 Concentrations } & \multirow{2}{*}{$\begin{array}{c}\text { Reference } \\
\text { Guideline }^{a} \text { o } \\
\text { Standard }^{b}\end{array}$} \\
\hline & & & Minimum & Average & Maximum & \\
\hline Gross Alpha & $\mu \mathrm{Ci} / \mathrm{mL}$ & 4 & $<5.68 \mathrm{E}-10$ & $-0.13 \pm 9.50 \mathrm{E}-10$ & $<1.40 \mathrm{E}-09$ & $3 \mathrm{E}-08^{c}$ \\
\hline Gross Beta & $\mu \mathrm{Ci} / \mathrm{mL}$ & 4 & $1.40 \mathrm{E}-09$ & $2.09 \pm 1.46 \mathrm{E}-09$ & $2.93 \mathrm{E}-09$ & $1 \mathrm{E}-06^{d}$ \\
\hline Tritium & $\mu \mathrm{Ci} / \mathrm{mL}$ & 4 & $<3.34 \mathrm{E}-08$ & $1.05 \pm 0.45 E-07$ & $2.84 \mathrm{E}-07$ & $2 \mathrm{E}-03$ \\
\hline Sr-90 & $\mu \mathrm{Ci} / \mathrm{mL}$ & 2 & $6.82 \mathrm{E}-10$ & $9.61 \pm 7.34 \mathrm{E}-10$ & $1.24 \mathrm{E}-09$ & $1 \mathrm{E}-06$ \\
\hline Cs-137 & $\mu \mathrm{Ci} / \mathrm{mL}$ & 2 & $<2.00 \mathrm{E}-09$ & $-0.20 \pm 2.03 E-09$ & $<2.05 E-09$ & $3 \mathrm{E}-06$ \\
\hline $\mathrm{pH}$ & SU & 4 & 7.28 & 7.48 & 7.93 & $6.5-8.5$ \\
\hline
\end{tabular}

$\mathrm{N}$ - Number of samples

a DOE ingestion-based DCGs for $100 \mathrm{mrem} / \mathrm{yr}$ dose limit are provided as a guideline for radiological results in the absence of water quality standards.

b New York State Water Quality Standards for Class "C" surface waters as a comparative reference for nonradiological results.

c Alpha as Am-241

d Beta as Sr-90 
This page intentionally left blank 


\section{APPENDIX B-6}

\section{Potable Water (Drinking Water) Data}

TABLE B-6A

2008 Water Quality Results in Potable Water at the WVDP

\begin{tabular}{|l|c|c|c|c|c|}
\hline \multicolumn{1}{|c|}{ Analyte } & Units & $\boldsymbol{N}$ & WNDNKMP & \multicolumn{2}{c|}{ WNDNKEL $^{*}$ Standard $^{a}$} \\
\hline Gross Alpha & $\mu \mathrm{Ci} / \mathrm{mL}$ & 1 & $-7.10 \pm 6.51 \mathrm{E}-10$ & NA & $1.5 \mathrm{E}-08$ \\
\hline Gross Beta & $\mu \mathrm{Ci} / \mathrm{mL}$ & 1 & $1.12 \pm 0.82 \mathrm{E}-09$ & NA & $5 \mathrm{E}-08$ \\
\hline Tritium & $\mu \mathrm{Ci} / \mathrm{mL}$ & 1 & $6.11 \pm 3.26 \mathrm{E}-08$ & $\mathrm{NA}$ & $2 \mathrm{E}-05$ \\
\hline Haloacetic Acids-Five (5) & $\mathrm{mg} / \mathrm{L}$ & 1 & $\mathrm{NA}$ & 0.033 & 0.06 \\
\hline Total Trihalomethanes & $\mathrm{mg} / \mathrm{L}$ & 1 & $\mathrm{NA}$ & 0.058 & 0.08 \\
\hline
\end{tabular}

$\mathrm{N}$ - Number of samples

NA - Not applicable, constituent not analyzed

a New York State Department of Health MCLs for drinking water used as a comparative reference 
TABLE B-6B

2008 Water Quality Results in Utility Room Potable Water

\begin{tabular}{|c|c|c|c|c|c|}
\hline \multirow{2}{*}{ Analyte } & \multirow{2}{*}{ Units } & \multirow{2}{*}{$\mathbf{N}$} & \multicolumn{2}{|c|}{ Utility Room Concentrations } & \multirow{2}{*}{$\begin{array}{c}\text { Standard } \\
\text { or } \\
\text { Guideline }^{a}\end{array}$} \\
\hline & & & Minimum & Maximum & \\
\hline Antimony, Total & $\mathrm{mg} / \mathrm{L}$ & 1 & NA & $<0.0004$ & 0.006 \\
\hline Arsenic, Total & $\mathrm{mg} / \mathrm{L}$ & 1 & NA & $<0.001$ & 0.05 \\
\hline Barium, Total & $\mathrm{mg} / \mathrm{L}$ & 1 & NA & $<0.20$ & 2.00 \\
\hline Beryllium, Total & $\mathrm{mg} / \mathrm{L}$ & 1 & NA & $<0.0003$ & 0.004 \\
\hline Cadmium, Total & $\mathrm{mg} / \mathrm{L}$ & 1 & NA & $<0.001$ & 0.005 \\
\hline Chromium, Total & $\mathrm{mg} / \mathrm{L}$ & 1 & NA & $<0.007$ & 0.10 \\
\hline Cyanide, Total & $\mathrm{mg} / \mathrm{L}$ & 1 & NA & $<0.01$ & 0.2 \\
\hline Fluoride & $\mathrm{mg} / \mathrm{L}$ & 1 & NA & $<0.20$ & 2.2 \\
\hline Free Residual Chlorine & $\mathrm{mg} / \mathrm{L}$ & 1,098 & 0.47 & 2.20 & $0.2-4.0$ \\
\hline Iron, Total & $\mathrm{mg} / \mathrm{L}$ & 1 & NA & $<0.05$ & 0.3 \\
\hline Manganese, Total & $\mathrm{mg} / \mathrm{L}$ & 1 & NA & $<0.01$ & -- \\
\hline Mercury, Total & $\mathrm{mg} / \mathrm{L}$ & 1 & NA & $<0.0002$ & 0.002 \\
\hline Nickel, Total & $\mathrm{mg} / \mathrm{L}$ & 1 & NA & $<0.005$ & -- \\
\hline TOC & $\mathrm{mg} / \mathrm{L}$ & 10 & $<1.0$ & 1.9 & -- \\
\hline Selenium, Total & $\mathrm{mg} / \mathrm{L}$ & 1 & NA & $<0.002$ & 0.05 \\
\hline Thallium, Total & $\mathrm{mg} / \mathrm{L}$ & 1 & NA & $<0.0003$ & 0.0005 \\
\hline Turbidity & NTU & 2,195 & 0.1 & 0.9 & $1.0^{b}$ \\
\hline Zinc, Total & $\mathrm{mg} / \mathrm{L}$ & 1 & NA & $<0.01$ & -- \\
\hline
\end{tabular}

Note: Chemical constituent sampling is required by, and reported to, the Cattaraugus County Department of Health. $\mathrm{N}$ - Number of samples

NA - Not applicable, constituents sampled annually

-- No guideline or standard available for these analytes

a New York State Department of Health MCLs for drinking water or EPA MCLGs, whichever is more stringent.

${ }^{b}$ A treatment standard of 0.3 NTU applies to the 95th percentile on a monthly basis.

TABLE B-6C

2008 Water Quality Results in Utility Room Raw (Untreated) Water

\begin{tabular}{|c|c|c|c|c|c|}
\hline \multirow{2}{*}{ Analyte } & \multirow{2}{*}{ Units } & \multirow{2}{*}{$N$} & \multicolumn{3}{|c|}{ Untreated Raw Water Concentrations } \\
\hline & & & Minimum & Average & Maximum \\
\hline Alkalinity & $\mathrm{mg} / \mathrm{L}$ & 10 & 32.4 & 71.1 & 96.6 \\
\hline Iron, Total & $\mathrm{mg} / \mathrm{L}$ & 54 & 0.13 & 0.52 & 3.6 \\
\hline Solids, Total Dissolved & $\mathrm{mg} / \mathrm{L}$ & 21 & 76 & 117 & 142 \\
\hline TOC & $\mathrm{mg} / \mathrm{L}$ & 10 & 1.6 & 2.3 & 3.1 \\
\hline
\end{tabular}

Note: Chemical constituent sampling is required by, and reported to, the Cattaraugus County Department of Health. $\mathrm{N}$ - Number of samples 
TABLE B-6D

2008 Biological and Chlorine Results From Various Site Tap Water Locations (Analyzed by Cattaraugus County Health Department)

\begin{tabular}{|l|c|c|c|c|}
\hline \multicolumn{1}{|c|}{ Analyte } & Units & $\boldsymbol{N}$ & $\begin{array}{c}\text { Various Site Tap Water Locations } \\
\text { Results }\end{array}$ & Standard $^{a}$ \\
\hline E. coli & NA & 12 & Negative & one positive sample \\
\hline Free Residual Chlorine & mg/L & 12 & Range: $0.02-1.06$ & 4.0 (max) \\
\hline Total Coliform & NA & 12 & Negative & two or more positive samples \\
\hline
\end{tabular}

$\mathrm{N}$ - Number of samples

NA - Not applicable

a New York State Department of Health MCLs for drinking water or EPA MCLGs, whichever is more stringent

TABLE B-6E

2008 Nitrate Results From the Utility Room Raw Tap Water (Analyzed by Cattaraugus County Health Department)

\begin{tabular}{|c|c|c|c|c|c|}
\hline \multicolumn{1}{|c|}{ Analyte } & Units & $\mathbf{N}$ & Date Collected & Annual Concentration $^{\text {Standard }^{a}}$ \\
\hline Nitrate-N & $\mathrm{mg} / \mathrm{L}$ & 1 & $3 / 5 / 08$ & $<1.0$ & 10 \\
\hline
\end{tabular}

$\mathrm{N}$ - Number of samples

a New York State Department of Health MCLs for drinking water or EPA MCLGs, whichever is more stringent

TABLE B-6F

2008 Copper and Lead Results From On-Site Tap Water Locations at the WVDP

\begin{tabular}{|l|c|c|c|c|c|c|c|c|}
\hline \multicolumn{1}{|c|}{ Analyte } & Units & $\mathbf{N}$ & WNDNK01 & WNDNK06 & WNDNK10 & WNDNK13 & \multicolumn{2}{|c|}{ WNDNK15 $^{2}$ Standard $^{a}$} \\
\hline Copper, Total & $\mathrm{mg} / \mathrm{L}$ & 1 & 0.0073 & 0.262 & 0.0607 & 0.425 & 0.239 & 1.3 \\
\hline Lead, Total & $\mathrm{mg} / \mathrm{L}$ & 1 & 0.0029 & 0.0072 & $<0.001$ & 0.0013 & 0.0156 & $<0.015$ \\
\hline
\end{tabular}

$\mathrm{N}$ - Number of samples

a New York State Department of Health MCLs for drinking water used as a comparative reference 
This page intentionally left blank 


\section{APPENDIX C}

\section{Summary of Air Monitoring Data}

TABLE C-1

2008 Effluent Airborne Radioactivity at Main Stack (ANSTACK)

\begin{tabular}{|c|c|c|c|c|c|c|}
\hline Isotope $^{a}$ & $\mathbf{N}$ & $\begin{array}{c}\text { Total } \\
\text { Activity Released }^{b} \\
\text { (Ci) }\end{array}$ & $\begin{array}{c}\text { Average } \\
\text { Concentration } \\
(\mu \mathrm{Ci} / \mathrm{mL})\end{array}$ & $\begin{array}{c}\text { Maximum } \\
\text { Concentration } \\
(\mu \mathrm{Ci} / \mathrm{mL})\end{array}$ & $\begin{array}{c}D C G^{c} \\
(\mu C i / m L) \\
\end{array}$ & $\begin{array}{c}\text { Ratio of } \\
\text { Concentration } \\
\text { to DCG }\end{array}$ \\
\hline Gross Alpha & 26 & $4.61 \pm 0.56 \mathrm{E}-07$ & $6.20 \pm 0.75 \mathrm{E}-16$ & $1.47 \mathrm{E}-15$ & -- & -- \\
\hline Gross Beta & 26 & $1.24 \pm 0.02 \mathrm{E}-05$ & $1.67 \pm 0.03 \mathrm{E}-14$ & $8.28 \mathrm{E}-14$ & -- & -- \\
\hline $\mathrm{H}-3$ & 26 & $1.79 \pm 0.04 \mathrm{E}-03$ & $3.36 \pm 0.22 \mathrm{E}-14$ & $7.34 \mathrm{E}-12$ & $1 \mathrm{E}-07$ & $<0.00001$ \\
\hline Co-60 & 2 & $0.44 \pm 6.95 \mathrm{E}-08$ & $0.60 \pm 9.34 \mathrm{E}-17$ & $<1.42 \mathrm{E}-16$ & $8 \mathrm{E}-11$ & $<0.00001$ \\
\hline Sr-90 & 2 & $2.46 \pm 0.25 \mathrm{E}-06$ & $3.31 \pm 0.33 \mathrm{E}-15$ & $4.00 \mathrm{E}-15$ & $9 \mathrm{E}-12$ & 0.0003 \\
\hline I-129 & 2 & $2.10 \pm 0.12 \mathrm{E}-05$ & $2.83 \pm 0.17 \mathrm{E}-14$ & $3.53 \mathrm{E}-14$ & $7 \mathrm{E}-11$ & 0.0004 \\
\hline Cs-137 & 2 & $4.77 \pm 0.24 \mathrm{E}-06$ & $6.42 \pm 0.32 \mathrm{E}-15$ & $6.93 \mathrm{E}-15$ & $4 \mathrm{E}-10$ & $<0.0001$ \\
\hline Eu-154 & 2 & $-0.46 \pm 1.60 \mathrm{E}-07$ & $-0.62 \pm 2.15 \mathrm{E}-16$ & $<2.98 \mathrm{E}-16$ & $5 \mathrm{E}-11$ & $<0.0001$ \\
\hline $\mathrm{U}-232^{d}$ & 2 & $1.00 \pm 2.70 \mathrm{E}-09$ & $1.35 \pm 3.63 \mathrm{E}-18$ & $<5.30 \mathrm{E}-18$ & $2 \mathrm{E}-14$ & $<0.0002$ \\
\hline $\mathrm{U}-233 / 234^{d}$ & 2 & $1.68 \pm 0.59 \mathrm{E}-08$ & $2.26 \pm 0.78 \mathrm{E}-17$ & $2.34 \mathrm{E}-17$ & $9 \mathrm{E}-14$ & 0.0003 \\
\hline $\mathrm{U}-235 / 236^{d}$ & 2 & $3.11 \pm 2.64 \mathrm{E}-09$ & $4.18 \pm 3.55 \mathrm{E}-18$ & $<4.70 \mathrm{E}-18$ & $1 \mathrm{E}-13$ & $<0.0001$ \\
\hline $\mathrm{U}-238^{d}$ & 2 & $1.15 \pm 0.49 \mathrm{E}-08$ & $1.55 \pm 0.66 \mathrm{E}-17$ & $1.53 \mathrm{E}-17$ & $1 \mathrm{E}-13$ & 0.0002 \\
\hline Pu-238 & 2 & $4.39 \pm 1.22 \mathrm{E}-08$ & $5.90 \pm 1.64 \mathrm{E}-17$ & 5.97E-17 & $3 \mathrm{E}-14$ & 0.0020 \\
\hline Pu-239/240 & 2 & $1.15 \pm 0.19 \mathrm{E}-07$ & $1.54 \pm 0.26 \mathrm{E}-16$ & $1.47 \mathrm{E}-16$ & $2 \mathrm{E}-14$ & 0.0077 \\
\hline Am-241 & 2 & $2.58 \pm 0.35 \mathrm{E}-07$ & $3.46 \pm 0.47 \mathrm{E}-16$ & $3.51 \mathrm{E}-16$ & $2 \mathrm{E}-14$ & 0.0173 \\
\hline \multicolumn{6}{|l|}{ Sum of Ratios } & 0.028 \\
\hline
\end{tabular}

$\mathrm{N}$ - Number of samples

-- DCGs are not specified for gross alpha and beta activity.

a Half-lives are listed in Table UI-4.

$b$ Total volume released at $50,000 \mathrm{cfm}=7.44 \mathrm{E}+14 \mathrm{~mL} / \mathrm{year}$

c Derived concentration guides (DCGs) are listed for reference only. They are applicable to average concentrations at the site boundary but not to stack concentrations, as might be inferred from their inclusion in this table.

${ }^{d}$ Total Uranium: $3.78 \pm 0.09 \mathrm{E}-02 \mathrm{~g}$; average $=5.08 \mathrm{E} \pm 0.12 \mathrm{E}-11 \mu \mathrm{g} / \mathrm{mL}$ 
TABLE C-2

2008 Effluent Airborne Radioactivity at Vitrification System HVAC (ANVITSK)

\begin{tabular}{|c|c|c|c|c|c|}
\hline Isotope & $N$ & $\begin{array}{c}\text { Total } \\
\text { Activity Released } \\
\text { (Ci) }\end{array}$ & $\begin{array}{c}\text { Average } \\
\text { Concentration } \\
(\mu \mathrm{Ci} / \mathrm{mL})\end{array}$ & $\begin{array}{c}\text { Maximum } \\
\text { Concentration } \\
(\mu \mathrm{Ci} / \mathrm{mL})\end{array}$ & $\begin{array}{c}D C G^{a} \\
(\mu C i / m L)\end{array}$ \\
\hline Gross Alpha & 26 & $2.15 \pm 1.39 \mathrm{E}-08$ & $5.79 \pm 3.73 E-17$ & $3.34 \mathrm{E}-16$ & -- \\
\hline Gross Beta & 26 & $4.59 \pm 0.47 \mathrm{E}-07$ & $1.23 \pm 0.13 \mathrm{E}-15$ & $2.56 \mathrm{E}-15$ & -- \\
\hline Co-60 & 2 & $-1.11 \pm 1.56 \mathrm{E}-08$ & $-2.97 \pm 4.20 \mathrm{E}-17$ & $<5.92 \mathrm{E}-17$ & $8 \mathrm{E}-11$ \\
\hline Sr-90 & 2 & $-1.18 \pm 1.84 \mathrm{E}-08$ & $-3.18 \pm 4.93 \mathrm{E}-17$ & $<7.65 \mathrm{E}-17$ & $9 \mathrm{E}-12$ \\
\hline I-129 & 2 & $2.67 \pm 0.78 \mathrm{E}-07$ & $7.18 \pm 2.09 \mathrm{E}-16$ & $1.38 \mathrm{E}-15$ & $7 E-11$ \\
\hline Cs-137 & 2 & $-0.26 \pm 1.41 E-08$ & $-0.69 \pm 3.79 \mathrm{E}-17$ & $<5.64 \mathrm{E}-17$ & $4 \mathrm{E}-10$ \\
\hline Eu-154 & 2 & $-4.02 \pm 5.34 \mathrm{E}-08$ & $-1.08 \pm 1.44 \mathrm{E}-16$ & $<2.46 \mathrm{E}-16$ & $5 \mathrm{E}-11$ \\
\hline $\mathrm{U}-232^{b}$ & 2 & $-0.77 \pm 1.43 E-09$ & $-2.08 \pm 3.84 \mathrm{E}-18$ & $<6.10 \mathrm{E}-18$ & $2 \mathrm{E}-14$ \\
\hline $\mathrm{U}-233 / 234^{b}$ & 2 & $7.68 \pm 3.36 \mathrm{E}-09$ & $2.06 \pm 0.90 \mathrm{E}-17$ & $2.21 \mathrm{E}-17$ & $9 \mathrm{E}-14$ \\
\hline $\mathrm{U}-235 / 236^{b}$ & 2 & $0.81 \pm 1.25 \mathrm{E}-09$ & $2.17 \pm 3.35 \mathrm{E}-18$ & $<5.78 \mathrm{E}-18$ & $1 \mathrm{E}-13$ \\
\hline $\mathrm{U}-238^{b}$ & 2 & $9.93 \pm 3.74 \mathrm{E}-09$ & $2.67 \pm 1.01 \mathrm{E}-17$ & $2.87 \mathrm{E}-17$ & $1 \mathrm{E}-13$ \\
\hline Pu-238 & 2 & $0.35 \pm 1.48 \mathrm{E}-09$ & $0.95 \pm 3.98 \mathrm{E}-18$ & $<5.90 \mathrm{E}-18$ & $3 \mathrm{E}-14$ \\
\hline $\mathrm{Pu}-239 / 240$ & 2 & $1.64 \pm 1.70 \mathrm{E}-09$ & $4.41 \pm 4.58 \mathrm{E}-18$ & $<7.25 \mathrm{E}-18$ & $2 \mathrm{E}-14$ \\
\hline Am-241 & 2 & $-0.12 \pm 1.58 E-09$ & $-0.32 \pm 4.24 \mathrm{E}-18$ & $<6.62 \mathrm{E}-18$ & $2 \mathrm{E}-14$ \\
\hline
\end{tabular}

$\mathrm{N}$ - Number of samples

-- DCGs are not specified for gross alpha and beta activity.

a Derived concentration guides (DCGs) are listed for reference only. They are applicable to average concentrations at the site boundary but not to stack concentrations, as might be inferred from their inclusion in this table.

$b$ Total Uranium: $2.08 \pm 0.05 \mathrm{E}-02 \mathrm{~g}$; average $=5.58 \pm 0.14 \mathrm{E}-11 \mu \mathrm{g} / \mathrm{mL}$

TABLE C-3

2008 Effluent Airborne Radioactivity at 01-14 Building (ANCSSTK)

\begin{tabular}{|c|c|c|c|c|c|}
\hline Isotope & $N$ & $\begin{array}{c}\text { Total } \\
\text { Activity Released } \\
\text { (Ci) } \\
\end{array}$ & $\begin{array}{c}\text { Average } \\
\text { Concentration } \\
(\mu \mathrm{Ci} / \mathrm{mL})\end{array}$ & $\begin{array}{c}\text { Maximum } \\
\text { Concentration } \\
(\mu \mathrm{Ci} / \mathrm{mL})\end{array}$ & $\begin{array}{c}D C G^{a} \\
(\mu C i / m L)\end{array}$ \\
\hline Gross Alpha & 26 & $1.34 \pm 0.58 \mathrm{E}-08$ & $9.31 \pm 4.02 \mathrm{E}-17$ & $2.54 \mathrm{E}-16$ & -- \\
\hline Gross Beta & 26 & $1.35 \pm 0.18 \mathrm{E}-07$ & $9.35 \pm 1.26 \mathrm{E}-16$ & $2.32 \mathrm{E}-15$ & -- \\
\hline Co-60 & 2 & $0.44 \pm 6.67 \mathrm{E}-09$ & $0.31 \pm 4.62 \mathrm{E}-17$ & $<6.97 \mathrm{E}-17$ & $8 \mathrm{E}-11$ \\
\hline Sr-90 & 2 & $9.24 \pm 8.33 \mathrm{E}-09$ & $6.40 \pm 5.77 \mathrm{E}-17$ & $1.40 \mathrm{E}-16$ & $9 \mathrm{E}-12$ \\
\hline I-129 & 2 & $2.41 \pm 1.79 \mathrm{E}-08$ & $1.67 \pm 1.24 \mathrm{E}-16$ & $1.49 \mathrm{E}-16$ & $7 \mathrm{E}-11$ \\
\hline Cs-137 & 2 & $3.26 \pm 5.47 \mathrm{E}-09$ & $2.25 \pm 3.79 \mathrm{E}-17$ & $<5.48 \mathrm{E}-17$ & $4 \mathrm{E}-10$ \\
\hline Eu-154 & 2 & $0.30 \pm 1.83 \mathrm{E}-08$ & $0.21 \pm 1.27 \mathrm{E}-16$ & $<1.87 \mathrm{E}-16$ & $5 \mathrm{E}-11$ \\
\hline $\mathrm{U}-232^{b}$ & 2 & $-4.79 \pm 6.16 \mathrm{E}-10$ & $-3.32 \pm 4.27 \mathrm{E}-18$ & $<6.34 \mathrm{E}-18$ & $2 \mathrm{E}-14$ \\
\hline $\mathrm{U}-233 / 234^{b}$ & 2 & $4.91 \pm 1.88 \mathrm{E}-09$ & $3.40 \pm 1.30 \mathrm{E}-17$ & $4.98 \mathrm{E}-17$ & $9 \mathrm{E}-14$ \\
\hline $\mathrm{U}-235 / 236^{b}$ & 2 & $1.32 \pm 0.97 \mathrm{E}-09$ & $9.14 \pm 6.71 \mathrm{E}-18$ & $1.19 \mathrm{E}-17$ & $1 \mathrm{E}-13$ \\
\hline $\mathrm{U}-238^{b}$ & 2 & $3.01 \pm 1.36 \mathrm{E}-09$ & $2.08 \pm 9.39 \mathrm{E}-17$ & $2.38 \mathrm{E}-17$ & $1 \mathrm{E}-13$ \\
\hline Pu-238 & 2 & $-0.26 \pm 4.68 \mathrm{E}-10$ & $-0.18 \pm 3.24 \mathrm{E}-18$ & $<5.39 \mathrm{E}-18$ & $3 E-14$ \\
\hline $\mathrm{Pu}-239 / 240$ & 2 & $1.43 \pm 5.62 \mathrm{E}-10$ & $0.99 \pm 3.89 \mathrm{E}-18$ & $<5.59 \mathrm{E}-18$ & $2 \mathrm{E}-14$ \\
\hline Am-241 & 2 & $-1.72 \pm 4.67 \mathrm{E}-10$ & $-1.19 \pm 3.23 \mathrm{E}-18$ & $<6.04 \mathrm{E}-18$ & $2 \mathrm{E}-14$ \\
\hline
\end{tabular}

$\mathrm{N}$ - Number of samples

-- DCGs are not specified for gross alpha and beta activity.

a Derived concentration guides (DCGs) are listed for reference only. They are applicable to average concentrations at the site boundary but not to stack concentrations, as might be inferred from their inclusion in this table.

$b$ Total Uranium: $7.30 \pm 0.16 \mathrm{E}-03 \mathrm{~g}$; average $=5.06 \pm 0.11 \mathrm{E}-11 \mu \mathrm{g} / \mathrm{mL}$ 
TABLE C-4

2008 Effluent Airborne Radioactivity at Contact Size-Reduction Facility (ANCSRFK)

\section{Ventilation Off;}

System Did Not Operate During CY 2008

TABLE C-5

2008 Effluent Airborne Radioactivity at Supernatant Treatment System (ANSTSTK)

\begin{tabular}{|c|c|c|c|c|c|}
\hline Isotope & $N$ & $\begin{array}{c}\text { Total } \\
\text { Activity Released } \\
\text { (Ci) }\end{array}$ & $\begin{array}{c}\text { Average } \\
\text { Concentration } \\
(\mu \mathrm{Ci} / \mathrm{mL})\end{array}$ & $\begin{array}{c}\text { Maximum } \\
\text { Concentration } \\
(\mu \mathrm{Ci} / \mathrm{mL})\end{array}$ & $\begin{array}{c}D C G^{a} \\
(\mu \mathrm{Ci} / \mathrm{mL})\end{array}$ \\
\hline Gross Alpha & 26 & $2.64 \pm 2.69 \mathrm{E}-09$ & $3.94 \pm 4.01 \mathrm{E}-17$ & $4.93 \mathrm{E}-16$ & -- \\
\hline Gross Beta & 26 & $2.83 \pm 0.87 E-08$ & $4.22 \pm 1.30 \mathrm{E}-16$ & $1.79 \mathrm{E}-15$ & -- \\
\hline $\mathrm{H}-3$ & 26 & $4.16 \pm 5.33 \mathrm{E}-06$ & $6.21 \pm 7.96 \mathrm{E}-14$ & $3.99 E-13$ & $1 \mathrm{E}-07$ \\
\hline Co-60 & 2 & $-0.25 \pm 3.43 E-09$ & $-0.38 \pm 5.12 E-17$ & $<7.69 \mathrm{E}-17$ & $8 \mathrm{E}-11$ \\
\hline Sr-90 & 2 & $-2.68 \pm 4.06 \mathrm{E}-09$ & $-4.01 \pm 6.06 \mathrm{E}-17$ & $<8.06 \mathrm{E}-17$ & $9 \mathrm{E}-12$ \\
\hline $\mathrm{I}-129$ & 2 & $6.03 \pm 0.19 E-06$ & $9.01 \pm 0.29 E-14$ & $8.83 E-14$ & $7 E-11$ \\
\hline Cs-137 & 2 & $0.86 \pm 2.43 \mathrm{E}-09$ & $1.28 \pm 3.63 \mathrm{E}-17$ & $<5.15 \mathrm{E}-17$ & $4 \mathrm{E}-10$ \\
\hline Eu-154 & 2 & $-3.16 \pm 7.34 \mathrm{E}-09$ & $-0.47 \pm 1.10 \mathrm{E}-16$ & $<1.55 \mathrm{E}-16$ & $5 \mathrm{E}-11$ \\
\hline $\mathrm{U}-232^{b}$ & 2 & $0.15 \pm 2.38 \mathrm{E}-10$ & $0.22 \pm 3.55 \mathrm{E}-18$ & $<5.66 \mathrm{E}-18$ & $2 \mathrm{E}-14$ \\
\hline$U-233 / 234^{b}$ & 2 & $1.96 \pm 0.84 \mathrm{E}-09$ & $2.92 \pm 1.26 \mathrm{E}-17$ & $3.82 \mathrm{E}-17$ & $9 \mathrm{E}-14$ \\
\hline $\mathrm{U}-235 / 236^{b}$ & 2 & $4.02 \pm 4.57 \mathrm{E}-10$ & $6.00 \pm 6.83 \mathrm{E}-18$ & $1.09 \mathrm{E}-17$ & $1 \mathrm{E}-13$ \\
\hline$U-238^{b}$ & 2 & $7.16 \pm 4.12 \mathrm{E}-10$ & $1.07 \pm 0.62 \mathrm{E}-17$ & $1.34 \mathrm{E}-17$ & $1 \mathrm{E}-13$ \\
\hline $\mathrm{Pu}-238$ & 2 & $0.86 \pm 3.85 \mathrm{E}-10$ & $1.28 \pm 5.75 \mathrm{E}-18$ & $<7.13 \mathrm{E}-18$ & $3 E-14$ \\
\hline $\mathrm{Pu}-239 / 240$ & 2 & $2.69 \pm 4.11 \mathrm{E}-10$ & $4.02 \pm 6.14 \mathrm{E}-18$ & $<9.40 \mathrm{E}-18$ & $2 \mathrm{E}-14$ \\
\hline Am-241 & 2 & $0.07 \pm 2.78 \mathrm{E}-10$ & $0.11 \pm 4.16 \mathrm{E}-18$ & $<6.56 \mathrm{E}-18$ & $2 \mathrm{E}-14$ \\
\hline
\end{tabular}

$\mathrm{N}$ - Number of samples

-- DCGs are not specified for gross alpha and beta activity.

a Derived concentration guides (DCGs) are listed for reference only. They are applicable to average concentrations at the site boundary but not to stack concentrations, as might be inferred from their inclusion in this table.

$b$ Total Uranium: $3.93 \pm 0.09 \mathrm{E}-03 \mathrm{~g}$; average $=5.86 \pm 0.13 \mathrm{E}-11 \mu \mathrm{g} / \mathrm{mL}$ 
TABLE C-6

2008 Effluent Airborne Radioactivity at Container Sorting and Packaging Facility (ANCSPFK)

\begin{tabular}{|c|c|c|c|c|c|}
\hline Isotope & $N$ & $\begin{array}{c}\text { Total } \\
\text { Activity Released } \\
\text { (Ci) }\end{array}$ & $\begin{array}{c}\text { Average } \\
\text { Concentration } \\
(\mu \mathrm{Ci} / \mathrm{mL})\end{array}$ & $\begin{array}{c}\text { Maximum } \\
\text { Concentration } \\
(\mu \mathrm{Ci} / \mathrm{mL})\end{array}$ & $\begin{array}{c}D C G^{a} \\
(\mu C i / m L)\end{array}$ \\
\hline Gross Alpha & 26 & $1.91 \pm 0.76 \mathrm{E}-09$ & $1.09 \pm 0.44 \mathrm{E}-16$ & $6.37 \mathrm{E}-16$ & -- \\
\hline Gross Beta & 26 & $2.59 \pm 0.24 \mathrm{E}-08$ & $1.48 \pm 0.14 \mathrm{E}-15$ & $6.43 \mathrm{E}-15$ & -- \\
\hline Co-60 & 2 & $-7.73 \pm 7.81 \mathrm{E}-10$ & $-4.41 \pm 4.46 \mathrm{E}-17$ & $<6.43 \mathrm{E}-17$ & $8 \mathrm{E}-11$ \\
\hline Sr-90 & 2 & $6.68 \pm 9.42 \mathrm{E}-10$ & $3.81 \pm 5.38 \mathrm{E}-17$ & $3.54 \mathrm{E}-17$ & $9 \mathrm{E}-12$ \\
\hline I-129 & 2 & $1.14 \pm 0.07 \mathrm{E}-07$ & $6.51 \pm 0.38 \mathrm{E}-15$ & $6.75 \mathrm{E}-15$ & $7 \mathrm{E}-11$ \\
\hline Cs-137 & 2 & $8.53 \pm 6.44 \mathrm{E}-10$ & $4.87 \pm 3.68 \mathrm{E}-17$ & $7.45 \mathrm{E}-17$ & $4 \mathrm{E}-10$ \\
\hline Eu-154 & 2 & $-0.97 \pm 2.36 \mathrm{E}-09$ & $-0.55 \pm 1.35 \mathrm{E}-16$ & $<1.93 \mathrm{E}-16$ & $5 \mathrm{E}-11$ \\
\hline $\mathrm{U}-232^{b}$ & 2 & $4.79 \pm 8.06 \mathrm{E}-11$ & $-2.73 \pm 4.61 \mathrm{E}-18$ & $<7.19 \mathrm{E}-18$ & $2 \mathrm{E}-14$ \\
\hline$U-233 / 234^{b}$ & 2 & $3.11 \pm 1.50 \mathrm{E}-10$ & $1.78 \pm 0.86 \mathrm{E}-17$ & $1.90 \mathrm{E}-17$ & $9 E-14$ \\
\hline $\mathrm{U}-235 / 236^{b}$ & 2 & $1.60 \pm 5.35 \mathrm{E}-11$ & $0.92 \pm 3.06 \mathrm{E}-18$ & $<5.35 \mathrm{E}-18$ & $1 \mathrm{E}-13$ \\
\hline $\mathrm{U}-238^{b}$ & 2 & $4.26 \pm 1.76 \mathrm{E}-10$ & $2.43 \pm 1.00 \mathrm{E}-17$ & $2.93 \mathrm{E}-17$ & $1 \mathrm{E}-13$ \\
\hline $\mathrm{Pu}-238$ & 2 & $-4.68 \pm 7.55 \mathrm{E}-11$ & $-2.67 \pm 4.31 \mathrm{E}-18$ & $<6.55 \mathrm{E}-18$ & $3 E-14$ \\
\hline $\mathrm{Pu}-239 / 240$ & 2 & $6.56 \pm 7.59 \mathrm{E}-11$ & $3.75 \pm 4.34 \mathrm{E}-18$ & $7.39 \mathrm{E}-18$ & $2 \mathrm{E}-14$ \\
\hline Am-241 & 2 & $0.30 \pm 7.58 \mathrm{E}-11$ & $0.17 \pm 4.33 \mathrm{E}-18$ & $<6.56 \mathrm{E}-18$ & $2 \mathrm{E}-14$ \\
\hline
\end{tabular}

$\mathrm{N}$ - Number of samples

-- DCGs are not specified for gross alpha and beta activity.

a Derived concentration guides (DCGs) are listed for reference only. They are applicable to average concentrations at the site boundary but not to stack concentrations, as might be inferred from their inclusion in this table.

$b$ Total Uranium: $1.02 \pm 0.03 \mathrm{E}-03 \mathrm{~g}$; average $=5.85 \pm 0.15 \mathrm{E}-11 \mu \mathrm{g} / \mathrm{mL}$

\section{TABLE C-7}

\section{Effluent Airborne Radioactivity at Outdoor Ventilation Enclosures/Portable Ventilation Units (OVEs/PVUs)}

\begin{tabular}{|c|c|c|c|c|c|}
\hline Isotope & $N$ & $\begin{array}{c}\text { Total } \\
\text { Activity Released } \\
\text { (Ci) } \\
\end{array}$ & $\begin{array}{c}\text { Average } \\
\text { Concentration } \\
(\mu \mathrm{Ci} / \mathrm{mL})\end{array}$ & $\begin{array}{c}\text { Maximum } \\
\text { Concentration } \\
(\mu \mathrm{Ci} / \mathrm{mL})\end{array}$ & $\begin{array}{c}D_{C G}{ }^{a} \\
(\mu C i / m L)\end{array}$ \\
\hline Gross Alpha & 72 & $5.86 \pm 2.56 \mathrm{E}-09$ & $1.13 \pm 0.49 \mathrm{E}-16$ & $6.69 \mathrm{E}-15$ & -- \\
\hline Gross Beta & 72 & $1.06 \pm 0.08 \mathrm{E}-07$ & $2.05 \pm 0.16 \mathrm{E}-15$ & $2.15 E-14$ & -- \\
\hline Co-60 & 2 & $-3.14 \pm 2.38 \mathrm{E}-09$ & $-6.05 \pm 4.59 \mathrm{E}-17$ & $<6.26 \mathrm{E}-17$ & $8 \mathrm{E}-11$ \\
\hline Sr-90 & 2 & $-0.21 \pm 1.76 \mathrm{E}-09$ & $-0.41 \pm 3.40 \mathrm{E}-17$ & $<5.07 \mathrm{E}-17$ & $9 \mathrm{E}-12$ \\
\hline Cs-137 & 2 & $0.13 \pm 1.86 \mathrm{E}-09$ & $0.26 \pm 3.59 \mathrm{E}-17$ & $<5.04 \mathrm{E}-17$ & $4 \mathrm{E}-10$ \\
\hline Eu-154 & 2 & $3.62 \pm 6.02 \mathrm{E}-09$ & $0.70 \pm 1.16 \mathrm{E}-16$ & $<1.61 \mathrm{E}-16$ & $5 \mathrm{E}-11$ \\
\hline $\mathrm{U}-232^{b}$ & 2 & $0.54 \pm 2.93 \mathrm{E}-10$ & $1.03 \pm 5.66 \mathrm{E}-18$ & $<8.64 \mathrm{E}-18$ & $2 \mathrm{E}-14$ \\
\hline$U-233 / 234^{b}$ & 2 & $2.16 \pm 0.55 \mathrm{E}-09$ & $4.17 \pm 1.07 \mathrm{E}-17$ & $3.85 \mathrm{E}-17$ & $9 \mathrm{E}-14$ \\
\hline$U-235 / 236^{b}$ & 2 & $3.40 \pm 2.62 \mathrm{E}-10$ & $6.56 \pm 5.05 \mathrm{E}-18$ & $9.10 \mathrm{E}-18$ & $1 \mathrm{E}-13$ \\
\hline$U-238^{b}$ & 2 & $2.44 \pm 0.60 \mathrm{E}-09$ & $4.71 \pm 1.15 \mathrm{E}-17$ & $4.69 \mathrm{E}-17$ & $1 \mathrm{E}-13$ \\
\hline $\mathrm{Pu}-238$ & 2 & $0.18 \pm 1.64 \mathrm{E}-10$ & $0.35 \pm 3.17 \mathrm{E}-18$ & $<4.28 \mathrm{E}-18$ & $3 \mathrm{E}-14$ \\
\hline $\mathrm{Pu}-239 / 240$ & 2 & $1.20 \pm 1.77 \mathrm{E}-10$ & $2.31 \pm 3.41 \mathrm{E}-18$ & $<6.11 \mathrm{E}-18$ & $2 \mathrm{E}-14$ \\
\hline Am-241 & 2 & $-0.54 \pm 1.61 E-10$ & $-1.04 \pm 3.11 \mathrm{E}-18$ & $<5.44 \mathrm{E}-18$ & $2 \mathrm{E}-14$ \\
\hline
\end{tabular}

$\mathrm{N}$ - Number of samples

-- DCGs are not specified for gross alpha and beta activity.

a Derived concentration guides (DCGs) are listed for reference only. They are applicable to average concentrations at the site boundary but not to stack concentrations, as might be inferred from their inclusion in this table.

$b$ Total Uranium: $5.57 \pm 0.12 \mathrm{E}-03 \mathrm{~g}$; average $=1.07 \pm 0.02 \mathrm{E}-10 \mu \mathrm{g} / \mathrm{mL}$ 
TABLE C-8

2008 Effluent Airborne Radioactivity at Remote-Handled Waste Facility (ANRHWFK)

\begin{tabular}{|c|c|c|c|c|c|}
\hline Isotope & $N$ & $\begin{array}{c}\text { Total } \\
\text { Activity Released } \\
\text { (Ci) } \\
\end{array}$ & $\begin{array}{c}\text { Average } \\
\text { Concentration } \\
(\mu \mathrm{Ci} / \mathrm{mL})\end{array}$ & $\begin{array}{c}\text { Maximum } \\
\text { Concentration } \\
(\mu \mathrm{Ci} / \mathrm{mL})\end{array}$ & $\begin{array}{c}D C G^{a} \\
(\mu C i / m L) \\
\end{array}$ \\
\hline Gross Alpha & 26 & $5.72 \pm 7.64 \mathrm{E}-09$ & $4.76 \pm 6.34 \mathrm{E}-17$ & $<3.74 \mathrm{E}-16$ & -- \\
\hline Gross Beta & 26 & $1.14 \pm 0.25 \mathrm{E}-07$ & $9.45 \pm 2.09 \mathrm{E}-16$ & $1.88 \mathrm{E}-15$ & -- \\
\hline Co-60 & 2 & $-0.99 \pm 1.13 E-08$ & $-8.23 \pm 9.36 \mathrm{E}-17$ & $<8.47 \mathrm{E}-17$ & $8 \mathrm{E}-11$ \\
\hline Sr-90 & 2 & $0.56 \pm 1.31 \mathrm{E}-08$ & $0.47 \pm 1.09 E-16$ & $<1.05 \mathrm{E}-16$ & $9 \mathrm{E}-12$ \\
\hline I-129 & 2 & $5.30 \pm 3.04 \mathrm{E}-08$ & $4.40 \pm 2.53 \mathrm{E}-16$ & $7.98 \mathrm{E}-16$ & $7 \mathrm{E}-11$ \\
\hline Cs-137 & 2 & $2.52 \pm 9.03 \mathrm{E}-09$ & $2.09 \pm 7.51 \mathrm{E}-17$ & $<6.77 \mathrm{E}-17$ & $4 \mathrm{E}-10$ \\
\hline Eu-154 & 2 & $-1.12 \pm 3.09 \mathrm{E}-08$ & $-0.93 \pm 2.57 \mathrm{E}-16$ & $<2.44 \mathrm{E}-16$ & $5 E-11$ \\
\hline $\mathrm{U}-232^{b}$ & 2 & $-0.74 \pm 9.89 \mathrm{E}-10$ & $-0.61 \pm 8.22 E-18$ & $<7.55 \mathrm{E}-18$ & $2 \mathrm{E}-14$ \\
\hline$U-233 / 234^{b}$ & 2 & $4.70 \pm 2.09 \mathrm{E}-09$ & $3.90 \pm 1.74 \mathrm{E}-17$ & $2.60 \mathrm{E}-17$ & $9 E-14$ \\
\hline $\mathrm{U}-235 / 236^{b}$ & 2 & $3.18 \pm 7.92 \mathrm{E}-10$ & $2.65 \pm 6.50 \mathrm{E}-18$ & $4.49 \mathrm{E}-18$ & $1 \mathrm{E}-13$ \\
\hline $\mathrm{U}-238^{b}$ & 2 & $3.19 \pm 1.75 \mathrm{E}-09$ & $2.65 \pm 1.45 \mathrm{E}-17$ & $2.23 \mathrm{E}-17$ & $1 \mathrm{E}-13$ \\
\hline $\mathrm{Pu}-238$ & 2 & $6.00 \pm 7.40 \mathrm{E}-10$ & $4.98 \pm 6.15 E-18$ & $<5.81 \mathrm{E}-18$ & $3 E-14$ \\
\hline $\mathrm{Pu}-239 / 240$ & 2 & $3.84 \pm 7.02 \mathrm{E}-10$ & $3.19 \pm 5.83 E-18$ & $<5.64 \mathrm{E}-18$ & $2 E-14$ \\
\hline Am-241 & 2 & $-5.51 \pm 8.29 \mathrm{E}-10$ & $-4.58 \pm 6.89 \mathrm{E}-18$ & $<8.05 \mathrm{E}-18$ & $2 \mathrm{E}-14$ \\
\hline
\end{tabular}

$\mathrm{N}$ - Number of samples

-- DCGs are not specified for gross alpha and beta activity.

a Derived concentration guides (DCGs) are listed for reference only. They are applicable to average concentrations at the site boundary but not to stack concentrations, as might be inferred from their inclusion in this table.

$b$ Total Uranium: $1.15 \pm 0.03 \mathrm{E}-02 \mathrm{~g}$; average $=9.56 \pm 0.23 \mathrm{E}-11 \mu \mathrm{g} / \mathrm{mL}$

TABLE C-9

2008 Ambient Airborne Radioactivity at Background Great Valley Location (AFGRVAL)

\begin{tabular}{|c|c|c|c|}
\hline \multirow[t]{2}{*}{ Isotope } & \multirow[t]{2}{*}{$N$} & \multicolumn{2}{|c|}{$\begin{array}{c}\text { AFGRVAL } \\
\mu \mathrm{Ci} / \mathrm{mL}\end{array}$} \\
\hline & & Average & Maximum \\
\hline Gross Alpha & $25^{a}$ & $1.14 \pm 0.65 E-15$ & $1.99 \mathrm{E}-15$ \\
\hline Gross Beta & $25^{a}$ & $1.83 \pm 0.23 \mathrm{E}-14$ & $2.50 \mathrm{E}-14$ \\
\hline $\mathrm{K}-40$ & 2 & $3.57 \pm 2.61 \mathrm{E}-15$ & $3.66 \mathrm{E}-15$ \\
\hline Co-60 & 2 & $-0.20 \pm 1.05 E-16$ & $<1.11 \mathrm{E}-16$ \\
\hline Sr-90 & 2 & $0.45 \pm 1.40 \mathrm{E}-16$ & $<1.48 \mathrm{E}-16$ \\
\hline $1-129$ & 2 & $-0.49 \pm 1.54 \mathrm{E}-16$ & $<1.83 \mathrm{E}-16$ \\
\hline Cs-137 & 2 & $-2.03 \pm 8.80 \mathrm{E}-17$ & $<8.92 \mathrm{E}-17$ \\
\hline Eu-154 & 2 & $-0.80 \pm 2.88 \mathrm{E}-16$ & $<2.97 \mathrm{E}-16$ \\
\hline $\mathrm{U}-232^{b}$ & 2 & $-1.06 \pm 8.41 \mathrm{E}-18$ & $<1.06 \mathrm{E}-17$ \\
\hline$U-233 / 234^{b}$ & 2 & $5.11 \pm 2.88 \mathrm{E}-17$ & $7.30 \mathrm{E}-17$ \\
\hline$U-235 / 236^{b}$ & 2 & $3.23 \pm 8.19 \mathrm{E}-18$ & $<1.03 \mathrm{E}-17$ \\
\hline $\mathrm{U}-238^{b}$ & 2 & $2.54 \pm 1.97 \mathrm{E}-17$ & $3.13 E-17$ \\
\hline Pu-238 & 2 & $-4.90 \pm 7.87 \mathrm{E}-18$ & $<8.52 \mathrm{E}-18$ \\
\hline $\mathrm{Pu}-239 / 240$ & 2 & $-0.96 \pm 7.98 \mathrm{E}-18$ & $<8.29 \mathrm{E}-18$ \\
\hline Am-241 & 2 & $1.10 \pm 8.70 \mathrm{E}-18$ & $<1.19 \mathrm{E}-17$ \\
\hline
\end{tabular}

$\mathrm{N}$ - Number of samples

a One bi-weekly sample was not analyzed due to air sampler malfunction.

$b$ Total Uranium: AFGRVAL average $=1.02 \pm 0.04 \mathrm{E}-10 \mu \mathrm{g} / \mathrm{mL}$ 
This page intentionally left blank 


\section{APPENDIX D}

\section{Summary of Groundwater Monitoring Data}

\section{Groundwater Sampling Methodology}

Groundwater samples are collected from monitoring wells using either dedicated Teflon ${ }^{\circledR}$ well bailers or bladder pumps. Bailers are used in low-yield wells; bladder pumps are used in wells with good wateryielding characteristics. This sampling equipment is dedicated to an individual well to reduce the likelihood of sample contamination from external materials or cross contamination.

To ensure that only representative groundwater is sampled, three well volumes are removed (purged) from the well before the actual samples are collected. In low-yield wells, pumping or bailing to dryness provides sufficient purging. Conductivity and $\mathrm{pH}$ are measured before and after sampling to confirm the geochemical stability of the groundwater during sampling.

The bailer, a tube with a check valve at the bottom, is lowered slowly into the well to minimize agitation of the water column. The bailer containing the groundwater is then withdrawn from the well and emptied into a sample container. Bladder pumps use compressed air to gently squeeze a Teflon ${ }^{\circledR}$ bladder that prevents air contact with the groundwater as it is pumped into a sample container with a minimum of agitation and mixing. A check valve ensures that the water flows in only one direction.

Groundwater samples are cooled and preserved, with chemicals if required, to minimize chemical and/ or biological changes after sample collection. A strict chain-of-custody protocol is followed for all samples collected by the WVDP.

Historically the groundwater reporting year included samples from the fourth quarter of the previous year through the end of the third quarter of the reporting year. In an effort to align groundwater sampling data with the remainder of the calendar year environmental monitoring data in this report, the groundwater data presented in this summary reflects five quarters of sampling from the beginning of December 2007 through the end of December 2008.

\section{Key to bolding convention:}

Tables D- $1^{\text {ma }}$ through $D-7^{\text {m }}$ contain a bolding convention devised to help the reader, when viewing the data, to quickly see the range of detectable measurements within a data series. A data series is a set of chemical or radionuclide measurements (e.g., gross alpha, gross beta, tritium) from a single location or from similar locations. Note that some tables contain data that should not be technically evaluated under this convention.

Results for each analyte constitute a single data series. If a radiological result is larger than the uncertainty term, the measurement is considered positive. Otherwise, a result is considered nondetectable. Chemical results preceded by "less than" $(<)$ are considered nondetectable. The bolding convention is not applied to data series consisting of less than three values.

If all results in a data series are positive, the lowest and highest values are bolded.

If a data series contains some positive results, the highest value is bolded.

If all values in a data series are nondetectable, no values are bolded. 
TABLE D-1

2007/2008 Indicator Results From the Sand and Gravel Unit

\begin{tabular}{|c|c|c|c|c|c|c|c|}
\hline $\begin{array}{c}\text { Location } \\
\text { Code }\end{array}$ & $\begin{array}{l}\text { Hydraulic } \\
\text { Position }\end{array}$ & $\begin{array}{c}\text { Date } \\
\text { Collected }\end{array}$ & $\begin{array}{l}p H \\
S U\end{array}$ & $\begin{array}{c}\text { Conductivity } \\
\text { pmhos/cm@ } \\
25^{\circ} \mathrm{C}\end{array}$ & $\begin{array}{c}\text { Gross Alpha } \\
\mu \mathrm{Ci} / \mathrm{mL}\end{array}$ & $\begin{array}{c}\text { Gross Beta } \\
\mu \mathrm{Ci} / \mathrm{mL}\end{array}$ & $\begin{array}{l}\text { Tritium } \\
\mu \mathrm{Ci} / \mathrm{mL}\end{array}$ \\
\hline 301 & UP(1) & Dec-07 & 6.73 & 1046 & $-1.35 \pm 5.69 \mathrm{E}-09$ & $6.26 \pm 7.49 \mathrm{E}-09$ & $1.84 \pm 4.43 \mathrm{E}-08$ \\
\hline 301 & UP(2) & Mar-08 & 6.74 & 506 & $5.03 \pm 9.86 \mathrm{E}-10$ & $4.59 \pm 1.29 \mathrm{E}-09$ & $0.11 \pm 3.17 \mathrm{E}-08$ \\
\hline 301 & UP(3) & Jun-08 & 6.73 & 2083 & $0.96 \pm 1.17 \mathrm{E}-08$ & $3.95 \pm 4.92 E-09$ & $0.10 \pm 4.81 E-08$ \\
\hline 301 & UP(4) & Sep-08 & 6.72 & 2171 & $7.26 \pm 6.20 \mathrm{E}-09$ & $8.32 \pm 4.91 \mathrm{E}-09$ & $-0.77 \pm 4.61 \mathrm{E}-08$ \\
\hline 301 & $\mathrm{UP}(1)$ & Dec-08 & 6.92 & 1013 & $-0.84 \pm 5.11 \mathrm{E}-09$ & 8.60土3.31E-09 & $5.40 \pm 4.72 \mathrm{E}-08$ \\
\hline 302 & UP(1) & Dec-07 & 6.90 & 5842 & $2.23 \pm 2.65 \mathrm{E}-08$ & $0.56 \pm 1.44 \mathrm{E}-08$ & $3.11 \pm 4.43 \mathrm{E}-08$ \\
\hline 302 & UP(3) & Jun-08 & 6.75 & 5496 & $2.31 \pm 2.82 \mathrm{E}-08$ & $0.34 \pm 1.38 \mathrm{E}-08$ & $-2.46 \pm 4.81 \mathrm{E}-08$ \\
\hline 302 & UP(1) & Dec-08 & 7.02 & 5123 & $-0.35 \pm 2.16 \mathrm{E}-08$ & $1.14 \pm 1.14 \mathrm{E}-08$ & $0.37 \pm 4.68 \mathrm{E}-08$ \\
\hline 401 & UP(1) & Dec-07 & 6.70 & 3209 & $-0.20 \pm 1.41 \mathrm{E}-08$ & $-0.42 \pm 1.37 \mathrm{E}-08$ & $4.76 \pm 4.47 \mathrm{E}-08$ \\
\hline 401 & UP(2) & Mar-08 & 6.76 & 2301 & $4.58 \pm 4.62 \mathrm{E}-09$ & $1.00 \pm 0.52 \mathrm{E}-08$ & $7.66 \pm 4.61 \mathrm{E}-08$ \\
\hline 401 & UP(3) & Jun-08 & 6.76 & 3114 & $0.21 \pm 1.63 \mathrm{E}-08$ & $-0.90 \pm 9.59 E-09$ & $1.31 \pm 4.80 \mathrm{E}-08$ \\
\hline 401 & UP(4) & Sep-08 & 6.84 & 2778 & $8.81 \pm 7.05 E-09$ & $3.84 \pm 4.60 \mathrm{E}-09$ & $-2.20 \pm 4.53 \mathrm{E}-08$ \\
\hline 401 & UP(1) & Dec-08 & 7.03 & 2102 & $-2.59 \pm 9.35 E-09$ & $2.14 \pm 3.91 \mathrm{E}-09$ & $-0.90 \pm 4.62 \mathrm{E}-08$ \\
\hline 402 & UP(1) & Dec-07 & 7.19 & 4816 & $-0.71 \pm 1.98 \mathrm{E}-08$ & $-0.30 \pm 1.40 \mathrm{E}-08$ & $4.50 \pm 4.56 \mathrm{E}-08$ \\
\hline 402 & UP(3) & Jun-08 & 6.90 & 4860 & $-0.48 \pm 2.14 \mathrm{E}-08$ & $1.28 \pm 1.07 \mathrm{E}-08$ & $1.45 \pm 4.74 \mathrm{E}-08$ \\
\hline 402 & $\mathrm{UP}(1)$ & Dec-08 & 7.13 & 5126 & $0.58 \pm 2.22 \mathrm{E}-08$ & $1.34 \pm 1.11 \mathrm{E}-08$ & $-0.39 \pm 4.85 E-08$ \\
\hline 403 & UP(1) & Dec-07 & 6.82 & 1044 & $-1.91 \pm 2.67 \mathrm{E}-09$ & $3.39 \pm 4.98 \mathrm{E}-09$ & $2.06 \pm 4.45 \mathrm{E}-08$ \\
\hline 403 & UP(3) & Jun-08 & 7.32 & 1305 & $3.00 \pm 6.15 \mathrm{E}-09$ & $5.13 \pm 3.19 E-09$ & $1.93 \pm 3.29 E-08$ \\
\hline 403 & $\operatorname{UP}(1)$ & Dec-08 & 7.18 & 1074 & $-0.44 \pm 2.53 \mathrm{E}-09$ & $3.18 \pm 1.91 \mathrm{E}-09$ & 7.09 $\pm 4.79 \mathrm{E}-08$ \\
\hline 706 & $\mathrm{UP}(1)$ & Dec-07 & 6.80 & 749 & $-0.65 \pm 3.08 \mathrm{E}-09$ & $3.83 \pm 3.51 E-09$ & $-2.03 \pm 4.44 \mathrm{E}-08$ \\
\hline 706 & $\operatorname{UP}(2)$ & Mar-08 & 7.15 & 726 & $4.35 \pm 8.52 \mathrm{E}-10$ & $5.35 \pm 1.79 \mathrm{E}-09$ & $3.82 \pm 4.54 \mathrm{E}-08$ \\
\hline 706 & UP(3) & Jun-08 & 6.76 & 1250 & $-2.03 \pm 6.02 E-09$ & 7.14 $2.96 \mathrm{E}-09$ & $2.62 \pm 4.65 \mathrm{E}-08$ \\
\hline 706 & UP(4) & Sep-08 & 6.71 & 982 & $1.07 \pm 2.10 \mathrm{E}-09$ & $6.34 \pm 2.22 \mathrm{E}-09$ & $-2.48 \pm 4.51 \mathrm{E}-08$ \\
\hline 706 & UP(1) & Dec-08 & 6.79 & 746 & $-1.07 \pm 1.61 \mathrm{E}-09$ & 3.74 $2.33 E-09$ & $0.34 \pm 4.69 \mathrm{E}-08$ \\
\hline 1304 & UP(1) & Dec-07 & 6.97 & 2088 & $-0.47 \pm 6.74 \mathrm{E}-09$ & $4.16 \pm 6.96 \mathrm{E}-09$ & $1.07 \pm 4.50 \mathrm{E}-08$ \\
\hline 1304 & UP(2) & Mar-08 & 6.36 & 5532 & $3.81 \pm 7.46 \mathrm{E}-09$ & $1.36 \pm 0.59 \mathrm{E}-08$ & $6.12 \pm 4.59 \mathrm{E}-08$ \\
\hline 1304 & UP(3) & Jun-08 & 7.08 & 4503 & $1.52 \pm 1.86 \mathrm{E}-08$ & $0.56 \pm 1.10 \mathrm{E}-08$ & $-0.17 \pm 3.37 E-08$ \\
\hline 1304 & UP(4) & Sep-08 & 7.00 & 2419 & $0.61 \pm 4.32 \mathrm{E}-09$ & $4.06 \pm 4.18 \mathrm{E}-09$ & $3.54 \pm 4.62 \mathrm{E}-08$ \\
\hline 1304 & $U P(1)$ & Dec-08 & 7.20 & 2216 & $-8.21 \pm 5.94 \mathrm{E}-09$ & $1.68 \pm 4.68 \mathrm{E}-09$ & $3.66 \pm 4.78 \mathrm{E}-08$ \\
\hline NB1S & UP(1) & Dec-07 & 6.77 & 481 & $-0.09 \pm 1.32 \mathrm{E}-09$ & $1.80 \pm 1.78 \mathrm{E}-09$ & $-0.55 \pm 4.53 E-08$ \\
\hline 201 & DOWN(1) & Dec-07 & 6.34 & 2203 & $-3.91 \pm 5.47 \mathrm{E}-09$ & $2.15 \pm 1.06 \mathrm{E}-08$ & $8.73 \pm 4.56 \mathrm{E}-08$ \\
\hline 1302 & DOWN(1) & Dec-07 & 7.00 & 1097 & $4.88 \pm 4.42 \mathrm{E}-09$ & $5.34 \pm 5.49 \mathrm{E}-09$ & $3.85 \pm 4.46 \mathrm{E}-08$ \\
\hline 1302 & $\operatorname{DOWN}(1)$ & Dec-08 & 6.93 & 1111 & $-0.66 \pm 4.05 E-09$ & $-0.52 \pm 3.46 \mathrm{E}-09$ & $3.48 \pm 4.80 \mathrm{E}-08$ \\
\hline
\end{tabular}

Note: Bolding convention applied to these data. (See p. D- $1^{\text {tw }}$.)

Sample collection quarter is noted in parentheses next to hydraulic position. Hydraulic position is relative to other wells within the same hydrogeologic unit. 
TABLE D-1 (continued)

2007/2008 Indicator Results From the Sand and Gravel Unit

\begin{tabular}{|c|c|c|c|c|c|c|c|}
\hline $\begin{array}{l}\text { Location } \\
\text { Code }\end{array}$ & $\begin{array}{c}\text { Hydraulic } \\
\text { Position }\end{array}$ & $\begin{array}{c}\text { Date } \\
\text { Collected }\end{array}$ & $\begin{array}{l}p H \\
S U\end{array}$ & $\begin{array}{c}\text { Conductivity } \\
\text { umhos/cm@ } \\
25^{\circ} \mathrm{C}\end{array}$ & $\begin{array}{c}\text { Gross Alpha } \\
\mu C i / m L\end{array}$ & $\begin{array}{c}\text { Gross Beta } \\
\mu \mathrm{Ci} / \mathrm{mL}\end{array}$ & $\begin{array}{l}\text { Tritium } \\
\mu \mathrm{Ci} / \mathrm{mL}\end{array}$ \\
\hline 103 & DOWN(1) & Dec-07 & 8.13 & 4866 & $-4.44 \pm 9.05 E-09$ & $5.71 \pm 1.67 \mathrm{E}-08$ & $7.15 \pm 3.25 \mathrm{E}-08$ \\
\hline 103 & DOWN(2) & Mar-08 & 8.59 & 6706 & $1.15 \pm 1.06 \mathrm{E}-08$ & $1.12 \pm 0.15 \mathrm{E}-07$ & $5.89 \pm 4.85 \mathrm{E}-08$ \\
\hline 103 & DOWN(3) & Jun-08 & 7.89 & 6361 & $1.12 \pm 0.82 \mathrm{E}-08$ & $1.02 \pm 0.16 \mathrm{E}-07$ & $0.44 \pm 3.40 \mathrm{E}-08$ \\
\hline 103 & DOWN(4) & Sep-08 & 7.97 & 3284 & $0.74 \pm 5.25 \mathrm{E}-09$ & $3.49 \pm 0.66 \mathrm{E}-08$ & $-1.56 \pm 4.84 \mathrm{E}-08$ \\
\hline 103 & \begin{tabular}{|l|} 
DOWN(1) \\
\end{tabular} & Dec-08 & 8.47 & 2394 & $-0.41 \pm 1.22 \mathrm{E}-08$ & $2.45 \pm 0.64 \mathrm{E}-08$ & $0.36 \pm 4.74 \mathrm{E}-08$ \\
\hline \\
\hline 104 & DOWN(1) & Dec-07 & 7.01 & 2588 & $-4.53 \pm 5.23 \mathrm{E}-09$ & $9.24 \pm 0.22 \mathrm{E}-05$ & $2.37 \pm 0.48 \mathrm{E}-07$ \\
\hline 104 & DOWN(2) & Mar-08 & 7.07 & 2229 & $0.00 \pm 3.63 \mathrm{E}-09$ & $7.59 \pm 0.19 \mathrm{E}-05$ & $2.20 \pm 0.50 \mathrm{E}-07$ \\
\hline 104 & DOWN(3) & Jun-08 & 7.05 & 2380 & $0.00 \pm 5.28 \mathrm{E}-09$ & $9.10 \pm 0.20 \mathrm{E}-05$ & $1.97 \pm 0.51 \mathrm{E}-07$ \\
\hline 104 & DOWN(4) & Sep-08 & 7.00 & 2462 & $0.07 \pm 1.24 \mathrm{E}-08$ & $8.99 \pm 0.24 \mathrm{E}-05$ & $2.07 \pm 0.51 \mathrm{E}-07$ \\
\hline 104 & DOWN(1) & Dec-08 & 6.97 & 2394 & $3.68 \pm 4.25 \mathrm{E}-09$ & $7.65 \pm 0.18 \mathrm{E}-05$ & $2.13 \pm 0.51 \mathrm{E}-07$ \\
\hline \\
\hline 111 & DOWN(1) & Dec-07 & 6.42 & 503 & $-0.13 \pm 1.18 \mathrm{E}-09$ & $2.10 \pm 0.07 E-06$ & $5.77 \pm 4.58 \mathrm{E}-08$ \\
\hline 111 & DOWN(2) & Mar-08 & 6.55 & 606 & $2.82 \pm 1.69 \mathrm{E}-09$ & $3.74 \pm 0.11 \mathrm{E}-06$ & $1.52 \pm 0.49 \mathrm{E}-07$ \\
\hline 111 & DOWN(3) & Jun-08 & 6.75 & 797 & $8.39 \pm 3.56 \mathrm{E}-09$ & $5.65 \pm 0.16 \mathrm{E}-06$ & $1.05 \pm 0.49 \mathrm{E}-07$ \\
\hline 111 & DOWN(4) & Sep-08 & 6.52 & 1063 & $4.81 \pm 6.53 \mathrm{E}-09$ & $7.73 \pm 0.21 E-06$ & $1.01 \pm 0.49 \mathrm{E}-07$ \\
\hline 111 & \begin{tabular}{|l|} 
DOWN(1) \\
\end{tabular} & Dec-08 & 6.40 & 842 & $5.97 \pm 2.28 \mathrm{E}-09$ & $5.39 \pm 0.14 \mathrm{E}-06$ & $7.78 \pm 4.79 \mathrm{E}-08$ \\
\hline \\
\hline 205 & DOWN(1) & Dec-07 & 7.04 & 3602 & $-0.77 \pm 1.39 \mathrm{E}-08$ & $0.82 \pm 1.47 \mathrm{E}-08$ & $-1.07 \pm 4.42 \mathrm{E}-08$ \\
\hline 205 & DOWN(3) & Jun-08 & 7.12 & 4210 & $0.74 \pm 1.71 \mathrm{E}-08$ & $5.90 \pm 8.96 \mathrm{E}-09$ & $-7.27 \pm 4.64 \mathrm{E}-08$ \\
\hline 205 & DOWN(1) & Dec-08 & 7.22 & 2636 & $-0.94 \pm 1.36 \mathrm{E}-08$ & $1.20 \pm 0.62 \mathrm{E}-08$ & $1.51 \pm 4.67 \mathrm{E}-08$ \\
\hline 406 & DOWN(1) & Dec-07 & 6.63 & 1479 & $4.49 \pm 3.45 \mathrm{E}-09$ & $7.47 \pm 2.98 \mathrm{E}-09$ & $3.56 \pm 3.21 \mathrm{E}-08$ \\
\hline 406 & DOWN(2) & Mar-08 & 6.68 & 1716 & $0.00 \pm 1.70 \mathrm{E}-09$ & $4.10 \pm 2.65 \mathrm{E}-09$ & $1.13 \pm 4.78 \mathrm{E}-08$ \\
\hline 406 & $\operatorname{DOWN}(3)$ & Jun-08 & 6.94 & 1036 & $4.01 \pm 2.28 \mathrm{E}-09$ & $5.06 \pm 2.17 \mathrm{E}-09$ & $4.86 \pm 4.85 \mathrm{E}-08$ \\
\hline 406 & DOWN(4) & Sep-08 & 6.90 & 886 & $0.00 \pm 1.79 \mathrm{E}-09$ & $6.96 \pm 3.87 \mathrm{E}-09$ & $0.78 \pm 4.88 \mathrm{E}-08$ \\
\hline 406 & DOWN(1) & Dec-08 & 7.14 & 1050 & $-1.48 \pm 2.41 \mathrm{E}-09$ & $7.16 \pm 3.08 \mathrm{E}-09$ & $1.85 \pm 4.90 \mathrm{E}-08$ \\
\hline 408 & DOV & Dec-07 & 7.29 & & $.24 \mathrm{E}-07$ & $E-04$ & $1.02 \pm 0.98 \mathrm{E}-07$ \\
\hline 408 & DOWN(2) & Mar-08 & 7.11 & 3240 & $0.93 \pm 3.88 \mathrm{E}-09$ & $2.91 \pm 0.01 \mathrm{E}-04$ & $0.22 \pm 1.08 \mathrm{E}-07$ \\
\hline 408 & DOWN(3) & Jun-08 & 6.88 & 4042 & $5.21 \pm 8.90 \mathrm{E}-09$ & $4.26 \pm 0.10 \mathrm{E}-04$ & $7.92 \pm 4.82 \mathrm{E}-08$ \\
\hline 408 & DOWN(4) & Sep-08 & 7.19 & 3574 & $-0.49 \pm 2.11 \mathrm{E}-08$ & $2.28 \pm 0.07 E-04$ & $4.48 \pm 4.78 \mathrm{E}-08$ \\
\hline 408 & DOWN(1) & Dec-08 & 7.21 & 3644 & $1.78 \pm 3.49 \mathrm{E}-09$ & $3.17 \pm 0.05 \mathrm{E}-04$ & $5.13 \pm 4.77 \mathrm{E}-08$ \\
\hline 501 & DOWN(1) & Dec-07 & 7.44 & 2822 & $-3.43 \pm 5.86 \mathrm{E}-09$ & $1.45 \pm 0.04 \mathrm{E}-04$ & $1.40 \pm 0.47 \mathrm{E}-07$ \\
\hline 501 & $\operatorname{DOWN}(2)$ & Mar-08 & 7.43 & 2255 & $4.77 \pm 5.17 \mathrm{E}-09$ & $1.00 \pm 0.02 E-04$ & $7.99 \pm 4.82 \mathrm{E}-08$ \\
\hline 501 & DOWN(3) & Jun-08 & 7.36 & 2952 & $1.51 \pm 5.92 \mathrm{E}-09$ & $1.49 \pm 0.03 E-04$ & $5.26 \pm 4.79 \mathrm{E}-08$ \\
\hline 501 & DOWN(4) & Sep-08 & 7.37 & 2806 & $-0.28 \pm 1.13 \mathrm{E}-08$ & $1.33 \pm 0.02 \mathrm{E}-04$ & $4.84 \pm 4.83 \mathrm{E}-08$ \\
\hline 501 & DOWN(1) & Dec-08 & 7.39 & 2746 & $4.00 \pm 5.22 \mathrm{E}-09$ & $1.19 \pm 0.03 \mathrm{E}-04$ & $9.96 \pm 4.85 \mathrm{E}-08$ \\
\hline
\end{tabular}

Note: Bolding convention applied to these data. (See p. D-1 ${ }^{\text {m. }}$.)

Sample collection quarter is noted in parentheses next to hydraulic position. Hydraulic position is relative to other wells within the same hydrogeologic unit. 
TABLE D-1 (continued)

2007/2008 Indicator Results From the Sand and Gravel Unit

\begin{tabular}{|c|c|c|c|c|c|c|c|}
\hline $\begin{array}{c}\text { Location } \\
\text { Code }\end{array}$ & $\begin{array}{l}\text { Hydraulic } \\
\text { Position }\end{array}$ & $\begin{array}{c}\text { Date } \\
\text { Collected }\end{array}$ & $\begin{array}{l}p H \\
S U\end{array}$ & $\begin{array}{c}\text { Conductivity } \\
\mu m h o s / c m @ \\
25^{\circ} \mathrm{C}\end{array}$ & $\begin{array}{c}\text { Gross Alpha } \\
\mu \mathrm{Ci} / \mathrm{mL}\end{array}$ & $\begin{array}{c}\text { Gross Beta } \\
\mu \mathrm{Ci} / \mathrm{mL}\end{array}$ & $\begin{array}{l}\text { Tritium } \\
\mu \mathrm{Ci} / \mathrm{mL}\end{array}$ \\
\hline 502 & $\operatorname{DOWN}(1)$ & Dec-07 & 7.43 & 2759 & $-5.40 \pm 5.29 E-09$ & $1.42 \pm 0.03 \mathrm{E}-04$ & $1.32 \pm 0.47 E-07$ \\
\hline 502 & $\operatorname{DOWN}(2)$ & Mar-08 & 7.41 & 2414 & $3.23 \pm 4.56 \mathrm{E}-09$ & $1.40 \pm 0.03 E-04$ & $1.08 \pm 0.49 \mathrm{E}-07$ \\
\hline 502 & $\operatorname{DOWN}(3)$ & Jun-08 & 7.31 & 2700 & $2.97 \pm 6.30 \mathrm{E}-09$ & $1.45 \pm 0.03 E-04$ & $2.91 \pm 4.77 E-08$ \\
\hline 502 & $\operatorname{DOWN}(4)$ & Sep-08 & 7.35 & 2696 & $-0.58 \pm 1.95 E-08$ & $1.53 \pm 0.04 \mathrm{E}-04$ & $0.94 \pm 4.79 \mathrm{E}-08$ \\
\hline 502 & DOWN(1) & Dec-08 & 7.37 & 2719 & $5.08 \pm 4.83 \mathrm{E}-09$ & $1.39 \pm 0.03 \mathrm{E}-04$ & $1.17 \pm 0.49 \mathrm{E}-07$ \\
\hline $602 \mathrm{~A}$ & $\operatorname{DOWN}(1)$ & Dec-07 & 7.04 & 736 & $1.41 \pm 2.73 \mathrm{E}-09$ & $1.14 \pm 0.34 \mathrm{E}-08$ & $1.43 \pm 0.47 \mathrm{E}-07$ \\
\hline $602 \mathrm{~A}$ & $\operatorname{DOWN}(3)$ & Jun-08 & 6.91 & 927 & $1.50 \pm 1.40 \mathrm{E}-09$ & 8.62 $23.34 \mathrm{E}-09$ & $9.86 \pm 4.94 \mathrm{E}-08$ \\
\hline $602 \mathrm{~A}$ & $\operatorname{DOWN}(1)$ & Dec-08 & 6.86 & 790 & $-1.91 \pm 1.70 \mathrm{E}-09$ & $1.90 \pm 0.28 \mathrm{E}-08$ & $1.54 \pm 0.51 \mathrm{E}-07$ \\
\hline 604 & $\operatorname{DOWN}(1)$ & Dec-07 & 6.10 & 1712 & $-2.10 \pm 4.74 \mathrm{E}-09$ & $6.02 \pm 4.87 \mathrm{E}-09$ & $1.76 \pm 4.50 \mathrm{E}-08$ \\
\hline 604 & $\operatorname{DOWN}(3)$ & Jun-08 & 6.42 & 1346 & $3.82 \pm 6.23 \mathrm{E}-09$ & $7.32 \pm 3.16 \mathrm{E}-09$ & $-3.58 \pm 4.72 E-08$ \\
\hline 604 & $\operatorname{DOWN}(1)$ & Dec-08 & 6.31 & 1794 & $-0.38 \pm 5.01 E-09$ & $1.03 \pm 0.27 \mathrm{E}-08$ & $4.29 \pm 4.76 \mathrm{E}-08$ \\
\hline 8605 & DOWN(1) & Dec-07 & 6.95 & 1204 & $4.35 \pm 3.99 \mathrm{E}-09$ & $8.20 \pm 0.20 \mathrm{E}-06$ & $1.48 \pm 0.34 \mathrm{E}-07$ \\
\hline 8605 & $\operatorname{DOWN}(2)$ & Mar-08 & 6.65 & 788 & $8.65 \pm 3.29 E-09$ & $8.61 \pm 0.22 \mathrm{E}-06$ & $1.97 \pm 0.50 \mathrm{E}-07$ \\
\hline 8605 & $\operatorname{DOWN}(3)$ & Jun-08 & 6.92 & 1376 & $1.05 \pm 0.60 \mathrm{E}-08$ & $9.42 \pm 0.25 \mathrm{E}-06$ & $1.09 \pm 0.50 \mathrm{E}-07$ \\
\hline 8605 & DOWN(4) & Sep-08 & 6.86 & 2309 & $0.37 \pm 1.12 \mathrm{E}-08$ & $7.08 \pm 0.21 E-06$ & $6.15 \pm 4.88 \mathrm{E}-08$ \\
\hline 8605 & $\operatorname{DOWN}(1)$ & Dec-08 & 6.96 & 1696 & $1.86 \pm 0.59 \mathrm{E}-08$ & $9.36 \pm 0.24 \mathrm{E}-06$ & $1.36 \pm 0.49 \mathrm{E}-07$ \\
\hline 8607 & $\operatorname{DOWN}(1)$ & Dec-07 & 6.31 & 1068 & $9.45 \pm 5.63 E-09$ & $1.60 \pm 0.58 \mathrm{E}-08$ & $5.30 \pm 4.47 \mathrm{E}-08$ \\
\hline 8607 & $\operatorname{DOWN}(2)$ & Mar-08 & 6.16 & 1285 & $-0.60 \pm 1.18 \mathrm{E}-09$ & $2.37 \pm 0.29 E-08$ & $-2.15 \pm 4.45 E-08$ \\
\hline 8607 & $\operatorname{DOWN}(3)$ & Jun-08 & 6.70 & 1811 & $-0.28 \pm 1.01 E-08$ & $1.32 \pm 0.56 \mathrm{E}-08$ & $2.19 \pm 4.79 \mathrm{E}-08$ \\
\hline 8607 & DOWN(4) & Sep-08 & 6.64 & 1767 & $0.00 \pm 3.32 \mathrm{E}-09$ & $1.71 \pm 0.45 \mathrm{E}-08$ & $-0.51 \pm 4.55 \mathrm{E}-08$ \\
\hline 8607 & $\operatorname{DOWN}(1)$ & Dec-08 & 6.70 & 993 & $-2.62 \pm 6.68 \mathrm{E}-09$ & $1.62 \pm 0.41 \mathrm{E}-08$ & $2.35 \pm 4.69 \mathrm{E}-08$ \\
\hline 8609 & $\operatorname{DOWN}(1)$ & Dec-07 & 6.98 & 2306 & $-1.90 \pm 5.68 \mathrm{E}-09$ & $1.77 \pm 0.06 \mathrm{E}-06$ & $2.52 \pm 0.49 \mathrm{E}-07$ \\
\hline 8609 & $\operatorname{DOWN}(2)$ & Mar-08 & 6.93 & 2236 & $2.14 \pm 4.63 E-09$ & $1.64 \pm 0.06 \mathrm{E}-06$ & $2.57 \pm 0.51 E-07$ \\
\hline 8609 & $\operatorname{DOWN}(3)$ & Jun-08 & 6.89 & 2304 & $0.60 \pm 4.58 \mathrm{E}-09$ & $1.63 \pm 0.07 \mathrm{E}-06$ & $1.56 \pm 0.51 \mathrm{E}-07$ \\
\hline 8609 & $\operatorname{DOWN}(4)$ & Sep-08 & 6.99 & 2338 & $0.57 \pm 1.73 \mathrm{E}-08$ & $2.37 \pm 0.09 E-06$ & $2.40 \pm 0.51 \mathrm{E}-07$ \\
\hline 8609 & $\operatorname{DOWN}(1)$ & Dec-08 & 6.98 & 2237 & $-0.61 \pm 3.60 \mathrm{E}-09$ & $1.30 \pm 0.06 \mathrm{E}-06$ & $1.64 \pm 0.50 \mathrm{E}-07$ \\
\hline 105 & $\operatorname{DOWN}(1)$ & Dec-07 & 7.22 & 2697 & $-2.70 \pm 5.92 \mathrm{E}-09$ & $1.02 \pm 0.02 E-04$ & $2.44 \pm 0.48 \mathrm{E}-07$ \\
\hline 105 & $\operatorname{DOWN}(2)$ & Mar-08 & 7.14 & 2426 & $0.00 \pm 4.05 E-09$ & $9.19 \pm 0.23 E-05$ & $2.25 \pm 0.51 \mathrm{E}-07$ \\
\hline 105 & $\operatorname{DOWN}(3)$ & Jun-08 & 7.39 & 2557 & $1.00 \pm 7.61 \mathrm{E}-09$ & $9.01 \pm 0.21 \mathrm{E}-05$ & $1.98 \pm 0.51 \mathrm{E}-07$ \\
\hline 105 & $\operatorname{DOWN}(4)$ & Sep-08 & 7.16 & 1574 & $0.83 \pm 1.71 \mathrm{E}-08$ & $8.71 \pm 0.25 E-05$ & $1.60 \pm 0.50 \mathrm{E}-07$ \\
\hline 105 & $\operatorname{DOWN}(1)$ & Dec-08 & 7.24 & 2752 & $3.11 \pm 5.70 \mathrm{E}-09$ & $9.64 \pm 0.24 \mathrm{E}-05$ & $1.76 \pm 0.50 \mathrm{E}-07$ \\
\hline
\end{tabular}

Note: Bolding convention applied to these data. (See p. D- $1^{\text {[x. }}$.)

Sample collection quarter is noted in parentheses next to hydraulic position. Hydraulic position is relative to other wells within the same hydrogeologic unit. 
TABLE D-1 (continued)

2007/2008 Indicator Results From the Sand and Gravel Unit

\begin{tabular}{|c|c|c|c|c|c|c|c|}
\hline $\begin{array}{c}\text { Location } \\
\text { Code }\end{array}$ & $\begin{array}{c}\text { Hydraulic } \\
\text { Position }\end{array}$ & $\begin{array}{c}\text { Date } \\
\text { Collected }\end{array}$ & $\begin{array}{l}p H \\
s U\end{array}$ & \begin{tabular}{|c|} 
Conductivity \\
$\mu m h o s / c m @ ~$ \\
$25^{\circ} \mathrm{C}$
\end{tabular} & $\begin{array}{c}\text { Gross Alpha } \\
\mu \mathrm{Ci} / \mathrm{mL}\end{array}$ & $\begin{array}{c}\text { Gross Beta } \\
\mu \mathrm{Ci} / \mathrm{mL}\end{array}$ & $\begin{array}{l}\text { Tritium } \\
\mu \mathrm{Ci} / \mathrm{mL}\end{array}$ \\
\hline 106 & DOWN(1) & Dec-07 & 6.72 & 2068 & $5.45 \pm 7.56 \mathrm{E}-09$ & $5.76 \pm 0.21 \mathrm{E}-07$ & $8.02 \pm 0.56 E-07$ \\
\hline 106 & $\operatorname{DOWN}(2)$ & Mar-08 & 7.03 & 2144 & $2.45 \pm 3.19 \mathrm{E}-09$ & $1.04 \pm 0.05 \mathrm{E}-06$ & $5.24 \pm 0.55 E-07$ \\
\hline 106 & DOWN(3) & Jun-08 & 7.20 & 2098 & $-1.33 \pm 4.53 \mathrm{E}-09$ & $1.02 \pm 0.05 \mathrm{E}-06$ & $5.59 \pm 0.56 \mathrm{E}-07$ \\
\hline 106 & DOWN(4) & Sep-08 & 6.87 & 1442 & $-5.73 \pm 8.48 \mathrm{E}-09$ & $9.64 \pm 0.48 \mathrm{E}-07$ & $5.64 \pm 0.40 \mathrm{E}-07$ \\
\hline 106 & DOWN(1) & Dec-08 & 6.82 & 2287 & $4.62 \pm 4.39 \mathrm{E}-09$ & $1.53 \pm 0.06 \mathrm{E}-06$ & $6.33 \pm 0.57 \mathrm{E}-07$ \\
\hline 116 & DOWN(1) & Dec-07 & 6.98 & 2233 & $-2.70 \pm 4.57 \mathrm{E}-09$ & $8.97 \pm 0.20 \mathrm{E}-06$ & $1.54 \pm 0.47 \mathrm{E}-07$ \\
\hline 116 & DOWN(3) & Jun-08 & 7.35 & 2320 & $2.15 \pm 5.80 \mathrm{E}-09$ & $1.10 \pm 0.03 \mathrm{E}-05$ & $1.17 \pm 0.50 \mathrm{E}-07$ \\
\hline 116 & DOWN(1) & Dec-08 & 7.07 & 2206 & $-1.53 \pm 2.64 \mathrm{E}-09$ & $1.12 \pm 0.03 \mathrm{E}-05$ & $1.36 \pm 0.49 \mathrm{E}-07$ \\
\hline 605 & DOWN(1) & Dec-07 & 7.04 & 742 & $-1.51 \pm 2.51 \mathrm{E}-09$ & $2.66 \pm 0.64 \mathrm{E}-08$ & $2.54 \pm 4.48 \mathrm{E}-08$ \\
\hline 605 & DOWN(3) & Jun-08 & 6.97 & 1069 & $0.78 \pm 1.35 \mathrm{E}-09$ & $2.45 \pm 0.34 \mathrm{E}-08$ & $-4.11 \pm 4.70 \mathrm{E}-08$ \\
\hline 605 & DOWN(1) & Dec-08 & 6.94 & 693 & $-1.15 \pm 3.45 \mathrm{E}-09$ & $2.42 \pm 0.61 \mathrm{E}-08$ & $2.53 \pm 4.82 \mathrm{E}-08$ \\
\hline 801 & DOWN(1) & Dec-07 & 6.75 & 1384 & $-0.61 \pm 2.79 \mathrm{E}-09$ & $1.17 \pm 0.03 \mathrm{E}-05$ & $9.42 \pm 4.62 \mathrm{E}-08$ \\
\hline 801 & $\operatorname{DOWN}(2)$ & Mar-08 & 7.03 & 1240 & $-0.81 \pm 1.94 \mathrm{E}-09$ & $1.27 \pm 0.03 \mathrm{E}-05$ & $7.25 \pm 4.84 \mathrm{E}-08$ \\
\hline 801 & DOWN(3) & Jun-08 & 7.00 & 1628 & $-0.95 \pm 3.31 \mathrm{E}-09$ & $1.29 \pm 0.03 E-05$ & $5.80 \pm 4.88 \mathrm{E}-08$ \\
\hline 801 & DOWN(4) & Sep-08 & 6.69 & 1596 & $4.62 \pm 7.86 \mathrm{E}-09$ & $1.07 \pm 0.03 \mathrm{E}-05$ & $4.24 \pm 4.79 \mathrm{E}-08$ \\
\hline 801 & DOWN(1) & Dec-08 & 6.80 & 1045 & $0.22 \pm 1.44 \mathrm{E}-09$ & $7.75 \pm 0.20 \mathrm{E}-06$ & $9.89 \pm 4.85 \mathrm{E}-08$ \\
\hline 802 & DOWN(1) & Dec-07 & 6.50 & 484 & $1.48 \pm 2.48 \mathrm{E}-09$ & $8.40 \pm 0.57 \mathrm{E}-08$ & $1.43 \pm 0.46 E-07$ \\
\hline 802 & DOWN(2) & Mar-08 & 7.76 & 174 & $1.55 \pm 1.34 \mathrm{E}-09$ & $2.78 \pm 0.33 \mathrm{E}-08$ & $2.90 \pm 3.22 \mathrm{E}-08$ \\
\hline 802 & DOWN(3) & Jun-08 & 6.91 & 406 & $8.75 \pm 5.48 \mathrm{E}-10$ & $7.19 \pm 0.35 \mathrm{E}-08$ & $1.48 \pm 3.38 \mathrm{E}-08$ \\
\hline 802 & DOWN(4) & Sep-08 & 6.76 & 1338 & $1.45 \pm 1.50 \mathrm{E}-09$ & $3.30 \pm 0.13 E-07$ & $8.45 \pm 4.69 \mathrm{E}-08$ \\
\hline 802 & DOWN(1) & Dec-08 & 6.84 & 942 & $-2.77 \pm 4.00 \mathrm{E}-09$ & $2.19 \pm 0.11 \mathrm{E}-07$ & $6.71 \pm 3.38 \mathrm{E}-08$ \\
\hline 803 & DOWN(1) & Dec-07 & 7.10 & 1486 & $0.77 \pm 5.63 \mathrm{E}-09$ & $1.53 \pm 0.63 \mathrm{E}-08$ & $1.35 \pm 0.33 \mathrm{E}-07$ \\
\hline 803 & DOWN(2) & Mar-08 & 7.60 & 1267 & $2.21 \pm 2.50 \mathrm{E}-09$ & $1.83 \pm 0.36 \mathrm{E}-08$ & $9.29 \pm 4.64 \mathrm{E}-08$ \\
\hline 803 & $\operatorname{DOWN}(3)$ & Jun-08 & 6.94 & 1291 & $8.14 \pm 7.92 \mathrm{E}-09$ & $1.82 \pm 0.54 \mathrm{E}-08$ & $-1.40 \pm 4.75 \mathrm{E}-08$ \\
\hline 803 & DOWN(4) & Sep-08 & 7.06 & 1238 & $0.68 \pm 2.51 \mathrm{E}-09$ & $1.52 \pm 0.31 \mathrm{E}-08$ & $6.61 \pm 3.29 \mathrm{E}-08$ \\
\hline 803 & DOWN(1) & Dec-08 & 6.97 & 1454 & $-1.72 \pm 6.08 \mathrm{E}-09$ & $1.94 \pm 0.42 \mathrm{E}-08$ & $9.71 \pm 4.81 \mathrm{E}-08$ \\
\hline 804 & DOWN(1) & Dec-07 & 6.68 & 910 & $3.23 \pm 5.00 \mathrm{E}-09$ & $1.42 \pm 0.11 \mathrm{E}-07$ & $3.63 \pm 4.53 \mathrm{E}-08$ \\
\hline 804 & DOWN(2) & Mar-08 & 7.57 & 1726 & $0.00 \pm 2.19 \mathrm{E}-09$ & $2.81 \pm 0.15 \mathrm{E}-07$ & $0.29 \pm 4.75 \mathrm{E}-08$ \\
\hline 804 & DOWN(3) & Jun-08 & 6.68 & 1510 & $1.44 \pm 7.57 \mathrm{E}-09$ & $1.82 \pm 0.13 \mathrm{E}-07$ & $-0.57 \pm 3.36 \mathrm{E}-08$ \\
\hline 804 & DOWN(4) & Sep-08 & 6.70 & 1012 & $2.20 \pm 2.41 \mathrm{E}-09$ & $1.36 \pm 0.08 \mathrm{E}-07$ & $1.17 \pm 4.90 \mathrm{E}-08$ \\
\hline 804 & DOWN(1) & Dec-08 & 6.99 & 1009 & $-0.70 \pm 4.28 \mathrm{E}-09$ & $1.46 \pm 0.08 \mathrm{E}-07$ & $2.73 \pm 4.90 \mathrm{E}-08$ \\
\hline
\end{tabular}

Note: Bolding convention applied to these data. (See p. D- $1^{\text {ap }}$.)

NS - Not sampled

Sample collection quarter is noted in parentheses next to hydraulic position. Hydraulic position is relative to other wells within the same hydrogeologic unit. 
TABLE D-1 (concluded)

2007/2008 Indicator Results From the Sand and Gravel Unit

\begin{tabular}{|c|c|c|c|c|c|c|c|}
\hline $\begin{array}{c}\text { Location } \\
\text { Code }\end{array}$ & $\begin{array}{l}\text { Hydraulic } \\
\text { Position }\end{array}$ & $\begin{array}{c}\text { Date } \\
\text { Collected }\end{array}$ & $\begin{array}{l}p H \\
S U\end{array}$ & $\begin{array}{c}\text { Conductivity } \\
\mu m h o s / c m @ \\
25^{\circ} \mathrm{C}\end{array}$ & $\begin{array}{c}\text { Gross Alpha } \\
\mu \mathrm{Ci} / \mathrm{mL}\end{array}$ & $\begin{array}{c}\text { Gross Beta } \\
\mu \mathrm{Ci} / \mathrm{mL}\end{array}$ & $\begin{array}{l}\text { Tritium } \\
\mu \mathrm{Ci} / \mathrm{mL}\end{array}$ \\
\hline 8603 & DOWN(1) & Dec-07 & 6.99 & 2652 & $-0.68 \pm 6.35 \mathrm{E}-09$ & $8.79 \pm 0.20 \mathrm{E}-05$ & $2.06 \pm 0.48 \mathrm{E}-07$ \\
\hline 8603 & DOWN(3) & Jun-08 & 7.21 & 2492 & $3.73 \pm 4.51 \mathrm{E}-09$ & $8.04 \pm 0.13 E-05$ & $1.60 \pm 0.50 \mathrm{E}-07$ \\
\hline 8603 & DOWN(1) & Dec-08 & 7.22 & 2655 & $4.47 \pm 4.65 \mathrm{E}-09$ & $8.18 \pm 0.19 \mathrm{E}-05$ & $2.44 \pm 0.51 \mathrm{E}-07$ \\
\hline 8604 & DOWN(1) & Dec-07 & 7.25 & 2644 & $-2.03 \pm 6.09 \mathrm{E}-09$ & $1.04 \pm 0.02 E-04$ & $1.47 \pm 0.47 \mathrm{E}-07$ \\
\hline 8604 & DOWN(3) & Jun-08 & 7.14 & 2320 & $-0.68 \pm 4.80 \mathrm{E}-09$ & $8.58 \pm 0.19 E-05$ & $2.28 \pm 0.51 \mathrm{E}-07$ \\
\hline 8604 & DOWN(1) & Dec-08 & 7.23 & 2429 & $3.24 \pm 3.25 \mathrm{E}-09$ & $8.86 \pm 0.15 \mathrm{E}-05$ & $2.21 \pm 0.51 \mathrm{E}-07$ \\
\hline & & & & & & & \\
\hline 8612 & DOWN(1) & Dec-07 & 7.07 & 1616 & $2.36 \pm 5.98 \mathrm{E}-09$ & $4.13 \pm 6.28 \mathrm{E}-09$ & $2.44 \pm 0.49 \mathrm{E}-07$ \\
\hline 8612 & DOWN(2) & Mar-08 & 6.55 & 1553 & $0.22 \pm 2.15 \mathrm{E}-09$ & $2.11 \pm 2.46 \mathrm{E}-09$ & $2.36 \pm 0.51 \mathrm{E}-07$ \\
\hline 8612 & DOWN(3) & Jun-08 & 7.08 & 1669 & $1.53 \pm 8.06 \mathrm{E}-09$ & $1.82 \pm 4.61 \mathrm{E}-09$ & $2.00 \pm 0.50 \mathrm{E}-07$ \\
\hline 8612 & DOWN(4) & Sep-08 & 7.14 & 1676 & $-0.41 \pm 2.63 \mathrm{E}-09$ & $2.26 \pm 2.70 \mathrm{E}-09$ & $1.54 \pm 0.51 \mathrm{E}-07$ \\
\hline 8612 & DOWN(1) & Dec-08 & 7.35 & 1700 & $-2.30 \pm 6.88 \mathrm{E}-09$ & $4.07 \pm 3.45 \mathrm{E}-09$ & $1.86 \pm 0.36 \mathrm{E}-07$ \\
\hline GSEEP & DOWN(1) & Dec-07 & 6.72 & 1084 & $0.56 \pm 4.14 \mathrm{E}-09$ & $9.74 \pm 5.41 \mathrm{E}-09$ & $3.90 \pm 0.50 \mathrm{E}-07$ \\
\hline GSEEP & DOWN(2) & Mar-08 & 6.61 & 1049 & $1.60 \pm 1.61 \mathrm{E}-09$ & $6.78 \pm 2.71 \mathrm{E}-09$ & $4.16 \pm 0.51 \mathrm{E}-07$ \\
\hline GSEEP & DOWN(3) & Jun-08 & 6.64 & 1371 & $0.38 \pm 5.88 \mathrm{E}-09$ & $5.96 \pm 4.25 \mathrm{E}-09$ & $2.75 \pm 0.52 \mathrm{E}-07$ \\
\hline GSEEP & DOWN(4) & Sep-08 & 6.48 & 982 & $5.37 \pm 3.84 \mathrm{E}-09$ & $9.58 \pm 3.21 \mathrm{E}-09$ & $3.37 \pm 0.51 \mathrm{E}-07$ \\
\hline GSEEP & DOWN(1) & Dec-08 & 6.62 & 1386 & $-3.17 \pm 2.83 \mathrm{E}-09$ & $1.12 \pm 0.24 \mathrm{E}-08$ & $4.83 \pm 0.54 \mathrm{E}-07$ \\
\hline SP04 & | & Der-07 & NS & NS & $870+6$ 28F-09 & $395+0905-08$ & $168+047 F_{-} 07$ \\
\hline SP04 & DOWN(3) & Jun-08 & $\overline{N S}$ & $\overline{N S}$ & $0.47 \pm 1.08 \mathrm{E}-08$ & $8.99 \pm 0.61 \mathrm{E}-08$ & $1.58 \pm 0.51 \mathrm{E}-07$ \\
\hline SP04 & DOWN(1) & Dec-08 & NS & NS & $-3.79 \pm 3.78 \mathrm{E}-09$ & $1.28 \pm 0.09 \mathrm{E}-07$ & $1.99 \pm 0.50 \mathrm{E}-07$ \\
\hline SP06 & DOWN(1) & Dec-07 & NS & NS & $-0.98 \pm 3.40 \mathrm{E}-09$ & $8.29 \pm 4.25 \mathrm{E}-09$ & $1.22 \pm 0.46 \mathrm{E}-07$ \\
\hline SP06 & $\operatorname{DOWN}(3)$ & Jun-08 & NS & NS & $9.48 \pm 5.63 \mathrm{E}-09$ & $5.24 \pm 4.98 \mathrm{E}-09$ & $3.59 \pm 4.82 \mathrm{E}-08$ \\
\hline SP06 & DOWN(1) & Dec-08 & NS & NS & $0.84 \pm 3.44 \mathrm{E}-09$ & $1.02 \pm 0.23 \mathrm{E}-08$ & $7.57 \pm 4.88 \mathrm{E}-08$ \\
\hline SP11 & DOWN(1) & Dec-07 & 6.97 & 1575 & $0.74 \pm 5.45 \mathrm{E}-09$ & $1.36 \pm 0.14 \mathrm{E}-07$ & $1.12 \pm 0.47 \mathrm{E}-07$ \\
\hline SP11 & DOWN(3) & Jun-08 & NS & NS & $6.75 \pm 8.24 \mathrm{E}-09$ & $1.38 \pm 0.11 E-07$ & $9.32 \pm 4.87 \mathrm{E}-08$ \\
\hline SP11 & DOWN(1) & Dec-08 & NS & NS & $0.31 \pm 3.66 \mathrm{E}-09$ & $1.36 \pm 0.08 \mathrm{E}-07$ & $1.45 \pm 0.51 \mathrm{E}-07$ \\
\hline SP12 & DOWN(1) & Dec-07 & 7.30 & 1053 & $2.33 \pm 5.90 \mathrm{E}-09$ & $6.56 \pm 5.19 \mathrm{E}-09$ & $1.03 \pm 0.46 \mathrm{E}-07$ \\
\hline SP12 & DOWN(3) & Jun-08 & 7.99 & 1333 & $5.08 \pm 7.73 \mathrm{E}-09$ & $4.92 \pm 7.16 \mathrm{E}-09$ & $1.79 \pm 0.51 \mathrm{E}-07$ \\
\hline SP12 & DOWN(1) & Dec-08 & 7.61 & 1532 & $-2.56 \pm 5.58 \mathrm{E}-09$ & $5.54 \pm 3.51 \mathrm{E}-09$ & $2.22 \pm 0.51 \mathrm{E}-07$ \\
\hline WP-A & DOWN(4) & Sep-08 & 8.29 & 109 & $-2.09 \pm 2.95 \mathrm{E}-10$ & $1.62 \pm 0.19 \mathrm{E}-08$ & $1.18 \pm 0.04 \mathrm{E}-05$ \\
\hline WP-C & DOWN(4) & Sep-08 & 7.10 & 169 & $-2.36 \pm 3.33 \mathrm{E}-10$ & $2.28 \pm 0.22 \mathrm{E}-08$ & $3.65 \pm 0.11 \mathrm{E}-05$ \\
\hline WP-H & DOWN(4) & Sep-08 & 6.55 & 1312 & $4.13 \pm 7.69 \mathrm{E}-09$ & $6.96 \pm 0.18 \mathrm{E}-06$ & $1.14 \pm 0.05 \mathrm{E}-06$ \\
\hline
\end{tabular}

Note: Bolding convention applied to these data. (See p. D-1 ${ }^{\text {m. }}$.)

NS - Not sampled

Sample collection quarter is noted in parentheses next to hydraulic position. Hydraulic position is relative to other wells within the same hydrogeologic unit. 
TABLE D-2

2007/2008 Indicator Results From the Lavery Till-Sand Unit

\begin{tabular}{|c|c|c|c|c|c|c|c|}
\hline $\begin{array}{c}\text { Location } \\
\text { Code }\end{array}$ & $\begin{array}{l}\text { Hydraulic } \\
\text { Position }\end{array}$ & $\begin{array}{c}\text { Date } \\
\text { Collected }\end{array}$ & $\begin{array}{l}p H \\
s U\end{array}$ & $\begin{array}{c}\text { Conductivity } \\
\text { pmhos/cm@ } \\
25 \circ C\end{array}$ & $\begin{array}{c}\text { Gross Alpha } \\
\mu \mathrm{Ci} / \mathrm{mL}\end{array}$ & $\begin{array}{c}\text { Gross Beta } \\
\mu \mathrm{Ci} / \mathrm{mL}\end{array}$ & $\begin{array}{l}\text { Tritium } \\
\mu C i / m L\end{array}$ \\
\hline 204 & DOWN(1) & Dec-07 & 7.55 & 1454 & $0.00 \pm 7.85 \mathrm{E}-09$ & $-1.54 \pm 7.19 E-09$ & $5.02 \pm 4.55 \mathrm{E}-08$ \\
\hline 204 & $\operatorname{DOWN}(2)$ & Mar-08 & 7.37 & 1378 & $1.79 \pm 2.03 \mathrm{E}-09$ & $4.33 \pm 2.69 \mathrm{E}-09$ & $-1.20 \pm 4.51 \mathrm{E}-08$ \\
\hline 204 & $\operatorname{DOWN}(3)$ & Jun-08 & 7.53 & 1458 & 5.71士4.92E-09 & $1.73 \pm 4.20 \mathrm{E}-09$ & $0.00 \pm 4.75 E-08$ \\
\hline 204 & DOWN(4) & Sep-08 & 7.28 & 1372 & $3.24 \pm 3.23 E-09$ & $0.99 \pm 2.05 E-09$ & $-0.76 \pm 4.54 E-08$ \\
\hline 204 & $\operatorname{DOWN}(1)$ & Dec-08 & 7.56 & 1382 & $-5.68 \pm 5.99 E-09$ & $5.43 \pm 3.18 \mathrm{E}-09$ & $-2.05 \pm 4.65 E-08$ \\
\hline 206 & $\operatorname{DOWN}(1)$ & Dec-07 & 7.47 & 1648 & $-2.29 \pm 7.67 \mathrm{E}-09$ & $-0.87 \pm 7.16 \mathrm{E}-09$ & $3.51 \pm 4.55 \mathrm{E}-08$ \\
\hline 206 & $\operatorname{DOWN}(3)$ & Jun-08 & 7.37 & 1670 & $0.59 \pm 9.23 \mathrm{E}-09$ & $-1.17 \pm 5.29 E-09$ & $0.62 \pm 4.78 \mathrm{E}-08$ \\
\hline 206 & DOWN(1) & Dec-08 & 7.48 & 1689 & $-1.11 \pm 6.78 \mathrm{E}-09$ & $4.18 \pm 3.10 \mathrm{E}-09$ & $5.19 \pm 4.82 E-08$ \\
\hline 208 & $\operatorname{DOWN}(1)$ & Dec-07 & 7.74 & 317 & $0.18 \pm 1.04 \mathrm{E}-09$ & $0.64 \pm 1.43 \mathrm{E}-09$ & $-4.56 \pm 4.34 \mathrm{E}-08$ \\
\hline
\end{tabular}

Note: Bolding convention applied to these data. (See p. D- $1^{\text {⿷匚巾 }}$.)

Sample collection quarter is noted in parentheses next to hydraulic position. Hydraulic position is relative to other wells within the same hydrogeologic unit. 
TABLE D-3

2007/2008 Indicator Results From the Weathered Lavery Till Unit

\begin{tabular}{|c|c|c|c|c|c|c|c|}
\hline $\begin{array}{c}\text { Location } \\
\text { Code }\end{array}$ & $\begin{array}{l}\text { Hydraulic } \\
\text { Position }\end{array}$ & $\begin{array}{c}\text { Date } \\
\text { Collected }\end{array}$ & $\begin{array}{l}p H \\
S U\end{array}$ & $\begin{array}{c}\text { Conductivity } \\
\text { umhos/cm@ } \\
25 \circ C\end{array}$ & $\begin{array}{c}\text { Gross Alpha } \\
\mu \mathrm{Ci} / \mathrm{mL}\end{array}$ & $\begin{array}{c}\text { Gross Beta } \\
\mu \mathrm{Ci} / \mathrm{mL}\end{array}$ & $\begin{array}{l}\text { Tritium } \\
\mu \mathrm{Ci} / \mathrm{mL}\end{array}$ \\
\hline 908R & $\mathrm{UP}(1)$ & Dec-08 & 7.30 & 1226 & $1.84 \pm 3.89 \mathrm{E}-09$ & $6.98 \pm 2.52 \mathrm{E}-09$ & $-2.18 \pm 3.31 \mathrm{E}-08$ \\
\hline 1005 & UP(1) & Dec-07 & 7.12 & 862 & $0.57 \pm 3.24 \mathrm{E}-09$ & $3.17 \pm 5.14 \mathrm{E}-09$ & $1.14 \pm 4.44 \mathrm{E}-08$ \\
\hline 1005 & UP(3) & Jun-08 & 7.00 & 826 & $2.07 \pm 4.97 \mathrm{E}-09$ & $2.57 \pm 2.42 E-09$ & $1.49 \pm 4.61 \mathrm{E}-08$ \\
\hline 1005 & $\mathrm{UP}(1)$ & Dec-08 & 7.20 & 802 & $2.14 \pm 4.19 E-09$ & $2.38 \pm 2.24 \mathrm{E}-09$ & $-4.98 \pm 4.58 E-08$ \\
\hline $1008 \mathrm{C}$ & UP(1) & Dec-07 & 7.49 & 637 & $-0.14 \pm 1.58 \mathrm{E}-09$ & $-1.35 \pm 2.81 E-09$ & $0.64 \pm 4.45 \mathrm{E}-08$ \\
\hline $1008 \mathrm{C}$ & $U P(3)$ & Jun-08 & 7.29 & 632 & 7.75 $\pm 1.82 E-09$ & $2.28 \pm 1.84 \mathrm{E}-09$ & $-0.52 \pm 4.72 E-08$ \\
\hline $1008 \mathrm{C}$ & UP(4) & Sep-08 & 7.51 & 596 & $1.96 \pm 9.77 \mathrm{E}-10$ & $1.00 \pm 1.79 \mathrm{E}-09$ & $0.78 \pm 3.22 \mathrm{E}-08$ \\
\hline $1008 \mathrm{C}$ & $\mathrm{UP}(1)$ & Dec-08 & 7.69 & 618 & $-1.20 \pm 3.06 \mathrm{E}-09$ & $1.68 \pm 3.61 \mathrm{E}-09$ & $-2.32 \pm 4.72 \mathrm{E}-08$ \\
\hline 906 & DOWN(1) & Dec-07 & 7.48 & 438 & $1.93 \pm 2.78 \mathrm{E}-09$ & $4.53 \pm 3.24 E-09$ & $3.35 \pm 4.52 E-08$ \\
\hline 906 & DOWN(3) & Jun-08 & 7.35 & 552 & 2.32士1.27E-09 & $0.69 \pm 2.32 \mathrm{E}-09$ & $-5.54 \pm 4.72 E-08$ \\
\hline 906 & DOWN(1) & Dec-08 & 7.38 & 570 & $1.71 \pm 2.26 \mathrm{E}-09$ & $0.17 \pm 2.05 E-09$ & $2.73 \pm 4.82 \mathrm{E}-08$ \\
\hline 908 & DOWN(1) & Dec-07 & 6.72 & 2156 & $4.07 \pm 7.11 \mathrm{E}-09$ & $1.65 \pm 1.07 E-08$ & $3.79 \pm 4.48 \mathrm{E}-08$ \\
\hline 908 & DOWN(3) & Jun-08 & 6.86 & 2758 & $0.72 \pm 1.55 \mathrm{E}-08$ & $1.35 \pm 0.70 \mathrm{E}-08$ & $2.86 \pm 3.28 \mathrm{E}-08$ \\
\hline 908 & DOWN(1) & Dec-08 & 6.87 & 2628 & $-1.31 \pm 7.48 \mathrm{E}-09$ & $1.30 \pm 0.58 \mathrm{E}-08$ & $-2.92 \pm 4.72 E-08$ \\
\hline 1006 & DOWN(1) & Dec-07 & 6.94 & 1733 & $0.79 \pm 4.49 \mathrm{E}-09$ & 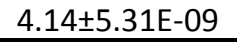 & $-3.29 \pm 4.36 \mathrm{E}-08$ \\
\hline 1006 & DOWN(3) & Jun-08 & 6.97 & 1702 & 8.65 $23.83 E-09$ & $1.85 \pm 3.37 \mathrm{E}-09$ & $1.62 \pm 4.63 \mathrm{E}-08$ \\
\hline 1006 & DOWN(1) & Dec-08 & 7.22 & 1655 & $0.73 \pm 4.39 \mathrm{E}-09$ & $3.60 \pm 2.82 \mathrm{E}-09$ & $-0.12 \pm 4.67 \mathrm{E}-08$ \\
\hline 1007 & DOWN(1) & Dec-07 & 7.06 & 1368 & $7.30 \pm 8.20 \mathrm{E}-09$ & $1.93 \pm 7.20 \mathrm{E}-09$ & $3.29 \pm 4.44 \mathrm{E}-08$ \\
\hline NDATR & DOWN(1) & Dec-07 & 7.80 & 528 & $0.39 \pm 2.22 \mathrm{E}-09$ & $5.26 \pm 0.18 \mathrm{E}-07$ & $5.88 \pm 0.52 E-07$ \\
\hline NDATR & DOWN(2) & Mar-08 & 7.80 & 750 & $2.22 \pm 2.64 \mathrm{E}-09$ & $9.20 \pm 0.17 \mathrm{E}-07$ & $2.74 \pm 0.51 \mathrm{E}-07$ \\
\hline NDATR & DOWN(3) & Jun-08 & 7.76 & 904 & 3.47士1.42E-09 & $4.82 \pm 0.13 \mathrm{E}-07$ & $3.15 \pm 0.12 E-06$ \\
\hline NDATR & DOWN(4) & Sep-08 & 7.67 & 876 & $2.53 \pm 1.48 \mathrm{E}-09$ & $6.89 \pm 0.18 \mathrm{E}-07$ & $2.67 \pm 0.11 \mathrm{E}-06$ \\
\hline NDATR & DOWN(1) & Dec-08 & 8.19 & 446 & $-0.27 \pm 1.08 \mathrm{E}-09$ & 4.15 $\pm 0.11 \mathrm{E}-07$ & $4.94 \pm 0.56 \mathrm{E}-07$ \\
\hline 909 & DOWN(1) & Dec-07 & 6.82 & 1271 & $-2.16 \pm 2.80 \mathrm{E}-09$ & 2.82士0.11E-07 & $8.10 \pm 0.55 E-07$ \\
\hline 909 & $\operatorname{DOWN}(2)$ & Mar-08 & 6.86 & 804 & $1.98 \pm 1.59 E-09$ & $2.90 \pm 0.12 \mathrm{E}-07$ & $6.34 \pm 0.57 \mathrm{E}-07$ \\
\hline 909 & DOWN(3) & Jun-08 & 6.79 & 1222 & $1.26 \pm 2.19 \mathrm{E}-09$ & $3.07 \pm 0.16 \mathrm{E}-07$ & $6.21 \pm 0.57 E-07$ \\
\hline 909 & DOWN(1) & Dec-08 & 6.79 & 1362 & $-1.76 \pm 5.02 \mathrm{E}-09$ & $2.88 \pm 0.12 \mathrm{E}-07$ & $7.62 \pm 0.59 \mathrm{E}-07$ \\
\hline
\end{tabular}

Note: Bolding convention applied to these data. (See p. D- $1^{\text {吅. }}$.)

Sample collection quarter is noted in parentheses next to hydraulic position. Hydraulic position is relative to other wells within the same hydrogeologic unit. 
TABLE D-4

2007/2008 Indicator Results From the Unweathered Lavery Till Unit

\begin{tabular}{|c|c|c|c|c|c|c|c|}
\hline $\begin{array}{c}\text { Location } \\
\text { Code }\end{array}$ & $\begin{array}{l}\text { Hydraulic } \\
\text { Position }\end{array}$ & $\begin{array}{c}\text { Date } \\
\text { Collected }\end{array}$ & $\begin{array}{l}p H \\
S U\end{array}$ & \begin{tabular}{|c} 
Conductivity \\
$\mu m h o s / c m @$ \\
$25 \circ C$
\end{tabular} & $\begin{array}{c}\text { Gross Alpha } \\
\mu \mathrm{Ci} / \mathrm{mL}\end{array}$ & $\begin{array}{c}\text { Gross Beta } \\
\mu \mathrm{Ci} / \mathrm{mL}\end{array}$ & $\begin{array}{l}\text { Tritium } \\
\mu \mathrm{Ci} / \mathrm{mL}\end{array}$ \\
\hline 405 & $\mathrm{UP}(1)$ & Dec-07 & 7.32 & 1887 & $-0.93 \pm 6.56 \mathrm{E}-09$ & $7.03 \pm 7.17 \mathrm{E}-09$ & $3.74 \pm 4.55 \mathrm{E}-08$ \\
\hline 405 & $\mathrm{UP}(2)$ & Mar-08 & 7.23 & 1981 & $5.57 \pm 4.88 \mathrm{E}-09$ & $1.01 \pm 0.54 \mathrm{E}-08$ & $0.65 \pm 4.77 \mathrm{E}-08$ \\
\hline 405 & UP(3) & Jun-08 & 7.01 & 3254 & $0.44 \pm 1.19 \mathrm{E}-08$ & $4.23 \pm 6.72 E-09$ & $1.55 \pm 4.74 \mathrm{E}-08$ \\
\hline 405 & UP(4) & Sep-08 & 7.19 & 2080 & $0.98 \pm 3.60 \mathrm{E}-09$ & $7.26 \pm 3.69 \mathrm{E}-09$ & $0.78 \pm 4.87 \mathrm{E}-08$ \\
\hline 405 & $\mathrm{UP}(1)$ & Dec-08 & 7.27 & 1638 & $-6.66 \pm 5.46 \mathrm{E}-09$ & $3.94 \pm 2.92 \mathrm{E}-09$ & $2.54 \pm 4.92 \mathrm{E}-08$ \\
\hline 1303 & $\mathrm{UP}(1)$ & Dec-07 & 7.76 & 266 & $1.08 \pm 1.25 \mathrm{E}-09$ & $1.17 \pm 1.19 \mathrm{E}-09$ & $-4.22 \pm 4.34 \mathrm{E}-08$ \\
\hline 1303 & $\mathrm{UP}(2)$ & Mar-08 & 7.36 & 276 & $4.17 \pm 5.43 \mathrm{E}-10$ & $0.21 \pm 1.03 E-09$ & $-8.60 \pm 4.62 \mathrm{E}-08$ \\
\hline 1303 & $\mathrm{UP}(3)$ & Jun-08 & 7.62 & 312 & $1.53 \pm 1.08 \mathrm{E}-09$ & $0.67 \pm 1.11 \mathrm{E}-09$ & $-6.78 \pm 4.68 \mathrm{E}-08$ \\
\hline 1303 & UP(4) & Sep-08 & 7.92 & 261 & $6.92 \pm 6.90 \mathrm{E}-10$ & $0.86 \pm 1.24 \mathrm{E}-09$ & $-2.79 \pm 4.69 \mathrm{E}-08$ \\
\hline 1303 & UP(1) & Dec-08 & 7.68 & 274 & $-2.26 \pm 8.49 \mathrm{E}-10$ & $0.66 \pm 1.33 \mathrm{E}-09$ & $-0.97 \pm 4.85 E-08$ \\
\hline 110 & DOWN(1) & Dec-07 & 7.66 & 550 & $1.02 \pm 1.58 \mathrm{E}-09$ & $1.55 \pm 1.99 \mathrm{E}-09$ & $1.10 \pm 0.06 \mathrm{E}-06$ \\
\hline 110 & DOWN(2) & Mar-08 & 7.53 & 521 & $2.06 \pm 2.82 \mathrm{E}-09$ & $4.26 \pm 2.39 \mathrm{E}-09$ & $9.61 \pm 0.59 \mathrm{E}-07$ \\
\hline 110 & DOWN(3) & Jun-08 & 7.40 & 1130 & $2.12 \pm 1.26 \mathrm{E}-09$ & $0.15 \pm 2.27 \mathrm{E}-09$ & $1.02 \pm 0.06 \mathrm{E}-06$ \\
\hline 110 & DOWN(4) & Sep-08 & 7.47 & 520 & $1.33 \pm 1.06 \mathrm{E}-09$ & $0.95 \pm 1.50 \mathrm{E}-09$ & $9.88 \pm 0.59 \mathrm{E}-07$ \\
\hline 110 & DOWN(1) & Dec-08 & 7.61 & 548 & $-0.60 \pm 2.72 E-09$ & $2.05 \pm 2.99 \mathrm{E}-09$ & $9.76 \pm 0.43 E-07$ \\
\hline 704 & DOWN(1) & Dec-07 & 6.51 & 993 & $0.13 \pm 4.95 \mathrm{E}-09$ & $2.40 \pm 5.49 \mathrm{E}-09$ & $1.84 \pm 4.45 \mathrm{E}-08$ \\
\hline 704 & $\operatorname{DOWN}(2)$ & Mar-08 & 6.62 & 788 & $1.23 \pm 0.98 \mathrm{E}-09$ & $5.66 \pm 2.10 \mathrm{E}-09$ & $6.93 \pm 4.63 \mathrm{E}-08$ \\
\hline 704 & DOWN(3) & Jun-08 & 6.56 & 964 & $2.65 \pm 1.73 E-09$ & $3.06 \pm 3.05 E-09$ & $-0.57 \pm 4.76 E-08$ \\
\hline 704 & DOWN(4) & Sep-08 & 6.26 & 954 & $-0.28 \pm 1.81 E-09$ & $5.37 \pm 2.30 \mathrm{E}-09$ & $0.64 \pm 4.57 E-08$ \\
\hline 704 & DOWN(1) & Dec-08 & 6.83 & 832 & $-1.45 \pm 2.18 \mathrm{E}-09$ & $3.51 \pm 1.97 \mathrm{E}-09$ & $-3.39 \pm 4.65 E-08$ \\
\hline 707 & DOWN(1) & Dec-07 & 6.69 & 433 & $0.00 \pm 2.59 \mathrm{E}-09$ & $2.27 \pm 3.70 \mathrm{E}-09$ & $9.00 \pm 4.54 \mathrm{E}-08$ \\
\hline 707 & DOWN(3) & Jun-08 & 6.41 & 612 & $1.07 \pm 0.99 \mathrm{E}-09$ & $1.27 \pm 2.31 \mathrm{E}-09$ & $0.04 \pm 4.72 \mathrm{E}-08$ \\
\hline 707 & DOWN(1) & Dec-08 & 6.81 & 460 & $-0.75 \pm 2.25 E-09$ & $4.25 \pm 3.09 \mathrm{E}-09$ & $5.49 \pm 4.77 E-08$ \\
\hline 107 & DOWN(1) & Dec-07 & 7.24 & 802 & $-1.90 \pm 2.28 \mathrm{E}-09$ & $9.75 \pm 4.76 \mathrm{E}-09$ & $1.45 \pm 0.46 \mathrm{E}-07$ \\
\hline 107 & $\operatorname{DOWN}(2)$ & Mar-08 & 7.41 & 700 & $0.85 \pm 1.11 \mathrm{E}-09$ & $1.39 \pm 0.22 \mathrm{E}-08$ & $1.09 \pm 0.47 \mathrm{E}-07$ \\
\hline 107 & DOWN(3) & Jun-08 & 7.26 & 690 & $0.58 \pm 2.61 \mathrm{E}-09$ & $1.21 \pm 0.28 \mathrm{E}-08$ & $7.50 \pm 4.92 \mathrm{E}-08$ \\
\hline 107 & DOWN(4) & Sep-08 & 6.72 & 704 & $1.23 \pm 1.70 \mathrm{E}-09$ & $1.38 \pm 0.34 \mathrm{E}-08$ & $1.65 \pm 0.48 \mathrm{E}-07$ \\
\hline 107 & DOWN(1) & Dec-08 & 7.41 & 662 & $0.75 \pm 3.55 \mathrm{E}-09$ & $1.27 \pm 0.28 \mathrm{E}-08$ & $1.40 \pm 0.49 \mathrm{E}-07$ \\
\hline 108 & DOWN(1) & Dec-07 & 7.76 & 548 & $0.24 \pm 1.37 \mathrm{E}-09$ & $1.31 \pm 1.84 \mathrm{E}-09$ & $9.28 \pm 4.55 \mathrm{E}-08$ \\
\hline 108 & DOWN(3) & Jun-08 & 7.66 & 581 & $2.28 \pm 1.25 E-09$ & $-0.06 \pm 1.89 E-09$ & $1.27 \pm 0.48 \mathrm{E}-07$ \\
\hline 108 & DOWN(1) & Dec-08 & 7.84 & 564 & $-0.35 \pm 1.81 E-09$ & $0.59 \pm 2.04 \mathrm{E}-09$ & $2.00 \pm 0.49 E-07$ \\
\hline 409 & DOWN(1) & Dec-07 & 8.06 & 346 & $2.32 \pm 2.07 E-09$ & $1.48 \pm 2.12 \mathrm{E}-09$ & $-2.29 \pm 3.08 E-08$ \\
\hline 409 & $\operatorname{DOWN}(2)$ & Mar-08 & 7.95 & 330 & $1.49 \pm 1.77 \mathrm{E}-09$ & $2.97 \pm 2.06 \mathrm{E}-09$ & $-1.77 \pm 4.44 \mathrm{E}-08$ \\
\hline 409 & DOWN(3) & Jun-08 & 8.04 & 346 & $1.64 \pm 0.87 \mathrm{E}-09$ & $-1.19 \pm 1.80 \mathrm{E}-09$ & $-0.84 \pm 4.58 E-08$ \\
\hline 409 & DOWN(4) & Sep-08 & 7.80 & 336 & $1.34 \pm 1.06 \mathrm{E}-09$ & $0.69 \pm 1.74 \mathrm{E}-09$ & $0.08 \pm 4.52 \mathrm{E}-08$ \\
\hline 409 & DOWN(1) & Dec-08 & 7.79 & 336 & $-0.76 \pm 1.68 \mathrm{E}-09$ & $1.50 \pm 2.28 \mathrm{E}-09$ & $-0.08 \pm 4.66 \mathrm{E}-08$ \\
\hline 910 & DOWN(1) & Dec-07 & 7.86 & 647 & $-1.50 \pm 1.36 \mathrm{E}-09$ & $1.54 \pm 0.03 E-06$ & $1.36 \pm 0.32 \mathrm{E}-07$ \\
\hline 910 & DOWN(2) & Mar-08 & 7.87 & 612 & $3.43 \pm 1.32 \mathrm{E}-09$ & $1.38 \pm 0.04 \mathrm{E}-06$ & $2.73 \pm 4.75 \mathrm{E}-08$ \\
\hline 910 & DOWN(3) & Jun-08 & 7.51 & 440 & $0.91 \pm 1.21 \mathrm{E}-09$ & $1.48 \pm 0.05 \mathrm{E}-06$ & $-3.26 \pm 4.75 \mathrm{E}-08$ \\
\hline $910 \mathrm{R}$ & DOWN(1) & Dec-08 & 6.57 & 1532 & $6.72 \pm 4.93 \mathrm{E}-09$ & $7.70 \pm 2.94 \mathrm{E}-09$ & $-1.26 \pm 3.31 \mathrm{E}-08$ \\
\hline
\end{tabular}

Note: Bolding convention applied to these data. (See p. D- $1^{\text {wa }}$.)

Sample collection quarter is noted in parentheses next to hydraulic position. Hydraulic position is relative to other wells within the same hydrogeologic unit. 
TABLE D-5

2007/2008 Indicator Results From the Kent Recessional Sequence

\begin{tabular}{|c|c|c|c|c|c|c|c|}
\hline $\begin{array}{c}\text { Location } \\
\text { Code }\end{array}$ & $\begin{array}{c}\text { Hydraulic } \\
\text { Position }\end{array}$ & $\begin{array}{c}\text { Date } \\
\text { Collected }\end{array}$ & $\begin{array}{l}p H \\
S U\end{array}$ & $\begin{array}{c}\text { Conductivity } \\
\text { umhos/cm@ } \\
25 \text { oC }\end{array}$ & $\begin{array}{c}\text { Gross Alpha } \\
\mu \mathrm{Ci} / \mathrm{mL}\end{array}$ & $\begin{array}{c}\text { Gross Beta } \\
\mu \mathrm{Ci} / \mathrm{mL}\end{array}$ & $\begin{array}{l}\text { Tritium } \\
\mu \mathrm{Ci} / \mathrm{mL}\end{array}$ \\
\hline 901 & $\mathrm{UP}(1)$ & Dec-07 & 7.70 & 370 & $2.37 \pm 0.90 \mathrm{E}-09$ & $2.46 \pm 1.44 E-09$ & $-4.83 \pm 3.12 \mathrm{E}-08$ \\
\hline 901 & UP(3) & Jun-08 & 7.64 & 378 & $2.08 \pm 1.06 \mathrm{E}-09$ & $1.36 \pm 2.34 \mathrm{E}-09$ & $-0.02 \pm 4.66 \mathrm{E}-08$ \\
\hline 901 & UP(4) & Sep-08 & 7.62 & 352 & $1.03 \pm 1.07 E-09$ & $1.57 \pm 1.80 \mathrm{E}-09$ & $-4.26 \pm 4.43 E-08$ \\
\hline 901 & UP(1) & Dec-08 & 7.69 & 355 & $2.60 \pm 2.36 \mathrm{E}-09$ & $2.60 \pm 2.96 \mathrm{E}-09$ & $-5.47 \pm 4.70 \mathrm{E}-08$ \\
\hline 902 & UP(1) & Dec-07 & 7.85 & 434 & $-0.12 \pm 1.27 E-09$ & $0.75 \pm 1.67 \mathrm{E}-09$ & $1.39 \pm 4.46 \mathrm{E}-08$ \\
\hline 902 & UP(3) & Jun-08 & 8.49 & 363 & $9.60 \pm 7.54 \mathrm{E}-10$ & $0.13 \pm 1.91 E-09$ & $0.95 \pm 4.59 \mathrm{E}-08$ \\
\hline 902 & $\mathrm{UP}(1)$ & Dec-08 & 7.64 & 498 & $-0.13 \pm 2.42 \mathrm{E}-09$ & $4.22 \pm 2.60 \mathrm{E}-09$ & $2.14 \pm 4.80 \mathrm{E}-08$ \\
\hline $1008 \mathrm{~B}$ & UP(1) & Dec-07 & 7.88 & 382 & $-0.83 \pm 1.16 \mathrm{E}-09$ & $1.27 \pm 1.70 \mathrm{E}-09$ & $-1.28 \pm 3.13 E-08$ \\
\hline $1008 \mathrm{~B}$ & $\mathrm{UP}(1)$ & Dec-08 & 7.95 & 410 & $0.24 \pm 2.22 \mathrm{E}-09$ & $-0.30 \pm 2.53 \mathrm{E}-09$ & $-2.04 \pm 3.35 E-08$ \\
\hline 903 & $\operatorname{DOWN}(1)$ & Dec-07 & 7.37 & 962 & $-2.46 \pm 2.26 \mathrm{E}-09$ & $0.25 \pm 3.51 \mathrm{E}-09$ & $-4.85 \pm 4.40 E-08$ \\
\hline 903 & $\operatorname{DOWN}(3)$ & Jun-08 & 7.50 & 954 & $0.66 \pm 1.15 \mathrm{E}-09$ & $0.38 \pm 2.27 \mathrm{E}-09$ & $-5.26 \pm 4.54 E-08$ \\
\hline 903 & DOWN(1) & Dec-08 & 7.51 & 912 & $-1.18 \pm 4.24 \mathrm{E}-09$ & $2.12 \pm 2.18 \mathrm{E}-09$ & $-3.75 \pm 4.78 \mathrm{E}-08$ \\
\hline 8610 & $\operatorname{DOWN}(1)$ & Dec-07 & 7.65 & 1179 & $0.60 \pm 5.23 E-09$ & $4.52 \pm 5.40 \mathrm{E}-09$ & $-4.03 \pm 4.32 \mathrm{E}-08$ \\
\hline 8610 & $\operatorname{DOWN}(3)$ & Jun-08 & 7.61 & 1249 & $2.37 \pm 4.85 E-09$ & 7.52 $44.99 E-09$ & $2.48 \pm 4.65 \mathrm{E}-08$ \\
\hline 8610 & DOWN(1) & Dec-08 & 7.78 & 1366 & $-0.98 \pm 2.45 E-09$ & $3.87 \pm 1.89 \mathrm{E}-09$ & $-2.04 \pm 3.34 \mathrm{E}-08$ \\
\hline 8611 & $\operatorname{DOWN}(1)$ & Dec-07 & 7.60 & 1023 & $4.50 \pm 4.16 \mathrm{E}-09$ & $0.41 \pm 4.21 E-09$ & $-4.21 \pm 4.32 E-08$ \\
\hline 8611 & $\operatorname{DOWN}(3)$ & Jun-08 & 7.42 & 1020 & $1.12 \pm 5.24 \mathrm{E}-09$ & $2.44 \pm 2.50 \mathrm{E}-09$ & $-2.97 \pm 4.53 \mathrm{E}-08$ \\
\hline 8611 & DOWN(1) & Dec-08 & 7.83 & 1068 & $0.25 \pm 3.04 \mathrm{E}-09$ & $2.22 \pm 1.92 E-09$ & $-2.40 \pm 4.59 \mathrm{E}-08$ \\
\hline
\end{tabular}

Note: Bolding convention applied to these data. (See p. D- $1^{\text {⿷匚巾 }}$.)

Sample collection quarter is noted in parentheses next to hydraulic position. Hydraulic position is relative to other wells within the same hydrogeologic unit. 
TABLE D-6

2007/2008 Results for Metals in Groundwater Title 6 NYCRR Appendix 33 List

\begin{tabular}{|c|c|c|c|c|c|c|c|c|c|c|}
\hline $\begin{array}{c}\text { Location } \\
\text { Code }\end{array}$ & $\begin{array}{c}\text { Hydraulic } \\
\text { Position }\end{array}$ & $\begin{array}{c}\text { Date } \\
\text { Collected }\end{array}$ & $\begin{array}{c}\text { Antimony } \\
\mu g / L\end{array}$ & $\begin{array}{c}\text { Arsenic } \\
\mu g / L\end{array}$ & $\begin{array}{c}\text { Barium } \\
\mu g / L\end{array}$ & $\begin{array}{c}\text { Beryllium } \\
\mu \mathrm{g} / \mathrm{L}\end{array}$ & $\begin{array}{c}\text { Cadmium } \\
\mu \mathrm{g} / \mathrm{L}\end{array}$ & $\begin{array}{c}\text { Chromium } \\
\mu \mathrm{g} / \mathrm{L}\end{array}$ & $\begin{array}{c}\text { Cobalt } \\
\mu g / L\end{array}$ & $\begin{array}{c}\text { Copper } \\
\mu g / L\end{array}$ \\
\hline \multicolumn{11}{|c|}{ Sand and Gravel Unit } \\
\hline 301 & UP(1) & Dec-07 & $<10$ & $<10$ & 161 & $<1$ & $<5$ & 100 & $<50$ & $<25$ \\
\hline 301 & UP(4) & Sep-08 & $<0.5$ & $<2$ & 276 & $<0.1$ & $<1$ & 44 & 3 & $<3$ \\
\hline 706 & UP(1) & Dec-07 & $<10$ & $<10$ & 104 & 1 & $<5$ & 919 & $<50$ & $<25$ \\
\hline 706 & $U P(2)$ & Mar-08 & $<10$ & $<10$ & 80 & $<1$ & $<5$ & 60 & $<50$ & $<25$ \\
\hline 706 & UP(3) & Jun-08 & $<10$ & $<10$ & 156 & $<1$ & $<5$ & 214 & $<50$ & $<25$ \\
\hline 706 & UP(4) & Sep-08 & $<10$ & $<10$ & 133 & $<1$ & $<5$ & 203 & $<50$ & $<25$ \\
\hline 706 & UP(1) & Dec-08 & $<10$ & $<10$ & 91 & $<1$ & $<5$ & 236 & $<50$ & $<25$ \\
\hline 1304 & UP(1) & Dec-07 & $<10$ & $<10$ & 97 & $<1$ & $<5$ & $<5$ & $<50$ & $<25$ \\
\hline 1304 & UP(2) & Mar-08 & $<10$ & $<10$ & 287 & $<1$ & $<5$ & $<5$ & $<50$ & $<25$ \\
\hline 1304 & UP(3) & Jun-08 & $<10$ & $<10$ & 195 & 1 & $<5$ & $<5$ & $<50$ & $<25$ \\
\hline 1304 & UP(4) & Sep-08 & $<10$ & $<10$ & 128 & $<1$ & $<5$ & $<5$ & $<50$ & $<25$ \\
\hline 1304 & UP(1) & Dec-08 & $<10$ & $<10$ & 86 & $<1$ & $<5$ & $<5$ & $<50$ & $<25$ \\
\hline 1302 & DOWN(1) & Dec-07 & $<10$ & $<10$ & 136 & $<1$ & $<5$ & 8 & $<50$ & $<25$ \\
\hline 1302 & DOWN(1) & Dec-08 & $<10$ & $<10$ & 72 & $<1$ & $<5$ & $<5$ & $<50$ & $<25$ \\
\hline 104 & DOWN(1) & Dec-07 & $<10$ & $<10$ & 335 & $<1$ & $<5$ & 2620 & $<50$ & $<25$ \\
\hline 104 & DOWN(4) & Sep-08 & $<0.5$ & $<2$ & 285 & $<0.1$ & $<1$ & 72 & $<1$ & $<3$ \\
\hline 111 & DOWN(1) & Dec-07 & $<10$ & $<10$ & $<200$ & $<1$ & $<5$ & $<10$ & $<50$ & $<25$ \\
\hline 111 & DOWN(1) & Dec-08 & $<2$ & $<10$ & $<200$ & $<1$ & $<5$ & $<10$ & $<50$ & $<25$ \\
\hline 408 & DOWN(1) & Dec-07 & $<10$ & $<10$ & 535 & $<1$ & $<5$ & 23 & $<50$ & $<25$ \\
\hline 408 & DOWN(4) & Sep-08 & $<0.5$ & $<2$ & 597 & $<0.1$ & $<1$ & 13 & 1 & $<3$ \\
\hline 501 & DOWN(1) & Dec-07 & $<10$ & $<10$ & 574 & $<1$ & $<5$ & $<10$ & $<50$ & $<25$ \\
\hline 501 & DOWN(4) & Sep-08 & $<0.5$ & $<2$ & 583 & $<0.1$ & $<1$ & $<2$ & $<1$ & $<3$ \\
\hline 502 & DOWN(1) & Dec-07 & $<10$ & $<10$ & 755 & $<1$ & $<5$ & 1470 & $<50$ & 63 \\
\hline 502 & DOWN(3) & Jun-08 & NS & $<10$ & 624 & NS & $<5$ & 1585 & $<50$ & 43 \\
\hline 502 & DOWN(4) & Sep-08 & $<0.5$ & 6 & 720 & $<0.1$ & $<1$ & 2100 & 7 & 76 \\
\hline 502 & DOWN(1) & Dec-08 & NS & $<10$ & 645 & NS & $<5$ & 1970 & $<50$ & 64 \\
\hline 8605 & DOWN(1) & Dec-07 & $<10$ & $<10$ & $<200$ & $<1$ & $<5$ & $<10$ & $<50$ & $<25$ \\
\hline 8605 & DOWN(1) & Dec-08 & $<2$ & $<10$ & $<200$ & $<1$ & $<5$ & $<10$ & $<50$ & $<25$ \\
\hline 8609 & DOWN(1) & Dec-07 & $<10$ & $<10$ & 490 & $<1$ & $<5$ & $<10$ & $<50$ & $<25$ \\
\hline 8609 & DOWN(4) & Sep-08 & $<0.5$ & $<2$ & 518 & $<0.1$ & $<1$ & 6 & $<1$ & $<3$ \\
\hline
\end{tabular}

Note: Bolding convention applied to these data. (See p. D- $1^{\text {m. }}$.)

NS - Not sampled.

Sample collection quarter is noted in parentheses next to hydraulic position. Hydraulic position is relative to other wells within the same hydrogeologic unit. 
TABLE D-6 (continued)

2007/2008 Results for Metals in Groundwater

Title 6 NYCRR Appendix 33 List

\begin{tabular}{|c|c|c|c|c|c|c|c|c|c|c|}
\hline $\begin{array}{c}\text { Location } \\
\text { Code }\end{array}$ & $\begin{array}{l}\text { Hydraulic } \\
\text { Position }\end{array}$ & $\begin{array}{c}\text { Date } \\
\text { Collected }\end{array}$ & $\begin{array}{c}\text { Antimony } \\
\mu g / L\end{array}$ & $\begin{array}{c}\text { Arsenic } \\
\mu g / L\end{array}$ & $\begin{array}{c}\text { Barium } \\
\mu g / L\end{array}$ & $\begin{array}{c}\text { Beryllium } \\
\mu g / L\end{array}$ & $\begin{array}{c}\text { Cadmium } \\
\mu \mathrm{g} / \mathrm{L}\end{array}$ & $\begin{array}{c}\text { Chromium } \\
\mu g / L\end{array}$ & $\begin{array}{c}\text { Cobalt } \\
\mu g / L\end{array}$ & $\begin{array}{c}\text { Copper } \\
\mu g / L\end{array}$ \\
\hline \multicolumn{11}{|c|}{ Weathered Till Unit } \\
\hline NDATR & DOWN(1) & Dec-07 & $<10$ & $<10$ & 37 & $<1$ & $<5$ & $<5$ & $<50$ & $<25$ \\
\hline NDATR & $\operatorname{DOWN}(2)$ & Mar-08 & $<10$ & $<10$ & 35 & $<1$ & $<5$ & $<5$ & $<50$ & $<25$ \\
\hline NDATR & DOWN(3) & Jun-08 & $<10$ & $<10$ & 52 & $<1$ & $<5$ & $<5$ & $<50$ & $<25$ \\
\hline NDATR & DOWN(4) & Sep-08 & $<10$ & $<10$ & 70 & $<1$ & $<5$ & $<5$ & $<50$ & $<25$ \\
\hline NDATR & DOWN(1) & Dec-08 & $<10$ & $<10$ & 50 & $<1$ & $<5$ & $<5$ & $<50$ & $<25$ \\
\hline 909 & DOWN(1) & Dec-07 & $<10$ & 19 & 515 & $<1$ & $<5$ & 27 & $<50$ & 30 \\
\hline 909 & DOWN(1) & Dec-08 & $<10$ & 13 & 396 & $<1$ & $<5$ & 7 & $<50$ & $<25$ \\
\hline \multicolumn{11}{|c|}{ Unweathered Till Unit } \\
\hline 405 & UP(1) & Dec-07 & $<10$ & $<10$ & 105 & 1 & $<5$ & 752 & $<50$ & $<25$ \\
\hline 405 & $U P(2)$ & Mar-08 & $<10$ & $<10$ & 149 & $<1$ & $<5$ & 689 & $<50$ & $<25$ \\
\hline 405 & UP(3) & Jun-08 & $<10$ & $<10$ & 108 & $<1$ & $<5$ & 73 & $<50$ & $<25$ \\
\hline 405 & UP(4) & Sep-08 & $<10$ & $<10$ & 96 & $<1$ & $<5$ & 92 & $<50$ & $<25$ \\
\hline 405 & UP(1) & Dec-08 & $<10$ & $<10$ & 75 & $<1$ & $<5$ & 62 & $<50$ & $<25$ \\
\hline 1303 & UP(1) & Dec-07 & $<10$ & $<10$ & 170 & $<1$ & $<5$ & 8 & $<50$ & $<25$ \\
\hline 1303 & $\operatorname{UP}(2)$ & Mar-08 & $<10$ & 15 & 264 & 1 & $<5$ & 24 & $<50$ & $<25$ \\
\hline 1303 & $U P(3)$ & Jun-08 & $<10$ & 110 & 1020 & 5 & $<5$ & 164 & 109 & 152 \\
\hline 1303 & UP(4) & Sep-08 & $<10$ & 21 & 284 & $<1$ & $<5$ & 26 & $<50$ & $<25$ \\
\hline 1303 & UP(1) & Dec-08 & $<10$ & 10 & 195 & $<1$ & $<5$ & 12 & $<50$ & $<25$ \\
\hline
\end{tabular}

Note: Bolding convention applied to these data. (See p. D-1 ${ }^{\text {tax }}$.)

Sample collection quarter is noted in parentheses next to hydraulic position. Hydraulic position is relative to other wells within the same hydrogeologic unit. 
TABLE D-6 (continued)

2007/2008 Results for Metals in Groundwater

Title 6 NYCRR Appendix 33 List

\begin{tabular}{|c|c|c|c|c|c|c|c|c|c|c|c|}
\hline $\begin{array}{c}\text { Location } \\
\text { Code }\end{array}$ & $\begin{array}{c}\text { Hydraulic } \\
\text { Position }\end{array}$ & $\begin{array}{c}\text { Date } \\
\text { Collected }\end{array}$ & $\begin{array}{l}\text { Lead } \\
\mu g / L\end{array}$ & $\begin{array}{c}\text { Mercury } \\
\mu g / L\end{array}$ & $\begin{array}{c}\text { Nickel } \\
\mu g / L\end{array}$ & $\begin{array}{c}\text { Selenium } \\
\mu \mathrm{g} / \mathrm{L}\end{array}$ & $\begin{array}{c}\text { Silver } \\
\mu g / L\end{array}$ & $\begin{array}{c}\text { Thallium } \\
\mu g / L\end{array}$ & $\begin{array}{c}\text { Tin } \\
\mu g / L\end{array}$ & $\begin{array}{c}\text { Vanadium } \\
\mu g / L\end{array}$ & $\begin{array}{l}\text { Zinc } \\
\mu g / L\end{array}$ \\
\hline \multicolumn{12}{|c|}{ Sand and Gravel Unit } \\
\hline 301 & UP(1) & Dec-07 & $<3$ & $<0.2$ & 69 & $<5$ & $<10$ & $<10$ & $<3000$ & $<50$ & $<20$ \\
\hline 301 & UP(4) & Sep-08 & $<0.5$ & $<0.03$ & 110 & $<1$ & $<1$ & $<0.3$ & 15 & $<1$ & 6 \\
\hline 706 & $\mathrm{UP}(1)$ & Dec-07 & $<3$ & $<0.2$ & 1410 & $<5$ & $<10$ & $<10$ & $<3000$ & $<50$ & $<20$ \\
\hline 706 & $U P(2)$ & Mar-08 & $<3$ & $<0.2$ & 536 & $<5$ & $<10$ & $<10$ & $<3000$ & $<50$ & $<20$ \\
\hline 706 & UP(3) & Jun-08 & $<3$ & $<0.2$ & 1010 & $<5$ & $<10$ & $<10$ & $<3000$ & $<50$ & $<20$ \\
\hline 706 & UP(4) & Sep-08 & $<3$ & $<0.2$ & 647 & $<5$ & $<10$ & $<10$ & $<3000$ & $<50$ & $<20$ \\
\hline 706 & UP(1) & Dec-08 & $<3$ & $<0.2$ & 788 & $<5$ & $<10$ & $<10$ & $<3000$ & $<50$ & $<20$ \\
\hline 1304 & UP(1) & Dec-07 & $<3$ & $<0.2$ & $<40$ & $<5$ & $<10$ & $<10$ & $<3000$ & $<50$ & $<20$ \\
\hline 1304 & UP(2) & Mar-08 & $<3$ & $<0.2$ & $<40$ & $<5$ & $<10$ & $<10$ & $<3000$ & $<50$ & $<20$ \\
\hline 1304 & UP(3) & Jun-08 & $<3$ & $<0.2$ & $<40$ & $<5$ & $<10$ & $<10$ & $<3000$ & $<50$ & $<20$ \\
\hline 1304 & UP(4) & Sep-08 & $<3$ & $<0.2$ & $<40$ & $<5$ & $<10$ & $<10$ & $<3000$ & $<50$ & $<20$ \\
\hline 1304 & UP(1) & Dec-08 & $<3$ & $<0.2$ & $<40$ & $<5$ & $<10$ & $<10$ & $<3000$ & $<50$ & $<20$ \\
\hline 1302 & DOWN(1) & Dec-07 & 5 & $<0.2$ & $<40$ & $<5$ & $<10$ & $<10$ & $<3000$ & $<50$ & 26 \\
\hline 1302 & DOWN(1) & Dec-08 & $<3$ & $<0.2$ & $<40$ & $<5$ & $<10$ & $<10$ & $<3000$ & $<50$ & $<20$ \\
\hline 104 & DOWN(1) & Dec-07 & $<3$ & $<0.2$ & 94 & $<5$ & $<10$ & $<10$ & $<3000$ & $<50$ & $<20$ \\
\hline 104 & DOWN(4) & Sep-08 & $<0.5$ & $<0.03$ & 18 & $<1$ & $<1$ & 1 & 7 & $<1$ & 3 \\
\hline 111 & DOWN(1) & Dec-07 & $<3$ & $<0.2$ & $<40$ & $<5$ & $<10$ & $<10$ & $<3000$ & $<50$ & $<20$ \\
\hline 111 & DOWN(1) & Dec-08 & $<3$ & $<0.2$ & $<40$ & $<5$ & $<10$ & $<10$ & $<3000$ & $<50$ & $<20$ \\
\hline 408 & DOWN(1) & Dec-07 & $<3$ & $<0.2$ & 74 & $<5$ & $<10$ & $<10$ & $<3000$ & $<50$ & $<20$ \\
\hline 408 & DOWN(4) & Sep-08 & $<0.5$ & $<0.03$ & 110 & $<1$ & $<1$ & $<0.3$ & 17 & $<1$ & 3 \\
\hline 501 & DOWN(1) & Dec-07 & $<3$ & $<0.2$ & $<40$ & $<5$ & $<10$ & $<10$ & $<3000$ & $<50$ & $<20$ \\
\hline 501 & DOWN(4) & Sep-08 & $<0.5$ & $<0.03$ & 2 & $<1$ & $<1$ & $<0.3$ & 11 & $<1$ & 2 \\
\hline 502 & DOWN(1) & Dec-07 & $<3$ & $<0.2$ & 125 & $<5$ & $<10$ & $<10$ & $<3000$ & $<50$ & $<20$ \\
\hline 502 & DOWN(3) & Jun-08 & $<3$ & $<0.2$ & 146 & $<5$ & $<10$ & NS & NS & $<50$ & $<20$ \\
\hline 502 & DOWN(4) & Sep-08 & 1 & $<0.03$ & 222 & $<1$ & $<1$ & $<0.3$ & 10 & 3 & 6 \\
\hline 502 & DOWN(1) & Dec-08 & $<3$ & $<0.2$ & 222 & $<5$ & $<10$ & NS & NS & $<50$ & $<20$ \\
\hline 8605 & DOWN(1) & Dec-07 & $<3$ & $<0.2$ & $<40$ & $<5$ & $<10$ & $<10$ & $<3000$ & $<50$ & $<20$ \\
\hline 8605 & DOWN(1) & Dec-08 & $<3$ & $<0.2$ & $<40$ & $<5$ & $<10$ & $<10$ & $<3000$ & $<50$ & $<20$ \\
\hline 8609 & DOWN(1) & Dec-07 & $<3$ & $<0.2$ & $<40$ & $<5$ & $<10$ & $<10$ & $<3000$ & $<50$ & $<20$ \\
\hline 8609 & DOWN(4) & Sep-08 & $<0.5$ & $<0.03$ & 3 & $<1$ & $<1$ & $<0.3$ & 14 & $<1$ & 2 \\
\hline
\end{tabular}

Note: Bolding convention applied to these data. (See p. D- $1^{\text {m. }}$.)

NA - Not sampled.

Sample collection quarter is noted in parentheses next to hydraulic position. Hydraulic position is relative to other wells within the same hydrogeologic unit. 
TABLE D-6 (concluded)

2007/2008 Results for Metals in Groundwater

Title 6 NYCRR Appendix 33 List

\begin{tabular}{|c|c|c|c|c|c|c|c|c|c|c|c|}
\hline $\begin{array}{c}\text { Location } \\
\text { Code }\end{array}$ & $\begin{array}{c}\text { Hydraulic } \\
\text { Position }\end{array}$ & $\begin{array}{c}\text { Date } \\
\text { Collected }\end{array}$ & $\begin{array}{l}\text { Lead } \\
\mu g / L\end{array}$ & $\begin{array}{c}\text { Mercury } \\
\mu g / L\end{array}$ & $\begin{array}{c}\text { Nickel } \\
\mu g / L\end{array}$ & $\begin{array}{c}\text { Selenium } \\
\mu \mathrm{g} / \mathrm{L}\end{array}$ & $\begin{array}{l}\text { Silver } \\
\mu g / L\end{array}$ & $\begin{array}{c}\text { Thallium } \\
\mu \mathrm{g} / \mathrm{L}\end{array}$ & $\begin{array}{c}\text { Tin } \\
\mu g / L \\
\end{array}$ & $\begin{array}{c}\text { Vanadium } \\
\mu \mathrm{g} / \mathrm{L}\end{array}$ & $\begin{array}{l}\text { Zinc } \\
\mu g / L \\
\end{array}$ \\
\hline \multicolumn{12}{|c|}{ Weathered Till Unit } \\
\hline NDATR & DOWN(1) & Dec-07 & $<3$ & $<0.2$ & $<40$ & $<5$ & $<10$ & $<10$ & $<3000$ & $<50$ & $<20$ \\
\hline NDATR & DOWN(2) & Mar-08 & $<3$ & $<0.2$ & $<40$ & $<5$ & $<10$ & $<10$ & $<3000$ & $<50$ & 22 \\
\hline NDATR & DOWN(3) & Jun-08 & $<3$ & $<0.2$ & $<40$ & $<5$ & $<10$ & $<10$ & $<3000$ & $<50$ & $<20$ \\
\hline NDATR & DOWN(4) & Sep-08 & $<3$ & $<0.2$ & $<40$ & $<5$ & $<10$ & $<10$ & $<3000$ & $<50$ & $<20$ \\
\hline NDATR & DOWN(1) & Dec-08 & $<3$ & $<0.2$ & $<40$ & $<5$ & $<10$ & $<10$ & $<3000$ & $<50$ & $<20$ \\
\hline 909 & DOWN(1) & Dec-07 & 12 & $<0.2$ & $<40$ & $<5$ & $<10$ & $<10$ & $<3000$ & $<50$ & 81 \\
\hline 909 & DOWN(1) & Dec-08 & $<3$ & $<0.2$ & $<40$ & $<5$ & $<10$ & $<10$ & $<3000$ & $<50$ & $<20$ \\
\hline \multicolumn{12}{|c|}{ Unweathered Till Unit } \\
\hline 405 & $\mathrm{UP}(1)$ & Dec-07 & $<3$ & $<0.2$ & 1160 & $<5$ & $<10$ & $<10$ & $<3000$ & $<50$ & $<20$ \\
\hline 405 & $\mathrm{UP}(2)$ & Mar-08 & $<3$ & $<0.2$ & 1485 & $<5$ & $<10$ & $<10$ & $<3000$ & $<50$ & $<20$ \\
\hline 405 & UP(3) & Jun-08 & $<3$ & $<0.2$ & 1310 & $<5$ & $<10$ & $<10$ & $<3000$ & $<50$ & $<20$ \\
\hline 405 & UP(4) & Sep-08 & $<3$ & $<0.2$ & 1740 & $<5$ & $<10$ & $<10$ & $<3000$ & $<50$ & $<20$ \\
\hline 405 & $\mathrm{UP}(1)$ & Dec-08 & $<3$ & $<0.2$ & 1610 & $<5$ & $<10$ & $<10$ & $<3000$ & $<50$ & $<20$ \\
\hline 1303 & UP(1) & Dec-07 & $<3$ & $<0.2$ & $<40$ & $<5$ & $<10$ & $<10$ & $<3000$ & $<50$ & $<20$ \\
\hline 1303 & $\mathrm{UP}(2)$ & Mar-08 & 12 & $<0.2$ & $<40$ & $<5$ & $<10$ & $<10$ & $<3000$ & $<50$ & 69 \\
\hline 1303 & UP(3) & Jun-08 & 64 & $<0.2$ & 257 & $<5$ & $<10$ & $<10$ & $<3000$ & 186 & 494 \\
\hline 1303 & UP(4) & Sep-08 & 15 & $<0.2$ & $<40$ & $<5$ & $<10$ & $<10$ & $<3000$ & $<50$ & 73 \\
\hline 1303 & $\operatorname{UP}(1)$ & Dec-08 & 6 & $<0.2$ & $<40$ & $<5$ & $<10$ & $<10$ & $<3000$ & $<50$ & 34 \\
\hline
\end{tabular}

Note: Bolding convention applied to these data. (See p. D-1 ${ }^{\text {巴a }}$.)

Sample collection quarter is noted in parentheses next to hydraulic position. Hydraulic position is relative to other wells within the same hydrogeologic unit. 
TABLE D-7

2007/2008 Radioactivity in Groundwater From Selected Monitoring Locations

\begin{tabular}{|c|c|c|c|c|c|c|c|c|}
\hline Location & $\begin{array}{l}\text { Hydraulic } \\
\text { Position }\end{array}$ & $\begin{array}{c}\text { Date } \\
\text { Collected }\end{array}$ & $\begin{array}{c}C-14 \\
\mu C i / m L\end{array}$ & $\begin{array}{c}S r-90 \\
\mu C i / m L\end{array}$ & $\begin{array}{c}T c-99 \\
\mu C i / m L\end{array}$ & $\begin{array}{c}I-129 \\
\mu C i / m L\end{array}$ & $\begin{array}{l}\text { Cs-137 } \\
\mu \mathrm{Ci} / \mathrm{mL}\end{array}$ & $\begin{array}{l}R a-226 \\
\mu C i / m L\end{array}$ \\
\hline \multicolumn{9}{|c|}{ Sand and Gravel Unit } \\
\hline 401 & UP(1) & Dec-07 & $0.04 \pm 2.89 \mathrm{E}-08$ & $1.65 \pm 0.69 \mathrm{E}-09$ & $-1.04 \pm 1.71 \mathrm{E}-09$ & $2.42 \pm 4.90 \mathrm{E}-10$ & $1.82 \pm 1.86 \mathrm{E}-09$ & $2.99 \pm 0.61 \mathrm{E}-09$ \\
\hline 401 & UP(1) & Dec-08 & $-1.65 \pm 3.39 E-08$ & $1.61 \pm 0.80 \mathrm{E}-09$ & $0.00 \pm 2.39 \mathrm{E}-09$ & $2.37 \pm 3.70 \mathrm{E}-10$ & $-1.22 \pm 2.50 \mathrm{E}-09$ & $5.34 \pm 2.26 \mathrm{E}-10$ \\
\hline 706 & UP(1) & Dec-07 & $0.80 \pm 2.87 \mathrm{E}-08$ & $2.57 \pm 0.91 \mathrm{E}-09$ & $-1.12 \pm 1.70 \mathrm{E}-09$ & $3.42 \pm 5.60 \mathrm{E}-10$ & $5.79 \pm 1.76 \mathrm{E}-10$ & $2.29 \pm 2.75 \mathrm{E}-10$ \\
\hline 1304 & UP(1) & Dec-07 & $2.27 \pm 2.94 \mathrm{E}-08$ & $-2.52 \pm 4.42 \mathrm{E}-10$ & $-1.98 \pm 1.68 \mathrm{E}-09$ & $6.18 \pm 6.52 \mathrm{E}-10$ & \begin{tabular}{|l|}
$0.30 \pm 1.83 \mathrm{E}-09$ \\
\end{tabular} & $2.59 \pm 1.87 \mathrm{E}-10$ \\
\hline 1304 & UP(1) & Dec-08 & $-1.10 \pm 3.41 \mathrm{E}-08$ & $1.85 \pm 0.75 \mathrm{E}-09$ & $-2.64 \pm 2.42 \mathrm{E}-09$ & $1.94 \pm 6.40 \mathrm{E}-10$ & $-1.18 \pm 1.92 \mathrm{E}-09$ & $6.49 \pm 2.70 \mathrm{E}-10$ \\
\hline 1302 & DOWN(1) & Dec-07 & $0.47 \pm 2.85 \mathrm{E}-08$ & $4.60 \pm 0.91 \mathrm{E}-09$ & $-0.79 \pm 1.72 \mathrm{E}-09$ & $2.76 \pm 3.97 \mathrm{E}-10$ & $-0.08 \pm 1.78 \mathrm{E}-09$ & $1.41 \pm 1.81 \mathrm{E}-10$ \\
\hline 111 & DOWN(1) & Dec-07 & NS & $1.06 \pm 0.01 \mathrm{E}-06$ & NS & NS & NS & NS \\
\hline 406 & DOWN(1) & Dec-07 & $1.33 \pm 2.89 \mathrm{E}-08$ & $9.78 \pm 7.65 \mathrm{E}-10$ & $-0.02 \pm 1.74 \mathrm{E}-09$ & $9.89 \pm 9.68 \mathrm{E}-10$ & $-0.24 \pm 2.05 E-09$ & $1.79 \pm 0.47 \mathrm{E}-09$ \\
\hline 406 & DOWN(1) & Dec-08 & $-2.93 \pm 3.31 \mathrm{E}-08$ & $2.56 \pm 0.88 \mathrm{E}-09$ & $1.35 \pm 2.48 \mathrm{E}-09$ & $0.50 \pm 5.18 \mathrm{E}-10$ & $0.31 \pm 1.94 \mathrm{E}-09$ & $2.12 \pm 1.71 \mathrm{E}-10$ \\
\hline 408 & DOWN(1) & Dec-07 & $-1.78 \pm 3.35 E-08$ & $1.64 \pm 0.01 \mathrm{E}-04$ & $1.09 \pm 0.23 \mathrm{E}-08$ & $3.79 \pm 9.57 \mathrm{E}-10$ & \begin{tabular}{|l|}
$-3.51 \pm 6.72 E-09$ \\
\end{tabular} & $8.85 \pm 3.10 \mathrm{E}-10$ \\
\hline 408 & DOWN(1) & Dec-08 & $-3.21 \pm 3.49 \mathrm{E}-08$ & $1.41 \pm 0.01 \mathrm{E}-04$ & $1.39 \pm 0.29 \mathrm{E}-08$ & $-8.79 \pm 9.78 \mathrm{E}-10$ & $1.93 \pm 2.46 \mathrm{E}-09$ & $6.90 \pm 3.13 \mathrm{E}-10$ \\
\hline 501 & DOWN(1) & Dec-07 & NS & $7.90 \pm 0.01 \mathrm{E}-05$ & NS & NS & NS & NS \\
\hline 501 & DOWN(1) & Dec-08 & NS & $7.16 \pm 0.01 \mathrm{E}-05$ & NS & NS & NS & NS \\
\hline 502 & DOWN(1) & Dec-07 & NS & $7.47 \pm 0.01 \mathrm{E}-05$ & NS & NS & NS & NS \\
\hline 502 & DOWN(1) & Dec-08 & NS & $7.10 \pm 0.01 \mathrm{E}-05$ & NS & NS & NS & NS \\
\hline 8605 & DOWN(1) & Dec-07 & NS & $4.75 \pm 0.03 E-06$ & NS & NS & NS & NS \\
\hline 8609 & DOWN(1) & Dec-07 & NS & $7.96 \pm 0.10 \mathrm{E}-07$ & NS & NS & NS & NS \\
\hline 8609 & DOWN(1) & Dec-08 & NS & $7.74 \pm 0.10 \mathrm{E}-07$ & NS & NS & $\mathrm{NS}$ & NS \\
\hline 116 & DOWN(1) & Dec-07 & NS & $4.95 \pm 0.03 E-06$ & NS & NS & NS & NS \\
\hline 801 & DOWN(1) & Dec-07 & NS & $6.07 \pm 0.03 E-06$ & NS & NS & NS & NS \\
\hline 801 & DOWN(1) & Dec-08 & NS & $4.13 \pm 0.02 \mathrm{E}-06$ & NS & NS & NS & NS \\
\hline 8603 & DOWN(1) & Dec-07 & NS & $4.39 \pm 0.01 \mathrm{E}-05$ & NS & NS & NS & NS \\
\hline Weathere & d Till Unit & & & & & & & \\
\hline NDATR & DOWN(1) & Dec-07 & $-0.09 \pm 3.82 \mathrm{E}-08$ & $2.84 \pm 0.06 E-07$ & $0.79 \pm 2.22 \mathrm{E}-09$ & $1.58 \pm 0.80 \mathrm{E}-09$ & $1.45 \pm 1.84 \mathrm{E}-09$ & $3.51 \pm 2.85 \mathrm{E}-10$ \\
\hline NDATR & DOWN(3) & Jun-08 & $-1.77 \pm 2.95 \mathrm{E}-08$ & $2.78 \pm 0.07 \mathrm{E}-07$ & $-0.82 \pm 1.89 \mathrm{E}-09$ & $1.82 \pm 0.96 \mathrm{E}-09$ & $0.39 \pm 1.38 \mathrm{E}-09$ & $2.16 \pm 1.35 \mathrm{E}-10$ \\
\hline NDATR & DOWN(1) & Dec-08 & $0.32 \pm 3.49 \mathrm{E}-08$ & $2.48 \pm 0.07 E-07$ & $0.65 \pm 2.48 \mathrm{E}-09$ & $0.00 \pm 7.48 \mathrm{E}-10$ & $0.73 \pm 1.92 \mathrm{E}-09$ & $0.67 \pm 1.46 \mathrm{E}-10$ \\
\hline 909 & DOWN(1) & Dec-07 & $3.53 \pm 3.26 \mathrm{E}-08$ & $1.58 \pm 0.04 \mathrm{E}-07$ & $2.76 \pm 2.40 \mathrm{E}-09$ & $9.32 \pm 2.00 \mathrm{E}-09$ & $1.31 \pm 1.34 \mathrm{E}-09$ & $6.68 \pm 3.26 \mathrm{E}-10$ \\
\hline 909 & DOWN(1) & Dec-08 & $3.00 \pm 3.60 \mathrm{E}-08$ & $1.79 \pm 0.06 \mathrm{E}-07$ & $0.00 \pm 2.42 \mathrm{E}-09$ & $6.88 \pm 1.56 \mathrm{E}-09$ & $0.19 \pm 1.30 \mathrm{E}-09$ & $2.41 \pm 1.25 \mathrm{E}-10$ \\
\hline Unweat & ered Till Unit & & & & & & & \\
\hline 405 & UP(1) & Dec-07 & $0.06 \pm 4.03 \mathrm{E}-08$ & $1.56 \pm 0.61 \mathrm{E}-09$ & $-1.60 \pm 2.19 \mathrm{E}-09$ & $1.36 \pm 1.05 \mathrm{E}-09$ & $2.42 \pm 1.94 \mathrm{E}-09$ & $1.29 \pm 2.32 \mathrm{E}-10$ \\
\hline 1303 & UP(1) & Dec-07 & $1.07 \pm 2.88 \mathrm{E}-08$ & $1.70 \pm 5.42 \mathrm{E}-10$ & $-1.30 \pm 1.70 \mathrm{E}-09$ & $0.39 \pm 8.03 E-10$ & $1.22 \pm 1.89 \mathrm{E}-09$ & $3.39 \pm 2.25 \mathrm{E}-10$ \\
\hline
\end{tabular}

Note: Bolding convention applied to these data. (See p. D-1 ${ }^{\text {w }}$.)

NS - Not sampled.

Sample collection quarter is noted in parentheses next to hydraulic position. Hydraulic position is relative to other wells within the same hydrogeologic unit. 
TABLE D-7 (concluded) 2007/2008 Radioactivity in Groundwater From Selected Monitoring Locations

\begin{tabular}{|c|c|c|c|c|c|c|c|c|}
\hline Location & $\begin{array}{c}\text { Hydraulic } \\
\text { Position }\end{array}$ & $\begin{array}{c}\text { Date } \\
\text { Collected }\end{array}$ & $\begin{array}{l}R a-228 \\
\mu C i / m L\end{array}$ & $\begin{array}{c}U-232 \\
\mu C i / m L\end{array}$ & $\begin{array}{c}U 233 / 234 \\
\mu \mathrm{Ci} / \mathrm{mL}\end{array}$ & $\begin{array}{c}\text { U235/236 } \\
\mu \mathrm{Ci} / \mathrm{mL}\end{array}$ & $\begin{array}{c}U-238 \\
\mu \mathrm{Ci} / \mathrm{mL}\end{array}$ & $\begin{array}{c}\text { Total U } \\
\mu g / m L\end{array}$ \\
\hline \multicolumn{9}{|c|}{ Sand and Gravel Unit } \\
\hline 401 & UP(1) & Dec-07 & $8.81 \pm 3.51 \mathrm{E}-10$ & $-1.22 \pm 3.03 \mathrm{E}-11$ & $8.22 \pm 7.55 \mathrm{E}-11$ & $-0.51 \pm 3.20 \mathrm{E}-11$ & $6.74 \pm 6.97 \mathrm{E}-11$ & $3.72 \pm 0.32 \mathrm{E}-04$ \\
\hline 401 & UP(1) & Dec-08 & $3.55 \pm 3.23 \mathrm{E}-10$ & $-1.08 \pm 0.82 \mathrm{E}-10$ & $0.85 \pm 1.02 \mathrm{E}-10$ & $1.01 \pm 1.06 \mathrm{E}-10$ & $1.07 \pm 1.05 \mathrm{E}-10$ & $2.70 \pm 1.18 \mathrm{E}-04$ \\
\hline 706 & UP(1) & Dec-07 & $0.47 \pm 3.31 \mathrm{E}-10$ & $0.53 \pm 6.40 \mathrm{E}-11$ & $1.19 \pm 1.00 \mathrm{E}-10$ & $0.00 \pm 4.07 \mathrm{E}-11$ & $8.29 \pm 8.12 \mathrm{E}-11$ & $2.90 \pm 0.15 \mathrm{E}-04$ \\
\hline 1304 & UP(1) & Dec-07 & $1.17 \pm 0.53 \mathrm{E}-09$ & $1.53 \pm 5.76 \mathrm{E}-11$ & $3.10 \pm 1.27 \mathrm{E}-10$ & $1.00 \pm 2.66 \mathrm{E}-11$ & $1.32 \pm 0.82 \mathrm{E}-10$ & $5.43 \pm 0.14 \mathrm{E}-04$ \\
\hline 1304 & UP(1) & Dec-08 & $1.33 \pm 0.14 \mathrm{E}-08$ & $-0.11 \pm 1.18 \mathrm{E}-10$ & $1.94 \pm 1.48 \mathrm{E}-10$ & $2.71 \pm 5.31 \mathrm{E}-11$ & $1.49 \pm 1.31 \mathrm{E}-10$ & $3.47 \pm 0.33 \mathrm{E}-04$ \\
\hline 1302 & DOWN(1) & Dec-07 & $5.98 \pm 4.02 \mathrm{E}-10$ & $2.94 \pm 6.31 \mathrm{E}-11$ & $2.32 \pm 1.22 \mathrm{E}-10$ & $5.82 \pm 6.11 \mathrm{E}-11$ & $5.43 \pm 6.14 \mathrm{E}-11$ & $4.14 \pm 0.15 E-04$ \\
\hline 406 & DOWN(1) & Dec-07 & $2.51 \pm 2.80 \mathrm{E}-10$ & $-0.59 \pm 4.57 \mathrm{E}-11$ & $1.43 \pm 1.25 \mathrm{E}-10$ & $-1.33 \pm 4.54 \mathrm{E}-11$ & $1.09 \pm 5.85 \mathrm{E}-11$ & $3.27 \pm 0.17 E-04$ \\
\hline 406 & DOWN(1) & Dec-08 & $5.44 \pm 0.89 \mathrm{E}-09$ & $2.20 \pm 5.91 \mathrm{E}-11$ & $1.71 \pm 1.36 \mathrm{E}-10$ & $7.65 \pm 9.07 E-11$ & $1.32 \pm 1.15 \mathrm{E}-10$ & $0.00 \pm 5.56 \mathrm{E}-04$ \\
\hline 408 & DOWN(1) & Dec-07 & $7.64 \pm 0.93 E-09$ & $7.65 \pm 7.70 \mathrm{E}-11$ & $4.82 \pm 1.79 \mathrm{E}-10$ & $4.20 \pm 5.76 \mathrm{E}-11$ & $4.57 \pm 1.73 \mathrm{E}-10$ & $1.49 \pm 0.05 \mathrm{E}-03$ \\
\hline 408 & DOWN(1) & Dec-08 & $6.82 \pm 0.60 \mathrm{E}-09$ & $-2.11 \pm 6.68 \mathrm{E}-11$ & $6.94 \pm 2.80 \mathrm{E}-10$ & $1.86 \pm 1.44 \mathrm{E}-10$ & $2.47 \pm 1.62 \mathrm{E}-10$ & $1.04 \pm 0.03 \mathrm{E}-03$ \\
\hline \multicolumn{9}{|c|}{ Weathered Till Unit } \\
\hline NDATR & DOWN(1) & Dec-07 & $7.42 \pm 4.13 \mathrm{E}-10$ & $4.93 \pm 7.53 \mathrm{E}-11$ & $6.62 \pm 1.93 \mathrm{E}-10$ & $7.00 \pm 6.80 \mathrm{E}-11$ & $5.48 \pm 1.75 \mathrm{E}-10$ & $1.66 \pm 0.04 \mathrm{E}-03$ \\
\hline NDATR & DOWN(3) & Jun-08 & $6.26 \pm 3.32 \mathrm{E}-10$ & $-0.09 \pm 1.14 \mathrm{E}-10$ & $1.96 \pm 0.34 \mathrm{E}-09$ & $9.61 \pm 7.81 E-11$ & $1.62 \pm 0.30 \mathrm{E}-09$ & $4.40 \pm 0.06 \mathrm{E}-03$ \\
\hline NDATR & DOWN(1) & Dec-08 & $3.23 \pm 0.90 \mathrm{E}-09$ & $-5.27 \pm 7.24 \mathrm{E}-11$ & $4.28 \pm 2.16 \mathrm{E}-10$ & $4.74 \pm 7.56 \mathrm{E}-11$ & $4.56 \pm 2.17 \mathrm{E}-10$ & $1.19 \pm 0.06 \mathrm{E}-03$ \\
\hline 909 & DOWN(1) & Dec-07 & $3.48 \pm 2.99 \mathrm{E}-10$ & $0.33 \pm 6.37 \mathrm{E}-11$ & $5.00 \pm 1.60 \mathrm{E}-10$ & NS & $3.40 \pm 1.31 \mathrm{E}-10$ & $1.07 \pm 0.03 \mathrm{E}-03$ \\
\hline 909 & DOWN(1) & Dec-08 & $3.50 \pm 2.78 \mathrm{E}-10$ & $-0.40 \pm 9.56 \mathrm{E}-11$ & $4.18 \pm 2.01 \mathrm{E}-10$ & $7.58 \pm 8.58 \mathrm{E}-11$ & $4.42 \pm 2.10 \mathrm{E}-10$ & $9.78 \pm 1.08 \mathrm{E}-04$ \\
\hline \multicolumn{9}{|c|}{ Unweathered Till Unit } \\
\hline 405 & UP(1) & Dec-07 & $4.98 \pm 4.68 \mathrm{E}-10$ & $-0.63 \pm 4.66 \mathrm{E}-11$ & $3.89 \pm 1.56 \mathrm{E}-10$ & $7.75 \pm 7.14 \mathrm{E}-11$ & $2.93 \pm 1.32 \mathrm{E}-10$ & $9.47 \pm 0.23 \mathrm{E}-04$ \\
\hline 1303 & UP(1) & Dec-07 & $4.45 \pm 3.07 \mathrm{E}-10$ & $8.08 \pm 8.13 \mathrm{E}-11$ & $3.00 \pm 1.30 \mathrm{E}-10$ & $5.66 \pm 5.55 \mathrm{E}-11$ & $1.42 \pm 0.93 \mathrm{E}-10$ & $5.19 \pm 0.16 \mathrm{E}-04$ \\
\hline
\end{tabular}

Note: Bolding convention applied to these data. (See p. D- $1^{\text {⿷匚巾 }}$.)

NS - Not sampled.

Sample collection quarter is noted in parentheses next to hydraulic position. Hydraulic position is relative to other wells within the same hydrogeologic unit. 
TABLE D-8

\section{Practical Quantitation Limits (PQLs)}

\section{COMPOUND}

6 NYCRR $^{a}$ Appendix 33 Volatiles

$\begin{array}{lc}\text { Acetone } & 10 \\ \text { Acetonitrile } & 100 \\ \text { Acrolein } & 11 \\ \text { Acrylonitrile } & 10 \\ \text { Allyl chloride } & 5 \\ \text { Benzene } & 5 \\ \text { Bromodichloromethane } & 5 \\ \text { Bromoform } & 5 \\ \text { Bromomethane } & 10 \\ \text { Carbon disulfide } & 10 \\ \text { Carbon tetrachloride } & 5 \\ \text { Chlorobenzene } & 5 \\ \text { Chloroethane } & 10 \\ \text { Chloroform } & 5 \\ \text { Chloromethane } & 10 \\ \text { Chloroprene } & 5 \\ \text { 1,2-Dibromo-3-chloropropane } & 5 \\ \text { Dibromochloromethane } & 5 \\ \text { 1,2-Dibromoethane } & 5 \\ \text { Dichlorodifluoromethane (DCDFMeth) } & 5 \\ \text { 1,1-Dichloroethane (1,1-DCA) } & 5 \\ \text { 1,2-Dichloroethane (1,2-DCA) } & 5 \\ \text { 1,1-Dichloroethylene (1,1-DCE) } & 5 \\ \text { 1,2-Dichloropropane } & 5 \\ \text { Ethyl benzene } & 5 \\ \text { Ethyl methacrylate } & 5 \\ \text { 2-Hexanone } & 10\end{array}$

\section{NYCRR $^{a}$ Appendix 33 Metals}

Aluminum $^{b}$

200

Antimony

Arsenic

Barium

Beryllium

Cadmium

Chromium

Cobalt

PQL

$(\mu \mathrm{g} / \mathrm{L})$
COMPOUND

6 NYCRR $^{a}$ Appendix 33 Volatiles

Isobutyl alcohol $\quad 100$

Methacrylonitrile 5

Methyl ethyl ketone $\quad 10$

Methyl iodide 5

Methyl methacrylate 5

4-Methyl-2-pentanone 10

Methylene bromide 10

Methylene chloride 5

Pentachloroethane 5

Propionitrile $\quad 50$

Styrene 5

1,1,1,2-Tetrachloroethane 5

1,1,2,2-Tetrachloroethane 5

Tetrachloroethylene 5

Toluene 5

1,1,1-Trichloroethane (1,1,1-TCA) 5

1,1,2-Trichloroethane 5

1,2,3-Trichloropropane 5

Vinyl acetate 10

Vinyl chloride $\quad 10$

Xylene (total) 5

cis-1,3-Dichloropropene 5

trans-1,2-Dichloroethylene (1,2-DCE[trans]) 5

trans-1,3-Dichloropropene 5

trans-1,4-Dichloro-2-butene 5

Trichloroethylene (TCE) 5

Trichlorofluoromethane 5

6 NYCRR $^{a}$ Appendix 33 Metals

Lead 3

Manganese $^{b} \quad 15$

Mercury $\quad 0.2$

Nickel 40

Selenium 5

Silver 10

Thallium 10

$\begin{array}{ll}\text { Tin } & 3,000\end{array}$

Note: Specific quantitation limits are highly matrix dependent and may not always be achievable.

$a$ Title 6 of the Official Compilation of Codes, Rules, and Regulations of the State of New York.

${ }_{b}$ Not a 6 NYCRR Appendix 33 parameter; sampled for the north plateau early warning program. 
TABLE D-8 (continued)

Practical Quantitation Limits (PQLs)

\section{COMPOUND}

6 NYCRR $^{a}$ Appendix 33 Semivolatiles

$\begin{array}{ll}\text { Acenaphthene } & 10 \\ \text { Acenaphthylene } & 10 \\ \text { Acetophenone } & 10 \\ \text { 2-Acetylaminofluorene } & 10 \\ \text { 4-Aminobiphenyl } & 10 \\ \text { Aniline } & 10 \\ \text { Anthracene } & 10 \\ \text { Aramite } & 20 \\ \text { Benzo[a]anthracene } & 10 \\ \text { Benzo[a]pyrene } & 10 \\ \text { Benzo[b]fluoranthene } & 10 \\ \text { Benzo[ghi]perylene } & 10 \\ \text { Benzo[k]fluoranthene } & 10 \\ \text { Benzyl alcohol } & 10 \\ \text { Bis(2-chlorethyl)ether } & 10 \\ \text { Bis(2-chloroethoxy)methane } & 10 \\ \text { Bis(2-chloroisopropyl)ether } & 10 \\ \text { Bis(2-ethylhexyl)phthalate } & 10 \\ \text { 4-Bromophenyl phenyl ether } & 10 \\ \text { Butyl benzyl phthalate } & 10 \\ \text { Chlorobenzilate } & 10 \\ \text { 2-Chloronaphthalene } & 10 \\ \text { 2-Chlorophenol } & 10 \\ \text { 4-Chlorophenyl phenyl ether } & 10 \\ \text { Chrysene } & 10 \\ \text { Di-n-butyl phthalate } & 10 \\ \text { Di-n-octyl phthalate } & 10 \\ \text { Diallate } & 10 \\ \text { Dibenz[a,h]anthracene } & 10 \\ \text { Dibenzofuran } & 10 \\ \text { 3,3-Dichlorobenzidine } & 10 \\ \text { 2,4-Dichlorophenol } & 10 \\ \text { 2,6-Dichlorophenol } & 10 \\ \text { Diethyl phthalate } & 10 \\ \text { Dimethoate } & 10 \\ \text { 7, 12-Dimethylbenz[a]anthracene } & 10 \\ \text { 3,3-Dimethylbenzidine } & 20 \\ \text { 2,4-Dimethylphenol } & 10 \\ \text { Dimethyl phthalate } & 10 \\ \text { 4,6-Dinitro-o-cresol } & 25 \\ \text { 2,4-Dinitrophenol } & 25 \\ & \end{array}$

COMPOUND PQL

$(\mu \mathrm{PQ} / \mathrm{L})$

$(\mu \mathrm{g} / \mathrm{L})$

6 NYCRR $^{a}$ Appendix 33 Semivolatiles

2,4-Dinitrotoluene $\quad 10$

2,6-Dinitrotoluene 10

Diphenylamine 10

Ethyl methanesulfonate $\quad 10$

Famphur 15

Fluoranthene 10

Fluorene 10

Hexachlorobenzene 10

Hexachlorobutadiene 10

Hexachlorocyclopentadiene 24

Hexachloroethane 10

Hexachlorophene 250

Hexachloropropene 10

Indeno(1,2,3,-cd)pyrene 10

Isodrin 10

Isophorone $\quad 10$

Isosafrole 10

Kepone 50

Methapyrilene 40

Methyl methanesulfonate $\quad 10$

3-Methylcholanthrene 10

2-Methylnaphthalene 10

1,4-Naphthoquinone 10

1-Naphthylamine 10

2-Naphthylamine 10

Nitrobenzene 10

5-Nitro-o-toluidine 10

4-Nitroquinoline 1-oxide $\quad 40$

$\mathrm{N}$-Nitrosodi-n-butylamine $\quad 10$

$\mathrm{N}$-Nitrosodiethylamine $\quad 10$

$\mathrm{N}$-Nitrosodimethylamine $\quad 10$

N-Nitrosodipropylamine 10

$\mathrm{N}$-Nitrosodiphenylamine $\quad 10$

$\mathrm{N}$-Nitrosomethylethylamine $\quad 10$

$\mathrm{N}$-Nitrosomorpholine 10

$\mathrm{N}$-Nitrosopiperidine 50

N-Nitrosopyrrolidine 10

Naphthalene $\quad 10$

0,0,0-Triethyl phosphorothioate $\quad 10$

0,0-Diethyl 0-2-pyrazinyl-phosphorothioate 10

Note: Specific quantitation limits are highly matrix dependent and may not always be achievable.

a Title 6 of the Official Compilation of Codes, Rules, and Regulations of the State of New York. 
TABLE D-8 (concluded)

Practical Quantitation Limits (PQLs)

\section{COMPOUND}

6 NYCRR $^{a}$ Appendix 33 Semivolatiles

$\mathrm{p}$-(Dimethylamino)azobenzene

p-Chloroaniline

p-Chloro-m-cresol

p-Cresol

p-Dichlorobenzene

p-Nitroaniline

p-Nitrophenol

p-Phenylenediamine

Parathion

Pentachlorobenzene

Pentachloronitrobenzene

Pentachlorophenol

Phenacetin

Phenanthrene

Phenol

Pronamide

Pyrene

Safrole

1,2,4,5-Tetrachlorobenzene

Other Organic Compounds

1,2-Dichloroethelyne (Total)

Tributyl phosphate
PQL

$(\mu \mathrm{g} / \mathrm{L})$

COMPOUND

6 NYCRR $^{a}$ Appendix 33 Semivolatiles

2,3,4,6-Tetrachlorophenol

Tetraethyl dithiopyrophosphate

1,2,4-Trichlorobenzene

2,4,5-Trichlorophenol

2,4,6-Trichlorophenol

alpha,alpha-Dimethylphenethylamine

$\mathrm{m}$-Cresol

m-Dichlorobenzene

$\mathrm{m}$-Dinitrobenzene

m-Nitroaniline

o-Cresol

o-Dichlorobenzene

o-Nitroaniline

o-Nitrophenol

o-Toluidine

sym-Trinitrobenzene

2-Picoline

Pyridine

1,4-Dioxane
PQL

( $\mu g / L)$

10

10

10

25

10

50

10

10

10

25

10

10

25

10

10

10

10

10

10

Note: Specific quantitation limits are highly matrix dependent and may not always be achievable.

a Title 6 of the Official Compilation of Codes, Rules, and Regulations of the State of New York. 
This page intentionally left blank 


\section{APPENDIXE}

\section{Summary of Biological Data}

The following tables contain a bolding convention devised to help the reader, when viewing the data, to quickly see the range of detectable measurements within a data series. A data series is a set of chemical or radionuclide measurements (e.g., gross alpha, gross beta, tritium) from a single location or from similar locations. Note that some tables contain data that should not be technically evaluated under this convention.

\section{Key to bolding convention:}

Results for each constituent constitute a single data series. If a radiological result is larger than the uncertainty term, the measurement is considered positive. Otherwise, a result is considered nondetectable.

If all results in a data series are positive, the lowest and highest values are bolded.

If a data series contains some positive results, the highest value is bolded.

If all values in a data series are nondetectable, no values are bolded.

TABLE E-1

2008 Radioactivity Concentrations in Milk

\begin{tabular}{|c|c|c|c|c|}
\hline Location & $\begin{array}{c}\mathbf{K}-40 \\
(\mu \mathrm{Ci} / \mathrm{mL})\end{array}$ & $\begin{array}{c}\text { Sr-90 } \\
(\mu \mathrm{Ci} / \mathrm{mL})\end{array}$ & $\begin{array}{c}\mathbf{I - 1 2 9} \\
(\mu \mathrm{Ci} / \mathrm{mL})\end{array}$ & $\begin{array}{c}\text { Cs-137 } \\
(\mu \mathrm{Ci} / \mathrm{mL})\end{array}$ \\
\hline
\end{tabular}

BFMWIDR

(SE Farm)

4th Quarter

$1.20 \pm 0.15 \mathrm{E}-06$

$2.05 \pm 0.66 \mathrm{E}-09$

$-1.91 \pm 2.35 \mathrm{E}-10$

$2.23 \pm 3.23 E-09$

Note: Frequency of sampling was reduced to annual during 2008. The dairy was sold in the fall of 2008. A replacement sample point is being selected to provide similar representation. 
TABLE E-2

2008 Radioactivity Concentrations in Venison

Location

\% Moisture

$\mathbf{H}-\mathbf{3}$
$(\mu \mathrm{Ci} / \mathrm{mL})$

K-40

Sr-90

$(\mu \mathrm{Ci} / \mathrm{g}-\mathrm{dry}) \quad(\mu \mathrm{Ci} / \mathrm{g}-\mathrm{dry})$

Cs-137

( $\mu \mathrm{Ci} / \mathrm{g}-\mathrm{dry})$

Deer Flesh Background

(BFDCTRL 10/08)

73.3

0.87+1.11E-07

$1.02 \pm 0.08 \mathrm{E}-05$

$-2.13 \pm 2.49 \mathrm{E}-09$

$2.96 \pm 1.43 \mathrm{E}-08$

Deer Flesh Background

(BFDCTRL 10/08)

75.1

1.21士1.01E-07

1.16 $\pm 0.12 E-05$

$4.00 \pm 5.18 \mathrm{E}-09$

$0.00 \pm 4.72 \mathrm{E}-08$

Deer Flesh Background

(BFDCTRL 10/08)

71.4

7.32 $\pm 1.20 E-07$

$9.83 \pm 1.06 \mathrm{E}-06$

$1.92 \pm 4.56 \mathrm{E}-09$

$5.40 \pm 2.80 \mathrm{E}-08$

Deer Flesh Near-Site

(BFDNEAR 10/08)

75.6

7.40土9.98E-08

1.36 $\pm 0.14 E-05 \quad 0.66 \pm 5.09 E-09$

$1.17 \pm 0.35 \mathrm{E}-07$

Deer Flesh Near-Site

(BFDNEAR 11/08)

73.2

$0.86 \pm 1.13 E-07$

1.08 $\pm 0.10 E-05 \quad 3.57 \pm 3.70 E-09$

$6.85 \pm 3.20 \mathrm{E}-08$

Deer Flesh Near-Site

(BFDNEAR 12/08)

73.2

1.55 $\pm 1.05 E-07$

1.19 $\pm 0.10 \mathrm{E}-05$

$2.63 \pm 3.90 \mathrm{E}-09$

$0.00 \pm 1.87 \mathrm{E}-08$

Note: Bolding convention applied to these data. See page $\mathrm{E}-1^{\text {tw }}$.

TABLE E-3

2008 Radioactivity Concentrations in Food Crops

The frequency of sampling of food crops has been decreased from annual to once every five years, consistent with guidance on periodic confirmatory sampling in DOE/EH-0173T.

Food crops will next be sampled in CY 2012.

TABLE E-4

2008 Radioactivity Concentrations in Edible Portions of Fish

The frequency of sampling fish has been decreased from annual to once every five years, consistent with guidance on periodic confirmatory sampling in DOE/EH-0173T.

Fish will next be sampled in CY 2012. 


\section{APPENDIX F}

\section{Special Sampling in 2008 to Characterize Subsurface Soil and Groundwater Within the North Plateau Plume}

Subsurface soil on the north plateau was sampled in the summer and fall of 2008 as part of a program to better characterize chemical and radiological constituents in subsurface soil and groundwater from the north plateau plume area beneath and downgradient of the Main Plant Process Building.

Locations at which the samples were taken are presented in Figures A-14 and A-15. Table F-1A lists the samples collected at each depth from each borehole shown on Figure A-15.

Applicable guidelines, standards, screening levels, and background concentrations against which sampling results were compared are presented in Appendix F-2. Radiological results for subsurface soil and groundwater are presented and summarized in Appendix F-3, and nonradiological results are similarly presented in Appendix F-4.

Refer to Chapter 2 ("Environmental Monitoring") and Chapter 4 ("Groundwater Protection") for a discussion of the results for each sampling medium. 
This page intentionally left blank 


\section{APPENDIX F-1}

\section{Geoprobe $^{\circledR}$ Subsurface Soil and Groundwater Boring Location and Depth Summary}

TABLE F-1A

Geoprobe ${ }^{\circledR}$ Soil and Groundwater Sampling Summary

\begin{tabular}{|c|c|c|c|c|c|c|c|}
\hline $\begin{array}{c}\text { Boring } \\
\text { ID }\end{array}$ & $\begin{array}{c}\text { Ground } \\
\text { Surface } \\
\text { Elevation } \\
\text { (feet amsl) }\end{array}$ & $\begin{array}{l}\text { Depth to } \\
\text { Top of } \\
\text { Saturated } \\
\text { Zone } \\
\text { (feet bgs) }\end{array}$ & $\begin{array}{c}\text { Thickness of } \\
\text { Saturated } \\
\text { Zone } \\
\text { (feet) }\end{array}$ & $\begin{array}{c}\text { Top of } \\
\text { Unweathered } \\
\text { Lavery Till } \\
\text { (feet bgs) }\end{array}$ & $\begin{array}{c}\text { Sand \& } \\
\text { Gravel Soil } \\
\text { Sample } \\
\text { Intervals } \\
\text { (feet bgs) }\end{array}$ & $\begin{array}{l}\text { Unweathered } \\
\text { Lavery Till Soil } \\
\text { Sample } \\
\text { Intervals } \\
\text { (feet bgs) }\end{array}$ & $\begin{array}{c}\text { Sand \& Gravel } \\
\text { Groundwater } \\
\text { Sample } \\
\text { Intervals } \\
\text { (feet bgs) }\end{array}$ \\
\hline GP29-08 & $1,410.50$ & 14 & 23.5 & 37.5 & $\begin{array}{c}2-4 \\
7-9 \\
12-14 \\
14-16 \\
28-30 \\
30-32 \\
35-37\end{array}$ & No ULT Sample ${ }^{a}$ & $\begin{array}{c}17-19^{b} \\
29-31 \\
35-37\end{array}$ \\
\hline GP30-08 & $1,409.83$ & 20 & 17 & 37 & $\begin{array}{l}4-6^{b} \\
10-12 \\
15-17 \\
21-23 \\
28-30 \\
35-37\end{array}$ & $37-39$ & $\begin{array}{c}20-22^{b} \\
28-30 \\
35-37\end{array}$ \\
\hline $\begin{array}{c}\text { GP72-08 } \\
\text { (Inside } \\
\text { MPPB) }\end{array}$ & $1,410.21$ & 16 & 25 & 41 & $\begin{array}{c}4-6 \\
9-11 \\
14-16^{b} \\
18-20 \\
25-27^{b} \\
34-36 \\
38-40 \\
\end{array}$ & No ULT Sample ${ }^{a}$ & $\begin{array}{l}20-22 \\
25-27 \\
31-33 \\
38-40\end{array}$ \\
\hline $\begin{array}{c}\text { GP75-08 } \\
\text { (Inside } \\
\text { MPPB) }\end{array}$ & $1,415.21$ & $\overline{N A^{c}}$ & $\overline{N A^{c}}$ & $\overline{N A^{c}}$ & $4-6$ & $\overline{N A^{c}}$ & $N A^{c}$ \\
\hline $\begin{array}{c}\text { GP76-08 } \\
\text { (Inside } \\
\text { MPPB) }\end{array}$ & $1,415.21$ & 19.5 & 18.5 & 38 & $\begin{array}{c}4-6 \\
10-12 \\
15-17 \\
19-21 \\
24-26 \\
36-38 \\
\end{array}$ & $38-40$ & $\begin{array}{l}20-22 \\
34-36\end{array}$ \\
\hline
\end{tabular}

amsl - above mean sea level bgs - below ground surface

a No ULT sample required; activity levels returned to background or near background levels (WVNSCO, August 2007).

$b$ Duplicate samples collected at this location.

$c$ NA - Not available due to refusal 
TABLE F-1A (continued)

Geoprobe ${ }^{\circledR}$ Soil and Groundwater Sampling Summary

\begin{tabular}{|c|c|c|c|c|c|c|c|}
\hline $\begin{array}{c}\text { Boring } \\
\text { Location }\end{array}$ & $\begin{array}{c}\text { Ground } \\
\text { Surface } \\
\text { Elevation } \\
\text { (feet amsl) }\end{array}$ & $\begin{array}{l}\text { Depth to } \\
\text { Top of } \\
\text { Saturated } \\
\text { Zone } \\
\text { (feet bgs) }\end{array}$ & $\begin{array}{c}\text { Thickness of } \\
\text { Saturated } \\
\text { Zone } \\
\text { (feet) }\end{array}$ & $\begin{array}{c}\text { Top of } \\
\text { Unweathered } \\
\text { Lavery Till } \\
\text { (feet bgs) }\end{array}$ & $\begin{array}{c}\text { Sand \& } \\
\text { Gravel Soil } \\
\text { Sample } \\
\text { Intervals } \\
\text { (feet bgs) }\end{array}$ & \begin{tabular}{|c|} 
Unweathered \\
Lavery Till Soil \\
Sample \\
Intervals \\
(feet bgs) \\
\end{tabular} & $\begin{array}{c}\text { Sand \& Gravel } \\
\text { Groundwater } \\
\text { Sample } \\
\text { Intervals } \\
\text { (feet bgs) } \\
\end{array}$ \\
\hline $\begin{array}{c}\text { GP78-08 } \\
\text { (Inside } \\
\text { MPPB) }\end{array}$ & $1,410.21$ & 18 & 19 & 37 & $\begin{array}{c}4-6 \\
10-12 \\
15-17 \\
18-20 \\
20-22 \\
22-24 \\
35-37\end{array}$ & $37-39$ & $\begin{array}{l}20-22 \\
28-30 \\
34-36\end{array}$ \\
\hline $\begin{array}{l}\text { GP80-08 } \\
\text { (Inside } \\
\text { MPPB) }\end{array}$ & $1,415.21$ & 21 & 19 & 40 & $\begin{array}{c}9-11 \\
15-17 \\
19-21 \\
25-27^{b} \\
32-34 \\
39-41\end{array}$ & $41-43$ & $\begin{array}{l}25-27 \\
32-34 \\
39-41\end{array}$ \\
\hline GP83-08 & $1,409.00$ & 20 & 20.5 & 41.5 & $\begin{array}{l}14-16 \\
30-32 \\
38-40 \\
\end{array}$ & $40-42$ & $\begin{array}{l}22-24 \\
30-32 \\
38-40 \\
\end{array}$ \\
\hline $\begin{array}{l}\text { GP100-08 } \\
\text { (Inside } \\
\text { MPPB) }\end{array}$ & $1,415.21$ & 18 & 19 & 37 & $\begin{array}{c}4-6 \\
10-12 \\
16-18 \\
18-20 \\
30-32 \\
32-34\end{array}$ & $37-39$ & $\begin{array}{l}20-22 \\
35-37\end{array}$ \\
\hline GP101-08 & $1,410.30$ & 18 & 15 & 33 & $\begin{array}{c}4-6 \\
9-11 \\
14-16 \\
20-22 \\
32-34 \\
\end{array}$ & $32-34$ & $\begin{array}{l}21-23 \\
28-30\end{array}$ \\
\hline GP102-08 & $1,409.11$ & 14 & 15 & 29 & $\begin{array}{l}14-16 \\
16-18 \\
20-22\end{array}$ & No ULT Sample $e^{a}$ & $27-29$ \\
\hline GP103-08 & $1,410.53$ & 16 & 21.5 & 37.5 & $\begin{array}{c}16-18 \\
30-32 \\
34-36^{b}\end{array}$ & $\begin{array}{r}\text { No ULT } \\
\text { Sample }^{a}\end{array}$ & $\begin{array}{c}21-23^{b} \\
30-32 \\
35-37\end{array}$ \\
\hline GP104-08 & $1,405.91$ & 15 & 9 & 24 & $\begin{array}{c}16-18^{b} \\
20-22 \\
22-24\end{array}$ & $24-26$ & $21-23$ \\
\hline
\end{tabular}

amsl - above mean sea level

bgs - below ground surface

a No ULT sample required; activity levels returned to background or near background levels (WVNSCO, August 2007).

$b$ Duplicate samples collected at this location.

c NA - Not available due to refusal 
TABLE F-1A (concluded)

Geoprobe $^{\circledR}$ Soil and Groundwater Sampling Summary

\begin{tabular}{|c|c|c|c|c|c|c|c|}
\hline $\begin{array}{l}\text { Boring } \\
\text { Location }\end{array}$ & $\begin{array}{l}\text { Ground } \\
\text { Surface } \\
\text { Elevation } \\
\text { (feet amsl) }\end{array}$ & $\begin{array}{c}\text { Depth to } \\
\text { Top of } \\
\text { Saturated } \\
\text { Zone } \\
\text { (feet bgs) }\end{array}$ & $\begin{array}{c}\text { Thickness of } \\
\text { Saturated } \\
\text { Zone } \\
\text { (feet) }\end{array}$ & $\begin{array}{c}\text { Top of } \\
\text { Unweathered } \\
\text { Lavery Till } \\
\text { (feet bgs) }\end{array}$ & $\begin{array}{c}\text { Sand \& } \\
\text { Gravel Soil } \\
\text { Sample } \\
\text { Intervals } \\
\text { (feet bgs) }\end{array}$ & $\begin{array}{c}\text { Unweathered } \\
\text { Lavery Till Soil } \\
\text { Sample } \\
\text { Intervals } \\
\text { (feet bgs) }\end{array}$ & $\begin{array}{c}\text { Sand \& Gravel } \\
\text { Groundwater } \\
\text { Sample } \\
\text { Intervals } \\
\text { (feet bgs) }\end{array}$ \\
\hline GP105-08 & $1,405.04$ & 17 & 19 & 36 & $\begin{array}{l}10-12 \\
12-14 \\
28-30 \\
34-36\end{array}$ & $\begin{array}{r}\text { No ULT } \\
\text { Sample }^{a}\end{array}$ & $\begin{array}{l}16-18 \\
28-30 \\
34-36\end{array}$ \\
\hline GP106-08 & $1,403.39$ & 14 & 17 & 31 & $\begin{array}{l}14-16 \\
20-22 \\
22-24\end{array}$ & $\begin{array}{r}\text { No ULT } \\
\text { Sample }^{a}\end{array}$ & $\begin{array}{l}16-18 \\
20-22 \\
28-30\end{array}$ \\
\hline GP107-08 & $1,403.80$ & 12 & 20.5 & 32.5 & $\begin{array}{l}12-14 \\
22-24 \\
30-32\end{array}$ & $32-34$ & $\begin{array}{l}15-17 \\
22-24 \\
30-32\end{array}$ \\
\hline GP108-08 & $1,405.93$ & 12 & $N A^{c}$ & $N A^{c}$ & $12-14$ & $N A^{c}$ & $N A^{c}$ \\
\hline GP109-08 & $1,402.60$ & 12 & 23.5 & 35.5 & $\begin{array}{l}12-14 \\
34-36\end{array}$ & $36-38$ & $\begin{array}{l}14-16 \\
28-30 \\
34-36\end{array}$ \\
\hline
\end{tabular}

amsl - above mean sea level

bgs - below ground surface

a No ULT sample required; activity levels returned to background or near background levels (WVNSCO, August 2007).

$b$ Duplicate samples collected at this location.

c NA - Not available due to refusal 
This page intentionally left blank 


\section{APPENDIX F-2}

\section{Applicable Guidelines, Screening Levels, and Background Concentrations}

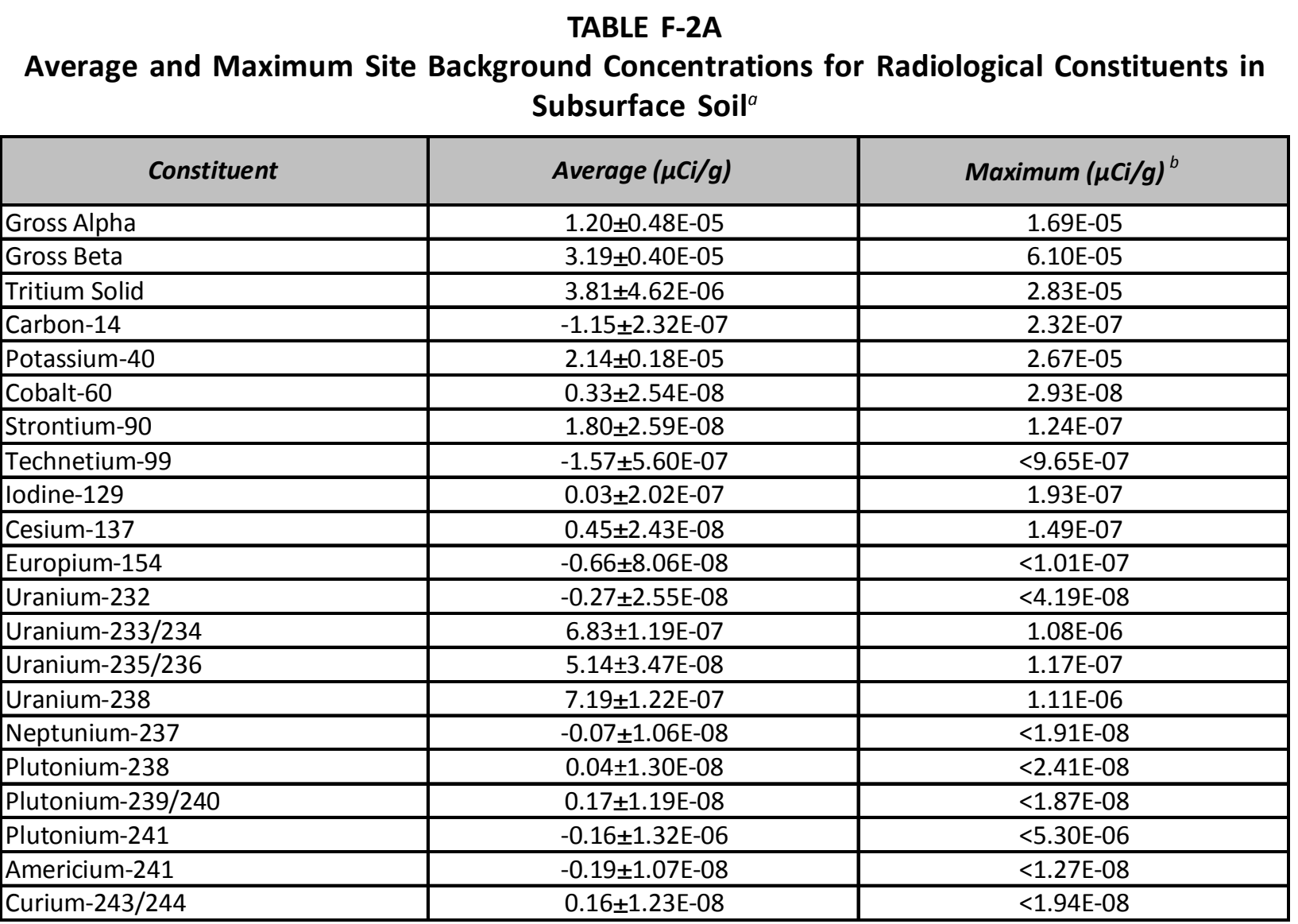

a Data were from Geoprobe ${ }^{\circledR}$ background subsurface soil samples collected in 2008 and BH-38, collected in 1993. Locations are shown in Figure A-14.

${ }^{b}$ Maximum was selected from detected results only. If the radionuclide was not detected, the highest nondetect value was selected ("<" values). 
TABLE F-2B

Average and Maximum Site Background ${ }^{a}$ Concentrations for Radiological Constituents in Groundwater

\begin{tabular}{|c|c|c|}
\hline Constituent & $\begin{array}{l}\text { Average } \\
(\mu \mathrm{Ci} / \mathrm{mL})\end{array}$ & $\begin{array}{c}\text { Maximum }^{b} \\
(\mu \mathrm{Ci} / \mathrm{mL})\end{array}$ \\
\hline Gross Alpha & $1.06 \pm 5.69 \mathrm{E}-09$ & $2.19 \mathrm{E}-08$ \\
\hline Gross Beta & $6.19 \pm 5.11 \mathrm{E}-09$ & $2.82 \mathrm{E}-08$ \\
\hline Tritium & $2.11 \pm 8.55 \mathrm{E}-08$ & $9.41 \mathrm{E}-07$ \\
\hline Carbon-14 & $-0.50 \pm 2.63 \mathrm{E}-08$ & $7.43 \mathrm{E}-09$ \\
\hline Potassium-40 & NA & NA \\
\hline Cobalt-60 & NA & NA \\
\hline Strontium-90 & $2.69 \pm 1.35 \mathrm{E}-09$ & $7.38 \mathrm{E}-09$ \\
\hline Technetium-99 & $-0.37 \pm 1.91 E-09$ & $3.98 \mathrm{E}-09$ \\
\hline lodine-129 & $2.39 \pm 7.38 \mathrm{E}-10$ & $1.58 \mathrm{E}-09$ \\
\hline Cesium-137 & $0.18 \pm 2.39 \mathrm{E}-08$ & $1.90 \mathrm{E}-08$ \\
\hline Europium-154 & NA & NA \\
\hline Uranium-232 & $0.23 \pm 1.00 \mathrm{E}-10$ & $3.78 \mathrm{E}-10$ \\
\hline Uranium-233/234 & $4.88 \pm 1.94 \mathrm{E}-10$ & $8.20 \mathrm{E}-09$ \\
\hline Uranium-235/236 & $4.52 \pm 6.03 \mathrm{E}-11$ & $1.93 \mathrm{E}-10$ \\
\hline Uranium-238 & $3.18 \pm 1.48 \mathrm{E}-10$ & $5.30 \mathrm{E}-09$ \\
\hline Neptunium-237 & NA & NA \\
\hline Plutonium-238 & $5.94 \pm 9.59 \mathrm{E}-11$ & $2.20 \mathrm{E}-10$ \\
\hline Plutonium-239/240 & $4.95 \pm 8.35 \mathrm{E}-11$ & $2.70 \mathrm{E}-10$ \\
\hline Plutonium-241 & NA & NA \\
\hline Americium-241 & $4.32 \pm 4.76 \mathrm{E}-11$ & $1.80 \mathrm{E}-10$ \\
\hline Curium-243/244 & NA & NA \\
\hline
\end{tabular}

NA - Not available

a Background radiological concentrations for groundwater were taken from the "Phase 1 Decommissioning Plan for the West Valley Demonstration Project" (March 2009). Data were taken from samples collected as part of the routine WVDP groundwater monitoring program between 1991 and 2007 at wells NB1S, 204, 301, 401, 405, 706, 901, and 908.

$b$ Maximum was selected from detected results only. If the radionuclide was not detected, the highest nondetect value was selected ("<" values). 
TABLE F-2C

Site-Specific Soil Screening Levels (SSLs) for Metals Concentrations in North Plateau Soils

\begin{tabular}{|c|c|c|c|c|c|}
\hline Metal & $\begin{array}{l}\text { Sand and Gravel } \\
\text { (S\&G) Unit } \\
\text { Maximum }^{a} \\
\text { Concentration } \\
\text { (mg/kg) }\end{array}$ & $\begin{array}{c}\text { Unweathered } \\
\text { Lavery Till (ULT) } \\
\text { Unit Maximum }^{a} \\
\text { Concentration } \\
\text { (mg/kg) }\end{array}$ & $\begin{array}{c}\text { Combined Geologic } \\
\text { Units (S\&G and ULT) } \\
\text { Maximum }{ }^{b} \\
\text { Concentration } \\
\text { (mg/kg) }\end{array}$ & $\begin{array}{c}\text { TAGM } 4046 \\
\text { Cleanup Level } \\
\text { (mg/kg) }\end{array}$ & $\begin{array}{c}S S L^{b} \\
(\mathrm{mg} / \mathrm{kg})\end{array}$ \\
\hline Aluminum, total & 15,400 & 14,000 & 15,400 & $\mathrm{SB}^{c}$ & 15,400 \\
\hline Antimony, total & 2.04 & 2.28 & 2.28 & $\mathrm{SB}^{c}$ & 2.28 \\
\hline Arsenic, total & 12.5 & 10.0 & 12.5 & 7.5 or $\mathrm{SB}^{c}$ & 12.5 \\
\hline Barium, total & 139 & 151 & 151 & 300 or $\mathrm{SB}^{c}$ & 300 \\
\hline Beryllium, total & 0.814 & 0.744 & 0.814 & 0.16 or $\mathrm{SB}^{c}$ & 0.814 \\
\hline Cadmium, total & 0.533 & 0.483 & 0.533 & 1 or $\mathrm{SB}^{c}$ & 1 \\
\hline Calcium, total & 25,300 & 57,600 & 57,600 & $\mathrm{SB}^{c}$ & 57,600 \\
\hline Chromium, total & 21.8 & 20.2 & 21.8 & 10 or $\mathrm{SB}^{c}$ & 21.8 \\
\hline Cobalt, total & 13.4 & 13.7 & 13.7 & 30 or $\mathrm{SB}^{c}$ & 30 \\
\hline Copper, total & 26.5 & 30.0 & 30.0 & 25 or $\mathrm{SB}^{c}$ & 30.0 \\
\hline Iron, total & 29,400 & 30,700 & 30,700 & 2,000 or $\mathrm{SB}^{c}$ & 30,700 \\
\hline Lead, total & 30.9 & 16.7 & 30.9 & $\mathrm{SB}^{c}$ & 30.9 \\
\hline Magnesium, total & 8,910 & 10,900 & 10,900 & $\mathrm{SB}^{c}$ & 10,900 \\
\hline Manganese, total & 740 & 484 & 740 & $\mathrm{SB}^{c}$ & 740 \\
\hline Mercury, total & 0.0197 & 0.0212 & 0.0212 & 0.1 & 0.1 \\
\hline Nickel, total & 37.3 & 34.5 & 37.3 & 13 or $\mathrm{SB}^{c}$ & 37.3 \\
\hline Potassium, total & 1,860 & 2,580 & 2,580 & $\mathrm{SB}^{c}$ & 2,580 \\
\hline Selenium, total & 8.8 & 7.2 & 8.8 & 2 or $\mathrm{SB}^{c}$ & 8.8 \\
\hline Silver, total & 0.621 & 0.449 & 0.621 & $\mathrm{SB}^{c}$ & 0.621 \\
\hline Sodium, total & 143 & 150 & 150 & $\mathrm{SB}^{c}$ & 150 \\
\hline Thallium, total & 0.308 & 0.325 & 0.325 & $\mathrm{SB}^{c}$ & 0.325 \\
\hline Vanadium, total & 25.3 & 29.1 & 29.1 & 150 or $\mathrm{SB}^{c}$ & 150 \\
\hline Zinc, total & 99.7 & 76.4 & 99.7 & 20 or $\mathrm{SB}^{c}$ & 99.7 \\
\hline
\end{tabular}

a Maximum observed concentration from Geoprobe background soil samples collected in 2008, and $\mathrm{BH}-38$.

$b$ Screening criteria were set equal to the higher of the TAGM 4046 cleanup level or the maximum background concentration.

c SB - Site background 
TABLE F-2D

Groundwater Screening Levels (GSLs) for Metals in the North Plateau S\&G Unit

\begin{tabular}{|c|c|c|c|c|}
\hline Analyte $^{a}$ & $\begin{array}{c}\text { Range of Background } \\
\text { Concentrations }^{b} \\
(\mu g / L)\end{array}$ & $\begin{array}{c}\text { Upper 95\% } \\
\text { Background } \\
\text { Value }^{c} \\
(\mu g / L)\end{array}$ & $\begin{array}{c}\text { TOGS 1.1.1 Water } \\
\text { Quality Standard } \\
(\mu \mathrm{g} / \mathrm{L})\end{array}$ & $\begin{array}{l}G S L^{d} \\
(\mu g / L)\end{array}$ \\
\hline Antimony, total & $0.500-19.7$ & 15.1 & 3 & 15.1 \\
\hline Arsenic, total & $1.50-34.4$ & 20.9 & 25 & 25.0 \\
\hline Barium, total & $71.7-499$ & 441 & 1,000 & 1,000 \\
\hline Beryllium, total & $0.100-2.50$ & 1.85 & 3 & 3 \\
\hline Cadmium, total & $0.300-5.30$ & 7.27 & 5 & 7.27 \\
\hline Chromium, total ${ }^{e}$ & $5.00-65.7$ & 52.3 & 50 & 52.3 \\
\hline Cobalt, total & $2.05-60.9$ & 67.8 & NE & 67.8 \\
\hline Copper, total & $1.40-90.5$ & 59.9 & 200 & 200 \\
\hline Lead, total & $0.500-120$ & 42.7 & 25 & 42.7 \\
\hline Mercury, total & $0.0300-0.400$ & 0.263 & 0.7 & 0.7 \\
\hline 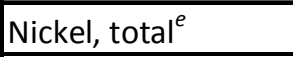 & $10.0-77.8$ & 59.5 & 100 & 100 \\
\hline Selenium, total & $1.00-25.0$ & 10.1 & 10 & 10.1 \\
\hline Silver, total & $0.0800-10.0$ & 15.5 & 50 & 50 \\
\hline Thallium, total & $0.300-13.1$ & 13.9 & 0.5 & 13.9 \\
\hline Tin, total & $5.60-3000$ & 4083 & $\mathrm{NE}$ & 4,083 \\
\hline Vanadium, total & $0.600-73.1$ & 69.6 & $\mathrm{NE}$ & 69.6 \\
\hline Zinc, total & $5.71-256$ & 127 & 2,000 & 2,000 \\
\hline
\end{tabular}

NE - No TOGS 1.1.1 water quality standard established for this analyte

a Analytes listed are those identified in the 6 NYCRR Part 373-2 Appendix 33 List.

$b$ Background data collected from wells 301, 401, 706, and 1302 in the S\&G unit on the north plateau for samples collected from 1991 to December 2008.

c The upper $95 \%$ background value is set equal to the mean plus two standard deviations. Data were rounded to three significant digits or the closest integer. (See Appendix E.)

$d$ GSLs were set equal to the larger of the background concentration or the TOGS 1.1.1 Water Quality Standards.

$e$ Elevated chromium and nickel concentrations attributed to well corrosion were noted in wells 301, 401, and 706 over the monitoring period. All results suspected to be affected by corrosion (i.e., all chromium and nickel results for 301 and 401, and all results after May 2004 from 706) were excluded from the background calculation. 
TABLE F-2E

Soils Cleanup Objectives and Levels ${ }^{a}$

\begin{tabular}{|c|c|c|c|}
\hline Analyte & Units & $\begin{array}{c}\text { TAGM \#4046 Eastern U.S. Background } \\
\text { Concentrations for Soil }{ }^{a}\end{array}$ & $\begin{array}{c}6 \text { NYCRR Subpart 375-6.8(a) } \\
\text { Remedial Soil Cleanup Objectives }\end{array}$ \\
\hline Aluminum & $\mathrm{mg} / \mathrm{kg}(\mathrm{ppm})$ & 33,000 & -- \\
\hline Antimony & $\mathrm{mg} / \mathrm{kg}(\mathrm{ppm})$ & -- & -- \\
\hline Arsenic & $\mathrm{mg} / \mathrm{kg}(\mathrm{ppm})$ & $3-12^{c}$ & 13 \\
\hline Barium & $\mathrm{mg} / \mathrm{kg}(\mathrm{ppm})$ & $15-600$ & 350 \\
\hline Beryllium & $\mathrm{mg} / \mathrm{kg}(\mathrm{ppm})$ & $0-1.75$ & 7.2 \\
\hline Cadmium & $\mathrm{mg} / \mathrm{kg}(\mathrm{ppm})$ & $0.1-1$ & 2.5 \\
\hline Calcium & $\mathrm{mg} / \mathrm{kg}$ (ppm) & $130-35,000$ & -- \\
\hline Chromium & $\mathrm{mg} / \mathrm{kg}(\mathrm{ppm})$ & $1.5-40^{c}$ & 30 \\
\hline Cobalt & $\mathrm{mg} / \mathrm{kg}(\mathrm{ppm})$ & $2.5-60^{c}$ & -- \\
\hline Copper & $\mathrm{mg} / \mathrm{kg}(\mathrm{ppm})$ & $1-50$ & 50 \\
\hline Iron & $\mathrm{mg} / \mathrm{kg}(\mathrm{ppm})$ & $2,000-550,000$ & -- \\
\hline Lead & $\mathrm{mg} / \mathrm{kg}(\mathrm{ppm})$ & $4-61^{d}$ & 63 \\
\hline Magnesium & $\mathrm{mg} / \mathrm{kg}(\mathrm{ppm})$ & $100-5,000$ & -- \\
\hline Manganese & $\mathrm{mg} / \mathrm{kg}(\mathrm{ppm})$ & $50-5,000$ & 1,600 \\
\hline Mercury & $\mathrm{mg} / \mathrm{kg}(\mathrm{ppm})$ & $0.001-0.2$ & 0.18 \\
\hline Nickel & $\mathrm{mg} / \mathrm{kg}(\mathrm{ppm})$ & $0.5-25$ & 30 \\
\hline \begin{tabular}{|l|} 
Potassium \\
\end{tabular} & $\mathrm{mg} / \mathrm{kg}(\mathrm{ppm})$ & $8,500-43,000^{c}$ & -- \\
\hline Selenium & $\mathrm{mg} / \mathrm{kg}(\mathrm{ppm})$ & $0.1-3.9$ & 3.9 \\
\hline Silver & $\mathrm{mg} / \mathrm{kg}(\mathrm{ppm})$ & -- & 2 \\
\hline Sodium & $\mathrm{mg} / \mathrm{kg}(\mathrm{ppm})$ & $6,000-8,000$ & -- \\
\hline Thallium & $\mathrm{mg} / \mathrm{kg}(\mathrm{ppm})$ & -- & -- \\
\hline Vanadium & $\mathrm{mg} / \mathrm{kg}(\mathrm{ppm})$ & $1-300$ & -- \\
\hline Zinc & $\mathrm{mg} / \mathrm{kg}(\mathrm{ppm})$ & $9-50$ & 109 \\
\hline
\end{tabular}

-- No reference level available for these analytes

a Source: New York State Department of Environmental Conservation "Technical and Administrative Guidance Memorandum (TAGM) \#4046"

b Source: 6 NYCRR Subpart 375-6.8(a) Remedial Soil Cleanup Objectives: Unrestricted Use Soil Cleanup Objectives

c New York State background

${ }^{d}$ Background levels for lead vary widely. Average levels in undeveloped, rural areas may range from 4-61 ppm. Average background levels in metropolitan or suburban areas or near highways are much higher and typically range from 200-500 ppm. 
TABLE F-2F

Screening Concentrations for Contaminated Sediment ${ }^{a}$

\begin{tabular}{|c|c|c|c|}
\hline Analyte & Units & Lowest Effect Level $^{b}$ & Severe Effect Level \\
\hline Aluminum & $\mathrm{mg} / \mathrm{kg}(\mathrm{ppm})$ & -- & -- \\
\hline Antimony & $\mathrm{mg} / \mathrm{kg}(\mathrm{ppm})$ & $2.0(\mathrm{~L})$ & $25.0(\mathrm{~L})$ \\
\hline Arsenic & $\mathrm{mg} / \mathrm{kg}(\mathrm{ppm})$ & $6.0(P)$ & $33.0(P)$ \\
\hline Barium & $\mathrm{mg} / \mathrm{kg}(\mathrm{ppm})$ & -- & -- \\
\hline Beryllium & $\mathrm{mg} / \mathrm{kg}(\mathrm{ppm})$ & -- & -- \\
\hline Cadmium & $\mathrm{mg} / \mathrm{kg}(\mathrm{ppm})$ & $0.6(P)$ & $9.0(\mathrm{~L})$ \\
\hline Calcium & $\mathrm{mg} / \mathrm{kg}(\mathrm{ppm})$ & -- & -- \\
\hline Chromium & $\mathrm{mg} / \mathrm{kg}(\mathrm{ppm})$ & $26.0(P)$ & $110.0(P)$ \\
\hline Cobalt & $\mathrm{mg} / \mathrm{kg}(\mathrm{ppm})$ & -- & -- \\
\hline Copper & $\mathrm{mg} / \mathrm{kg}(\mathrm{ppm})$ & $16.0(\mathrm{P})$ & $110.0(P)$ \\
\hline Iron & $\%$ & $2.0(P)$ & $4.0(P)$ \\
\hline Lead & $\mathrm{mg} / \mathrm{kg}(\mathrm{ppm})$ & $31.0(P)$ & $110.0(\mathrm{~L})$ \\
\hline Magnesium & $\mathrm{mg} / \mathrm{kg}(\mathrm{ppm})$ & -- & -- \\
\hline Manganese & $\mathrm{mg} / \mathrm{kg}(\mathrm{ppm})$ & $460.0(\mathrm{P})$ & $1,100.0(\mathrm{~L})$ \\
\hline Mercury & $\mathrm{mg} / \mathrm{kg}(\mathrm{ppm})$ & $0.15(\mathrm{~L})$ & $1.3(\mathrm{~L})$ \\
\hline Nickel & $\mathrm{mg} / \mathrm{kg}(\mathrm{ppm})$ & $16.0(\mathrm{P})$ & $50.0(\mathrm{~L})$ \\
\hline Potassium & $\mathrm{mg} / \mathrm{kg}(\mathrm{ppm})$ & -- & -- \\
\hline Selenium & $\mathrm{mg} / \mathrm{kg}(\mathrm{ppm})$ & -- & -- \\
\hline Silver & $\mathrm{mg} / \mathrm{kg}(\mathrm{ppm})$ & $1.0(\mathrm{~L})$ & $2.2(\mathrm{~L})$ \\
\hline Sodium & $\mathrm{mg} / \mathrm{kg}(\mathrm{ppm})$ & -- & -- \\
\hline Thallium & $\mathrm{mg} / \mathrm{kg}(\mathrm{ppm})$ & -- & -- \\
\hline Vanadium & $\mathrm{mg} / \mathrm{kg}(\mathrm{ppm})$ & -- & -- \\
\hline Zinc & $\mathrm{mg} / \mathrm{kg}(\mathrm{ppm})$ & $120.0(\mathrm{P} / \mathrm{L})$ & $270.0(\mathrm{~L})$ \\
\hline
\end{tabular}

$L$ - An " $L$ " following a criterion indicates that it was taken from Long and Morgan (1990).

$P$ - A "P" following a criterion indicates that it was taken from Persaud et al. (1992).

-- No reference value available for these analytes

a Source: New York State Department of Environmental Conservation "Technical Guidance for Screening Contaminated Sediments," January 1999

$b$ The Lowest Effect Level for each metal is the lowest of the either the Persaud et al. (1992) Lowest Effect Level or the Long and Morgan (1990) Effect Range-Low

c The Severe Effect Level for each metal is the lowest of either the Persaud et al. (1992) Severe Effect Level or the Long and Morgan (1990) Effect Range-Moderate 
TABLE F-2G

\section{Screening Thresholds for In-Water and Riparian Management of Sediment and Dredge} Material $^{a}$

\begin{tabular}{|l|c|c|}
\hline \multicolumn{1}{|c|}{ Analyte } & Units & No Appreciable Contamination Level \\
\hline Arsenic & $\mathrm{mg} / \mathrm{kg}(\mathrm{ppm})$ & $<14$ \\
\hline Cadmium & $\mathrm{mg} / \mathrm{kg}(\mathrm{ppm})$ & $<1.2$ \\
\hline Copper & $\mathrm{mg} / \mathrm{kg}(\mathrm{ppm})$ & $<33$ \\
\hline Lead & $\mathrm{mg} / \mathrm{kg}(\mathrm{ppm})$ & $<33$ \\
\hline Mercury & $\mathrm{mg} / \mathrm{kg}(\mathrm{ppm})$ & $<0.17$ \\
\hline
\end{tabular}

a Source: Draft New York State Department of Environmental Conservation Technical and Operational Guidance Series (TOGS) \#5.1.9, “In-Water and Riparian Management of Sediment and Dredge Material”

TABLE F-2H

Radionuclide Comparison Values for Soils

\begin{tabular}{|c|c|c|c|c|}
\hline \multirow{2}{*}{ Radionuclide } & \multirow{2}{*}{ Units } & \multicolumn{2}{|c|}{ Consultation Triggers for Soil Contamination ${ }^{a}$} & \multirow{2}{*}{$\begin{array}{l}\text { NUREG-1757 Screening Values of } \\
\text { Common Radionuclides for Soil } \\
\text { Surface Contamination Levels }\end{array}$} \\
\hline & & $\begin{array}{l}\text { Residential Soil } \\
\text { Concentration }\end{array}$ & $\begin{array}{c}\text { Industrial/Commercial } \\
\text { Concentration }\end{array}$ & \\
\hline Co-60 & $\mu \mathrm{Ci} / \mathrm{g}$ & $4 \mathrm{E}-06$ & $6 \mathrm{E}-06$ & $3.8 \mathrm{E}-06$ \\
\hline Sr-90 & $\mu \mathrm{Ci} / \mathrm{g}$ & -- & -- & 1.7E-06 \\
\hline Sr-90+D ${ }^{c}$ & $\mu \mathrm{Ci} / \mathrm{g}$ & $2.3 \mathrm{E}-05$ & $1.07 \mathrm{E}-03$ & -- \\
\hline Cs-137 & $\mu \mathrm{Ci} / \mathrm{g}$ & -- & -- & $1.1 \mathrm{E}-05$ \\
\hline Cs-137+D ${ }^{c}$ & $\mu \mathrm{Ci} / \mathrm{g}$ & $6 \mathrm{E}-06$ & $1.1 \mathrm{E}-05$ & -- \\
\hline U-234 & $\mu \mathrm{Ci} / \mathrm{g}$ & 4.01E-04 & $3.31 \mathrm{E}-03$ & $1.3 \mathrm{E}-05$ \\
\hline U-235 & $\mu \mathrm{Ci} / \mathrm{g}$ & - & - & $8 \mathrm{E}-06$ \\
\hline $\mathrm{U}-235+\mathrm{D}^{c}$ & $\mu \mathrm{Ci} / \mathrm{g}$ & 2.0E-05 & $3.9 \mathrm{E}-05$ & 2.9E-07 \\
\hline U-238 & $\mu \mathrm{Ci} / \mathrm{g}$ & -- & -- & $1.4 \mathrm{E}-05$ \\
\hline $\mathrm{U}-238+\mathrm{D}^{c}$ & $\mu \mathrm{Ci} / \mathrm{g}$ & 7.4E-05 & 1.79E-04 & $5 \mathrm{E}-07$ \\
\hline Total U & $\mu \mathrm{g} / \mathrm{g}$ & 4.7E+01 & $1.23 \mathrm{E}+03$ & -- \\
\hline \begin{tabular}{|l} 
Pu-238 \\
\end{tabular} & $\mu \mathrm{Ci} / \mathrm{g}$ & 2.97E-04 & 1.64E-03 & $2.5 \mathrm{E}-06$ \\
\hline Pu-239 & $\mu \mathrm{Ci} / \mathrm{g}$ & $2.59 \mathrm{E}-04$ & $1.43 \mathrm{E}-03$ & $2.3 \mathrm{E}-06$ \\
\hline Am-241 & $\mu \mathrm{Ci} / \mathrm{g}$ & $1.87 \mathrm{E}-04$ & 5.68E-04 & $2.1 \mathrm{E}-06$ \\
\hline
\end{tabular}

-- No reference trigger available

a Memorandum of Understanding between the Environmental Protection Agency and the Nuclear Regulatory Commission "Consultation and Finality on Decommissioning and Decontamination of Contaminated Sites," September 2002.

${ }_{b}$ U.S. Nuclear Regulatory Commission. Consolidated Decommissioning Guidance: Characterization, Survey, and Determination of Radiological Criteria. NUREG-1757, Vol. 2, Rev. 1. September 2006.

c Concentrations apply to the parent radionuclide but assume that the daughter products are present in equilibrium. 
This page intentionally left blank 


\section{APPENDIX F-3}

\section{Radiological Results for 2008 Subsurface Soil and Groundwater From the WVDP North Plateau}

TABLE F-3A

Comparison of Radiological Concentrations in Subsurface Soil With Background

\begin{tabular}{|c|c|c|c|c|}
\hline Location & Depth & Constituent & Result $(\mu \mathrm{Ci} / g)$ & $\begin{array}{l}\text { Greater Than } \\
\text { Background? }\end{array}$ \\
\hline GP10008 & $4-6^{\prime}$ & Americium-241 & $9.64 \pm 5.64 \mathrm{E}-08$ & Yes \\
\hline GP10008 & $4-6^{\prime}$ & Cesium-137 & $1.49 \pm 0.52 E-07$ & Yes \\
\hline GP10008 & $4-6^{\prime}$ & Gross Alpha & $9.80 \pm 3.16 \mathrm{E}-06$ & No \\
\hline GP10008 & $4-6^{\prime}$ & Gross Beta & $1.43 \pm 0.31 \mathrm{E}-05$ & No \\
\hline GP10008 & $4-6^{\prime}$ & Plutonium-238 & $2.73 \pm 2.29 E-08$ & Yes \\
\hline GP10008 & $4-6^{\prime}$ & Plutonium-239/240 & $6.04 \pm 3.35 \mathrm{E}-08$ & Yes \\
\hline GP10008 & $4-6^{\prime}$ & Potassium-40 & $1.29 \pm 0.16 \mathrm{E}-05$ & No \\
\hline GP10008 & $4-6^{\prime}$ & Strontium-90 & $2.66 \pm 0.83 \mathrm{E}-07$ & Yes \\
\hline GP10008 & $4-6^{\prime}$ & Tritium Solid & $1.06 \pm 0.07 E-05$ & Yes \\
\hline GP10008 & $4-6^{\prime}$ & Uranium-233/234 & $6.36 \pm 1.11 \mathrm{E}-07$ & No \\
\hline GP10008 & $4-6^{\prime}$ & Uranium-235/236 & $4.93 \pm 3.14 \mathrm{E}-08$ & No \\
\hline GP10008 & $4-6^{\prime}$ & Uranium-238 & $6.90 \pm 1.16 \mathrm{E}-07$ & No \\
\hline GP10008 & $10-12^{\prime}$ & Cesium-137 & $8.28 \pm 0.94 \mathrm{E}-06$ & Yes \\
\hline GP10008 & $10-12^{\prime}$ & Gross Alpha & $9.54 \pm 6.00 \mathrm{E}-06$ & No \\
\hline GP10008 & $10-12^{\prime}$ & Gross Beta & $3.13 \pm 0.04 \mathrm{E}-03$ & Yes \\
\hline GP10008 & $10-12^{\prime}$ & lodine-129 & $3.03 \pm 2.17 \mathrm{E}-07$ & Yes \\
\hline GP10008 & $10-12^{\prime}$ & Potassium-40 & $1.40 \pm 0.27 \mathrm{E}-05$ & No \\
\hline GP10008 & $10-12^{\prime}$ & Strontium-90 & $1.64 \pm 0.03 E-03$ & Yes \\
\hline GP10008 & $10-12^{\prime}$ & Tritium Solid & $1.42 \pm 0.08 \mathrm{E}-05$ & Yes \\
\hline GP10008 & $10-12^{\prime}$ & Uranium-233/234 & $4.06 \pm 3.81 \mathrm{E}-06$ & No \\
\hline GP10008 & $16-18^{\prime}$ & Cesium-137 & $2.26 \pm 0.23 \mathrm{E}-05$ & Yes \\
\hline GP10008 & $16-18^{\prime}$ & Gross Alpha & $8.46 \pm 3.54 \mathrm{E}-06$ & No \\
\hline GP10008 & $16-18^{\prime}$ & Gross Beta & $1.37 \pm 0.01 \mathrm{E}-02$ & Yes \\
\hline GP10008 & $16-18^{\prime}$ & Potassium-40 & $9.80 \pm 3.37 \mathrm{E}-06$ & No \\
\hline GP10008 & $16-18^{\prime}$ & Strontium-90 & $7.93 \pm 0.06 \mathrm{E}-03$ & Yes \\
\hline GP10008 & $16-18^{\prime}$ & Tritium Solid & $9.35 \pm 0.74 \mathrm{E}-06$ & Yes \\
\hline GP10008 & $18-20^{\prime}$ & Cesium-137 & $6.42 \pm 0.87 \mathrm{E}-06$ & Yes \\
\hline GP10008 & $18-20^{\prime}$ & Gross Alpha & $7.60 \pm 4.76 \mathrm{E}-06$ & No \\
\hline GP10008 & $18-20^{\prime}$ & Gross Beta & $8.40 \pm 0.06 \mathrm{E}-03$ & Yes \\
\hline GP10008 & $18-20^{\prime}$ & Potassium-40 & $1.60 \pm 0.36 \mathrm{E}-05$ & No \\
\hline GP10008 & $18-20^{\prime}$ & Strontium-90 & $4.93 \pm 0.05 E-03$ & Yes \\
\hline GP10008 & $18-20^{\prime}$ & Tritium Solid & $9.77 \pm 5.48 \mathrm{E}-07$ & No \\
\hline GP10008 & $30-32^{\prime}$ & Cesium-137 & $7.15 \pm 3.35 E-08$ & Yes \\
\hline GP10008 & $30-32^{\prime}$ & Gross Alpha & $7.96 \pm 2.83 \mathrm{E}-06$ & No \\
\hline GP10008 & $30-32^{\prime}$ & Gross Beta & $8.00 \pm 0.58 \mathrm{E}-05$ & Yes \\
\hline GP10008 & $30-32^{\prime}$ & Potassium-40 & $2.39 \pm 0.17 \mathrm{E}-05$ & Yes \\
\hline GP10008 & $30-32^{\prime}$ & Strontium-90 & $2.54 \pm 0.06 \mathrm{E}-05$ & Yes \\
\hline GP10008 & $30-32^{\prime}$ & Tritium Solid & $5.78 \pm 4.88 \mathrm{E}-07$ & No \\
\hline GP10008 & $30-32^{\prime}$ & Uranium-233/234 & $8.78 \pm 1.38 \mathrm{E}-07$ & Yes \\
\hline GP10008 & $30-32^{\prime}$ & Uranium-235/236 & $4.36 \pm 3.34 \mathrm{E}-08$ & No \\
\hline GP10008 & $30-32^{\prime}$ & Uranium-238 & $1.01 \pm 0.15 \mathrm{E}-06$ & Yes \\
\hline GP10008 & $32-34^{\prime}$ & Gross Alpha & $7.92 \pm 3.49 \mathrm{E}-06$ & No \\
\hline GP10008 & $32-34^{\prime}$ & Gross Beta & $2.40 \pm 0.40 \mathrm{E}-05$ & No \\
\hline
\end{tabular}

Note: Due to the large volume of data, only positive detections are presented. No screening criteria for subsurface soil are available. However, dose-based derived concentration guidelines specific to WVDP subsurface soil have been proposed in the draft Phase I Decommissioning Plan (DOE, March 2009). 
TABLE F-3A (continued)

Comparison of Radiological Concentrations in Subsurface Soil With Background

\begin{tabular}{|c|c|c|c|c|}
\hline Location & Depth & Constituent & Result $(\mu \mathrm{Ci} / g)$ & $\begin{array}{l}\text { Greater Than } \\
\text { Background? }\end{array}$ \\
\hline GP10008 & $32-34^{\prime}$ & Potassium-40 & $1.54 \pm 0.13 E-05$ & No \\
\hline GP10008 & $32-34^{\prime}$ & Strontium-90 & $2.53 \pm 0.20 \mathrm{E}-06$ & Yes \\
\hline GP10008 & $32-34^{\prime}$ & Uranium-233/234 & $7.66 \pm 1.24 \mathrm{E}-07$ & No \\
\hline GP10008 & $32-34^{\prime}$ & Uranium-235/236 & $5.79 \pm 3.42 E-08$ & No \\
\hline GP10008 & $32-34^{\prime}$ & Uranium-238 & $8.02 \pm 1.27 E-07$ & No \\
\hline GP10008 & $37-39^{\prime}$ & Gross Alpha & $6.96 \pm 3.00 \mathrm{E}-06$ & No \\
\hline GP10008 & $37-39^{\prime}$ & Gross Beta & $4.87 \pm 0.49 \mathrm{E}-05$ & Yes \\
\hline GP10008 & $37-39^{\prime}$ & Potassium-40 & $2.25 \pm 0.20 \mathrm{E}-05$ & No \\
\hline GP10008 & $37-39^{\prime}$ & Strontium-90 & $6.43 \pm 0.28 \mathrm{E}-06$ & $\overline{Y e s}$ \\
\hline GP10008 & $37-39^{\prime}$ & Uranium-233/234 & $1.04 \pm 0.20 \mathrm{E}-06$ & Yes \\
\hline GP10008 & $37-39^{\prime}$ & Uranium-235/236 & $7.82 \pm 5.99 \mathrm{E}-08$ & No \\
\hline GP10008 & $37-39^{\prime}$ & Uranium-238 & $1.26 \pm 0.22 \mathrm{E}-06$ & Yes \\
\hline GP10108 & $4-6^{\prime}$ & Americium-241 & $1.97 \pm 0.65 \mathrm{E}-07$ & Yes \\
\hline GP10108 & $4-6^{\prime}$ & Cesium-137 & $4.11 \pm 0.33 \mathrm{E}-06$ & Yes \\
\hline GP10108 & $4-6^{\prime}$ & Gross Alpha & $8.89 \pm 3.71 \mathrm{E}-06$ & No \\
\hline GP10108 & $4-6^{\prime}$ & Gross Beta & $2.73 \pm 0.32 \mathrm{E}-05$ & No \\
\hline GP10108 & $4-6^{\prime}$ & Plutonium-238 & $3.06 \pm 2.36 \mathrm{E}-08$ & Yes \\
\hline GP10108 & $4-6^{\prime}$ & Plutonium-239/240 & $6.34 \pm 3.32 \mathrm{E}-08$ & Yes \\
\hline GP10108 & $4-6^{\prime}$ & Potassium-40 & $1.97 \pm 0.19 \mathrm{E}-05$ & No \\
\hline GP10108 & $4-6^{\prime}$ & Strontium-90 & $1.29 \pm 0.13 \mathrm{E}-06$ & Yes \\
\hline GP10108 & $4-6^{\prime}$ & Uranium-233/234 & $9.20 \pm 1.47 \mathrm{E}-07$ & Yes \\
\hline GP10108 & $4-6^{\prime}$ & Uranium-235/236 & $1.39 \pm 0.59 \mathrm{E}-07$ & Yes \\
\hline GP10108 & $4-6^{\prime}$ & Uranium-238 & $8.66 \pm 1.42 \mathrm{E}-07$ & No \\
\hline GP10108 & $9-11^{\prime}$ & Gross Alpha & $9.87 \pm 4.44 \mathrm{E}-06$ & No \\
\hline GP10108 & $9-11^{\prime}$ & Gross Beta & $2.16 \pm 0.40 \mathrm{E}-05$ & No \\
\hline GP10108 & $9-11^{\prime}$ & Potassium-40 & $1.61 \pm 0.16 \mathrm{E}-05$ & No \\
\hline GP10108 & $9-11^{\prime}$ & Strontium-90 & $1.25 \pm 0.52 \mathrm{E}-07$ & Yes \\
\hline GP10108 & $9-11^{\prime}$ & Uranium-233/234 & $1.48 \pm 0.19 \mathrm{E}-06$ & Yes \\
\hline GP10108 & $9-11^{\prime}$ & Uranium-235/236 & $7.41 \pm 4.53 E-08$ & No \\
\hline GP10108 & $9-11^{\prime}$ & Uranium-238 & $1.06 \pm 0.16 \mathrm{E}-06$ & Yes \\
\hline GP10108 & $14-16^{\prime}$ & Cesium-137 & $8.84 \pm 4.78 \mathrm{E}-08$ & Yes \\
\hline GP10108 & $14-16^{\prime}$ & Gross Alpha & $9.76 \pm 4.07 \mathrm{E}-06$ & No \\
\hline GP10108 & $14-16^{\prime}$ & Gross Beta & $1.84 \pm 0.34 \mathrm{E}-05$ & No \\
\hline GP10108 & $14-16^{\prime}$ & Potassium-40 & $1.32 \pm 0.14 \mathrm{E}-05$ & No \\
\hline GP10108 & $14-16^{\prime}$ & Strontium-90 & $1.39 \pm 0.15 \mathrm{E}-06$ & Yes \\
\hline GP10108 & $14-16^{\prime}$ & Uranium-233/234 & $9.58 \pm 1.55 \mathrm{E}-07$ & Yes \\
\hline GP10108 & $14-16^{\prime}$ & Uranium-235/236 & $9.80 \pm 4.96 \mathrm{E}-08$ & No \\
\hline GP10108 & $14-16^{\prime}$ & Uranium-238 & $7.43 \pm 1.38 \mathrm{E}-07$ & No \\
\hline GP10108 & $20-22^{\prime}$ & Cesium-137 & $5.19 \pm 2.92 E-08$ & $\overline{\text { Yes }}$ \\
\hline GP10108 & $20-22^{\prime}$ & Gross Alpha & $8.40 \pm 4.30 \mathrm{E}-06$ & No \\
\hline GP10108 & $20-22^{\prime}$ & Gross Beta & $3.43 \pm 0.48 \mathrm{E}-05$ & No \\
\hline GP10108 & $20-22^{\prime}$ & Potassium-40 & $1.99 \pm 0.20 \mathrm{E}-05$ & No \\
\hline GP10108 & $20-22^{\prime}$ & Strontium-90 & $2.49 \pm 0.18 \mathrm{E}-06$ & Yes \\
\hline GP10108 & $20-22^{\prime}$ & Tritium Solid & $1.18 \pm 0.55 \mathrm{E}-06$ & No \\
\hline GP10108 & $20-22^{\prime}$ & Uranium-233/234 & $7.78 \pm 1.38 \mathrm{E}-07$ & No \\
\hline GP10108 & $20-22^{\prime}$ & Uranium-235/236 & $4.76 \pm 3.69 \mathrm{E}-08$ & No \\
\hline GP10108 & $20-22^{\prime}$ & Uranium-238 & $9.38 \pm 1.46 \mathrm{E}-07$ & Yes \\
\hline
\end{tabular}

Note: Due to the large volume of data, only positive detections are presented. No screening criteria for subsurface soil are available. However, dose-based derived concentration guidelines specific to WVDP subsurface soil have been proposed in the draft Phase I Decommissioning Plan (DOE, March 2009). 
TABLE F-3A (continued)

Comparison of Radiological Concentrations in Subsurface Soil With Background

\begin{tabular}{|c|c|c|c|c|}
\hline Location & Depth & Constituent & Result $(\mu \mathrm{Ci} / g)$ & $\begin{array}{l}\text { Greater Than } \\
\text { Background? }\end{array}$ \\
\hline GP10108 & $32-34^{\prime}$ & Gross Alpha & $8.09 \pm 3.80 \mathrm{E}-06$ & No \\
\hline GP10108 & $32-34^{\prime}$ & Gross Beta & $2.06 \pm 0.34 \mathrm{E}-05$ & No \\
\hline GP10108 & $32-34^{\prime}$ & Potassium-40 & $1.82 \pm 0.22 \mathrm{E}-05$ & No \\
\hline GP10108 & $32-34^{\prime}$ & Strontium-90 & $6.31 \pm 0.81 E-07$ & Yes \\
\hline GP10108 & $32-34^{\prime}$ & Uranium-233/234 & $6.02 \pm 1.33 \mathrm{E}-07$ & No \\
\hline GP10108 & $32-34^{\prime}$ & Uranium-235/236 & $5.03 \pm 3.48 \mathrm{E}-08$ & No \\
\hline GP10108 & $32-34^{\prime}$ & Uranium-238 & $7.27 \pm 1.33 \mathrm{E}-07$ & No \\
\hline GP10208 & $14-16^{\prime}$ & Americium-241 & $1.35 \pm 0.63 \mathrm{E}-07$ & Yes \\
\hline GP10208 & $14-16^{\prime}$ & Cesium-137 & $1.05 \pm 0.10 \mathrm{E}-06$ & Yes \\
\hline GP10208 & $14-16^{\prime}$ & Gross Alpha & $1.23 \pm 0.38 \mathrm{E}-05$ & No \\
\hline GP10208 & $14-16^{\prime}$ & Gross Beta & $4.10 \pm 0.10 \mathrm{E}-04$ & Yes \\
\hline GP10208 & $14-16^{\prime}$ & Plutonium-239/240 & $4.92 \pm 3.06 \mathrm{E}-08$ & Yes \\
\hline GP10208 & $14-16^{\prime}$ & Plutonium-241 & $3.18 \pm 2.70 \mathrm{E}-07$ & No \\
\hline GP10208 & $14-16^{\prime}$ & Potassium-40 & $2.25 \pm 0.18 \mathrm{E}-05$ & No \\
\hline GP10208 & $14-16^{\prime}$ & Strontium-90 & $2.20 \pm 0.02 \mathrm{E}-04$ & Yes \\
\hline GP10208 & $14-16^{\prime}$ & Uranium-232 & $9.10 \pm 5.15 E-08$ & Yes \\
\hline GP10208 & $14-16^{\prime}$ & Uranium-233/234 & $1.28 \pm 0.16 \mathrm{E}-06$ & Yes \\
\hline GP10208 & $14-16^{\prime}$ & Uranium-235/236 & $3.49 \pm 0.86 \mathrm{E}-07$ & Yes \\
\hline GP10208 & $14-16^{\prime}$ & Uranium-238 & $1.37 \pm 0.17 \mathrm{E}-06$ & Yes \\
\hline GP10208 & $16-18^{\prime}$ & Americium-241 & $4.25 \pm 3.32 \mathrm{E}-08$ & Yes \\
\hline GP10208 & $16-18^{\prime}$ & Cesium-137 & $1.30 \pm 0.69 \mathrm{E}-07$ & Yes \\
\hline GP10208 & $16-18^{\prime}$ & Gross Alpha & $1.68 \pm 0.70 \mathrm{E}-05$ & No \\
\hline GP10208 & $16-18$ & Gross Beta & $3.20 \pm 0.14 \mathrm{E}-04$ & Yes \\
\hline GP10208 & $16-18^{\prime}$ & Potassium-40 & $1.93 \pm 0.19 \mathrm{E}-05$ & No \\
\hline GP10208 & $16-18^{\prime}$ & Strontium-90 & $1.45 \pm 0.01 E-04$ & Yes \\
\hline GP10208 & $16-18^{\prime}$ & Uranium-232 & $4.43 \pm 4.05 E-08$ & No \\
\hline GP10208 & $16-18^{\prime}$ & Uranium-233/234 & $1.04 \pm 0.14 \mathrm{E}-06$ & Yes \\
\hline GP10208 & $16-18^{\prime}$ & Uranium-235/236 & $1.70 \pm 0.60 \mathrm{E}-07$ & Yes \\
\hline GP10208 & $16-18^{\prime}$ & Uranium-238 & $1.17 \pm 0.15 \mathrm{E}-06$ & Yes \\
\hline GP10208 & $20-22^{\prime}$ & Gross Alpha & $6.70 \pm 4.12 \mathrm{E}-06$ & No \\
\hline GP10208 & $20-22^{\prime}$ & Gross Beta & $4.79 \pm 0.58 \mathrm{E}-05$ & Yes \\
\hline GP10208 & $20-22^{\prime}$ & lodine-129 & $2.14 \pm 1.87 \mathrm{E}-07$ & No \\
\hline GP10208 & $20-22^{\prime}$ & Potassium-40 & $1.87 \pm 0.20 \mathrm{E}-05$ & No \\
\hline GP10208 & $20-22^{\prime}$ & Strontium-90 & $1.28 \pm 0.04 \mathrm{E}-05$ & Yes \\
\hline GP10208 & $20-22^{\prime}$ & Uranium-233/234 & $7.76 \pm 1.17 \mathrm{E}-07$ & No \\
\hline GP10208 & $20-22^{\prime}$ & Uranium-235/236 & $1.09 \pm 0.45 \mathrm{E}-07$ & Yes \\
\hline GP10208 & $20-22^{\prime}$ & Uranium-238 & $7.48 \pm 1.15 \mathrm{E}-07$ & No \\
\hline GP10308 & $16-18^{\prime}$ & Gross Alpha & $8.16 \pm 3.76 \mathrm{E}-06$ & No \\
\hline GP10308 & $16-18^{\prime}$ & Gross Beta & $2.30 \pm 0.38 \mathrm{E}-05$ & No \\
\hline GP10308 & $16-18^{\prime}$ & Potassium-40 & $1.47 \pm 0.12 \mathrm{E}-05$ & No \\
\hline GP10308 & $16-18^{\prime}$ & Strontium-90 & $2.46 \pm 0.63 \mathrm{E}-07$ & Yes \\
\hline GP10308 & $16-18^{\prime}$ & Uranium-233/234 & $7.03 \pm 1.30 \mathrm{E}-07$ & No \\
\hline GP10308 & $16-18$ & Uranium-235/236 & $8.89 \pm 5.32 \mathrm{E}-08$ & No \\
\hline GP10308 & $16-18^{\prime}$ & Uranium-238 & $7.80 \pm 1.33 \mathrm{E}-07$ & No \\
\hline
\end{tabular}

Note: Due to the large volume of data, only positive detections are presented. No screening criteria for subsurface soil are available. However, dose-based derived concentration guidelines specific to WVDP subsurface soil have been proposed in the draft Phase I Decommissioning Plan (DOE, March 2009). 
TABLE F-3A (continued)

Comparison of Radiological Concentrations in Subsurface Soil With Background

\begin{tabular}{|c|c|c|c|c|}
\hline Location & Depth & Constituent & Result ( $\mu \mathrm{Ci} / g)$ & $\begin{array}{l}\text { Greater Than } \\
\text { Background? }\end{array}$ \\
\hline GP10308 & $30-32^{\prime}$ & Gross Alpha & $6.96 \pm 5.69 \mathrm{E}-06$ & No \\
\hline GP10308 & $30-32^{\prime}$ & Gross Beta & $2.03 \pm 0.02 \mathrm{E}-03$ & Yes \\
\hline GP10308 & $30-32^{\prime}$ & Potassium-40 & $1.90 \pm 0.14 \mathrm{E}-05$ & No \\
\hline GP10308 & $30-32^{\prime}$ & Strontium-90 & $1.06 \pm 0.02 \mathrm{E}-03$ & Yes \\
\hline GP10308 & $30-32^{\prime}$ & Uranium-233/234 & $8.88 \pm 1.49 E-07$ & Yes \\
\hline GP10308 & $30-32^{\prime}$ & Uranium-235/236 & $1.14 \pm 0.58 \mathrm{E}-07$ & No \\
\hline GP10308 & $30-32^{\prime}$ & Uranium-238 & $7.62 \pm 1.36 \mathrm{E}-07$ & No \\
\hline GP10308 & $34-36^{\prime}$ & Gross Alpha & $7.12 \pm 3.70 \mathrm{E}-06$ & No \\
\hline GP10308 & $34-36^{\prime}$ & Gross Beta & $5.77 \pm 0.52 \mathrm{E}-05$ & Yes \\
\hline GP10308 & $34-36^{\prime}$ & Potassium-40 & $2.21 \pm 0.20 \mathrm{E}-05$ & No \\
\hline GP10308 & $34-36^{\prime}$ & Strontium-90 & $1.85 \pm 0.05 \mathrm{E}-05$ & Yes \\
\hline GP10308 & $34-36^{\prime}$ & Uranium-233/234 & $7.30 \pm 1.37 \mathrm{E}-07$ & No \\
\hline GP10308 & $34-36^{\prime}$ & Uranium-235/236 & $6.01 \pm 4.71 \mathrm{E}-08$ & No \\
\hline GP10308 & $34-36$ & Uranium-238 & $8.98 \pm 1.44 \mathrm{E}-07$ & No \\
\hline GP10308 & $34-36^{\prime}$ (dup) & Gross Alpha & $7.20 \pm 3.99 \mathrm{E}-06$ & No \\
\hline GP10308 & 34-36' (dup) & Gross Beta & $3.88 \pm 0.48 \mathrm{E}-05$ & Yes \\
\hline GP10308 & $34-36$ (dup) & Potassium-40 & $2.21 \pm 0.17 \mathrm{E}-05$ & No \\
\hline GP10308 & $34-36^{\prime}$ (dup) & Strontium-90 & $8.62 \pm 0.32 \mathrm{E}-06$ & Yes \\
\hline GP10308 & 34-36' (dup) & Uranium-233/234 & $1.02 \pm 0.16 \mathrm{E}-06$ & Yes \\
\hline GP10308 & $34-36^{\prime}$ (dup) & Uranium-235/236 & $1.15 \pm 0.53 \mathrm{E}-07$ & Yes \\
\hline GP10308 & $34-36^{\prime}$ (dup) & Uranium-238 & $8.04 \pm 1.42 \mathrm{E}-07$ & No \\
\hline GP10408 & $16-18^{\prime}$ & Gross Alpha & $1.13 \pm 0.36 \mathrm{E}-05$ & No \\
\hline GP10408 & $16-18^{\prime}$ & Gross Alpha & $6.93 \pm 2.57 \mathrm{E}-06$ & No \\
\hline GP10408 & $16-18^{\prime}$ & Gross Beta & $2.60 \pm 0.40 \mathrm{E}-05$ & No \\
\hline GP10408 & $16-18^{\prime}$ & Gross Beta & $1.86 \pm 0.32 \mathrm{E}-05$ & No \\
\hline GP10408 & $16-18^{\prime}$ & Potassium-40 & $1.74 \pm 0.17 \mathrm{E}-05$ & No \\
\hline GP10408 & $16-18$ & Potassium-40 & $1.82 \pm 0.17 \mathrm{E}-05$ & No \\
\hline GP10408 & $16-18^{\prime}$ & Strontium-90 & $5.82 \pm 0.26 \mathrm{E}-06$ & Yes \\
\hline GP10408 & $16-18$ & Strontium-90 & $1.23 \pm 0.52 \mathrm{E}-07$ & Yes \\
\hline GP10408 & $16-18^{\prime}$ & Uranium-233/234 & $7.28 \pm 1.14 \mathrm{E}-07$ & No \\
\hline GP10408 & $16-18^{\prime}$ & Uranium-233/234 & $7.59 \pm 1.23 \mathrm{E}-07$ & No \\
\hline GP10408 & $16-18$ & Uranium-235/236 & $8.84 \pm 3.98 \mathrm{E}-08$ & No \\
\hline GP10408 & $16-18^{\prime}$ & Uranium-235/236 & $2.01 \pm 0.64 \mathrm{E}-07$ & $\overline{Y e s}$ \\
\hline GP10408 & $16-18$ & Uranium-238 & $7.54 \pm 1.16 \mathrm{E}-07$ & No \\
\hline GP10408 & $16-18$ & Uranium-238 & $8.50 \pm 1.31 \mathrm{E}-07$ & No \\
\hline GP10408 & $20-22^{\prime}$ & Gross Alpha & $1.26 \pm 0.42 \mathrm{E}-05$ & No \\
\hline GP10408 & $20-22^{\prime}$ & Gross Beta & $8.44 \pm 0.20 \mathrm{E}-04$ & Yes \\
\hline GP10408 & $20-22^{\prime}$ & Potassium-40 & $1.59 \pm 0.22 \mathrm{E}-05$ & No \\
\hline GP10408 & $20-22^{\prime}$ & Strontium-90 & $3.95 \pm 0.03 E-04$ & Yes \\
\hline GP10408 & $20-22^{\prime}$ & Uranium-232 & $5.02 \pm 3.32 \mathrm{E}-08$ & Yes \\
\hline GP10408 & $20-22^{\prime}$ & Uranium-233/234 & $6.73 \pm 1.09 \mathrm{E}-07$ & No \\
\hline GP10408 & $20-22^{\prime}$ & Uranium-235/236 & $9.09 \pm 3.98 \mathrm{E}-08$ & No \\
\hline GP10408 & $20-22^{\prime}$ & Uranium-238 & $6.43 \pm 1.06 \mathrm{E}-07$ & No \\
\hline GP10408 & $22-24^{\prime}$ & Gross Alpha & $8.33 \pm 3.59 \mathrm{E}-06$ & No \\
\hline GP10408 & $22-24^{\prime}$ & Gross Beta & $1.21 \pm 0.02 \mathrm{E}-03$ & Yes \\
\hline GP10408 & $22-24^{\prime}$ & Potassium-40 & $3.02 \pm 0.27 E-05$ & $\overline{Y e s}$ \\
\hline GP10408 & $22-24^{\prime}$ & Strontium-90 & $4.78 \pm 0.02 E-04$ & Yes \\
\hline GP10408 & $22-24$ & Uranium-233/234 & $9.23 \pm 1.35 \mathrm{E}-07$ & Yes \\
\hline GP10408 & $22-24^{\prime}$ & Uranium-235/236 & $1.23 \pm 0.51 \mathrm{E}-07$ & Yes \\
\hline GP10408 & $22-24^{\prime}$ & Uranium-238 & $1.13 \pm 0.15 \mathrm{E}-06$ & Yes \\
\hline
\end{tabular}

Note: Due to the large volume of data, only positive detections are presented. No screening criteria for subsurface soil are available. However, dose-based derived concentration guidelines specific to WVDP subsurface soil have been proposed in the draft Phase I Decommissioning Plan (DOE, March 2009). 
TABLE F-3A (continued)

Comparison of Radiological Concentrations in Subsurface Soil With Background

\begin{tabular}{|c|c|c|c|c|}
\hline Location & Depth & Constituent & Result $(\mu \mathrm{Ci} / g)$ & $\begin{array}{l}\text { Greater Than } \\
\text { Background? }\end{array}$ \\
\hline GP10408 & $24-26^{\prime}$ & Gross Alpha & $5.33 \pm 2.38 \mathrm{E}-06$ & No \\
\hline GP10408 & $24-26^{\prime}$ & Gross Beta & $3.88 \pm 0.43 E-05$ & Yes \\
\hline GP10408 & $24-26^{\prime}$ & Potassium-40 & $2.09 \pm 0.28 \mathrm{E}-05$ & No \\
\hline GP10408 & $24-26^{\prime}$ & Strontium-90 & $1.20 \pm 0.04 \mathrm{E}-05$ & Yes \\
\hline GP10408 & $24-26^{\prime}$ & Uranium-233/234 & $9.90 \pm 1.98 \mathrm{E}-07$ & Yes \\
\hline GP10408 & $24-26^{\prime}$ & Uranium-235/236 & $7.61 \pm 5.65 \mathrm{E}-08$ & No \\
\hline GP10408 & $24-26^{\prime}$ & Uranium-238 & $8.60 \pm 1.83 \mathrm{E}-07$ & No \\
\hline GP10508 & $10-12^{\prime}$ & Gross Alpha & $6.18 \pm 4.72 \mathrm{E}-06$ & No \\
\hline GP10508 & $10-12^{\prime}$ & Gross Beta & $2.94 \pm 1.29 E-05$ & No \\
\hline GP10508 & $10-12^{\prime}$ & Potassium-40 & $1.73 \pm 0.30 \mathrm{E}-05$ & No \\
\hline GP10508 & $10-12^{\prime}$ & Strontium-90 & $2.14 \pm 0.66 \mathrm{E}-06$ & Yes \\
\hline GP10508 & $10-12^{\prime}$ & Tritium Solid & $6.70 \pm 3.53 \mathrm{E}-06$ & No \\
\hline GP10508 & $12-14^{\prime}$ & Cobalt-60 & $1.93 \pm 1.72 \mathrm{E}-07$ & Yes \\
\hline GP10508 & $12-14^{\prime}$ & Gross Alpha & $9.47 \pm 4.75 \mathrm{E}-06$ & No \\
\hline GP10508 & $12-14^{\prime}$ & Gross Beta & $2.19 \pm 1.08 \mathrm{E}-05$ & No \\
\hline GP10508 & $12-14^{\prime}$ & Potassium-40 & $1.57 \pm 0.32 \mathrm{E}-05$ & No \\
\hline GP10508 & $12-14^{\prime}$ & Tritium Solid & $4.45 \pm 3.49 \mathrm{E}-06$ & No \\
\hline GP10508 & $28-30^{\prime}$ & Gross Beta & $1.77 \pm 0.04 \mathrm{E}-03$ & Yes \\
\hline GP10508 & $28-30^{\prime}$ & Potassium-40 & $1.66 \pm 0.27 E-05$ & No \\
\hline GP10508 & $28-30^{\prime}$ & Strontium-90 & $7.62 \pm 0.28 \mathrm{E}-04$ & Yes \\
\hline GP10508 & $34-36^{\prime}$ & Gross Alpha & $8.30 \pm 4.70 \mathrm{E}-06$ & No \\
\hline GP10508 & $34-36^{\prime}$ & Gross Beta & $5.30 \pm 1.45 \mathrm{E}-05$ & Yes \\
\hline GP10508 & $34-36^{\prime}$ & Potassium-40 & $1.71 \pm 0.34 \mathrm{E}-05$ & No \\
\hline GP10508 & $34-36^{\prime}$ & Strontium-90 & $6.34 \pm 1.04 \mathrm{E}-06$ & Yes \\
\hline GP10508 & $34-36^{\prime}$ & Tritium Solid & $3.49 \pm 3.33 \mathrm{E}-06$ & No \\
\hline GP10508 & $34-36^{\prime}$ & Uranium-233/234 & $2.36 \pm 2.17 E-06$ & No \\
\hline GP10608 & $14-16^{\prime}$ & Gross Alpha & $5.44 \pm 2.77 \mathrm{E}-06$ & No \\
\hline GP10608 & $14-16^{\prime}$ & Gross Beta & $1.96 \pm 0.41 \mathrm{E}-05$ & No \\
\hline GP10608 & $14-16^{\prime}$ & Potassium-40 & $1.37 \pm 0.11 \mathrm{E}-05$ & No \\
\hline GP10608 & $14-16^{\prime}$ & Strontium-90 & $6.57 \pm 1.67 \mathrm{E}-07$ & Yes \\
\hline GP10608 & $14-16^{\prime}$ & Tritium Solid & $2.80 \pm 2.16 \mathrm{E}-06$ & No \\
\hline GP10608 & $14-16^{\prime}$ & Uranium-233/234 & $7.20 \pm 1.13 E-07$ & No \\
\hline GP10608 & $14-16^{\prime}$ & Uranium-235/236 & $1.20 \pm 0.46 \mathrm{E}-07$ & Yes \\
\hline GP10608 & $14-16^{\prime}$ & Uranium-238 & $7.18 \pm 1.13 \mathrm{E}-07$ & No \\
\hline GP10608 & $20-22^{\prime}$ & Gross Alpha & $1.01 \pm 0.37 \mathrm{E}-05$ & No \\
\hline GP10608 & $20-22^{\prime}$ & Gross Beta & $1.38 \pm 0.09 E-04$ & Yes \\
\hline GP10608 & $20-22^{\prime}$ & Potassium-40 & $1.68 \pm 0.17 E-05$ & No \\
\hline GP10608 & $20-22^{\prime}$ & Strontium-90 & $6.56 \pm 0.14 \mathrm{E}-05$ & Yes \\
\hline GP10608 & $20-22^{\prime}$ & Uranium-233/234 & $6.78 \pm 1.14 \mathrm{E}-07$ & No \\
\hline GP10608 & $20-22^{\prime}$ & Uranium-235/236 & $1.77 \pm 0.59 \mathrm{E}-07$ & Yes \\
\hline GP10608 & $20-22^{\prime}$ & Uranium-238 & $7.05 \pm 1.16 \mathrm{E}-07$ & No \\
\hline GP10608 & $22-24^{\prime}$ & Americium-241 & $3.42 . \pm 3.32 \mathrm{E}-08$ & Yes \\
\hline GP10608 & $22-24^{\prime}$ & Gross Alpha & $8.55 \pm 3.52 \mathrm{E}-06$ & No \\
\hline GP10608 & $22-24^{\prime}$ & Gross Beta & $2.49 \pm 0.43 E-05$ & No \\
\hline GP10608 & $22-24^{\prime}$ & Potassium-40 & $2.41 \pm 0.20 \mathrm{E}-05$ & Yes \\
\hline GP10608 & $22-24^{\prime}$ & Strontium-90 & $9.23 \pm 2.38 \mathrm{E}-07$ & Yes \\
\hline GP10608 & $22-24^{\prime}$ & Technetium-99 & $4.08 \pm 3.71 \mathrm{E}-07$ & No \\
\hline GP10608 & $22-24^{\prime}$ & Uranium-233/234 & $8.98 \pm 1.57 \mathrm{E}-07$ & Yes \\
\hline GP10608 & $22-24^{\prime}$ & Uranium-235/236 & $2.24 \pm 0.79 E-07$ & Yes \\
\hline GP10608 & $22-24^{\prime}$ & Uranium-238 & $9.16 \pm 1.59 \mathrm{E}-07$ & No \\
\hline
\end{tabular}

Note: Due to the large volume of data, only positive detections are presented. No screening criteria for subsurface soil are available. However, dose-based derived concentration guidelines specific to WVDP subsurface soil have been proposed in the draft Phase I Decommissioning Plan (DOE, March 2009). 
TABLE F-3A (continued)

Comparison of Radiological Concentrations in Subsurface Soil With Background

\begin{tabular}{|c|c|c|c|c|}
\hline Location & Depth & Constituent & Result $(\mu \mathrm{Ci} / g)$ & $\begin{array}{l}\text { Greater Than } \\
\text { Background? }\end{array}$ \\
\hline GP10708 & $12-14^{\prime}$ & Gross Alpha & $6.62 \pm 3.53 \mathrm{E}-06$ & No \\
\hline GP10708 & $12-14^{\prime}$ & Gross Beta & $3.06 \pm 0.47 \mathrm{E}-05$ & No \\
\hline GP10708 & $12-14^{\prime}$ & Potassium-40 & $1.36 \pm 0.12 \mathrm{E}-05$ & No \\
\hline GP10708 & $12-14^{\prime}$ & Strontium-90 & $2.09 \pm 0.28 \mathrm{E}-06$ & Yes \\
\hline GP10708 & $12-14^{\prime}$ & Uranium-233/234 & $6.90 \pm 1.58 \mathrm{E}-07$ & No \\
\hline GP10708 & $12-14^{\prime}$ & Uranium-235/236 & $1.85 \pm 0.83 \mathrm{E}-07$ & Yes \\
\hline GP10708 & $12-14^{\prime}$ & Uranium-238 & $8.04 \pm 1.71 \mathrm{E}-07$ & No \\
\hline GP10708 & $22-24^{\prime}$ & Gross Alpha & $6.49 \pm 3.01 \mathrm{E}-06$ & No \\
\hline GP10708 & $22-24^{\prime}$ & Gross Beta & $8.21 \pm 0.20 \mathrm{E}-04$ & Yes \\
\hline GP10708 & $22-24^{\prime}$ & Neptunium-237 & $1.86 \pm 1.52 \mathrm{E}-08$ & Yes \\
\hline GP10708 & $22-24^{\prime}$ & Potassium-40 & $1.60 \pm 0.15 E-05$ & No \\
\hline GP10708 & $22-24^{\prime}$ & Strontium-90 & $3.61 \pm 0.01 E-04$ & Yes \\
\hline GP10708 & $22-24^{\prime}$ & Uranium-233/234 & $6.87 \pm 1.28 \mathrm{E}-07$ & No \\
\hline GP10708 & $22-24^{\prime}$ & Uranium-235/236 & $5.51 \pm 3.89 \mathrm{E}-08$ & No \\
\hline GP10708 & $22-24^{\prime}$ & Uranium-238 & $6.42 \pm 1.24 \mathrm{E}-07$ & No \\
\hline GP10708 & $30-32^{\prime}$ & Gross Alpha & $9.96 \pm 3.80 \mathrm{E}-06$ & No \\
\hline GP10708 & $30-32^{\prime}$ & Gross Beta & $7.63 \pm 0.19 E-04$ & Yes \\
\hline GP10708 & $30-32^{\prime}$ & Potassium-40 & $1.50 \pm 0.14 \mathrm{E}-05$ & No \\
\hline GP10708 & $30-32^{\prime}$ & Strontium-90 & $3.79 \pm 0.01 E-04$ & Yes \\
\hline GP10708 & $30-32^{\prime}$ & Uranium-233/234 & $7.65 \pm 1.32 \mathrm{E}-07$ & No \\
\hline GP10708 & $30-32^{\prime}$ & Uranium-238 & $6.67 \pm 1.25 \mathrm{E}-07$ & No \\
\hline GP10708 & $32-34^{\prime}$ & Gross Alpha & $8.14 \pm 3.29 E-06$ & No \\
\hline GP10708 & $32-34^{\prime}$ & Gross Beta & $3.28 \pm 0.13 \mathrm{E}-04$ & Yes \\
\hline GP10708 & $32-34^{\prime}$ & Potassium-40 & $2.83 \pm 0.29 \mathrm{E}-05$ & Yes \\
\hline GP10708 & $32-34^{\prime}$ & Strontium-90 & $1.50 \pm 0.01 \mathrm{E}-04$ & Yes \\
\hline GP10708 & $32-34^{\prime}$ & Uranium-233/234 & 7.91土1.31E-07 & No \\
\hline GP10708 & $32-34^{\prime}$ & Uranium-235/236 & $5.47 \pm 3.64 \mathrm{E}-08$ & No \\
\hline GP10708 & $32-34^{\prime}$ & Uranium-238 & $8.05 \pm 1.32 \mathrm{E}-07$ & No \\
\hline GP10808 & $12-14^{\prime}$ & Americium-241 & $2.79 \pm 2.76 \mathrm{E}-08$ & Yes \\
\hline GP10808 & $12-14^{\prime}$ & Cesium-137 & $1.74 \pm 0.46 \mathrm{E}-07$ & Yes \\
\hline GP10808 & $12-14^{\prime}$ & Gross Alpha & $5.73 \pm 2.61 \mathrm{E}-06$ & No \\
\hline GP10808 & $12-14^{\prime}$ & Gross Beta & $2.42 \pm 0.41 \mathrm{E}-05$ & No \\
\hline GP10808 & $12-14^{\prime}$ & Potassium-40 & $1.46 \pm 0.14 \mathrm{E}-05$ & No \\
\hline GP10808 & $12-14^{\prime}$ & Strontium-90 & $1.32 \pm 0.10 \mathrm{E}-06$ & Yes \\
\hline GP10808 & $12-14^{\prime}$ & Uranium-233/234 & $1.01 \pm 0.15 \mathrm{E}-06$ & Yes \\
\hline GP10808 & $12-14^{\prime}$ & Uranium-235/236 & $4.27 \pm 3.76 \mathrm{E}-08$ & No \\
\hline GP10808 & $12-14^{\prime}$ & Uranium-238 & $1.07 \pm 0.15 \mathrm{E}-06$ & Yes \\
\hline GP10908 & $12-14^{\prime}$ & Gross Alpha & $6.62 \pm 3.17 \mathrm{E}-06$ & No \\
\hline GP10908 & $12-14^{\prime}$ & Gross Beta & $1.85 \pm 0.40 \mathrm{E}-05$ & No \\
\hline GP10908 & $12-14^{\prime}$ & Potassium-40 & $1.56 \pm 0.16 \mathrm{E}-05$ & No \\
\hline GP10908 & $12-14^{\prime}$ & Strontium-90 & $2.79 \pm 1.65 E-07$ & Yes \\
\hline GP10908 & $12-14^{\prime}$ & Uranium-233/234 & $7.80 \pm 1.80 \mathrm{E}-07$ & No \\
\hline GP10908 & $12-14^{\prime}$ & Uranium-235/236 & $1.29 \pm 0.73 E-07$ & No \\
\hline GP10908 & $12-14^{\prime}$ & Uranium-238 & $7.64 \pm 1.78 \mathrm{E}-07$ & No \\
\hline
\end{tabular}

Note: Due to the large volume of data, only positive detections are presented. No screening criteria for subsurface soil are available. However, dose-based derived concentration guidelines specific to WVDP subsurface soil have been proposed in the draft Phase I Decommissioning Plan (DOE, March 2009). 
TABLE F-3A (continued)

Comparison of Radiological Concentrations in Subsurface Soil With Background

\begin{tabular}{|c|c|c|c|c|}
\hline Location & Depth & Constituent & Result ( $\mu \mathrm{Ci} / g)$ & $\begin{array}{l}\text { Greater Than } \\
\text { Background? }\end{array}$ \\
\hline GP10908 & $34-36^{\prime}$ & Gross Alpha & $5.14 \pm 1.16 \mathrm{E}-06$ & No \\
\hline GP10908 & $34-36^{\prime}$ & Gross Beta & $5.20 \pm 0.07 E-04$ & Yes \\
\hline GP10908 & $34-36^{\prime}$ & Potassium-40 & $2.21 \pm 0.16 \mathrm{E}-05$ & No \\
\hline GP10908 & $34-36^{\prime}$ & Strontium-90 & $2.25 \pm 0.01 \mathrm{E}-04$ & Yes \\
\hline GP10908 & $34-36^{\prime}$ & Uranium-233/234 & $6.68 \pm 1.66 \mathrm{E}-07$ & No \\
\hline GP10908 & $34-36^{\prime}$ & Uranium-235/236 & $5.89 \pm 5.17 \mathrm{E}-08$ & No \\
\hline GP10908 & $34-36^{\prime}$ & Uranium-238 & $7.66 \pm 1.77 \mathrm{E}-07$ & No \\
\hline GP10908 & $36-38^{\prime}$ & Gross Alpha & $9.30 \pm 1.53 \mathrm{E}-06$ & No \\
\hline GP10908 & $36-38^{\prime}$ & Gross Beta & $7.30 \pm 0.28 \mathrm{E}-05$ & Yes \\
\hline GP10908 & $36-38^{\prime}$ & Potassium-40 & $3.06 \pm 0.24 \mathrm{E}-05$ & Yes \\
\hline GP10908 & $36-38^{\prime}$ & Strontium-90 & $2.02 \pm 0.03 E-05$ & Yes \\
\hline GP10908 & $36-38$ & Tritium Solid & $2.14 \pm 1.96 \mathrm{E}-06$ & No \\
\hline GP10908 & $36-38^{\prime}$ & Uranium-232 & $1.25 \pm 0.51 \mathrm{E}-07$ & Yes \\
\hline GP10908 & $36-38$ & Uranium-233/234 & $8.71 \pm 1.88 \mathrm{E}-07$ & No \\
\hline GP10908 & $36-38^{\prime}$ & Uranium-235/236 & $1.14 \pm 0.69 \mathrm{E}-07$ & No \\
\hline GP10908 & $36-38^{\prime}$ & Uranium-238 & $1.02 \pm 0.20 \mathrm{E}-06$ & Yes \\
\hline GP2908 & $2-4^{\prime}$ & Gross Alpha & $1.01 \pm 0.41 \mathrm{E}-05$ & No \\
\hline GP2908 & $2-4^{\prime}$ & Gross Beta & $1.56 \pm 0.34 \mathrm{E}-05$ & No \\
\hline GP2908 & $2-4^{\prime}$ & Plutonium-239/240 & $2.09 \pm 1.93 \mathrm{E}-08$ & No \\
\hline GP2908 & $2-4^{\prime}$ & Potassium-40 & $1.62 \pm 0.18 \mathrm{E}-05$ & No \\
\hline GP2908 & $2-4^{\prime}$ & Uranium-232 & $3.40 \pm 1.53 \mathrm{E}-08$ & Yes \\
\hline GP2908 & $2-4^{\prime}$ & Uranium-233/234 & $8.06 \pm 1.40 \mathrm{E}-07$ & No \\
\hline GP2908 & $2-4^{\prime}$ & Uranium-235/236 & $8.58 \pm 4.49 \mathrm{E}-08$ & No \\
\hline GP2908 & $2-4^{\prime}$ & Uranium-238 & $8.55 \pm 1.43 \mathrm{E}-07$ & No \\
\hline GP2908 & $7-9^{\prime}$ & Cesium-137 & $2.73 \pm 0.60 \mathrm{E}-07$ & Yes \\
\hline GP2908 & $7-9^{\prime}$ & Gross Alpha & $8.80 \pm 4.17 \mathrm{E}-06$ & No \\
\hline GP2908 & $7-9^{\prime}$ & Gross Beta & $2.07 \pm 0.38 \mathrm{E}-05$ & No \\
\hline GP2908 & $7-9^{\prime}$ & Potassium-40 & $1.61 \pm 0.18 \mathrm{E}-05$ & No \\
\hline GP2908 & $7-9^{\prime}$ & Strontium-90 & $7.26 \pm 1.12 \mathrm{E}-07$ & Yes \\
\hline GP2908 & $7-9^{\prime}$ & Uranium-233/234 & $7.48 \pm 1.36 \mathrm{E}-07$ & No \\
\hline GP2908 & $7-9^{\prime}$ & Uranium-235/236 & $7.26 \pm 4.44 \mathrm{E}-08$ & No \\
\hline GP2908 & $7-9^{\prime}$ & Uranium-238 & $9.65 \pm 1.50 \mathrm{E}-07$ & Yes \\
\hline GP2908 & $12-14^{\prime}$ & Americium-241 & $3.57 \pm 1.06 \mathrm{E}-07$ & Yes \\
\hline GP2908 & $12-14^{\prime}$ & Cesium-137 & $1.28 \pm 0.17 \mathrm{E}-06$ & Yes \\
\hline GP2908 & $12-14^{\prime}$ & Gross Alpha & $1.82 \pm 0.57 \mathrm{E}-05$ & No \\
\hline GP2908 & $12-14^{\prime}$ & Gross Beta & $4.63 \pm 0.54 \mathrm{E}-05$ & Yes \\
\hline GP2908 & $12-14^{\prime}$ & Plutonium-238 & $6.59 \pm 3.34 \mathrm{E}-08$ & Yes \\
\hline GP2908 & $12-14^{\prime}$ & Plutonium-239/240 & $7.95 \pm 3.63 \mathrm{E}-08$ & Yes \\
\hline GP2908 & $12-14^{\prime}$ & Potassium-40 & $1.60 \pm 0.16 \mathrm{E}-05$ & No \\
\hline GP2908 & $12-14^{\prime}$ & Strontium-90 & $1.79 \pm 0.18 \mathrm{E}-05$ & Yes \\
\hline GP2908 & $12-14^{\prime}$ & Uranium-233/234 & $1.12 \pm 0.17 \mathrm{E}-06$ & Yes \\
\hline GP2908 & $12-14^{\prime}$ & Uranium-235/236 & $9.26 \pm 5.18 \mathrm{E}-08$ & No \\
\hline GP2908 & $12-14^{\prime}$ & Uranium-238 & $9.10 \pm 1.52 \mathrm{E}-07$ & No \\
\hline
\end{tabular}

Note: Due to the large volume of data, only positive detections are presented. No screening criteria for subsurface soil are available. However, dose-based derived concentration guidelines specific to WVDP subsurface soil have been proposed in the draft Phase I Decommissioning Plan (DOE, March 2009). 
TABLE F-3A (continued)

Comparison of Radiological Concentrations in Subsurface Soil With Background

\begin{tabular}{|c|c|c|c|c|}
\hline Location & Depth & Constituent & Result $(\mu \mathrm{Ci} / g)$ & $\begin{array}{l}\text { Greater Than } \\
\text { Background? }\end{array}$ \\
\hline GP2908 & $14-16^{\prime}$ & Americium-241 & $4.49 \pm 1.03 \mathrm{E}-07$ & Yes \\
\hline GP2908 & $14-16^{\prime}$ & Cesium-137 & $2.02 \pm 0.22 \mathrm{E}-06$ & Yes \\
\hline GP2908 & $14-16^{\prime}$ & Curium-243/244 & $2.47 \pm 2.42 \mathrm{E}-08$ & No \\
\hline GP2908 & $14-16^{\prime}$ & Gross Alpha & $9.77 \pm 3.93 \mathrm{E}-06$ & No \\
\hline GP2908 & $14-16^{\prime}$ & Gross Beta & $3.31 \pm 0.12 \mathrm{E}-04$ & Yes \\
\hline GP2908 & $14-16^{\prime}$ & Plutonium-238 & $3.84 \pm 2.67 \mathrm{E}-08$ & Yes \\
\hline GP2908 & $14-16^{\prime}$ & Plutonium-239/240 & $1.46 \pm 0.51 \mathrm{E}-07$ & Yes \\
\hline GP2908 & $14-16^{\prime}$ & Potassium-40 & $1.82 \pm 0.20 \mathrm{E}-05$ & No \\
\hline GP2908 & $14-16^{\prime}$ & Strontium-90 & $1.52 \pm 0.02 \mathrm{E}-04$ & Yes \\
\hline GP2908 & $14-16^{\prime}$ & Uranium-232 & $4.65 \pm 3.04 \mathrm{E}-08$ & Yes \\
\hline GP2908 & $14-16^{\prime}$ & Uranium-233/234 & $1.60 \pm 0.19 \mathrm{E}-06$ & Yes \\
\hline GP2908 & $14-16^{\prime}$ & Uranium-235/236 & $1.27 \pm 0.54 \mathrm{E}-07$ & Yes \\
\hline GP2908 & $14-16^{\prime}$ & Uranium-238 & $1.65 \pm 0.20 \mathrm{E}-06$ & Yes \\
\hline GP2908 & $28-30^{\prime}$ & Americium-241 & $3.18 \pm 2.91 \mathrm{E}-08$ & Yes \\
\hline GP2908 & $28-30^{\prime}$ & Gross Alpha & $1.66 \pm 1.03 \mathrm{E}-05$ & No \\
\hline GP2908 & $28-30^{\prime}$ & Gross Beta & $3.30 \pm 0.04 \mathrm{E}-03$ & Yes \\
\hline GP2908 & $28-30^{\prime}$ & Potassium-40 & $2.08 \pm 0.22 \mathrm{E}-05$ & No \\
\hline GP2908 & $28-30^{\prime}$ & Strontium-90 & $2.05 \pm 0.02 \mathrm{E}-03$ & Yes \\
\hline GP2908 & $28-301$ & Uranium-233/234 & $8.54 \pm 1.46 \mathrm{E}-07$ & No \\
\hline GP2908 & $28-30^{\prime}$ & Uranium-235/236 & $5.75 \pm 4.85 \mathrm{E}-08$ & No \\
\hline GP2908 & $28-30^{\prime}$ & Uranium-238 & $7.97 \pm 1.41 \mathrm{E}-07$ & No \\
\hline GP2908 & $30-32^{\prime}$ & Gross Alpha & $2.89 \pm 1.18 \mathrm{E}-05$ & Yes \\
\hline GP2908 & $30-32^{\prime}$ & Gross Beta & $1.85 \pm 0.03 \mathrm{E}-03$ & Yes \\
\hline GP2908 & $30-32^{\prime}$ & Potassium-40 & $1.78 \pm 0.17 \mathrm{E}-05$ & No \\
\hline GP2908 & $30-32^{\prime}$ & Strontium-90 & $9.84 \pm 0.11 \mathrm{E}-04$ & Yes \\
\hline GP2908 & $30-32^{\prime}$ & Uranium-233/234 & $6.34 \pm 1.19 \mathrm{E}-07$ & No \\
\hline GP2908 & $30-32^{\prime}$ & Uranium-235/236 & $6.41 \pm 4.43 \mathrm{E}-08$ & No \\
\hline GP2908 & $30-32^{\prime}$ & Uranium-238 & $7.79 \pm 1.33 \mathrm{E}-07$ & No \\
\hline GP2908 & $35-37^{\prime}$ & Gross Alpha & $6.58 \pm 3.68 \mathrm{E}-06$ & No \\
\hline GP2908 & $35-37^{\prime}$ & Gross Beta & $5.33 \pm 0.54 \mathrm{E}-05$ & Yes \\
\hline GP2908 & $35-37^{\prime}$ & Potassium-40 & $1.89 \pm 0.21 \mathrm{E}-05$ & No \\
\hline GP2908 & $35-37^{\prime}$ & Strontium-90 & $1.15 \pm 0.04 \mathrm{E}-05$ & Yes \\
\hline GP2908 & $35-37^{\prime}$ & Uranium-233/234 & $1.02 \pm 0.16 \mathrm{E}-06$ & Yes \\
\hline GP2908 & $35-37^{\prime}$ & Uranium-235/236 & $7.00 \pm 4.14 \mathrm{E}-08$ & No \\
\hline GP2908 & $35-37^{\prime}$ & Uranium-238 & $9.20 \pm 1.51 \mathrm{E}-07$ & Yes \\
\hline GP3008 & $4-6^{\prime}$ & Gross Alpha & $1.12 \pm 0.43 \mathrm{E}-05$ & No \\
\hline GP3008 & $4-6^{\prime}$ & Gross Beta & $2.72 \pm 0.45 \mathrm{E}-05$ & No \\
\hline GP3008 & $4-6^{\prime}$ & Potassium-40 & $1.85 \pm 0.16 \mathrm{E}-05$ & No \\
\hline GP3008 & $4-6^{\prime}$ & Strontium-90 & $4.43 \pm 4.07 \mathrm{E}-08$ & No \\
\hline GP3008 & $4-6^{\prime}$ & Uranium-233/234 & $1.03 \pm 0.38 \mathrm{E}-06$ & No \\
\hline GP3008 & $4-6^{\prime}$ & Uranium-235/236 & $2.06 \pm 1.65 \mathrm{E}-07$ & No \\
\hline GP3008 & $4-6^{\prime}$ & Uranium-238 & $8.81 \pm 3.42 \mathrm{E}-07$ & No \\
\hline GP3008 & $4-6^{\prime}$ (dup) & Americium-241 & $1.01 \pm 0.44 \mathrm{E}-07$ & Yes \\
\hline GP3008 & $4-6^{\prime}$ (dup) & Cesium-137 & $1.37 \pm 0.28 \mathrm{E}-07$ & Yes \\
\hline GP3008 & $4-6^{\prime}$ (dup) & Gross Alpha & $9.94 \pm 3.82 \mathrm{E}-06$ & No \\
\hline GP3008 & $4-6^{\prime}$ (dup) & Gross Beta & $2.23 \pm 0.43 \mathrm{E}-05$ & No \\
\hline GP3008 & 4-6' (dup) & Potassium-40 & $1.76 \pm 0.16 \mathrm{E}-05$ & No \\
\hline GP3008 & $4-6^{\prime}$ (dup) & Strontium-90 & $1.16 \pm 0.51 \mathrm{E}-07$ & Yes \\
\hline GP3008 & 4-6' (dup) & Uranium-233/234 & $7.94 \pm 1.86 \mathrm{E}-07$ & No \\
\hline GP3008 & $4-6^{\prime}$ (dup) & Uranium-235/236 & $1.54 \pm 0.84 \mathrm{E}-07$ & Yes \\
\hline GP3008 & $4-6^{\prime}$ (dup) & Uranium-238 & $8.17 \pm 1.89 \mathrm{E}-07$ & No \\
\hline
\end{tabular}

Note: Due to the large volume of data, only positive detections are presented. No screening criteria for subsurface soil are available. However, dose-based derived concentration guidelines specific to WVDP subsurface soil have been proposed in the draft Phase I Decommissioning Plan (DOE, March 2009). 
TABLE F-3A (continued)

Comparison of Radiological Concentrations in Subsurface Soil With Background

\begin{tabular}{|c|c|c|c|c|}
\hline Location & Depth & Constituent & Result $(\mu \mathrm{Ci} / \mathrm{g})$ & $\begin{array}{l}\text { Greater Than } \\
\text { Background? }\end{array}$ \\
\hline GP3008 & $10-12^{\prime}$ & Cesium-137 & $9.53 \pm 5.19 \mathrm{E}-08$ & Yes \\
\hline GP3008 & $10-12^{\prime}$ & Gross Alpha & $1.03 \pm 0.39 \mathrm{E}-05$ & No \\
\hline GP3008 & $10-12^{\prime}$ & Gross Beta & $1.98 \pm 0.10 \mathrm{E}-04$ & Yes \\
\hline GP3008 & $10-12^{\prime}$ & Potassium-40 & $1.77 \pm 0.18 \mathrm{E}-05$ & No \\
\hline GP3008 & $10-12^{\prime}$ & Strontium-90 & $1.01 \pm 0.06 \mathrm{E}-04$ & Yes \\
\hline GP3008 & $10-12^{\prime}$ & Uranium-233/234 & $7.59 \pm 1.78 \mathrm{E}-07$ & No \\
\hline GP3008 & $10-12^{\prime}$ & Uranium-235/236 & $8.44 \pm 6.05 \mathrm{E}-08$ & No \\
\hline GP3008 & $10-12^{\prime}$ & Uranium-238 & $1.08 \pm 0.21 \mathrm{E}-06$ & Yes \\
\hline GP3008 & $15-17^{\prime}$ & Cesium-137 & $4.18 \pm 2.90 \mathrm{E}-08$ & No \\
\hline GP3008 & $15-17^{\prime}$ & Gross Alpha & $1.02 \pm 0.39 \mathrm{E}-05$ & No \\
\hline GP3008 & $15-17^{\prime}$ & Gross Beta & $8.11 \pm 0.20 \mathrm{E}-04$ & Yes \\
\hline GP3008 & $15-17^{\prime}$ & Potassium-40 & $1.96 \pm 0.17 \mathrm{E}-05$ & No \\
\hline GP3008 & $15-17^{\prime}$ & Strontium-90 & $4.77 \pm 0.12 \mathrm{E}-04$ & Yes \\
\hline GP3008 & $15-17^{\prime}$ & Uranium-233/234 & $9.25 \pm 1.74 \mathrm{E}-07$ & Yes \\
\hline GP3008 & $15-17^{\prime}$ & Uranium-235/236 & $1.24 \pm 0.65 \mathrm{E}-07$ & No \\
\hline GP3008 & $15-17^{\prime}$ & Uranium-238 & $9.23 \pm 1.74 \mathrm{E}-07$ & No \\
\hline GP3008 & $21-23^{\prime}$ & Gross Alpha & $6.16 \pm 3.27 \mathrm{E}-06$ & No \\
\hline GP3008 & $21-23^{\prime}$ & Gross Beta & $4.89 \pm 0.05 \mathrm{E}-03$ & Yes \\
\hline GP3008 & $21-23^{\prime}$ & Potassium-40 & $2.27 \pm 0.21 \mathrm{E}-05$ & No \\
\hline GP3008 & $21-23^{\prime}$ & Strontium-90 & $2.97 \pm 0.03 \mathrm{E}-03$ & Yes \\
\hline GP3008 & $21-23^{\prime}$ & Uranium-233/234 & $1.06 \pm 0.24 \mathrm{E}-06$ & Yes \\
\hline GP3008 & $21-23^{\prime}$ & Uranium-235/236 & $9.64 \pm 7.73 \mathrm{E}-08$ & No \\
\hline GP3008 & $21-23^{\prime}$ & Uranium-238 & $1.03 \pm 0.24 \mathrm{E}-06$ & Yes \\
\hline GP3008 & $28-30^{\prime}$ & Gross Alpha & $8.84 \pm 3.60 \mathrm{E}-06$ & No \\
\hline GP3008 & $28-30^{\prime}$ & Gross Beta & $3.40 \pm 0.04 \mathrm{E}-03$ & Yes \\
\hline GP3008 & $28-30^{\prime}$ & Potassium-40 & $1.92 \pm 0.19 \mathrm{E}-05$ & No \\
\hline GP3008 & $28-30^{\prime}$ & Strontium-90 & $1.99 \pm 0.02 \mathrm{E}-03$ & Yes \\
\hline GP3008 & $28-30^{\prime}$ & Uranium-233/234 & $4.93 \pm 1.48 \mathrm{E}-07$ & No \\
\hline GP3008 & $28-30^{\prime}$ & Uranium-235/236 & $1.40 \pm 0.78 \mathrm{E}-07$ & Yes \\
\hline GP3008 & $28-30^{\prime}$ & Uranium-238 & $6.12 \pm 1.60 \mathrm{E}-07$ & No \\
\hline GP3008 & $35-37^{\prime}$ & Gross Alpha & $5.30 \pm 2.85 \mathrm{E}-06$ & No \\
\hline GP3008 & $35-37^{\prime}$ & Gross Beta & $8.58 \pm 0.73 \mathrm{E}-05$ & Yes \\
\hline GP3008 & $35-37^{\prime}$ & Potassium-40 & $1.64 \pm 0.13 \mathrm{E}-05$ & No \\
\hline GP3008 & $35-37^{\prime}$ & Strontium-90 & $2.45 \pm 0.05 \mathrm{E}-05$ & Yes \\
\hline GP3008 & $35-37^{\prime}$ & Uranium-233/234 & $8.14 \pm 1.75 E-07$ & No \\
\hline GP3008 & $35-37^{\prime}$ & Uranium-235/236 & $1.27 \pm 0.69 \mathrm{E}-07$ & No \\
\hline GP3008 & $35-37^{\prime}$ & Uranium-238 & $8.36 \pm 1.77 \mathrm{E}-07$ & No \\
\hline GP3008 & $37-39^{\prime}$ & Gross Alpha & $9.32 \pm 4.01 \mathrm{E}-06$ & No \\
\hline GP3008 & $37-39^{\prime}$ & Gross Beta & $3.17 \pm 0.49 \mathrm{E}-05$ & No \\
\hline GP3008 & $37-39^{\prime}$ & Potassium-40 & $2.33 \pm 0.19 \mathrm{E}-05$ & No \\
\hline GP3008 & $37-39^{\prime}$ & Strontium-90 & $2.77 \pm 0.21 \mathrm{E}-06$ & Yes \\
\hline GP3008 & $37-39^{\prime}$ & Uranium-233/234 & $9.02 \pm 1.87 \mathrm{E}-07$ & No \\
\hline GP3008 & $37-39^{\prime}$ & Uranium-238 & $9.84 \pm 1.95 \mathrm{E}-07$ & Yes \\
\hline
\end{tabular}

Note: Due to the large volume of data, only positive detections are presented. No screening criteria for subsurface soil are available. However, dose-based derived concentration guidelines specific to WVDP subsurface soil have been proposed in the draft Phase I Decommissioning Plan (DOE, March 2009). 
TABLE F-3A (continued)

Comparison of Radiological Concentrations in Subsurface Soil With Background

\begin{tabular}{|c|c|c|c|c|}
\hline Location & Depth & Constituent & Result $(\mu \mathrm{Ci} / g)$ & $\begin{array}{l}\text { Greater Than } \\
\text { Background? }\end{array}$ \\
\hline GP7208 & $4-6^{\prime}$ & Cesium-137 & $1.02 \pm 0.08 \mathrm{E}-06$ & Yes \\
\hline GP7208 & $4-6^{\prime}$ & Gross Alpha & $6.08 \pm 3.07 \mathrm{E}-06$ & No \\
\hline GP7208 & $4-6^{\prime}$ & Gross Beta & $1.97 \pm 0.36 \mathrm{E}-05$ & No \\
\hline GP7208 & $4-6^{\prime}$ & Potassium-40 & $1.12 \pm 0.10 \mathrm{E}-05$ & No \\
\hline GP7208 & $4-6^{\prime}$ & Strontium-90 & $9.48 \pm 1.03 \mathrm{E}-07$ & Yes \\
\hline GP7208 & $4-6^{\prime}$ & Uranium-233/234 & $6.49 \pm 1.65 \mathrm{E}-07$ & No \\
\hline GP7208 & $4-6^{\prime}$ & Uranium-235/236 & $1.42 \pm 0.79 \mathrm{E}-07$ & Yes \\
\hline GP7208 & $4-6^{\prime}$ & Uranium-238 & $6.81 \pm 1.69 \mathrm{E}-07$ & No \\
\hline GP7208 & $9-11^{\prime}$ & Gross Alpha & $1.13 \pm 0.34 \mathrm{E}-05$ & No \\
\hline GP7208 & $9-11^{\prime}$ & Gross Beta & $2.02 \pm 0.36 \mathrm{E}-05$ & No \\
\hline GP7208 & $9-11^{\prime}$ & Potassium-40 & $1.92 \pm 0.19 \mathrm{E}-05$ & No \\
\hline GP7208 & $9-11^{\prime}$ & Uranium-233/234 & $8.95 \pm 1.92 \mathrm{E}-07$ & No \\
\hline GP7208 & $\frac{1+}{9-11^{\prime}}$ & Uranium-235/236 & $9.39 \pm 6.32 \mathrm{E}-08$ & No \\
\hline GP7208 & $9-11^{\prime}$ & Uranium-238 & $7.59 \pm 1.77 \mathrm{E}-07$ & No \\
\hline GP7208 & $14-16^{\prime}$ & Americium-241 & $2.18 \pm 1.00 \mathrm{E}-08$ & Yes \\
\hline GP7208 & $14-16^{\prime}$ & Cesium-137 & $8.69 \pm 1.81 \mathrm{E}-07$ & Yes \\
\hline GP7208 & $14-16^{\prime}$ & Gross Alpha & $7.23 \pm 3.04 \mathrm{E}-06$ & No \\
\hline GP7208 & $14-16^{\prime}$ & Gross Beta & $2.27 \pm 0.03 \mathrm{E}-03$ & Yes \\
\hline GP7208 & $14-16^{\prime}$ & Iodine-129 & $5.82 \pm 4.47 \mathrm{E}-07$ & Yes \\
\hline GP7208 & $14-16^{\prime}$ & Potassium-40 & $1.74 \pm 0.22 \mathrm{E}-05$ & No \\
\hline GP7208 & $14-16^{\prime}$ & Strontium-90 & $1.10 \pm 0.01 \mathrm{E}-03$ & $\overline{\text { Yes }}$ \\
\hline GP7208 & $14-16^{\prime}$ & Uranium-233/234 & $8.59 \pm 1.96 \mathrm{E}-07$ & No \\
\hline GP7208 & $14-16^{\prime}$ & Uranium-235/236 & $8.04 \pm 5.95 \mathrm{E}-08$ & No \\
\hline GP7208 & $14-16^{\prime}$ & Uranium-238 & $9.61 \pm 2.06 \mathrm{E}-07$ & Yes \\
\hline GP7208 & $14-16^{\prime}$ (dup) & Cesium-137 & $1.12 \pm 0.36 \mathrm{E}-07$ & Yes \\
\hline GP7208 & $14-16^{\prime}$ (dup) & Cobalt-60 & $2.25 \pm 2.16 \mathrm{E}-08$ & No \\
\hline GP7208 & $14-16^{\prime}$ (dup) & Gross Alpha & $1.03 \pm 0.39 \mathrm{E}-05$ & No \\
\hline GP7208 & $14-16^{\prime}$ (dup) & Gross Beta & $1.61 \pm 0.03 \mathrm{E}-03$ & Yes \\
\hline GP7208 & $14-16^{\prime}$ (dup) & Potassium-40 & $1.72 \pm 0.16 \mathrm{E}-05$ & No \\
\hline GP7208 & $14-16^{\prime}$ (dup) & Strontium-90 & $8.76 \pm 0.03 \mathrm{E}-04$ & Yes \\
\hline GP7208 & $14-16^{\prime}$ (dup) & Technetium-99 & $6.31 \pm 3.98 \mathrm{E}-07$ & Yes \\
\hline GP7208 & $14-16^{\prime}$ (dup) & Uranium-232 & $3.34 \pm 3.24 \mathrm{E}-08$ & No \\
\hline GP7208 & $14-16^{\prime}$ (dup) & Uranium-233/234 & $7.04 \pm 1.70 \mathrm{E}-07$ & No \\
\hline GP7208 & $14-16^{\prime}$ (dup) & Uranium-235/236 & $1.24 \pm 0.72 \mathrm{E}-07$ & No \\
\hline GP7208 & $14-16^{\prime}$ (dup) & Uranium-238 & $8.49 \pm 1.85 \mathrm{E}-07$ & No \\
\hline GP7208 & $18-20^{\prime}$ & Americium-241 & $2.03 \pm 0.64 \mathrm{E}-07$ & Yes \\
\hline GP7208 & $18-20^{\prime}$ & Cesium-137 & $5.06 \pm 0.65 \mathrm{E}-07$ & Yes \\
\hline GP7208 & $18-20^{\prime}$ & Cobalt-60 & $2.34 \pm 2.22 \mathrm{E}-08$ & No \\
\hline GP7208 & $18-20^{\prime}$ & Gross Alpha & $5.07 \pm 2.99 \mathrm{E}-06$ & No \\
\hline GP7208 & $18-20^{\prime}$ & Gross Beta & $4.22 \pm 0.04 \mathrm{E}-03$ & Yes \\
\hline GP7208 & $18-20^{\prime}$ & Plutonium-239/240 & $1.81 \pm 0.61 \mathrm{E}-07$ & Yes \\
\hline GP7208 & $18-20^{\prime}$ & Plutonium-241 & $8.70 \pm 4.70 \mathrm{E}-07$ & No \\
\hline GP7208 & $18-20^{\prime}$ & Potassium-40 & $1.87 \pm 0.14 \mathrm{E}-05$ & No \\
\hline GP7208 & $18-20^{\prime}$ & Strontium-90 & $2.05 \pm 0.01 \mathrm{E}-03$ & Yes \\
\hline GP7208 & $18-20^{\prime}$ & Technetium-99 & $2.22 \pm 0.49 \mathrm{E}-06$ & Yes \\
\hline GP7208 & $18-20^{\prime}$ & Uranium-233/234 & $7.17 \pm 1.65 \mathrm{E}-07$ & No \\
\hline GP7208 & $18-20^{\prime}$ & Uranium-235/236 & $1.14 \pm 0.66 \mathrm{E}-07$ & No \\
\hline GP7208 & $18-20^{\prime}$ & Uranium-238 & $8.64 \pm 1.80 \mathrm{E}-07$ & No \\
\hline
\end{tabular}

Note: Due to the large volume of data, only positive detections are presented. No screening criteria for subsurface soil are available. However, dose-based derived concentration guidelines specific to WVDP subsurface soil have been proposed in the draft Phase I Decommissioning Plan (DOE, March 2009). 
TABLE F-3A (continued)

Comparison of Radiological Concentrations in Subsurface Soil With Background

\begin{tabular}{|c|c|c|c|c|}
\hline Location & Depth & Constituent & Result $(\mu \mathrm{Ci} / g)$ & $\begin{array}{l}\text { Greater Than } \\
\text { Background? }\end{array}$ \\
\hline GP7208 & $34-36^{\prime}$ & Cesium-137 & $6.77 \pm 5.36 \mathrm{E}-08$ & Yes \\
\hline GP7208 & $34-36^{\prime}$ & Gross Alpha & $9.74 \pm 3.92 \mathrm{E}-06$ & No \\
\hline GP7208 & $34-36^{\prime}$ & Gross Beta & $1.70 \pm 0.03 \mathrm{E}-03$ & Yes \\
\hline GP7208 & $34-36^{\prime}$ & Potassium-40 & $1.67 \pm 0.14 \mathrm{E}-05$ & No \\
\hline GP7208 & $34-36^{\prime}$ & Strontium-90 & $8.22 \pm 0.03 E-04$ & Yes \\
\hline GP7208 & $34-36^{\prime}$ & Uranium-233/234 & $7.36 \pm 1.71 \mathrm{E}-07$ & No \\
\hline GP7208 & $34-36^{\prime}$ & Uranium-235/236 & $6.37 \pm 5.32 \mathrm{E}-08$ & No \\
\hline GP7208 & $34-36^{\prime}$ & Uranium-238 & $6.95 \pm 1.65 \mathrm{E}-07$ & No \\
\hline GP7208 & $38-40^{\prime}$ & Gross Alpha & $7.95 \pm 3.47 \mathrm{E}-06$ & No \\
\hline GP7208 & $38-40^{\prime}$ & Gross Beta & $3.77 \pm 0.50 \mathrm{E}-05$ & No \\
\hline GP7208 & $38-40^{\prime}$ & Potassium-40 & $1.65 \pm 0.16 \mathrm{E}-05$ & No \\
\hline GP7208 & $38-40^{\prime}$ & Strontium-90 & $4.82 \pm 0.24 \mathrm{E}-06$ & Yes \\
\hline GP7208 & $38-40^{\prime}$ & Technetium-99 & $1.39 \pm 0.47 \mathrm{E}-06$ & Yes \\
\hline GP7208 & $38-40^{\prime}$ & Uranium-233/234 & $6.50 \pm 1.56 \mathrm{E}-07$ & No \\
\hline GP7208 & $38-40^{\prime}$ & Uranium-235/236 & $4.56 \pm 4.22 \mathrm{E}-08$ & No \\
\hline GP7208 & $38-40^{\prime}$ & Uranium-238 & $7.64 \pm 1.67 \mathrm{E}-07$ & No \\
\hline GP7508 & $4-6^{\prime}$ & Gross Alpha & $1.09 \pm 0.34 \mathrm{E}-05$ & No \\
\hline GP7508 & $4-6^{\prime}$ & Gross Beta & $2.56 \pm 0.36 \mathrm{E}-05$ & No \\
\hline GP7508 & $4-6^{\prime}$ & Plutonium-239/240 & $2.83 \pm 2.37 \mathrm{E}-08$ & $\overline{Y e s}$ \\
\hline GP7508 & $4-6^{\prime}$ & Potassium-40 & $1.17 \pm 0.12 \mathrm{E}-05$ & No \\
\hline GP7508 & $4-6^{\prime}$ & Strontium-90 & $6.67 \pm 1.09 \mathrm{E}-07$ & Yes \\
\hline GP7508 & $4-6^{\prime}$ & Tritium Solid & $6.52 \pm 0.69 \mathrm{E}-06$ & No \\
\hline GP7508 & $4-6^{\prime}$ & Uranium-233/234 & $5.35 \pm 0.98 \mathrm{E}-07$ & No \\
\hline GP7508 & $4-6^{\prime}$ & Uranium-235/236 & $9.75 \pm 4.22 \mathrm{E}-08$ & No \\
\hline GP7508 & $4-6^{\prime}$ & Uranium-238 & $5.73 \pm 1.02 \mathrm{E}-07$ & No \\
\hline GP7608 & $4-6^{\prime}$ & Cesium-137 & $7.14 \pm 6.73 \mathrm{E}-08$ & No \\
\hline GP7608 & $4-6^{\prime}$ & Gross Alpha & $1.04 \pm 0.58 \mathrm{E}-05$ & No \\
\hline GP7608 & $4-6^{\prime}$ & Gross Beta & $3.96 \pm 1.37 \mathrm{E}-05$ & No \\
\hline GP7608 & $4-6^{\prime}$ & Potassium-40 & $1.26 \pm 0.19 \mathrm{E}-05$ & No \\
\hline GP7608 & $4-6^{\prime}$ & Strontium-90 & $4.38 \pm 0.91 \mathrm{E}-07$ & Yes \\
\hline GP7608 & $4-6^{\prime}$ & Tritium Solid & $1.14 \pm 0.19 \mathrm{E}-05$ & Yes \\
\hline GP7608 & $4-6^{\prime}$ & Uranium-233/234 & $6.59 \pm 5.28 \mathrm{E}-07$ & No \\
\hline GP7608 & $4-6^{\prime}$ & Uranium-238 & $9.10 \pm 5.94 \mathrm{E}-07$ & No \\
\hline GP7608 & $10-12^{\prime}$ & Cesium-137 & $5.55 \pm 1.85 \mathrm{E}-07$ & Yes \\
\hline GP7608 & $10-12^{\prime}$ & Gross Beta & $2.42 \pm 0.05 \mathrm{E}-03$ & Yes \\
\hline GP7608 & $10-12^{\prime}$ & Potassium-40 & $1.40 \pm 0.24 \mathrm{E}-05$ & No \\
\hline GP7608 & $10-12^{\prime}$ & Strontium-90 & $1.26 \pm 0.01 \mathrm{E}-03$ & Yes \\
\hline GP7608 & $10-12^{\prime}$ & Technetium-99 & $1.29 \pm 0.41 \mathrm{E}-06$ & Yes \\
\hline GP7608 & $10-12^{\prime}$ & Tritium Solid & $1.38 \pm 0.20 \mathrm{E}-05$ & Yes \\
\hline GP7608 & $10-12^{\prime}$ & Uranium-238 & $1.42 \pm 0.77 \mathrm{E}-06$ & No \\
\hline GP7608 & $15-17^{\prime}$ & Cesium-137 & $6.17 \pm 0.74 \mathrm{E}-06$ & Yes \\
\hline GP7608 & $15-17^{\prime}$ & Gross Alpha & $1.06 \pm 0.91 \mathrm{E}-05$ & No \\
\hline GP7608 & $15-17^{\prime}$ & Gross Beta & $1.67 \pm 0.01 \mathrm{E}-02$ & Yes \\
\hline GP7608 & $15-17^{\prime}$ & Potassium-40 & $1.30 \pm 0.25 \mathrm{E}-05$ & No \\
\hline GP7608 & $15-17^{\prime}$ & Strontium-90 & $9.33 \pm 0.02 \mathrm{E}-03$ & Yes \\
\hline GP7608 & $15-17^{\prime}$ & Technetium-99 & $9.31 \pm 0.60 \mathrm{E}-06$ & Yes \\
\hline GP7608 & $15-17^{\prime}$ & Tritium Solid & $3.44 \pm 1.38 \mathrm{E}-06$ & No \\
\hline GP7608 & $15-17^{\prime}$ & Uranium-233/234 & $6.33 \pm 5.78 \mathrm{E}-07$ & No \\
\hline GP7608 & $15-17^{\prime}$ & Uranium-238 & $5.20 \pm 4.81 \mathrm{E}-07$ & No \\
\hline
\end{tabular}

Note: Due to the large volume of data, only positive detections are presented. No screening criteria for subsurface soil are available. However, dose-based derived concentration guidelines specific to WVDP subsurface soil have been proposed in the draft Phase I Decommissioning Plan (DOE, March 2009). 
TABLE F-3A (continued)

Comparison of Radiological Concentrations in Subsurface Soil With Background

\begin{tabular}{|c|c|c|c|c|}
\hline Location & Depth & Constituent & Result ( $\mu \mathrm{Ci} / g)$ & $\begin{array}{l}\text { Greater Than } \\
\text { Background? }\end{array}$ \\
\hline GP7608 & $\overline{19-21^{\prime}}$ & Americium-241 & $6.84 \pm 1.90 \mathrm{E}-06$ & Yes \\
\hline GP7608 & $19-21^{\prime}$ & Cesium-137 & $2.22 \pm 0.21 \mathrm{E}-04$ & Yes \\
\hline GP7608 & $19-21^{\prime}$ & Europium-154 & $5.44 \pm 3.72 \mathrm{E}-07$ & Yes \\
\hline GP7608 & $19-21^{\prime}$ & Gross Alpha & $1.75 \pm 0.82 \mathrm{E}-05$ & No \\
\hline GP7608 & $19-21^{\prime}$ & Gross Beta & $1.20 \pm 0.01 \mathrm{E}-02$ & Yes \\
\hline GP7608 & $19-21^{\prime}$ & Plutonium-238 & $5.60 \pm 4.91 \mathrm{E}-07$ & Yes \\
\hline GP7608 & $19-21^{\prime}$ & Plutonium-239/240 & $3.69 \pm 1.26 \mathrm{E}-06$ & Yes \\
\hline GP7608 & $19-21^{\prime}$ & Potassium-40 & $1.89 \pm 0.29 \mathrm{E}-05$ & No \\
\hline GP7608 & $19-21^{\prime}$ & Strontium-90 & $6.30 \pm 0.01 E-03$ & Yes \\
\hline GP7608 & $19-21^{\prime}$ & Technetium-99 & $6.10 \pm 3.72 \mathrm{E}-07$ & Yes \\
\hline GP7608 & $19-21^{\prime}$ & Uranium-233/234 & $1.64 \pm 0.86 \mathrm{E}-06$ & Yes \\
\hline GP7608 & $19-21^{\prime}$ & Uranium-238 & $1.19 \pm 0.74 \mathrm{E}-06$ & No \\
\hline GP7608 & $24-26^{\prime}$ & Cesium-137 & $2.33 \pm 0.23 \mathrm{E}-05$ & Yes \\
\hline GP7608 & $24-26^{\prime}$ & Gross Alpha & $9.05 \pm 7.76 \mathrm{E}-06$ & No \\
\hline GP7608 & $24-26^{\prime}$ & Gross Beta & $1.60 \pm 0.04 \mathrm{E}-03$ & Yes \\
\hline GP7608 & $24-26^{\prime}$ & Potassium-40 & $2.45 \pm 0.33 \mathrm{E}-05$ & No \\
\hline GP7608 & $24-26^{\prime}$ & Strontium-90 & $8.77 \pm 0.05 E-04$ & Yes \\
\hline GP7608 & $24-26^{\prime}$ & Technetium-99 & $5.25 \pm 4.16 \mathrm{E}-07$ & No \\
\hline GP7608 & $24-26^{\prime}$ & Uranium-233/234 & $1.49 \pm 0.80 \mathrm{E}-06$ & Yes \\
\hline GP7608 & $24-26^{\prime}$ & Uranium-238 & $9.69 \pm 6.53 \mathrm{E}-07$ & No \\
\hline GP7608 & $36-38^{\prime}$ & Cesium-137 & $2.97 \pm 0.37 \mathrm{E}-06$ & Yes \\
\hline GP7608 & $36-38^{\prime}$ & Gross Alpha & $1.22 \pm 0.68 \mathrm{E}-05$ & No \\
\hline GP7608 & $36-38^{\prime}$ & Gross Beta & $6.01 \pm 1.57 \mathrm{E}-05$ & Yes \\
\hline GP7608 & $36-38^{\prime}$ & Potassium-40 & $2.27 \pm 0.30 \mathrm{E}-05$ & No \\
\hline GP7608 & $36-38^{\prime}$ & Strontium-90 & $7.81 \pm 0.48 \mathrm{E}-06$ & Yes \\
\hline GP7608 & $36-38^{\prime}$ & Uranium-233/234 & $1.21 \pm 0.72 \mathrm{E}-06$ & No \\
\hline GP7608 & $36-38^{\prime}$ & Uranium-238 & $1.45 \pm 0.76 \mathrm{E}-06$ & No \\
\hline GP7608 & $38-40^{\prime}$ & Americium-241 & $1.27 \pm 0.53 \mathrm{E}-07$ & Yes \\
\hline GP7608 & $38-40^{\prime}$ & Carbon-14 & $1.09 \pm 0.94 \mathrm{E}-07$ & No \\
\hline GP7608 & $38-40^{\prime}$ & Cesium-137 & $3.91 \pm 0.29 \mathrm{E}-06$ & Yes \\
\hline GP7608 & $38-40^{\prime}$ & Gross Alpha & $1.97 \pm 1.12 \mathrm{E}-05$ & No \\
\hline GP7608 & $38-40^{\prime}$ & Gross Beta & $5.81 \pm 1.61 \mathrm{E}-05$ & Yes \\
\hline GP7608 & $38-40^{\prime}$ & Plutonium-239/240 & $6.43 \pm 3.50 \mathrm{E}-08$ & Yes \\
\hline GP7608 & $38-40^{\prime}$ & Potassium-40 & $2.75 \pm 0.20 \mathrm{E}-05$ & Yes \\
\hline GP7608 & $38-40^{\prime}$ & Strontium-90 & $1.47 \pm 0.04 \mathrm{E}-05$ & Yes \\
\hline GP7608 & $38-40^{\prime}$ & Uranium-233/234 & $2.33 \pm 0.36 \mathrm{E}-06$ & Yes \\
\hline GP7608 & $38-40^{\prime}$ & Uranium-235/236 & $1.03 \pm 0.77 \mathrm{E}-07$ & No \\
\hline GP7608 & $38-40^{\prime}$ & Uranium-238 & $8.05 \pm 2.08 \mathrm{E}-07$ & No \\
\hline GP7808 & $4-6^{\prime}$ & Gross Alpha & $6.83 \pm 2.81 \mathrm{E}-06$ & No \\
\hline GP7808 & $4-6^{\prime}$ & Gross Beta & $1.99 \pm 0.34 \mathrm{E}-05$ & No \\
\hline GP7808 & $4-6^{\prime}$ & lodine-129 & $2.49 \pm 1.99 \mathrm{E}-07$ & No \\
\hline GP7808 & $4-6^{\prime}$ & Potassium-40 & $1.83 \pm 0.17 E-05$ & No \\
\hline GP7808 & $4-6^{\prime}$ & Strontium-90 & $8.31 \pm 1.34 \mathrm{E}-07$ & Yes \\
\hline GP7808 & $4-6^{\prime}$ & Tritium Solid & $1.71 \pm 0.56 \mathrm{E}-06$ & No \\
\hline GP7808 & $4-6^{\prime}$ & Uranium-233/234 & $6.49 \pm 1.09 \mathrm{E}-07$ & No \\
\hline GP7808 & $4-6^{\prime}$ & Uranium-235/236 & $4.05 \pm 2.81 \mathrm{E}-08$ & No \\
\hline GP7808 & $4-6^{\prime}$ & Uranium-238 & $7.27 \pm 1.15 \mathrm{E}-07$ & No \\
\hline
\end{tabular}

Note: Due to the large volume of data, only positive detections are presented. No screening criteria for subsurface soil are available. However, dose-based derived concentration guidelines specific to WVDP subsurface soil have been proposed in the draft Phase I Decommissioning Plan (DOE, March 2009). 
TABLE F-3A (continued)

Comparison of Radiological Concentrations in Subsurface Soil With Background

\begin{tabular}{|c|c|c|c|c|}
\hline Location & Depth & Constituent & Result ( $\mu \mathrm{Ci} / g)$ & $\begin{array}{l}\text { Greater Than } \\
\text { Background? }\end{array}$ \\
\hline GP7808 & $10-12^{\prime}$ & Cesium-137 & $2.70 \pm 0.68 \mathrm{E}-07$ & Yes \\
\hline GP7808 & $10-12^{\prime}$ & Gross Alpha & $7.16 \pm 3.62 \mathrm{E}-06$ & No \\
\hline GP7808 & $10-12^{\prime}$ & Gross Beta & $3.64 \pm 0.05 E-03$ & Yes \\
\hline GP7808 & $10-12^{\prime}$ & Potassium-40 & $1.47 \pm 0.16 \mathrm{E}-05$ & No \\
\hline GP7808 & $10-12^{\prime}$ & Strontium-90 & $2.12 \pm 0.01 \mathrm{E}-03$ & Yes \\
\hline GP7808 & $10-12^{\prime}$ & Technetium-99 & $6.28 \pm 4.18 \mathrm{E}-07$ & Yes \\
\hline GP7808 & $10-12^{\prime}$ & Uranium-233/234 & $6.25 \pm 1.07 E-07$ & No \\
\hline GP7808 & $10-12^{\prime}$ & Uranium-235/236 & $7.97 \pm 3.85 E-08$ & No \\
\hline GP7808 & $10-12^{\prime}$ & Uranium-238 & $7.08 \pm 1.14 \mathrm{E}-07$ & No \\
\hline GP7808 & $15-17^{\prime}$ & Cesium-137 & $1.83 \pm 0.43 \mathrm{E}-06$ & Yes \\
\hline GP7808 & $15-17^{\prime}$ & Cobalt-60 & $2.76 \pm 2.03 \mathrm{E}-07$ & Yes \\
\hline GP7808 & $15-17^{\prime}$ & Gross Alpha & $1.33 \pm 0.60 \mathrm{E}-05$ & No \\
\hline GP7808 & $15-17^{\prime}$ & Gross Beta & $6.55 \pm 0.06 \mathrm{E}-03$ & Yes \\
\hline GP7808 & $15-17^{\prime}$ & Potassium-40 & $1.49 \pm 0.28 \mathrm{E}-05$ & No \\
\hline GP7808 & $15-17^{\prime}$ & Strontium-90 & $3.46 \pm 0.05 E-03$ & Yes \\
\hline GP7808 & $15-17^{\prime}$ & Tritium Solid & $3.36 \pm 0.70 \mathrm{E}-06$ & No \\
\hline GP7808 & $18-20^{\prime}$ & Cesium-137 & $2.04 \pm 0.48 \mathrm{E}-06$ & Yes \\
\hline GP7808 & $18-20^{\prime}$ & Gross Alpha & $8.92 \pm 4.53 \mathrm{E}-06$ & No \\
\hline GP7808 & $18-20^{\prime}$ & Gross Beta & $6.88 \pm 0.06 \mathrm{E}-03$ & Yes \\
\hline GP7808 & $18-20^{\prime}$ & Potassium-40 & $2.02 \pm 0.34 \mathrm{E}-05$ & No \\
\hline GP7808 & $18-20^{\prime}$ & Strontium-90 & $3.73 \pm 0.05 E-03$ & Yes \\
\hline GP7808 & $18-20^{\prime}$ & Tritium Solid & $1.99 \pm 0.64 \mathrm{E}-06$ & No \\
\hline GP7808 & $20-22^{\prime}$ & Cobalt-60 & $2.22 \pm 1.69 \mathrm{E}-07$ & Yes \\
\hline GP7808 & $20-22^{\prime}$ & Europium-154 & $6.06 \pm 4.43 \mathrm{E}-07$ & Yes \\
\hline GP7808 & $20-22^{\prime}$ & Gross Alpha & $7.17 \pm 4.97 E-06$ & No \\
\hline GP7808 & $20-22^{\prime}$ & Gross Beta & $8.24 \pm 0.06 \mathrm{E}-03$ & Yes \\
\hline GP7808 & $20-22^{\prime}$ & Potassium-40 & $2.10 \pm 0.32 \mathrm{E}-05$ & No \\
\hline GP7808 & $20-22^{\prime}$ & Strontium-90 & $4.42 \pm 0.05 \mathrm{E}-03$ & Yes \\
\hline GP7808 & $20-22^{\prime}$ & Tritium Solid & $1.99 \pm 0.59 \mathrm{E}-06$ & No \\
\hline GP7808 & $22-24^{\prime}$ & Cesium-137 & $4.75 \pm 3.20 \mathrm{E}-07$ & Yes \\
\hline GP7808 & $22-24^{\prime}$ & Cobalt-60 & $2.27 \pm 1.50 \mathrm{E}-07$ & Yes \\
\hline GP7808 & $22-24^{\prime}$ & Gross Alpha & $1.51 \pm 0.52 \mathrm{E}-05$ & No \\
\hline GP7808 & $22-24^{\prime}$ & Gross Beta & $8.72 \pm 0.07 \mathrm{E}-03$ & Yes \\
\hline GP7808 & $22-24^{\prime}$ & Potassium-40 & $1.68 \pm 0.39 \mathrm{E}-05$ & No \\
\hline GP7808 & $22-24^{\prime}$ & Strontium-90 & $4.80 \pm 0.06 \mathrm{E}-03$ & Yes \\
\hline GP7808 & $22-24^{\prime}$ & Tritium Solid & $2.12 \pm 0.70 \mathrm{E}-06$ & No \\
\hline GP7808 & $35-37^{\prime}$ & Gross Alpha & $1.08 \pm 0.16 \mathrm{E}-05$ & No \\
\hline GP7808 & $35-37^{\prime}$ & Gross Beta & $4.41 \pm 0.23 \mathrm{E}-05$ & Yes \\
\hline GP7808 & $35-37^{\prime}$ & Potassium-40 & $2.99 \pm 0.26 \mathrm{E}-05$ & Yes \\
\hline GP7808 & $35-37^{\prime}$ & Strontium-90 & $3.65 \pm 0.24 \mathrm{E}-06$ & Yes \\
\hline GP7808 & $35-37^{\prime}$ & Uranium-233/234 & $9.15 \pm 1.89 \mathrm{E}-07$ & Yes \\
\hline GP7808 & $35-37^{\prime}$ & Uranium-235/236 & $7.43 \pm 5.52 E-08$ & No \\
\hline GP7808 & $35-37^{\prime}$ & Uranium-238 & $1.03 \pm 0.20 \mathrm{E}-06$ & Yes \\
\hline GP7808 & $37-39^{\prime}$ & Gross Alpha & $1.10 \pm 0.33 \mathrm{E}-05$ & No \\
\hline GP7808 & $37-39^{\prime}$ & Gross Beta & $3.70 \pm 0.45 \mathrm{E}-05$ & No \\
\hline GP7808 & $37-39^{\prime}$ & Potassium-40 & $2.56 \pm 0.20 \mathrm{E}-05$ & Yes \\
\hline GP7808 & $37-39^{\prime}$ & Strontium-90 & $3.40 \pm 0.22 \mathrm{E}-06$ & Yes \\
\hline GP7808 & $37-39^{\prime}$ & Uranium-233/234 & $8.84 \pm 1.83 E-07$ & No \\
\hline GP7808 & $37-39^{\prime}$ & Uranium-235/236 & $1.44 \pm 0.74 \mathrm{E}-07$ & Yes \\
\hline GP7808 & $37-39^{\prime}$ & Uranium-238 & $9.44 \pm 1.88 \mathrm{E}-07$ & Yes \\
\hline
\end{tabular}

Note: Due to the large volume of data, only positive detections are presented. No screening criteria for subsurface soil are available. However, dose-based derived concentration guidelines specific to WVDP subsurface soil have been proposed in the draft Phase I Decommissioning Plan (DOE, March 2009). 
TABLE F-3A (continued)

Comparison of Radiological Concentrations in Subsurface Soil With Background

\begin{tabular}{|c|c|c|c|c|}
\hline Location & Depth & Constituent & Result $(\mu \mathrm{Ci} / g)$ & $\begin{array}{l}\text { Greater Than } \\
\text { Background? }\end{array}$ \\
\hline GP8008 & $9-11^{\prime}$ & Cobalt-60 & $2.41 \pm 2.14 \mathrm{E}-08$ & No \\
\hline GP8008 & $9-11^{\prime}$ & Gross Alpha & $1.37 \pm 0.34 \mathrm{E}-05$ & No \\
\hline GP8008 & $9-11^{\prime}$ & Gross Beta & $2.55 \pm 0.36 \mathrm{E}-05$ & No \\
\hline GP8008 & $9-11^{\prime}$ & Potassium-40 & $2.05 \pm 0.20 \mathrm{E}-05$ & No \\
\hline GP8008 & $9-11^{\prime}$ & Uranium-233/234 & $7.76 \pm 1.28 \mathrm{E}-07$ & No \\
\hline GP8008 & $9-11^{\prime}$ & Uranium-235/236 & $4.23 \pm 3.03 E-08$ & No \\
\hline GP8008 & $9-11^{\prime}$ & Uranium-238 & $7.23 \pm 1.23 \mathrm{E}-07$ & No \\
\hline GP8008 & $15-17^{\prime}$ & Americium-241 & $8.93 \pm 3.71 \mathrm{E}-08$ & Yes \\
\hline GP8008 & $15-17^{\prime}$ & Cesium-137 & $1.34 \pm 0.11 \mathrm{E}-06$ & Yes \\
\hline GP8008 & $15-17^{\prime}$ & Curium-243/244 & $2.21 \pm 1.97 \mathrm{E}-08$ & No \\
\hline GP8008 & $15-17^{\prime}$ & Gross Alpha & $1.24 \pm 0.33 \mathrm{E}-05$ & No \\
\hline GP8008 & $15-17^{\prime}$ & Gross Beta & $2.86 \pm 0.38 \mathrm{E}-05$ & No \\
\hline GP8008 & $15-17^{\prime}$ & Plutonium-239/240 & $4.17 \pm 2.99 \mathrm{E}-08$ & Yes \\
\hline GP8008 & $15-17^{\prime}$ & Potassium-40 & $1.80 \pm 0.18 \mathrm{E}-05$ & No \\
\hline GP8008 & $15-17^{\prime}$ & Strontium-90 & $2.35 \pm 0.17 \mathrm{E}-06$ & Yes \\
\hline GP8008 & $15-17^{\prime}$ & Uranium-233/234 & $7.33 \pm 1.26 \mathrm{E}-07$ & No \\
\hline GP8008 & $15-17^{\prime}$ & Uranium-235/236 & $6.70 \pm 3.79 \mathrm{E}-08$ & No \\
\hline GP8008 & $15-17^{\prime}$ & Uranium-238 & $6.92 \pm 1.22 \mathrm{E}-07$ & No \\
\hline GP8008 & $19-21^{\prime}$ & Cesium-137 & $2.08 \pm 1.83 \mathrm{E}-08$ & No \\
\hline GP8008 & $19-21^{\prime}$ & Gross Alpha & $1.64 \pm 0.37 \mathrm{E}-05$ & No \\
\hline GP8008 & $19-21^{\prime}$ & Gross Beta & $2.38 \pm 0.34 \mathrm{E}-05$ & No \\
\hline GP8008 & $19-21^{\prime}$ & Potassium-40 & $1.96 \pm 0.16 \mathrm{E}-05$ & No \\
\hline GP8008 & $19-21^{\prime}$ & Strontium-90 & $8.30 \pm 5.59 \mathrm{E}-08$ & Yes \\
\hline GP8008 & $19-21^{\prime}$ & Tritium Solid & $8.03 \pm 4.99 E-07$ & No \\
\hline GP8008 & $19-21^{\prime}$ & Uranium-233/234 & $6.31 \pm 1.10 \mathrm{E}-07$ & No \\
\hline GP8008 & $19-21^{\prime}$ & Uranium-235/236 & $6.80 \pm 3.63 \mathrm{E}-08$ & No \\
\hline GP8008 & $19-21^{\prime}$ & Uranium-238 & $6.96 \pm 1.15 \mathrm{E}-07$ & No \\
\hline GP8008 & $25-27^{\prime}$ & Americium-241 & $5.61 \pm 1.13 \mathrm{E}-07$ & Yes \\
\hline GP8008 & $25-27^{\prime}$ & Cesium-137 & $1.00 \pm 0.07 E-05$ & Yes \\
\hline GP8008 & $25-27^{\prime}$ & Curium-243/244 & $1.53 \pm 0.61 \mathrm{E}-07$ & Yes \\
\hline GP8008 & $25-27^{\prime}$ & Gross Alpha & $1.11 \pm 0.40 \mathrm{E}-05$ & No \\
\hline GP8008 & $25-27^{\prime}$ & Gross Beta & $1.37 \pm 0.02 E-03$ & Yes \\
\hline GP8008 & $25-27^{\prime}$ & Plutonium-239/240 & $3.80 \pm 3.52 \mathrm{E}-08$ & No \\
\hline GP8008 & $25-27^{\prime}$ & Plutonium-241 & $6.06 \pm 5.59 \mathrm{E}-07$ & No \\
\hline GP8008 & $25-27^{\prime}$ & Potassium-40 & $1.82 \pm 0.15 \mathrm{E}-05$ & No \\
\hline GP8008 & $25-27^{\prime}$ & Strontium-90 & $5.60 \pm 0.03 E-04$ & Yes \\
\hline GP8008 & $25-27^{\prime}$ & Uranium-233/234 & $6.86 \pm 1.23 \mathrm{E}-07$ & No \\
\hline GP8008 & $25-27^{\prime}$ & Uranium-235/236 & $1.31 \pm 0.54 \mathrm{E}-07$ & Yes \\
\hline GP8008 & $25-27^{\prime}$ & Uranium-238 & $8.05 \pm 1.32 \mathrm{E}-07$ & No \\
\hline GP8008 & $25-27^{\prime}$ (dup) & Cesium-137 & $1.28 \pm 0.12 \mathrm{E}-06$ & Yes \\
\hline GP8008 & $25-27^{\prime}$ (dup) & Gross Alpha & $1.19 \pm 0.34 \mathrm{E}-05$ & No \\
\hline GP8008 & $25-27^{\prime}$ (dup) & Gross Beta & $7.83 \pm 0.17 \mathrm{E}-04$ & Yes \\
\hline GP8008 & $25-27^{\prime}$ (dup) & Potassium-40 & $1.84 \pm 0.15 \mathrm{E}-05$ & No \\
\hline GP8008 & $25-27^{\prime}$ (dup) & Strontium-90 & $3.68 \pm 0.02 \mathrm{E}-04$ & Yes \\
\hline GP8008 & $25-27^{\prime}$ (dup) & Uranium-233/234 & $7.31 \pm 1.18 \mathrm{E}-07$ & No \\
\hline GP8008 & $25-27^{\prime}$ (dup) & Uranium-235/236 & $1.03 \pm 0.44 \mathrm{E}-07$ & No \\
\hline GP8008 & $25-27^{\prime}$ (dup) & Uranium-238 & $6.99 \pm 1.15 \mathrm{E}-07$ & No \\
\hline
\end{tabular}

Note: Due to the large volume of data, only positive detections are presented. No screening criteria for subsurface soil are available. However, dose-based derived concentration guidelines specific to WVDP subsurface soil have been proposed in the draft Phase I Decommissioning Plan (DOE, March 2009). 
TABLE F-3A (concluded)

Comparison of Radiological Concentrations in Subsurface Soil With Background

\begin{tabular}{|c|c|c|c|c|}
\hline Location & Depth & Constituent & Result $(\mu \mathrm{Ci} / \mathrm{g})$ & $\begin{array}{l}\text { Greater Than } \\
\text { Background? }\end{array}$ \\
\hline GP8008 & $32-24^{\prime}$ & Cesium-137 & $4.40 \pm 2.40 \mathrm{E}-08$ & Yes \\
\hline GP8008 & $32-24^{\prime}$ & Gross Alpha & $3.97 \pm 2.41 \mathrm{E}-06$ & No \\
\hline GP8008 & $32-24^{\prime}$ & Gross Beta & $1.99 \pm 0.03 \mathrm{E}-03$ & Yes \\
\hline GP8008 & $32-24^{\prime}$ & Potassium-40 & $1.63 \pm 0.15 \mathrm{E}-05$ & No \\
\hline GP8008 & $32-24^{\prime}$ & Strontium-90 & $9.49 \pm 0.03 E-04$ & Yes \\
\hline GP8008 & $32-24^{\prime}$ & Uranium-233/234 & $7.05 \pm 1.20 \mathrm{E}-07$ & No \\
\hline GP8008 & $32-24^{\prime}$ & Uranium-235/236 & $6.35 \pm 3.59 \mathrm{E}-08$ & No \\
\hline GP8008 & $32-24^{\prime}$ & Uranium-238 & $8.52 \pm 1.32 \mathrm{E}-07$ & No \\
\hline GP8008 & $39-41^{\prime}$ & Gross Alpha & $4.59 \pm 2.11 \mathrm{E}-06$ & No \\
\hline GP8008 & $39-41^{\prime}$ & Gross Beta & $2.96 \pm 0.38 \mathrm{E}-05$ & No \\
\hline GP8008 & $39-41^{\prime}$ & Potassium-40 & $1.66 \pm 0.14 \mathrm{E}-05$ & No \\
\hline GP8008 & $39-41^{\prime}$ & Strontium-90 & $5.33 \pm 0.24 \mathrm{E}-06$ & Yes \\
\hline GP8008 & $39-41^{\prime}$ & Uranium-233/234 & $5.17 \pm 0.99 E-07$ & No \\
\hline GP8008 & $39-41^{\prime}$ & Uranium-235/236 & $3.92 \pm 2.72 \mathrm{E}-08$ & No \\
\hline GP8008 & $39-41^{\prime}$ & Uranium-238 & $8.20 \pm 1.24 \mathrm{E}-07$ & No \\
\hline GP8008 & $41-43^{\prime}$ & Gross Alpha & $9.01 \pm 2.93 \mathrm{E}-06$ & No \\
\hline GP8008 & $41-43^{\prime}$ & Gross Beta & $3.16 \pm 0.40 \mathrm{E}-05$ & No \\
\hline GP8008 & $41-43^{\prime}$ & Potassium-40 & $2.47 \pm 0.23 \mathrm{E}-05$ & Yes \\
\hline GP8008 & $41-43^{\prime}$ & Strontium-90 & $2.35 \pm 0.17 \mathrm{E}-06$ & Yes \\
\hline GP8008 & $41-43^{\prime}$ & Uranium-233/234 & $8.99 \pm 1.87 E-07$ & No \\
\hline GP8008 & $41-43^{\prime}$ & Uranium-235/236 & $1.22 \pm 0.69 \mathrm{E}-07$ & No \\
\hline GP8008 & $41-43^{\prime}$ & Uranium-238 & $9.44 \pm 1.92 \mathrm{E}-07$ & No \\
\hline GP8308 & $14-16^{\prime}$ & Gross Alpha & $9.48 \pm 3.09 \mathrm{E}-06$ & No \\
\hline GP8308 & $14-16^{\prime}$ & Gross Beta & $3.13 \pm 0.39 \mathrm{E}-05$ & No \\
\hline GP8308 & $14-16^{\prime}$ & Potassium-40 & $1.66 \pm 0.15 \mathrm{E}-05$ & No \\
\hline GP8308 & $14-16^{\prime}$ & Strontium-90 & $7.86 \pm 0.28 \mathrm{E}-06$ & Yes \\
\hline GP8308 & $14-16^{\prime}$ & Uranium-233/234 & $9.17 \pm 1.35 \mathrm{E}-07$ & Yes \\
\hline GP8308 & $14-16^{\prime}$ & Uranium-235/236 & $1.65 \pm 0.57 \mathrm{E}-07$ & Yes \\
\hline GP8308 & $14-16^{\prime}$ & Uranium-238 & $7.73 \pm 1.24 \mathrm{E}-07$ & No \\
\hline GP8308 & $30-32^{\prime}$ & Gross Alpha & $1.05 \pm 0.30 \mathrm{E}-05$ & No \\
\hline GP8308 & $30-32^{\prime}$ & Gross Beta & $1.18 \pm 0.02 \mathrm{E}-03$ & Yes \\
\hline GP8308 & $30-32^{\prime}$ & Potassium-40 & $1.97 \pm 0.19 \mathrm{E}-05$ & No \\
\hline GP8308 & $30-32^{\prime}$ & Strontium-90 & $7.55 \pm 0.03 E-04$ & Yes \\
\hline GP8308 & $30-32^{\prime}$ & Uranium-233/234 & $7.07 \pm 1.26 \mathrm{E}-07$ & No \\
\hline GP8308 & $30-32^{\prime}$ & Uranium-235/236 & $2.06 \pm 0.70 \mathrm{E}-07$ & Yes \\
\hline GP8308 & $30-32^{\prime}$ & Uranium-238 & $6.75 \pm 1.24 \mathrm{E}-07$ & No \\
\hline GP8308 & $38-40^{\prime}$ & Gross Alpha & $1.72 \pm 0.46 \mathrm{E}-05$ & No \\
\hline GP8308 & $38-40^{\prime}$ & Gross Beta & $8.32 \pm 0.21 \mathrm{E}-04$ & Yes \\
\hline GP8308 & $38-40^{\prime}$ & Potassium-40 & $2.44 \pm 0.18 \mathrm{E}-05$ & Yes \\
\hline GP8308 & $38-40^{\prime}$ & Strontium-90 & $3.64 \pm 0.02-04$ & Yes \\
\hline GP8308 & $38-40^{\prime}$ & Uranium-233/234 & $1.03 \pm 0.16 \mathrm{E}-06$ & Yes \\
\hline GP8308 & $38-40^{\prime}$ & Uranium-235/236 & $2.19 \pm 0.78 \mathrm{E}-07$ & Yes \\
\hline GP8308 & $38-40^{\prime}$ & Uranium-238 & $8.67 \pm 1.52 E-07$ & No \\
\hline GP8308 & $40-42^{\prime}$ & Gross Alpha & $8.79 \pm 3.23 E-06$ & No \\
\hline GP8308 & $40-42^{\prime}$ & Gross Beta & $3.31 \pm 0.46 \mathrm{E}-05$ & No \\
\hline GP8308 & $40-42^{\prime}$ & lodine-129 & $2.37 \pm 2.19 E-07$ & No \\
\hline GP8308 & $40-42^{\prime}$ & Potassium-40 & $2.30 \pm 0.18 \mathrm{E}-05$ & No \\
\hline GP8308 & $40-42^{\prime}$ & Strontium-90 & $1.47 \pm 0.14 \mathrm{E}-06$ & $\overline{\text { Yes }}$ \\
\hline GP8308 & $40-42^{\prime}$ & Uranium-233/234 & $9.77 \pm 1.40 \mathrm{E}-07$ & Yes \\
\hline GP8308 & $40-42^{\prime}$ & Uranium-235/236 & $2.23 \pm 0.68 \mathrm{E}-07$ & Yes \\
\hline GP8308 & $40-42^{\prime}$ & Uranium-238 & $1.13 \pm 0.15 \mathrm{E}-06$ & Yes \\
\hline
\end{tabular}

Note: Due to the large volume of data, only positive detections are presented. No screening criteria for subsurface soil are available. However, dose-based derived concentration guidelines specific to WVDP subsurface soil have been proposed in the draft Phase I Decommissioning Plan (DOE, March 2009). 
TABLE F-3B

\section{Comparison of Radiological Concentrations in Groundwater With Background}

\begin{tabular}{|c|c|c|c|c|}
\hline Location & Depth & Constituent & Result ( $\mu \mathrm{Ci} / \mathrm{mL})$ & $\begin{array}{l}\text { Greater Than } \\
\text { Background? }\end{array}$ \\
\hline GP10008 & $20-22^{\prime}$ & Strontium-90 & $2.88 \pm 0.01 \mathrm{E}-04$ & Yes \\
\hline GP10008 & $20-22^{\prime}$ & Technetium-99 & $4.97 \pm 0.36 \mathrm{E}-08$ & Yes \\
\hline GP10008 & $20-22^{\prime}$ & Tritium & $2.12 \pm 1.02 \mathrm{E}-07$ & Yes \\
\hline GP10008 & $20-22^{\prime}$ & Uranium-232 & $1.65 \pm 1.24 \mathrm{E}-10$ & No \\
\hline GP10008 & $20-22^{\prime}$ & Uranium-233/234 & $4.92 \pm 1.90 \mathrm{E}-10$ & No \\
\hline GP10008 & $20-22^{\prime}$ & Uranium-238 & $2.56 \pm 1.36 \mathrm{E}-10$ & No \\
\hline GP10008 & $35-37^{\prime}$ & Strontium-90 & $1.14 \pm 0.02 \mathrm{E}-05$ & Yes \\
\hline GP10008 & $35-37^{\prime}$ & Uranium-233/234 & $1.39 \pm 1.03 \mathrm{E}-10$ & No \\
\hline GP10008 & $35-37^{\prime}$ & Uranium-238 & $1.68 \pm 1.23 \mathrm{E}-10$ & No \\
\hline GP10108 & $21-23^{\prime}$ & Strontium-90 & $1.36 \pm 0.24 \mathrm{E}-07$ & Yes \\
\hline GP10108 & $28-30^{\prime}$ & Carbon-14 & $4.00 \pm 3.48 \mathrm{E}-08$ & Yes \\
\hline GP10108 & $28-30^{\prime}$ & Strontium-90 & $3.25 \pm 0.35 \mathrm{E}-07$ & Yes \\
\hline GP10108 & $28-30^{\prime}$ & Uranium-233/234 & $1.57 \pm 1.16 \mathrm{E}-10$ & No \\
\hline GP10108 & $28-30^{\prime}$ & Uranium-238 & $1.07 \pm 0.97 \mathrm{E}-10$ & No \\
\hline GP10208 & $27-29^{\prime}$ & Iodine-129 & $3.70 \pm 0.84 \mathrm{E}-09$ & Yes \\
\hline GP10208 & $\overline{27-29^{\prime}}$ & Strontium-90 & $5.05 \pm 0.37 E-07$ & $\overline{Y e s}$ \\
\hline GP10208 & $27-29^{\prime}$ & Technetium-99 & $2.49 \pm 1.77 \mathrm{E}-09$ & Yes \\
\hline GP10208 & $27-29^{\prime}$ & Tritium & $1.57 \pm 0.14 \mathrm{E}-06$ & Yes \\
\hline GP10208 & $27-29^{\prime}$ & Uranium-233/234 & $2.34 \pm 0.95 \mathrm{E}-10$ & No \\
\hline GP10208 & $27-29^{\prime}$ & Uranium-238 & $1.79 \pm 0.83 \mathrm{E}-10$ & No \\
\hline GP10308 & $21-23^{\prime}$ & Strontium-90 & $4.40 \pm 0.08 \mathrm{E}-07$ & Yes \\
\hline GP10308 & $21-23^{\prime}$ & Tritium & $1.53 \pm 1.12 \mathrm{E}-07$ & No \\
\hline GP10308 & $21-23^{\prime}$ & Uranium-233/234 & $2.93 \pm 1.46 \mathrm{E}-10$ & No \\
\hline GP10308 & $21-23^{\prime}$ (dup) & Strontium-90 & $4.00 \pm 0.08 \mathrm{E}-07$ & Yes \\
\hline GP10308 & $21-23^{\prime}$ (dup) & Uranium-233/234 & $1.98 \pm 1.41 \mathrm{E}-10$ & No \\
\hline GP10308 & $21-23^{\prime}$ (dup) & Uranium-238 & $1.53 \pm 1.27 \mathrm{E}-10$ & No \\
\hline GP10308 & $30-32^{\prime}$ & lodine-129 & $1.13 \pm 1.00 \mathrm{E}-09$ & No \\
\hline GP10308 & $30-32^{\prime}$ & Strontium-90 & $2.11 \pm 0.01 \mathrm{E}-04$ & Yes \\
\hline GP10308 & $30-32^{\prime}$ & Technetium-99 & $7.44 \pm 2.91 E-09$ & Yes \\
\hline GP10308 & $30-32^{\prime}$ & Tritium & $1.79 \pm 1.18 \mathrm{E}-07$ & Yes \\
\hline GP10308 & $30-32^{\prime}$ & Uranium-233/234 & $3.91 \pm 1.60 \mathrm{E}-10$ & No \\
\hline GP10308 & $30-32^{\prime}$ & Uranium-238 & $2.45 \pm 1.33 \mathrm{E}-10$ & No \\
\hline GP10308 & $35-37^{\prime}$ & Strontium-90 & $9.69 \pm 0.04 \mathrm{E}-06$ & Yes \\
\hline GP10308 & $35-37^{\prime}$ & Tritium & $3.34 \pm 1.30 \mathrm{E}-07$ & Yes \\
\hline GP10308 & $35-37^{\prime}$ & Uranium-233/234 & $1.54 \pm 1.29 \mathrm{E}-10$ & No \\
\hline GP10308 & $35-37^{\prime}$ & Uranium-238 & $1.07 \pm 0.99 \mathrm{E}-10$ & No \\
\hline GP10408 & $21-23^{\prime}$ & Strontium-90 & $1.23 \pm 0.01 \mathrm{E}-04$ & Yes \\
\hline GP10408 & $21-23^{\prime}$ & Technetium-99 & $8.84 \pm 1.96 \mathrm{E}-09$ & Yes \\
\hline GP10408 & $21-23^{\prime}$ & Tritium & $1.15 \pm 1.01 \mathrm{E}-07$ & No \\
\hline GP10408 & $21-23^{\prime}$ & Uranium-233/234 & $3.88 \pm 1.19 \mathrm{E}-10$ & No \\
\hline GP10408 & $21-23^{\prime}$ & Uranium-235/236 & $6.11 \pm 4.90 \mathrm{E}-11$ & No \\
\hline GP10408 & $21-23^{\prime}$ & Uranium-238 & $2.24 \pm 0.90 \mathrm{E}-10$ & No \\
\hline GP10508 & $16-18^{\prime}$ & Strontium-90 & $1.85 \pm 0.23 \mathrm{E}-07$ & Yes \\
\hline GP10508 & $16-18^{\prime}$ & Uranium-233/234 & $1.72 \pm 0.78 \mathrm{E}-10$ & No \\
\hline GP10508 & $16-18^{\prime}$ & Uranium-238 & $8.26 \pm 5.39 \mathrm{E}-11$ & No \\
\hline
\end{tabular}

Note: Due to the large volume of data, only positive detections are presented. 
TABLE F-3B (continued)

\section{Comparison of Radiological Concentrations in Groundwater With Background}

\begin{tabular}{|c|c|c|c|c|}
\hline Location & Depth & Constituent & Result ( $\mu \mathrm{Ci} / \mathrm{mL})$ & $\begin{array}{l}\text { Greater Than } \\
\text { Background? }\end{array}$ \\
\hline GP10508 & $28-30^{\prime}$ & lodine-129 & $7.97 \pm 6.86 \mathrm{E}-10$ & No \\
\hline GP10508 & $28-30^{\prime}$ & Strontium-90 & $2.40 \pm 0.01 \mathrm{E}-04$ & Yes \\
\hline GP10508 & $28-30^{\prime}$ & Technetium-99 & $1.34 \pm 0.21 \mathrm{E}-08$ & Yes \\
\hline GP10508 & $28-30^{\prime}$ & Uranium-233/234 & $3.98 \pm 1.20 \mathrm{E}-10$ & No \\
\hline GP10508 & $28-30^{\prime}$ & Uranium-235/236 & $7.15 \pm 5.31 \mathrm{E}-11$ & No \\
\hline GP10508 & $28-30^{\prime}$ & Uranium-238 & $3.39 \pm 1.12 \mathrm{E}-10$ & No \\
\hline GP10508 & $34-36^{\prime}$ & Strontium-90 & $9.04 \pm 0.15 \mathrm{E}-06$ & Yes \\
\hline GP10508 & $34-36^{\prime}$ & Tritium & $1.22 \pm 1.01 \mathrm{E}-07$ & No \\
\hline GP10508 & $34-36^{\prime}$ & Uranium-233/234 & $4.04 \pm 1.25 \mathrm{E}-10$ & No \\
\hline GP10508 & $34-36^{\prime}$ & Uranium-238 & $2.06 \pm 0.89 \mathrm{E}-10$ & No \\
\hline GP10608 & $16-18^{\prime}$ & Cesium-137 & $3.07 \pm 2.84 \mathrm{E}-09$ & No \\
\hline GP10608 & $16-18^{\prime}$ & Strontium-90 & $4.38 \pm 0.63 \mathrm{E}-08$ & Yes \\
\hline GP10608 & $16-18^{\prime}$ & Uranium-233/234 & $1.22 \pm 0.66 \mathrm{E}-10$ & No \\
\hline GP10608 & $16-18^{\prime}$ & Uranium-238 & $9.13 \pm 5.81 \mathrm{E}-11$ & No \\
\hline GP10608 & $20-22^{\prime}$ & Americium-241 & $7.89 \pm 6.53 \mathrm{E}-11$ & No \\
\hline GP10608 & $20-22^{\prime}$ & Strontium-90 & $2.18 \pm 0.01 \mathrm{E}-05$ & Yes \\
\hline GP10608 & $20-22^{\prime}$ & Technetium-99 & $4.48 \pm 1.90 \mathrm{E}-09$ & Yes \\
\hline GP10608 & $20-22^{\prime}$ & Tritium & $2.02 \pm 0.93 \mathrm{E}-07$ & Yes \\
\hline GP10608 & $20-22^{\prime}$ & Uranium-233/234 & $8.43 \pm 6.73 \mathrm{E}-11$ & No \\
\hline GP10608 & $20-22^{\prime}$ & Uranium-238 & $9.57 \pm 6.63 \mathrm{E}-11$ & No \\
\hline GP10608 & $28-30^{\prime}$ & Strontium-90 & $3.62 \pm 0.02 \mathrm{E}-06$ & Yes \\
\hline GP10608 & $28-30^{\prime}$ & Tritium & $1.29 \pm 0.91 \mathrm{E}-07$ & No \\
\hline GP10608 & $28-30^{\prime}$ & Uranium-233/234 & $1.68 \pm 0.81 \mathrm{E}-10$ & No \\
\hline GP10608 & $28-30^{\prime}$ & Uranium-238 & $9.20 \pm 5.86 \mathrm{E}-11$ & No \\
\hline GP10708 & $15-17^{\prime}$ & Strontium-90 & $1.83 \pm 0.01 \mathrm{E}-05$ & Yes \\
\hline GP10708 & $15-17^{\prime}$ & Uranium-233/234 & $1.46 \pm 0.80 \mathrm{E}-10$ & No \\
\hline GP10708 & $15-17^{\prime}$ & Uranium-238 & $1.46 \pm 0.80 \mathrm{E}-10$ & No \\
\hline GP10708 & $22-24^{\prime}$ & Strontium-90 & $4.53 \pm 0.01 \mathrm{E}-05$ & Yes \\
\hline GP10708 & $22-24^{\prime}$ & Technetium-99 & $4.70 \pm 2.16 \mathrm{E}-09$ & Yes \\
\hline GP10708 & $22-24^{\prime}$ & Tritium & $1.40 \pm 0.91 \mathrm{E}-07$ & No \\
\hline GP10708 & $22-24^{\prime}$ & Uranium-233/234 & $1.83 \pm 0.82 \mathrm{E}-10$ & No \\
\hline GP10708 & $22-24^{\prime}$ & Uranium-238 & $1.48 \pm 0.74 \mathrm{E}-10$ & No \\
\hline GP10708 & $30-32^{\prime}$ & Strontium-90 & $1.80 \pm 0.01 \mathrm{E}-04$ & Yes \\
\hline GP10708 & $30-32^{\prime}$ & Technetium-99 & $1.05 \pm 0.20 \mathrm{E}-08$ & Yes \\
\hline GP10708 & $30-32^{\prime}$ & Tritium & $5.72 \pm 1.05 \mathrm{E}-07$ & Yes \\
\hline GP10708 & $30-32^{\prime}$ & Uranium-233/234 & $3.23 \pm 1.09 \mathrm{E}-10$ & No \\
\hline GP10708 & $30-32^{\prime}$ & Uranium-238 & $3.27 \pm 1.09 \mathrm{E}-10$ & No \\
\hline GP10908 & $14-16^{\prime}$ & Strontium-90 & $1.03 \pm 0.04 \mathrm{E}-07$ & Yes \\
\hline GP10908 & $14-16^{\prime}$ & Uranium-233/234 & $6.25 \pm 5.45 \mathrm{E}-11$ & No \\
\hline GP10908 & $14-16^{\prime}$ & Uranium-238 & $6.50 \pm 5.43 \mathrm{E}-11$ & No \\
\hline GP10908 & $28-30^{\prime}$ & Strontium-90 & $3.99 \pm 0.01 \mathrm{E}-05$ & Yes \\
\hline GP10908 & $28-30^{\prime}$ & Tritium & $1.26 \pm 0.90 \mathrm{E}-07$ & No \\
\hline GP10908 & $28-30^{\prime}$ & Uranium-233/234 & $1.26 \pm 0.84 \mathrm{E}-10$ & No \\
\hline GP10908 & $28-30^{\prime}$ & Uranium-238 & $9.02 \pm 6.47 \mathrm{E}-11$ & No \\
\hline GP10908 & $34-36^{\prime}$ & Strontium-90 & $1.88 \pm 0.01 \mathrm{E}-04$ & Yes \\
\hline GP10908 & $34-36^{\prime}$ & Technetium-99 & $7.00 \pm 2.34 \mathrm{E}-09$ & Yes \\
\hline GP10908 & $34-36^{\prime}$ & Uranium-233/234 & $3.19 \pm 1.18 \mathrm{E}-10$ & No \\
\hline GP10908 & $34-36^{\prime}$ & Uranium-238 & $2.14 \pm 0.94 \mathrm{E}-10$ & No \\
\hline
\end{tabular}

Note: Due to the large volume of data, only positive detections are presented. 
TABLE F-3B (continued)

\section{Comparison of Radiological Concentrations in Groundwater With Background}

\begin{tabular}{|c|c|c|c|c|}
\hline Location & Depth & Constituent & Result $(\mu \mathrm{Ci} / \mathrm{mL})$ & $\begin{array}{l}\text { Greater Than } \\
\text { Background? }\end{array}$ \\
\hline GP2908 & $17-19^{\prime}$ & Strontium-90 & $4.21 \pm 0.03 E-05$ & Yes \\
\hline GP2908 & $17-19^{\prime}$ & Technetium-99 & $7.73 \pm 2.91 \mathrm{E}-09$ & Yes \\
\hline GP2908 & $17-19^{\prime}$ & Tritium & $1.30 \pm 1.00 \mathrm{E}-07$ & No \\
\hline GP2908 & $17-19^{\prime}$ & Uranium-232 & $9.97 \pm 2.21 \mathrm{E}-10$ & Yes \\
\hline GP2908 & $17-19^{\prime}$ & Uranium-233/234 & $1.06 \pm 0.08 \mathrm{E}-08$ & Yes \\
\hline GP2908 & $17-19^{\prime}$ & Uranium-235/236 & $3.80 \pm 1.59 \mathrm{E}-10$ & Yes \\
\hline GP2908 & 17-19' & Uranium-238 & $1.24 \pm 0.08 \mathrm{E}-08$ & $\overline{\text { Yes }}$ \\
\hline GP2908 & 17-19' (dup) & lodine-129 & $2.44 \pm 0.84 \mathrm{E}-09$ & Yes \\
\hline GP2908 & 17-19' (dup) & Strontium-90 & $4.05 \pm 0.03 E-05$ & Yes \\
\hline GP2908 & 17-19' (dup) & Technetium-99 & $7.62 \pm 2.91 \mathrm{E}-09$ & Yes \\
\hline GP2908 & 17-19' (dup) & Uranium-232 & $5.85 \pm 1.95 \mathrm{E}-10$ & Yes \\
\hline GP2908 & 17-19' (dup) & Uranium-233/234 & $9.12 \pm 0.68 \mathrm{E}-09$ & Yes \\
\hline GP2908 & 17-19' (dup) & Uranium-235/236 & $4.63 \pm 1.56 \mathrm{E}-10$ & Yes \\
\hline GP2908 & 17-19' (dup) & Uranium-238 & $1.10 \pm 0.08 \mathrm{E}-08$ & Yes \\
\hline GP2908 & $29-31^{\prime}$ & Americium-241 & $5.42 \pm 5.11 \mathrm{E}-11$ & No \\
\hline GP2908 & $29-31^{\prime}$ & Strontium-90 & $1.81 \pm 0.01 E-04$ & Yes \\
\hline GP2908 & $29-31^{\prime}$ & Technetium-99 & $1.20 \pm 0.31 \mathrm{E}-08$ & Yes \\
\hline GP2908 & $29-31^{\prime}$ & Tritium & $2.75 \pm 0.97 E-07$ & Yes \\
\hline GP2908 & $29-31^{\prime}$ & Uranium-233/234 & $5.71 \pm 1.74 \mathrm{E}-10$ & No \\
\hline GP2908 & $29-31^{\prime}$ & Uranium-238 & $4.66 \pm 1.57 \mathrm{E}-10$ & No \\
\hline GP2908 & $35-37^{\prime}$ & Strontium-90 & 4.77士0.04E-05 & $\overline{\text { Yes }}$ \\
\hline GP2908 & $35-37^{\prime}$ & Technetium-99 & $4.48 \pm 3.00 \mathrm{E}-09$ & Yes \\
\hline GP2908 & $35-37^{\prime}$ & Uranium-233/234 & $3.80 \pm 1.73 \mathrm{E}-10$ & No \\
\hline GP2908 & $35-37^{\prime}$ & Uranium-238 & $2.71 \pm 1.42 \mathrm{E}-10$ & No \\
\hline GP3008 & $20-22^{\prime}$ & Strontium-90 & $5.07 \pm 0.01 E-04$ & Yes \\
\hline GP3008 & $20-22^{\prime}$ & Technetium-99 & $4.59 \pm 0.40 E-08$ & Yes \\
\hline GP3008 & $20-22^{\prime}$ & Tritium & $1.30 \pm 1.19 \mathrm{E}-07$ & No \\
\hline GP3008 & $20-22^{\prime}$ & Uranium-233/234 & $2.74 \pm 1.39 \mathrm{E}-10$ & No \\
\hline GP3008 & $20-22^{\prime}$ (dup) & Strontium-90 & $5.33 \pm 0.01 E-04$ & Yes \\
\hline GP3008 & $20-22^{\prime}$ (dup) & Technetium-99 & $4.54 \pm 0.40 \mathrm{E}-08$ & Yes \\
\hline GP3008 & $20-22^{\prime}$ (dup) & Uranium-233/234 & $3.99 \pm 1.77 \mathrm{E}-10$ & No \\
\hline GP3008 & $20-22^{\prime}$ (dup) & Uranium-238 & $2.06 \pm 1.25 \mathrm{E}-10$ & No \\
\hline GP3008 & $28-30^{\prime}$ & Strontium-90 & $2.53 \pm 0.01 E-04$ & Yes \\
\hline GP3008 & $28-30^{\prime}$ & Technetium-99 & $2.63 \pm 0.35 E-08$ & Yes \\
\hline GP3008 & $28-30^{\prime}$ & Tritium & $1.64 \pm 1.07 E-07$ & Yes \\
\hline GP3008 & $28-30^{\prime}$ & Uranium-233/234 & $5.33 \pm 1.99 \mathrm{E}-10$ & No \\
\hline GP3008 & $28-30^{\prime}$ & Uranium-238 & $3.79 \pm 1.69 \mathrm{E}-10$ & No \\
\hline GP3008 & $35-37^{\prime}$ & Americium-241 & $7.35 \pm 7.15 \mathrm{E}-11$ & No \\
\hline GP3008 & $35-37^{\prime}$ & Strontium-90 & $6.75 \pm 0.15 E-06$ & Yes \\
\hline GP3008 & $35-37^{\prime}$ & Tritium & 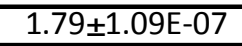 & Yes \\
\hline GP3008 & $35-37^{\prime}$ & Uranium-233/234 & $3.03 \pm 1.49 \mathrm{E}-10$ & No \\
\hline GP3008 & $35-37^{\prime}$ & Uranium-238 & $2.75 \pm 1.39 \mathrm{E}-10$ & No \\
\hline GP7208 & $20-22^{\prime}$ & Americium-241 & $9.01 \pm 8.27 \mathrm{E}-11$ & No \\
\hline GP7208 & $20-22^{\prime}$ & Iodine-129 & $1.35 \pm 1.01 \mathrm{E}-09$ & No \\
\hline GP7208 & $20-22^{\prime}$ & Plutonium-239/240 & $1.19 \pm 0.80 \mathrm{E}-10$ & No \\
\hline GP7208 & $20-22^{\prime}$ & Strontium-90 & $2.42 \pm 0.01 E-04$ & Yes \\
\hline GP7208 & $20-22^{\prime}$ & Technetium-99 & $3.89 \pm 0.39 \mathrm{E}-08$ & Yes \\
\hline GP7208 & $20-22^{\prime}$ & Tritium & $1.28 \pm 1.18 \mathrm{E}-07$ & No \\
\hline GP7208 & $20-22^{\prime}$ & Uranium-233/234 & $2.20 \pm 0.40 \mathrm{E}-09$ & Yes \\
\hline GP7208 & $20-22^{\prime}$ & Uranium-235/236 & $3.00 \pm 1.57 \mathrm{E}-10$ & Yes \\
\hline GP7208 & $20-22^{\prime}$ & Uranium-238 & $1.71 \pm 0.35 \mathrm{E}-09$ & Yes \\
\hline
\end{tabular}

Note: Due to the large volume of data, only positive detections are presented. 
TABLE F-3B (continued)

\section{Comparison of Radiological Concentrations in Groundwater With Background}

\begin{tabular}{|c|c|c|c|c|}
\hline Location & Depth & Constituent & Result ( $\mu \mathrm{Ci} / \mathrm{mL})$ & $\begin{array}{l}\text { Greater Than } \\
\text { Background? }\end{array}$ \\
\hline GP7208 & $31-33^{\prime}$ & Strontium-90 & $3.18 \pm 0.01 E-04$ & Yes \\
\hline GP7208 & $31-33^{\prime}$ & Technetium-99 & $2.92 \pm 0.37 \mathrm{E}-08$ & Yes \\
\hline GP7208 & $31-33^{\prime}$ & Uranium-233/234 & $6.41 \pm 2.02 \mathrm{E}-10$ & No \\
\hline GP7208 & $31-33^{\prime}$ & Uranium-235/236 & $7.49 \pm 7.35 \mathrm{E}-11$ & No \\
\hline GP7208 & $31-33^{\prime}$ & Uranium-238 & $2.90 \pm 1.38 \mathrm{E}-10$ & No \\
\hline GP7208 & $38-40^{\prime}$ & Strontium-90 & $1.96 \pm 0.03 \mathrm{E}-05$ & Yes \\
\hline GP7208 & $38-40^{\prime}$ & Technetium-99 & $2.89 \pm 2.80 \mathrm{E}-09$ & No \\
\hline GP7208 & $38-40^{\prime}$ & Uranium-233/234 & $5.62 \pm 1.96 \mathrm{E}-10$ & No \\
\hline GP7208 & $38-40^{\prime}$ & Uranium-238 & $2.87 \pm 1.41 \mathrm{E}-10$ & No \\
\hline GP7608 & $20-22^{\prime}$ & Americium-241 & $1.50 \pm 0.92 \mathrm{E}-10$ & Yes \\
\hline GP7608 & $20-22^{\prime}$ & Cesium-137 & $1.19 \pm 0.17 \mathrm{E}-07$ & Yes \\
\hline GP7608 & $20-22^{\prime}$ & Plutonium-238 & $1.23 \pm 0.78 \mathrm{E}-10$ & No \\
\hline GP7608 & $20-22^{\prime}$ & Plutonium-239/240 & $4.49 \pm 1.48 \mathrm{E}-10$ & Yes \\
\hline GP7608 & $20-22^{\prime}$ & Strontium-90 & $7.33 \pm 0.01 \mathrm{E}-04$ & Yes \\
\hline GP7608 & $20-22^{\prime}$ & Technetium-99 & $7.39 \pm 0.42 \mathrm{E}-08$ & Yes \\
\hline GP7608 & $20-22^{\prime}$ & Tritium & $2.00 \pm 1.08 \mathrm{E}-07$ & Yes \\
\hline GP7608 & $20-22^{\prime}$ & Uranium-232 & $3.21 \pm 2.00 \mathrm{E}-10$ & Yes \\
\hline GP7608 & $20-22^{\prime}$ & Uranium-233/234 & $9.93 \pm 2.87 \mathrm{E}-10$ & Yes \\
\hline GP7608 & $20-22^{\prime}$ & Uranium-238 & $3.69 \pm 1.78 \mathrm{E}-10$ & No \\
\hline GP7608 & $34-36^{\prime}$ & Americium-241 & $1.66 \pm 1.09 \mathrm{E}-10$ & Yes \\
\hline GP7608 & $34-36^{\prime}$ & Cesium-137 & $1.46 \pm 0.67 \mathrm{E}-08$ & No \\
\hline GP7608 & $34-36^{\prime}$ & Strontium-90 & $4.94 \pm 0.09 \mathrm{E}-06$ & Yes \\
\hline GP7608 & $34-36^{\prime}$ & Uranium-233/234 & $2.94 \pm 1.40 \mathrm{E}-10$ & No \\
\hline GP7608 & $34-36^{\prime}$ & Uranium-238 & $1.68 \pm 1.07 \mathrm{E}-10$ & No \\
\hline GP7808 & $20-22^{\prime}$ & lodine-129 & $1.79 \pm 1.43 \mathrm{E}-09$ & No \\
\hline GP7808 & $20-22^{\prime}$ & Strontium-90 & $3.76 \pm 0.01 \mathrm{E}-04$ & Yes \\
\hline GP7808 & $20-22^{\prime}$ & Technetium-99 & $4.58 \pm 0.35 \mathrm{E}-08$ & Yes \\
\hline GP7808 & $20-22^{\prime}$ & Uranium-233/234 & $5.95 \pm 1.89 \mathrm{E}-10$ & No \\
\hline GP7808 & $20-22^{\prime}$ & Uranium-235/236 & $8.18 \pm 7.55 \mathrm{E}-11$ & No \\
\hline GP7808 & $20-22^{\prime}$ & Uranium-238 & $3.44 \pm 1.46 \mathrm{E}-10$ & No \\
\hline GP7808 & $28-30^{\prime}$ & Strontium-90 & $1.34 \pm 0.01 \mathrm{E}-04$ & Yes \\
\hline GP7808 & $28-30^{\prime}$ & Technetium-99 & $8.52 \pm 2.34 \mathrm{E}-09$ & Yes \\
\hline GP7808 & $28-30^{\prime}$ & Uranium-232 & $1.36 \pm 1.07 \mathrm{E}-10$ & No \\
\hline GP7808 & $28-30^{\prime}$ & Uranium-233/234 & $3.70 \pm 1.53 \mathrm{E}-10$ & No \\
\hline GP7808 & $28-30^{\prime}$ & Uranium-235/236 & $1.13 \pm 0.87 \mathrm{E}-10$ & No \\
\hline GP7808 & $28-30^{\prime}$ & Uranium-238 & $2.10 \pm 1.14 \mathrm{E}-10$ & No \\
\hline GP7808 & $34-36^{\prime}$ & Strontium-90 & $7.16 \pm 0.16 \mathrm{E}-06$ & Yes \\
\hline GP7808 & $34-36^{\prime}$ & Uranium-233/234 & $2.84 \pm 1.26 \mathrm{E}-10$ & No \\
\hline GP7808 & $34-36^{\prime}$ & Uranium-238 & $1.32 \pm 0.90 \mathrm{E}-10$ & No \\
\hline GP8008 & $25-27^{\prime}$ & lodine-129 & $6.68 \pm 4.89 \mathrm{E}-10$ & No \\
\hline GP8008 & $25-27^{\prime}$ & Strontium-90 & $4.67 \pm 0.01 \mathrm{E}-04$ & Yes \\
\hline GP8008 & $25-27^{\prime}$ & Technetium-99 & $4.19 \pm 0.44 \mathrm{E}-08$ & Yes \\
\hline GP8008 & $25-27^{\prime}$ & Tritium & $2.56 \pm 1.22 \mathrm{E}-07$ & Yes \\
\hline GP8008 & $25-27^{\prime}$ & Uranium-233/234 & $3.16 \pm 1.50 \mathrm{E}-10$ & No \\
\hline GP8008 & $25-27^{\prime}$ & Uranium-238 & $1.45 \pm 1.04 \mathrm{E}-10$ & No \\
\hline GP8008 & $32-34^{\prime}$ & Strontium-90 & $2.03 \pm 0.01 \mathrm{E}-04$ & Yes \\
\hline GP8008 & $32-34^{\prime}$ & Technetium-99 & $2.10 \pm 0.34 \mathrm{E}-08$ & Yes \\
\hline GP8008 & $32-34^{\prime}$ & Uranium-233/234 & $5.01 \pm 2.10 \mathrm{E}-10$ & No \\
\hline GP8008 & $32-34^{\prime}$ & Uranium-238 & $4.47 \pm 1.91 \mathrm{E}-10$ & No \\
\hline
\end{tabular}

Note: Due to the large volume of data, only positive detections are presented. 
TABLE F-3B (concluded)

Comparison of Radiological Concentrations in Groundwater With Background

\begin{tabular}{|c|c|c|c|c|}
\hline Location & Depth & Constituent & Result ( $\mu \mathrm{Ci} / \mathrm{mL})$ & $\begin{array}{l}\text { Greater Than } \\
\text { Background? }\end{array}$ \\
\hline GP8008 & $39-41^{\prime}$ & lodine-129 & $4.72 \pm 3.87 \mathrm{E}-10$ & No \\
\hline GP8008 & $39-41^{\prime}$ & Strontium-90 & $2.26 \pm 0.03 E-05$ & Yes \\
\hline GP8008 & $39-41^{\prime}$ & Uranium-233/234 & $4.43 \pm 1.72 \mathrm{E}-10$ & No \\
\hline GP8008 & $39-41^{\prime}$ & Uranium-238 & $2.45 \pm 1.28 \mathrm{E}-10$ & No \\
\hline GP8308 & $22-24^{\prime}$ & Strontium-90 & $1.43 \pm 0.02 \mathrm{E}-05$ & Yes \\
\hline GP8308 & $22-24^{\prime}$ & Technetium-99 & $7.93 \pm 1.93 \mathrm{E}-09$ & Yes \\
\hline GP8308 & $22-24^{\prime}$ & Tritium & $1.34 \pm 0.97 \mathrm{E}-07$ & No \\
\hline GP8308 & $22-24^{\prime}$ & Uranium-233/234 & $8.48 \pm 5.89 \mathrm{E}-11$ & No \\
\hline GP8308 & $22-24^{\prime}$ & Uranium-238 & $7.00 \pm 5.59 \mathrm{E}-11$ & No \\
\hline GP8308 & $30-32^{\prime}$ & Strontium-90 & $2.21 \pm 0.01 \mathrm{E}-04$ & Yes \\
\hline GP8308 & $30-32^{\prime}$ & Technetium-99 & $1.39 \pm 0.21 \mathrm{E}-08$ & Yes \\
\hline GP8308 & $30-32^{\prime}$ & Tritium & $2.64 \pm 1.00 \mathrm{E}-07$ & Yes \\
\hline GP8308 & $30-32^{\prime}$ & Uranium-233/234 & $4.49 \pm 1.31 \mathrm{E}-10$ & No \\
\hline GP8308 & $30-32^{\prime}$ & Uranium-235/236 & $7.82 \pm 5.42 \mathrm{E}-11$ & No \\
\hline GP8308 & $30-32^{\prime}$ & Uranium-238 & $2.41 \pm 0.96 \mathrm{E}-10$ & No \\
\hline GP8308 & $38-40^{\prime}$ & Americium-241 & $6.19 \pm 6.18 \mathrm{E}-11$ & No \\
\hline GP8308 & $38-40^{\prime}$ & Strontium-90 & $1.12 \pm 0.01 \mathrm{E}-04$ & Yes \\
\hline GP8308 & $38-40^{\prime}$ & Technetium-99 & $5.96 \pm 1.86 \mathrm{E}-09$ & Yes \\
\hline GP8308 & $38-40^{\prime}$ & Tritium & $1.98 \pm 0.97 \mathrm{E}-07$ & Yes \\
\hline GP8308 & $38-40^{\prime}$ & Uranium-232 & $5.04 \pm 4.70 \mathrm{E}-11$ & No \\
\hline GP8308 & $38-40^{\prime}$ & Uranium-233/234 & $4.76 \pm 1.38 \mathrm{E}-10$ & No \\
\hline GP8308 & $38-40^{\prime}$ & Uranium-235/236 & $7.46 \pm 6.13 \mathrm{E}-11$ & No \\
\hline GP8308 & $38-40^{\prime}$ & Uranium-238 & $2.80 \pm 1.06 \mathrm{E}-10$ & No \\
\hline
\end{tabular}

Note: Due to the large volume of data, only positive detections are presented. 
TABLE F-3C

Concentration Ranges of Radiological Constituents in 2008 Geoprobe ${ }^{\circledR}$ Soil Samples

\begin{tabular}{|c|c|c|c|c|c|}
\hline \multirow{2}{*}{$\begin{array}{r}\begin{array}{r}\text { Radiological } \\
\text { Constituent }\end{array} \\
\text { Gross alpha } \\
\end{array}$} & \multicolumn{3}{|c|}{$\begin{array}{c}\text { Range } \\
\text { of Observed Concentrations } \\
(\mu \mathrm{Ci} / \mathrm{g})^{a}\end{array}$} & \multirow{2}{*}{$\begin{array}{c}\text { Location of Maximum } \\
\text { Concentration }\end{array}$} & \multirow{2}{*}{$\begin{array}{c}\text { Depth of Maximum } \\
\text { Concentration }\end{array}$} \\
\hline & 4.09E-06 & - & 2.89E-05 & & \\
\hline Gross beta & $1.43 \mathrm{E}-05$ & - & 1.67E-02 & GP7608 & $15-17^{\prime}$ \\
\hline Tritium Solid & $<4.25 \mathrm{E}-07$ & - & $1.42 \mathrm{E}-05$ & GP10008 & $10-12^{\prime}$ \\
\hline Carbon-14 & $<6.00 \mathrm{E}-08$ & - & $<6.48 \mathrm{E}-07$ & GP10608 & $22-24^{\prime}$ \\
\hline Potassium-40 & $9.80 \mathrm{E}-06$ & - & 3.06E-05 & GP10908 & $36-38$ \\
\hline Cobalt-60 & $<1.47 \mathrm{E}-08$ & - & $2.76 \mathrm{E}-07$ & GP7808 & $15-17^{\prime}$ \\
\hline Strontium-90 & $<3.19 \mathrm{E}-08$ & - & $9.33 \mathrm{E}-03$ & GP7608 & $15-17^{\prime}$ \\
\hline Technetium-99 & $<2.96 \mathrm{E}-07$ & - & $9.31 \mathrm{E}-06$ & GP7608 & $15-17^{\prime}$ \\
\hline lodine-129 & $<3.32 \mathrm{E}-08$ & - & $5.82 \mathrm{E}-07$ & GP7208 & $14-16^{\prime}$ \\
\hline Cesium-137 & $<1.26 \mathrm{E}-08$ & - & $2.22 \mathrm{E}-04$ & GP7608 & $19-21^{\prime}$ \\
\hline Europium-154 & $<4.32 \mathrm{E}-08$ & - & $6.06 \mathrm{E}-07$ & GP7808 & $20-22^{\prime}$ \\
\hline Uranium-232 ${ }^{b}$ & $<8.80 \mathrm{E}-09$ & - & $1.30 \mathrm{E}-07$ & GP10908 & $36-38^{\prime}$ \\
\hline Uranium-233/234 & $<3.16 \mathrm{E}-07$ & - & 4.06E-06 & GP10008 & $10-12^{\prime}$ \\
\hline Uranium-235/236 & $<2.93 \mathrm{E}-08$ & - & $3.49 \mathrm{E}-07$ & GP10208 & $14-16^{\prime}$ \\
\hline Uranium-238 & $<5.20 \mathrm{E}-07$ & - & $1.65 \mathrm{E}-06$ & GP2908 & $14-16^{\prime}$ \\
\hline Neptunium-237 & $<4.99 \mathrm{E}-09$ & - & $1.86 \mathrm{E}-08$ & GP10708 & $22-24^{\prime}$ \\
\hline Plutonium-238 ${ }^{b}$ & $<8.10 \mathrm{E}-09$ & - & $5.60 \mathrm{E}-07$ & GP7608 & 19-21' \\
\hline Plutonium-239/240 & $<8.07 \mathrm{E}-09$ & - & $3.69 E-06$ & GP7608 & $19-21^{\prime}$ \\
\hline Plutonium-241 & $<2.26 \mathrm{E}-07$ & - & 8.70E-07 & GP7208 & $18-20^{\prime}$ \\
\hline Americium-241 & $<2.58 \mathrm{E}-09$ & - & $6.84 \mathrm{E}-06$ & GP7608 & $19-21^{\prime}$ \\
\hline Curium-243/244 & $<6.35 \mathrm{E}-09$ & - & $1.53 \mathrm{E}-07$ & GP8008 & $25-27^{\prime}$ \\
\hline
\end{tabular}

${ }^{a}$ All samples from the 18 plume area characterization Geoprobes ${ }^{\circledR}$ are included in this determination of range of concentrations.

${ }^{b}$ Analysis for U-232 and Pu-238 were not specified in the Sampling and Analysis Plan (WVNSCO, 2007), however they are included in the radiological analyte list because they are site-specific to the WVDP and are typically included in WVDP sample analysis requests.

c One result is typically reported for U-233/234, U-235/236, Pu-239/240, and Cm-243/244 because the peaks for each radionuclide are difficult to differentiate from each other during analysis. 
TABLE F-3D

Concentration Ranges of Radiological Constituents in 2008 Geoprobe ${ }^{\circledR}$ Groundwater Samples

\begin{tabular}{|c|c|c|c|c|c|}
\hline Constituent & \multicolumn{3}{|c|}{$\begin{array}{c}\text { Range of Observed } \\
\text { Concentrations }(\mu \mathrm{Ci} / \mathrm{mL})\end{array}$} & $\begin{array}{c}\text { Location of Maximum } \\
\text { Concentration }\end{array}$ & $\begin{array}{c}\text { Depth of Maximum } \\
\text { Concentration }\end{array}$ \\
\hline Gross Alpha & $<5.96 \mathrm{E}-10$ & - & $2.99 \mathrm{E}-08$ & GP2908 & $17-19^{\prime}$ \\
\hline Gross Beta & $1.44 \mathrm{E}-07$ & - & $1.40 \mathrm{E}-03$ & GP7608 & $20-22^{\prime}$ \\
\hline Tritium & $<8.69 \mathrm{E}-08$ & - & $1.57 \mathrm{E}-06$ & GP10208 & $27-29^{\prime}$ \\
\hline Carbon-14 & $<2.44 \mathrm{E}-08$ & - & $4.00 \mathrm{E}-08$ & GP10108 & $28-30^{\prime}$ \\
\hline Potassium-40 & $<1.80 \mathrm{E}-08$ & - & 4.31E-08 & GP7608 & $20-22^{\prime}$ \\
\hline Cobalt-60 & $<9.80 \mathrm{E}-10$ & - & $6.02 \mathrm{E}-09$ & GP10508 & $16-18^{\prime}$ \\
\hline Strontium-90 & $4.38 \mathrm{E}-08$ & - & 7.33E-04 & GP7608 & $20-22^{\prime}$ \\
\hline Technetium-99 & $<1.64 \mathrm{E}-09$ & - & $7.39 \mathrm{E}-08$ & GP7608 & $20-22^{\prime}$ \\
\hline lodine-129 & $<1.62 \mathrm{E}-10$ & - & $3.70 \mathrm{E}-09$ & GP10208 & $27-29^{\prime}$ \\
\hline Cesium-137 & $<8.94 \mathrm{E}-10$ & - & $1.19 \mathrm{E}-07$ & GP7608 & $20-22^{\prime}$ \\
\hline Europium-154 & $<2.40 \mathrm{E}-09$ & - & $<1.55 \mathrm{E}-08$ & GP10008 & $20-22^{\prime}$ \\
\hline Uranium-232 $^{a}$ & $<2.20 \mathrm{E}-11$ & - & $1.00 \mathrm{E}-09$ & GP2908 & $17-19^{\prime}$ \\
\hline Uranium-233/234 & $<6.25 \mathrm{E}-11$ & - & $1.06 \mathrm{E}-08$ & GP2908 & 17-19' \\
\hline Uranium-235/236 & $<1.84 \mathrm{E}-11$ & - & $4.63 \mathrm{E}-10$ & GP2908 & 17-19' \\
\hline Uranium-238 & $<5.90 \mathrm{E}-11$ & - & $1.24 \mathrm{E}-08$ & GP2908 & 17-19' \\
\hline Neptunium-237 & $<1.78 \mathrm{E}-11$ & - & $1.32 \mathrm{E}-09$ & GP7608 & $20-22^{\prime}$ \\
\hline Plutonium-238 ${ }^{a}$ & $<1.80 \mathrm{E}-11$ & - & $1.20 \mathrm{E}-10$ & GP7608 & $20-22^{\prime}$ \\
\hline Plutonium-239/240 & $<1.78 \mathrm{E}-11$ & - & $4.49 \mathrm{E}-10$ & GP7608 & $20-22^{\prime}$ \\
\hline Plutonium-241 & $<1.19 \mathrm{E}-08$ & - & $2.35 \mathrm{E}-08$ & GP8308 & $38-40^{\prime}$ \\
\hline Americium-241 & $<1.92 \mathrm{E}-11$ & - & $1.66 \mathrm{E}-10$ & GP7608 & $34-36^{\prime}$ \\
\hline Curium-243/244 ${ }^{b}$ & $<2.24 \mathrm{E}-11$ & - & $9.56 \mathrm{E}-11$ & GP2908 & $29-31^{\prime}$ \\
\hline
\end{tabular}

a Analysis for U-232 and Pu-238 were not specified in the Sampling and Analysis Plan (WVNSCO, 2007), however they are included in the radiological analyte list because they are site-specific to the WVDP and are typically included in WVDP sample analysis requests.

${ }^{b}$ One result is typically reported for U-233/234, U-235/236, Pu-239/240, and $\mathrm{Cm}-243 / 244$ because the peaks for each radionuclide are difficult to differentiate from each other during analysis. 
TABLE F-3E

Maximum Radiological Concentrations in Groundwater From the 2008 North Plateau Geoprobe ${ }^{\circledR}$ Characterization Program

\begin{tabular}{|c|c|c|c|}
\hline $\begin{array}{c}\text { Geoprobe }{ }^{\circ} \text { Boring } \\
\text { Location }\end{array}$ & Depth & $\begin{array}{c}\text { Radionuclide with Maximum } \\
\text { Concentration }\end{array}$ & $\begin{array}{c}\text { Concentration } \\
(\mu \mathrm{Ci} / \mathrm{mL})\end{array}$ \\
\hline GP2908 & $\begin{array}{l}17-19^{\prime} \\
29-31^{\prime} \\
35-37^{\prime}\end{array}$ & $\begin{array}{l}\text { Strontium-90 } \\
\text { Strontium-90 } \\
\text { Strontium-90 }\end{array}$ & $\begin{array}{l}4.21 \mathrm{E}-05 \\
1.81 \mathrm{E}-04 \\
4.77 \mathrm{E}-05\end{array}$ \\
\hline GP3008 & $\begin{array}{l}20-22^{\prime} \\
28-30^{\prime} \\
35-37^{\prime}\end{array}$ & $\begin{array}{l}\text { Strontium-90 } \\
\text { Strontium-90 } \\
\text { Strontium-90 }\end{array}$ & $\begin{array}{l}5.33 \mathrm{E}-04 \\
2.53 \mathrm{E}-04 \\
6.75 \mathrm{E}-06\end{array}$ \\
\hline GP7208 & $\begin{array}{l}20-22^{\prime} \\
31-33^{\prime} \\
38-40^{\prime}\end{array}$ & $\begin{array}{l}\text { Strontium-90 } \\
\text { Strontium-90 } \\
\text { Strontium-90 }\end{array}$ & $\begin{array}{l}2.42 \mathrm{E}-04 \\
3.18 \mathrm{E}-04 \\
1.96 \mathrm{E}-05\end{array}$ \\
\hline GP7608 & $\begin{array}{l}20-22^{\prime} \\
34-36^{\prime}\end{array}$ & $\begin{array}{l}\text { Strontium-90 } \\
\text { Strontium-90 }\end{array}$ & $\begin{array}{l}7.33 \mathrm{E}-04 \\
4.94 \mathrm{E}-06\end{array}$ \\
\hline GP7808 & $\begin{array}{l}20-22^{\prime} \\
28-30^{\prime} \\
34-36^{\prime}\end{array}$ & $\begin{array}{l}\text { Strontium-90 } \\
\text { Strontium-90 } \\
\text { Strontium-90 }\end{array}$ & $\begin{array}{l}3.76 \mathrm{E}-04 \\
1.34 \mathrm{E}-04 \\
7.16 \mathrm{E}-06 \\
\end{array}$ \\
\hline GP8008 & $\begin{array}{l}25-27^{\prime} \\
32-34^{\prime} \\
39-41^{\prime}\end{array}$ & $\begin{array}{l}\text { Strontium-90 } \\
\text { Strontium-90 } \\
\text { Strontium-90 }\end{array}$ & $\begin{array}{l}4.67 \mathrm{E}-04 \\
2.03 \mathrm{E}-04 \\
2.26 \mathrm{E}-05 \\
\end{array}$ \\
\hline GP8308 & $\begin{array}{l}22-24^{\prime} \\
30-32^{\prime} \\
38-40^{\prime}\end{array}$ & $\begin{array}{l}\text { Strontium-90 } \\
\text { Strontium-90 } \\
\text { Strontium-90 }\end{array}$ & $\begin{array}{l}1.43 \mathrm{E}-05 \\
2.21 \mathrm{E}-04 \\
1.12 \mathrm{E}-04 \\
\end{array}$ \\
\hline GP10008 & $\begin{array}{l}20-22^{\prime} \\
35-37^{\prime}\end{array}$ & $\begin{array}{l}\text { Strontium-90 } \\
\text { Strontium-90 }\end{array}$ & $\begin{array}{l}2.88 \mathrm{E}-04 \\
1.14 \mathrm{E}-05 \\
\end{array}$ \\
\hline GP10108 & $\begin{array}{l}21-23^{\prime} \\
28-30^{\prime} \\
\end{array}$ & $\begin{array}{l}\text { Strontium-90 } \\
\text { Strontium-90 }\end{array}$ & $\begin{array}{l}1.36 \mathrm{E}-07 \\
3.25 \mathrm{E}-07 \\
\end{array}$ \\
\hline GP10208 & $27-29^{\prime}$ & Tritium & $1.57 \mathrm{E}-06$ \\
\hline GP10308 & $\begin{array}{l}21-23^{\prime} \\
30-32^{\prime} \\
35-37^{\prime} \\
\end{array}$ & $\begin{array}{l}\text { Strontium-90 } \\
\text { Strontium-90 } \\
\text { Strontium-90 } \\
\end{array}$ & $\begin{array}{l}4.40 \mathrm{E}-07 \\
2.11 \mathrm{E}-04 \\
9.69 \mathrm{E}-06 \\
\end{array}$ \\
\hline GP10408 & $21-23^{\prime}$ & Strontium-90 & $1.23 \mathrm{E}-04$ \\
\hline GP10508 & $\begin{array}{l}16-18^{\prime} \\
28-30^{\prime} \\
34-36^{\prime}\end{array}$ & $\begin{array}{l}\text { Strontium-90 } \\
\text { Strontium-90 } \\
\text { Strontium-90 }\end{array}$ & $\begin{array}{l}1.85 \mathrm{E}-07 \\
2.40 \mathrm{E}-04 \\
9.04 \mathrm{E}-06\end{array}$ \\
\hline GP10608 & $\begin{array}{l}16-18^{\prime} \\
20-22^{\prime} \\
28-30^{\prime} \\
\end{array}$ & $\begin{array}{l}\text { Strontium-90 } \\
\text { Strontium-90 } \\
\text { Strontium-90 }\end{array}$ & $\begin{array}{l}4.38 \mathrm{E}-08 \\
2.18 \mathrm{E}-05 \\
3.62 \mathrm{E}-06\end{array}$ \\
\hline GP10708 & $\begin{array}{l}15-17^{\prime} \\
22-24^{\prime} \\
30-32^{\prime}\end{array}$ & $\begin{array}{l}\text { Strontium-90 } \\
\text { Strontium-90 } \\
\text { Strontium-90 }\end{array}$ & $\begin{array}{l}1.83 \mathrm{E}-05 \\
4.53 \mathrm{E}-05 \\
1.80 \mathrm{E}-04 \\
\end{array}$ \\
\hline GP10908 & $\begin{array}{l}14-16^{\prime} \\
28-30^{\prime} \\
34-36^{\prime}\end{array}$ & $\begin{array}{l}\text { Strontium-90 } \\
\text { Strontium-90 } \\
\text { Strontium-90 }\end{array}$ & $\begin{array}{l}1.03 \mathrm{E}-07 \\
3.99 \mathrm{E}-05 \\
1.88 \mathrm{E}-04\end{array}$ \\
\hline
\end{tabular}

Note: Groundwater was not collected at Geoprobe ${ }^{\circ}$ locations GP7508 and GP10808 due to refusal during drilling. 
This page intentionally left blank 


\section{APPENDIX F-4}

\section{Nonradiological Results for 2008 Subsurface Soil and Groundwater From the WVDP North Plateau}

TABLE F-4A

Metals Results For 2008 Geoprobe $^{\circledR}$ Soil Samples

\begin{tabular}{|c|c|c|c|c|c|c|}
\hline Location & \begin{tabular}{|c} 
Aluminum \\
$(\mathrm{mg} / \mathrm{kg})$
\end{tabular} & $\begin{array}{l}\text { Antimony } \\
(\mathrm{mg} / \mathrm{kg})\end{array}$ & $\begin{array}{l}\text { Arsenic } \\
(\mathrm{mg} / \mathrm{kg})\end{array}$ & $\begin{array}{l}\text { Barium } \\
(\mathrm{mg} / \mathrm{kg})\end{array}$ & $\begin{array}{r}\text { Beryllium } \\
(\mathrm{mg} / \mathrm{kg})\end{array}$ & $\begin{array}{c}\text { Cadmium } \\
(\mathrm{mg} / \mathrm{kg})\end{array}$ \\
\hline $\begin{array}{l}\text { Site-Specific Soil } \\
\text { Screening Level (SSL) }\end{array}$ & 15,400 & 2.28 & 12.5 & 300 & 0.814 & 1 \\
\hline Site Background (SB) & 15,400 & 150 & 12.5 & 30.0 & 0.814 & 0.533 \\
\hline TAGM 4046 & $S B$ & $S B$ & 7.5 or $S B$ & 300 or $S B$ & 0.16 or $S B$ & $S B$ \\
\hline Lab Detection Limit & $C R D L=50$ & $C R D L=6$ & $C R D L=1$ & $C R D L=20$ & $C R D L=0.5$ & $C R D L=0.5$ \\
\hline GP2908 2-4' & 10,000 & ND & $8.38 \mathrm{~J}$ & 64 & $0.26 \mathrm{~J}$ & ND \\
\hline$\overline{\mid G P 2908 \quad 7-9^{\prime}}$ & 11,000 & $0.59 \mathrm{~J}$ & $6.55 \mathrm{~J}$ & 36.8 & $0.274 \mathrm{~J}$ & ND \\
\hline \begin{tabular}{|ll} 
GP2908 12-14' \\
\end{tabular} & 8,680 & ND & $7.43 \mathrm{~J}$ & 38.3 & $0.247 \mathrm{~J}$ & ND \\
\hline GP2908 14-16' & 9,750 & ND & $9.43 \mathrm{~J}$ & 62.7 & $0.304 \mathrm{~J}$ & ND \\
\hline GP2908 28-30' & 10,800 & $\mathrm{ND}$ & $7.54 \mathrm{~J}$ & 89.7 & $0.311 \mathrm{~J}$ & ND \\
\hline GP2908 30-32' & 7,000 & ND & $8.41 \mathrm{~J}$ & 48.6 & $0.162 \mathrm{~J}$ & ND \\
\hline GP2908 35-37' & 6,770 & $0.393 \mathrm{~J}$ & $4.49 \mathrm{~J}$ & 53.1 & $0.215 \mathrm{~J}$ & ND \\
\hline GP3008 4-6' & $11,600 \mathrm{~J}$ & $\mathrm{ND}$ & 10.6 & $88 \mathrm{~J}$ & $0.391 \mathrm{~J}$ & ND \\
\hline GP3008 4-6' DUP & $7,750 \mathrm{~J}$ & $2.79 \mathrm{~J}$ & 13.1 & $37.7 \mathrm{~J}$ & ND & $0.192 \mathrm{~J}$ \\
\hline GP3008 10-12' & 9,260 & $0.397 \mathrm{~J}$ & 8.43 & 63.3 & $0.218 \mathrm{~J}$ & ND \\
\hline GP3008 15-17' & 9,470 & $0.494 \mathrm{~J}$ & 6.44 & $76.4 \mathrm{~J}$ & $0.198 \mathrm{~J}$ & ND \\
\hline GP3008 21-23' & 11,500 & $0.525 \mathrm{~J}$ & 11.2 & 106 & $0.366 \mathrm{~J}$ & ND \\
\hline GP3008 28-30' & 11,500 & $0.462 \mathrm{~J}$ & 8.64 & 92 & $0.333 \mathrm{~J}$ & $\overline{N D}$ \\
\hline GP3008 35-37' & 11,500 & $0.375 \mathrm{~J}$ & 4.69 & 80 & $0.255 \mathrm{~J}$ & ND \\
\hline GP3008 37-39' & 11,700 & $\mathrm{ND}$ & 7.65 & 90.4 & $0.227 \mathrm{~J}$ & $0.137 \mathrm{~J}$ \\
\hline GP7208 4-6' & $9,590 \mathrm{~J}$ & $2.75 \mathrm{~J}$ & 4.38 & $69 \mathrm{~J}$ & $1.3 \mathrm{~J}$ & $0.449 \mathrm{~J}$ \\
\hline GP7208 9-11' & $10,700 \mathrm{~J}$ & ND & 8.38 & $113 \mathrm{~J}$ & $0.586 \mathrm{~J}$ & $0.374 \mathrm{~J}$ \\
\hline GP7208 14-16' & $10,700 \mathrm{~J}$ & ND & 9.91 & $69.1 \mathrm{~J}$ & $0.359 \mathrm{~J}$ & $0.145 \mathrm{~J}$ \\
\hline GP7208 14-16' DUP & 11,200 & 1.78 & 8.78 & 70 & 0.559 & 0.288 \\
\hline GP7208 18-20' & $10,900 \mathrm{~J}$ & ND & 6.89 & $66.2 \mathrm{~J}$ & $0.552 \mathrm{~J}$ & $0.345 \mathrm{~J}$ \\
\hline $\mid$ GP7208 34-36' $^{\prime}$ & $8,210 \mathrm{~J}$ & ND & $65.4 \mathrm{~F} / 10.6 / 9.5 / 11.1$ & $71.1 \mathrm{~J}$ & $0.44 \mathrm{~J}$ & $0.29 \mathrm{~J}$ \\
\hline GP7208 38-40' & $7,850 \mathrm{~J}$ & $2.82 \mathrm{~J}$ & 8.91 & $36 \mathrm{~J}$ & $0.388 \mathrm{~J}$ & $0.359 \mathrm{~J}$ \\
\hline GP7508 4-6' & 10,800 & 1.67 & $9.47 \mathrm{~J}$ & $99.4 \mathrm{~J}$ & 0.544 & 1.04 \\
\hline GP7608 4-6' & 6,790 & $0.636 \mathrm{~J}$ & $\overline{N D}$ & 37.6 & $0.161 \mathrm{~J}$ & ND \\
\hline GP7608 10-12' & 11,800 & $0.715 \mathrm{~J}$ & 9.36 & 45.2 & $0.238 \mathrm{~J}$ & $\overline{N D}$ \\
\hline$\overline{\mid G P 7608 \text { 15-17' }}$ & 9,840 & $0.497 \mathrm{~J}$ & $8.95 \mathrm{~J}$ & 51.8 & $0.22 \mathrm{~J}$ & ND \\
\hline GP7608 19-21' & 9,000 & $0.741 \mathrm{~J}$ & $9.41 \mathrm{~J}$ & 75.4 & $0.307 \mathrm{~J}$ & ND \\
\hline GP7608 24-26' & 6,750 & $3.35 \mathrm{~J}$ & $12 \mathrm{~J}$ & 52.3 & ND & $0.356 \mathrm{~J}$ \\
\hline GP7608 36-38' & 12,200 & ND & $6.9 \mathrm{~J}$ & 75.1 & $0.266 \mathrm{~J}$ & ND \\
\hline GP7608 38-40' & 15,300 & ND & $7.37 \mathrm{~J}$ & 135 & $0.426 \mathrm{~J}$ & $0.125 \mathrm{~J}$ \\
\hline
\end{tabular}

CRDL - Contract-required detection limit

F - Homogeneity issues yielded significantly different results between sample and replicates

$\mathrm{J}$ - Data are estimated

ND - Not detected 
TABLE F-4A (continued) Metals Results For 2008 Geoprobe $^{\circledR}$ Soil Samples

\begin{tabular}{|c|c|c|c|c|c|c|}
\hline Location & $\begin{array}{c}\text { Aluminum } \\
(\mathrm{mg} / \mathrm{kg})\end{array}$ & $\begin{array}{c}\text { Antimony } \\
(\mathrm{mg} / \mathrm{kg})\end{array}$ & $\begin{array}{l}\text { Arsenic } \\
(\mathrm{mg} / \mathrm{kg})\end{array}$ & $\begin{array}{l}\text { Barium } \\
(\mathrm{mg} / \mathrm{kg})\end{array}$ & $\begin{array}{c}\text { Beryllium } \\
(\mathrm{mg} / \mathrm{kg})\end{array}$ & $\begin{array}{c}\text { Cadmium } \\
(\mathrm{mg} / \mathrm{kg})\end{array}$ \\
\hline $\begin{array}{l}\text { Site-Specific Soil } \\
\text { Screening Level (SSL) }\end{array}$ & 15,400 & 2.28 & 12.5 & 300 & 0.814 & 1 \\
\hline Site Background (SB) & 15,400 & 150 & 12.5 & 30.0 & 0.814 & 0.533 \\
\hline TAGM 4046 & $S B$ & $S B$ & 7.5 or $S B$ & 300 or $S B$ & 0.16 or $S B$ & $S B$ \\
\hline Lab Detection Limit & $C R D L=50$ & $C R D L=6$ & $C R D L=1$ & $C R D L=20$ & $C R D L=0.5$ & $C R D L=0.5$ \\
\hline GP7808 4-6' & 10,100 & ND & $7.58 \mathrm{~J}$ & $91.2 \mathrm{~J}$ & 0.532 & 1.04 \\
\hline $\mid \overline{\mid G P 780810-12^{\prime}}$ & 10,700 & ND & $8.55 \mathrm{~J}$ & $67.2 \mathrm{~J}$ & 0.505 & 1.02 \\
\hline $\mid \overline{\text { GP7808 } 15-17^{\prime}}$ & 10,300 & ND & $7.99 \mathrm{~J}$ & $70.5 \mathrm{~J}$ & 0.487 & 0.857 \\
\hline GP7808 18-20' & 9,650 & ND & $7.76 \mathrm{~J}$ & $64.3 \mathrm{~J}$ & 0.445 & 0.846 \\
\hline GP7808 20-22' & 7,740 & $\overline{N D}$ & $7.6 \mathrm{~J}$ & $54 \mathrm{~J}$ & 0.42 & 0.744 \\
\hline GP7808 22-24' & 10,200 & ND & $7.73 \mathrm{~J}$ & $60.2 \mathrm{~J}$ & 0.582 & 1.05 \\
\hline GP7808 35-37' & 10,900 & ND & $7.11 \mathrm{~J}$ & $73 \mathrm{~J}$ & 0.537 & 0.924 \\
\hline \begin{tabular}{|ll} 
GP7808 37-39' \\
\end{tabular} & 13,300 & ND & $7.48 \mathrm{~J}$ & $145 \mathrm{~J}$ & 0.726 & 1.14 \\
\hline 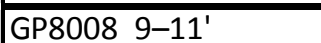 & $13,300 \mathrm{~J}$ & ND & 9.83 & $87.1 \mathrm{~J}$ & $\mathrm{ND}$ & $\mathrm{ND}$ \\
\hline GP8008 15-17' & $10,500 \mathrm{~J}$ & ND & 8.95 & 68.5 & ND & ND \\
\hline GP8008 19-21' & $13,000 \mathrm{~J}$ & ND & 8.39 & 86.2 & ND & ND \\
\hline GP8008 25-27' & $10,300 \mathrm{~J}$ & ND & 8.5 & 56.3 & ND & ND \\
\hline GP8008 25-27' DUP & $10,300 \mathrm{~J}$ & ND & 8.21 & 77.6 & ND & ND \\
\hline GP8008 32-34' & $9,790 \mathrm{~J}$ & ND & 9.44 & 69.4 & ND & ND \\
\hline GP8008 39-41' & $9,220 \mathrm{~J}$ & ND & 4.92 & 62.5 & ND & ND \\
\hline GP8008 41-43' & $12,600 \mathrm{~J}$ & ND & 8.64 & 86.9 & ND & ND \\
\hline GP8308 14-16' & $10,900 \mathrm{~J}$ & $\overline{N D}$ & $6.02 \mathrm{~J}$ & $80.9 \mathrm{~J}$ & $0.142 \mathrm{~J}$ & ND \\
\hline GP8308 30-32' & $8,860 \mathrm{~J}$ & ND & $10.2 \mathrm{~J}$ & $61.2 \mathrm{~J}$ & $0.221 \mathrm{~J}$ & ND \\
\hline GP8308 38-40' & $9,050 \mathrm{~J}$ & ND & $11.5 \mathrm{~J}$ & $63.7 \mathrm{~J}$ & 0.253 & $\mathrm{ND}$ \\
\hline GP8308 $40-42^{\prime}$ & $12,300 \mathrm{~J}$ & ND & $7.41 \mathrm{~J}$ & $75.2 \mathrm{~J}$ & $0.167 \mathrm{~J}$ & ND \\
\hline 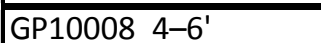 & 5,790 & ND & $9.22 \mathrm{~J}$ & $31.6 \mathrm{~J}$ & $0.17 \mathrm{~J}$ & $\mathrm{ND}$ \\
\hline GP10008 10-12' & 10,800 & $1.08 \mathrm{~J}$ & $9.21 \mathrm{~J}$ & $64.1 \mathrm{~J}$ & $0.166 \mathrm{~J}$ & ND \\
\hline GP10008 16-18' & 7,300 & $0.568 \mathrm{~J}$ & $8.93 \mathrm{~J}$ & $42.4 \mathrm{~J}$ & $0.173 \mathrm{~J}$ & ND \\
\hline GP10008 18-20' & 8,020 & $0.365 \mathrm{~J}$ & $9.62 \mathrm{~J}$ & $48.9 \mathrm{~J}$ & $0.205 \mathrm{~J}$ & ND \\
\hline GP10008 30-32' & 10,300 & ND & $8.3 \mathrm{~J}$ & $74.6 \mathrm{~J}$ & $0.143 \mathrm{~J}$ & $0.166 \mathrm{~J}$ \\
\hline GP10008 32-34' & 8,490 & ND & $8.33 \mathrm{~J}$ & $30.4 \mathrm{~J}$ & $0.265 \mathrm{~J}$ & ND \\
\hline GP10008 37-39' & 14,900 & ND & $8.02 \mathrm{~J}$ & $132 \mathrm{~J}$ & $0.401 \mathrm{~J}$ & ND \\
\hline GP10108 4-6' & 10,700 & $0.522 \mathrm{~J}$ & 10.5 & 69.3 & $0.298 \mathrm{~J}$ & ND \\
\hline GP10108 9-11' & 9,310 & ND & 5.15 & 41.2 & $0.237 \mathrm{~J}$ & ND \\
\hline GP10108 14-16' & 11,300 & $0.364 \mathrm{~J}$ & 7.03 & 51 & $0.216 \mathrm{~J}$ & ND \\
\hline 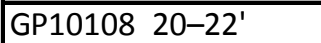 & 7,930 & $0.529 \mathrm{~J}$ & 9.54 & 53.5 & $0.269 \mathrm{~J}$ & ND \\
\hline GP10108 32-34' & 10,400 & $0.48 \mathrm{~J}$ & 6.79 & 67.3 & $0.23 \mathrm{~J}$ & ND \\
\hline GP10208 14-16' & 10,700 & ND & $15.8 \mathrm{~J}$ & 67.8 & $0.396 \mathrm{~J}$ & ND \\
\hline 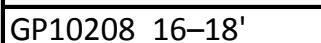 & 8,660 & ND & $7.55 \mathrm{~J}$ & 81.4 & $0.293 \mathrm{~J}$ & ND \\
\hline GP10208 20-22' & 10,400 & ND & $8.36 \mathrm{~J}$ & 69.4 & $0.295 \mathrm{~J}$ & ND \\
\hline GP10308 16-18' & 9,260 & $\overline{N D}$ & $9.82 \mathrm{~J}$ & $73.2 \mathrm{~J}$ & $0.244 \mathrm{~J}$ & ND \\
\hline GP10308 30-32' & 7,510 & ND & $10.2 \mathrm{~J}$ & $54.6 \mathrm{~J}$ & $0.23 \mathrm{~J}$ & $0.17 \mathrm{~J}$ \\
\hline GP10308 34-36' & 7,720 & ND & $7.02 \mathrm{~J}$ & $43.1 \mathrm{~J}$ & ND & ND \\
\hline GP10308 34-36' DUP & 6,420 & ND & $10.3 \mathrm{~J}$ & $60.4 \mathrm{~J}$ & ND & ND \\
\hline
\end{tabular}

CRDL - Contract-required detection limit

$\mathrm{J}$ - Data are estimated

ND - Not detected 
TABLE F-4A (continued) Metals Results For 2008 Geoprobe ${ }^{\circledR}$ Soil Samples

\begin{tabular}{|l|c|c|c|c|c|c|}
\hline \multicolumn{1}{|c|}{ Location } & $\begin{array}{c}\text { Aluminum } \\
(\mathbf{m g} / \mathbf{k g})\end{array}$ & $\begin{array}{c}\text { Antimony } \\
(\mathbf{m g} / \mathbf{k g})\end{array}$ & $\begin{array}{c}\text { Arsenic } \\
(\mathbf{m g} / \mathbf{k g})\end{array}$ & $\begin{array}{c}\text { Barium } \\
(\mathbf{m g} / \mathbf{k g})\end{array}$ & $\begin{array}{c}\text { Beryllium } \\
(\mathbf{m g} / \mathbf{k g})\end{array}$ & $\begin{array}{c}\text { Cadmium } \\
(\mathbf{m g} / \mathbf{k g})\end{array}$ \\
\hline $\begin{array}{l}\text { Site-Specific Soil } \\
\text { Screening Level (SSL) }\end{array}$ & 15,400 & 2.28 & 12.5 & 300 & 0.814 & 1 \\
\hline Site Background (SB) & 15,400 & 150 & 12.5 & 30.0 & 0.814 & 0.533 \\
\hline TAGM 4046 & $S B$ & $S B$ & 7.5 or SB & 300 or SB & 0.16 or SB & $S B$ \\
\hline Lab Detection Limit & CRDL =50 & CRDL =6 & CRDL $=1$ & $C R D L=20$ & $C R D L=0.5$ & $C R D L=0.5$ \\
\hline GP10408 16-18' DUP & 8,840 & $0.761 \mathrm{~J}$ & 9.37 & 63.6 & $0.148 \mathrm{~J}$ & $0.21 \mathrm{~J}$ \\
\hline GP10408 20-22' & 9,720 & $\mathrm{ND}$ & $13.8 \mathrm{~J}$ & 67 & $0.31 \mathrm{~J}$ & $0.217 \mathrm{~J}$ \\
\hline GP10408 22-24' & 15,100 & $0.569 \mathrm{~J}$ & $10.8 \mathrm{~J}$ & 170 & $0.436 \mathrm{~J}$ & $0.358 \mathrm{~J}$ \\
\hline GP10408 24-26' & 11,000 & $\mathrm{ND}$ & $6.69 \mathrm{~J}$ & 78 & $0.182 \mathrm{~J}$ & $0.33 \mathrm{~J}$ \\
\hline GP10508 10-12' & 12,100 & $0.382 \mathrm{~J}$ & 10.6 & 75.8 & $0.283 \mathrm{~J}$ & $\mathrm{ND}$ \\
\hline GP10508 12-14' & 9,880 & $0.6 \mathrm{~J}$ & 7.85 & 74.6 & $0.225 \mathrm{~J}$ & $0.263 \mathrm{~J}$ \\
\hline GP10508 28-30' & 8,000 & $\mathrm{ND}$ & 8.21 & 52.5 & $0.2 \mathrm{~J}$ & $0.176 \mathrm{~J}$ \\
\hline GP10508 34-36' & 8,230 & $\mathrm{ND}$ & 113 & 104 & $0.23 \mathrm{~J}$ & $0.261 \mathrm{~J}$ \\
\hline GP10608 14-16' & 7,200 & $\mathrm{ND}$ & 11.3 & 64.6 & 0.528 & $0.378 \mathrm{~J}$ \\
\hline GP10608 20-22' & 8,730 & $0.42 \mathrm{~J}$ & 6.36 & 87.1 & 0.419 & $0.356 \mathrm{~J}$ \\
\hline GP10608 22-24' & 11,100 & $\mathrm{ND}$ & 8.51 & 93.6 & $0.554 \mathrm{~J}$ & $0.351 \mathrm{~J}$ \\
\hline GP10708 12-14' & 11,200 & $0.485 \mathrm{~J}$ & $9.21 \mathrm{~J}$ & 85.5 & $0.396 \mathrm{~J}$ & 0.877 \\
\hline GP10708 22-24' & 9,700 & $0.515 \mathrm{~J}$ & $5.75 \mathrm{~J}$ & 58.5 & $0.228 \mathrm{~J}$ & 0.756 \\
\hline GP10708 30-32' & 9,750 & $0.584 \mathrm{~J}$ & $8.28 \mathrm{~J}$ & 57.2 & $0.258 \mathrm{~J}$ & 0.882 \\
\hline GP10708 32-34' & 16,500 & $\mathrm{ND}$ & $5.03 \mathrm{~J}$ & 109 & $0.41 \mathrm{~J}$ & 1.13 \\
\hline GP10808 12-14' & 10,300 & $0.867 \mathrm{~J}$ & $10.9 \mathrm{~J}$ & 74.5 & $0.521 \mathrm{~J}$ & $\mathrm{ND}$ \\
\hline GP10908 12-14' & 9,910 & $0.486 \mathrm{~J}$ & 7.37 & $75.7 \mathrm{~J}$ & 0.315 & $\mathrm{ND}$ \\
\hline GP10908 34-36' & 10,600 & $0.527 \mathrm{~J}$ & 9.06 & $81.3 \mathrm{~J}$ & $0.17 \mathrm{~J}$ & $0.172 \mathrm{~J}$ \\
\hline GP10908 36-38' & 14,500 & $0.619 \mathrm{~J}$ & 7.07 & $88.1 \mathrm{~J}$ & $0.272 \mathrm{~J}$ & $0.247 \mathrm{~J}$ \\
\hline
\end{tabular}

CRDL - Contract-required detection limit

$\mathrm{J}$ - Data are estimated

ND - Not detected 
TABLE F-4A (continued)

Metals Results For 2008 Geoprobe ${ }^{\circledR}$ Soil Samples

\begin{tabular}{|c|c|c|c|c|c|c|}
\hline Location & $\begin{array}{l}\text { Calcium } \\
(\mathrm{mg} / \mathrm{kg})\end{array}$ & $\begin{array}{c}\text { Chromium } \\
(\mathrm{mg} / \mathrm{kg})\end{array}$ & $\begin{array}{c}\text { Cobalt } \\
(\mathrm{mg} / \mathrm{kg})\end{array}$ & $\begin{array}{c}\text { Copper } \\
(\mathrm{mg} / \mathrm{kg})\end{array}$ & $\begin{array}{c}\text { Iron } \\
(\mathrm{mg} / \mathrm{kg})\end{array}$ & $\begin{array}{c}\text { Lead } \\
(\mathrm{mg} / \mathrm{kg})\end{array}$ \\
\hline $\begin{array}{l}\text { Site-Specific Soil } \\
\text { Screening Level (SSL) }\end{array}$ & 57,600 & 21.8 & 30 & 30 & 30,700 & 30.9 \\
\hline Site Background (SB) & 57,600 & 150 & 13.7 & 30.0 & 30,700 & 30.9 \\
\hline TAGM 4046 & $S B$ & 10 or $S B$ & 30 or $S B$ & 25 or $S B$ & 2000 or $S B$ & $S B$ \\
\hline Lab Detection Limit & $C R D L=500$ & $C R D L=1$ & $C R D L=5$ & $C R D L=2.5$ & $C R D L=10$ & $C R D L=0.5$ \\
\hline GP2908 2-4' & $4,110 \mathrm{~J}$ & 10.3 & $8.16 \mathrm{~J}$ & $19.3 \mathrm{~J}$ & 20,300 & $20.9 \mathrm{~J}$ \\
\hline GP2908 7-9' & $4,330 \mathrm{~J}$ & 13.4 & $8.68 \mathrm{~J}$ & $18 \mathrm{~J}$ & 21,700 & $12 \mathrm{~J}$ \\
\hline GP2908 12-14' & $5,210 \mathrm{~J}$ & 11 & $8.57 \mathrm{~J}$ & $15.4 \mathrm{~J}$ & 17,800 & $14 \mathrm{~J}$ \\
\hline GP2908 14-16' & $2,420 \mathrm{~J}$ & 9.5 & $7.26 \mathrm{~J}$ & $18.7 \mathrm{~J}$ & 23,200 & $14.2 \mathrm{~J}$ \\
\hline GP2908 28-30' & 2,140 & 14.7 & 12.5 & $23.3 \mathrm{~J}$ & 25,900 & $11 \mathrm{~J}$ \\
\hline GP2908 30-32' & $1,480 \mathrm{~J}$ & 8.31 & $7.59 \mathrm{~J}$ & $18.7 \mathrm{~J}$ & 18,700 & $11.8 \mathrm{~J}$ \\
\hline GP2908 35-37' & $23,700 \mathrm{~J}$ & 10.1 & $7.05 \mathrm{~J}$ & $17.6 \mathrm{~J}$ & 18,100 & $8.63 \mathrm{~J}$ \\
\hline GP3008 4-6' & $2,380 \mathrm{~J}$ & 13.7 & $9.32 \mathrm{~J}$ & $28.8 \mathrm{~J}$ & $26,100 \mathrm{~J}$ & $17.8 \mathrm{~J}$ \\
\hline GP3008 4-6' DUP & $67,800 \mathrm{~J}$ & 10.9 & $4.84 \mathrm{~J}$ & $13.6 \mathrm{~J}$ & $14,600 \mathrm{~J}$ & $21.2 \mathrm{~J}$ \\
\hline GP3008 10-12' & $7,130 \mathrm{~J}$ & 10.5 & $7.26 \mathrm{~J}$ & 25.2 & $20,100 \mathrm{~J}$ & $16.4 \mathrm{~J}$ \\
\hline GP3008 15-17' & $5,710 \mathrm{~J}$ & 12.6 & $7.89 \mathrm{~J}$ & 23.1 & $21,300 \mathrm{~J}$ & $13.5 \mathrm{~J}$ \\
\hline GP3008 21-23' & $16,800 \mathrm{~J}$ & 14.2 & $10.3 \mathrm{~J}$ & 31.5 & $26,300 \mathrm{~J}$ & $14.3 \mathrm{~J}$ \\
\hline GP3008 28-30' & $5,290 \mathrm{~J}$ & 15.3 & $11.8 \mathrm{~J}$ & 27.4 & $25,800 \mathrm{~J}$ & $13.1 \mathrm{~J}$ \\
\hline GP3008 35-37' & $28,000 \mathrm{~J}$ & 15.7 & $10.3 \mathrm{~J}$ & 23.8 & $24,100 \mathrm{~J}$ & $18.4 \mathrm{~J}$ \\
\hline GP3008 37-39' & $32,800 \mathrm{~J}$ & 16.2 & $11.2 \mathrm{~J}$ & 24.3 & $24,800 \mathrm{~J}$ & $10.7 \mathrm{~J}$ \\
\hline GP7208 4-6' & 57,200 & 13.8 & 4.5 & 18.9 & 14,200 & $7.58 \mathrm{~J}$ \\
\hline GP7208 9-11' & 1,860 & 11.7 & 8.98 & 24.9 & 23,800 & $13.9 \mathrm{~J}$ \\
\hline GP7208 14-16' & 2,520 & $7.74 \mathrm{~J}$ & 6.88 & 19.4 & 26,700 & $15.9 \mathrm{~J}$ \\
\hline GP7208 14-16' DUP & 1,900 & $11.4 \mathrm{~J}$ & 8.29 & 25.8 & 25,900 & $14.7 \mathrm{~J}$ \\
\hline GP7208 18-20' & 4,810 & 11.5 & 8.21 & 27.5 & 25,200 & $8.4 \mathrm{~J}$ \\
\hline GP7208 34-36' & 2,000 & 10.9 & 6.4 & 27 & 22,100 & $135 \mathrm{~F} / 12.5 / 10.2 / 17.9$ \\
\hline GP720838-40' & 30,800 & 9.2 & 6.53 & 22.4 & 21,200 & 14.5 \\
\hline GP7508 4-6' & $5,240 \mathrm{~J}$ & 13.5 & 8.35 & 27.9 & 23,600 & 14 \\
\hline GP7608 4-6' & 3,540 & 7.6 & 5.61 & 23 & 15,800 & ND \\
\hline GP7608 10-12' & 3,180 & 12.1 & 8.47 & 19.4 & 21,900 & $15.3 \mathrm{~J}$ \\
\hline GP7608 15-17' & 3,770 & 10.7 & 8.35 & 23.6 & 20,400 & $13.9 \mathrm{~J}$ \\
\hline GP7608 19-21' & 9,500 & 10.6 & 8.26 & 26.5 & 21,400 & $12.8 \mathrm{~J}$ \\
\hline GP7608 24-26' & 143,000 & 9.43 & 5.38 & 14.5 & 13,600 & $14.7 \mathrm{~J}$ \\
\hline GP7608 36-38' & 30,900 & 16.5 & 10.7 & 26.6 & 24,700 & $11.3 \mathrm{~J}$ \\
\hline GP7608 38-40' & 31,300 & 20.7 & 13.4 & 28.4 & 28,200 & $15.7 \mathrm{~J}$ \\
\hline GP7808 4-6' & $9,930 \mathrm{~J}$ & $13.4 \mathrm{~J}$ & $9.5 \mathrm{~J}$ & 42.2 & 25,700 & 13.1 \\
\hline GP7808 10-12' & $5,930 \mathrm{~J}$ & $14.4 \mathrm{~J}$ & $9.08 \mathrm{~J}$ & $30.3 \mathrm{~J}$ & 26,000 & $17 \mathrm{~J}$ \\
\hline GP7808 15-17' & $4,390 \mathrm{~J}$ & $14.2 \mathrm{~J}$ & $9.01 \mathrm{~J}$ & $23.4 \mathrm{~J}$ & 23,300 & $11.8 \mathrm{~J}$ \\
\hline GP7808 18-20' & $2,160 \mathrm{~J}$ & $11.8 \mathrm{~J}$ & $7.34 \mathrm{~J}$ & $30.8 \mathrm{~J}$ & 23,900 & $14.3 \mathrm{~J}$ \\
\hline GP7808 20-22' & $2,370 \mathrm{~J}$ & 10.7 & $7.93 \mathrm{~J}$ & $23.5 \mathrm{~J}$ & 19,000 & $13.4 \mathrm{~J}$ \\
\hline GP7808 22-24' & $4,150 \mathrm{~J}$ & $15 \mathrm{~J}$ & $9.66 \mathrm{~J}$ & $58.6 \mathrm{~J}$ & 27,200 & $13.4 \mathrm{~J}$ \\
\hline GP7808 35-37' & $31,100 \mathrm{~J}$ & $15.3 \mathrm{~J}$ & $11.1 \mathrm{~J}$ & $30.1 \mathrm{~J}$ & 27,600 & $11.9 \mathrm{~J}$ \\
\hline GP7808 37-39' & $24,100 \mathrm{~J}$ & $19.9 \mathrm{~J}$ & $13.3 \mathrm{~J}$ & $26.1 \mathrm{~J}$ & 26,200 & $13.1 \mathrm{~J}$ \\
\hline
\end{tabular}

CRDL - Contract-required detection limit

F - Homogeneity issues yielded significantly different results between sample and replicates

$\mathrm{J}$ - Data are estimated

ND - Not detected 
TABLE F-4A (continued)

Metals Results For 2008 Geoprobe ${ }^{\circledR}$ Soil Samples

\begin{tabular}{|c|c|c|c|c|c|c|}
\hline Location & $\begin{array}{l}\text { Calcium } \\
(\mathrm{mg} / \mathrm{kg})\end{array}$ & $\begin{array}{c}\text { Chromium } \\
\text { (mg/kg) }\end{array}$ & $\begin{array}{c}\text { Cobalt } \\
\text { ( } \mathrm{mg} / \mathrm{kg})\end{array}$ & $\begin{array}{c}\text { Copper } \\
\text { (mg/kg) }\end{array}$ & $\begin{array}{c}\text { Iron } \\
(\mathrm{mg} / \mathrm{kg})\end{array}$ & $\begin{array}{c}\text { Lead } \\
(\mathrm{mg} / \mathrm{kg})\end{array}$ \\
\hline \begin{tabular}{|l} 
Site-Specific Soil \\
Screening Level (SSL)
\end{tabular} & 57,600 & 21.8 & 30 & 30 & 30,700 & 30.9 \\
\hline Site Background (SB) & 57,600 & 150 & 13.7 & 30.0 & 30,700 & 30.9 \\
\hline TAGM 4046 & $S B$ & 10 or $S B$ & 30 or $S B$ & 25 or $S B$ & 2000 or $S B$ & $S B$ \\
\hline Lab Detection Limit & $C R D L=500$ & $C R D L=1$ & $C R D L=5$ & $C R D L=2.5$ & $C R D L=10$ & $C R D L=0.5$ \\
\hline GP8008 9-11' & $1,750 \mathrm{~J}$ & 12.1 & 8.98 & 24 & $3,2500 \mathrm{~J}$ & 15.6 \\
\hline GP8008 15-17' & $1,910 \mathrm{~J}$ & 12.4 & 7.34 & 20.6 & $24,600 \mathrm{~J}$ & 14.1 \\
\hline GP8008 19-21' & $3,210 \mathrm{~J}$ & 14.4 & 8.37 & 24 & $30,200 \mathrm{~J}$ & 15.5 \\
\hline GP8008 25-27' & $10,300 \mathrm{~J}$ & 10.8 & 7.2 & 28 & $26,000 \mathrm{~J}$ & 14.8 \\
\hline GP8008 25-27' DUP & $7,300 \mathrm{~J}$ & 13 & 9.64 & 34.4 & $28,300 \mathrm{~J}$ & 14.6 \\
\hline GP8008 32-34' & $10,100 \mathrm{~J}$ & 11.8 & 7.79 & 26.5 & $24,200 \mathrm{~J}$ & 15.5 \\
\hline GP8008 39-41' & $30,800 \mathrm{~J}$ & 13.8 & 8.64 & 22.2 & $22,500 \mathrm{~J}$ & 8.8 \\
\hline GP8008 41-43' & $33,300 \mathrm{~J}$ & 17.5 & 11.7 & 24.1 & $29,400 \mathrm{~J}$ & 11 \\
\hline GP8308 14-16' & $9,310 \mathrm{~J}$ & $14 \mathrm{~J}$ & 8.55 & 22.1 & $24,000 \mathrm{~J}$ & $8.69 \mathrm{~J}$ \\
\hline GP8308 30-32' & $6,330 \mathrm{~J}$ & $10.8 \mathrm{~J}$ & 8.71 & 25.9 & $22,400 \mathrm{~J}$ & $11.9 \mathrm{~J}$ \\
\hline GP8308 38-40' & 42,800 & $9.48 \mathrm{~J}$ & 7.04 & 24.8 & $21,400 \mathrm{~J}$ & $13.4 \mathrm{~J}$ \\
\hline GP8308 40-42' & $33,800 \mathrm{~J}$ & $15.1 \mathrm{~J}$ & 9.91 & 24.5 & $24,400 \mathrm{~J}$ & $12.4 \mathrm{~J}$ \\
\hline GP10008 4-6' & $2,670 \mathrm{~J}$ & $6.4 \mathrm{~J}$ & $4.38 \mathrm{~J}$ & $19.1 \mathrm{~J}$ & 14,400 & 11.8 \\
\hline GP10008 10-12' & $11,200 \mathrm{~J}$ & 11.4 & 7.61 & 18.7 & 23,500 & $12.8 \mathrm{~J}$ \\
\hline GP10008 16-18' & $3,340 \mathrm{~J}$ & 9.75 & 6 & 22.9 & 18,700 & $14.2 \mathrm{~J}$ \\
\hline GP10008 18-20' & 4,810 & 11.2 & 6.62 & 22.8 & 20,500 & $13.7 \mathrm{~J}$ \\
\hline GP10008 30-32' & $33,000 \mathrm{~J}$ & $14.3 \mathrm{~J}$ & $10.1 \mathrm{~J}$ & $23.1 \mathrm{~J}$ & 22,200 & 10.8 \\
\hline GP10008 32-34' & $27,500 \mathrm{~J}$ & $10.4 \mathrm{~J}$ & $7.79 \mathrm{~J}$ & $24.2 \mathrm{~J}$ & 20,000 & 10.5 \\
\hline 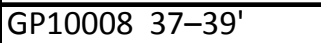 & $30,900 \mathrm{~J}$ & $21 \mathrm{~J}$ & $13.4 \mathrm{~J}$ & $26.7 \mathrm{~J}$ & 28,500 & 15.5 \\
\hline GP10108 4-6' & $12,900 \mathrm{~J}$ & 13.1 & 9.88 & 24.6 & $22,700 \mathrm{~J}$ & $16.3 \mathrm{~J}$ \\
\hline GP10108 9-11' & $1,960 \mathrm{~J}$ & 9.78 & 6.75 & 16.1 & $16,700 \mathrm{~J}$ & $12.6 \mathrm{~J}$ \\
\hline GP10108 14-16' & $4,780 \mathrm{~J}$ & 11.2 & 7.75 & 22.6 & $22,500 \mathrm{~J}$ & $17.7 \mathrm{~J}$ \\
\hline GP10108 20-22' & $1,700 \mathrm{~J}$ & 9.96 & 7.45 & 28.2 & $21,600 \mathrm{~J}$ & $16.2 \mathrm{~J}$ \\
\hline GP10108 32-34' & $25,800 \mathrm{~J}$ & 14.3 & 10.1 & 23.1 & $23,500 \mathrm{~J}$ & $12.4 \mathrm{~J}$ \\
\hline GP10208 14-16' & $1,860 \mathrm{~J}$ & 10.9 & 8.82 & 26.5 & 24,300 & $16 \mathrm{~J}$ \\
\hline GP10208 16-18' & $5,800 \mathrm{~J}$ & 8.71 & 6.18 & 24.6 & 21,200 & $10.4 \mathrm{~J}$ \\
\hline GP10208 20-22' & $8,370 \mathrm{~J}$ & 11.1 & 7.61 & 24.9 & 25,100 & $12 \mathrm{~J}$ \\
\hline GP10308 16-18' & 7,720 & 10.5 & 6.99 & 21.4 & $21,500 \mathrm{~J}$ & 17 \\
\hline GP10308 30-32' & 48,500 & 8.83 & 5.53 & 23.8 & $17,300 \mathrm{~J}$ & 13.9 \\
\hline GP10308 34-36' & 27,300 & 10.3 & 8.7 & 25.9 & $19,300 \mathrm{~J}$ & 12.6 \\
\hline GP10308 34-36' DUP & 23,000 & 8.81 & 7.24 & 19.6 & $16,700 \mathrm{~J}$ & 10.3 \\
\hline GP10408 16-18' & $21,400 \mathrm{~J}$ & 12.8 & 8.24 & 27.1 & $26,200 \mathrm{~J}$ & $14.8 \mathrm{~J}$ \\
\hline GP10408 16-18' DUP & $18,700 \mathrm{~J}$ & 10.2 & 6.76 & 25.6 & $21,000 \mathrm{~J}$ & $13 \mathrm{~J}$ \\
\hline GP10408 20-22' & $12,400 \mathrm{~J}$ & 11 & 8.34 & 26.5 & $22,600 \mathrm{~J}$ & $19.5 \mathrm{~J}$ \\
\hline GP10408 22-24' & $18,600 \mathrm{~J}$ & 19.3 & 16.8 & 27.1 & $29,400 \mathrm{~J}$ & $13.5 \mathrm{~J}$ \\
\hline GP10408 24-26' & $32,200 \mathrm{~J}$ & 15 & 9.86 & 24.5 & $23,900 \mathrm{~J}$ & $12.3 \mathrm{~J}$ \\
\hline
\end{tabular}

CRDL - Contract-required detection limit

$\mathrm{J}$ - Data are estimated

ND - Not detected 
TABLE F-4A (continued)

Metals Results For 2008 Geoprobe ${ }^{\circledR}$ Soil Samples

\begin{tabular}{|c|c|c|c|c|c|c|}
\hline Location & $\begin{array}{l}\text { Calcium } \\
\text { (mg/kg) }\end{array}$ & $\begin{array}{c}\text { Chromium } \\
\text { (mg/kg) }\end{array}$ & $\begin{array}{c}\text { Cobalt } \\
\text { (mg/kg) }\end{array}$ & $\begin{array}{l}\text { Copper } \\
(\mathrm{mg} / \mathrm{kg})\end{array}$ & $\begin{array}{c}\text { Iron } \\
\text { (mg/kg) }\end{array}$ & $\begin{array}{c}\text { Lead } \\
(\mathrm{mg} / \mathrm{kg})\end{array}$ \\
\hline $\begin{array}{l}\text { Site-Specific Soil } \\
\text { Screening Level (SSL) }\end{array}$ & 57,600 & 21.8 & 30 & 30 & 30,700 & 30.9 \\
\hline Site Background (SB) & 57,600 & 150 & 13.7 & 30.0 & 30,700 & 30.9 \\
\hline TAGM 4046 & $S B$ & 10 or $S B$ & 30 or $S B$ & 25 or $S B$ & 2000 or $S B$ & $S B$ \\
\hline Lab Detection Limit & $C R D L=500$ & $C R D L=1$ & $C R D L=5$ & $C R D L=2.5$ & $C R D L=10$ & $C R D L=0.5$ \\
\hline GP10508 10-12' & 2,470 & 14.2 & 9.48 & $32.4 \mathrm{~J}$ & $29,400 \mathrm{~J}$ & $15.6 \mathrm{~J}$ \\
\hline GP10508 12-14' & 18,200 & 9.72 & 7.04 & $20.1 \mathrm{~J}$ & $24,500 \mathrm{~J}$ & $12.2 \mathrm{~J}$ \\
\hline GP10508 28-30' & 13,300 & 9.84 & 6.43 & $25.4 \mathrm{~J}$ & $20,400 \mathrm{~J}$ & $15.9 \mathrm{~J}$ \\
\hline GP10508 34-36' & 30,400 & 9.37 & 6.17 & $22.3 \mathrm{~J}$ & $23,600 \mathrm{~J}$ & $13.6 \mathrm{~J}$ \\
\hline GP10608 14-16' & 4,580 & 12.2 & 6.55 & 27.2 & $21,200 \mathrm{~J}$ & $20.3 \mathrm{~J}$ \\
\hline GP10608 20-22' & 16,800 & 11.5 & 8.03 & 20.5 & $22,500 \mathrm{~J}$ & $10.5 \mathrm{~J}$ \\
\hline GP10608 22-24' & 31,900 & 15.9 & 9.66 & 24.1 & $24,700 \mathrm{~J}$ & $14.5 \mathrm{~J}$ \\
\hline GP10708 12-14' & $1,540 \mathrm{~J}$ & 14.3 & 10.1 & $22.5 \mathrm{~J}$ & 23,100 & 11.9 \\
\hline GP10708 22-24' & $7,690 \mathrm{~J}$ & 10 & 5.49 & $20 \mathrm{~J}$ & 19,500 & 8.85 \\
\hline GP10708 30-32' & $11,300 \mathrm{~J}$ & 10.5 & 5.77 & $26 \mathrm{~J}$ & 20,000 & 30.5 \\
\hline GP10708 32-34' & $25,100 \mathrm{~J}$ & 20.6 & 12.5 & $24 \mathrm{~J}$ & 26,900 & 14.6 \\
\hline GP10808 12-14' & $2,160 \mathrm{~J}$ & 11.4 & 8.07 & 30.9 & $23,600 \mathrm{~J}$ & 13.1 \\
\hline GP10908 12-14' & $17,600 \mathrm{~J}$ & $13 \mathrm{~J}$ & 7.3 & 26.9 & 24,400 & $15 \mathrm{~J}$ \\
\hline GP10908 34-36' & $24,300 \mathrm{~J}$ & $13.7 \mathrm{~J}$ & 11.4 & 23.8 & 24,200 & $11.9 \mathrm{~J}$ \\
\hline GP10908 36-38' & $33,000 \mathrm{~J}$ & $19.1 \mathrm{~J}$ & 12.5 & 28 & 28,400 & $13.5 \mathrm{~J}$ \\
\hline
\end{tabular}

CRDL - Contract-required detection limit

$\mathrm{J}$ - Data are estimated 
TABLE F-4A (continued)

Metals Results For 2008 Geoprobe $^{\circledR}$ Soil Samples

\begin{tabular}{|c|c|c|c|c|c|c|}
\hline Location & $\begin{array}{c}\text { Magnesium } \\
(\mathrm{mg} / \mathrm{kg})\end{array}$ & $\begin{array}{c}\text { Manganese } \\
(\mathrm{mg} / \mathrm{kg})\end{array}$ & $\begin{array}{l}\text { Mercury } \\
(\mathrm{mg} / \mathrm{kg})\end{array}$ & $\begin{array}{c}\text { Nickel } \\
(\mathrm{mg} / \mathrm{kg})\end{array}$ & $\begin{array}{l}\text { Potassium } \\
(\mathrm{mg} / \mathrm{kg})\end{array}$ & $\begin{array}{r}\text { Selenium } \\
(\mathrm{mg} / \mathrm{kg})\end{array}$ \\
\hline \begin{tabular}{|l|} 
Site-Specific Soil \\
Screening Level (SSL)
\end{tabular} & 10,900 & 740 & 0.10 & 37.3 & 2,580 & 8.8 \\
\hline Site Background (SB) & 10,900 & 740 & 0.0212 & 30.0 & 2,580 & 8.8 \\
\hline TAGM 4046 & $S B$ & $S B$ & 0.1 & 13 or $S B$ & $S B$ & $S B$ \\
\hline Lab Detection Lmit & $C R D L=500$ & $C R D L=1.5$ & $C R D L=0.02$ & $C R D L=4$ & $C R D L=500$ & $C R D L=0.5$ \\
\hline GP2908 2-4' & 3,550 & 534 & 0.0218 & 16.5 & 645 & ND \\
\hline GP2908 7-9' & 3,440 & 520 & 0.0196 & 16.9 & 534 & ND \\
\hline GP2908 12-14' & 3,250 & 461 & 0.0151 & 14.2 & 508 & ND \\
\hline GP2908 14-16' & 3,340 & 259 & $0.0032 \mathrm{~J}$ & 15.9 & 638 & $\mathrm{ND}$ \\
\hline GP2908 28-30' & 4,670 & 490 & $0.00612 \mathrm{~J}$ & 27.1 & 988 & ND \\
\hline GP2908 30-32' & 2,800 & 304 & $0.00415 \mathrm{~J}$ & 14.8 & 561 & ND \\
\hline GP2908 35-37' & 6,380 & 268 & $0.00378 \mathrm{~J}$ & 15.5 & 680 & ND \\
\hline GP3008 4-6' & 3,650 & $642 \mathrm{~J}$ & $0.0102 \mathrm{~J}$ & $20.9 \mathrm{~J}$ & $729 \mathrm{~J}$ & $\mathrm{ND}$ \\
\hline GP3008 4-6' DUP & 3,850 & $482 \mathrm{~J}$ & $0.00533 \mathrm{~J}$ & $10.6 \mathrm{~J}$ & $444 \mathrm{~J}$ & ND \\
\hline GP3008 10-12' & 3,380 & $586 \mathrm{~J}$ & 0.0227 & $15.7 \mathrm{~J}$ & $547 \mathrm{~J}$ & ND \\
\hline GP3008 15-17' & 3,620 & $609 \mathrm{~J}$ & $0.00829 \mathrm{~J}$ & $16.9 \mathrm{~J}$ & $644 \mathrm{~J}$ & ND \\
\hline GP3008 21-23' & 5,330 & $416 \mathrm{~J}$ & $0.00414 \mathrm{~J}$ & $27.7 \mathrm{~J}$ & $928 \mathrm{~J}$ & ND \\
\hline GP3008 28-30' & 4,890 & $424 \mathrm{~J}$ & $0.00381 \mathrm{~J}$ & $28.7 \mathrm{~J}$ & $931 \mathrm{~J}$ & ND \\
\hline GP3008 35-37' & 9,220 & $342 \mathrm{~J}$ & $0.00261 \mathrm{~J}$ & $25.3 \mathrm{~J}$ & $1,270 \mathrm{~J}$ & ND \\
\hline GP3008 37-39' & 11,300 & $430 \mathrm{~J}$ & $0.00443 \mathrm{~J}$ & $27.2 \mathrm{~J}$ & $1,230 \mathrm{~J}$ & ND \\
\hline GP7208 4-6' & $11,300 \mathrm{~J}$ & 890 & $0.00972 \mathrm{~J}$ & 12.8 & $700 \mathrm{~J}$ & $\mathrm{ND}$ \\
\hline GP7208 9-11' & 3,560 & 636 & 0.0118 & 20.1 & $637 \mathrm{~J}$ & ND \\
\hline GP7208 14-16' & 3,480 & 729 & 0.0113 & 17.7 & $417 \mathrm{~J}$ & ND \\
\hline GP7208 14-16' DUP & 3,420 & 602 & 0.0166 & 19.1 & 582 & ND \\
\hline GP7208 18-20' & 4,440 & 508 & $0.00985 \mathrm{~J}$ & 20.4 & $643 \mathrm{~J}$ & ND \\
\hline GP7208 34-36' & 3,450 & 308 & 0.014 & 18.2 & $699 \mathrm{~J}$ & ND \\
\hline GP7208 38-40' & 7,050 & 314 & $0.00396 \mathrm{~J}$ & 17.1 & $639 \mathrm{~J}$ & ND \\
\hline GP7508 4-6' & 3,530 & $2160 \mathrm{~J}$ & 0.0164 & 18.9 & 872 & ND \\
\hline GP7608 4-6' & 2,740 & $538 \mathrm{~J}$ & ND & 12.8 & 521 & $\mathrm{ND}$ \\
\hline GP7608 10-12' & 3,160 & $669 \mathrm{~J}$ & $\mathrm{ND}$ & 17.2 & 706 & ND \\
\hline GP7608 15-17' & 2,940 & $624 \mathrm{~J}$ & ND & 16 & 553 & ND \\
\hline GP7608 19-21' & 4,980 & $385 \mathrm{~J}$ & $\mathrm{ND}$ & 18.8 & 768 & ND \\
\hline GP7608 24-26' & 82,600 & $380 \mathrm{~J}$ & $\mathrm{ND}$ & 13.6 & 1010 & ND \\
\hline GP7608 36-38' & 10,000 & $445 \mathrm{~J}$ & ND & 26.6 & 1370 & ND \\
\hline GP7608 38-40' & 10,100 & $444 \mathrm{~J}$ & ND & 33 & 1710 & ND \\
\hline GP7808 4-6' & $5,270 \mathrm{~J}$ & $729 \mathrm{~J}$ & 0.00864 & $20.7 \mathrm{~J}$ & $756 \mathrm{~J}$ & ND \\
\hline GP7808 $10-12^{\prime}$ & $4,980 \mathrm{~J}$ & $404 \mathrm{~J}$ & 0.0141 & $22.7 \mathrm{~J}$ & $651 \mathrm{~J}$ & ND \\
\hline GP7808 15-17' & $3,950 \mathrm{~J}$ & $940 \mathrm{~J}$ & 0.00862 & $18.4 \mathrm{~J}$ & $747 \mathrm{~J}$ & ND \\
\hline GP7808 18-20' & $4,170 \mathrm{~J}$ & $490 \mathrm{~J}$ & 0.00963 & $20.3 \mathrm{~J}$ & $815 \mathrm{~J}$ & $\mathrm{ND}$ \\
\hline GP7808 20-22' & $3,400 \mathrm{~J}$ & $454 \mathrm{~J}$ & 0.0107 & $19.8 \mathrm{~J}$ & $798 \mathrm{~J}$ & ND \\
\hline GP7808 22-24' & $4,350 \mathrm{~J}$ & $416 \mathrm{~J}$ & 0.0105 & $25.7 \mathrm{~J}$ & $880 \mathrm{~J}$ & ND \\
\hline GP7808 35-37' & $10,500 \mathrm{~J}$ & $350 \mathrm{~J}$ & 0.0126 & $26 \mathrm{~J}$ & $1,120 \mathrm{~J}$ & $\mathrm{ND}$ \\
\hline GP7808 37-39' & $9,830 \mathrm{~J}$ & $358 \mathrm{~J}$ & 0.00931 & $32.7 \mathrm{~J}$ & $1,700 \mathrm{~J}$ & ND \\
\hline
\end{tabular}

CRDL - Contract-required detection limit

$\mathrm{J}$ - Data are estimated

ND - Not detected 
TABLE F-4A (continued)

Metals Results For 2008 Geoprobe $^{\circledR}$ Soil Samples

\begin{tabular}{|c|c|c|c|c|c|c|}
\hline Location & $\begin{array}{l}\text { Magnesium } \\
(\mathrm{mg} / \mathrm{kg})\end{array}$ & $\begin{array}{c}\text { Manganese } \\
(\mathrm{mg} / \mathrm{kg})\end{array}$ & $\begin{array}{l}\text { Mercury } \\
(\mathrm{mg} / \mathrm{kg}) \\
\end{array}$ & $\begin{array}{c}\text { Nickel } \\
(\mathrm{mg} / \mathrm{kg})\end{array}$ & $\begin{array}{l}\text { Potassium } \\
(\mathrm{mg} / \mathrm{kg})\end{array}$ & $\begin{array}{l}\text { Selenium } \\
(\mathrm{mg} / \mathrm{kg})\end{array}$ \\
\hline $\begin{array}{l}\text { Site-Specific Soil } \\
\text { Screening Level (SSL) }\end{array}$ & 10,900 & 740 & 0.10 & 37.3 & 2,580 & 8.8 \\
\hline Site Background (SB) & 10,900 & 740 & 0.0212 & 30 & 2580 & 8.8 \\
\hline TAGM 4046 & $S B$ & $S B$ & 0.1 & 30.0 & $S B$ & $S B$ \\
\hline Lab Detection Limit & $C R D L=500$ & $C R D L=1.5$ & $C R D L=0.02$ & $C R D L=4$ & $C R D L=500$ & $S B$ \\
\hline GP8008 9-11' & $4,360 \mathrm{~J}$ & $1120 \mathrm{~J}$ & 0.0128 & 18.7 & $\mathrm{R}$ & $0.569 \mathrm{~J}$ \\
\hline GP8008 15-17' & $3,320 \mathrm{~J}$ & $467 \mathrm{~J}$ & $0.00861 \mathrm{~J}$ & 15.5 & $\mathrm{R}$ & ND \\
\hline GP8008 19-21' & $4,270 \mathrm{~J}$ & $424 \mathrm{~J}$ & $0.00878 \mathrm{~J}$ & 20 & $\mathrm{R}$ & ND \\
\hline GP8008 25-27' & $4,000 \mathrm{~J}$ & $426 \mathrm{~J}$ & $0.00875 \mathrm{~J}$ & 18.6 & $\mathrm{R}$ & ND \\
\hline GP8008 25-27' DUP & $4,630 \mathrm{~J}$ & $608 \mathrm{~J}$ & $0.00903 \mathrm{~J}$ & 22.3 & $\mathrm{R}$ & ND \\
\hline GP8008 32-34' & $4,520 \mathrm{~J}$ & $464 \mathrm{~J}$ & $0.00884 \mathrm{~J}$ & 19.2 & $\mathrm{R}$ & ND \\
\hline GP8008 39-41' & $10,600 \mathrm{~J}$ & $329 \mathrm{~J}$ & $0.00948 \mathrm{~J}$ & 20.9 & $\mathrm{R}$ & ND \\
\hline GP8008 41-43' & $10,800 \mathrm{~J}$ & $474 \mathrm{~J}$ & 0.0115 & 28.4 & $\mathrm{R}$ & ND \\
\hline GP8308 14-16' & $6,730 \mathrm{~J}$ & $368 \mathrm{~J}$ & $0.00426 \mathrm{~J}$ & 18.7 & $1,020 \mathrm{~J}$ & ND \\
\hline GP8308 30-32' & $4,330 \mathrm{~J}$ & $470 \mathrm{~J}$ & $0.00578 \mathrm{~J}$ & 20.1 & $890 \mathrm{~J}$ & ND \\
\hline GP8308 38-40' & $5,950 \mathrm{~J}$ & $547 \mathrm{~J}$ & $0.00394 \mathrm{~J}$ & 16.2 & 867 & ND \\
\hline GP8308 40-42' & $11,500 \mathrm{~J}$ & $389 \mathrm{~J}$ & $0.00613 \mathrm{~J}$ & 24.2 & 1850 & ND \\
\hline GP10008 4-6' & 2,390 & $412 \mathrm{~J}$ & 0.0184 & $10.5 \mathrm{~J}$ & 408 & $0.588 \mathrm{~J}$ \\
\hline GP10008 10-12' & 3,350 & $720 \mathrm{~J}$ & 0.0314 & 15.8 & 587 & ND \\
\hline GP10008 16-18' & 2,980 & $713 \mathrm{~J}$ & 0.0148 & 13.8 & 406 & ND \\
\hline GP10008 18-20' & 3,340 & $632 \mathrm{~J}$ & 0.0156 & 15.6 & 428 & ND \\
\hline GP10008 30-32' & 11,200 & $403 \mathrm{~J}$ & 0.0217 & $23.6 \mathrm{~J}$ & 1150 & ND \\
\hline GP10008 32-34' & 8,030 & $375 \mathrm{~J}$ & 0.0138 & $18.3 \mathrm{~J}$ & 788 & ND \\
\hline GP10008 37-39' & 10,800 & $450 \mathrm{~J}$ & 0.0226 & $34.1 \mathrm{~J}$ & 1690 & ND \\
\hline GP10108 4-6' & $5,960 \mathrm{~J}$ & $534 \mathrm{~J}$ & 0.0146 & 21.3 & 917 & ND \\
\hline GP10108 9-11' & $2,710 \mathrm{~J}$ & $408 \mathrm{~J}$ & 0.0183 & 14.5 & 445 & ND \\
\hline GP10108 14-16' & $3,780 \mathrm{~J}$ & $473 \mathrm{~J}$ & 0.0299 & 16.3 & 552 & $\mathrm{ND}$ \\
\hline GP10108 20-22' & $3,270 \mathrm{~J}$ & $402 \mathrm{~J}$ & 0.0128 & 18.5 & 590 & ND \\
\hline GP10108 32-34' & $10,300 \mathrm{~J}$ & $344 \mathrm{~J}$ & $0.00347 \mathrm{~J}$ & 24.7 & 1120 & ND \\
\hline GP10208 14-16' & 3,390 & $735 \mathrm{~J}$ & $0.00496 \mathrm{~J}$ & 19.7 & $895 \mathrm{~J}$ & $\mathrm{ND}$ \\
\hline GP10208 16-18' & 3,040 & $621 \mathrm{~J}$ & $0.00374 \mathrm{~J}$ & 14.9 & $754 \mathrm{~J}$ & ND \\
\hline GP10208 20-22' & 4,430 & $430 \mathrm{~J}$ & $0.00521 \mathrm{~J}$ & 18.4 & $832 \mathrm{~J}$ & ND \\
\hline GP10308 16-18' & 6,190 & 458 & $0.00623 \mathrm{~J}$ & 15.7 & $736 \mathrm{~J}$ & $\mathrm{ND}$ \\
\hline GP10308 30-32' & 26,600 & 285 & $0.00214 \mathrm{~J}$ & 13.2 & $679 \mathrm{~J}$ & ND \\
\hline GP10308 34-36' & 9,360 & 298 & $0.00651 \mathrm{~J}$ & 18.1 & $1,060 \mathrm{~J}$ & ND \\
\hline GP10308 34-36' DUP & 8,060 & 323 & $0.00458 \mathrm{~J}$ & 15.7 & $801 \mathrm{~J}$ & ND \\
\hline GP10408 16-18' & $4,560 \mathrm{~J}$ & $684 \mathrm{~J}$ & 0.0148 & $18.8 \mathrm{~J}$ & 945 & ND \\
\hline GP10408 16-18' DUP & 7,970 & $374 \mathrm{~J}$ & 0.0114 & $15.9 \mathrm{~J}$ & 910 & ND \\
\hline GP10408 20-22' & 4,980 & $415 \mathrm{~J}$ & 0.0121 & $18.9 \mathrm{~J}$ & 964 & $\mathrm{ND}$ \\
\hline GP10408 22-24' & 7,200 & $976 \mathrm{~J}$ & 0.0218 & $42.6 \mathrm{~J}$ & 1880 & ND \\
\hline GP10408 24-26' & 12,800 & $370 \mathrm{~J}$ & 0.0133 & $24.3 \mathrm{~J}$ & 1610 & ND \\
\hline
\end{tabular}

CRDL - Contract-required detection limit

$\mathrm{J}$ - Data are estimated

ND - Not detected

$\mathrm{R}$ - Data are rejected 
TABLE F-4A (continued)

Metals Results For 2008 Geoprobe $^{\circledR}$ Soil Samples

\begin{tabular}{|l|c|c|c|c|c|c|}
\hline \multicolumn{1}{|c|}{ Location } & $\begin{array}{c}\text { Magnesium } \\
(\mathbf{m g} / \mathbf{k g})\end{array}$ & $\begin{array}{c}\text { Manganese } \\
(\mathbf{m g} / \mathbf{k g})\end{array}$ & $\begin{array}{c}\text { Mercury } \\
(\mathbf{m g} / \mathbf{k g})\end{array}$ & $\begin{array}{c}\text { Nickel } \\
(\mathbf{m g} / \mathbf{k g})\end{array}$ & $\begin{array}{c}\text { Potassium } \\
(\mathbf{m g} / \mathbf{k g})\end{array}$ & $\begin{array}{c}\text { Selenium } \\
(\mathbf{m g} / \mathbf{k g})\end{array}$ \\
\hline $\begin{array}{l}\text { Site-Specific Soil } \\
\text { Screening Level (SSL) }\end{array}$ & 10,900 & 740 & 0.10 & 37.3 & 2,580 & 8.8 \\
\hline Site Background (SB) & 10,900 & 740 & 0.0212 & 30 & 2580 & 8.8 \\
\hline TAGM 4046 & $S B$ & $S B$ & 0.1 & 30.0 & $S B$ & $S B$ \\
\hline Lab Detection Limit & $C R D L=500$ & $C R D L=1.5$ & $C R D L=0.02$ & $C R D L=4$ & $C R D L=500$ & $S B$ \\
\hline GP10508 10-12' & 4,530 & 423 & 0.0183 & 22.8 & $823 \mathrm{~J}$ & $\mathrm{ND}$ \\
\hline GP10508 12-14' & 5,950 & 420 & 0.013 & 16.3 & $673 \mathrm{~J}$ & $\mathrm{ND}$ \\
\hline GP10508 28-30' & 4,800 & 337 & $0.00694 \mathrm{~J}$ & 16 & $746 \mathrm{~J}$ & $\mathrm{ND}$ \\
\hline GP10508 34-36' & 5,560 & 1770 & $0.0105 \mathrm{~J}$ & 16.4 & $615 \mathrm{~J}$ & $\mathrm{ND}$ \\
\hline GP10608 14-16' & 4,900 & $210 \mathrm{~J}$ & $0.00377 \mathrm{~J}$ & 16.6 & $710 \mathrm{~J}$ & $\mathrm{ND}$ \\
\hline GP10608 20-22' & 4,390 & $622 \mathrm{~J}$ & $0.00269 \mathrm{~J}$ & 18 & $580 \mathrm{~J}$ & $\mathrm{ND}$ \\
\hline GP10608 22-24' & 10,200 & $430 \mathrm{~J}$ & $0.0147 \mathrm{~J}$ & 26.7 & $1,160 \mathrm{~J}$ & $\mathrm{ND}$ \\
\hline GP10708 12-14' & 3,720 & 495 & 0.0114 & 20.3 & $1,130 \mathrm{~J}$ & $\mathrm{ND}$ \\
\hline GP10708 22-24' & 4,210 & 167 & $0.00472 \mathrm{~J}$ & 15.7 & $846 \mathrm{~J}$ & $\mathrm{ND}$ \\
\hline GP10708 30-32' & 5,140 & 603 & $0.00763 \mathrm{~J}$ & 17.7 & $1,010 \mathrm{~J}$ & $\mathrm{ND}$ \\
\hline GP10708 32-34' & 9,090 & 466 & 0.0837 & 31.7 & $2,300 \mathrm{~J}$ & $0.966 \mathrm{~J}$ \\
\hline GP10808 12-14' & 3,450 & 389 & $0.005 \mathrm{~J}$ & 20.8 & $605 \mathrm{~J}$ & $\mathrm{ND}$ \\
\hline GP10908 12-14' & 4,490 & 499 & $0.00478 \mathrm{~J}$ & $18.1 \mathrm{~J}$ & $648 \mathrm{~J}$ & $\mathrm{ND}$ \\
\hline GP10908 34-36' & 8,470 & 472 & $0.0056 \mathrm{~J}$ & $24.3 \mathrm{~J}$ & $1,190 \mathrm{~J}$ & $\mathrm{ND}$ \\
\hline GP10908 36-38' & 12,100 & 398 & $0.00593 \mathrm{~J}$ & $30.9 \mathrm{~J}$ & $1,750 \mathrm{~J}$ & $\mathrm{ND}$ \\
\hline
\end{tabular}

CRDL - Contract-required detection limit

$\mathrm{J}$ - Data are estimated

ND - Not detected 
TABLE F-4A (continued)

Metals Results For 2008 Geoprobe $^{\circledR}$ Soil Samples

\begin{tabular}{|c|c|c|c|c|c|}
\hline Location & $\begin{array}{c}\text { Silver } \\
(\mathrm{mg} / \mathrm{kg})\end{array}$ & $\begin{array}{l}\text { Sodium } \\
(\mathrm{mg} / \mathrm{kg})\end{array}$ & $\begin{array}{l}\text { Thallium } \\
(\mathrm{mg} / \mathrm{kg})\end{array}$ & $\begin{array}{c}\text { Vanadium } \\
\text { (mg/kg) }\end{array}$ & $\begin{array}{c}\text { Zinc } \\
(\mathrm{mg} / \mathrm{kg})\end{array}$ \\
\hline \begin{tabular}{|l|} 
Site-Specific Soil \\
Screening Level (SSL) \\
\end{tabular} & 0.621 & 150 & 0.325 & 150 & 99.7 \\
\hline Site Background (SB) & 0.621 & 150 & 0.325 & 30.0 & 99.7 \\
\hline TAGM 4046 & $S B$ & $S B$ & $S B$ & 150 or $S B$ & 20 or $S B$ \\
\hline Lab Detection Lmit & $C R D L=1$ & $C R D L=500$ & $C R D L=1$ & $C R D L=5$ & $C R D L=2$ \\
\hline GP2908 $2-4^{\prime}$ & $\mathrm{ND}$ & 227 & $\mathrm{ND}$ & $17 \mathrm{~J}$ & 72.2 \\
\hline GP2908 7-9' & ND & 124 & ND & $12 \mathrm{~J}$ & 59.3 \\
\hline GP2908 12-14' & $\mathrm{ND}$ & 107 & ND & $12.6 \mathrm{~J}$ & 54.6 \\
\hline GP2908 14-16' & $\mathrm{ND}$ & 74.6 & ND & $13.9 \mathrm{~J}$ & 58.1 \\
\hline GP2908 28-30' & ND & 204 & ND & $13.4 \mathrm{~J}$ & 66.8 \\
\hline GP2908 30-32' & ND & 220 & ND & $13.3 \mathrm{~J}$ & 50.6 \\
\hline GP2908 35-37' & ND & 201 & ND & $8.22 \mathrm{~J}$ & 47.7 \\
\hline GP3008 4-6' & $0.232 \mathrm{~J}$ & 115 & $0.127 \mathrm{~J}$ & $16.1 \mathrm{~J}$ & $80.1 \mathrm{~J}$ \\
\hline GP3008 4-6' DUP & $\mathrm{ND}$ & 115 & $0.154 \mathrm{~J}$ & $16.3 \mathrm{~J}$ & $50.5 \mathrm{~J}$ \\
\hline GP3008 10-12' & $0.18 \mathrm{~J}$ & 52.6 & $0.152 \mathrm{~J}$ & $16.1 \mathrm{~J}$ & 66.4 \\
\hline GP3008 15-17' & $0.181 \mathrm{~J}$ & 121 & $0.0998 \mathrm{~J}$ & $11.8 \mathrm{~J}$ & 74 \\
\hline GP3008 21-23' & ND & 202 & $0.168 \mathrm{~J}$ & $13.8 \mathrm{~J}$ & 83.7 \\
\hline GP3008 28-30' & $0.224 \mathrm{~J}$ & 318 & $0.242 \mathrm{~J}$ & $16.3 \mathrm{~J}$ & 66.8 \\
\hline GP3008 35-37' & 0.117 & 339 & $0.251 \mathrm{~J}$ & $21.6 \mathrm{~J}$ & 57.5 \\
\hline GP3008 37-39' & ND & 293 & $0.231 \mathrm{~J}$ & $20.1 \mathrm{~J}$ & 58.3 \\
\hline GP7208 4-6' & $\mathrm{ND}$ & $325 \mathrm{~J}$ & $0.109 \mathrm{~J}$ & $9.17 \mathrm{~J}$ & $78.8 \mathrm{~J}$ \\
\hline GP7208 9-11' & $\mathrm{ND}$ & $64.8 \mathrm{~J}$ & $0.11 \mathrm{~J}$ & $14.7 \mathrm{~J}$ & $75.4 \mathrm{~J}$ \\
\hline GP7208 14-16' & ND & $60.6 \mathrm{~J}$ & $0.11 \mathrm{~J}$ & $17.5 \mathrm{~J}$ & $104 \mathrm{~J}$ \\
\hline GP7208 14-16' DUP & $\mathrm{ND}$ & $131 \mathrm{~J}$ & 0.122 & 15.9 & $72.6 \mathrm{~J}$ \\
\hline GP7208 18-20' & $\mathrm{ND}$ & $182 \mathrm{~J}$ & $0.209 \mathrm{~J}$ & $18 \mathrm{~J}$ & $80.1 \mathrm{~J}$ \\
\hline GP7208 34-36' & $\overline{N D}$ & $210 \mathrm{~J}$ & $0.16 \mathrm{~J}$ & $15.5 \mathrm{~J}$ & $73.5 \mathrm{~J}$ \\
\hline GP7208 38-40' & $\mathrm{ND}$ & $215 \mathrm{~J}$ & $0.155 \mathrm{~J}$ & $12.7 \mathrm{~J}$ & $59.4 \mathrm{~J}$ \\
\hline GP7508 $4-6^{\prime}$ & $0.148 \mathrm{~J}$ & 99.6 & $0.133 \mathrm{~J}$ & 15.9 & $79.6 \mathrm{~J}$ \\
\hline GP7608 4-6' & $\mathrm{ND}$ & 53.4 & ND & $\mathrm{ND}$ & 56 \\
\hline GP7608 10-12' & $\mathrm{ND}$ & 110 & $0.133 \mathrm{~J}$ & $15.9 \mathrm{~J}$ & 67.2 \\
\hline GP7608 $15-17^{\prime}$ & ND & 99.2 & $0.132 \mathrm{~J}$ & $15.1 \mathrm{~J}$ & 65.9 \\
\hline GP7608 19-21' & $\mathrm{ND}$ & 231 & $0.112 \mathrm{~J}$ & $13.7 \mathrm{~J}$ & 77.4 \\
\hline GP7608 24-26' & $\mathrm{ND}$ & 232 & $0.28 \mathrm{~J}$ & $27.3 \mathrm{~J}$ & 33.7 \\
\hline GP7608 36-38' & $\mathrm{ND}$ & 154 & $0.259 \mathrm{~J}$ & $22.1 \mathrm{~J}$ & 57.2 \\
\hline GP7608 38-40' & $\mathrm{ND}$ & 133 & $0.324 \mathrm{~J}$ & $34.6 \mathrm{~J}$ & 70.5 \\
\hline GP7808 4-6' & 0.359 & $\mathrm{ND}$ & ND & 17 & $110 \mathrm{~J}$ \\
\hline GP7808 10-12' & ND & ND & ND & 16.8 & $81.8 \mathrm{~J}$ \\
\hline GP7808 $15-17^{\prime}$ & 0.62 & ND & ND & 12.8 & $68.2 \mathrm{~J}$ \\
\hline GP7808 18-20' & ND & $\mathrm{ND}$ & ND & 14.9 & $79.5 \mathrm{~J}$ \\
\hline GP7808 20-22' & $\mathrm{ND}$ & $\mathrm{ND}$ & ND & 12.7 & $57.1 \mathrm{~J}$ \\
\hline GP7808 22-24' & $\mathrm{ND}$ & ND & ND & 14.8 & $96.7 \mathrm{~J}$ \\
\hline GP7808 35-37' & 0.322 & $\mathrm{ND}$ & 0.34 & 20.1 & $62.8 \mathrm{~J}$ \\
\hline GP7808 37-39' & ND & $\mathrm{ND}$ & ND & 21.9 & $62.7 \mathrm{~J}$ \\
\hline
\end{tabular}

CRDL - Contract-required detection limit

$\mathrm{J}$ - Data are estimated

ND - Not detected 
TABLE F-4A (continued)

\section{Metals Results For 2008 Geoprobe ${ }^{\circledR}$ Soil Samples}

\begin{tabular}{|c|c|c|c|c|c|}
\hline Location & $\begin{array}{c}\text { Silver } \\
(\mathrm{mg} / \mathrm{kg})\end{array}$ & $\begin{array}{l}\text { Sodium } \\
\text { (mg/kg) }\end{array}$ & $\begin{array}{l}\text { Thallium } \\
\text { (mg/kg) }\end{array}$ & $\begin{array}{l}\text { Vanadium } \\
\text { (mg/kg) }\end{array}$ & $\begin{array}{c}\text { Zinc } \\
(\mathrm{mg} / \mathrm{kg})\end{array}$ \\
\hline $\begin{array}{l}\text { Site-Specific Soil } \\
\text { Screening Level (SSL) }\end{array}$ & 0.621 & 150 & 0.325 & 150 & 99.7 \\
\hline Site Background (SB) & 0.621 & 150 & 0.325 & 30 & 99.7 \\
\hline TAGM 4046 & $S B$ & $S B$ & $S B$ & 150 or $S B$ & 20 or $S B$ \\
\hline Lab Detection Limit & $C R D L=1$ & $C R D L=500$ & $C R D L=1$ & 30.0 & $C R D L=2$ \\
\hline GP8008 9-11' & $0.666 \mathrm{~J}$ & $49.6 \mathrm{~J}$ & $0.162 \mathrm{~J}$ & 18.7 & 67.8 \\
\hline GP8008 15-17' & ND & 81.4 & $0.15 \mathrm{~J}$ & 14.4 & 62.7 \\
\hline GP8008 19-21' & ND & $51.6 \mathrm{~J}$ & $0.141 \mathrm{~J}$ & 14.2 & 71.1 \\
\hline GP8008 25-27' & ND & 139 & $0.177 \mathrm{~J}$ & 16.4 & 68.7 \\
\hline GP8008 25-27' DUP & ND & 106 & $0.302 \mathrm{~J}$ & 25.4 & 76.2 \\
\hline GP8008 32-34' & ND & 142 & $0.229 \mathrm{~J}$ & 16.4 & 69.6 \\
\hline GP8008 39-41' & ND & 250 & $0.203 \mathrm{~J}$ & 16.9 & 56.6 \\
\hline GP8008 41-43' & ND & 209 & $0.218 \mathrm{~J}$ & 18.6 & 102 \\
\hline GP8308 14-16' & $0.23 \mathrm{~J}$ & 48.1 & $0.177 \mathrm{~J}$ & $42.2 \mathrm{~J}$ & $51.8 \mathrm{~J}$ \\
\hline GP8308 30-32' & $0.37 \mathrm{~J}$ & 188 & $0.22 \mathrm{~J}$ & $15.9 \mathrm{~J}$ & $62.3 \mathrm{~J}$ \\
\hline GP8308 38-40' & ND & $148 \mathrm{~J}$ & $0.207 \mathrm{~J}$ & $14.8 \mathrm{~J}$ & $62.1 \mathrm{~J}$ \\
\hline GP8308 40-42' & ND & $198 \mathrm{~J}$ & $0.281 \mathrm{~J}$ & $22.4 \mathrm{~J}$ & $51.3 \mathrm{~J}$ \\
\hline GP10008 4-6' & ND & $48.5 \mathrm{~J}$ & $0.163 \mathrm{~J}$ & $12.9 \mathrm{~J}$ & 51.8 \\
\hline GP10008 10-12' & $0.206 \mathrm{~J}$ & $122 \mathrm{~J}$ & $0.119 \mathrm{~J}$ & $10.9 \mathrm{~J}$ & $66.1 \mathrm{~J}$ \\
\hline GP10008 16-18' & $0.26 \mathrm{~J}$ & $58.7 \mathrm{~J}$ & $0.106 \mathrm{~J}$ & $12.6 \mathrm{~J}$ & $57.6 \mathrm{~J}$ \\
\hline GP10008 18-20' & $0.222 \mathrm{~J}$ & $107 \mathrm{~J}$ & $0.124 \mathrm{~J}$ & $14.3 \mathrm{~J}$ & $60.8 \mathrm{~J}$ \\
\hline GP10008 30-32' & ND & $139 \mathrm{~J}$ & $0.267 \mathrm{~J}$ & $22.6 \mathrm{~J}$ & 55.7 \\
\hline GP10008 32-34' & ND & $158 \mathrm{~J}$ & $0.2 \mathrm{~J}$ & $15.5 \mathrm{~J}$ & $45.1 \mathrm{~J}$ \\
\hline GP10008 37-39' & ND & $183 \mathrm{~J}$ & $0.379 \mathrm{~J}$ & $23.1 \mathrm{~J}$ & 68.7 \\
\hline GP10108 4-6' & ND & 85.8 & $0.201 \mathrm{~J}$ & $16.3 \mathrm{~J}$ & 79.7 \\
\hline GP10108 9-11' & $0.212 \mathrm{~J}$ & 62.2 & $0.146 \mathrm{~J}$ & $15.8 \mathrm{~J}$ & 52.9 \\
\hline GP10108 14-16' & $0.287 \mathrm{~J}$ & 54.9 & $0.164 \mathrm{~J}$ & $20.5 \mathrm{~J}$ & 70.3 \\
\hline GP10108 20-22' & $0.217 \mathrm{~J}$ & 115 & $0.177 \mathrm{~J}$ & $14.9 \mathrm{~J}$ & 77.4 \\
\hline GP10108 32-34' & ND & 152 & $0.209 \mathrm{~J}$ & $17.3 \mathrm{~J}$ & 56.2 \\
\hline GP10208 14-16' & $0.418 \mathrm{~J}$ & 124 & $0.145 \mathrm{~J}$ & $17.6 \mathrm{~J}$ & 63.6 \\
\hline GP10208 16-18' & $0.317 \mathrm{~J}$ & 143 & $0.107 \mathrm{~J}$ & $15.3 \mathrm{~J}$ & 62.3 \\
\hline GP10208 20-22' & $0.16 \mathrm{~J}$ & 95.9 & $0.107 \mathrm{~J}$ & $14.3 \mathrm{~J}$ & 83.2 \\
\hline GP10308 16-18' & ND & 58.3 & $0.192 \mathrm{~J}$ & $14.1 \mathrm{~J}$ & 72.5 \\
\hline GP10308 30-32' & ND & 249 & $0.151 \mathrm{~J}$ & $14.3 \mathrm{~J}$ & 52.1 \\
\hline GP10308 34-36' & ND & 160 & $0.248 \mathrm{~J}$ & $17.4 \mathrm{~J}$ & 50.2 \\
\hline GP10308 34-36' DUP & ND & 157 & $0.157 \mathrm{~J}$ & $12 \mathrm{~J}$ & $42.9 \mathrm{~J}$ \\
\hline GP10408 16-18' & ND & $120 \mathrm{~J}$ & $0.131 \mathrm{~J}$ & 14.2 & 76.9 \\
\hline GP10408 16-18' DUP & ND & $142 \mathrm{~J}$ & $0.111 \mathrm{~J}$ & 14.3 & 72 \\
\hline GP10408 20-22' & ND & $101 \mathrm{~J}$ & $0.142 \mathrm{~J}$ & 14.4 & 76.7 \\
\hline GP10408 22-24' & ND & $150 \mathrm{~J}$ & $0.271 \mathrm{~J}$ & 28.9 & 69.1 \\
\hline GP10408 24-26' & ND & $128 \mathrm{~J}$ & $0.279 \mathrm{~J}$ & 23.1 & 54.5 \\
\hline
\end{tabular}

CRDL - Contract-required detection limit

$\mathrm{J}$ - Data are estimated

ND - Not detected 
TABLE F-4A (concluded)

Metals Results For 2008 Geoprobe ${ }^{\circledR}$ Soil Samples

\begin{tabular}{|c|c|c|c|c|c|}
\hline Location & $\begin{array}{c}\text { Silver } \\
(\mathrm{mg} / \mathrm{kg})\end{array}$ & $\begin{array}{l}\text { Sodium } \\
\text { (mg/kg) }\end{array}$ & $\begin{array}{l}\text { Thallium } \\
\text { (mg/kg) }\end{array}$ & $\begin{array}{c}\text { Vanadium } \\
\text { (mg/kg) }\end{array}$ & $\begin{array}{c}\text { Zinc } \\
(\mathrm{mg} / \mathrm{kg})\end{array}$ \\
\hline $\begin{array}{l}\text { Site-Specific Soil } \\
\text { Screening Level (SSL) }\end{array}$ & 0.621 & 150 & 0.325 & 150 & 99.7 \\
\hline Site Background (SB) & 0.621 & 150 & 0.325 & 30.0 & 99.7 \\
\hline TAGM 4046 & $S B$ & $S B$ & $S B$ & 150 or $S B$ & 20 or $S B$ \\
\hline Lab Detection Limit & $C R D L=1$ & $C R D L=500$ & $C R D L=1$ & 30.0 & $C R D L=2$ \\
\hline GP10508 10-12' & ND & $1120 \mathrm{~J}$ & $0.156 \mathrm{~J}$ & 14 & $87 \mathrm{~J}$ \\
\hline GP10508 12-14' & ND & $651 \mathrm{~J}$ & $0.149 \mathrm{~J}$ & 13.3 & $63 \mathrm{~J}$ \\
\hline GP10508 28-30' & ND & $188 \mathrm{~J}$ & $0.134 \mathrm{~J}$ & 12.3 & $63.1 \mathrm{~J}$ \\
\hline GP10508 34-36' & ND & $124 \mathrm{~J}$ & $0.258 \mathrm{~J}$ & 13.8 & $52.7 \mathrm{~J}$ \\
\hline GP10608 14-16' & ND & 102 & 0.116 & $17.9 \mathrm{~J}$ & 63.4 \\
\hline GP10608 20-22' & $0.2 \mathrm{~J}$ & 106 & $0.103 \mathrm{~J}$ & $10.5 \mathrm{~J}$ & 64.2 \\
\hline GP10608 22-24' & $0.358 \mathrm{~J}$ & 102 & $0.323 \mathrm{~J}$ & $30.4 \mathrm{~J}$ & 59.3 \\
\hline GP10708 12-14' & 0.701 & 69.9 & $0.141 \mathrm{~J}$ & $17.2 \mathrm{~J}$ & $75.1 \mathrm{~J}$ \\
\hline GP10708 22-24' & $0.408 \mathrm{~J}$ & 97 & $0.0696 \mathrm{~J}$ & $8.3 \mathrm{~J}$ & $55.7 \mathrm{~J}$ \\
\hline GP10708 30-32' & 0.548 & 138 & $0.307 \mathrm{~J}$ & $13 \mathrm{~J}$ & $75.2 \mathrm{~J}$ \\
\hline GP10708 32-34' & $0.535 \mathrm{~J}$ & 222 & $0.275 \mathrm{~J}$ & $27 \mathrm{~J}$ & $65.7 \mathrm{~J}$ \\
\hline GP10808 12-14' & ND & 129 & $0.132 \mathrm{~J}$ & 17.1 & 73.9 \\
\hline GP10908 12-14' & ND & $108 \mathrm{~J}$ & $0.0988 \mathrm{~J}$ & $12.5 \mathrm{~J}$ & 71.6 \\
\hline GP10908 34-36' & ND & $181 \mathrm{~J}$ & $0.206 \mathrm{~J}$ & $17.8 \mathrm{~J}$ & 57 \\
\hline GP10908 36-38' & ND & $187 \mathrm{~J}$ & $0.294 \mathrm{~J}$ & $27.3 \mathrm{~J}$ & 71.9 \\
\hline
\end{tabular}

CRDL - Contract-required detection limit

$\mathrm{J}$ - Data are estimated

ND - Not detected 
TABLE F-4B

Metals Detected in 2008 Geoprobe ${ }^{\circledR}$ Soil Samples Above Site-Specific Soil Screening Levels (SSLs)

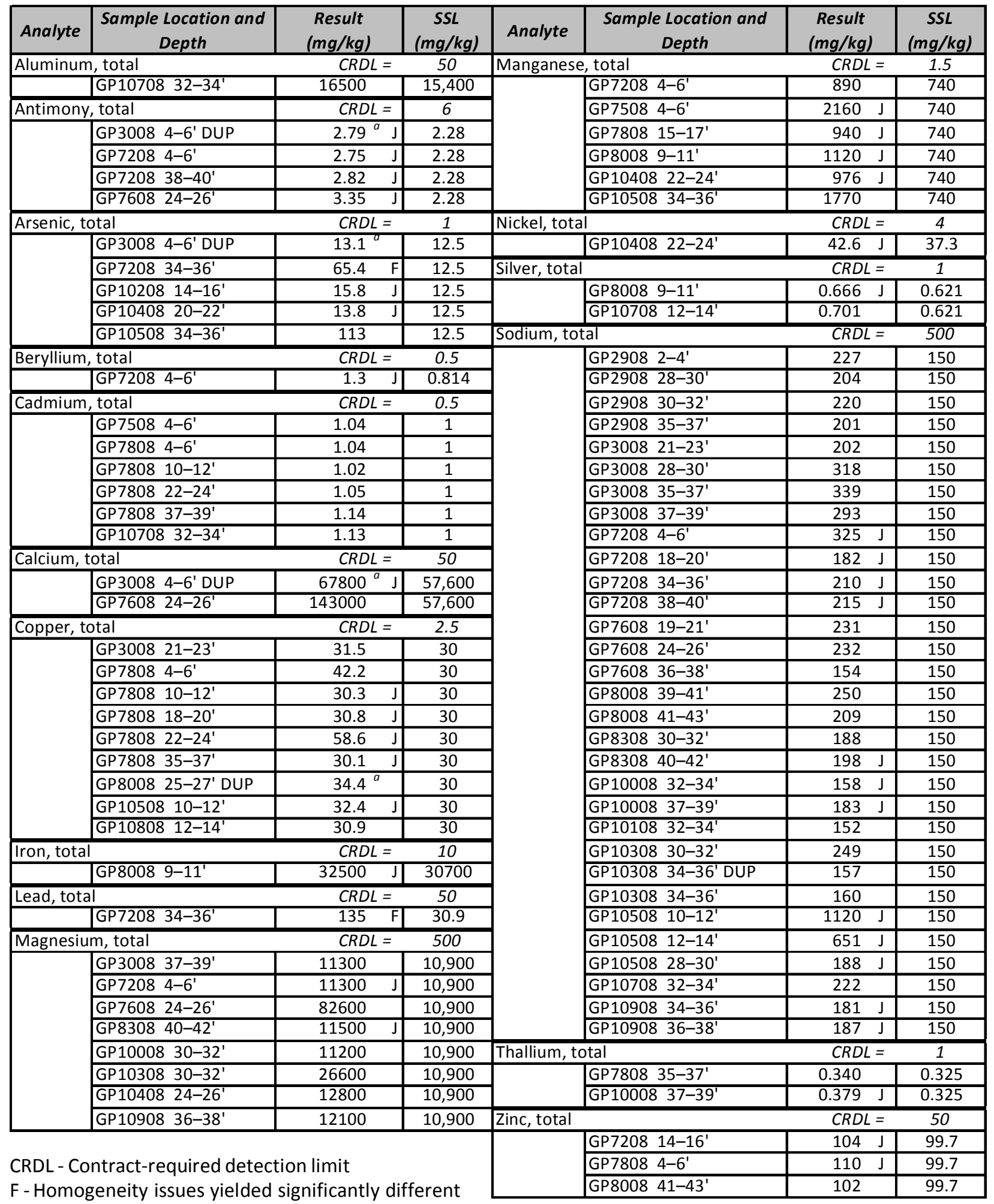

$\mathrm{F}$ - Homogeneity issues yielded significantly different

results between sample and replicates. Replicates are less than the SSLS.

$\mathrm{J}$ - Data are estimated

a Concentration reported in original sample was less than the SSL. 
TABLE F-4C

\section{Metals Results For 2008 Geoprobe ${ }^{\circledR}$ Groundwater Samples}

\begin{tabular}{|c|c|c|c|c|c|c|}
\hline Location & $\begin{array}{c}\text { Antimony } \\
(\mu \mathrm{g} / \mathrm{L})\end{array}$ & $\begin{array}{c}\text { Arsenic } \\
(\mu \mathrm{g} / \mathrm{L})\end{array}$ & $\begin{array}{l}\text { Barium } \\
(\mu g / L)\end{array}$ & $\begin{array}{c}\text { Beryllium } \\
(\mu g / L)\end{array}$ & $\begin{array}{c}\text { Cadmium } \\
(\mu g / L)\end{array}$ & $\begin{array}{c}\text { Chromium } \\
(\mu \mathrm{g} / \mathrm{L})\end{array}$ \\
\hline $\begin{array}{l}\text { Groundwater Screening } \\
\text { Level }\end{array}$ & 15.1 & 25.0 & 1,000 & 3 & 7.27 & 52.3 \\
\hline Site Background & 15.1 & 20.9 & 441 & 1.85 & 7.27 & 52.3 \\
\hline TOGS 1.1.1 & 3 & 25 & 1,000 & 3 & 5 & 50 \\
\hline Detection Limit & $M D L=3$ & $C R D L=10$ & $C R D L=200$ & $C R D L=1$ & $C R D L=5$ & $C R D L=10$ \\
\hline GP2908 17-19' & 0.661 & 13.7 & 377 & 0.915 & ND & 28.9 \\
\hline GP2908 17-19' DUP & 0.955 & 20.9 & 360 & 1.25 & ND & 15.6 \\
\hline GP2908 29-31' & ND & ND & 261 & $0.142 \mathrm{~J}$ & $1.01 \mathrm{~J}$ & ND \\
\hline GP2908 35-37' & ND & 76 & 1140 & 1.26 & $1.21 \mathrm{~J}$ & 44.7 \\
\hline GP3008 20-22' & 0.547 & $25.4 \mathrm{~J}$ & 681 & 1.41 & $1.1 \mathrm{~J}$ & $28.6 \mathrm{~J}$ \\
\hline GP3008 20-22' DUP & ND & $7.2 \mathrm{~J}$ & 562 & $0.371 \mathrm{~J}$ & $1.16 \mathrm{~J}$ & $9.59 \mathrm{~J}$ \\
\hline GP3008 28-30' & 0.839 & 29.2 & 629 & 1.61 & $1.58 \mathrm{~J}$ & $51.3 \mathrm{~J}$ \\
\hline GP3008 35-37' & 1.04 & 49.5 & 932 & 3.38 & 1.7 & $107 \mathrm{~J}$ \\
\hline GP7208 20-22' & ND & ND & 237 & $0.381 \mathrm{~J}$ & ND & 11.4 \\
\hline GP7208 31-33' & ND & ND & 497 & ND & ND & $4.67 \mathrm{~J}$ \\
\hline GP7208 38-40' & ND & 177 & 1980 & 5.24 & 7.43 & 158 \\
\hline GP7608 20-22' & ND & $4.25 \mathrm{~J}$ & 536 & $0.167 \mathrm{~J}$ & $1.42 \mathrm{~J}$ & ND \\
\hline GP7608 34-36' & ND & $32.4 \mathrm{~J}$ & 515 & 1.55 & $1.56 \mathrm{~J}$ & 32 \\
\hline GP7808 20-22' & $0.567 \mathrm{~J}$ & 37.9 & 529 & 2.18 & ND & 66.2 \\
\hline GP7808 28-30' & $0.724 \mathrm{~J}$ & 15.5 & 854 & 0.955 & ND & 95.8 \\
\hline GP7808 34-36' & ND & 9.27 & 527 & 0.753 & ND & 62.8 \\
\hline GP8008 25-27' & ND & ND & 302 & 0.27 & 1.32 & 5.22 \\
\hline GP8008 32-34' & ND & 2.95 & 404 & 0.211 & 1.28 & 11.7 \\
\hline GP8008 39-41' & 0.513 & 32.7 & 794 & 3.14 & 1.69 & 83.1 \\
\hline GP8308 22-24' & $8.14 \mathrm{~J}$ & ND & $311 \mathrm{~J}$ & $0.476 \mathrm{~J}$ & ND & $20.9 \mathrm{~J}$ \\
\hline GP8308 30-32' & 0.686 & ND & $599 \mathrm{~J}$ & $0.335 \mathrm{~J}$ & ND & $6.96 \mathrm{~J}$ \\
\hline GP8308 38-40' & 0.911 & 30.5 & $1040 \mathrm{~J}$ & 1.8 & ND & $84.8 \mathrm{~J}$ \\
\hline GP10008 20-22' & ND & $1.67 \mathrm{~J}$ & 532 & ND & $1.15 \mathrm{~J}$ & ND \\
\hline GP10008 35-37' & $0.636 \mathrm{~J}$ & 15.1 & 554 & 1.12 & $1.16 \mathrm{~J}$ & 83.1 \\
\hline GP10108 21-23' & 0.682 & 13.4 & 340 & 0.807 & ND & $21.6 \mathrm{~J}$ \\
\hline GP10108 28-30' & ND & 7.54 & 303 & 0.588 & ND & $16.1 \mathrm{~J}$ \\
\hline GP10208 27-29' & $\mathrm{ND}$ & 20.3 & 237 & 1.25 & $1.44 \mathrm{~J}$ & 16.9 \\
\hline GP10308 21-23' & 1.2 & ND & $13.3 \mathrm{~J}$ & 0.532 & ND & ND \\
\hline GP10308 21-23' DUP & 0.52 & ND & $299 \mathrm{~J}$ & $0.292 \mathrm{~J}$ & $1.02 \mathrm{~J}$ & ND \\
\hline GP10308 30-32' & 0.53 & ND & $5.61 \mathrm{~J}$ & 0.108 & ND & ND \\
\hline GP10308 35-37' & ND & 8.1 & ND & 2 & ND & ND \\
\hline GP10408 21-23' & ND & 5.56 & 340 & $0.31 \mathrm{~J}$ & $1.32 \mathrm{~J}$ & 6.9 \\
\hline GP10508 16-18' & ND & 5.15 & 694 & $0.401 \mathrm{~J}$ & $1.44 \mathrm{~J}$ & 9.54 \\
\hline GP10508 28-30' & $1 \mathrm{~J}$ & 13 & 491 & 0.815 & $1.73 \mathrm{~J}$ & 36.1 \\
\hline GP10508 34-36' & ND & $2.1 \mathrm{~J}$ & 444 & ND & $1.46 \mathrm{~J}$ & $3.35 \mathrm{~J}$ \\
\hline GP10608 16-18' & 0.86 & 29.2 & 566 & 1.75 & ND & $61.8 \mathrm{~J}$ \\
\hline GP10608 20-22' & 0.946 & 36 & 1120 & 2.2 & ND & $88.4 \mathrm{~J}$ \\
\hline GP10608 28-30' & $0.641 \mathrm{~J}$ & 24.2 & 751 & 1.24 & 1.33 & $64.9 \mathrm{~J}$ \\
\hline GP10708 15-17' & 1.1 & 178 & 1990 & 9.97 & 16.3 & 244 \\
\hline GP10708 22-24' & 0.624 & 9.45 & 593 & 0.7 & $2.18 \mathrm{~J}$ & 28.8 \\
\hline GP10708 30-32' & ND & ND & 382 & ND & ND & $2.73 \mathrm{~J}$ \\
\hline GP10908 14-16' & $0.567 \mathrm{~J}$ & 37.2 & $884 \mathrm{~J}$ & 2.83 & $2.09 \mathrm{~J}$ & 71.2 \\
\hline GP10908 28-30' & $0.949 \mathrm{~J}$ & 53 & $780 \mathrm{~J}$ & $2.47 \mathrm{~J}$ & $2.28 \mathrm{~J}$ & 84.3 \\
\hline GP10908 34-36' & $0.526 \mathrm{~J}$ & ND & $834 \mathrm{~J}$ & ND & $1.77 \mathrm{~J}$ & $2.14 \mathrm{~J}$ \\
\hline
\end{tabular}

CRDL - Contract-required detection limit

ND - Not detected

NE - TOGS 1.1.1 water quality standard is not established for this analyte

$\mathrm{J}$ - Data are estimated 
TABLE F-4C (continued)

Metals Results For 2008 Geoprobe ${ }^{\circledR}$ Groundwater Samples

\begin{tabular}{|c|c|c|c|c|c|c|}
\hline Location & $\begin{array}{l}\text { Cobalt } \\
(\mu \mathrm{g} / \mathrm{L})\end{array}$ & $\begin{array}{c}\text { Copper } \\
(\mu g / L)\end{array}$ & $\begin{array}{c}\text { Lead } \\
(\mu g / L)\end{array}$ & $\begin{array}{c}\text { Mercury } \\
(\mu g / L)\end{array}$ & $\begin{array}{l}\text { Nickel } \\
(\mu g / L)\end{array}$ & $\begin{array}{c}\text { Selenium } \\
(\mu g / L)\end{array}$ \\
\hline $\begin{array}{l}\text { Groundwater Screening } \\
\text { Level }\end{array}$ & 67.8 & 200 & 42.7 & 0.7 & 100 & 10.1 \\
\hline Site Background & 67.8 & 59.9 & 42.7 & 0.263 & 59.5 & 10.1 \\
\hline TOGS 1.1.1 & $N E$ & 200 & 25 & 0.7 & 100 & 10 \\
\hline Detection Limit & $C R D L=50$ & $C R D L=25$ & $C R D L=3$ & $C R D L=0.2$ & $C R D L=40$ & $C R D L=5$ \\
\hline GP2908 17-19' & 16 & 65.9 & 25 & $0.162 \mathrm{~J}$ & 34.4 & ND \\
\hline GP2908 17-19' DUP & 10.4 & 37.2 & 34 & ND & 19.7 & ND \\
\hline GP2908 29-31' & $1.77 \mathrm{~J}$ & $4.27 \mathrm{~J}$ & 4.15 & ND & 5.3 & ND \\
\hline GP2908 35-37' & 21.9 & 85.2 & 42.6 & ND & 57.6 & ND \\
\hline GP3008 20-22' & 14.4 & $61.3 \mathrm{~J}$ & $39.4 \mathrm{~J}$ & ND & $33.9 \mathrm{~J}$ & ND \\
\hline GP3008 20-22' DUP & $4.87 \mathrm{~J}$ & $23.8 \mathrm{~J}$ & $12 \mathrm{~J}$ & ND & $12.2 \mathrm{~J}$ & ND \\
\hline GP3008 28-30' & 29.4 & $93.9 \mathrm{~J}$ & 52.4 & ND & $68.7 \mathrm{~J}$ & ND \\
\hline GP3008 35-37' & 44.6 & $136 \mathrm{~J}$ & 132 & ND & $102 \mathrm{~J}$ & ND \\
\hline GP7208 20-22' & $4.17 \mathrm{~J}$ & 13 & 6.72 & ND & 11.3 & ND \\
\hline GP7208 31-33' & $2.71 \mathrm{~J}$ & $8.37 \mathrm{~J}$ & 3.64 & ND & 8.48 & ND \\
\hline GP7208 38-40' & 142 & 320 & 139 & ND & 295 & ND \\
\hline GP7608 20-22' & ND & $3.58 \mathrm{~J}$ & $2.89 \mathrm{~J}$ & ND & ND & ND \\
\hline GP7608 34-36' & 10.8 & 43.5 & $55.6 \mathrm{~J}$ & ND & ND & ND \\
\hline GP7808 20-22' & 31.8 & 118 & 57.9 & ND & $74.1 \mathrm{~J}$ & ND \\
\hline $\begin{array}{ll}\text { GP7808 } 28-30^{\prime} \\
\end{array}$ & 15.1 & 72.3 & 24.6 & ND & $54.5 \mathrm{~J}$ & ND \\
\hline GP7808 34-36' & 10.4 & 51.3 & 32.3 & ND & $36.6 \mathrm{~J}$ & ND \\
\hline GP8008 25-27' & 1.64 & 8.27 & 4.07 & ND & 6.09 & ND \\
\hline GP8008 32-34' & 4.65 & 14.6 & 7.38 & ND & 16.7 & ND \\
\hline GP8008 39-41' & 44.9 & 396 & 135 & ND & 117 & ND \\
\hline GP8308 22-24' & 12.7 & $60.7 \mathrm{~J}$ & 16.8 & 0.603 & 28 & ND \\
\hline GP8308 30-32' & 5.79 & $8.63 \mathrm{~J}$ & 8.16 & ND & 6.41 & ND \\
\hline GP8308 $38-40^{\prime}$ & 31.7 & $105 \mathrm{~J}$ & 70.8 & ND & $\frac{0.71}{67}$ & ND \\
\hline GP10008 20-22' & $1.16 \mathrm{~J}$ & $4.91 \mathrm{~J}$ & 2.13 & ND & $4.31 \mathrm{~J}$ & ND \\
\hline GP10008 35-37' & 14 & $62.7 \mathrm{~J}$ & 67 & ND & 41.4 & ND \\
\hline GP10108 21-23' & 11.4 & $37.6 \mathrm{~J}$ & 22.3 & ND & $22.2 \mathrm{~J}$ & ND \\
\hline GP10108 28-30' & 8.46 & $28 \mathrm{~J}$ & 12.6 & ND & $20.2 \mathrm{~J}$ & ND \\
\hline GP10208 27-29' & 8.19 & 18.3 & 29.4 & ND & 15 & ND \\
\hline GP10308 21-23' & $1 \mathrm{~J}$ & $8.02 \mathrm{~J}$ & 10.1 & ND & ND & ND \\
\hline GP10308 21-23' DUP & 6.73 & $8.27 \mathrm{~J}$ & 7.41 & ND & 7.92 & ND \\
\hline GP10308 30-32' & ND & $9.08 \mathrm{~J}$ & 3.39 & ND & $1.06 \mathrm{~J}$ & ND \\
\hline GP10308 35-37' & ND & ND & 39 & ND & ND & ND \\
\hline GP10408 21-23' & $3.52 \mathrm{~J}$ & 17.4 & 14 & ND & 11 & ND \\
\hline GP10508 16-18' & $2.96 \mathrm{~J}$ & 19.3 & 7.39 & $0.0404 \mathrm{~J}$ & 10.2 & ND \\
\hline GP10508 28-30' & 13 & 48 & 22.1 & $0.0559 \mathrm{~J}$ & 34.9 & ND \\
\hline GP10508 34-36' & $2.8 \mathrm{~J}$ & $5.74 \mathrm{~J}$ & 2.15 & $0.0329 \mathrm{~J}$ & 5.36 & ND \\
\hline GP10608 16-18' & 37.1 & 156 & 49.4 & ND & $84.8 \mathrm{~J}$ & ND \\
\hline GP10608 20-22' & 52.3 & 220 & 70.9 & ND & $118 \mathrm{~J}$ & ND \\
\hline GP10608 28-30' & 29.9 & 107 & 38.4 & ND & $62.8 \mathrm{~J}$ & ND \\
\hline GP10708 15-17' & 120 & 464 & 281 & ND & 293 & $1.15 \mathrm{~J}$ \\
\hline GP10708 22-24' & 15 & 55 & 18.1 & ND & 34.4 & ND \\
\hline GP10708 30-32' & $1.99 \mathrm{~J}$ & $5.4 \mathrm{~J}$ & $1.8 \mathrm{~J}$ & ND & 6.75 & ND \\
\hline GP10908 14-16' & 35.9 & 131 & 77.3 & $0.0725 \mathrm{~J}$ & 82.3 & ND \\
\hline GP10908 28-30' & 50.5 & 200 & 69.8 & ND & 110 & ND \\
\hline GP10908 34-36' & ND & ND & $1.13 \mathrm{~J}$ & ND & $2.91 \mathrm{~J}$ & ND \\
\hline
\end{tabular}

CRDL - Contract-required detection limit

ND - Not detected

NE - TOGS 1.1.1 water quality standard is not established for this analyte

$\mathrm{J}$ - Data are estimated 
TABLE F-4C (concluded)

Metals Results For 2008 Geoprobe ${ }^{\circledR}$ Groundwater Samples

\begin{tabular}{|c|c|c|c|c|c|}
\hline Location & $\begin{array}{l}\text { Silver } \\
(\mu g / L)\end{array}$ & $\begin{array}{c}\text { Thallium } \\
(\mu g / L)\end{array}$ & $\begin{array}{c}\text { Tin } \\
(\mu \mathrm{g} / \mathrm{L})\end{array}$ & $\begin{array}{c}\text { Vanadium } \\
(\mu \mathrm{g} / \mathrm{L})\end{array}$ & $\begin{array}{c}\text { Zinc } \\
(\mu g / L)\end{array}$ \\
\hline $\begin{array}{l}\text { Groundwater Screening } \\
\text { Level }\end{array}$ & 50 & 13.9 & 4,083 & 69.6 & 2,000 \\
\hline Site Background & 15.5 & 13.9 & 4,083 & 69.6 & 127 \\
\hline TOGS 1.1.1 & 50 & 0.5 & $N E$ & $N E$ & 2,000 \\
\hline Detection Limit & $C R D L=10$ & $C R D L=10$ & $C R D L=3000$ & $C R D L=50$ & $C R D L=20$ \\
\hline GP2908 17-19' & ND & $0.803 \mathrm{~J}$ & ND & 40.8 & 201 \\
\hline GP2908 17-19' DUP & ND & $0.576 \mathrm{~J}$ & ND & 22.2 & 116 \\
\hline GP2908 29-31' & ND & ND & ND & $1.61 \mathrm{~J}$ & 35.7 \\
\hline GP2908 35-37' & ND & $0.506 \mathrm{~J}$ & ND & 44.5 & 247 \\
\hline GP3008 20-22' & ND & $0.674 \mathrm{~J}$ & ND & $38.8 \mathrm{~J}$ & $177 \mathrm{~J}$ \\
\hline GP3008 20-22' DUP & ND & ND & ND & $14.1 \mathrm{~J}$ & $60.8 \mathrm{~J}$ \\
\hline GP3008 28-30' & ND & 1.13 & ND & $46 \mathrm{~J}$ & $243 \mathrm{~J}$ \\
\hline GP3008 35-37' & ND & 1.07 & ND & $85.3 \mathrm{~J}$ & $370 \mathrm{~J}$ \\
\hline GP7208 20-22' & $1.93 \mathrm{~J}$ & $0.938 \mathrm{~J}$ & ND & 9.94 & 50.9 \\
\hline GP7208 31-33' & $1.86 \mathrm{~J}$ & ND & ND & ND & 33.6 \\
\hline GP7208 38-40' & ND & 2.17 & ND & 200 & 856 \\
\hline GP7608 20-22' & ND & $0.793 \mathrm{~J}$ & ND & ND & $9.97 \mathrm{~J}$ \\
\hline GP7608 34-36' & ND & $0.599 \mathrm{~J}$ & ND & 11.3 & 85.3 \\
\hline GP7808 20-22' & ND & $1.76 \mathrm{~J}$ & $4.96 \mathrm{~J}$ & 75.2 & 319 \\
\hline GP7808 $28-30^{\prime}$ & ND & $0.531 \mathrm{~J}$ & 13.2 & 31.5 & 321 \\
\hline GP7808 34-36' & ND & $0.354 \mathrm{~J}$ & ND & 24.2 & 217 \\
\hline GP8008 25-27' & ND & $0.96 \mathrm{~J}$ & ND & 4.72 & 37.1 \\
\hline GP8008 32-34' & ND & ND & ND & 4.92 & 44.3 \\
\hline GP8008 39-41' & ND & $0.449 \mathrm{~J}$ & ND & 77.7 & 515 \\
\hline GP8308 22-24' & ND & ND & ND & 27.8 & $219 \mathrm{~J}$ \\
\hline GP8308 30-32' & ND & ND & ND & ND & $28.2 \mathrm{~J}$ \\
\hline GP8308 $38-40^{\prime}$ & ND & $0.662 \mathrm{~J}$ & ND & 48.5 & $359 \mathrm{~J}$ \\
\hline GP10008 20-22' & ND & $0.753 \mathrm{~J}$ & ND & $1.76 \mathrm{~J}$ & 21.8 \\
\hline GP10008 35-37' & ND & $0.54 \mathrm{~J}$ & ND & 19.4 & 244 \\
\hline GP10108 21-23' & ND & $0.953 \mathrm{~J}$ & ND & $32.4 \mathrm{~J}$ & $122 \mathrm{~J}$ \\
\hline GP10108 28-30' & ND & $0.485 \mathrm{~J}$ & ND & $16.1 \mathrm{~J}$ & $133 \mathrm{~J}$ \\
\hline GP10208 27-29' & ND & $0.564 \mathrm{~J}$ & ND & 8.9 & 42.9 \\
\hline GP10308 21-23' & ND & $0.999 \mathrm{~J}$ & $6.68 \mathrm{~J}$ & ND & $4.39 \mathrm{~J}$ \\
\hline GP10308 21-23' DUP & ND & ND & ND & $2.2 \mathrm{~J}$ & $37.8 \mathrm{~J}$ \\
\hline GP10308 30-32' & ND & $0.309 \mathrm{~J}$ & $8.79 \mathrm{~J}$ & ND & 11.3 \\
\hline GP10308 35-37' & ND & $0.348 \mathrm{~J}$ & ND & ND & ND \\
\hline GP10408 21-23' & ND & $0.882 \mathrm{~J}$ & ND & 9.2 & 53.5 \\
\hline GP10508 16-18' & ND & $0.529 \mathrm{~J}$ & ND & 11.6 & 66.1 \\
\hline GP10508 28-30' & ND & ND & ND & 24.3 & 124 \\
\hline GP10508 34-36' & ND & ND & ND & $1.51 \mathrm{~J}$ & 24.3 \\
\hline GP10608 16-18' & ND & $0.64 \mathrm{~J}$ & ND & 72.1 & 431 \\
\hline GP10608 20-22' & ND & $0.679 \mathrm{~J}$ & ND & 92.5 & 630 \\
\hline GP10608 28-30' & ND & $0.569 \mathrm{~J}$ & ND & 41.1 & 337 \\
\hline GP10708 15-17' & 5.8 & 3.46 & ND & 226 & 1310 \\
\hline GP10708 22-24' & ND & $0.355 \mathrm{~J}$ & ND & 29.4 & 181 \\
\hline GP10708 30-32' & ND & $\mathrm{ND}$ & ND & ND & 24.2 \\
\hline GP10908 14-16' & ND & 1.16 & ND & $60.2 \mathrm{~J}$ & 383 \\
\hline GP10908 28-30' & ND & 1.16 & ND & $96.4 \mathrm{~J}$ & 551 \\
\hline GP10908 34-36' & ND & ND & ND & ND & 20 \\
\hline
\end{tabular}

CRDL - Contract-required detection limit

ND - Not detected

NE - TOGS 1.1.1 water quality standard is not established for this analyte

$\mathrm{J}$ - Data are estimated 
TABLE F-4D

\section{Metals Detected in 2008 Geoprobe ${ }^{\circledR}$ Groundwater Samples Above Groundwater Screening Levels (GSLs)}

\begin{tabular}{|c|c|c|c|c|c|c|c|}
\hline Analyte & $\begin{array}{c}\text { Sample Location and } \\
\text { Depth }\end{array}$ & $\begin{array}{l}\text { Result } \\
(\mu g / L)\end{array}$ & $\begin{array}{c}G S L \\
(u g / L)\end{array}$ & Analyte & $\begin{array}{c}\text { Sample Location and } \\
\text { Depth }\end{array}$ & $\begin{array}{l}\text { Result } \\
(\mu g / L)\end{array}$ & $\begin{array}{c}G S L \\
(u g / L)\end{array}$ \\
\hline \multicolumn{2}{|c|}{ Arsenic, total } & $C R D L=$ & 10 & \multicolumn{2}{|l|}{ Cobalt, total } & $C R D L=$ & 50 \\
\hline \multirow[t]{14}{*}{$\begin{array}{ll} \\
\end{array}$} & GP2908 35-37' & 76 & 25 & & GP7208 38-40' & 142 & 67.8 \\
\hline & GP3008 20-22' & $25.4 \mathrm{~J}$ & 25 & & GP10708 15-17' & 120 & 67.8 \\
\hline & GP3008 28-30' & 29.2 & 25 & \multicolumn{2}{|c|}{ Copper, total } & $C R D L=$ & 25 \\
\hline & GP3008 35-37' & 49.5 & 25 & & GP7208 38-40' & 320 & 200 \\
\hline & GP7208 38-40' & 177 & 25 & & GP8008 39-41' & 396 & 200 \\
\hline & GP7608 34-36' & $32.4 \mathrm{~J}$ & 25 & & \begin{tabular}{|ll} 
GP10608 20-22' \\
\end{tabular} & 220 & 200 \\
\hline & GP7808 20-22' & 37.9 & 25 & & GP10708 15-17' & 464 & 200 \\
\hline & GP8008 39-41' & 32.7 & 25 & \multicolumn{2}{|l|}{ Lead, total } & $C R D L=$ & 3 \\
\hline & \begin{tabular}{|l} 
GP8308 38-40' \\
\end{tabular} & 30.5 & 25 & & GP3008 28-30' & 52.4 & 42.7 \\
\hline & GP10608 16-18' & 29.2 & 25 & & GP3008 35-37' & 132 & 42.7 \\
\hline & \begin{tabular}{|l|} 
GP10608 20-22' \\
\end{tabular} & 36 & 25 & & GP7208 38-40' & 139 & 42.7 \\
\hline & GP10708 15-17' & 178 & 25 & & GP7608 34-36' & $55.6 \mathrm{~J}$ & 42.7 \\
\hline & GP10908 14-16' & 37.2 & 25 & & GP7808 20-22' & 57.9 & 42.7 \\
\hline & GP10908 28-30' & 53 & 25 & & GP8008 39-41' & 135 & 42.7 \\
\hline \multicolumn{2}{|c|}{ Barium, total } & $C R D L=$ & 200 & & GP8308 38-40' & 70.8 & 42.7 \\
\hline & GP2908 35-37' & 1140 & 1000 & & GP10008 35-37' & 67 & 42.7 \\
\hline & \begin{tabular}{|l} 
GP7208 38-40' \\
\end{tabular} & 1980 & 1000 & & GP10608 16-18' & 49.4 & 42.7 \\
\hline & GP8308 38-40' & $1040 \mathrm{~J}$ & 1000 & & GP10608 20-22' & 70.9 & 42.7 \\
\hline & GP10608 20-22' & 1120 & 1000 & & GP10708 15-17' & 281 & 42.7 \\
\hline & GP10708 15-17' & 1990 & 1000 & & GP10908 14-16' & 77.3 & 42.7 \\
\hline \multicolumn{2}{|c|}{ Beryllium, total } & $C R D L=$ & 1 & & GP10908 28-30' & 69.8 & 42.7 \\
\hline & GP3008 35-37' & 3.38 & 3 & Nickel, total & & $C R D L=$ & 40 \\
\hline & GP7208 38-40' & 5.24 & 3 & & GP3008 35-37' & $102 \mathrm{~J}$ & 100 \\
\hline & GP8008 39-41' & 3.14 & 3 & & GP7208 38-40' & 295 & 100 \\
\hline & GP10708 15-17' & 9.97 & 3 & & GP8008 39-41' & 117 & 100 \\
\hline Cadmium, & tal & $C R D L=$ & 5 & & GP10608 20-22' & $118 \mathrm{~J}$ & 100 \\
\hline & GP7208 38-40' & 7.43 & 7.27 & & GP10708 15-17' & 293 & 100 \\
\hline & GP10708 15-17' & 16.3 & 7.27 & & GP10908 28-30' & 110 & 100 \\
\hline Chromium, & otal & $C R D L=$ & 10 & Vanadium, & otal & $C R D L=$ & 50 \\
\hline & GP3008 35-37' & $107 \mathrm{~J}$ & 52.3 & & GP3008 35-37' & $85.3 \mathrm{~J}$ & 69.6 \\
\hline & \begin{tabular}{|l} 
GP7208 38-40' \\
\end{tabular} & 158 & 52.3 & & GP7208 38-40' & 200 & 69.6 \\
\hline & GP7808 20-22' & 66.2 & 52.3 & & GP7808 20-22' & 75.2 & 69.6 \\
\hline & GP7808 28-30' & 95.8 & 52.3 & & GP8008 39-41' & 77.7 & 69.6 \\
\hline & GP7808 34-36' & 62.8 & 52.3 & & GP10608 16-18' & 72.1 & 69.6 \\
\hline & GP8008 39-41' & 83.1 & 52.3 & & GP10608 20-22' & 92.5 & 69.6 \\
\hline & \begin{tabular}{|ll} 
GP8308 38-40' \\
\end{tabular} & $84.8 \mathrm{~J}$ & 52.3 & & $\begin{array}{|ll|}\text { GP10708 15-17' } \\
\end{array}$ & 226 & 69.6 \\
\hline & GP10008 35-37' & 83.1 & 52.3 & & GP10908 28-30' & $96.4 \mathrm{~J}$ & 69.6 \\
\hline & GP10608 16-18' & $61.8 \mathrm{~J}$ & 52.3 & & & & \\
\hline & GP10608 20-22' & $88.4 \mathrm{~J}$ & 52.3 & & & & \\
\hline & GP10608 28-30' & $64.9 \mathrm{~J}$ & 52.3 & & & & \\
\hline & GP10708 15-17' & 244 & 52.3 & & & & \\
\hline & GP10908 14-16' & 71.2 & 52.3 & & & & \\
\hline & GP10908 28-30' & 84.3 & 52.3 & & & & \\
\hline
\end{tabular}

CRDL - Contract-required detection limit

J - Data are estimated 
This page intentionally left blank 


\section{APPENDIX G}

\section{Summary of Direct Radiation Monitoring Data}

TABLE G-1

Summary of 2008 Semiannual Averages of Off-Site TLD Measurements ${ }^{a}$

(mR \pm 2 SD/quarter)

\begin{tabular}{|c|c|c|c|}
\hline $\begin{array}{c}\text { Location } \\
\text { Number }^{b}\end{array}$ & 1st Half & 2nd Half & $\begin{array}{c}\text { Location } \\
\text { Average }\end{array}$ \\
\hline DFTLD1 & $17 \pm 2$ & $15 \pm 1$ & $16 \pm 1$ \\
\hline DFTLD02 & $c$ & $16 \pm 1$ & $16 \pm 1$ \\
\hline DFTLD03 & $14 \pm 1$ & $13 \pm 1$ & $13 \pm 1$ \\
\hline DFTLD04 & $17 \pm 1$ & $14 \pm 1$ & $15 \pm 1$ \\
\hline DFTLD05 & $17 \pm 1$ & $16 \pm 1$ & $16 \pm 1$ \\
\hline DFTLD06 & $16 \pm 1$ & $15 \pm 1$ & $16 \pm 1$ \\
\hline DFTLD07 & $14 \pm 2$ & $13 \pm 1$ & $13 \pm 1$ \\
\hline DFTLD08 & $17 \pm 1$ & $16 \pm 1$ & $16 \pm 1$ \\
\hline DFTLD09 & $16 \pm 1$ & $17 \pm 2$ & $16 \pm 1$ \\
\hline DFTLD10 & $15 \pm 1$ & $15 \pm 1$ & $15 \pm 1$ \\
\hline DFTLD11 & $15 \pm 1$ & $15 \pm 1$ & $15 \pm 1$ \\
\hline DFTLD12 & $17 \pm 2$ & $c$ & $17 \pm 2$ \\
\hline DFTLD13 & $17 \pm 1$ & $17 \pm 1$ & $17 \pm 1$ \\
\hline DFTLD14 & $16 \pm 2$ & $15 \pm 1$ & $15 \pm 1$ \\
\hline DFTLD15 & $15 \pm 1$ & $15 \pm 2$ & $16 \pm 1$ \\
\hline DFTLD16 & $16 \pm 1$ & $16 \pm 1$ & $14 \pm 1$ \\
\hline DFTLD20 & $15 \pm 1$ & $14 \pm 1$ & $17 \pm 1$ \\
\hline DFTLD23 & $17 \pm 1$ & $16 \pm 1$ & \\
\hline
\end{tabular}

${ }^{a}$ The frequency of collection at the TLD locations was reduced from quarterly to semannual in 2008, however data are reported in units of $m R$ per quarter for comparability with historical results.

${ }^{b}$ Off-site locations are shown on Figures A-11 and A-12.

$c$ TLDs at these locations were lost in the field.

Conversion factor: Milliroentgen $(\mathrm{mR})$ units are used to report exposure rates in air. To convert $\mathrm{mR}$ to mrem (dose to humans), a conversion factor of 1.03 must be applied. For example, a reported exposure rate of $18.1 \mathrm{mR} /$ quarter would be equivalent to $18.6 \mathrm{mrem} /$ quarter (based upon dose-equivalent phantom calibration using cesium-137). 
TABLE G-2

Summary of 2008 Semiannual Averages of On-Site TLD Measurements ${ }^{a}$ (mR \pm 2 SD/quarter)

\begin{tabular}{|c|c|c|c|}
\hline $\begin{array}{c}\text { Location } \\
\text { Number }^{b}\end{array}$ & 1st Half & 2nd Half & $\begin{array}{c}\text { Location } \\
\text { Average }\end{array}$ \\
\hline DNTLD24 & $771 \pm 68$ & $651 \pm 63$ & $711 \pm 66$ \\
\hline DNTLD28 & $18 \pm 1$ & $17 \pm 1$ & $18 \pm 1$ \\
\hline DNTLD33 & $20 \pm 1$ & $18 \pm 1$ & $19 \pm 1$ \\
\hline DNTLD35 & $19 \pm 1$ & $18 \pm 1$ & $18 \pm 1$ \\
\hline DNTLD36 & $16 \pm 2$ & $15 \pm 1$ & $34 \pm 5$ \\
\hline DNTLD38 & $34 \pm 4$ & $34 \pm 6$ & $98 \pm 14$ \\
\hline DNTLD40 & $113 \pm 18$ & $84 \pm 9$ & $14 \pm 1$ \\
\hline DNTLD43 & $15 \pm 1$ & $14 \pm 1$ & \\
\hline
\end{tabular}

a The frequency of collection at the TLD locations was reduced from quarterly to semannual in 2008, however data are reported in units of $\mathrm{mR}$ per quarter for comparability with historical results.

$b$ On-site locations are shown on Figure A-10.

Conversion factor: Milliroentgen $(\mathrm{mR})$ units are used to report exposure rates in air. To convert $\mathrm{mR}$ to $\mathrm{mrem}$ (dose to humans), a conversion factor of 1.03 must be applied. For example, a reported exposure rate of $18.1 \mathrm{mR} / \mathrm{quarter}$ would be equivalent to $18.6 \mathrm{mrem} /$ quarter (based upon dose-equivalent phantom calibration using cesium-137). 


\section{APPENDIX H}

\section{Summary of Quality Assurance Crosscheck Analyses}

\section{TABLE H-1 \\ Crosscheck Sample Comparisons From the DOE Mixed Analyte Performance Evaluation Program (MAPEP) ${ }^{a}$; Study 18, February 2008}

\begin{tabular}{|c|c|c|c|c|c|c|c|}
\hline Analyte & Matrix & Units & Actual & Reported & $\begin{array}{c}\text { Acceptance } \\
\text { Range }\end{array}$ & Accept $?^{b}$ & $\begin{array}{c}\text { Analyzed } \\
\text { by: }\end{array}$ \\
\hline \multicolumn{8}{|c|}{ MAPEP - 08 - GrF18 Gross Alpha/Beta Air Filter } \\
\hline Gross Alpha & Air Filter & $\mathrm{Bq} / \mathrm{sample}$ & 0.348 & 0.0926 & $>0.0-0.696$ & Yes & ELAB \\
\hline Gross Beta & Air Filter & $\mathrm{Bq} / \mathrm{sample}$ & 0.286 & 0.300 & $0.143-0.429$ & Yes & ELAB \\
\hline \multicolumn{8}{|c|}{ MAPEP - 08 - RdF18 Radiological Air Filter } \\
\hline Am-241 & Air Filter & $\mathrm{Bq} / \mathrm{sample}$ & 0.158 & 0.123 & $0.111-0.205$ & Pass & GEL \\
\hline Cs-137 & Air Filter & $\mathrm{Bq} / \mathrm{sample}$ & 2.70 & 2.47 & $1.89-3.51$ & Yes & GEL \\
\hline Co-60 & Air Filter & $\mathrm{Bq} / \mathrm{sample}$ & 1.31 & 1.16 & $0.92-1.70$ & Yes & GEL \\
\hline $\mathrm{Pu}-238$ & Air Filter & $\mathrm{Bq} / \mathrm{sa}$ mple & 0.1053 & 0.120 & $0.0737-0.1369$ & Yes & GEL \\
\hline $\mathrm{Pu}-239 / 240$ & Air Filter & $\mathrm{Bq} / \mathrm{sa}$ mple & 0.1141 & 0.116 & $0.0799-0.1483$ & Yes & GEL \\
\hline Sr-90 & Air Filter & $\mathrm{Bq} / \mathrm{sample}$ & 1.548 & 1.48 & $1.084-2.012$ & Yes & GEL \\
\hline U-233/234 & Air Filter & $\mathrm{Bq} / \mathrm{sample}$ & 0.218 & 0.213 & $0.153-0.283$ & Yes & GEL \\
\hline U-238 & Air Filter & $\mathrm{Bq} / \mathrm{sample}$ & 0.225 & 0.191 & $0.158-0.293$ & Yes & GEL \\
\hline \multicolumn{8}{|c|}{ MAPEP - 08 - GrW18 Gross Alpha/Beta Water Standard } \\
\hline Gross Alpha & Water & $\mathrm{Bq} / \mathrm{L}$ & 1.399 & 1.03 & $>0.0-2.798$ & Yes & ELAB \\
\hline Gross Beta & Water & $\mathrm{Bq} / \mathrm{L}$ & 2.43 & 2.50 & $1.22-3.65$ & Yes & ELAB \\
\hline Gross Alpha & Water & $\mathrm{Bq} / \mathrm{L}$ & 1.399 & 2.01 & $>0.0-2.798$ & Yes & GEL \\
\hline Gross Beta & Water & $\mathrm{Bq} / \mathrm{L}$ & 2.43 & 2.21 & $1.22-3.65$ & Yes & GEL \\
\hline \multicolumn{8}{|c|}{ MAPEP - 08 - MaW18 Water Standard - Radiological } \\
\hline Cs-137 & Water & $\mathrm{Bq} / \mathrm{L}$ & c & $<0.0761$ & c & Yes & $E L A B$ \\
\hline Co-60 & Water & $\mathrm{Bq} / \mathrm{L}$ & 8.40 & 8.18 & $5.88-10.92$ & Yes & ELAB \\
\hline $\mathrm{H}-3$ & Water & $\mathrm{Bq} / \mathrm{L}$ & 472 & 480 & $330-614$ & Yes & ELAB \\
\hline Sr-90 & Water & $\mathrm{Bq} / \mathrm{L}$ & 11.40 & 11.1 & $7.98-14.82$ & Yes & ELAB \\
\hline Am-241 & Water & $\mathrm{Bq} / \mathrm{L}$ & 1.23 & 1.27 & $0.86-1.60$ & Yes & GEL \\
\hline Cs-137 & Water & $\mathrm{Bq} / \mathrm{L}$ & $c$ & 0.0648 & $c$ & Yes & GEL \\
\hline Co-60 & Water & $\mathrm{Bq} / \mathrm{L}$ & 8.40 & 8.41 & $5.88-10.92$ & Yes & GEL \\
\hline $\mathrm{H}-3$ & Water & $\mathrm{Bq} / \mathrm{L}$ & 472 & 483 & $330-614$ & Yes & GEL \\
\hline $\mathrm{Pu}-238$ & Water & $\mathrm{Bq} / \mathrm{L}$ & 0.73 & 0.673 & $0.51-0.95$ & Yes & GEL \\
\hline $\mathrm{Pu}-239 / 240$ & Water & $\mathrm{Bq} / \mathrm{L}$ & 0.0141 & 0.0221 & C & Yes & GEL \\
\hline Sr-90 & Water & $\mathrm{Bq} / \mathrm{L}$ & 11.40 & 12.0 & $7.98-14.82$ & Yes & GEL \\
\hline Tc-99 & Water & $\mathrm{Bq} / \mathrm{L}$ & 11.2 & 9.98 & $7.8-14.6$ & Yes & GEL \\
\hline U-233/234 & Water & $\mathrm{Bq} / \mathrm{L}$ & 3.63 & 3.61 & $2.54-4.72$ & Yes & GEL \\
\hline U-238 & Water & $\mathrm{Bq} / \mathrm{L}$ & 3.74 & 3.89 & $2.62-4.86$ & Yes & GEL \\
\hline
\end{tabular}

ELAB - WVDP Environmental Laboratory

GEL - General Engineering Laboratory

Note: This report includes only those matrix/analyte combinations performed in support of the analysis of samples collected at the WVDP and for which results are presented in this Annual Site Environmental Report.

a MAPEP monitors performance and requests corrective action as required.

b "Yes" - Result acceptable; "Pass" - Result acceptable with warning; "No" - Result not acceptable.

c Although no actual value or acceptance range was provided, the results were assessed by MAPEP as acceptable. 
TABLE H-1 (continued)

Crosscheck Sample Comparisons From the DOE Mixed Analyte Performance Evaluation Program (MAPEP) ${ }^{a}$; Study 18, February 2008

\begin{tabular}{|c|c|c|c|c|c|c|c|}
\hline Analyte & Matrix & Units & Actual & Reported & $\begin{array}{c}\text { Acceptance } \\
\text { Range }\end{array}$ & Accept? ${ }^{b}$ & $\begin{array}{c}\text { Analyzed } \\
\text { by: }\end{array}$ \\
\hline \multicolumn{8}{|c|}{ MAPEP - 08- MaW18 Water Standard - Metals } \\
\hline Antimony & Water & $\mathrm{mg} / \mathrm{L}$ & 0.96 & 0.953 & $0.67-1.25$ & Yes & GEL \\
\hline Arsenic & Water & $\mathrm{mg} / \mathrm{L}$ & $<0.01$ & $<0.015$ & & Yes & GEL \\
\hline Barium & Water & $\mathrm{mg} / \mathrm{L}$ & 0.659 & 0.68 & $0.461-0.857$ & Yes & GEL \\
\hline Beryllium & Water & $\mathrm{mg} / \mathrm{L}$ & 0.329 & 0.327 & $0.230-0.428$ & Yes & GEL \\
\hline Cadmium & Water & $\mathrm{mg} / \mathrm{L}$ & 0.439 & 0.439 & $0.307-0.571$ & Yes & GEL \\
\hline Chromium & Water & $\mathrm{mg} / \mathrm{L}$ & 0.494 & 0.509 & $0.346-0.642$ & Yes & GEL \\
\hline Cobalt & Water & $\mathrm{mg} / \mathrm{L}$ & 0.110 & 0.112 & $0.077-0.143$ & Yes & GEL \\
\hline Copper & Water & $\mathrm{mg} / \mathrm{L}$ & 0.0329 & 0.0336 & $0.0230-0.0428$ & Yes & GEL \\
\hline Lead & Water & $\mathrm{mg} / \mathrm{L}$ & 0.549 & 0.540 & $0.384-0.714$ & Yes & GEL \\
\hline Mercury & Water & $\mathrm{mg} / \mathrm{L}$ & $<0.002$ & 0.000984 & c & Yes & GEL \\
\hline Nickel & Water & $\mathrm{mg} / \mathrm{L}$ & 0.99 & 1.00 & $0.69-1.29$ & Yes & GEL \\
\hline Selenium & Water & $\mathrm{mg} / \mathrm{L}$ & 0.0823 & 0.0802 & $0.0576-0.1070$ & Yes & GEL \\
\hline Thallium & Water & $\mathrm{mg} / \mathrm{L}$ & 0.96 & 0.941 & $0.67-1.25$ & Yes & GEL \\
\hline Uranium - total & Water & $\mathrm{mg} / \mathrm{L}$ & 0.303 & 0.310 & $0.212-0.394$ & Yes & GEL \\
\hline Vanadium & Water & $\mathrm{mg} / \mathrm{L}$ & $<0.01$ & $<0.005$ & $c$ & Yes & GEL \\
\hline Zinc & Water & $\mathrm{mg} / \mathrm{L}$ & $<0.01$ & $<0.010$ & c & Yes & GEL \\
\hline \multicolumn{8}{|c|}{ MAPEP - 08 - MaS18 Soil Standard - Metals } \\
\hline Antimony & Soil & $\mathrm{mg} / \mathrm{kg}$ & 23.5 & 20.1 & $16.5-30.6$ & Yes & GEL \\
\hline Arsenic & Soil & $\mathrm{mg} / \mathrm{kg}$ & 20.2 & 18.8 & $14.1-26.3$ & Yes & GEL \\
\hline Barium & Soil & $\mathrm{mg} / \mathrm{kg}$ & 244 & 217 & $171-317$ & Yes & GEL \\
\hline Beryllium & Soil & $\mathrm{mg} / \mathrm{kg}$ & 13.8 & 13.7 & 9.7-17.9 & Yes & GEL \\
\hline Cadmium & Soil & $\mathrm{mg} / \mathrm{kg}$ & 9.49 & 8.29 & $6.64-12.34$ & Yes & GEL \\
\hline Chromium & Soil & $\mathrm{mg} / \mathrm{kg}$ & 70.7 & 62.9 & $49.5-91.9$ & Yes & GEL \\
\hline Cobalt & Soil & $\mathrm{mg} / \mathrm{kg}$ & 41.5 & 38.8 & $29.1-54.0$ & Yes & GEL \\
\hline Copper & Soil & $\mathrm{mg} / \mathrm{kg}$ & 87.0 & 90.5 & 60.9-113.1 & Yes & GEL \\
\hline Lead & Soil & $\mathrm{mg} / \mathrm{kg}$ & 79 & 74.4 & 55-103 & Yes & GEL \\
\hline Mercury & Soil & $\mathrm{mg} / \mathrm{kg}$ & $<0.04$ & 0.0172 & $c$ & Yes & GEL \\
\hline Nickel & Soil & $\mathrm{mg} / \mathrm{kg}$ & 145 & 130 & 102-189 & Yes & GEL \\
\hline Selenium & Soil & $\mathrm{mg} / \mathrm{kg}$ & 4.44 & 8.88 & $3.11-5.77$ & No & GEL \\
\hline Silver & Soil & $\mathrm{mg} / \mathrm{kg}$ & 92.4 & 93.9 & $64.7-120.1$ & Yes & GEL \\
\hline Thallium & Soil & $\mathrm{mg} / \mathrm{kg}$ & $<1.0$ & $<0.486$ & $\bar{c}$ & Yes & GEL \\
\hline Uranium - total & Soil & $\mathrm{mg} / \mathrm{kg}$ & 12.0 & 9.73 & 8.4-15.6 & Yes & GEL \\
\hline Vanadium & Soil & $\mathrm{mg} / \mathrm{kg}$ & 161 & 153 & 113-209 & Yes & GEL \\
\hline Zinc & Soil & $\mathrm{mg} / \mathrm{kg}$ & 319 & 282 & $223-415$ & Yes & GEL \\
\hline
\end{tabular}

GEL - General Engineering Laboratory

Note: This report includes only those matrix/analyte combinations performed in support of the analysis of samples collected at the WVDP and for which results are presented in this Annual Site Environmental Report.

a MAPEP monitors performance and requests corrective action as required.

b "Yes" - Result acceptable; "Pass" - Result acceptable with warning; "No" - Result not acceptable.

c Although no actual value or acceptable range was provided, the results were assessed by MAPEP as acceptable. 
TABLE H-1 (continued)

Crosscheck Sample Comparisons From the DOE Mixed Analyte Performance Evaluation Program (MAPEP) ${ }^{a}$; Study 18, February 2008

\begin{tabular}{|c|c|c|c|c|c|c|c|}
\hline Analyte & Matrix & Units & Actual & Reported & $\begin{array}{c}\text { Acceptance } \\
\text { Range }\end{array}$ & Accept $?^{b}$ & $\begin{array}{c}\text { Analyzed } \\
\text { by: }\end{array}$ \\
\hline \multicolumn{8}{|c|}{ MAPEP - 08 - MaS18 Soil Standard - Radiological } \\
\hline Am-241 & Soil & $\mathrm{Bq} / \mathrm{kg}$ & 127.2 & 121 & $89.0-165.4$ & Yes & GEL \\
\hline Cs-137 & Soil & $\mathrm{Bq} / \mathrm{kg}$ & 545 & 522 & $382-709$ & Yes & GEL \\
\hline Co-60 & Soil & $\mathrm{Bq} / \mathrm{kg}$ & 2.9 & 2.67 & & Yes & GEL \\
\hline $\mathrm{Pu}-238$ & Soil & $\mathrm{Bq} / \mathrm{kg}$ & 72.8 & 73.6 & $51.0-94.6$ & Yes & GEL \\
\hline $\mathrm{Pu}-239 / 240$ & Soil & $\mathrm{Bq} / \mathrm{kg}$ & 90.1 & 84.4 & $63.1-117.1$ & Yes & GEL \\
\hline $\mathrm{K}-40$ & Soil & $\mathrm{Bq} / \mathrm{kg}$ & 571 & 586 & $400-742$ & Yes & GEL \\
\hline Sr-90 & Soil & $\mathrm{Bq} / \mathrm{kg}$ & 493 & 473 & $345-641$ & Yes & GEL \\
\hline Tc-99 & Soil & $\mathrm{Bq} / \mathrm{kg}$ & 273 & 212 & 191-355 & Pass & GEL \\
\hline U-233/234 & Soil & $\mathrm{Bq} / \mathrm{kg}$ & 142 & 138 & 99-185 & Yes & GEL \\
\hline U-238 & Soil & $\mathrm{Bq} / \mathrm{kg}$ & 148 & 149 & 104-192 & Yes & GEL \\
\hline \multicolumn{8}{|c|}{ MAPEP - 08 - RdV18 Vegetation Standard - Radiological } \\
\hline Am-241 & Veg & Bq/sample & 0.240 & 0.121 & $0.168-0.312$ & No & GEL \\
\hline Cs-137 & Veg & $\mathrm{Bq} /$ sample & 3.41 & 2.49 & $2.39-4.43$ & Pass & GEL \\
\hline Co-60 & Veg & Bq/sample & 2.77 & 2.87 & $1.94-3.60$ & Yes & GEL \\
\hline $\mathrm{Pu}-238$ & Veg & Bq/sample & 0.147 & 0.114 & $0.103-0.191$ & Pass & GEL \\
\hline $\mathrm{Pu}-239 / 240$ & Veg & $\mathrm{Bq} /$ sample & 0.284 & 0.232 & $0.199-0.369$ & Yes & GEL \\
\hline Sr-90 & Veg & $\mathrm{Bq} / \mathrm{sample}$ & 1.273 & 1.11 & $0.891-1.655$ & Yes & GEL \\
\hline U-233/234 & Veg & $\mathrm{Bq} /$ sample & 0.346 & 0.356 & $0.242-0.450$ & Yes & GEL \\
\hline U-238 & Veg & Bq/sample & 0.359 & 0.463 & $0.251-0.467$ & Pass & GEL \\
\hline \multicolumn{8}{|c|}{ MAPEP - 08 - OrW18 Water Standard - Semivolatile Organic Compounds } \\
\hline Phenol & Water & $\mu \mathrm{g} / \mathrm{L}$ & & $<10.0$ & & Yes & GEL \\
\hline 2-Chlorophenol & Water & $\mu \mathrm{g} / \mathrm{L}$ & 118.3 & 109 & $43.6-193.1$ & Yes & GEL \\
\hline 1,3-Dichlorobenzene & Water & $\mu \mathrm{g} / \mathrm{L}$ & 83.8 & 75.1 & $15.8-151.7$ & Yes & $\overline{\mathrm{GEL}}$ \\
\hline 1,4-Dichlorobenzene & Water & $\mu \mathrm{g} / \mathrm{L}$ & & $<10.0$ & & Yes & GEL \\
\hline 1,2-Dichlorobenzene & Water & $\mu \mathrm{g} / \mathrm{L}$ & 39.7 & 35.9 & $6.1-73.2$ & Yes & GEL \\
\hline Hexachloroethane & Water & $\mu \mathrm{g} / \mathrm{L}$ & ${ }^{c}$ & $<10.0$ & ${ }^{c}$ & Yes & GEL \\
\hline Nitrobenzene & Water & $\mu \mathrm{g} / \mathrm{L}$ & & $<10.0$ & & Yes & GEL \\
\hline Isophorone & Water & $\mu \mathrm{g} / \mathrm{L}$ & & $<10.0$ & & Yes & GEL \\
\hline 2-Nitrophenol & Water & $\mu \mathrm{g} / \mathrm{L}$ & ${ }^{c}$ & $<10.0$ & c & Yes & GEL \\
\hline 2,4-Dimethylphenol & Water & $\mu \mathrm{g} / \mathrm{L}$ & 57.0 & 56.4 & $14.7-99.2$ & Yes & GEL \\
\hline 2,4-Dichlorophenol & Water & $\mu \mathrm{g} / \mathrm{L}$ & 60.5 & 60.6 & $24.0-97.1$ & Yes & GEL \\
\hline 1,2,4-Trichlorobenzene & Water & $\mu \mathrm{g} / \mathrm{L}$ & & $<10.0$ & & Yes & GEL \\
\hline Napthalene & Water & $\mu \mathrm{g} / \mathrm{L}$ & 103.3 & 91.7 & $37.1-169.6$ & Yes & $\overline{\mathrm{GEL}}$ \\
\hline Hexachlorobutadiene & Water & $\mu \mathrm{g} / \mathrm{L}$ & 51.7 & 43.6 & $8.2-95.2$ & Yes & GEL \\
\hline 4-Chloro-3-methylphenol & Water & $\mu \mathrm{g} / \mathrm{L}$ & & $<10.0$ & & Yes & $\overline{G E L}$ \\
\hline 2-Methylnaphthalene & Water & $\mu \mathrm{g} / \mathrm{L}$ & 57.1 & 62.8 & $15.7-98.5$ & Yes & GEL \\
\hline
\end{tabular}

GEL - General Engineering Laboratory

Note: This report includes only those matrix/analyte combinations performed in support of the analysis of samples collected at the WVDP and for which results are presented in this Annual Site Environmental Report.

a MAPEP monitors performance and requests corrective action as required.

b "Yes" - Result acceptable; "Pass" - Result acceptable with warning; "No" - Result not acceptable.

c Although no actual value or acceptable range was provided, the results were assessed by MAPEP as acceptable. 
TABLE H-1 (concluded)

Crosscheck Sample Comparisons From the DOE Mixed Analyte Performance Evaluation Program (MAPEP) ${ }^{a}$; Study 18, February 2008

\begin{tabular}{|c|c|c|c|c|c|c|c|}
\hline Analyte & Matrix & Units & Actual & Reported & $\begin{array}{c}\text { Acceptance } \\
\text { Range }\end{array}$ & Accept ${ }^{b}$ & $\begin{array}{c}\text { Analyzed } \\
\text { by: }\end{array}$ \\
\hline \multicolumn{8}{|c|}{ MAPEP - 08 - OrW18 Water Standard - Semivolatile Organic Compounds (concluded) } \\
\hline 2-Methylphenol & Water & $\mu g / L$ & 63.8 & 60.9 & $16.8-110.7$ & Yes & $\overline{G E L}$ \\
\hline Hexachlorocyclopentadiene & Water & $\mu g / L$ & & $<10.0$ & & Yes & GEL \\
\hline 3 Methyl and 4-Methylphenol & Water & $\mu \mathrm{g} / \mathrm{L}$ & & $<10.0$ & & Yes & GEL \\
\hline 2,4,6-Trichlorophenol & Water & $\mu \mathrm{g} / \mathrm{L}$ & & $<10.0$ & & Yes & $\overline{\text { GEL }}$ \\
\hline 2-Chloronaphthalene & Water & $\mu \mathrm{g} / \mathrm{L}$ & 91.5 & 78.2 & $37.1-145.9$ & Yes & $\overline{\text { GEL }}$ \\
\hline Dimethylphthalate & Water & $\mu g / L$ & 102.1 & 112 & $15.4-221.2$ & Yes & GEL \\
\hline Acenaphthylene & Water & $\mu \mathrm{g} / \mathrm{L}$ & & $<1.0$ & & Yes & GEL \\
\hline 2,6-Dinitrotoluene & Water & $\mu g / L$ & 139.5 & 117 & $70.3-208.7$ & Yes & GEL \\
\hline Acenaphthene & Water & $\mu g / L$ & 29.3 & 24.7 & $15.1-43.4$ & Yes & GEL \\
\hline 2,4-Dinitrotoluene & Water & $\mu \mathrm{g} / \mathrm{L}$ & 45.0 & 41.0 & $19.2-70.8$ & Yes & $\overline{\text { GEL }}$ \\
\hline 2,4-Dinitrophenol & Water & $\mu \mathrm{g} / \mathrm{L}$ & & $<20.0$ & & Yes & $\overline{G E L}$ \\
\hline Dibenzofuran & Water & $\mu g / L$ & c & $<10.0$ & 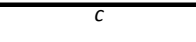 & Yes & $\overline{G E L}$ \\
\hline 4-Nitrophenol & Water & $\mu g / L$ & 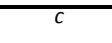 & $<10.0$ & $c$ & Yes & $\overline{G E L}$ \\
\hline Fluorene & Water & $\mu g / L$ & 35.2 & 32.0 & $16.0-54.3$ & Yes & $\overline{\text { GEL }}$ \\
\hline Diethylphthalate & Water & $\mu g / L$ & 61.1 & 61.2 & $13.3-108.8$ & Yes & $\overline{G E L}$ \\
\hline 4,6-Dinitro-2-methylphenol & Water & $\mu \mathrm{g} / \mathrm{L}$ & & $<10.0$ & & Yes & $\overline{\text { GEL }}$ \\
\hline 2,4,5-Trichlorophenol & Water & $\mu g / L$ & 88.5 & 81.7 & $38.5-138.6$ & Yes & $\overline{\text { GEL }}$ \\
\hline Hexachlorobenzene & Water & $\mu g / L$ & 48.8 & 11.1 & $24.7-73.0$ & No & GEL \\
\hline Pentachlorophenol & Water & $\mu \mathrm{g} / \mathrm{L}$ & & $<10.0$ & & Yes & GEL \\
\hline Phenanthrene & Water & $\mu g / L$ & 41.9 & 34.7 & $23.4-60.4$ & Yes & $\overline{\text { GEL }}$ \\
\hline Anthracene & Water & $\mu g / L$ & 33.5 & 24.4 & $16.9-50.2$ & Yes & GEL \\
\hline Di-n-butylphthalate & Water & $\mu \mathrm{g} / \mathrm{L}$ & 68.8 & 58.7 & $27.5-110.1$ & Yes & $\overline{\text { GEL }}$ \\
\hline Fluoranthene & Water & $\mu g / L$ & & $<1.0$ & & Yes & $\overline{\text { GEL }}$ \\
\hline Pyrene & Water & $\mu g / L$ & 46.9 & 18.4 & $17.7-76.2$ & Yes & $\overline{G E L}$ \\
\hline Butylbenzylphthalate & Water & $\mu g / L$ & & $<10.0$ & & Yes & $\overline{\text { GEL }}$ \\
\hline Benzo(a)anthracene & Water & $\mu g / L$ & 47.4 & $<1.0$ & $24.7-70.1$ & No & GEL \\
\hline Chrysene & Water & $\mu \mathrm{g} / \mathrm{L}$ & & 28.6 & & No & $\overline{G E L}$ \\
\hline Bis(2-ethylhexyl)phthalate & Water & $\mu g / L$ & 50.9 & 39.8 & $17.8-84.0$ & Yes & $\overline{\text { GEL }}$ \\
\hline Di-n-octylphthalate & Water & $\mu g / L$ & 54.4 & 34.4 & $16.8-92.0$ & Yes & $\overline{\text { GEL }}$ \\
\hline Benzo(b)fluoranthene & Water & $\mu \mathrm{g} / \mathrm{L}$ & 90.2 & 42.0 & $40.3-140.0$ & Yes & GEL \\
\hline Benzo(k)fluoranthene & Water & $\mu \mathrm{g} / \mathrm{L}$ & & $<1.0$ & & Yes & $\overline{G E L}$ \\
\hline Benzo(a)pyrene & Water & $\mu g / L$ & 85.2 & 45.1 & $32.5-138.0$ & Yes & GEL \\
\hline Indeno(1,2,3-c,d)pyrene & Water & $\mu \mathrm{g} / \mathrm{L}$ & & $<1.0$ & & Yes & $\overline{\text { GEL }}$ \\
\hline Dibenzo(a,h)anthracene & Water & $\mu \mathrm{g} / \mathrm{L}$ & & $<1.0$ & & Yes & $\overline{\text { GEL }}$ \\
\hline Benzo(g,h,i)perylene & Water & $\mu g / L$ & 125.1 & 92.2 & $58.7-191.5$ & Yes & GEL \\
\hline
\end{tabular}

GEL - General Engineering Laboratory

Note: This report includes only those matrix/analyte combinations performed in support of the analysis of samples collected at the WVDP and for which results are presented in this Annual Site Environmental Report.

${ }^{a}$ MAPEP monitors performance and requests corrective action as required.

$b$ "Yes" - Result acceptable; "Pass" - Result acceptable with warning; "No" - Result not acceptable.

c Although no actual value or acceptable range was provided, the results were assessed by MAPEP as acceptable. 
TABLE H-2

Crosscheck Sample Comparisons From the DOE Mixed Analyte Performance Evaluation Program (MAPEP) ${ }^{a}$; Study 19, June 2008

\begin{tabular}{|c|c|c|c|c|c|c|c|}
\hline Analyte & Matrix & Units & Actual & Reported & $\begin{array}{c}\text { Acceptance } \\
\text { Range }\end{array}$ & Accept? ${ }^{b}$ & $\begin{array}{c}\text { Analyzed } \\
\text { by: }\end{array}$ \\
\hline \multicolumn{8}{|c|}{ MAPEP - 08 - GrF19 Gross Alpha/Beta Air Filter } \\
\hline Gross Alpha & Air Filter & Bq/sample & ${ }^{c}$ & 0.00159 & $c$ & Yes & ELAB \\
\hline Gross Beta & Air Filter & Bq/sample & 0.525 & 0.515 & $0.263-0.788$ & Yes & ELAB \\
\hline \multicolumn{8}{|c|}{ MAPEP - 08 - RdF19 Radiological Air Filter } \\
\hline Am-241 & Air Filter & Bq/sample & $\bar{c}$ & $<0.002$ & c & Yes & GEL \\
\hline Cs-137 & Air Filter & Bq/sample & $\bar{c}$ & 0.024 & C & Yes & GEL \\
\hline Co-60 & Air Filter & Bq/sample & c & 0.051 & c & Yes & GEL \\
\hline Pu-238 & Air Filter & Bq/sample & 0.118 & 0.119 & $0.083-0.153$ & Yes & GEL \\
\hline Pu-239/240 & Air Filter & Bq/sample & 0.152 & 0.158 & $0.106-0.198$ & Yes & GEL \\
\hline Sr-90 & Air Filter & Bq/sample & 1.12 & 1.080 & $0.78-1.46$ & Yes & GEL \\
\hline U-233/234 & Air Filter & Bq/sample & 0.262 & 0.278 & $0.183-0.341$ & Yes & GEL \\
\hline $\mathrm{U}-238$ & Air Filter & Bq/sample & 0.272 & 0.285 & $0.190-0.354$ & Yes & GEL \\
\hline \multicolumn{8}{|c|}{ MAPEP - 08 - GrW19 Gross Alpha/Beta Water Standard } \\
\hline Gross Alpha & Water & $\mathrm{Bq} / \mathrm{L}$ & $<0.56$ & 0.0796 & 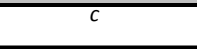 & Yes & ELAB \\
\hline Gross Beta & Water & $\mathrm{Bq} / \mathrm{L}$ & $<1.85$ & 0.116 & c & Yes & ELAB \\
\hline Gross Alpha & Water & $\mathrm{Bq} / \mathrm{L}$ & $<0.56$ & 0.158 & $c$ & Yes & GEL \\
\hline Gross Beta & Water & $\mathrm{Bq} / \mathrm{L}$ & $<1.85$ & 0.260 & c & Yes & GEL \\
\hline \multicolumn{8}{|c|}{ MAPEP - 08 - MaW19 Water Standard - Radiological } \\
\hline Cs-137 & Water & $\mathrm{Bq} / \mathrm{L}$ & 23.6 & 23.4 & $16.5-30.7$ & Yes & ELAB \\
\hline Co-60 & Water & $\mathrm{Bq} / \mathrm{L}$ & 11.6 & 11.2 & $8.1-15.1$ & Yes & ELAB \\
\hline $\mathrm{H}-3$ & Water & $\mathrm{Bq} / \mathrm{L}$ & 341 & 361 & 239-443 & Yes & ELAB \\
\hline Sr-90 & Water & $\mathrm{Bq} / \mathrm{L}$ & 6.45 & 6.31 & $4.52-8.39$ & Yes & ELAB \\
\hline Am-241 & Water & $\mathrm{Bq} / \mathrm{L}$ & & $<0.002$ & $c$ & Yes & GEL \\
\hline Cs-137 & Water & $\mathrm{Bq} / \mathrm{L}$ & 23.6 & 23.0 & $16.5-30.7$ & Yes & GEL \\
\hline Co-60 & Water & $\mathrm{Bq} / \mathrm{L}$ & 11.6 & 11.4 & $8.1-15.1$ & Yes & GEL \\
\hline $\mathrm{H}-3$ & Water & $\mathrm{Bq} / \mathrm{L}$ & 341 & 343.3 & 239-443 & Yes & GEL \\
\hline Pu-238 & Water & $\mathrm{Bq} / \mathrm{L}$ & 0.5 & 0.427 & $0.4-0.7$ & Yes & GEL \\
\hline Pu-239/240 & Water & $\mathrm{Bq} / \mathrm{L}$ & $c$ & 0.012 & & Yes & GEL \\
\hline Sr-90 & Water & $\mathrm{Bq} / \mathrm{L}$ & 6.45 & 6.40 & $4.52-8.39$ & Yes & GEL \\
\hline Tc-99 & Water & $\mathrm{Bq} / \mathrm{L}$ & 3.76 & 4.7 & $2.63-4.89$ & Pass & GEL \\
\hline U-233/234 & Water & $\mathrm{Bq} / \mathrm{L}$ & 3.44 & 3.220 & $2.41-4.47$ & Yes & GEL \\
\hline $\mathrm{U}-238$ & Water & $\mathrm{Bq} / \mathrm{L}$ & 3.55 & 3.343 & $2.49-4.62$ & Yes & GEL \\
\hline
\end{tabular}

ELAB - WVDP Environmental Laboratory

GEL - General Engineering Laboratory

Note: This report includes only those matrix/analyte combinations performed in support of the analysis of samples collected at the WVDP and for which results are presented in this Annual Site Environmental Report.

a MAPEP monitors performance and requests corrective action as required.

b "Yes" - Result acceptable; "Pass" - Result acceptable with warning; "No" - Result not acceptable.

c Although no actual value or acceptable range was provided, the results were assessed by MAPEP as acceptable. 
TABLE H-2 (continued)

Crosscheck Sample Comparisons From the DOE Mixed Analyte Performance Evaluation Program (MAPEP) ${ }^{a}$; Study 19, June 2008

\begin{tabular}{|c|c|c|c|c|c|c|c|}
\hline Analyte & Matrix & Units & Actual & Reported & Acceptance Range & Accept? ${ }^{b}$ & $\begin{array}{c}\text { Analyzed } \\
\text { by: }\end{array}$ \\
\hline \multicolumn{8}{|c|}{ MAPEP - 08-MaW19 Water Standard - Metals } \\
\hline Antimony & Water & $\mathrm{mg} / \mathrm{L}$ & 1.044 & 1.05 & $0.731-1.357$ & Yes & GEL \\
\hline Arsenic & Water & $\mathrm{mg} / \mathrm{L}$ & 3.692 & 3.54 & $2.584-4.800$ & Yes & GEL \\
\hline Barium & Water & $\mathrm{mg} / \mathrm{L}$ & 1.79 & 1.76 & $1.25-2.33$ & Yes & GEL \\
\hline Beryllium & Water & $\mathrm{mg} / \mathrm{L}$ & $<0.005$ & $<0.005$ & $f$ & Yes & GEL \\
\hline Cadmium & Water & $\mathrm{mg} / \mathrm{L}$ & 0.78 & 0.737 & $0.55-1.01$ & Yes & GEL \\
\hline Chromium & Water & $\mathrm{mg} / \mathrm{L}$ & 1.277 & 1.28 & $0.894-1.660$ & Yes & GEL \\
\hline Cobalt & Water & $\mathrm{mg} / \mathrm{L}$ & 2.672 & 2.62 & $1.870-3.474$ & Yes & GEL \\
\hline Copper & Water & $\mathrm{mg} / \mathrm{L}$ & 3.671 & 3.62 & $2.570-4.772$ & Yes & GEL \\
\hline Lead & Water & $\mathrm{mg} / \mathrm{L}$ & $<0.01$ & $<0.010$ & $c$ & Yes & GEL \\
\hline Mercury & Water & $\mathrm{mg} / \mathrm{L}$ & 0.01885 & 0.0195 & $0.01320-0.02451$ & Yes & GEL \\
\hline Nickel & Water & $\mathrm{mg} / \mathrm{L}$ & 2.499 & 2.40 & $1.749-3.249$ & Yes & GEL \\
\hline Thallium & Water & $\mathrm{mg} / \mathrm{L}$ & 2.637 & 2.62 & $1.846-3.428$ & Yes & GEL \\
\hline Uranium - total & Water & $\mathrm{mg} / \mathrm{L}$ & 0.287 & 0.322 & $0.201-0.373$ & Yes & GEL \\
\hline Vanadium & Water & $\mathrm{mg} / \mathrm{L}$ & 2.254 & 2.33 & $1.578-2.930$ & Yes & GEL \\
\hline Zinc & Water & $\mathrm{mg} / \mathrm{L}$ & 2.549 & 2.33 & $1.784-3.314$ & Yes & GEL \\
\hline \multicolumn{8}{|c|}{ MAPEP - 08 - MaS19 Soil Standard - Metals } \\
\hline Antimony & Soil & $\mathrm{mg} / \mathrm{kg}$ & 69.49 & 58.3 & $48.64-90.34$ & Yes & GEL \\
\hline Arsenic & Soil & $\mathrm{mg} / \mathrm{kg}$ & 79.93 & 81.5 & 55.95-103.91 & Yes & GEL \\
\hline Barium & Soil & $\mathrm{mg} / \mathrm{kg}$ & 248 & 201 & $174-322$ & Yes & GEL \\
\hline Beryllium & Soil & $\mathrm{mg} / \mathrm{kg}$ & 36.61 & 32.4 & $25.63-47.59$ & Yes & GEL \\
\hline Cadmium & Soil & $\mathrm{mg} / \mathrm{kg}$ & 12.02 & 10.2 & $8.41-15.63$ & Yes & GEL \\
\hline Chromium & Soil & $\mathrm{mg} / \mathrm{kg}$ & 81.23 & 66.0 & $56.86-105.60$ & Yes & GEL \\
\hline Cobalt & Soil & $\mathrm{mg} / \mathrm{kg}$ & 88.57 & 74.3 & $62.00-115.14$ & Yes & GEL \\
\hline Copper & Soil & $\mathrm{mg} / \mathrm{kg}$ & 79.02 & 77.5 & $55.31-102.73$ & Yes & GEL \\
\hline Lead & Soil & $\mathrm{mg} / \mathrm{kg}$ & 60.15 & 54.0 & $42.11-78.20$ & Yes & GEL \\
\hline Mercury & Soil & $\mathrm{mg} / \mathrm{kg}$ & 0.0167 & 0.0239 & $0.0117-0.0217$ & No & GEL \\
\hline Nickel & Soil & $\mathrm{mg} / \mathrm{kg}$ & 124.49 & 97.8 & $87.14-161.84$ & Pass & GEL \\
\hline Selenium & Soil & $\mathrm{mg} / \mathrm{kg}$ & 12.99 & 10.9 & $9.09-16.89$ & Yes & GEL \\
\hline Silver & Soil & $\mathrm{mg} / \mathrm{kg}$ & 61.6 & 56.9 & $43.1-80.1$ & Yes & GEL \\
\hline Thallium & Soil & $\mathrm{mg} / \mathrm{kg}$ & 89.71 & 72.0 & $62.80-116.62$ & Yes & GEL \\
\hline Uranium - total & Soil & $\mathrm{mg} / \mathrm{kg}$ & 24.5 & 21.4 & $17.2-31.9$ & Yes & GEL \\
\hline Vanadium & Soil & $\mathrm{mg} / \mathrm{kg}$ & 35.8 & 31.8 & $25.1-46.5$ & Yes & GEL \\
\hline Zinc & Soil & $\mathrm{mg} / \mathrm{kg}$ & 242.35 & 195 & $169.65-315.06$ & Yes & GEL \\
\hline
\end{tabular}

GEL - General Engineering Laboratory

Note: This report includes only those matrix/analyte combinations performed in support of the analysis of samples collected at the WVDP and for which results are presented in this Annual Site Environmental Report.

a MAPEP monitors performance and requests corrective action as required.

b "Yes" - Result acceptable; "Pass" - Result acceptable with warning; "No" - Result not acceptable.

c Although no actual value or acceptable range was provided, the results were assessed by MAPEP as acceptable. 
TABLE H-2 (continued)

Crosscheck Sample Comparisons From the DOE Mixed Analyte Performance Evaluation Program (MAPEP) ; Study 19, June 2008

\begin{tabular}{|c|c|c|c|c|c|c|c|}
\hline Analyte & Matrix & Units & Actual & Reported & $\begin{array}{c}\text { Acceptance } \\
\text { Range }\end{array}$ & Accept? $^{b}$ & $\begin{array}{c}\text { Analyzed } \\
\text { by: }\end{array}$ \\
\hline \multicolumn{8}{|c|}{ MAPEP - 09 - MaS19 Soil Standard - Radiological } \\
\hline Am-241 & Soil & $\mathrm{Bq} / \mathrm{kg}$ & 69.1 & 65.77 & $48.40-89.8$ & Yes & GEL \\
\hline Cs-137 & Soil & $\mathrm{Bq} / \mathrm{kg}$ & 2.8 & 3.5 & $\bar{c}$ & Yes & GEL \\
\hline Co-60 & Soil & $\mathrm{Bq} / \mathrm{kg}$ & 145 & 149.0 & $102-189$ & Yes & GEL \\
\hline $\mathrm{Pu}-238$ & Soil & $\mathrm{Bq} / \mathrm{kg}$ & c & 0.74 & c & Yes & GEL \\
\hline $\mathrm{Pu}-239 / 240$ & Soil & $\mathrm{Bq} / \mathrm{kg}$ & 55.6 & 51.07 & $38.9-72.3$ & Yes & GEL \\
\hline K-40 & Soil & $\mathrm{Bq} / \mathrm{kg}$ & 570 & 628 & 399-741 & Yes & GEL \\
\hline Sr-90 & Soil & $\mathrm{Bq} / \mathrm{kg}$ & 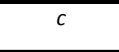 & 0.5 & $c$ & Yes & GEL \\
\hline Tc-99 & Soil & $\mathrm{Bq} / \mathrm{kg}$ & 335 & 302.7 & $235-436$ & Yes & GEL \\
\hline U-233/234 & Soil & $\mathrm{Bq} / \mathrm{kg}$ & 292 & 296 & $204-380$ & Yes & GEL \\
\hline$U-238$ & Soil & $\mathrm{Bq} / \mathrm{kg}$ & 303 & 309 & $212-394$ & Yes & GEL \\
\hline \multicolumn{8}{|c|}{ MAPEP - 08 - RdV19 Vegetation Standard - Radiological } \\
\hline Am-241 & Veg & Bq/sample & 0.286 & 0.257 & $0.200-0.372$ & Yes & GEL \\
\hline Cs-137 & Veg & Bq/sample & $\bar{c}$ & 0.073 & $\bar{c}$ & Yes & GEL \\
\hline Co-60 & Veg & Bq/sample & 4.7 & 4.703 & $3.3-6.1$ & Yes & GEL \\
\hline Pu-238 & Veg & Bq/sample & $\bar{c}$ & 0.002 & c & Yes & GEL \\
\hline Pu-239/240 & Veg & Bq/sample & 0.209 & 0.190 & $0.146-0.272$ & Yes & GEL \\
\hline Sr-90 & Veg & Bq/sample & 1.9 & 1.713 & $1.3-2.5$ & Yes & GEL \\
\hline U-233/234 & Veg & Bq/sample & 0.339 & 0.332 & $0.237-0.441$ & Yes & GEL \\
\hline$U-238$ & Veg & Bq/sample & 0.351 & 0.326 & $0.246-0.456$ & Yes & GEL \\
\hline \multicolumn{8}{|c|}{ MAPEP - 08 - OrW19 Water Standard - Semivolatile Organic Compounds } \\
\hline Phenol & Water & $\mu g / L$ & 88 & 47.1 & $9-210$ & Yes & GEL \\
\hline 2-Chlorophenol & Water & $\mu \mathrm{g} / \mathrm{L}$ & 149 & 146 & $54-244$ & Yes & GEL \\
\hline 1,3-Dichlorobenzene & Water & $\mu \mathrm{g} / \mathrm{L}$ & 32.7 & 29.5 & $6.6-58.8$ & Yes & GEL \\
\hline 1,4-Dichlorobenzene & Water & $\mu g / L$ & ${ }^{c}$ & $<9.52$ & $c^{c}$ & Yes & GEL \\
\hline 1,2-Dichlorobenzene & Water & $\mu g / L$ & $\bar{c}$ & $<9.52$ & $\bar{c}$ & Yes & GEL \\
\hline Hexachloroethane & Water & $\mu g / L$ & 82 & 72.2 & $13-150$ & Yes & GEL \\
\hline Nitrobenzene & Water & $\mu \mathrm{g} / \mathrm{L}$ & 140 & 155 & $57-222$ & Yes & GEL \\
\hline Isophorone & Water & $\mu \mathrm{g} / \mathrm{L}$ & $c^{c}$ & $<9.52$ & $c$ & Yes & GEL \\
\hline 2-Nitrophenol & Water & $\mu \mathrm{g} / \mathrm{L}$ & $\bar{c}$ & $<9.52$ & $\bar{c}$ & Yes & GEL \\
\hline 2,4-Dimethylphenol & Water & $\mu \mathrm{g} / \mathrm{L}$ & $\bar{c}$ & $<9.52$ & $\bar{c}$ & Yes & GEL \\
\hline 2,4-Dichlorophenol & Water & $\mu g / L$ & $\bar{c}$ & $<9.52$ & $\bar{c}$ & Yes & GEL \\
\hline 1,2,4-Trichlorobenzene & Water & $\mu g / L$ & 35.6 & 33.1 & $9.4-61.7$ & Yes & GEL \\
\hline Napthalene & Water & $\mu \mathrm{g} / \mathrm{L}$ & ${ }^{c}$ & $<0.952$ & $c$ & Yes & GEL \\
\hline Hexachlorobutadiene & Water & $\mu g / L$ & $\bar{c}$ & $<9.52$ & $\bar{c}$ & Yes & GEL \\
\hline 4-Chloro-3-methylphenol & Water & $\mu \mathrm{g} / \mathrm{L}$ & $\bar{c}$ & $<9.52$ & ${ }^{c}$ & Yes & GEL \\
\hline 2-Methylnaphthalene & Water & $\mu \mathrm{g} / \mathrm{L}$ & 94 & 101 & $29-159$ & Yes & GEL \\
\hline
\end{tabular}

GEL - General Engineering Laboratory

Note: This report includes only those matrix/analyte combinations performed in support of the analysis of samples collected at the WVDP and for which results are presented in this Annual Site Environmental Report.

a MAPEP monitors performance and requests corrective action as required.

b "Yes" - Result acceptable; "Pass" - Result acceptable with warning; "No" - Result not acceptable.

c Although no actual value or acceptable range was provided, the results were assessed by MAPEP as acceptable. 
TABLE H-2 (concluded)

Crosscheck Sample Comparisons From the DOE Mixed Analyte Performance Evaluation Program (MAPEP) ${ }^{a}$; Study 19, June 2008

\begin{tabular}{|c|c|c|c|c|c|c|c|}
\hline Analyte & Matrix & Units & Actual & Reported & $\begin{array}{c}\text { Acceptance } \\
\text { Range }\end{array}$ & Accept? ${ }^{b}$ & $\begin{array}{c}\text { Analyzed } \\
\text { by: }\end{array}$ \\
\hline \multicolumn{8}{|c|}{ MAPEP - 08 - OrW19 Water Standard - Semivolatile Organic Compounds (concluded) } \\
\hline 2-Methylphenol & Water & $\mu \mathrm{g} / \mathrm{L}$ & $\bar{c}$ & $<9.52$ & $\bar{c}$ & Yes & GEL \\
\hline Hexachlorocyclopentadiene & Water & $\mu \mathrm{g} / \mathrm{L}$ & $c^{c}$ & $<9.52$ & ${ }^{c}$ & Yes & GEL \\
\hline 3 Methyl and 4-Methylphenol & Water & $\mu g / L$ & $c^{c}$ & $<9.52$ & $\bar{c}$ & Yes & GEL \\
\hline 2,4,6-Trichlorophenol & Water & $\mu g / L$ & $\bar{c}$ & $<9.52$ & $\bar{c}$ & Yes & GEL \\
\hline 2-Chloronaphthalene & Water & $\mu \mathrm{g} / \mathrm{L}$ & 44.5 & 41.5 & $17.5-71.5$ & Yes & GEL \\
\hline Dimethylphthalate & Water & $\mu \mathrm{g} / \mathrm{L}$ & $\bar{c}$ & $<9.52$ & $\bar{c}$ & Yes & GEL \\
\hline Acenaphthylene & Water & $\mu \mathrm{g} / \mathrm{L}$ & 39.2 & 37.4 & $18.6-59.8$ & Yes & GEL \\
\hline 2,6-Dinitrotoluene & Water & $\mu g / L$ & 53.3 & 46.7 & $25.9-80.7$ & Yes & GEL \\
\hline Acenaphthene & Water & $\mu \mathrm{g} / \mathrm{L}$ & $\bar{c}$ & $<0.952$ & $\bar{c}$ & Yes & GEL \\
\hline 2,4-Dinitrotoluene & Water & $\mu \mathrm{g} / \mathrm{L}$ & 96 & 91.6 & $45-148$ & Yes & GEL \\
\hline 2,4-Dinitrophenol & Water & $\mu g / L$ & $\bar{c}$ & $<9.52$ & $\bar{c}$ & Yes & GEL \\
\hline Dibenzofuran & Water & $\mu g / L$ & $\bar{c}$ & $<9.52$ & $\bar{C}$ & Yes & GEL \\
\hline 4-Nitrophenol & Water & $\mu \mathrm{g} / \mathrm{L}$ & 93 & 50.0 & $9-225$ & Yes & GEL \\
\hline Fluorene & Water & $\mu g / L$ & 35.8 & 33.0 & $16.4-55.2$ & Yes & GEL \\
\hline Diethylphthalate & Water & $\mu g / L$ & 69.6 & 67.4 & $15.7-123.5$ & Yes & GEL \\
\hline 4,6-Dinitro-2-methylphenol & Water & $\mu \mathrm{g} / \mathrm{L}$ & $\bar{c}$ & $<9.52$ & $\bar{c}$ & Yes & GEL \\
\hline 2,4,5-Trichlorophenol & Water & $\mu \mathrm{g} / \mathrm{L}$ & 89 & 85.5 & $39-140$ & Yes & GEL \\
\hline Hexachlorobenzene & Water & $\mu g / L$ & $\bar{c}$ & $<9.52$ & $\bar{c}$ & Yes & GEL \\
\hline Pentachlorophenol & Water & $\mu \mathrm{g} / \mathrm{L}$ & 100 & 89.9 & $32-169$ & Yes & GEL \\
\hline Phenanthrene & Water & $\mu \mathrm{g} / \mathrm{L}$ & 110 & 91.6 & $61-160$ & Yes & GEL \\
\hline Anthracene & Water & $\mu \mathrm{g} / \mathrm{L}$ & $\bar{c}$ & $<0.952$ & $\bar{c}$ & Yes & GEL \\
\hline Di-n-butylphthalate & Water & $\mu \mathrm{g} / \mathrm{L}$ & 63.3 & 58.1 & $25.3-101.3$ & Yes & GEL \\
\hline Fluoranthene & Water & $\mu \mathrm{g} / \mathrm{L}$ & $c$ & $<0.952$ & $c$ & Yes & GEL \\
\hline Pyrene & Water & $\mu g / L$ & 57.3 & 60.9 & $21.9-92.8$ & Yes & GEL \\
\hline Butylbenzylphthalate & Water & $\mu \mathrm{g} / \mathrm{L}$ & $\sigma^{\prime}$ & $<9.52$ & $c$ & Yes & GEL \\
\hline Benzo(a)anthracene & Water & $\mu \mathrm{g} / \mathrm{L}$ & 109 & 95.3 & $58-161$ & Yes & GEL \\
\hline Chrysene & Water & $\mu g / L$ & 59.0 & 54.0 & $27.5-90.4$ & Yes & GEL \\
\hline Bis(2-ethylhexyl)phthalate & Water & $\mu g / L$ & $\bar{c}$ & $<9.52$ & $\bar{c}$ & Yes & GEL \\
\hline Di-n-octylphthalate & Water & $\mu g / L$ & 50.6 & 40.2 & $16.2-85.1$ & Yes & GEL \\
\hline Benzo(b)fluoranthene & Water & $\mu \mathrm{g} / \mathrm{L}$ & $\bar{c}$ & $<0.952$ & $c$ & Yes & GEL \\
\hline Benzo(k)fluoranthene & Water & $\mu \mathrm{g} / \mathrm{L}$ & 48.4 & 40.6 & $13.5-83.3$ & Yes & GEL \\
\hline Benzo(a)pyrene & Water & $\mu \mathrm{g} / \mathrm{L}$ & 76.6 & 78.8 & $29.1-124.0$ & Yes & GEL \\
\hline Indeno(1,2,3-c,d)pyrene & Water & $\mu \mathrm{g} / \mathrm{L}$ & $\bar{C}$ & $<0.952$ & $\bar{C}$ & Yes & GEL \\
\hline Dibenzo(a,h)anthracene & Water & $\mu g / L$ & $\bar{c}$ & $<0.952$ & & Yes & GEL \\
\hline Benzo(g,h,i)perylene & Water & $\mu \mathrm{g} / \mathrm{L}$ & $\bar{c}$ & $<0.952$ & $c$ & Yes & GEL \\
\hline
\end{tabular}

\section{GEL - General Engineering Laboratory}

Note: This report includes only those matrix/analyte combinations performed in support of the analysis of samples collected at the WVDP and for which results are presented in this Annual Site Environmental Report.

a MAPEP monitors performance and requests corrective action as required.

b "Yes" - Result acceptable; "Pass" - Result acceptable with warning; "No" - Result not acceptable.

c Although no actual value or acceptable range was provided, the results were assessed by MAPEP as acceptable. 
TABLE H-3

Comparisons of Results From Crosscheck Samples Analyzed for Water Quality Parameters as Part of the EPA's 2008 Discharge Monitoring Report - Quality Assurance (DMR-QA) Study 28 (August 2008) for the National Pollutant Discharge Elimination System (NPDES)

\begin{tabular}{|c|c|c|c|c|c|c|}
\hline Analyte & Units & Actual & Reported & $\begin{array}{c}\text { Acceptance } \\
\text { Range }^{a}\end{array}$ & Accept $^{b}$ & Analyzed by: \\
\hline Aluminum & $\mu \mathrm{g} / \mathrm{L}$ & 2820 & 2960 & $2,330-3,270$ & Yes & TestAmerica \\
\hline Ammonia (as Nitrogen) & $\mathrm{mg} / \mathrm{L}$ & 10.8 & 10.4 & $8.00-13.5$ & Yes & TestAmerica \\
\hline Antimony & $\mu \mathrm{g} / \mathrm{L}$ & 140 & 145 & $88.2-173$ & Yes & TestAmerica \\
\hline Arsenic & $\mu \mathrm{g} / \mathrm{L}$ & 126 & 138 & $102-150$ & Yes & TestAmerica \\
\hline Barium & $\mu \mathrm{g} / \mathrm{L}$ & 1460 & 1522 & $1,270-1,650$ & Yes & TestAmerica \\
\hline Biochemical oxygen demand & $\mathrm{mg} / \mathrm{L}$ & 84.1 & 106 & $42.5-126$ & Yes & TestAmerica \\
\hline Cadmium & $\mu \mathrm{g} / \mathrm{L}$ & 563 & 570 & $480-639$ & Yes & TestAmerica \\
\hline Chlorine (total residual) & $\mathrm{mg} / \mathrm{L}$ & 0.792 & 0.76 & $0.573-0.992$ & Yes & WWTF \\
\hline Chromium & $\mu \mathrm{g} / \mathrm{L}$ & 417 & 443 & $362-472$ & Yes & TestAmerica \\
\hline Chromium (hexavalent) & $\mu \mathrm{g} / \mathrm{L}$ & 463 & 476 & $376-545$ & Yes & TestAmerica \\
\hline Cobalt & $\mu \mathrm{g} / \mathrm{L}$ & 297 & 311 & $260-333$ & Yes & TestAmerica \\
\hline Copper & $\mu \mathrm{g} / \mathrm{L}$ & 352 & 352 & $317-388$ & Yes & TestAmerica \\
\hline Cyanide, total & $\mathrm{mg} / \mathrm{L}$ & 0.814 & 0.757 & $0.518-1.11$ & Yes & TestAmerica \\
\hline Iron & $\mu \mathrm{g} / \mathrm{L}$ & 1690 & 1772 & $1,500-1,900$ & Yes & TestAmerica \\
\hline Lead & $\mu \mathrm{g} / \mathrm{L}$ & 391 & 408 & $338-442$ & Yes & TestAmerica \\
\hline Manganese & $\mu \mathrm{g} / \mathrm{L}$ & 730 & 770 & $655-811$ & Yes & TestAmerica \\
\hline Mercury & $\mu \mathrm{g} / \mathrm{L}$ & 16.9 & 16.2 & $10.4-22.8$ & Yes & GEL \\
\hline Nickel & $\mu \mathrm{g} / \mathrm{L}$ & 1210 & 1254 & $1,100-1,350$ & Yes & TestAmerica \\
\hline Nitrate (as Nitrogen) & $\mathrm{mg} / \mathrm{L}$ & 9.18 & 9.15 & $7.15-11.1$ & Yes & TestAmerica \\
\hline Nitrite (as Nitrogen) & $\mathrm{mg} / \mathrm{L}$ & 3.13 & 2.90 & $2.66-3.60$ & Yes & TestAmerica \\
\hline Oil \& Grease (Gravimetric) & $\mathrm{mg} / \mathrm{L}$ & 65.0 & 46.6 & $43.8-77.6$ & Yes & TestAmerica \\
\hline $\mathrm{pH}$ & SU & 6.80 & 6.82 & $6.60-7.00$ & Yes & ELAB \\
\hline Phosphorus (total, as P) & $\mathrm{mg} / \mathrm{L}$ & 8.77 & 8.48 & $7.25-10.4$ & Yes & TestAmerica \\
\hline Selenium & $\mu \mathrm{g} / \mathrm{L}$ & 637 & 667 & $505-738$ & Yes & TestAmerica \\
\hline Silver & $\mu \mathrm{g} / \mathrm{L}$ & 228 & 228 & $195-261$ & Yes & TestAmerica \\
\hline Sulfate & $\mathrm{mg} / \mathrm{L}$ & 27.0 & 28.0 & $21.4-31.8$ & Yes & TestAmerica \\
\hline Settleable solids & $\mathrm{mL} / \mathrm{L}$ & 19.8 & 19 & $15.2-25.6$ & Yes & WWTF \\
\hline Suspended solids (total) & $\mathrm{mg} / \mathrm{L}$ & 76.0 & 70.4 & $61.7-84.9$ & Yes & TestAmerica \\
\hline Total dissolved solids & $\mathrm{mg} / \mathrm{L}$ & 238 & 244 & $176-300$ & Yes & ELAB \\
\hline Vanadium & $\mu \mathrm{g} / \mathrm{L}$ & 949 & 961 & $832-1,060$ & Yes & TestAmerica \\
\hline Zinc & $\mu \mathrm{g} / \mathrm{L}$ & 906 & 943 & $778-1,040$ & Yes & TestAmerica \\
\hline
\end{tabular}

GEL - General Engineering Laboratory

ELAB - WVDP Environmental Laboratory

TestAmerica - TestAmerica Laboratories, Inc., Buffalo

WWTF - WVDP Wastewater Treatment Facility Laboratory

Note: Samples provided by Environmental Research Associates (ERA)

a Acceptance limits are determined by ERA or the New York State Department of Health (NYSDOH), as applicable.

b "Yes" - Result acceptable; "Pass" - Result acceptable but outside warning limits; "No" - Result not acceptable. 
This page intentionally left blank 


\title{
APPENDIX I
}

\section{West Valley Demonstration Project Act}

\author{
West Valley Demonstration Project Act \\ (Public Law 96-368 [S. 2443]; October 1, 1980)
}

(As presented in Exhibit G of the Cooperative Agreement between United States Department of Energy and New York State Energy Research and Development Authority on the Western New York Nuclear Service Center at West Valley, New York; Effective October 1, 1980 as amended September 18, 1981.)

\section{EXHIBIT G}

\section{WEST VALLEY PROJECT DEMONSTRATION ACT}

PUBLIC LAW 96-368 [S. 2443]; October 1, 1980

\section{WEST VALLEY DEMONSTRATION PROJECT ACT}

For Legislative History of this and other Laws, see Table 1, Public Laws and Legislative History, at end of final volume

An Act to authorize the Department of Energy to carry out a high-level liquid nuclear waste management demonstration project at the Western Now

York Service Center in West Valley. New York.

Be it enacted by the Senate and House of Representatives of the United States of America in Congress assembled,

SECTION 1. This Act may be cited as the "West Valley Demonstration Project Act".

SEC. 2. (a) The Secretary shall carry out, in accordance with this Act, a high level radioactive waste management demonstration project at the Western New York Service Center in West Valley, New York, for the purpose of demonstrating solidification techniques which can be used for preparing high level radioactive waste for disposal. Under the project the Secretary shall carry out the follow- Activities. ing activities:

(1) The Secretary shall solidify, in a form suitable for transportation and disposal, the high level radioactive waste at the Center by vitrification or by such other technology which the Secretary determines to be the most effective for solidification.

(2) The Secretary shall develop containers suitable for the permanent disposal of the high level radioactive waste solidified at the Center.

(3) The Secretary shall, as soon as feasible, transport, in accordan ce with applicable provisions of law, the waste solidified at the Center to an appropriate Federal repository for permanent disposal.

(4) The Secretary shall, in accordance with applicable licensing requirements, dispose of low level radioactive waste and transuranic waste produced by the solidification of the high level radioactive waste under the project.

(5) The Secretary shall decontaminate and decommission-

(A) the tanks and other facilities of the Center in which the high level radioactive waste solidified under the project was stored,

(B) the facilities used in the solidification of the waste, and

(C) any material and hardware used in connection with the project.

in accordance with such requirements as the Commission may prescribe.

(b) Before undertaking the project and during the fiscal year ending September 30, 1981, the Secretary shall carry out the following:

(1) The Secretary shall hold in the vicinity of the Center public Hearings. hearings to inform the residents of the area in which the Center is located of the activities proposed to be undertaken under the project and to receive their comments on the project.

(2) The Secretary shall consider the various technologies available for the solidification and handling of high level radioactive waste taking into account the unique characteristics of such waste at the Center.

94 STAT. 1347

G-1 
(3) The Secretary shall-

(A) undertake detailed engineering and cost estimates for the project.

(B) prepare a plan for the safe removal of the high level radioactive waste at the Center for the purposes of solidification and include in the plan provisions respecting the safe breaching of the tanks in which the waste is stored, operating equipment to accomplish the removal, and sluicing techniques,

(C) conduct appropriate safety analyses of the project, and

(D) prepare required environmental impact analyses of the project.

(4) The Secretary shall enter into a cooperative agreement

42 USC 501 note.

State costs, percentage. with the State in accordance with the Federal Grant and Cooperative Agreement Act of 1977 under which the State will carry out the following:

(A) The State will make available to the Secretary the facilities of the Center and the high level radioactive waste at the Center which are necessary for the completion of the project. The facilities and the waste shall be made available without the transfer of title and for such period as may be required for completion of the project.

(B) The Secretary shall provide technical assistance in securing required license amendments.

(C) The State shall pay 10 per centum of the costs of the project, as determined by the Secretary. In determining the costs of the project, the Secretary shall consider the value of the use of the Center for the project. The State may not use Federal funds to pay its share of the cost of the project, but may use the perpetual care fund to pay such share.

(D) Submission jointly by the Department of Energy and the State of New York of an application for a licensing amendment as soon as possible with the Nuclear Regulatory Commission providing for the demonstration.

(c) Within one year from the date of the enactment of this Act, the Secretary shall enter into an agreement with the Commission to establish arrangements for review and consultation by the Commission with respect to the project: Provided, That review and consultation by the Commission pursuant to this subsection shall be conducted informally by the Commission and shall not include nor require formal procedures or actions by the Commission pursuant to the Atomic Energy Act of 1954, as amended, the Energy Reorganization Act of 1974, as amended, or any other law. The agreement shall provide for the following:

(1) The Secretary shall submit to the Commission, for its review and comment, a plan for the solidification of the high level radioactive waste at the Center, the removal of the waste for purposes of its solidification, the preparation of the waste for disposal, and the decontamination of the facilities to be used in solidifying the waste. In preparing its comments on the plan, the Commission shall specify with precision its objections to any provision of the plan. Upon submission of a plan to the Commission, the Secretary shall publish a notice in the Federal Register of the submission of the plan and of its availability for public inspection, and, upon receipt of the comments of the Commission respecting a plan, the Secretary shall publish a notice in the Federal Register of the receipt of the comments and of the availability of the comments for public inspection. If the Secre-

94 STAT. 1348 
tary does not revise the plan to meet objections specified in the comments of the Commission, the Secretary shall publish in the Federal Register a detailed statement for not so revising the plan.

(2) The Secretary shall consult with the Commission with respect to the form in which the high level radioactive waste at the Center shall be solidified and the containers to be used in the permanent disposal of such waste.

(3) The Secretary shall submit to the Commission safety analysis reports and such other information as the Commission may require to identify any danger to the public health and safety which may be presented by the project.

(4) The Secretary shall afford the Commission access to the Center to enable the Commission to monitor the activities under the project for the purpose of assuring the public health and safety.

(d) In carrying out the project, the Secretary shall consult with the Administrator of the Environmental Protection Agency, the Secretary of Transportation, the Director of the Geological Survey, and the commercial operator of the Center.

SEC. 3. (a) There are authorized to be appropriated to the Secretary for the project not more than $\$ 5,000,000$ for the fiscal year ending September 30, 1981.

(b) The total amount obligated for the project by the Secretary shall be 90 per centum of the costs of the project.

(c) The authority of the Secretary to enter into contracts under this Act shall be effective for any fiscal year only to such extent or in such amounts as are provided in advance by appropriation Acts.

SEC. 4. Not later than February 1, 1981, and on February 1 of each calendar year thereafter during the term of the project, the Secretary shall transmit to the Speaker of the House of Representatives and the President pro tempore of the Senate an up-to-date report containing a detailed description of the activities of the Secretary in carrying out the project, including agreements entered into and the costs incurred during the period reported on and the activities to be undertaken in the next fiscal year and the estimated costs thereof.

SEC. 5. (a) Other than the costs and responsibilities established by this Act for the project, nothing in this Act shall be construed as affecting any rights, obligations, or liabilities of the commercial operator of the Center, the State, or any person, as is appropriate, arising under the Atomic Energy Act of 1954 or under any other law, contract, or agreement for the operation, maintenance, or decontamination of any facility or property at the Center or for any wastes at the Center. Nothing in this Act shall be construed as affecting any applicable licensing requirement of the Atomic Energy Act of 1954 or the Energy Reorganization Act of 1974. This Act shall not apply or be extended to any facility or property at the Center which is not used in conducting the project. This Act may not be construed to expand or diminish the rights of the Federal Government.

(b) This Act does not authorize the Federal Government to acquire title to any high level radioactive waste at the Center or to the Center or any portion thereof.

SEC. 6. For the purposes of this Act:

(1) The term "Secretary" means the Secretary of Energy.

(2) The term "Commission" means the Nuclear Regulatory

Reports and

Commission.

(3) The term "State" means the State of New York.

94 STAT. 1349

Report to Speaker of the House and President pro tempore of the Senate. 42 USC 2021a note. 42 USC 2021a note. 42 USC 2011 note. 42 USC 5801 note. note.

\section{G-3}


P.L. 96-368

LAWS OF 96th CONG.-2nd SESS.
Oct. 1

(4) The term "high level radioactive waste" means the high level radioactive waste which was produced by the reprocessing at the Center of spent nuclear fuel. Such term includes both liquid wastes which are produced directly in reprocessing, dry solid material derived from such liquid waste, and such other material as the Commission designates as high level radioactive waste for purposes of protecting the public health and safety.

(5) The term "transuranic waste" means material contaminated with elements which have an atomic number greater than 92, including neptunium, plutonium, americium, and curium, and which are in concentrations greater than 10 nanocuries per gram, or in such other concentrations as the Commission may prescribe to protect the public health and safety.

(6) The term "low level radioactive waste" means radioactive waste not classified as high level radioactive waste, transuranic waste, or byproduct material as defined in section $11 \mathrm{e}$. (2) of the Atomic Energy Act of 1954.

(7) The term "project" means the project prescribed by section 2(a).

(8) The term "Center" means the Western New York Service Center in West Valley, New York.

Approved October 1, 1980. 